UNIVERSIDADE DE SÃO PAULO

FACULDADE DE EDUCAÇÃO

VIVIANE POTENZA GUIMARÃES PINHEIRO

Integração e regulação de valores e sentimentos nos projetos de vida de jovens: um estudo na perspectiva dos modelos organizadores do pensamento

São Paulo

2013 


\section{Integração e regulação de valores e sentimentos nos projetos de vida de jovens: um estudo na perspectiva dos modelos organizadores do pensamento}

Tese apresentada à Faculdade de Educação da Universidade de São Paulo para obtenção do título de Doutora em Educação.

Área de concentração: Psicologia e Educação

Orientadora: $\operatorname{Prof}^{\mathrm{a}} \mathrm{Dr}^{\mathrm{a}}$ Valéria Amorim Arantes

São Paulo

2013 
AUTORIZO A REPROUÇÃO E DIVULGAÇÃO TOTAL OU PARCIAL DESTE TRABALHO, POR QUALQUER MEIO CONVENCIONAL OU ELETRÔNICO, PARA FINS DE ESTUDO E PESQUISA, DESDE QUE CITADA A FONTE.

Catalogação na Publicação

Serviço de Biblioteca e Documentação

Faculdade de Educação da Universidade de São Paulo

377.2 Pinheiro, Viviane Potenza Guimarães

P654i Integração e regulação de valores e sentimentos nos projetos de vida de jovens : um estudo na perspectiva dos modelos organizadores do pensamento / Viviane Potenza Guimarães Pinheiro ; orientação Valéria Amorim Arantes. São Paulo : s.n., 2013.

384 p. : il. tabs. grafs

Tese (Doutorado - Programa de Pós-Graduação em Educação. Área de Concentração : Psicologia e Educação) - Faculdade de Educação da Universidade de São Paulo)

1. Educação moral 2. Jovens - Educação 3. Moral - Psicologia 4.Ensino médio 5. Valores 6. Emoções I. Arantes, Valéria Amorim, orient. 


\section{FOLHA DE APROVAÇÃo}

Viviane Potenza Guimarães Pinheiro

Integração e regulação de valores e sentimentos nos projetos de vida de jovens estudantes: um estudo na perspectiva da Teoria dos Modelos Organizadores do Pensamento

Tese apresentada à Faculdade de Educação da Universidade de São Paulo para obtenção do título de Doutora em Psicologia e Educação

Área de concentração: Psicologia e Educação

Orientadora: Prof ${ }^{\mathrm{a}} \mathrm{Dr}^{\mathrm{a}}$ Valéria Amorim Arantes

Aprovada em:

\section{Banca Examinadora}

Prof. Dr.

Instituição: Ass:

Prof. Dr.

Instituição: Ass:

Prof. Dr.

Instituição: Ass:

Prof. Dr.

Instituição: Ass:

Prof. Dr.

Instituição: Ass: 
A João, João Víctor e Leonardo,

por serem fonte primordial de meus projetos de vida... 


\section{AGRADECIMENTOS}

Chegar à finalização deste trabalho exigiu esforço, dedicação e abdicação que não seriam possíveis sem a ajuda e o apoio de muitas pessoas que se fizeram presentes ao longo de toda a sua elaboração.

Agradeço, em primeiro lugar, à $\operatorname{Prof}^{a} \operatorname{Dr}^{a}$ Valéria Amorim Arantes, que foi decisiva em todos os momentos da elaboração da presente tese: desde a escolha do tema, a análise conjunta dos protocolos, os momentos de repensar caminhos, até o incentivo à finalização do trabalho. Agradeço por ser parte de minha vida acadêmica e pessoal, durante todos esses anos de parceria na pesquisa, conversas, conselhos e orientações.

Ao Prof. Dr. Mário Sérgio Vasconcelos e à Prof ${ }^{a}$ Dr $^{a}$ Marília Pontes Sposito pelas valiosas contribuições à presente investigação. Os seus apontamentos foram decisivos para desestabilizar crenças e, assim, chegar às formulações finais dessa pesquisa.

Ao Prof. Dr. Ulisses Ferreira Araújo por ser responsável pelo meu interesse em relação à temática da moralidade e por auxiliar, juntamente à $\operatorname{Prof}^{\mathrm{a}} \operatorname{Dr}^{\mathrm{a}}$ Valéria Amorim Arantes, o custeio das viagens para coleta de dados por meio de pesquisas financiadas pelo CNPq (Conselho Nacional de Desenvolvimento Científico e Tecnológico) e pela FAPESP (Fundação de Amparo à Pesquisa do Estado de São Paulo).

Aos jovens participantes por disporem de seu tempo para responder aos questionários. Aos diretores, coordenadores e professores das escolas que participaram dessa investigação e me acolheram, oportunizando que todas as coletas fossem realizadas no prazo estabelecido.

À Livia Moreiras e ao Waldir Uller que me ajudaram na coleta de dados em algumas cidades. À Dina Melo e à Tânia Rodrigues que organizaram as coletas nas cidades de Macapá e Fortaleza e me receberam de forma muito hospitaleira.

Ao meu esposo, João Carlos, pelo apoio e afeto incondicionais, por me dar forças para sempre prosseguir e por cuidar daquilo que não consegui enquanto me dedicava a essa pesquisa.

Aos meus filhos, João Víctor e Leonardo, pela paciência que tiveram com a mamãe, nas viagens, ausências de corpo e alma em momentos cruciais de elaboração do trabalho.

Aos meus pais, Drausio e Sonia pela formação que me deram e por sempre estarem atentos aos meus passos, incentivando-me a superar obstáculos.

À minha sogra, D. Lucia, por cuidar de meus filhos sempre que estive ausente, fazendo, muitas vezes, um papel que eu deveria desempenhar. 
Às coordenadoras da Escola Pinheiro que supriram as minhas ausências e estiveram sempre dispostas a me ajudar, em todos os momentos em que precisei. Aos professores, pelo interesse pelo presente trabalho, e aos alunos da referida escola, pelas oportunidades de diálogo e de observação necessárias para a composição dos instrumentos de pesquisa.

À Universidade de São Paulo, na figura de seus professores e funcionários, que foi a minha "casa" por 16 anos, na realização de duas graduações, o mestrado e o doutorado. A minha formação nessa instituição foi fundamental para quem eu sou hoje, como pesquisadora e profissional da área de Educação. 
Se procurar bem você acaba encontrando. Não a explicação (duvidosa) da vida, Mas a poesia (inexplicável) da vida.

Carlos Drummond de Andrade 


\section{RESUMO}

PINHEIRO, V. P. G. Integração e regulação de valores e sentimentos nos projetos de vida de jovens: um estudo na perspectiva dos modelos organizadores do pensamento. 2013. 384 f. Tese (Doutorado) - Faculdade de Educação, Universidade de São Paulo, São Paulo. 2013.

O presente trabalho, inserido no campo da psicologia moral, buscou entender a funcionalidade da organização do pensamento de jovens diante de suas projeções sobre o futuro. O objetivo central da presente investigação foi compreender como se dão os processos de integração e regulação de valores e sentimentos que subjazem a elaboração de projetos de vida na juventude. Para tanto, esteve fundamentado em três eixos teóricos: conceitos de integração e regulação morais, embasados na perspectiva da psicologia que alia a moralidade ao self; projeto de vida na juventude; Teoria dos Modelos Organizadores do Pensamento. Para o desenvolvimento da pesquisa, elaboramos dois instrumentos: o primeiro, com questões referentes ao projeto de vida dos jovens; o segundo, um conflito moral que envolvia tal temática vivenciada por um personagem fictício. Responderam a esses questionários, de forma aberta, escrita e individual, 200 jovens estudantes de escolas públicas pertencentes a cada uma das regiões brasileiras. A análise dos dados advindos dos dois instrumentos pautouse nos referencias teóricos da Teoria dos Modelos Organizadores do Pensamento. A partir da leitura das respostas de cada participante, verificamos os elementos abstraídos e retidos como significativos, seus significados e as relações e/ou implicações entre eles, chegando à extração dos modelos organizadores diante de cada instrumento. Com base nessas análises, foi possível verificar que os contextos e o tipo de solicitação de organização do pensamento circunscrevem conteúdos importantes para os processos de integração e regulação de valores e sentimentos. Percebeu-se que, embora esses processos estejam fortemente influenciados por tais conteúdos, ocorrem de forma intimamente associada à forma como cada sujeito tece relações a seu respeito, a partir dos complexos de valores, sentimentos e significados mobilizados. Constatou-se, assim, que, diante de cada situação apresentada, existe um continuum entre os processos de integração e regulação de valores e sentimentos, constituídos pelas características constantes na identidade moral de cada sujeito e pela flexibilidade imposta pela sua representação dos conteúdos do meio. Dessa forma, evidenciou-se que os projetos de vida são passíveis de transformação, ao mesmo tempo em que são constituídos e 
constituem aspectos importantes do sistema moral dos jovens. Ao final, considerando-se tais descobertas, tecemos algumas implicações educacionais da presente investigação.

Palavras-chave: projetos de vida; juventude; moralidade; Teoria dos Modelos Organizadores do Pensamento. 


\begin{abstract}
PINHEIRO, V. P. G. Integration and regulation of values and feelings on life projects for young people: a study from the perspective of the organizing models of thought. 2013. 384f. Thesis (Ph.D.) - School of Education, University of São Paulo, São Paulo. 2013.

This work, in the field of moral psychology, sought to understand the functionality of the youth organization of thought belong to their projections on the future. The central objective of this research was to understand how the processes of integration and regulation of feelings and values occur, underling the development of projects of life in youth. This way, three themes support our research: concepts of integration and moral regulation, based on psychological perspective that combines morality to self; life project in youth; Theory of Organizing Models of Thought. To the development of this research, there are two instruments: issues relating to young people's design of life and a moral conflict involving a life project experienced by a fictional character. 200 students, from public schools belonging to each Brazilian regions, answered to these questionnaires, by open questions, and individual writing. The data analysis obtained from the two instruments was based on the referrals of Theory of Organizing Models of Thought. In the answers of each participant we could notice the abstracted elements, its meanings and the relation/ implication among them, leading to the extraction of organizing models from each instrument. With these analyzes, we found that contexts and the type of request point to important content about values and feelings integration and regulation processes. One can conclude that although these processes are heavily influenced by such content, they occur intimately associated with how each one establishes relationships between itself, from the mobilized complex of values, feelings and meanings. We found that facing different situations, there is a continuum between the processes of values and feelings integration and regulation, consisting of characteristics from moral identity and the flexibility required by context contents representation. Thus, it became clear that life projects are subject to change at the same time that are shown as important aspects of young people's moral system. At the end, considering these findings, we weave some education implications of this research.
\end{abstract}

Keywords: life projects; morality; Theory of Organizing Models of Thought. 


\section{LISTA DE TABELAS}

Tabela 1 - Regiões e cidades em que foram coletados os dados

Tabela 2 - Distribuição dos sujeitos nas regiões e cidades em que foram coletados os dados

Tabela 3 - Relações/implicações entre elementos centrais, sentimentos e seus significados no submodelo 1a.

Tabela 4 - Relações/implicações entre elementos centrais, sentimentos e seus significados no submodelo $1 \mathrm{~b}$

Tabela 5 - Relações/implicações entre elementos centrais, sentimentos e seus significados no submodelo 1c

Tabela 6 - Relações/implicações entre elementos centrais, sentimentos e seus significados no modelo 2

Tabela 7 - Relações/implicações entre elementos centrais, sentimentos e seus significados no modelo 3

Tabela 8 - Relações/implicações entre elementos centrais, sentimentos e seus significados no submodelo $4 \mathrm{a}$.

Tabela 9 - Relações/implicações entre elementos centrais, sentimentos e seus significados no submodelo $4 \mathrm{~b}$

Tabela 10 - Relações/implicações entre elementos centrais, sentimentos e seus significados no submodelo 5a.

Tabela 11 - Relações/implicações entre elementos centrais, sentimentos e seus significados no submodelo $5 \mathrm{~b}$

Tabela 12 - Relações/implicações entre elementos centrais, sentimentos e seus significados no submodelo 6 a.

Tabela 13 - Relações/implicações entre elementos centrais, sentimentos e seus significados no submodelo $6 \mathrm{~b}$

Tabela 14 - Relações/implicações entre elementos centrais, sentimentos e seus significados no submodelo $7 \mathrm{a}$.

Tabela 15 - Relações/implicações entre elementos centrais, sentimentos e seus significados no submodelo $7 \mathrm{~b}$.

Tabela 16 - Relações/implicações entre elementos centrais, sentimentos e seus significados no modelo "outras dinâmicas de organização do pensamento 1 "..... 
Tabela 17 - Relações/implicações entre elementos centrais, sentimentos e seus significados no modelo "outras dinâmicas de organização do pensamento 2".

Tabela 18 - Elementos, sentimentos e relações/implicações entre valores e sentimentos destacados nos modelos e submodelos organizadores aplicados pelos jovens participantes da pesquisa em relação aos seus projetos de vida.

Tabela 19 - Distribuição dos sujeitos em modelos e submodelos referentes à elaboração do projeto de vida.

Tabela 20 - Distribuição dos sujeitos nas categorias de modelos em relação aos processos de integração e regulação de valores e sentimentos na elaboração dos projetos de vida.

Tabela 21 - Distribuição dos sujeitos nas categorias de modelos em relação aos processos de integração/regulação de valores e sentimentos em níveis de complexidade na elaboração dos projetos de vida

Tabela 22 - Relações/implicações entre elementos centrais, sentimentos e seus significados no submodelo A1

Tabela 23 - Relações/implicações entre elementos centrais, sentimentos e seus significados no submodelo A2

Tabela 24 - Relações/implicações entre elementos centrais, sentimentos e seus significados no submodelo A3

Tabela 25 - Relações/implicações entre elementos centrais, sentimentos e seus significados no submodelo B1

Tabela 26 - Relações/implicações entre elementos centrais, sentimentos e seus significados no submodelo B2

Tabela 27 - Relações/implicações entre elementos centrais, sentimentos e seus significados no modelo $\mathrm{C}$

Tabela 28 - Relações/implicações entre elementos centrais, sentimentos e seus significados no submodelo D1

Tabela 29 - Relações/implicações entre elementos centrais, sentimentos e seus significados no submodelo D2

Tabela 30 - Relações/implicações entre elementos centrais, sentimentos e seus significados no submodelo E1

Tabela 31 - Relações/implicações entre elementos centrais, sentimentos e seus significados no submodelo E2 
Tabela 32 - Relações/implicações entre elementos centrais, sentimentos e seus significados no submodelo F1

Tabela 33 - Relações/implicações entre elementos centrais, sentimentos e seus significados no submodelo F2

Tabela 34 - Relações/implicações entre elementos centrais, sentimentos e seus significados no submodelo G1

Tabela 35 - Relações/implicações entre elementos centrais, sentimentos e seus significados no submodelo G2

Tabela 36 - Elementos, sentimentos e relações/implicações entre valores e sentimentos nos modelos e submodelos organizadores aplicados pelos jovens participantes da pesquisa em relação ao conflito moral.

Tabela 37 - Distribuição dos sujeitos em modelos e submodelos aplicados em relação ao conflito moral

Tabela 38 - Distribuição dos sujeitos nas categorias de modelos em relação aos processos de integração/regulação de valores e sentimentos diante do conflito moral

Tabela 39 - Distribuição dos sujeitos nas categorias de modelos em relação aos processos de integração/regulação de valores e sentimentos em diferentes articulações diante do conflito moral

Tabela 40 - Valores mobilizados na elaboração dos projetos de vida e diante do conflito moral

Tabela 41 - Integração de valores e suas significações na elaboração dos projetos de vida e no conflito moral

Tabela 42 - Sentimentos mobilizados na elaboração dos projetos de vida e diante do conflito moral

Tabela 43 - Integração de valores e de sentimentos positivos e negativos na elaboração dos projetos de vida

Tabela 44 - Integração de valores e de sentimentos positivos e negativos diante do conflito moral

Tabela 45 - Distribuição dos sujeitos nos modelos e submodelos organizadores elaborados nos projetos de vida e na resolução do conflito moral

Tabela 44 - Distribuição dos sujeitos nos modelos organizadores elaborados nos projetos de vida e na resolução do conflito moral 


\section{LISTA DE GRÁFICOS}

Gráfico 1 - Distribuição dos sujeitos nos modelos organizadores referentes à elaboração dos projetos de vida

Gráfico 2 - Categorias de modelos em relação aos processos de integração/regulação de valores e sentimentos nos projetos de vida

Gráfico 3 - Categorias de modelos em relação aos processos de integração/regulação de valores e sentimentos em níveis de complexidade na elaboração dos projetos de vida

Gráfico 4 - Representação da integração/regulação entre valores e sentimentos nos modelos organizadores do pensamento referentes ao conflito moral

Gráfico 5 - Distribuição dos sujeitos nos modelos organizadores referentes ao conflito moral

Gráfico 6 - Categorias de modelos em relação aos processos de integração/regulação de valores e sentimentos diante do conflito moral

Gráfico 7 - Categorias de modelos em relação aos processos de integração/regulação de valores e sentimentos em diferentes articulações diante do conflito moral

Gráfico 8 - Distribuição dos sujeitos nos modelos organizadores elaborados nos projetos de vida na resolução do conflito moral 


\section{SUMÁRIO}

Introdução

Capítulo I - Moralidade e funcionamento psíquico ........................................................ 26

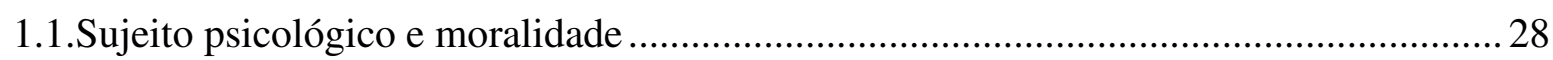

1.2. A integração da moralidade ao self: a ideia de identidade moral.................................36

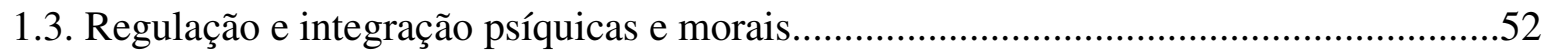

1.3.1. Regulação, self e consciência moral ..................................................................52

1.3.2. O papel regulatório da afetividade no psiquismo humano...................................57

Capítulo II - Juventude, projeto de vida e moralidade................................................67

2.1. Juventude: identidades e trajetórias na contemporaneidade........................................69

2.2. Condição juvenil no Brasil: alguns apontamentos......................................................75

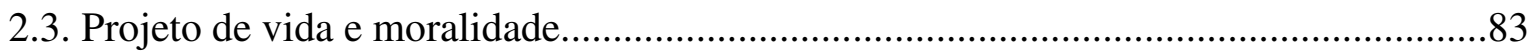

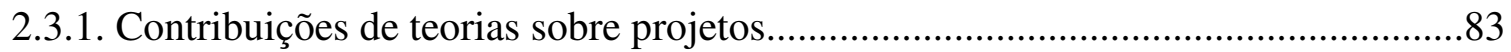

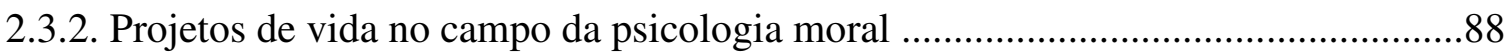

Capítulo III - Modelos organizadores do pensamento, funcionamento psíquico e

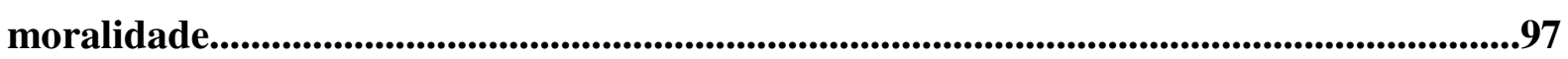

3.1. Modelos organizadores do pensamento e funcionamento psíquico............................100

3.2. Modelos organizadores do pensamento: contribuições e perspectivas para o estudo da moralidade

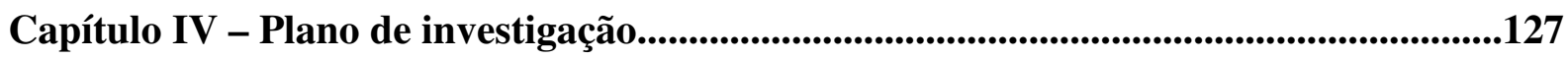

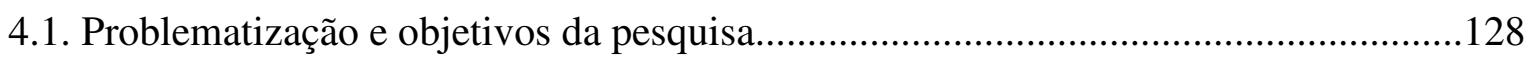

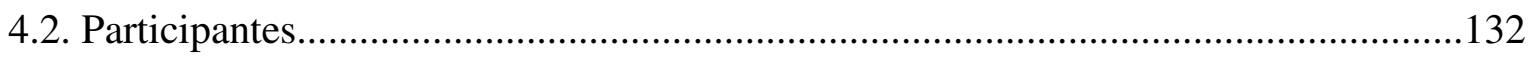

4.3. Construção dos instrumentos de pesquisa.................................................................135

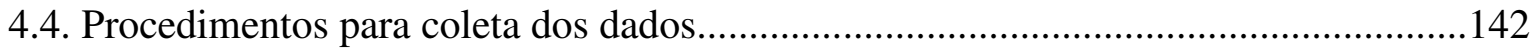

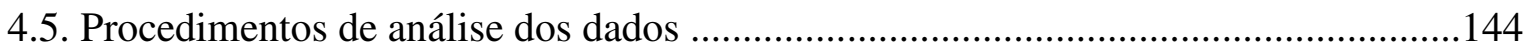


Capítulo V - Apresentação dos modelos organizadores referentes aos projetos de vida.

5.1. Considerações sobre a apresentação dos modelos organizadores do pensamento referentes aos projetos de vida dos jovens. 148

5.2. Descrição dos modelos organizadores relativos ao questionário sobre projeto de vida.

Capítulo VI - Apresentação e análise dos resultados referentes aos projetos de vida.

6.1. Considerações sobre a apresentação e a análise dos resultados relativos aos projetos de

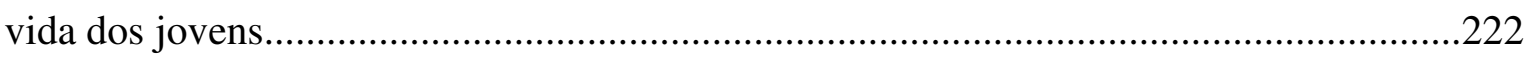

6.2. Descrição sumária dos modelos e submodelos. 223

6.3. Processos de integração e regulação de valores e sentimentos nos modelos e submodelos organizadores aplicados pelos participantes da pesquisa em relação aos seus projetos de vida. .226

6.4. Apresentação e análise quantitativa dos resultados referentes aos modelos organizadores aplicados pelos sujeitos participantes da pesquisa em relação ao seus projetos de vida.

Capítulo VII - Apresentação dos modelos organizadores referentes ao conflito moral. 248

7.1. Considerações sobre a apresentação dos modelos organizadores referentes ao conflito moral.

7.2. Descrição dos modelos organizadores do pensamento referentes ao conflito moral.

\section{Capítulo VIII - Apresentação e análise dos resultados referentes ao conflito

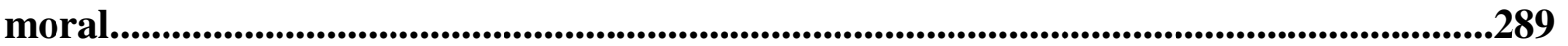

8.1 Considerações sobre a apresentação e a análise dos resultados relativos ao conflito moral.

8.2 Descrição sumária dos modelos e submodelos referentes às questões sobre o conflito moral. 
8.3. Processos de integração e regulação de valores e sentimentos nos modelos e submodelos organizadores aplicados pelos sujeitos participantes da pesquisa em relação ao conflito moral.

8.4. Apresentação e análise quantitativa dos resultados referentes aos modelos organizadores aplicados pelos sujeitos participantes da pesquisa em relação ao conflito moral

\section{Capítulo IX - Discussão dos resultados em relação aos processos de integração e} regulação de valores e sentimentos na elaboração dos projetos de vida e diante do conflito moral.

9.1. Processos de integração e regulação de valores e sentimentos na elaboração dos projetos de vida e diante de um conflito moral

9.2. Discussão dos resultados sobre a distribuição dos sujeitos nos modelos organizadores do pensamento na elaboração dos projetos de vida e diante do conflito moral.

9.3. Articulação de processos de integração e regulação de valores e sentimentos na elaboração dos projetos de vida e diante do conflito moral.

Capítulo X - Considerações finais

10.1. Processos de integração e regulação de valores e sentimentos diante de conteúdos relacionados aos projetos de vida: diversidade e regularidade na organização do pensamento dos jovens participantes. 345

10.2. Contribuições para a educação moral 367

Referências. 


\section{INTRODUÇÃO}

[...] essa dimensão da vida humana diz respeito à sua condição futurista, quer dizer, o fato de que, sendo real e, portanto, presente, atual, está projetada no futuro, intrinsecamente relacionada a ele na forma de antecipação ou projeção. (MARÍAS, 1984, p. 34, tradução nossa)

A vida humana, no que lhe cabe de mais peculiar, que é a condição de ser e estar no mundo, é fonte de mistérios que, em várias áreas do conhecimento, intentamos desvendar. No campo da psicologia, o mistério reside em como o sujeito pensa, sente e age no mundo.

Muitas teorias seguiram configurações que procuraram explicar o sujeito por uma de suas facetas (ora cognitiva, ora afetiva, ora social). No entanto, percebeu-se grande possibilidade de avanços na medida em que os trabalhos passaram a se voltar para uma abertura de possibilidades teóricas e metodológicas. Um marco para o desenrolar dessas investigações tem sido a busca por novos paradigmas, em que se pretende entender os fenômenos em sua complexidade.

Dentro dessa perspectiva, passou-se a procurar explicações sobre o psiquismo humano não baseadas em "verdades" predeterminadas, mas na intricada teia que reverbera juízos e ações elaborados pelo sujeito em sua condição de interação com os conteúdos existentes no mundo que o rodeia. Assim, entender o sujeito em sua complexidade significa vê-lo como um ser que age, pensa, sente, possui crenças, desejos e objetivos. Muito embora se saiba da necessidade de fragmentar os objetos de estudo, para promover um maior aprofundamento sobre sua conceituação teórica, admitir a complexidade do funcionamento psíquico humano traz a oportunidade de sempre estar aberto ao novo e, destarte, promover um conhecimento mais abrangente do que aquele que se suporia ao início de uma investigação.

Incorporando essa vertente dentro da área da psicologia moral, a presente pesquisa, assumindo seu caráter construtivista, ambiciona estudar a vida, como ela é pensada e projetada pelo jovem, no jogo de relações que se estabelecem entre seus valores e sentimentos. Assim sendo, toma como ponto de partida um estudo funcional do psiquismo humano, levando em consideração o sujeito "real" que atua no meio em que interage.

A tentativa de ampliar e aprofundar a compreensão sobre o papel dos valores e sentimentos no funcionamento psíquico humano diante de conteúdos referentes a projetos de 
vida funda-se em um percurso teórico-metodológico que temos traçado nos últimos anos ${ }^{1} \mathrm{em}$ comunhão com nosso desejo de promover discussões no âmbito da educação moral.

Seguindo uma corrente atual da psicologia moral que entende a moralidade como parte da identidade do sujeito (DAMON, 1995; BLASI, 1995, 2004; PUIG, 1996; NISAN, 2004; LAPSLEY; NARVAEZ, 2004; LAPSLEY \& HILL, 2008, entre outros), percebemos que a construção e a mobilização de valores nas diversas situações implicam um complexo de relações estabelecidas entre variados componentes do funcionamento psíquico. Assim, tomou importância, em nosso caminho teórico, enveredar para o estudo do papel regulatório dos sentimentos morais (ARAÚJO, 1998, 2003a; DE LA TAILLE, 2002; LEWIS, 2004). Em investigação anterior (PINHEIRO, 2009), partimos do objetivo de consolidar, por meio de pesquisa empírica, o estudo sobre a regulação exercida pelos sentimentos de vergonha e culpa para a elaboração do valor de generosidade frente a um conflito moral. No entanto, devido ao caráter metodológico da investigação alicerçado em não postular categorias prévias, mas estar aberto aos juízos formulados pelos sujeitos, em sua complexidade, não apenas confirmamos o papel regulatório de tais sentimentos, mas também verificamos que os valores integram-se na elaboração de juízos e que essa integração exerce papel central de regulação no psiquismo humano.

A perspectiva dos projetos de vida dos jovens acena-nos com a possibilidade de incorporar nessa ideia inicial, apontada pela investigação que empreendemos anteriormente, uma maior complexidade, uma vez que, ao relatar sobre as suas projeções, o jovem formulará juízos em que estarão presentes valores e sentimentos vivenciados no passado e no presente, assim como delineados para um futuro. Os projetos de vida, em nossa concepção, são projeções que comportam desejos, pensamentos, interesses e objetivos do sujeito. Configurando-se de forma complexa, os projetos de vida envolvem tanto características identitárias do sujeito, que o diferenciam dos demais ao mesmo tempo em que posicionam certa regularidade em seus juízos, quanto a abertura para as mudanças de pensamento, de acordo com a interação que o sujeito estabelece com o mundo.

Partimos da ideia de que os projetos de vida contêm conteúdos que revelam e são revelados por valores e sentimentos. Assim sendo, ao abrir a análise para uma diversidade de valores e sentimentos, morais ou não, cremos ser possível averiguar as relações estabelecidas entre eles nos juízos emitidos pelos jovens. Os aspectos de integração e de regulação entre

\footnotetext{
${ }^{1}$ Referimo-nos a duas investigações que empreendemos anteriormente, na Iniciação Científica, "Estados emocionais e os modelos organizadores do pensamento na resolução de conflitos éticos do cotidiano escolar", no ano de 2004, e, no Mestrado, "A generosidade e os sentimentos morais: um estudo na perspectiva dos Modelos Organizadores do Pensamento", em 2009, ambas sob orientação da Prof ${ }^{a}$ Dr $^{a}$ Valéria Amorim Arantes.
} 
valores e sentimentos seriam, nesse complexo que perfaz a elaboração de um projeto de vida, observados com um maior número de elementos, sugerindo relações que ainda não puderam ser estabelecidas em trabalhos anteriores.

Um referencial teórico-metodológico importante para trazer à luz a funcionalidade dos processos de integração e regulação de valores e sentimentos é a Teoria dos Modelos Organizadores do Pensamento (MORENO MARIMÓN et al., 1999). Segundo essa teoria, o sujeito constrói modelos de "realidade" a partir dos elementos que abstrai e significa diante do todo com o qual interage, tecendo relações e implicações para a formulação de juízos e ações morais. A formulação de um projeto de vida, dessa forma, compreende uma forma de organizar o pensamento mediante elementos observáveis, imaginados ou frutos de crenças e paradigmas cristalizados pelo jovem. Com a Teoria dos Modelos Organizadores do Pensamento, torna-se possível evidenciar os processos que subjazem a elaboração dos projetos de vida. Dentre tais processos, encontram-se a integração e a regulação entre valores e sentimentos.

Consoante o percurso teórico traçado, nossa investigação define como problema central compreender como se dá a integração e a regulação entre os valores e sentimentos nos projetos de vida dos jovens. Para tanto, delineamos a pesquisa empírica em um recorte metodológico que foi estruturado em duas bases distintas, porém complementares. A primeira diz respeito à aplicação de um questionário sobre projetos de vida, elaborado com base no instrumento consolidado internacionalmente pelo Stanford Center on Adolescence ${ }^{2}$. Tal questionário fundamentou-se em perguntas abertas voltadas ao que o jovem valoriza em sua rotina, o que deseja para o mundo e o que projeta em seu futuro. A segunda relaciona-se a três questões abertas que indagavam o sujeito a respeito de como se sentiria, pensaria e agiria diante de um conflito moral pertinente ao projeto de vida de um personagem fictício. Esse conflito moral, cuja temática foi elaborada com base em conversas e estudos piloto com jovens, utilizava-se de um projeto de vida voltado para os elementos trabalho e família. A escolha de tais elementos, além de ter sido conduzida pelo contato com estudantes de Ensino Médio, foi influenciada por uma série de estudos sobre o jovem no Brasil, nos quais se apresentaram, com destaque, os elementos família, trabalho, religião, estudo e momentos de lazer (CAMARANO et al., 2004; ABRAMO, 2005; LASSANCE, 2005; SPOSITO, 2005; THOMÉ, TELMO \& KOLLER, 2011; LIBÓRIO, COÊLHO \& CASTRO, 2011).

\footnotetext{
${ }^{2}$ Grupo de estudos e pesquisas da Universidade de Stanford (EUA), coordenado pelo Prof. William Damon.
} 
A aplicação de dois instrumentos distintos almejou atingir outro objetivo importante desta pesquisa: o de identificar e analisar a existência ou não de um continuum entre a integração e a regulação de valores e sentimentos, valendo-se para isso de um questionário que solicita ao sujeito posicionar-se a respeito de seus projetos de vida (questionário "projeto de vida") e de questões acerca de um conflito elaborado com base no projeto de vida de um personagem (questionário "conflito moral"). Em outras palavras, tendo em vista abordar ambas as perspectivas, desejamos compreender os processos de integração e regulação entre valores e sentimentos diante de projetos de vida em duas situações distintas: uma em que o sujeito pensa sobre si mesmo, elabora sua própria projeção sobre o futuro em um processo que lhe exige reflexão e concatenamento de ideias; outra em que o participante defronta-se com um conflito que não é o seu e se posiciona rapidamente para a sua resolução. Enquanto o primeiro instrumento está fortemente relacionado ao self, naquilo que ele posiciona como mais importante em sua constituição identitária, o segundo utiliza-se de uma tomada de perspectiva do outro em que, diante dos elementos que estão expostos na "realidade" daquela situação, o sujeito expõe seus pensamentos e sentimentos.

Muito embora tratem da mesma temática, as duas análises são distintas em suas solicitações, visto que exigem do sujeito diferentes formas de organizar seu pensamento. São complementares porque os processos inerentes ao funcionamento psíquico em cada uma das situações estão também imbricados na composição do self, naquilo que ele tem de peremptório, ou seja, no que mostra de regularidades, e no que possui de mudança, de nãoregularidades de seu pensamento.

Ambas as análises deram-se por meio do instrumento teórico-metodológico da Teoria dos Modelos Organizadores do Pensamento (MORENO MARIMÓN et al., 1999) que nos permitiu vislumbrar a complexidade que perfaz os processos de regulação e de integração entre valores e sentimentos nos projetos de vida dos jovens. Com tal forma de análise, não estabelecemos categorias prévias, mas nos detemos às respostas dos jovens de forma a perceber como organizaram seus projetos de vida ou emitiram juízos diante de uma situação de conflito moral com essa temática. Dessa forma, foi-nos possível estabelecer o continuum que envolve a integração entre valores e sentimentos e a regulação exercida por ela no dinamismo do psiquismo humano.

Os jovens escolhidos para participar dessa pesquisa são provenientes das cinco regiões brasileiras, seguindo o índice populacional de cada uma delas. São 200 jovens, da faixa etária de 15 a 19 anos, estudantes do Ensino Médio de escolas públicas estaduais. Em cada região, coletamos, pessoalmente e com ajuda de integrantes das pesquisas promovidas pelos 
professores Ulisses Araújo e Valéria Amorim Arantes ${ }^{3}$, os dados em uma metrópole (acima de 1 milhão de habitantes) e em uma capital regional (com menos de 250 mil habitantes). Sem a intenção de tecer comparações entre jovens de regiões distintas, nossa coleta objetivou tornar-se mais rica, não se restringindo a uma localidade, mas englobando estudantes que, a despeito de estudarem em escolas públicas, mostraram-se oriundos de bases culturais diversas.

Para apresentar o percurso teórico e de pesquisa empírica, o presente trabalho estruturou-se em dez capítulos. Os três primeiros dizem respeito ao quadro teórico, com a abordagem dos conceitos que fundamentam o presente estudo. As teorias apresentadas são, em sua maioria, provenientes do campo de estudos da Psicologia Moral, mas não desprezamos a busca em outros campos do conhecimento, como a Sociologia, a Antropologia e a Filosofia. Espera-se que essa primeira parte traga contribuições fundamentais para os demais capítulos, que consistem na apresentação da pesquisa empírica, dos dados e dos resultados obtidos, assim como as considerações que puderam ser tecidas.

No primeiro capítulo, abordamos os conceitos de integração e regulação entre valores e sentimentos, dentro de um espectro que priorizou as relações entre a moralidade e o funcionamento psíquico humano. Partimos de uma concepção de sujeito psicológico (INHELDER; DE CAPRONA, 1992) e de que forma a moralidade está nele integrada (ARAÚJO, 1998), fazendo um comparativo ao sujeito epistêmico descrito por Piaget (1932) e Kohlberg $(1958,1971,1984)$ e à concepção de moral formulada por tais autores. Após tal delimitação teórica, apresentamos estudos que vêm se destacando no campo da Psicologia Moral por relacionarem a moralidade à identidade (DAMON, 1980, 1995; BLASI, 1992, 1995, 2004), trazendo indícios da complexidade que perfaz o sistema moral humano, na medida em que está em contínua relação com o contexto (NUCCI, 2004; TURIEL, 2002), com as relações interpessoais (BENHABIB, 1992; NISAN, 2004) e com aspectos do inconsciente (LAPSLEY; NARVAEZ, 2004). Por fim, nesse capítulo, tratamos especificamente do papel regulatório da afetividade, abordando estudos que se dedicaram a estudar a influência de estados emocionais no psiquismo humano (ARANTES, 2000a, 2003) e

\footnotetext{
${ }^{3}$ Embora com objetivos claramente distintos, a presente investigação insere-se em em um trabalho maior sobre os projetos de vida dos jovens, o qual envolve duas pesquisas propostas por Ulisses Araújo e Valéria Amorim Arantes. Essas pesquisas, que receberam o apoio da Fapesp - Fundação de Amparo à Pesquisa do Estado de São Paulo e do CNPq - Conselho Nacional de Desenvolvimento Científico e Tecnológico, constituem-se em duas etapas: a primeira, de caráter quantitativo, tem o objetivo de conhecer os projetos de vida dos jovens brasileiros a partir de uma amostra ampla; a segunda, de caráter qualitativo, procura entender, com uma parte da amostra da primeira etapa, qual é o papel dos sentimentos na organização dos projetos de vida desses jovens. Os dados aqui utilizados foram coletados entre sujeitos da segunda amostra desse trabalho mais amplo. Recebemos ajuda dos integrantes do projeto - Livia Moreiras e Waldir Uller, aos quais somos imensamente agradecidos.
} 
outros que procuraram estudar a regulação exercida por sentimentos morais (ARAÚJO, 1998, 2003a, 2007; PINHEIRO, 2009) no posicionamento dos valores como centrais ou periféricos no sistema moral dos sujeitos (DAMON, 1995). Chegamos, como hipótese final, a uma visão da complexidade que compõe os processos de integração entre valores e sentimentos, bem como do papel regulatório por eles exercido. Com base no trabalho de Moreno Marimón e Sastre (2010), intuímos que os valores e sentimentos compreendem "complexos" mobilizados de uma só vez quando o contexto os solicita.

Como o objetivo do presente trabalho está na compreensão em como se dão os processos de regulação e integração de valores e sentimentos nos projetos de vida dos jovens, o segundo capítulo visa a abordar alguns aspectos relacionados à juventude e aos projetos de vida, de forma a fundamentar nossa escolha pelos participantes e pela temática das suas projeções futuras. Emprestamos da sociologia teorias que ressaltam a diversidade que perfaz a constituição de identidades juvenis (SPOSITO, 2003, 2005; MELUCCI, 2007; PAIS, 2000, 2001) e buscamos aporte sobre o jovem brasileiro em alguns trabalhos da sociologia e outros da psicologia (ABRAMO, 1997, 2005; CAMARANO et al., 2004; SPOSITO, 2003, 2005; LASSANCE, 2005; THOMÉ; TELMO; KOLLER, 2011; SOUZA; OLIVEIRA, 2011; MARQUES; SANTOS; DELL'AGLIO, 2011), de forma a ampliar nossa compreensão sobre os sujeitos participantes de nosso estudo. Além dessa abordagem, dedicamo-nos a estudar sobre os projetos de vida e sua relação com a moralidade. Partindo de alguns apontamentos sobre o conceito de "projeto" (BOUTINET, 1999/2002; VELHO, 1994; MACHADO, 2004, 2006), buscamos abordar os projetos de vida propostos por Damon e colaboradores (DAMON; MENON; BRONK, 2003; DAMON, 2009; BUNDICK, 2009) e, na sua relação com os estudos sobre juventude e projeto, aproximamo-nos de uma conceituação que incorpora transitoriedade, ao mesmo tempo em que evidencia elementos identitários do sujeito.

O terceiro capítulo dedica-se à apresentação da Teoria dos Modelos Organizadores do Pensamento (MORENO MARIMÓN et al., 1999). Nesse capítulo, além de resgatar elementos que embasam tal teorização, procuramos dar indicações da relevância da sua adoção como instrumento teórico-metodológico da presente investigação. Por se envolver com os processos funcionais do psiquismo humano, essa teoria revela como os sujeitos pensam, sentem, desejam, creem diante das situações vivenciadas, ou seja, em contato com os conteúdos do meio, formulando suas representações sobre a realidade. Dessa ótica, cremos ser possível entender como os sujeitos elaboram seus projetos de vida, articulando e integrando nessa formulação, valores e sentimentos. 
Partindo do embasamento teórico dos três primeiros capítulos, seguimos ao plano de investigação, no quarto capítulo, abrangendo os objetivos, os participantes e o método da pesquisa. Em nossa problematização, apresentamos como objetivo principal deste trabalho entender como se dão os processos de integração e a regulação entre valores e sentimentos nos projetos de vida dos jovens participantes dessa investigação. Esse momento da tese também evidenciou a construção dos instrumentos metodológicos e do grupo de participantes, bem como elucidou os procedimentos de análise.

Os capítulos cinco, seis, sete e oito enfocam a descrição e a análise dos modelos organizadores do pensamento referentes aos projetos de vida e à resolução de um conflito com conteúdo consoante às projeções futuras de um personagem fictício. Após cada capítulo com a descrição dos modelos, apresentamos os resultados relacionados a ela. Em outras palavras, buscaremos compor um continuum entre a pesquisa qualitativa, com a descrição minuciosa dos modelos organizadores do pensamento, e a pesquisa quantitativa, que evidencia as tendências de aplicação de cada modelo, mostrando a quantidade de sujeitos que os aplicou. Na apresentação dos resultados, lançaremos mão de gráficos e tabelas de forma a ilustrar a distribuição dos jovens nos modelos.

No nono capítulo, trazemos uma análise que buscou identificar se existe ou não uma relação entre os processos de integração e regulação de valores e sentimentos na elaboração de modelos organizadores nas duas situações: de elaboração de projetos de vida e de resolução de um conflito moral com esse conteúdo. Após uma análise quantitativa, apontando as tendências de elaboração dos modelos organizadores, passaremos à descrição mais detalhada da aplicação de tais modelos por cinco sujeitos, de forma a explicitar o continuum que envolveu a integração e a regulação entre valores e sentimentos nos dois instrumentos.

Ao final, no décimo capítulo, tecemos nossas considerações, retomando os objetivos da presente investigação. Nesse capítulo, esboçamos alguns construtos teóricos, reforçando concepções, transformando outras e criando nossos próprios caminhos de compreensão sobre a temática abordada. Para além de tais indicações, trazemos alguns apontamentos para uma educação moral que considere os projetos de vida como conteúdos fundamentais para serem tratados na juventude. 


\section{CAPÍTULO I \\ MORALIDADE E FUNCIONAMENTO PSÍQUICO}

Entender sobre a regulação e a integração dos valores e sentimentos mobilizados pelos jovens em seus projetos de vida evoca, necessariamente, discutir sobre a temática da moralidade, a qual é fonte de reflexões e antagonismos no campo teórico da Psicologia Moral em que nos inserimos.

Nossa incursão nessa temática implicou o delineamento de um percurso teórico, cujo princípio se estabeleceu no marco construtivista, dentro de uma perspectiva funcional, ou seja, direcionando nossa atenção para a dinâmica do funcionamento psicológico do sujeito, a qual inclui seus desejos, condutas, pensamentos, escolhas, etc.

Vimos, em um passado recente, a moralidade ter seu estudo fundado na área da Psicologia com a obra O juízo moral na criança (1932), de Jean Piaget, em uma análise das estruturas cognitivas que buscava verificar como os sujeitos compreendem as regras morais. Nessa obra, Piaget formulou estágios progressivos e hierárquicos em direção a um princípio final, de justiça.

A genialidade dessa obra, bem como a postulação bem aceita dos princípios estruturalistas, levou a uma grande disseminação das ideias de Piaget, as quais foram utilizadas por teóricos importantes na área, como Kohlberg, que aprofundou tal análise em prol de estágios mais delineados e hierárquicos.

As teorias de Piaget e, posteriormente, de Kohlberg foram alvo de críticas que, embora reconheçam (e, às vezes, até incorporem) aspectos estruturalistas, indicavam a necessidade de trazer um paradigma mais abrangente sobre a moral (GILLIGAN, 1985; BENHABIB, 1992; NISAN, 2004, entre outros).

Apoiados nessas críticas, alguns estudos retomaram a abordagem sobre a moralidade na teoria aristotélica, propondo uma "ética das virtudes" (FLANAGAN, 1993; COMTESPONVILLE, 1995; DE LA TAILLE, 2002, 2006, 2009; TOGNETTA, 2003). Nessa perspectiva, assume-se que a moral não é prescritiva, porque não se referencia apenas nos outros, mas também no próprio sujeito, em sua busca virtuosa do Bem (Eudemonia).

Outra gama de estudos (COLBY; DAMON, 1993; BLASI, 1992, 1995, 2004; DAMON, 1995; TURIEL, 2002; NUCCI, 2004; NISAN, 2004; BENHABIB, 1992; LAPSLEY; NARVAEZ, 2004; ARAÚJO, 1998, 2003a, 2007; entre outros) tem se intensificado no objetivo de elaborar teorias que aproximem a moralidade à identidade do sujeito, buscando envolver aspectos cognitivos e afetivos, morais e não morais, não apenas 
voltados a uma moral deontológica e com base no outro (other-regarding), mas também atendendo às reais necessidades de cada ser (self-regarding).

Identificamo-nos com essa última vertente teórica, principalmente pelo fato de se aproximar de um sujeito real, dotado de pensamentos, sentimentos, desejos e objetivos. Em nossa acepção, a moralidade é um fenômeno complexo, que não pode ser vislumbrada de forma isolada ou fragmentada. Conforme sinaliza Wren (2004), seria muito mais fácil designar a moralidade como separada do self $f^{4}$, pois assim haveria menos confusões teóricas na literatura em psicologia moral. Segundo o autor, pensar em uma moralidade isolada do self significaria compreender o marco da moral como algo em si, que teria categorias centrais que explicariam suficientemente bem e de forma mais simplificada as formas de pensar moralmente que se aplicariam à realidade dos seres humanos e seus contextos.

Concordamos com Wren (2004) quando afirma que, infelizmente (ou talvez felizmente, em nosso ponto de vista), isso não é tão simples. O movimento dos estudos sobre a moralidade abriu-se para concepções muito mais amplas que vêm a considerar não apenas os aspectos cognitivos da moralidade, como algo que se desenvolve em si, isolados da vida real dos sujeitos, mas, para além desses fatores, englobar a complexidade que perfaz os juízos morais emitidos pelos seres humanos.

Engajaremo-nos, nos próximos tópicos deste capítulo, nesse movimento, buscando, essencialmente, aprofundar-nos nos aspectos do funcionamento psíquico no tocante à moralidade. Nossa intenção será de entender o sujeito real, em suas dinâmicas, para que possamos destrinchar o funcionamento moral por vias da regulação e integração entre valores e sentimentos. Acreditamos que tal aprofundamento, além de propiciar embasamento para a leitura de nossos dados, permitir-nos-á avançar em relação às concepções teóricas da psicologia moral.

\footnotetext{
${ }^{4} \mathrm{O}$ termo self não possui tradução estrita para a língua portuguesa. No presente estudo, optamos por não traduzilo livremente, para evitar equívocos teóricos. Por ser um vocábulo importante e de uso corrente na literatura atual da Psicologia Moral, será utilizado muitas vezes neste trabalho.
} 


\subsection{Sujeito psicológico e moralidade}

O sujeito psicológico interessa-nos enquanto sujeito conhecedor, mas com suas intenções e valores. (INHELDER; DE CAPRONA, 1992, p. 22)

O primeiro passo para atender à expectativa de compreender a regulação e a integração de valores e sentimentos nos projetos de vida dos jovens consiste no posicionamento de nossa visão sobre a moralidade pelo viés do funcionamento psíquico.

Tal posicionamento traz indicações claras à epistemologia genética postulada por Piaget. Em seus estudos, como se sabe, Piaget enfocou o sujeito epistêmico, o sujeito do conhecimento normativo, pois buscava compreender como ele apreende o real e organiza o pensamento científico. Inclusive na abordagem sobre a moralidade, esse autor, com base no entendimento do filósofo Immanuel Kant sobre a moralidade como obediência a uma lei suprema, enveredou pelo estudo das estruturas cognitivas que levam o sujeito a compreender as regras morais. A moral, para Piaget, "consiste em um sistema de regras, e a essência de toda moralidade deve ser procurada no respeito que o indivíduo adquire por essas leis" (1932, p. 23).

Tem-se, nessa obra de Piaget, uma formulação baseada em estágios progressivos e hierárquicos em direção ao princípio de justiça. A escolha por esse tipo de trabalho, em uma concepção cognitivo-evolutiva, deu-se, em nosso entender, pelo fato de o teórico estar envolvido, desde os seus primeiros estudos, na elaboração de uma teoria sobre o desenvolvimento dos seres humanos em relação à construção do conhecimento ${ }^{5}$.

Nessa obra, Piaget traz uma pesquisa empírica que realizou com crianças até dez anos de idade, utilizando-se de jogos de regras. Observando as formas de pensar das crianças a respeito das regras dos jogos, nos trouxe indicações sobre o desenvolvimento da moralidade em estádios, postulando um "caminho" hierárquico pelo qual todo sujeito deve passar. Tal "caminho" vai da anomia (ausência de regras), passando pela heteronomia (quando se imagina que as regras são externas) e chegando à autonomia (quando se constata que as regras foram construídas e assimiladas pelos sujeitos, que as aplicam sempre com vistas ao outro). Para Piaget, o avanço do sujeito nos estádios, que eram, segundo sua concepção, fases sucessivas de processos regulares experienciados nas situações vividas, ocorre pelas interações que este faz com o meio e seus pares. O sujeito chega aos estados de autonomia

\footnotetext{
${ }^{5}$ Piaget estava ciente de que sua obra enfocava apenas um dos aspectos concernentes à moral. Isso é revelado na abertura do livro $O$ juízo moral na criança (1932), quando adverte que "Propusemo-nos a estudar o juízo moral, e não os comportamentos ou sentimentos morais" (p. 21).
} 
assim que consegue sair do egocentrismo para cooperar com os outros e se submeter de forma consciente às regras sociais.

Por seu caráter estruturalista, percebe-se que a moral descrita por Piaget é estritamente deontológica, relacionada a deveres oriundos das normas da sociedade. Ela tem forte apelo cognitivista, pois Piaget acreditava que a moral tinha um desenvolvimento semelhante ao cognitivo. De acordo com o autor:

Todos notaram o parentesco que existe entre normas morais e as normas lógicas: a lógica é uma moral do pensamento, como a moral, uma lógica da ação. [...] A lógica não é coextensiva à inteligência, mas consiste no conjunto de regras de controle que a inteligência usa para dirigir-se. A moral desempenha um papel análogo quanto à vida afetiva. (1932, p. 296)

Claro está que o sujeito moral para Piaget é equivalente ao sujeito epistêmico. Isso significa que, de acordo com esse autor, o desenvolvimento moral aporta-se na construção de estruturas, a partir dos processos de equilibração dos conhecimentos que são assimilados pelos sujeitos. Chegar a uma moral autônoma significa passar pelos processos de heteronomia, assimilá-los e acomodá-los em direção à equilibração para níveis superiores, sempre em direção ao princípio de justiça.

O sujeito epistêmico também esteve presente em diversos estudos posteriores a Piaget, notadamente no trabalho desenvolvido por Kohlberg $(1958,1971,1984)$. Seguindo a teoria de Piaget, esse autor apresentou, no ano de 1958, uma tese de doutorado de espetacular influência na área de psicologia. Procurando aprofundar-se no estudo da moralidade pelo viés piagetiano, Kohlberg percebeu que a descrição dos estádios era ampla e necessitava de maiores estudos empíricos que a comprovassem, assim como a aprofundassem com mais elementos. De forma bastante inovadora, esse autor deixou de aplicar jogos para dedicar-se à compreensão sobre como os sujeitos, de diferentes faixas etárias (incluindo jovens e adultos), emitem juízos morais diante de dilemas hipotéticos ${ }^{6}$. A partir de investigações, aplicadas com o apoio de colaboradores e orientandos em muitos países, apresentou os resultados concernentes às respostas de sujeitos que foram solicitados a se posicionar diante dos dilemas morais. Encontrou seis estágios, que foram agrupados em três níveis: o nível préconvencional, em que os sujeitos se posicionam de forma bastante obediente às ordens

\footnotetext{
${ }^{6}$ O dilema mais famoso proposto por Kohlberg é o "Dilema de Heinz". Nesse dilema, Kohlberg apresentou aos sujeitos participantes de sua pesquisa uma pequena história em que Heinz, morador de uma pequena cidade da Europa, necessita de um medicamento para salvar a sua esposa. Tal medicamento custava uma grande quantia, e o máximo que o protagonista conseguiu arrecadar foi metade desse dinheiro. O único farmacêutico que tinha a fórmula a inventara com fins lucrativos e não concedeu a Heinz formas diferenciadas de pagamento. $\mathrm{O}$ dilema posto era: deveria Heinz roubar o medicamento? (KOHLBERG, 1984)
} 
externas; o nível convencional, no qual os sujeitos tinham como referência as regras e a expectativa do grupo social; e o nível pós-convencional, a partir do qual o sujeito compreende as regras da sociedade, mas não se limita a elas ${ }^{7}$.

Embora reconheçamos a pertinência de descrever cada nível postulado por Kohlberg para compreender a relação de sua teoria com a teoria de Piaget, acreditamos ser mais profícuo para este estudo abordar apenas os aspectos de sua teoria centrais para esse item de nosso quadro teórico.

Kohlberg realizou diversos estudos transculturais, solidificando a perspectiva cognitivo-evolutiva, com uma sequência de desenvolvimento da moral em relação ao princípio de justiça. Em outras palavras, postulou, com muita ênfase, que o desenvolvimento moral é acarretado por mudanças oriundas da cognição e que conduzem a níveis de justiça superior (DÍAZ-AGUADO; MEDRANO, 1999).

Outro aspecto que necessita ser apontado em relação à teoria kohlberguiana é a intencionalidade de desvincular a cognição dos aspectos emocionais. Para Kohlberg, o desenvolvimento afetivo é realmente algo distinto do desenvolvimento cognitivo. São, em sua concepção, aspectos paralelos e representam perspectivas distintas em seus contextos de mudança estrutural (KOHLBERG, 1971). A esse respeito, Narvaez e Vaydich (2008) comentam que as emoções, nessa perspectiva, deviam ser superadas pelo pensamento lógico. Segundo as autoras, Kohlberg evitou usar dilemas reais ou "hot-button issues" (questões que apimentam a discussão, tradução nossa) como uma forma de "cortar" os efeitos da emoção na razão.

Cabe, aqui, destacar que, apesar de se posicionar como um desdobramento da teoria piagetiana, essa teoria possui alguns aspectos que a diferenciam de sua fonte inicial. Mesmo tendo a mesma escolha por abordar uma estruturação do raciocínio moral em direção a estágios mais abrangentes, diferenciados e equilibrados, sabe-se que Kohlberg associou os estádios cognitivos descritos por Piaget aos seus estágios morais. A formulação de Kohlberg aposta em estágios muito bem definidos e hierárquicos no processo de desenvolvimento moral, o que não pode ser verificado na teoria piagetiana. Em Piaget, verifica-se uma intuição a respeito do fenômeno da moralidade como algo não passível de uma "precisão", em que todos os seres humanos se encaixariam perfeitamente em estágios predefinidos. Em nossa

\footnotetext{
${ }^{7}$ Embora tenha postulado seis estágios, Kolhberg admitiu, posteriormente, que o sexto estágio não foi alcançado por nenhum dos sujeitos que participaram de suas investigações. Todos os sujeitos que atingiram o nível pósconvencional, não chegaram a alcançar a compreensão dos princípios éticos universais, sendo enquadrados no nível cinco, cujo princípio encontra-se em verificar as regras da sociedade como pertinentes aos direitos humanos, buscando o diálogo como alternativa profícua para a resolução do dilema.
} 
leitura, Piaget não entende a anomia, a heteronomia e a autonomia como estágios demarcados, mas como fases que se repetem assim que se coloca ao sujeito um conjunto de regras.

O que fica, a despeito dessas considerações, entretanto, é o seu forte apelo cognitivoevolutista. Em ambos os autores, o aspecto mais importante da moral são os juízos, os quais, nessa perspectiva, antecipam a ação, orientando-a e direcionando-a. O juízo torna-se condição necessária para a ação moral ainda que não a garanta. Tem-se, dessa forma, uma visão de um sujeito cognoscente, ideal, cujos aspectos racionais sobrepõem-se aos demais constituintes do funcionamento psíquico humano.

Esse aspecto das teorias de Piaget e de Kohlberg recebeu inúmeras críticas (GILLIGAN, 1985; SELMAN, 1989; SASTRE et al., 1994; FLANAGAN, 1993; ARAÚJO, 2003a, 2005; ARANTES, 2000a; NARVAEZ; VAYDICH, 2008, entre outros). Entre os trabalhos que dirigiram críticas às formulações propostas por Piaget e Kohlberg, há de se destacar o de Carol Gilligan (1982). Orientanda de Kohlberg, Gilligan intrigou-se por encontrar, nas pesquisas de seu orientador, uma moral definida nos moldes masculinos, em que a mulher parece ser inferior em seu juízo moral. Assim, realizou uma série de investigações cujos resultados geraram o livro In a different voice (1985). Nesse trabalho, com base nas respostas aos mesmos dilemas propostos por Kohlberg, Gilligan apresenta que há diferenças entre os juízos emitidos por homens e mulheres. Em geral, descobriu que, enquanto os homens priorizavam o princípio de justiça, as mulheres priorizavam respostas que envolviam o cuidado, a preocupação e a responsabilidade para com os personagens envolvidos.

A partir dessa descoberta, a autora passou a questionar os resultados de Kohlberg, nos quais os homens atingiam níveis mais evoluídos de moralidade. Em suas palavras,

Quem parece deficiente no desenvolvimento moral, se é utilizada a escala de Kohlberg, são as mulheres cujos juízos parecem exemplificar a terceira etapa de sua sequência de seis. Nessa etapa, a moral se concebe em termos interpessoais e a bondade é equiparada com a ajuda e a complacência aos outros. (1985, p. 40-41, tradução nossa)

Em suas críticas a Kohlberg, Gilligan defendeu que a justiça não se constitui como única fonte para a moralidade, mas tem-se no cuidado e na preocupação para com os outros (em inglês, care) outra fonte. De acordo com sua teoria, se o princípio de justiça estava mais fortemente arraigado às características masculinas, o princípio de cuidado mostrava-se mais forte nos juízos femininos. Assim, como a autora enfatiza, não é possível entender que a moral dos homens é superior a das mulheres ou vice-versa. 
Com seu trabalho, Gilligan leva à constatação de que a moral é mais ampla do que o princípio de justiça. Para essa autora, no caminho do desenvolvimento moral, homens e mulheres vão chegando a um maior entendimento a respeito de ambas as orientações (cuidado e justiça), aplicando-as de acordo com as situações que vivem. Em outras palavras, a moralidade teria duas orientações, que podem estar presentes tanto nos homens quanto nas mulheres.

A pesquisa de Gilligan, embora tenha recebido críticas, principalmente por delimitar a moral em dois campos distintos (ainda que integrados), constitui-se em um grande sismo (DE LA TAILLE, 2006) no paradigma que vinha sendo elaborado por Piaget e, posteriormente, por Kohlberg. Tal teoria abriu as portas para novas reflexões no campo da moralidade que pudessem incluir tanto a questão de gênero, que é um dos grandes enfoques de estudos nessa área na atualidade (KOLLER, 1990; MONTENEGRO, 1999, 2003; ARANTES; SASTRE, GONZÁLEZ, 2007; PUPO, 2007; MARTINS, 2008; STACH-HAERTEL, 2009), quanto uma perspectiva mais abrangente sobre a moral, envolvendo não apenas o princípio da justiça, mas outros valores.

Frente às críticas propostas por Gilligan e outras que começaram, então, a serem destinadas à sua teoria ${ }^{8}$, Kohlberg publicou em 1984 um texto no qual procurou ampliar o seu estudo sobre o desenvolvimento moral, diferenciando estágios "hard" e "soft" do raciocínio da justiça, bem como abarcando o relacionamento entre juízo e ação moral ao incluir juízos de responsabilidade e justiça.

Com uma visão um pouco mais abrangente da moralidade, embora com o enfoque muito voltado para pressupostos cognitivo-evolucionistas, Kohlberg passou a orientar trabalhos que buscaram, mesmo centrados em seu paradigma, ampliar o estudo sobre a moral. Esses trabalhos e outros derivados de seus avanços e de suas limitações foram fundamentais para novas elaborações no campo da moralidade.

Devido à grande repercussão dos trabalhos de Kohlberg e de suas orientações como professor de Yale e, posteriormente, de Havard, houve um número extensivo de trabalhos que derivaram desse paradigma. O que se percebe, em nossas leituras sobre esses estudos, é uma forte conexão ao paradigma kohlberguiano, mesmo com a intenção de ampliá-lo. Os trabalhos que derivaram dessa corrente trouxeram, especialmente, o objetivo de lidar com alguns

\footnotetext{
${ }^{8}$ Foram muitas as críticas à teoria de Kohlberg, além das de Gilligan. Como não é intenção deste trabalho aprofundar-se nessas críticas, apenas se faz importante sinalizar, juntamente com autores como Sastre (1994) e Flanagan (1993), que Kohlberg priorizou demasiadamente o princípio de justiça, ao analisar os juízos morais. Ao assim fazê-lo, trouxe uma perspectiva de mão única, desprezando outros aspectos da moralidade humana, como os sentimentos, as emoções, os objetivos e os desejos dos sujeitos.
} 
aspectos que não foram abordados por Kohlberg em suas pesquisas, principalmente enfocando o uso de dilemas reais (DÍAZ-AGUADO; MEDRANO, 1999), as diferenças entre convenção e moralidade (TURIEL, 1988, 2002; SMETANA, 1989), os papéis sociais (SELMAN, 1971, 1989) e os conteúdos existentes nos contextos morais (DAMON, 1980).

Uma característica que marca esses estudos é a preservação dos estágios de desenvolvimento moral propostos por Kohlberg, associados aos outros aspectos destacados pelos autores. Entendemos que tais estudos, assim como o proposto por Gilligan, foram uma primeira centelha de avanços no campo da psicologia moral, já que trouxeram outras perspectivas de análise, para além da estruturação do desenvolvimento moral em relação ao princípio de justiça.

Percebemos que, apesar de terem apresentado avanços consideráveis, esses trabalhos não conseguiram e também não possuíam o objetivo, talvez pela força e influência da teoria de Kohlberg, de romper com o paradigma cognitivo-evolucionista de tal conceituação, insistindo numa ótica fragmentada sobre a moralidade.

No entanto, no contexto desses estudos, veio crescendo um olhar diferente para a moralidade humana, procurando ampliar o campo da psicologia moral, rompendo, de certa forma, com análises centradas apenas nos aspectos cognitivos. Visando abordar a moralidade como integrada à identidade dos sujeitos, alguns estudos buscaram realçar a complexidade inerente a esse componente do psiquismo humano.

Com esse movimento, acreditamos que os estudos puderam trazer à luz uma concepção de sujeito psicológico, que envolve tanto aspectos cognitivos quanto afetivos, sociais e físicos. Embora, em grande parte, não se refiram a um modelo que foi indicado por Piaget em seus últimos estudos, notadamente em sua parceria com Inhelder (INHELDER; PIAGET, 1976), e depois fonte de estudos dessa autora com outros colaboradores, como De Caprona e Cellérier (INHELDER; CELLÉRIER, 1992), pelo fato de intentarem ultrapassar a barreira do estruturalismo, suas ideias, no mais das vezes, vêm ao encontro de tal pensamento.

Acreditamos, com Araújo (1998, 2003a), na importância de vislumbrar o ser humano em uma visão heurística, contemplando a sua complexidade, que abarca seu momento histórico e cultural, seus interesses pessoais e suas relações com o mundo. Portanto, vemos como fundamental trazer, primeiramente, aportes sobre o sujeito psicológico, de forma a compreender como a moralidade atua em seu psiquismo. Assim, conseguiremos, mais à frente, trazer indicações sobre como funcionam os mecanismos de regulação e integração de valores e sentimentos no funcionamento psíquico do ser humano. 
O estudo do sujeito psicológico cinge-se à análise microgenética, que trata de elucidar os seus processos funcionais, de forma complementar a análise estrutural, isto é, macrogenética (INHELDER; DE CAPRONA, 1992). De acordo com esses autores, o sujeito psicológico

[...] é estudado por um observador que se dedica a descobrir a dinâmica das condutas do sujeito, os seus fins, a escolha dos meios e os controles, as heurísticas próprias do sujeito, podendo atingir um mesmo resultado por caminhos diferentes, a fim de que se possa penetrar no funcionamento psicológico e separar as características gerais dos procedimentos, ou encadeamentos finalizados e organizados das ações. (p. 21)

Para o estudo do sujeito psicológico, deve-se levar em consideração as particularidades do sujeito, analisando, no âmbito da microgênese, as condutas cognitivas, afetivas, entre outras, com o maior pormenor possível e em toda a sua complexidade natural, evidenciando o processo interativo entre sujeito e objeto (INHELDER; DE CAPRONA, 1992). Desta forma, chega-se a uma perspectiva funcional, na intenção de explicar a conduta por sua função, assim como de decompor o sistema nas suas partes, explicando o seu funcionamento e as suas propriedades enquanto construção ou todo integrado, através da forma pela qual os subsistemas interagem entre si.

Encontramos em Araújo (1998, 2003a) uma abordagem que também explicita a necessidade de abordar o sujeito em sua totalidade e em sua complexidade. Segundo Araújo,

[...] para melhor compreender esse ser psicológico complexo, podemos estudar separadamente seus aspectos cognitivos, afetivos, socioculturais e biológicos e suas relações com o mundo físico, interpessoal e sociocultural à sua volta. Não se deve, porém, perder a perspectiva de totalidade e de coordenação interna e externa desses sistemas, porque as diferenças que encontramos nas ações e nos juízos dos sujeitos psicológicos são resultantes de determinadas coordenações desses sistemas que se manifestam no momento da experiência com o mundo externo e interno. (2003a, p. 69)

De acordo com essa acepção trazida por Araújo, o sujeito psicológico apresenta, em seu funcionamento psíquico, sistemas fechados, com funcionamento e leis próprias, e abertos, em interação com os demais sistemas. O funcionamento desses sistemas ocorre de forma coordenada e integrada, pois, na interação do sujeito com o mundo, as temáticas enfrentadas pelo sujeito não o são de uma forma fragmentada. 
Esse autor apresenta a seguinte representação gráfica, inspirada no trabalho de Jean Marie Dolle (1993, apud Araújo, 2003a), em que procura exemplificar como funciona psiquicamente o sujeito psicológico e qual é o meio com o qual ele interage.

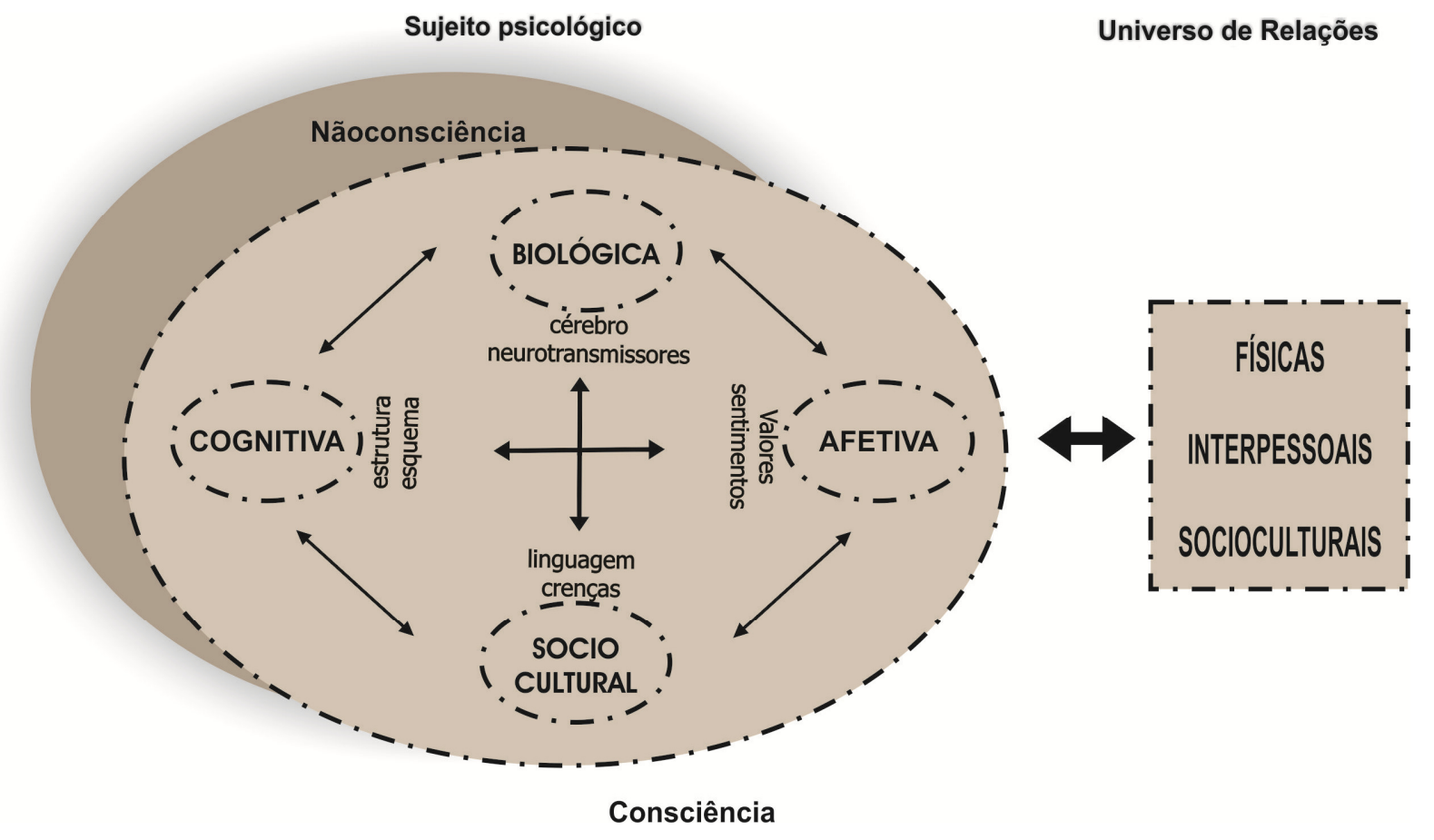

Entendendo que tal representação deve ser observada considerando o seu caráter dinâmico, verificamos interações contínuas e dialéticas entre os diferentes sistemas presentes na imagem que são representadas por setas bidirecionais que se inter-relacionam e coordenam esses sistemas com o mundo interno e externo. Portanto, o sujeito psicológico é composto por todos esses sistemas que, em interação contínua, relacionam-se com o meio. O sujeito psicológico não é, nem pode ser, interpretado como prioritariamente individual nem sociocultural.

Tal elucidação do sujeito psicológico é importante para o estudo da moralidade, que se circunscreve ao seu sistema afetivo. Com ela é possível entender que o sistema afetivo, por meio dos valores e sentimentos, além de possuir um funcionamento próprio, com suas leis e "forças" internas, também interage com os demais sistemas. Diante de situações que apresentam conteúdo moral, o sujeito, em seu funcionamento psíquico, não apenas atua com seus valores, mas também com sentimentos, pensamentos, crenças, desejos, aspectos biológicos, entre outros.

Estudar a funcionalidade psíquica do sujeito em relação à moralidade implica empreender a análise das interações entre esses sistemas, de forma a destrinchar como 
ocorrem na atuação ou elaboração dos juízos morais desse sujeito, sem perder de vista a sua totalidade.

\subsection{A integração da moralidade ao self: a ideia de identidade moral}

A identidade é fruto da história do que somos, do valor que lhe damos e do que desejamos ser. (PUIG, 1996)

Antes de enfocarmos as formas de organização do sujeito psicológico, no tocante à moralidade e sua relação com os demais sistemas, vemos como pertinente abordar uma ideia que vem sendo desenvolvida nos estudos da psicologia moral e que, de alguma forma, colabora com uma visão sobre a complexidade e seu consequente papel na funcionalidade psíquica em nossa abordagem sobre os aspectos de regulação e integração morais.

É tendência dos trabalhos atuais a indicação da moralidade como um dos aspectos que compõem a identidade. Considera-se que tal percepção tenha sido um dos maiores ganhos da psicologia moral na contemporaneidade e, embora seja vista como um "pré-paradigma" (FRIMER; WALKER, 2008), logo que não recebeu o suporte de muitas pesquisas empíricas que o embasassem, parece-nos promissora para um avanço significativo a respeito da compreensão sobre a moralidade.

A ideia de que a moralidade está integrada à identidade dos sujeitos ganhou força nos estudos de dois teóricos norte-americanos: Willian Damon e Augusto Blasi. Atualmente, grande parte das investigações atuais inspira-se nas teorias propostas por esses estudiosos, elaborando críticas ou reforçando suas apostas a partir de novas investigações.

Damon realizou diversos estudos com base, inicialmente, nas teorias de Piaget e Kohlberg (1971, 1984), em que constatou a necessidade de se pensar em um sujeito real, levando em consideração os contextos e as situações em que esse sujeito está inserido. Para Damon, a moralidade não pode ser entendida apenas em seu aspecto estrutural, visto que não há uma só estrutura que abarque todos os domínios. O autor, então, indica como aspecto necessário para uma melhor compreensão a respeito da moralidade o conceito de inconsistência moral, que pode ser explicado por meio de três princípios: 1) o princípio estrutural, que diz respeito ao fato de que, uma vez adquirida uma estrutura do conhecimento, ela não se aplica da mesma maneira em todas as situações (a estrutura não apresenta consistência); 2) o princípio do desenvolvimento, a partir do qual se pode verificar que os 
desequilíbrios provocados pelos novos conflitos geram novas aprendizagens, resultando em níveis mais altos de desenvolvimento. Devido a esse processo dinâmico, a inconsistência aparece regularmente; 3) o princípio funcional, de acordo com o qual é impossível haver estruturas universais que expliquem a moralidade para todos, visto que se deve considerar as diferentes situações sociais e os valores que estão presentes em cada situação.

De acordo com Damon (1980), o raciocínio e a conduta morais variam segundo distintas situações e os valores nelas presentes. Ao estudar sobre os valores de justiça e autoridade, sob o prisma de situações hipotéticas e reais, o autor verifica que não é possível atestar consistência ou inconsistência moral de acordo com algum princípio geral. Isso porque, consoante suas conclusões, o conteúdo do conflito apresentado influencia a forma como os sujeitos elaboram seus juízos e ações morais. Assim, o domínio moral não é o único existente, logo que as situações apresentam vários valores, morais ou não, com os quais os sujeitos precisam lidar em seu cotidiano.

Em estudo posterior (1988), Damon passou a questionar a sequência de estágios de Kohlberg, muito embora não a tenha desprezado. Em sua formulação, considerou que a moralidade e o self são dois sistemas conceituais diferentes que não se relacionam até a adolescência, em um desenvolvimento paralelo, embora incompleto. Na adolescência, segundo Damon, cada sistema se abre em novas formas de integração: os interesses morais e os interesses pessoais começam a ficar mais claramente definidos e conectados uns aos outros. Tal desenvolvimento estende-se até a vida adulta, mas, mesmo assim, pode se tornar parcial e incompleto.

Para Damon (1988),

O nível de julgamento moral de uma pessoa não determina o lugar que a sua visão de moralidade ocupa em sua vida. Para saber como cada indivíduo lida com a moralidade, nós precisamos saber não apenas as suas crenças morais, mas também a compreensão que ele tem de si em relação à moralidade." (p. 110, tradução nossa)

Assim, algumas pessoas podem considerar a moralidade como algo central para suas identidades, enquanto outros podem considerá-la como periférica. Tal formulação estruturouse com o trabalho que publicou com Colby, Some do care: contemporary lives of moral commitment (1992), em que revelaram uma pesquisa com pessoas que uniam seus objetivos de vida a causas morais (pessoas de vida moral exemplar). O objetivo central dessa investigação era analisar as intersecções entre o self e a moralidade, pois, 
Em nosso ponto de vista, a unidade ou o conflito entre objetivos pessoais e morais são centrais para a discussão da moralidade e o self, porque objetivos são importantes componentes da identidade do sujeito ou do autoconceito. (COLBY; DAMON, 1992, p. 150, tradução nossa)

Analisando os dados obtidos nas entrevistas com os sujeitos de moral exemplar, Colby e Damon constataram o seguinte:

- os sujeitos participantes da pesquisa pouco duvidam das decisões que tomam em assuntos morais;

- por não terem dúvidas ao resolver questões morais, esses sujeitos não se julgam mais corajosos que as demais pessoas;

- os sujeitos não pesam as consequências que suas decisões podem causar.

A partir dessas conclusões, os autores acabaram por entender que, quando feitas com grande certeza, como é o caso dos sujeitos analisados, as escolhas morais estão diretamente relacionadas ao juízo e à ação morais, constituindo indícios da unidade existente entre o self e a moralidade.

A moralidade, de acordo com esses autores, tem implicações na forma como os sujeitos vivem, mas oferece somente uma parte das soluções da vida real, não cobrindo todas as possibilidades que a vida lhes interpõe. O comportamento moral depende de algo por trás das crenças morais; depende, em parte, de como e quanto os valores morais são importantes para o senso de si mesmos como pessoas.

Os sujeitos entrevistados apresentavam grande integração entre o self e a moralidade, indicando que os seus objetivos (goals) uniam esses dois sistemas. Assim, Colby e Damon puderam chegar à conclusão de que algumas pessoas interligam moralidade e o self em uma proporção maior que outras. Essa proporção determina a sua conduta: se há grande integração, a conduta é tomada sem maiores dúvidas; se não há tamanha integração, o sujeito pesa suas atitudes antes de tomá-las.

Com objetivos diferentes de Damon, Augusto Blasi também empreendeu pesquisas sobre a moralidade, considerando-a parte da identidade do sujeito. Com a intenção de entender o "vácuo" (gap, em inglês) entre ação e juízo moral, o autor debruçou-se sobre o conceito de identidade. Essa sua escolha pode ser explicada pelo fato de que se incomodou com a corrente teórica que insistia em estudar o desenvolvimento moral de forma isolada. Para ele, uma teoria sobre a moral não pode desconsiderar os contextos reais de onde se originam os conflitos. Em sua visão, as pessoas emitem juízos morais para atuar sobre 
realidades concretas e em contextos específicos, não em situações abstratas. Assim, os aspectos cognitivos e de personalidade têm que ser considerados conjuntamente.

Blasi (1992) defende que, se queremos compreender essas relações, é necessário conhecer as características da personalidade que estejam relacionadas com as estruturas de pensamento moral. Posicionando-se como um seguidor dos trabalhos de Piaget e Kohlberg, o autor incorpora a teoria cognitivo-evolutiva do desenvolvimento moral, mas aponta como necessário considerar o contexto psicológico do sujeito quando raciocina acerca de um dilema moral, já que o pensamento e a conduta estão subordinados a um contexto.

Para poder avançar na compreensão da coerência entre os juízos e ações morais, Blasi considerou necessário aprofundar-se na natureza psicológica da integridade ou da coerência pessoal, para chegar, assim, a uma teoria completa do funcionamento moral.

Blasi (1992) dedicou-se a abordar o desenvolvimento da identidade, ao longo das faixas etárias, sem deixar de lado as implicações morais desse processo. Uma das discussões que realiza, nesse sentido, encontra-se em passar a ênfase de um modelo que se centra na ação moral para outro que tenha como foco a personalidade moral. Assim, passa a compreender que a moralidade é uma característica do sujeito, não somente o resultado de uma abstração do conhecimento, mas englobando a personalidade para motivar a ação.

De acordo com Blasi (1992), cada pessoa começa relativamente cedo seu desenvolvimento em relação à aquisição de uma imagem, uma percepção ou um esquema de si mesmo (self). No entanto, o "si mesmo" (self) não se caracteriza como uma coleção de características, ou traços de personalidade, mas uma organização que comporta informações acerca de si próprio e que supõe, por sua vez, uma determinada consistência psicológica ${ }^{9}$.

A identidade moral abrange diferenças individuais. Do ponto de vista de Blasi, é possível encontrar pessoas que, apesar de apresentarem a capacidade de raciocínio moral, não possuem uma identidade moral. O percurso de construção de uma identidade moral, parte, principalmente, do fato de se possuir a capacidade de raciocínio moral, mas não se restringe a apenas isso. Os sujeitos vão mudando as suas experiências em relação à sua identidade moral, desde entender a obediência, passando pela lealdade até, finalmente, identificando-se com a autonomia moral.

\footnotetext{
${ }^{9}$ Faz-se interessante observar que Blasi traz o conceito de consistência psicológica como fator que explica as intersecções entre moral e self. Nos trabalhos de Damon, como abordamos anteriormente, encontramos o conceito de inconsistência moral. Do nosso ponto de vista, não são teorias que se contrapõem, mas que, em nosso entender, se complementam. Acreditamos tanto na inconsistência do self ao se deparar com novas situações, valores e emoções, quanto na consistência da identidade moral, que garante que não sejamos "relativos" todo o tempo e que tenhamos uma "unidade".
} 
A partir dessa compreensão, o autor elabora um modelo, the self model of moral behavior (modelo pessoal do comportamento moral), em que usa o conceito de identidade como central para explicar a moralidade, tendo como objetivo integrar cognição e personalidade para explicar o comportamento moral.

De acordo com esse modelo, Blasi afirma que “(...) a identidade moral atua de forma central e a consistência do self é a motivação básica da ação moral” (1992, p. 99, tradução nossa).

$\mathrm{O}$ autor indica que o modelo possui quatro aspectos norteadores: o primeiro diz respeito ao fato de que a moralidade não é um sistema autônomo, ou seja, as competências morais devem ser integradas a toda a personalidade do sujeito; o segundo encontra-se no fato de que a integração da moralidade na personalidade deve respeitar as características da moralidade como ela é compreendida no contexto real e pelas características do funcionamento psíquico; o terceiro se concentra em afirmar que um juízo moral (tomado como aspecto cognitivo ou, nas palavras de Blasi, understanding ${ }^{10}$ ) guia a ação moral; por fim, no quarto, aponta que a intenção de agir moralmente depende da motivação pessoal.

Um ponto fundamental da teoria de Blasi repousa no fato de que ela abre espaço para um sujeito que tenha o potencial de construir sua própria vida e a personalidade que deseja ter. Os processos cognitivos sobre a moral não são impostos, mas elegidos pelo sujeito em sua liberdade de escolha. Por essa escolha livre, como assinala Bergman (2004), os sujeitos moldam sua própria identidade e também seus próprios desejos, frente à realidade moral objetiva, mas não simplesmente com obediência, internalização ou socialização (p. 35). Essa escolha é racional e não apenas uma mera submissão à pressão social.

Tal concepção faz com que se mantenham duas características na teoria de Blasi - a fonte cognitiva da moralidade e sua integração à personalidade, isto é, a capacidade pessoal de agente do self. Dessa forma, como enfatiza Walker (2004), Blasi buscou, ao identificar a lacuna existente entre esses dois aspectos, integrá-los de forma a revelar, de maneira apurada, a moralidade humana. Em seu modelo, Blasi, ao focar na identidade do sujeito, dá indicações de que a moralidade é fruto de um processo de engajamento moral, o que pressupõe certa responsabilidade pela ação moral. Esse processo constitui-se como um importante aspecto da conexão entre juízo e ação morais, porque implica o self na ação e porque reflete o senso pessoal de busca de uma verdade moral, por meio de processos afetivos. Além do mais, o

\footnotetext{
${ }^{10} \mathrm{O}$ autor, no início de seu texto Moral functioning: moral understanding and personality, que consta no volume organizado por Lapsley e Narvaez (2004) adverte que não aprova o uso do termo cognição em seus trabalhos, mas prefere o vocábulo "compreensão" (em inglês, understanding), que, em seu entender, abrange o processo cognitivo de uma forma ativa, isto é, do ponto de vista de um sujeito agente.
} 
modelo proposto por Blasi tem como ponto-chave o conceito de integração, no sentido de que o fundamento da personalidade é a consistência psicológica do self, que somente pode ocorrer integrando juízo e ação morais.

Em outras palavras, a conduta moral se converte em uma questão de consistência do self. A identidade moral estaria relacionada com a ação moral, proporcionando uma de suas motivações mais importantes. Esta relação é explicada pelo autor por meio do conceito de responsabilidade (no sentido de estrita obrigação, de acordo com o que cada um julga como correto) e de integridade.

É importante frisar que a teoria de Blasi preserva o raciocínio moral, de forma bastante acentuada, como um dos componentes da identidade. Os processos cognitivos, segundo o autor, devem ser integrados à personalidade, dentro de um conjunto mais amplo. Como destaca Bergman (2004), a influência entre moral e self acontece a partir do raciocínio moral (moral understanding) em direção à identidade moral e nunca o contrário.

Em trabalho posterior (1995), Blasi recorre ao conceito de integração ${ }^{11}$ para compreender os valores como integrados aos sistemas motivacionais e emocionais, os quais propiciam uma base para a construção da identidade e do autoconceito do sujeito. Em suas palavras, a personalidade, em toda a sua complexidade, é uma unidade, ou caminha para a unidade, que possui um centro funcional, um princípio de subordinação e coordenação. Assim, a personalidade seria um sistema organizado por graus de integração. Esses graus de integração dependeriam da coordenação de um determinado aspecto com outros subsistemas, assim como de sua hierarquia na organização da personalidade.

Esse aspecto pode ser a moral. Se um valor moral estiver isolado, isto é, não relacionado com outros valores, será considerado pouco integrado e, dessa forma, ocupará um lugar hierárquico inferior na organização da personalidade. Um exemplo dessa integração entre valores pode ser visualizado em um sujeito que tenha a justiça como valor moral, mas isolado de outros valores (morais ou não). Esse sujeito muito provavelmente não tenderá a agir justamente com os que o cercam.

Ainda para esse autor, um indício de que um valor é mais ou menos integrado ao sistema encontra-se no investimento afetivo que é determinado pelo aparecimento ou não de sentimentos negativos, como a culpa, o remorso, a vergonha e a tristeza, caso o sujeito esteja agindo contra os seus valores. A ausência de sentimentos morais, destarte, implica que a

\footnotetext{
${ }^{11}$ É a partir da teoria de Blasi que apostamos no conceito de integração moral, ao qual vinculamos também o conceito de regulação moral. Nos próximos tópicos do presente capítulo, teceremos considerações sobre tal vinculação.
} 
moralidade está isolada da personalidade ou, em outras palavras, esse valor está pouco integrado ao sistema de valores e, por conseguinte, ocupa uma posição inferior em sua hierarquia.

Assim como para Damon, Blasi acredita que a motivação para o raciocínio moral acontece na adolescência, permanecendo extrínseca na infância. Por esse motivo, o autor passou a estudar a moralidade em adultos, pois assim, de acordo com sua teoria, é possível verificar a integração entre a moralidade na identidade dos sujeitos.

Sobre esses últimos trabalhos e a teoria proposta por Blasi, Bergman (2004) aponta que

[...] a compreensão ou raciocínio moral (moral understanding) forma a identidade pessoal assim como a identificação com a moralidade forma $o$ senso de responsabilidade pessoal e desencadeia o poder proveniente da motivação do raciocínio moral para agir de forma consistente com o que cada um sabe e acredita. Dessa maneira, o objetivo e o subjetivo, o universal e o pessoal, o racional e o afetivo são integrados. Tal integração - ou integridade - é a marca do indivíduo moralmente desenvolvido. (p. 36, tradução nossa)

As pesquisas de Blasi foram um marco teórico deveras significativo nos estudos atuais sobre a moralidade. Isso porque, conforme nos informa Bergman (2004), preservou a centralidade do julgamento moral, da teoria de Kohlberg, mas não explicou o funcionamento moral somente a partir da razão, mas envolvendo outros aspectos, como na teoria de Colby e Damon. Além disso, tal teoria tem o mérito de tratar de temas até então não assumidos nos estudos sobre a moralidade, como da identidade, responsabilidade pessoal e motivação, sem sucumbir a uma perspectiva meramente subjetivista.

Muitos pesquisadores na área da moral vêm reverenciando os trabalhos de Blasi por acreditarem que eles conseguiram estender uma compreensão a respeito da relação entre juízo e ação morais, por via da motivação e da responsabilidade pessoal em relação à identidade. Tais conquistas não foram rebatidas por nenhum teórico até o presente momento.

No entanto, a despeito da aceitação por muitos teóricos dessa teoria formulada a partir do conceito de identidade, Blasi tem recebido críticas (NUCCI, 2001, 2004; NISAN, 2004) principalmente concernentes ao fato de que destinou demasiada atenção aos aspectos cognitivos da moral. As críticas ao modelo proposto por Blasi, e outras também destinadas a Damon, fizeram surgir algumas teorias muito interessantes a respeito da moralidade como inter-relacionada à identidade. Traremos algumas dessas críticas, pois acreditamos que são 
avanços no campo da psicologia moral e podem ser profícuas para a interpretação de nossos dados, no que se relaciona à integração e regulação morais.

Um primeiro aspecto que gostaríamos de trazer ao debate é o fato de que, tanto Damon quanto Blasi, não se afastaram totalmente de uma perspectiva cognitivo-evolucionista, na linha dos estudos promovidos por Piaget e, principalmente, por Kohlberg. Parece-nos que evitam contrastar com tal linha de desenvolvimento da moralidade dentro de níveis estruturados, uma vez que não destinam críticas a esse modelo. Como ambos acreditam que a moralidade e o self são sistemas que se desenvolvem em paralelo até a adolescência, dedicamse mais à integração da moralidade ao self após esse período.

Entendemos que não se devem desprezar as pesquisas de Piaget e Kohlberg, pois o desenvolvimento de uma moral deontológica é parte importante, em nosso entender, da moralidade. Ademais, tais estudos foram pioneiros no campo da psicologia moral, inaugurando formas de pensar sobre a moralidade na perspectiva psicológica. No entanto, não concordamos, assim como muitos autores (SASTRE et al., 1994; BENHABIB, 1992, FLANAGAN, 1993; ARANTES, 2000a, dentre outros) com a sua forma demasiadamente estruturada, em níveis, e priorizando apenas aspectos cognitivos da moralidade como forma de explicar seu funcionamento. A esse respeito, trazemos a crítica formulada por Sastre (1994) que indica a necessidade de procurarmos modelos teóricos mais abrangentes que, contrariamente à ânsia em fundamentar o juízo moral no princípio de justiça, contemplem a complexidade do funcionamento psíquico humano.

Sobre esse aspecto, a teoria de Damon apresenta-se de forma a contribuir com um paradigma mais abrangente, sem se voltar às teorias estruturalistas para explicar o desenvolvimento moral. $\mathrm{O}$ foco de interesse de sua teoria, como se pode observar no trabalho realizado em conjunto com Colby (COLBY; DAMON, 1992), consiste em ampliar a perspectiva ao vislumbrar a integração da moralidade ao self.

Já nos trabalhos de Blasi, vemos uma conceituação acentuadamente voltada para aspectos cognitivos, logo que sua teoria investe no raciocínio moral como motivação para ser fiel ao self nos juízos e ações morais. É sobre essa teoria que recai grande parte das críticas atuais, enfocando o seu aspecto cognitivista, embora seja consenso entre os teóricos a importância dos avanços trazidos por ela. De acordo com Nucci (2004), a teoria de Blasi quase chega a trazer um "mini-eu" à cena, que realmente toma as decisões depois de todos os mecanismos cognitivos estarem terminados.

A esse respeito, as críticas mais fortes provêm da teoria de Modecai Nisan (2004). Esse autor reconhece, assim como também o fazemos, que o modelo de identidade proposto 
por Blasi abandona uma concepção de moralidade que entende o sujeito como um ser passivo, que recebe ensinamentos, regras e princípios da sociedade, para perceber o sujeito como agente, que constrói sua identidade, criando uma maior consistência entre a sua percepção sobre o bem e o seu comportamento. Essa identidade, dessa forma, serve de base para a motivação moral, unindo juízo e ação. Nisan registra que "a explicação do comportamento em termos de identidade aproxima-se da experiência humana" (2004, p. 135, tradução nossa).

Mesmo considerando válido o modelo de identidade moral, Nisan questiona o fato de Blasi ter dado demasiada ênfase ao julgamento, colocando-o no cerne da moralidade humana, como elemento motivador do comportamento moral. Assim, embora Blasi tenha tecido críticas ao modelo racionalista, aceitando o fato de se afastar dele, esse autor, nas palavras de Nisan, aponta um movimento em que a moralidade vai se integrando à identidade, tornandose parte dela, mas mantendo certa independência. A moralidade, nesse ínterim, preserva as suas "supostas" características de objetividade, imparcialidade, tendo um status superior a outros aspectos constituintes do sujeito. Explica Nisan que a base dessa integração é um processo de compreensão da moralidade que auxilia a pessoa a clarificar seus desejos, promovendo a habilidade de controlar o comportamento e obtendo certa harmonia entre juízo e ação moral.

Como nos coloca Nisan, Blasi visualiza dois aspectos importantes da identidade: a autonomia da moralidade como um sistema que transcende o individual e a moralidade como um elemento inserido em uma percepção holística de toda personalidade. Em seu entender, “[...] ele (Blasi), além do mais, deve postular que a moralidade pode estar integrada na identidade da pessoa sem comprometer a sua autonomia" (NISAN, 2004, p. 136, tradução nossa), chegando ao conceito de julgamento moral autônomo ${ }^{12}$, o qual, guiado pela consciência, pela reflexão e por regras impostas, é tomado do ponto de vista de uma terceira pessoa, ou seja, livre de aspectos pessoais e situacionais.

Nisan sugere que esse modelo que coloca a racionalidade como característica central da identidade do sujeito é falho, pois, mesmo se considerando uma integração, o julgamento moral autônomo permanece sempre desvinculado da vida real do sujeito, já que é abstrato. Em seu lugar, o autor aposta em uma visão da identidade como constituída pelas particularidades do sujeito. Essas particularidades são características únicas da pessoa que foram formadas por sua história, família, comunidade, cultura, entre outras, “em um processo

\footnotetext{
${ }^{12}$ Tal conceito não foi formulado por Nisan, mas segue toda uma corrente filosófica, desde Kant, que foi apropriada pela psicologia moral. Nisan incorpora o termo julgamento moral autônomo para se referir a um tipo de juízo cujos aspectos cognitivos e estruturados predominam.
} 
de reflexão que leva em conta o dado, o possível e o imaginado" (2004, p. 137, tradução nossa).

Ampliando, ainda mais, esse ponto de vista, Nisan postula que, perante escolhas morais, nem sempre encontramos condições de objetividade e imparcialidade exigidas pelo julgamento moral autônomo; muito pelo contrário, muitas vezes o centro da discussão moral está em lidar com a situação frente a uma variada e complexa gama de considerações que podem, naquele momento, ser tecidas pela pessoa. Essas considerações podem envolver toda a sorte de valores, desejos, medos, angústias, interesses pessoais etc., que perfazem a sua identidade.

Dessa forma, a ponte entre juízo e ação moral pode ser realizada, segundo Nisan, em um processo que vai da identificação do problema à escolha de um comportamento. Esse processo passa por uma avaliação baseada em argumentos "objetivos" e por uma avaliação ancorada em considerações práticas, levando, por fim, a uma escolha alicerçada na identidade do sujeito.

[...] quando uma pessoa toma uma decisão em relação a um comportamento real e específico, sua escolha está baseada no que descrevi como sua identidade particular, sua definição pessoal em termos de suas características pessoais. O julgamento baseado na identidade particular, que é propenso a ter força motivacional, necessariamente difere do julgamento moral autônomo. (NISAN, 2004, p. 139, tradução nossa)

Em sua concepção de moralidade, Nisan toma as considerações pessoais, os valores, planos pessoais, desejos, sentimentos, relação com o social, entre outras, como elementos vitais para o juízo e ação morais, sem deixar de lado a existência do que ele denomina julgamento moral autônomo.

Incorporando esses elementos em sua teoria, Nisan expõe a existência de dois tipos de julgamento, que se entrelaçam, acontecendo ao mesmo tempo frente a uma situação moral: o julgamento de avaliação e o julgamento de escolha. O julgamento de avaliação ocorre quando o sujeito analisa a situação de acordo com a norma, com um princípio moral. Nesse tipo de julgamento, é obrigatório que a pessoa se sujeite a algo fixo, irredutível, mas, ao mesmo tempo, confiável, visto que a estabilidade promove limites claros sobre como se pode e se deve comportar para que a sociedade continue "funcionando". O julgamento de escolha, em contrapartida, envolve a tomada de decisão que o sujeito irá adotar para a situação tendo em 
vista a busca por ser uma boa pessoa, "uma pessoa que ele gostaria de ser"13. Esse julgamento é mais aberto e flexível, podendo ser guiado pelo sistema de valores do sujeito. O julgamento de escolha é subjetivo e depende de cada situação; ele concerne ao que o sujeito considera ser uma boa pessoa.

Nisan chama a atenção para a importância dos dois tipos de julgamento, indicando que, ao mesmo tempo em que eles não podem ser reduzidos um ao outro, também devem ser considerados de forma integrada, já que o que determina um deles acaba por incluir o outro e vice-versa.

A teoria formulada por Nisan acopla, de forma inter-relacionada, os dois julgamentos presentes nas situações em que se exige do sujeito um juízo e uma ação morais. Além do mais, nessa teoria, presenciamos um olhar para as particularidades do sujeito, as quais são, muitas vezes, mais importantes do que os valores morais para a tomada de decisão.

Reconhecemos nessa teoria aportes fundamentais a respeito das correlações entre a moralidade e a identidade, já que esta última é vista de uma forma mais ampla, constituindose de necessidades, valores, desejos, pensamentos e sentimentos dos sujeitos. No entanto, embora tenhamos percebido avanços nessa teoria, observamos que ela ainda não corresponde completamente ao modelo que julgamos interessante formular a respeito da identidade moral.

Como assinala Blasi (2004), em resposta às críticas de Nisan, o juízo moral não pode ser visto em etapas predefinidas, mas de uma forma cíclica. Ele parte de um julgamento global de uma ação considerada concretamente, para uma análise de diferentes valores e conceitos envolvidos, para uma consideração abstrata de cada valor, não apenas os concernentes à moralidade, e para um julgamento concreto diferenciado ao final.

Além disso, Blasi rechaça a ideia de que sua teoria apenas foca em aspectos cognitivos como elementos da motivação. Entretanto, em suas palavras, existe uma habilidade pessoal de traduzir o que se julga da situação (aspecto cognitivo) em motivação moral, bem como em relacionar essa motivação moral a outras motivações, e na forma como essas motivações interagem entre si. A solução para explicar essa força motivacional está no self, o aspecto da personalidade que subsiste conscientemente nos processos subjetivos e ativos, nos processo do controle de si mesmo (self-control), na definição da organização interna e da coerência. Há, para Blasi, dois processos: o de criação e estruturação da vontade do sujeito e o de

\footnotetext{
${ }^{13}$ Não concordamos com o autor nesse ponto. Muitas vezes, guiamo-nos por valores pessoais que nos levam a não ser uma boa pessoa. Às vezes, tomamos atitudes que vão contra aquilo que consideramos correto quando estamos avaliando o fato (julgamento de avaliação). Um exemplo dessa assertiva encontra-se no aluno que julga ser correto estudar, ser centrado e "ir bem na escola". No momento do estudo, porém, valores pessoais como divertimento com colegas ou assistir à televisão podem, em seu julgamento de escolha, atuar de forma mais consistente e levar o sujeito a deixar de lado o que considera correto (em seu julgamento de avaliação).
} 
apropriação de normas, princípios e valores morais que o sujeito realiza para o desenvolvimento do senso de si mesmo.

De acordo com Blasi,

[...], pelo menos para adultos, as várias características que são reconhecidas como elementos que definem o sujeito são organizadas hierarquicamente e o senso do self adquire unidade e profundidade; a pessoa, então, entende que poucos aspectos dele/dela mesmo(a) estão no centro ou na essência de sua existência. Eu chamo essa forma especial de definição pessoal identidade no sentido amplo ou identidade pessoal (self identity). É uma identidade pela qual o sujeito se sente responsável; além do mais, ela inspira ação e comprometimento. (2004, p. 342-343, tradução nossa)

Assim, Blasi recusa a ideia de Nisan de que a identidade é composta por um misto de necessidades, valores, desejos e características que são, em seu ver, experienciados passivamente como elementos que existem sem uma ordem. Para ele, em uma parte do self há processos ativos de seleção e de ordenação hierárquica dos valores. O que determina essa ordenação é o aspecto racional, pois o autor diferencia valores que estão associados à moralidade daqueles que, utilizando seus termos, são a "essência" da moralidade.

A respeito dessa discussão, não pretendemos, no presente item de nosso capítulo, eleger uma das opções expostas por esses autores. Basta-nos, por hora, indicar que percebemos, na teoria de Blasi, uma ênfase muito grande no julgamento moral, em seu aspecto racional e objetivo. Concordamos com a crítica de Nisan a respeito dessa postulação, pois entendemos que a motivação para a ação moral não pode estar nesse aspecto, mas, provavelmente, assentada nos valores, sentimentos, desejos, interesses e objetivos do sujeito. Contudo, também não apostamos totalmente na teoria proposta por Nisan, já que acreditamos em uma organização dos valores no sistema moral dos sujeitos (não de acordo com a proposta de Blasi, em que os valores morais seriam hierarquicamente superiores aos demais) e não apenas que eles coexistam de forma a serem eleitos apenas de acordo com a situação.

Além da proposta de Nisan, gostaríamos de apresentar a teoria de Seyla Benhabib (1992), em que se encontra um foco no julgamento fundado na percepção a respeito do outro, ou seja, nos relacionamentos que corroboram para a elaboração de perspectivas morais.

Tal teoria, de forma bastante pioneira, engloba um fato não delineado tanto pelas abordagens de Colby e Damon e de Blasi quanto as outras que partiram destas. Muito embora Benhabib tenha realizado suas formulações antes das últimas publicações desses autores, sua perspectiva, apoiada nas críticas aos trabalhos de Kohlberg e Gilligan, mostra-se atual e pode significar, em nosso entender, um avanço para os escritos contemporâneos. 
Conquanto o foco de Benhabib não esteja nos relacionamentos e nas contribuições de tais vínculos na identidade moral, a autora abre espaço para a compreensão sobre a forma como o sujeito vê o outro para elaborar seus juízos morais. Por esse motivo, acreditamos que seu trabalho aproxima-se da análise de Nisan, que procura ampliar as formas de julgamento moral para além de um juízo focado apenas no racionalismo. Em nosso entender, para emitir um julgamento moral, é necessário, ao longo desse processo, obter um panorama a respeito do outro com o qual estamos nos relacionando. É, nesse aspecto, que enxergamos na teoria de Benhabib uma grande contribuição.

Investida da teoria feminista, Benhabib (1992) verifica que privilegiar um juízo moral apenas em processos cognitivos e conscientes significa enquadrar a moralidade como algo "sem corpo" e "sem sexo". Partindo dessa constatação, a autora procura investigar a pluralidade do ser humano, e as diferenças entre os humanos, sem enquadrar essas pluralidades e diferenças em apenas um modelo moral e político como válido.

Nesse sentido, chega à elaboração teórica a respeito de dois tipos de relacionamentos que delineiam duas perspectivas morais: o outro "generalizado" e o outro "concreto".

O outro "generalizado" define-se por uma visão de cada indivíduo como um ser humano imbuído dos mesmos direitos e deveres que nós gostaríamos de possuir. Nessa perspectiva, assume-se que, assim como nós, o outro é um ser humano com necessidades concretas, desejos e sentimentos, mas o que constitui sua dignidade moral não é o que diferencia uma pessoa de outra, mas aquilo que se tem, como "agentes racionais", em comum. As relações desse tipo são geridas pelas normas de igualdade formal e a reciprocidade, que são primariamente públicas e institucionais. As categorias morais desse tipo de interação são as regras e obrigações e os consequentes sentimentos morais correspondem a respeito, dever e dignidade.

Por outro lado, o outro "concreto" caracteriza-se por um modo de ver o outro como um ser humano individual com uma história de vida concreta, identidade e constituição afetiva próprias. Desse ponto de vista, tem-se um olhar sobre as individualidades, procurando compreender as necessidades do outro, suas motivações, seus desejos. As regras que norteiam esse tipo de relacionamento são de equidade e reciprocidade "complementar", no sentido de esperar e assumir, frente ao outro, comportamentos em que se sinta reconhecido como um "concreto" (uma pessoa com necessidades específicas, talentos e capacidades). Essas regras são de ordem privada e não institucional. Como categorias morais, apresentam-se a responsabilidade e o compartilhar e, como sentimentos morais correspondentes, tem-se o amor, o cuidado, a simpatia e a solidariedade. 
Benhabib indica que na teoria moral universalista o ponto de vista predominante é o do outro "generalizado", trazendo uma perspectiva em que a reciprocidade e a justiça são identificadas em sujeitos desenraizados, "sem corpo" e "sem sexo". Dessa forma, almeja mostrar que, ao ignorar o ponto de vista do outro "concreto", embarca-se em teorias morais incoerentes. Isso porque:

Se tudo pertence aos sujeitos sem corpo, sem afeto, sob constante sofrimento, sua memória e história, suas relações e relacionamentos com os outros são subsumidos por um fenômeno superior, então nos resta uma máscara vazia na qual todo mundo é ninguém. (1992, p. 161, tradução nossa)

De acordo com Benhabib, não podemos pensar situações que envolvam a moral independentemente de nosso conhecimento a respeito das pessoas envolvidas, de suas histórias, atitudes e desejos.

Situações morais, assim como emoções e atitudes morais, apenas podem ser individualizadas se forem avaliadas à luz de nosso conhecimento sobre a história dos agentes envolvidos nelas. (ibid, p. 163, tradução nossa)

Entretanto, ao invés de se concentrar apenas no foco de uma moral centrada no outro "concreto", Benhabib amplia sua argumentação expondo que ambos pontos de vista são importantes e complementares. Nas palavras da autora, além de termos relações em que visualizamos outro individual, dotado de uma história, com sentimentos e valores, também se faz necessária a presença de uma relação em que se tenham regras e normas que devam ser obedecidas. A proposta de Benhabib é, em suma, desenvolver uma teoria moral abrangente em que os pontos de vista sejam reversíveis de acordo com os interesses, desejos, valores e atitudes do sujeito.

A mesma intuição de Benhabib a respeito do papel do outro e do ponto de vista do sujeito, em sua complexidade, pode ser encontrada no estudo de Lapsley e Narvaez (2004). Para esses autores, a personalidade é constituída de coerência, porém tal coerência não se reduz à mera estabilidade de comportamentos, visto que o sujeito interage com os conteúdos dos contextos que estão sempre em mudança.

A coerência é evidente na dinâmica, na interação recíproca entre as disposições, interesses, capacidades e potencialidades dos agentes e os contextos de aprendizagem, socialização e desenvolvimento em mudança constante. As pessoas e os contextos não são estáticos, de efeitos ortogonais, mas estão, em vez disso, em interação dinâmica. (LAPSLEY; 
NARVAEZ, 2004, p. 194). Consoante essa perspectiva, na interação entre a pessoa e o contexto, a coerência da personalidade é revelada.

Os autores introduzem o modelo de coerência da personalidade, o qual é constituído de três aspectos:

1) há uma organização do funcionamento da personalidade: os processos da personalidade não funcionam independentemente, mas são organizados coerentemente. São sistemas integrados que impõe regulação à grande possibilidade de configurações. Isso significa que a personalidade é um sistema cognitivo-afetivo e não é legítimo separar cognição e afetividade;

2) existe coerência entre o comportamento e as expectativas do contexto social. "Os indivíduos criam padrões estáveis de experiência pessoal, selecionando e moldando as circunstâncias que formam suas vidas cotidianas" (LAPSLEY; NARVAEZ, 2004, p. 196, tradução nossa);

3) o fenômeno do senso de coerência a si mesmo (self-coherence) guia nossos objetivos, nossas preferências e nossos valores e traz sentido (meaning) para o sujeito e sua motivação.

A interação dinâmica das estruturas de conhecimentos, afetos e contextos sociais é entendida pela análise de mecanismos de causa, estruturas e processos de compreensão das informações sociais. No modelo sociocognitivo, a ativação de representações mentais é um aspecto significativo do funcionamento coerente da identidade moral. Essas representações incluem conhecimentos acerca de situações sociais, representações do self, eventos presentes e imaginados no futuro, objetivos pessoais, crenças, expectativas e conhecimento de comportamentos alternativos e estratégias.

A possibilidade de configuração dessas representações não é, segundo Lapsley e Narvaez, infinita, logo há regulações entre as partes do sistema. Faz-se interessante destacar que as diferenças individuais ocorrem porque as pessoas têm objetivos em suas vidas que estruturam a organização do seu sistema cognitivo-afetivo, bem como influenciam a percepção, seleção e interpretação de vários aspectos do contexto.

Para Lapsley e Narvaez, os indivíduos constroem esquemas que se mostram como padrões para as diferenças entre as identidades morais. Com o apoio da teoria de Cantor (1990), os autores demonstram que esses esquemas são demasiadamente acessíveis, direcionando a atenção do sujeito para determinadas características de suas experiências. Tais esquemas apresentam-se salientemente na memória, assim permitem que certos elementos das 
situações sejam canalizados e que se mantenham algumas tendências da identidade moral. Além disso, há uma disposição dos sujeitos para desenvolver rotinas comportamentais nas áreas em que esses esquemas foram demarcados como acessíveis.

Os autores apostam que a identidade moral pode ser compreendida com o uso da noção de acessibilidade dos esquemas morais que são ativados no processamento de informações das situações.

[...] categorias morais (esquemas, episódios, scripts, protótipos) que são essenciais, centrais e importantes para a identidade moral também seriam aqueles demasiadamente acessíveis para interpretar a situação social. Tais categorias estariam constantemente a postos, ou pelo menos requisitadas primeiramente ou facilmente ativadas, para o discernimento do sentido dos eventos. E, uma vez ativados, esses construtos estariam disponíveis para os indivíduos interpretarem esses eventos sob a luz de seus compromissos morais. (LAPSLEY; NARVAEZ, 2004, p. 201)

Dessa forma, os significados dos eventos sociais são construídos rotineiramente, habitualmente e sem intencionalidade. De acordo com os autores, há forte evidência de que os sistemas mentais não conscientes direcionam a regulação do self e que as avaliações, percepções sociais, julgamentos, interações sociais e objetivos internos são operados sem intenção, tampouco com ações e desejos conscientes. Nesse ínterim, é incorreto pensar que a cognição equivale à cognição consciente.

[...] se a literatura na perspectiva sociocognitiva pode ser algum guia, muitas de nossas performances morais são realizadas sem cuidados explícitos. Muitas de nossas respostas são sem reflexão, altamente automatizadas e não o resultado de processos deliberados de tomada de decisão. Se isso é verdade, então o presente modelo também sugere que o funcionamento moral tem um componente procedimental assim como um deliberativo. (LAPSLEY; NARVAEZ, 2004, p. 204, tradução nossa)

Encerrando o presente tópico desse capítulo, chegamos à percepção da importância da concepção de identidade moral para a compreensão acerca do funcionamento moral no psiquismo humano. Se as teorias de Damon e Blasi mostraram-se pioneiras em encetar uma visão mais ampla a respeito da moralidade como integrada à identidade, é compreensível que haja muitas lacunas que estão por ser preenchidas pelos estudos no campo da psicologia moral. As teorias de Nisan, de Benhabib e de Lapsley e Narvaez intentam preencher algumas 
dessas lacunas. Contudo, há muito espaço para estudos que queiram desvendar os muitos aspectos que estão para ser analisados ${ }^{14}$.

Os avanços trazidos pelas teorias expostas corroboram para entendermos a moralidade em um espectro mais amplo e integrado. Do nosso ponto de vista, elas estão de acordo com a perspectiva de sujeito psicológico que apresentamos anteriormente, já que posiciona a moralidade dentro de um sistema maior, em sua integração e consistência, que é o self, e superam um paradigma firmado apenas no estruturalismo. Além disso, destaca-se, nessas teorias, a compreensão do sujeito como um ser ativo na formulação de juízos morais e comprometido com a sua própria identidade nessa formulação. Por fim, verifica-se, com base nesses aportes, a complexidade que envolve a identidade moral, que se estrutura de forma muito particular para cada sujeito e que se mostra fundamental para a elaboração de juízos e ações morais nos contextos apresentados.

Os indícios apresentados por essas teorias são importantes para o presente estudo, uma vez que reforçam a integração da moralidade como um dos aspectos do sujeito psicológico. Além disso, alguns aspectos despertados por essas teorias, ao trazer indícios sobre como ocorre tal integração, são profícuos para a nossa elaboração a respeito da regulação e integração morais. No próximo item deste capítulo, atentaremo-nos a tais aspectos, de forma a nos embasar para a leitura de nossos dados e atender aos objetivos da presente investigação.

\subsection{Regulação e integração psíquicas e morais}

Diante do que expusemos sobre o sujeito psicológico e do espaço que a moralidade ocupa em sua identidade, passaremos a elucidar de que forma os valores são mobilizados e organizados nos sistemas morais dos sujeitos. Acreditamos, para tanto, ser pertinente abordar as questões de regulação e integração psíquicas e morais.

\subsubsection{Regulação, self e consciência moral}

Entendemos a regulação como aspecto revelador da organização e funcionamento psíquico do ser humano.

\footnotetext{
${ }^{14}$ Acadêmicos de todo o mundo vêm se debruçando ao estudo da moralidade vinculada à identidade moral e, com isso, produzindo diferentes teorias que tentam decifrar tais relações (ver, por exemplo, a edição especial do The Journal of Moral Education, 2008). Dada a extensão do presente trabalho e a necessidade de ater-se ao nosso foco que é o da regulação e integração morais, restringimo-nos a apresentar as teorias do presente capítulo, que acreditamos embasar nossos objetivos.
} 
Para iniciarmos nossa reflexão sobre a regulação, novamente nos apoiaremos nas concepções de Piaget, a quem podemos atribuir as reflexões sobre esse termo no nível estrutural, ou seja, macrogenético. A regulação é um importante aspecto da teoria piagetiana, pois se volta ao processo de equilibração das estruturas cognitivas. De acordo com Piaget,

fala-se de regulação, de forma geral, quando a retomada de uma ação A é modificada pelos resultados desta, portanto quando há uma influência dos resultados de A sobre um novo desenrolar A'. A regulação pode se manifestar por uma correção de A (feedback negativo) ou pelo seu reforço (feedback positivo), mas nesse caso com a possibilidade de um acréscimo de erro. $(1975$, p. 24)

No âmago de sua teoria, a regulação atua como componente fundamental para a equilibração das ações e operações de pensamento, levando o sujeito a assimilar os sistemas, mas de uma forma reversível, sempre possibilitando novas aprendizagens. Visando compreender a aprendizagem numa perspectiva estrutural, Piaget constata que o caráter geral das regulações está em alcançar progressões parciais, mas sem a reversibilidade inteira e, consequentemente, com deslocamentos lentos ou brutos de equilíbrio (PIAGET, 1975, p. 61).

Segundo Piaget, a noção de equilíbrio apenas tem sentido numa perspectiva de autorregulação que evoca processos dialéticos entre o sujeito e o meio. Para que ocorra a regulação, intervêm alguns fatores de interação como valores e certas regras. Tais fatores de interação são frutos de sistemas de "forças", que envolvem tanto normas sociais quanto a ação individual.

Centrando-se ainda mais sobre o campo da moralidade, é importante ressaltar o papel do sujeito psicológico, que se vincula ao conceito de self, e os processos regulatórios. Para Piaget, o self regula o funcionamento das estruturas do sujeito assim como o faz com as relações com o mundo, uma vez que é construído, no processo de socialização, na percepção da diferenciação que o sujeito passa a ter entre si e o mundo que o rodeia. O self, na acepção de Piaget, regula internamente o funcionamento de suas estruturas e as relações com o mundo.

Ampliando o pensamento de Piaget sobre o papel regulatório do self, encontramos os estudos de Puig (1996 e 2007) para quem a moralidade é fruto de um complexo processo que tem como aspectos norteadores a indeterminação humana (somos seres plásticos e, portanto, "moldados" ao longo do tempo e de acordo com as experiências de vida; não somos previamente determinados), a construção moral que se dá entre o indivíduo e sua relação com os demais e a tendência que temos para o Bem. 
A moral deve ser feita mediante um esforço complexo de elaboração ou reelaboração das formas de vida e dos valores que são considerados corretos e adequados para cada situação. A moral é, portanto, um produto cultural cuja criação depende de cada sujeito e do conjunto de todos eles. (1996, p. 70)

Puig entende que a construção da moralidade é uma tarefa de cunho social, de uma construção dialógica, que supõe os seguintes elementos:

- parte de um duplo processo de adaptação: à sociedade, como aquisição de pautas sociais básicas, e a si mesmo, como reconhecimento dos desejos, pontos de vista e critérios pessoalmente valorizados;

- transmissão de elementos culturais de valor que são considerados desejáveis;

- desenvolvimento das capacidades pessoais de julgamento, compreensão e autorregulação que permitirão um enfrentamento autônomo diante dos conflitos de valor;

- construção da própria biografia como cristalização dinâmica de valores, como espaço de diferenciação e de criatividade moral.

Mostra-se importante, para nossa investigação, um conceito central da teoria de Puig, a consciência moral, por se tratar de um regulador moral por excelência. De acordo com esse autor, "a consciência moral de um sujeito instaura uma relação com ele mesmo, de modo que seus sentimentos, juízos e ações são sancionados como corretos ou incorretos por ele mesmo". (1996, p. 80)

Assim, a consciência moral atuaria como um "juiz" interior que, por meio de juízos valorativos, é capaz de determinar um critério moral. No entanto, essa consciência moral não pode partir apenas do sujeito; pelo contrário, requer uma consciência dialógica que possa, de modo intersubjetivo, se comprometer na construção de modos justos e eficazes de enfrentar a realidade. A partir desse tipo de relação, o sujeito pode atingir uma consciência moral autônoma, sob a qual ele raciocina diante de situações de grande diversidade e moralmente controversas.

A tese da consciência autônoma, levantada por Puig como um regulador moral superior, é a base para compreender a moralidade humana. Nas palavras do autor,

a moralidade se refere essencialmente à regulação dos conflitos interpessoais e sociais. (...) a moralidade consiste em uma forma de regular os comportamentos dos sujeitos para tornar possível uma convivência social ótima e uma vida pessoal desejável. (1996, p. 90) 
Os reguladores morais, instrumentos facilitadores para a confecção de juízos e para a realização de condutas que permitem a convivência consigo mesmo e com os demais, dependem do tipo de exigência e da complexidade sociomoral do meio. Eles podem ser definidos da seguinte forma:

Um regulador moral [...] é uma disposição do sujeito, de índole funcional, que lhe permite combinar o significado conflitivo da informação moral que recebe do meio com um tipo de juízo e ações que dão resposta adequada às problemáticas sociomorais. Isto é, um regulador dá significado pessoal e social à informação que recebe, e deste modo caracteriza os conflitos morais e os enfrenta construindo um tipo de conduta que permita solucionar ou, pelo menos, melhorar a situação problemática. O regulador moral deve "pensar" a solução, encontrar soluções, adotar estratégias e adaptá-las aos aspectos singulares da situação em que o sujeito se encontra. (PUIG, 1996, p. 90)

A consciência moral é, para Puig, um regulador formado durante a filogênese humana, que possui caráter funcional, visto que permite a atuação do sujeito no meio. Em seu processo filogenético, a construção de reguladores passa necessariamente por reguladores mais simples, de origem biológica, o que permite, uma vez calcados no núcleo funcional do genoma humano, a adaptação do sujeito ao meio em culturas simples. A partir da dificuldade de interação e da necessidade de regular convivências interpessoais mais complexas, apresenta-se outro regulador, o cérebro, que tem a qualidade de criar e aprender, de acordo com a socialização e com o programa cultural da sociedade. Tal regulador permite a atuação do sujeito na resolução de problemas mais complexos e móveis. No entanto, como as relações nas sociedades modernas tornam-se hipercomplexas, o cérebro não consegue promover a mediação entre propostas normativas que oferecem soluções contraditórias. Assim, surge a necessidade de construção de um terceiro tipo de regulador, a consciência ${ }^{15}$.

A consciência como regulador moral pode ser entendida como socialmente construída, permitindo o diálogo do sujeito consigo mesmo e com outras pessoas. Ela se baseia em princípios metamorais e sendo constituída por mecanismos que conseguem idealizar novas soluções para os conflitos e problemáticas que são enfrentadas pelo sujeito em seu cotidiano.

Concordamos com Araújo (2003a) ao perceber que a definição de consciência de Puig aproxima-se da definição de self, proposta por Piaget, por indicar um sujeito consciente que regula suas relações intra e interpessoais. Nesse sentido, a consciência é a instância do self

\footnotetext{
${ }^{15}$ A consciência, para Puig, é um regulador moral necessário para a elaboração de juízos e ações nas situações vivenciadas cotidianamente. Devido à complexidade do meio sociocultural, segundo o autor, vê-se necessária a criação de reguladores que extrapolem o sistema biológico, partindo para elaborações mais complexas que envolvem a construção do conhecimento sobre si mesmo e sobre o mundo.
} 
que regula as relações intrapsíquicas estabelecidas entre os diferentes sistemas que constituem o sujeito psicológico, em suas dimensões afetiva, sociocultural, biológica e cognitiva. Além disso, regula as relações interpsíquicas estabelecidas entre o sujeito e o meio físico, sociocultural e interpessoal.

Nas palavras de Araújo (2003a),

[...] o jogo dinâmico presente nas relações do sujeito consigo mesmo e com o mundo é regulado pela consciência (ou pelo self, dependendo da definição). Dependendo dos conteúdos presentes na interação, essa regulação poderá ter um caráter somente psíquico ou poderá ter um caráter moral, se esses conteúdos presentes nos conflitos forem de natureza moral. (p. 73)

Dessa forma, podemos verificar que o modelo de sujeito psicológico que apresentamos anteriormente, de acordo com o que expôs Araújo, mostra-se adequado para representar funcionalmente o self, visto que ele é constituído por sistemas (ou subsistemas em relação ao sistema mais amplo do self) que interagem entre si de maneira dinâmica e interdependente. A coordenação e a inter-relação entre os diferentes sistemas ocorrem pelos elementos reguladores.

Entendendo que o self, nessa perspectiva, é o elemento regulador por excelência do sujeito psicológico nos termos de Puig, Araújo (2003a) propõe a existência de outros reguladores no nível do funcionamento intrapsíquico, os quais coordenariam os seus diferentes subsistemas, ao mesmo tempo em que coordenariam as suas relações com o mundo externo.

Os reguladores desse nível, ainda segundo Araújo, podem ser definidos como elementos funcionais, responsáveis pela interação entre os diferentes sistemas. Eles podem ser psíquicos, se estiverem envolvidos com o funcionamento psíquico; ou podem ser morais, se estiverem envolvidos em relações e conteúdos de natureza moral. A interação entre os sistemas é mediada pelos reguladores, enquanto elementos pertencentes a um dos sistemas, mas que se relacionam com os demais.

Todos os sistemas, enquanto fechados, com leis próprias, e abertos, com possibilidade de interação com os demais, possuem seus reguladores psíquicos. Tais reguladores interferem tanto no interior do sistema, quanto nos demais. São exemplos de reguladores: os neurotransmissores, do sistema biológico; a linguagem, do sistema sociocultural; os esquemas de ação, do sistema cognitivo; os sentimentos, do sistema afetivo. Vale ressaltar que os reguladores psíquicos, pertencendo a um dos sistemas constituintes do sujeito psicológico, 
existem em interdependência com todos os demais sistemas, internos e externos. Segundo Araújo, é tarefa difícil classificá-los como cognitivos, biológicos, socioculturais, pois se "posicionam" na "interface entre os diversos sistemas internos, ao mesmo tempo em que regulam a relação do sujeito com o mundo externo" (2003, p. 76).

No presente estudo, pretendemos elucidar a regulação moral, portanto nos centraremos no papel regulatório dos valores e sentimentos, sobre os quais nos debruçaremos no próximo tópico desse capítulo.

\subsubsection{O papel regulatório da afetividade no psiquismo humano}

De acordo com o modelo que expusemos no tópico anterior, os valores e sentimentos exercem um papel de regulação nas relações intra e interpessoais, interferindo tanto no funcionamento dos outros sistemas quanto no funcionamento interpsíquico, do sujeito com o mundo externo. Em outras palavras, os reguladores morais, pertencentes ao sistema afetivo, influenciam as relações intrapessoais, podendo interferir nos demais sistemas (cognitivo, sociocultural, biológico) e as ações que decorrem dessas influências dependem e intervêm nos conteúdos externos.

Essa visão dos reguladores morais apresenta-se de uma forma complexa, incorporando diversos elementos que atuam concomitantemente. Dessa forma, vem ao encontro de uma corrente teórica que intenta articular a afetividade como elemento funcional no psiquismo humano.

Encontramos em Piaget (1954) indícios importantes sobre o papel da afetividade, que trouxeram elementos para avanços dos estudos atuais sobre a temática. Para o autor, toda ação e juízo comportam um aspecto cognitivo, representado pelas estruturas mentais, e um aspecto afetivo, que diz respeito a uma energética (a afetividade). Isso quer dizer que não existem estados afetivos sem elementos cognitivos, do mesmo modo que não existem comportamentos puramente cognitivos. Nas palavras de Piaget, "é impossível encontrar comportamentos que denotem unicamente afetividade, sem elementos cognitivos e vice-versa" (1954, p. 19, tradução nossa).

Piaget (1954) aponta que a afetividade possui papel funcional na inteligência. Ela se apresenta como fonte de energia para a cognição. Para tanto, utiliza uma metáfora como forma de ilustrar esse processo: a afetividade seria como a gasolina, que ativa o motor de um carro, mas não modifica a sua estrutura. Essa metáfora mostra que, para Piaget, existe uma 
intrínseca relação entre a gasolina e o motor (que representam a afetividade e a cognição), já que o motor (as estruturas mentais) não funciona se não houver combustível (a afetividade).

Piaget defende a tese de que a afetividade pode ser causa de comportamentos no sujeito, assim como intervém no funcionamento da inteligência e pode ser o motivo de aceleração ou atraso no desenvolvimento intelectual, ou seja, agindo como elemento regulador, mas ela mesma não gera estruturas cognitivas nem modifica o funcionamento das estruturas em que intervém. Assim, o sujeito, em sua relação com os objetos, com as pessoas e consigo mesmo, direciona, a partir de uma energia, seu interesse para uma coisa ou outra. A essa energética pode-se afirmar que corresponde uma ação cognitiva que organiza o funcionamento mental.

Esse autor focaliza a questão cognitiva considerando a afetividade como complementar e, ao mesmo tempo, essencial. Ele enfatiza o papel regulador do afetivo como força psicológica e agrega a ele os valores. Os valores, consoante suas ideias, pertencem à dimensão geral da afetividade no ser humano e surgem de uma troca afetiva que o sujeito realiza com o exterior, com objetos e pessoas (e, para Araújo, 2003a, também com as relações). Eles emergem da projeção dos sentimentos sobre os objetos os quais, com as trocas interpessoais e a intelectualização dos sentimentos, vão sendo cognitivamente organizados, gerando o sistema de valores que cada pessoa possui. Os valores, dentro dessa lógica, são oriundos do sistema de regulações energéticas que se estabelece entre o sujeito e o mundo externo desde o seu nascimento, a partir de suas relações com os objetos, com as pessoas e consigo mesmo.

Tal compreensão dos valores e dos sentimentos em Piaget é importante para entendermos a afetividade como componente fundamental para a regulação. Entretanto, embora reconheçamos todo o avanço da teoria piagetiana sobre a temática, concordamos com a crítica tecida por Carretero (1991):

(...) o problema surge se colocarmos que o energético não é apenas um fator impulsor da atividade, mas também tem uma estrutura, a qual não se constitui no maior interesse de estudo do psicólogo de Genebra. Na verdade, acreditamos que a posição de Piaget (...) padece de um certo racionalismo segundo o qual pareceria que a afetividade é simplesmente a gasolina, e talvez seja interessante pensar que ambos, conhecimento e desejo, possuem estrutura, funcionamento e energética, os dois têm motor e gasolina. (p. 12, tradução nossa)

A afetividade na teoria de Piaget carrega a marca dos estudos do epistemólogo suíço, em que se dá à cognição um status de superioridade perante os demais aspectos que 
constituem o funcionamento psíquico humano. Dessa forma, vemos nessa teoria a definição de sentimentos, emoções, desejos, interesses apenas como uma motivação que impulsiona o desenvolvimento cognitivo, em seu desenrolar no nível estrutural.

Partindo dos avanços e das possibilidades da teoria piagetiana, alguns teóricos passaram a enveredar pelo estudo da afetividade pelo viés da microgênese como aspecto importante para a regulação moral, não porque atua como uma energética, mas porque é indissociável em relação à cognição. Isso quer dizer que, uma vez frente a contextos morais, atuam necessariamente de forma integrada a afetividade e a cognição.

Entre essas teorias, destaca-se o trabalho de Arantes (2000a, 2000b, 2003). Nessa pesquisa, a autora analisou, de uma perspectiva cognitivo-afetiva ${ }^{16}$, a influência que os estados emocionais exercem no raciocínio moral dos sujeitos. Por meio da resolução de um conflito moral, em que a protagonista, uma professora, flagra um aluno fumando maconha na escola, os sujeitos, que haviam sido instigados a ter sentimentos positivos ou negativos (exceto alguns, considerados grupo neutro), foram questionados a respeito dos pensamentos, sentimentos e desejos da protagonista ao se defrontar com a situação ${ }^{17}$.

Com base na Teoria dos Modelos Organizadores do Pensamento, da qual trataremos em um próximo item, a autora examinou as respostas dadas pelos sujeitos e classificou-as em quatro modelos, sendo que as implicações dos modelos 1 e 2 eram semelhantes, assim como a dos modelos 3 e 4 . Nos modelos 1 e 2 , os sujeitos atribuíram à professora um papel passivo diante da situação-problema, defendendo a ideia de que ela não deveria atuar diretamente na resolução do caso. Esses sujeitos adotavam a postura de calar-se ou de encaminhar o caso para outra instância (família, direção da escola, profissionais capacitados etc.). Já nos modelos 3 e 4, a personagem era vista pelos sujeitos como possuidora de um papel ativo diante do conflito e, sendo assim, capaz de atuar diretamente em sua solução. Para esses sujeitos, a atuação direta da protagonista no caso era fundamental.

Esses resultados tornam-se significativos se considerarmos que grande parte dos sujeitos que aplicaram os modelos 3 e 4 experienciou sentimentos positivos antes da aplicação dos questionários, enquanto a maioria dos sujeitos que se enquadraram nos modelos 1 e 2 havia experienciado sentimentos negativos antes de responder às questões. Deste modo, os

${ }^{16}$ A autora denomina como cognitivo-afetiva uma perspectiva que engloba a análise de sentimentos, pensamentos, desejos e objetivos dos sujeitos e que implica a imbricação das emoções e do raciocínio moral.

${ }^{17}$ A amostra foi constituída com noventa professores de escolas públicas brasileiras. Desses noventa professores, trinta compuseram o grupo denominado positivo, em que foram previamente estimulados a experienciar sentimentos positivos; trinta fizeram parte do grupo denominado negativo, no qual foram instigados a experienciar sentimentos negativos antes de responder ao questionário; e trinta formaram o grupo denominado neutro, pois não experienciaram nenhum sentimento antes da aplicação dos questionários. 
resultados obtidos nessa investigação mostraram que o estado emocional prévio interfere no tratamento que se dá ao conflito. Isso levou a autora a inferir que pessoas supostamente alegres e satisfeitas tendem a organizar seus conflitos cotidianos em torno de valores morais como solidariedade, responsabilidade ou generosidade. Em contrapartida, pessoas supostamente tristes ou insatisfeitas acentuam a tendência de organizar formas passivas de resolução de conflitos.

A pesquisa conseguiu provar que a afetividade influencia, de maneira significativa, a forma como os seres humanos resolvem os conflitos de natureza moral. Para a autora,

[...] ao sermos solicitados a resolver problemas, a forma em que organizamos nosso raciocínio parece depender tanto dos aspectos cognitivos quanto dos aspectos afetivos presentes no funcionamento psíquico, sem que um seja mais importante que o outro. Assim como a organização de nossos pensamentos influencia nossos sentimentos, o sentir também configura nossa forma de pensar. A afetividade exerce, pois, um papel organizativo no funcionamento psíquico. (Arantes, 2003, p. 123)

Com essa afirmação, Arantes considera o papel da afetividade como funcional no psiquismo humano. Ao considerar sentimentos, emoções e afetos dos sujeitos diante de um conflito moral, dá-nos suporte para refletir sobre como a afetividade relaciona-se à moralidade humana, sendo que pode ser organizativa dos valores construídos pelo sujeito, assim como pode ser organizada por esses valores.

Encontramos também em Araújo (1998, 2003a) a discussão sobre o papel funcional dos sentimentos no estudo empreendido pelo autor a respeito do sentimento de vergonha, compreendendo-o como um regulador moral dos sistemas que compõem o sujeito psicológico. Buscando verificar o papel regulador desse sentimento, Araújo procurou estudar sua atuação em três situações hipotéticas que continham personagens que agiam contrariamente aos valores morais da honestidade, da generosidade e da coragem ${ }^{18}$.

$\mathrm{O}$ autor conseguiu indícios claros de que a vergonha atua como regulador moral, exercendo influência no julgamento e ação moral do sujeito com o mundo. No entanto, percebeu que tal regulação foi influenciada por muitos outros elementos intra e interpsíquicos, que atuam simultaneamente durante o juízo e as ações das pessoas. Em sua perspectiva, outros reguladores, de outros sistemas (biológico, sociocultural, cognitivo) atuam conjuntamente aos reguladores morais diante das situações cotidianas, de cunho moral ou não.

\footnotetext{
${ }^{18} \mathrm{O}$ estudo foi realizado com 540 sujeitos, estudantes de várias escolas públicas e privadas das cidades de Campinas e São Paulo (SP), tanto do sexo masculino quanto do sexo feminino, de três idades distintas: 8, 12 e 16 anos. Das três provas entregues, o sujeito deveria responder a apenas uma, de forma escrita e anônima. Embora possuíssem situações diferentes, envolvendo os valores morais elegidos para a investigação, as provas continham questões com o mesmo roteiro.
} 
A intensidade e o papel de cada regulador, em cada situação que solicita juízos e ações, não se podem prever e estão diretamente relacionados à natureza do conteúdo externo ao sujeito, que pode ser físico e/ou interpessoal e/ou sociocultural.

Seguindo a intuição da complexidade envolvida nas regulações exercidas pela afetividade no funcionamento psíquico, Araújo (2007) passou a trazer elaborações a respeito dos valores. O autor indica, com base na definição exposta por Piaget (1954), que os valores referem-se a trocas afetivas que o sujeito realiza com o exterior. Surgem da projeção de sentimentos positivos sobre objetos, e/ou pessoas, e/ou relações, e/ou sobre si mesmos.

Para Araújo, valores e contravalores (que são resultados de uma projeção negativa sobre objetos e/ou pessoas, e/ou relações, e/ou sobre si mesmos) vão sendo construídos pelo sujeito e vão se organizando em um sistema de valores a partir do qual se incorporam à identidade das pessoas, nas representações de si que elas fazem.

Sobre esse aspecto, encontra-se, no trabalho de Damon, o livro Greater Expectations (1995), uma discussão importante que, inclusive, serviu de base para as articulações realizadas por Araújo. Nesse livro, o autor aborda o processo de desenvolvimento do self e sua relação com a moralidade.

Nos primeiros anos de vida, o self é composto de uma coleção de características superficiais separadas, sem relação umas com as outras. No decorrer da infância, ele é compreendido em comparação com os outros, da mesma forma que a criança passa a perceber o que é certo e o que é errado. Já no final da infância, ao tomar consciência a respeito das conexões entre o self e a moralidade, as crianças passam a entender como podem afetar as outras pessoas e começam a perceber que uma pessoa deve se sentir mal quando age ao contrário de seu princípio moral. Na adolescência, o sujeito se propõe a projetos e filosofias pessoais através dos quais organiza o seu self, o que pode levá-lo a refletir sobre os objetivos morais de sua vida.

Partindo desse escopo sobre como o self se desenvolve em relação à moralidade, é possível perceber que, nessa construção da personalidade, o self não precisa, necessariamente, estar vinculado aos valores morais. Damon, nessa perspectiva, aposta que, para alguns sujeitos, os valores morais são, desde a infância, centrais na concepção que têm de si, enquanto que para outros, esses valores constituem-se como periféricos em relação ao que pensam ser.

Com esse trabalho, Damon dá indicações a respeito da complexidade que perfaz as relações entre a moralidade e o self, já que engloba, em sua teorização, não apenas valores com conteúdos morais, mas tudo o que se mostra importante para o sujeito. Ademais, leva- 
nos a criar uma imagem interessante a respeito do posicionamento dos valores no sistema moral dos sujeitos.

Araújo (2005) aproveita a imagem criada por Damon a respeito dos valores centrais e periféricos e, ressaltando que o sistema de valores do sujeito se organiza de maneira bastante complexa, indica como fator determinante para o posicionamento desses valores a carga afetiva que a eles se dirige.

O posicionamento dos valores como centrais ou periféricos, em sua perspectiva, é extremamente flexível, variando, sobremaneira, de acordo com os meios físico, interpessoal e sociocultural. Portanto, um mesmo valor pode ser central ou periférico, dependendo da situação na qual o sujeito se encontra. Se, por exemplo, um sujeito é extremamente honesto em suas relações familiares, tendo a honestidade como um valor central, no pagamento de impostos, pode sonegar e ser desonesto, tendo esse mesmo valor como periférico.

Com as trocas interpessoais e a intelectualização dos sentimentos, os valores são organizados a partir de julgamentos de valor que o sujeito realiza. Dessa maneira, de acordo com Araújo (2007), constitui-se o sistema de valores de cada sujeito. Ou seja, a construção de valores pressupõe uma ação do sujeito.

Ainda consoante os estudos desse autor, dependendo dos valores com os quais o sujeito construiu sua identidade, e de seu posicionamento central ou periférico, aparecerão os sentimentos morais, que, tais como a vergonha e a culpa, exercem o papel de reguladores. Muitos estudos têm se dedicado a tais sentimentos, denominados como autoconscientes (selfconscious emotions) pelo seu caráter regulatório (ARAÚJO, 2003a, 2007; DE LA TAILLE, 2002; BARRET, 1995). Esses estudos têm dissertado sobre o comparecimento de sentimentos como a vergonha e a culpa quando os sujeitos realizam julgamentos ou ações morais que infrinjam valores que possuem como centrais em sua identidade moral.

Em nosso trabalho anterior (PINHEIRO, 2009), procuramos estudar os valores e os sentimentos morais, buscando relações entre a generosidade e os sentimentos de vergonha e culpa. Apresentamos a jovens estudantes de escolas públicas e particulares da cidade de São Paulo $^{19}$ um conflito envolvendo a generosidade. Nessa situação, foi descrita uma pequena narrativa em que um dos protagonistas solicitava ajuda a outro para estudar para uma prova. Esse outro personagem tinha compromisso com uma garota ${ }^{20} \mathrm{e}$, por fim, não auxilia o amigo. Diante desse contexto, questionamos aos sujeitos se sentiriam vergonha ou culpa caso

\footnotetext{
${ }^{19}$ Participaram 160 estudantes, com equilíbrio da amostra masculina e feminina.

${ }^{20} \mathrm{O}$ mesmo conflito foi apresentado em duas versões (masculina e feminina), com o intuito de aproximá-lo dos jovens participantes.
} 
atuassem como o protagonista da história e analisamos os modelos organizadores aplicados. Os resultados mostraram que grande parte dos jovens participantes da pesquisa tendeu a apresentar a generosidade e manifestou sentimentos morais de culpa e vergonha, confirmando o papel regulatório desses sentimentos.

Além disso, observamos que a generosidade esteve vinculada a outro valor: a amizade. Quando o vínculo de amizade não foi abstraído pelos sujeitos, eles visaram a integrar outros valores como responsabilidade e prazer pessoal ${ }^{21}$. Percebemos que a centralidade e a integração assumidas pela generosidade e a amizade constituía uma forte regulação. Assim, quando a amizade era valorada de forma central, se integrava à generosidade, fortalecendo-a. Quando outros valores como responsabilidade ou prazer pessoal compareciam às respostas, a generosidade não era articulada, mostrando-se ora periférica na organização do sistema moral dos sujeitos, ora inexistente.

Tal descoberta ainda necessita de maiores suportes empíricos, mas evidencia um percurso interessante para avanços no campo da psicologia moral. Nossa hipótese é de que a integração entre os sentimentos morais e os valores de amizade e generosidade possa se dar também com outros valores e sentimentos. No campo dos valores, não apenas de conteúdo moral, mas também todos os outros oriundos de desejos, crenças, objetivos, pensamentos e saberes dos sujeitos. No campo dos sentimentos, não circunscritos somente aos sentimentos morais de culpa e vergonha, mas outros, positivos e negativos, que referendam ou não a organização do funcionamento moral do sujeito.

Esboçamos essa ideia em um ensaio publicado na Revista Brasileira de Educação (2011) a respeito dessa hipótese e os valores preconceituosos.

Tal teoria explicaria o porquê de algumas pessoas tenderem a juízos preconceituosos enquanto outras não. Os valores, ao se integrarem, acabam por rechaçar outros, com os quais não possuem tanta "afinidade". Explicando de outra maneira, se um sujeito elabora o preconceito contra negros e o preconceito contra homossexuais como valores centrais, tal organização psíquica fortalece juízos preconceituosos que podem levar o sujeito a recusar outros valores em seu sistema moral, como os valores de igualdade, tolerância e justiça. (PINHEIRO, 2011, p. 225)

Essa ideia encontra eco em um trabalho atual promovido por Moreno Marimón e Sastre (2010). Com um livro dedicado ao amor, as autoras elaboram uma conceituação a

\footnotetext{
${ }^{21}$ Consideramos o prazer pessoal como valor, pois estamos de acordo com as teorias que postulam como valor aquilo para o qual projetamos sentimentos positivos.
} 
respeito desse sentimento que pode trazer indicações para a reflexão acerca de outros sentimentos e também dos valores.

Segundo Moreno Marimón e Sastre, o amor não é um sentimento isolado, mas um complexo de sentimentos inserido em um contexto emocional e social, o qual abriga uma série de sentimentos e pensamentos de ordem muito distinta.

Em suas palavras,

É perfeitamente compreensível que alguém possa amar sua esposa ou esposo, sua mãe ou seu pai, seu filho ou filha, um amigo ou amiga, seu cachorro, a música ou a filosofia, e parece evidente que todos esses amores, que não são incompatíveis entre si, são de diversas índoles e proporcionam estados de ânimo muito diferentes. Entretanto, é o caráter polissêmico da palavra que faz com que se possa considerar algo mais do que um sentimento, considerar uma multiplicidade de sentimentos que estão estreitamente associados a cada uma das diferentes formas de amor. (MORENO MARIMÓN; SASTRE, 2010, p. 19, tradução nossa)

Destarte, para as autoras, é necessário interpretar o amor como um complexo de sentimentos, uma vez que ele contém uma grande variedade em si e não comparece de forma isolada, necessitando do acompanhamento de outros sentimentos associados, de acordo com o vínculo, com o status da relação e com o tipo de amor a que estejamos nos referindo, ou todos esses aspectos ao mesmo tempo.

Transpondo essa percepção a respeito do amor a outros âmbitos do funcionamento psíquico, Moreno Marimón e Sastre (2010) citam a necessidade de pensar os sentimentos, pensamentos e operações mentais como aspectos integrados, como sistemas que atuam dentro de um conjunto que lhes confira sentido, e nunca de uma forma isolada. Assim, qualquer sentimento agrega outros sentimentos que formam sistemas e configuram o sentimento em foco. Deve-se, consoante às autoras, preferir mencionar os termos "conjunto de sentimentos" ou "complexo emocional" (ou de emoções), mais do que emoção ou sentimento de forma isolada.

É importante, nesse ínterim, frisar a necessidade de contextualização, tanto do conhecimento quanto do sentimento. Para Moreno Marimón e Sastre (2010), a descontextualização precisa ser realizada somente para que seja possível ao sujeito perceber o que parece difícil diante de uma situação complexa, já que se faz necessário isolar o fato para simplificá-lo e compreendê-lo de forma mais adequada ao nosso sistema primário de pensamento. Depois desse momento, é possível reincorporar mentalmente o que foi simplificado ao conjunto de que forma parte e começar a vislumbrar as inter-relações que estabelece em seu entorno. Dessa forma, podemos afirmar, na concepção das autoras, que o 
contexto emocional é capaz de modificar determinado sentimento. Em outras palavras, todas as emoções implicadas nesses sentimento exercem uma pressão capaz de convertê-lo em algo diferente - seja de uma forma circunstancial ou permanente. Essa é uma das razões para que os sentimentos evoluam e mudem com o tempo, assim como adquiram, ocasionalmente, matizes diferentes que induzem a ações inesperadas.

Chamamos "contexto afetivo-emocional" a todos os sentimentos, emoções e pensamentos que rodeiam ou formam parte de um determinado sentimento, conferindo a ele um significado particular, devido, precisamente, à rede de inter-relações que se dá entre todos eles. Não existem sentimentos se não estão associados a pensamentos que lhes conferem a sua característica. (MORENO MARIMÓN; SASTRE, 2010, p. 22, tradução nossa)

Seguindo essa ideia, emoções, sentimentos e pensamentos constituem o que as autoras chamam de um tecido intra e interconectado que se ativa de maneira simultânea.

[...] Ao pensar ou ao ver uma pessoa com quem tivemos uma intensa relação afetiva, não experimentamos "amor" (como somente um sentimento), mas se ativa todo um conjunto ou sistema de emoções e pensamentos que podem nos provocar alegria, prazer, bem-estar e ilusão, mas também inquietude, dor, nostalgia, pena ou mal-estar, ou até uma mescla de todos esses sentimentos, dependendo do lugar que esse conjunto ocupe em nossa vida ou da relação que temos com aquela pessoa naquele momento. (MORENO MARIMÓN; SASTRE, 2010, p. 22, tradução nossa)

Defendemos que tal proposta a respeito do amor possa ser adequada para analisar outros sentimentos e também os valores. Moreno Marimón e Sastre (2010) trazem, em nosso entender, um avanço considerável ao refletir acerca da complexidade que envolve os sentimentos e suas inter-relações com outros aspectos que circunscrevem a dinâmica de nosso psiquismo.

Baseando-nos nas ideias dessas autoras, percebemos que tanto os valores quanto os sentimentos não podem ser entendidos como algo em si, mas como teias de implicados aspectos que concernem tanto aos princípios, regras e ao outro, quanto aos desejos, vontades, sentimentos, pensamentos e objetivos pessoais. Nossa aposta é a de que, diante de um contexto moral determinado, lançamos mão de uma série de aspectos afetivos e cognitivos de uma só vez, em um processo altamente complexo. Esses aspectos, implicados tanto na nossa identidade moral, quanto nos elementos contextuais, vão se regulando e se organizando por meio de sua integração no sistema moral.

O caminho traçado neste capítulo, para chegar a essa hipótese, evidenciou aspectos importantes para a compreensão sobre os processos de integração e regulação de valores, que 
nos serão úteis para a discussão de nossos resultados. Entender a moralidade dentro de um espectro que a considera como parte fundante da identidade de um sujeito real, que possui sentimentos, pensamentos, crenças, objetivos e desejos, em interação com o meio sociocultural, constitui-se em uma perspectiva que proporciona a possibilidade de verificar a organização do pensamento pelo viés do seu funcionamento, nos processos que lhe subjazem. Nesse ínterim, tomam proporções significativas para a análise do funcionamento psíquico no tocante à moralidade, as seguintes descobertas relativas à integração da moralidade ao self: a) a identidade moral compõe-se de valores que, integrados, levam o sujeito à individuação e à diferenciação perante dos demais; b) a forma como as situações vivenciadas, dentro de um conjunto que envolve conteúdos do contexto, configuram, juntamente aos aspectos de identidade, elementos fundamentais para a elaboração de juízos e ações morais; c) a dinâmica que envolve tal elaboração mostra-se extremamente complexa, evidenciando a imbricação entre diversos aspectos que permeiam a constituição do self, no que tange à consciência e à não consciência, e suas relações com o meio. Outrossim, mostra-se importante, conforme expusemos, entender que a organização do dinamismo do funcionamento psíquico frente a conteúdos de cunho moral, possui como norte processos de integração e de regulação entre valores e sentimentos.

Entendendo o estudo de tais processos como fundamentais para avanços na área de Psicologia Moral, empreendemos nossa investigação com enfoque nos valores e sentimentos dos projetos de vida dos jovens. De forma a assegurar uma maior compreensão sobre essa temática e sobre os participantes da pesquisa, no próximo capítulo teceremos considerações sobre as relações entre juventude, projeto de vida e moralidade. 


\section{CAPÍTULO II \\ JUVENTUDE, PROJETO DE VIDA E MORALIDADE}

Vimos, até o presente momento, procurando encetar uma visão sobre a regulação e a integração entre valores e sentimentos dentro do espectro de complexidade que envolve o sujeito psicológico. Tal visão apenas se pode consumar no prisma de um estudo funcionalista, em que se busca perceber os processos que são tecidos por detrás dos juízos e das ações morais.

Nesse viés funcional, há de se enfocar o sujeito real, com seus sentimentos, angústias, desejos, ideais, valores, crenças, pensamentos etc., bem como o meio com o qual interage, visto que é nessa interação que as situações, quando de cunho moral, lhe exigirão a mobilização de valores e sentimentos em interlocução constante com outros sistemas que o compõem.

Pertinente se faz, portanto, enveredar para uma discussão sobre quem é esse sujeito e de que forma interage com o conteúdo que lhe propomos na presente investigação. A priori, devemos destacar que, em nosso recorte investigativo, decidimos compor uma amostra de sujeitos, entre 15 e 19 anos, estudantes do Ensino Médio de escolas públicas das cinco regiões brasileiras, buscando estudar o papel regulatório e de integração de valores e sentimentos em seus projetos de vida. Portanto, compreendemos que, de forma a contextualizar esses sujeitos, faz-se mister debruçarmo-nos sobre a temática da juventude e dos projetos de vida, no que tange à moralidade humana.

De acordo com a Organização das Nações Unidas (ONU), são considerados jovens os sujeitos na faixa etária compreendida entre 15 e 24 anos. No Brasil, instituições como o IBGE fundamentam-se também nesse critério, admitindo-se, contudo, variações em função das situações sociais e das experiências individuais dos sujeitos (FREITAS, 2005).

Convém destacar que adotamos a delimitação trazida por Sposito (2003) que, em texto sobre dados relativos aos jovens brasileiros, reconhece a dificuldade de uma definição da categoria juventude que compreenda a particularidade de todos os sujeitos e realiza um “"[...] recorte operativo que inclui nessa definição ampla de juventude os adolescentes (entre 15 e 19 anos) e os jovens propriamente ditos (entre 20 e 24 anos) ${ }^{22 \%}$. Assim, consideramos a

\footnotetext{
${ }^{22}$ Em estudo recente (2009) que procurou abordar o estado da arte sobre juventude na pós-graduação brasileira de 1999 a 2006, Sposito indica o caráter instável das delimitações etárias. Segundo a autora, já existe um debate público em nosso país para um recorte para além dos 24 anos, o qual foi consolidado em muitos países europeus. Ainda se faz necessário ressaltar, para Sposito, que os recortes demográficos exprimam, também, o conjunto de definições em disputa na esfera pública em torno do que é ser jovem.
} 
adolescência como período inicial da juventude, a qual é vista como uma categoria mais abrangente.

Nosso estudo incide, pois, sobre os adolescentes. No entanto, sendo o termo adolescência prioritariamente empregado pelos estudos psicológicos, vemos que há certo posicionamento de trabalhos, de diversas áreas, incluindo de psicologia (COIMBRA; BOCCO; NASCIMENTO, 2005; PÁTARO, 2011) levantando restrições ao seu uso, principalmente pela tradição dessa área em tratar das fases da vida de uma forma rígida, estrutural, hierárquica e "sem corpo".

[...] A noção de adolescência emerge inteiramente vinculada à lógica desenvolvimentista, sendo uma etapa do desenvolvimento pela qual todos passariam obrigatória e similarmente. A psicologia, ou melhor, o pensamento psicológico que naquele momento predominava foi responsável por instituir algumas características que seriam inerentes a essa etapa da vida, com seus tempos e atributos específicos, diferenciando sujeitos normais e anormais de acordo com o grau de aproximação às normas estabelecidas para cada período. (COIMBRA; BOCCO; NASCIMENTO, 2005, p. 35)

Muito embora saibamos da correção terminológica do vocábulo adolescentes para o presente estudo, evitaremos, assim, o seu uso, tratando os sujeitos participantes de nossa investigação como jovens, para que possamos evidenciar nossa proposta de referendar um olhar para o sujeito e suas particularidades.

A decisão por abordar os processos psicológicos dos jovens referentes a regulação e integração de valores e sentimentos deu-se devido às suas formulações a respeito dos projetos de vida, que entendemos como uma elaboração psíquica tocante a essa fase da vida. Alguns estudos em psicologia moral (PIAGET, 1964; INHELDER; PIAGET, 1970; BLASI, 1993, 2004; DAMON, 1995, 2003, 2009) abordam o desenvolvimento da moralidade em separado do self até a adolescência, quando os dois sistemas se uniriam. A adolescência seria o momento de integração da moralidade e self e quando o sujeito teria autonomia para construir seu projeto de vida.

No próprio campo da psicologia moral, algumas teorias têm tecido críticas a essa visão por considerarem que o sujeito, em toda a sua trajetória de vida, lida com a moral de forma integrada à sua identidade (NUCCI, 2004; TURIEL, 2002; NARVAEZ; VANDRICH, 2008). Nesses estudos, de forma geral, observou-se que os sujeitos, desde tenra idade, reconhecem a moral nas situações cotidianas e elaboram esquemas e protótipos que se tornam acessíveis diante dos contextos morais. 
Ainda que tenhamos ciência sobre essa integração da moralidade ao self, não podemos deixar de imaginar a questão de projetos de vida como um construto que se inicia na adolescência. Para nós, torna-se significativo, ao formular um conceito sobre projeto de vida, perceber quem é o jovem, em que contexto está inserido, que elementos abstrai desse contexto e de que forma constitui sua identidade para que, então, possamos articular tais conhecimentos com seus processos funcionais em relação aos valores e sentimentos de suas projeções futuras.

Não encontramos, na psicologia moral, esse enfoque para os projetos de vida. Por esse motivo, debruçaremo-nos, a priori, em uma breve abordagem sobre a identidade dos jovens, envolvendo, sobretudo, as suas trajetórias e projeções para o futuro, com uma base não somente, mas em grande parte em estudos da sociologia. Ainda com base nesses estudos, traremos também algumas considerações sobre a situação juvenil no Brasil (já que nossa amostra constitui-se de jovens das cinco regiões sociopolíticas brasileiras). Acreditamos que essa abordagem poderá oportunizar uma interlocução com o conceito de projeto de vida, facilitando a compreensão dos valores e sentimentos nele mobilizados pelos jovens.

\subsection{Juventude: identidades e trajetórias na contemporaneidade}

A intenção de abordar o papel de integração e regulação dos valores e sentimentos nos projetos de vida dos jovens leva-nos, necessariamente, a questionar sobre a juventude e sobre a constituição da identidade, que, conforme abordamos em capítulo anterior, refere-se a um complexo, dentro do qual se encontra a moralidade em inter-relação constante com outros aspectos do psiquismo humano.

O presente tópico desse capítulo destinar-se-á a discutir a respeito da construção identitária dos jovens. Acreditamos que, nesse momento de nossa abordagem teórica, será necessário extrapolar, além dos estudos da psicologia, trabalhos da área de sociologia, pois trazem alguns aportes bastante interessantes, os quais podem subsidiar nossas análises posteriores a respeito dos projetos de vida.

Um dos estudos fundamentais a respeito da construção da identidade foi elaborado por Erik Erikson (1976) no campo da psicanálise, com grande repercussão nos estudos de várias áreas do conhecimento. Erikson entende a identidade como um processo localizado no âmago do indivíduo e também no núcleo central de sua cultura coletiva. A construção da identidade, para ele, constitui-se em um processo inconsciente. 
[...] processo de reflexão e observação simultâneas, um processo que ocorre em todos os níveis do funcionamento mental, pelo qual o indivíduo julga a si próprio à luz daquilo que percebe ser a maneira como os outros o julgam, à luz do modo como se percebe a si próprio em comparação com os demais e com os tipos que se tornaram importantes para ele. (1976, p. 21)

Assim, de acordo com Erikson, a constituição da identidade se dá ao longo da vida, a partir de diferentes pressões exercidas pelo meio sociocultural, pressões que ocasionam conflitos e crises no sujeito. Em cada estágio do desenvolvimento, o sujeito deve buscar uma solução para as crises que vivencia. Dessa forma, o senso de identidade vai sendo aos poucos estabelecido.

É no estágio da adolescência, entretanto, que o processo tem sua crise normativa e "é determinado de múltiplas maneiras, pelo que ocorreu antes, e determina grande parte do que ocorrerá depois" (ERIKSON, 1976, p. 22). Consoante ao autor, a adolescência é um período tumultuoso, em que o ser humano integra e consolida sua identidade, além de contar com o desenvolvimento fisiológico e a maturidade mental. Esses elementos servirão de subsídios para que o sujeito seja capaz de ultrapassar a crise de identidade e lidar com as próximas crises em seu desenvolvimento. A adolescência, destarte, é uma passagem, que integra os elementos de todas as demais crises, reproduzindo aquelas vivenciadas durante a infância, ao mesmo tempo em que fundamenta as crises dos próximos três estágios.

Para Erikson,

A adolescência é a última fase da infância. Contudo, o processo adolescente só está inteiramente concluído quando o indivíduo subordinou as suas identificações da infância a uma nova espécie de identificação, realizada com a absorção da sociabilidade e a aprendizagem competitiva com (e entre) os companheiros de sua idade. Essas novas identificações (...) forçam o indivíduo jovem a opções e decisões que, com um imediatismo crescente, levam a compromissos para toda a vida. (1976, p. 156)

Em consequência dessa análise, Erikson propõe o conceito de moratória, para identificar a adolescência como um período de latência entre a infância e a vida adulta, durante o qual o sujeito pode aguardar e se preparar para assumir posteriormente os papéis da vida adulta impostos pela sociedade. É nesse sentido que os conflitos vivenciados atendem não só a uma dimensão individual e biológica, mas evidenciam, no desenvolvimento humano, seu caráter social, pois é necessário que o sujeito consolide sua identidade a partir daquilo que a sociedade espera dele.

As ideias de Erikson ressoaram grandemente nos estudos sobre o conceito de identidade e, ademais, naqueles que incidiram sobre a juventude. Tal estudo foi muito 
importante no sentido de chamar a atenção para a problemática da juventude e sua relação com a identidade, além de levar em consideração o papel do social acerca dessa relação. No entanto, embora saibamos da importância desse trabalho para as discussões que se seguiram a partir de suas considerações, reconhecemos que a perspectiva de Erikson também corroborou para uma imagem da juventude como uma etapa da vida confusa, problemática e conflituosa.

Além disso, não é possível deixar de relacionar esse trabalho com a corrente tradicional da psicologia que, como vimos anteriormente, determina o desenvolvimento em etapas, já que a adolescência seria um estágio inserido em um percurso predeterminado pelo qual todos os sujeitos devem passar em direção à idade adulta. A análise de Erikson traz um sujeito ideal, destituído de características pessoais, que adquiriu, nas etapas anteriores, os requisitos para o pensamento autônomo e para a vida adulta.

$\mathrm{Na}$ psicologia, encontramos estudos que tecem críticas à formulação de Erikson, essencialmente de autores da psicologia sócio-histórica (COIMBRA; BOCCO; NASCIMENTO，2005; OZELLA，2003; OZELLA; AGUIAR，2008; BOCK，2004, OLIVEIRA, 2006, entre outros). Embora não sigamos os construtos teóricos da psicologia sócio-histórica, vemos nesses estudos uma concepção da adolescência como uma categoria historicamente construída, fruto de significações fundamentadas em uma realidade social e histórica determinada.

Não adentraremos nas considerações dessa área da psicologia, a despeito de reconhecer seus avanços, pois nossa intenção não está em referendar as críticas a respeito da construção do conceito de adolescência, mas ampliar esse espectro para as vivências juvenis, buscando suporte para uma concepção acerca dos projetos de vida. Para tanto, encontramos na sociologia alguns estudos que podem trazer elementos que venham ao encontro das expectativas da presente investigação.

Nesses estudos, encontramos uma crítica a uma concepção de juventude como uma categoria única, levando em consideração o momento atual em que os jovens se inserem. Margulis e Urresti (1996) sinalam para uma concepção de juventude como uma categoria socialmente construída, que se refere a uma multiplicidade de situações sociais em que essa etapa da vida se desenvolve. De acordo com os autores, que partiram de uma contraposição a uma entrevista concedida por Bordieu em 1978 (A juventude é apenas uma palavra ${ }^{23}$ ), o melhor seria não falar de juventude, mas sim de juventudes, devido à diferenciação social, das diferenças de classes e de segmentos sociais.

\footnotetext{
${ }^{23}$ Entrevista a Anne-Marie Métailié, publicada em Les Jeunes et le premier emploi, Paris, Association des Ages, 1978, que obteve grande repercussão no meio acadêmico.
} 
Sem adentrarmos na discussão sobre a leitura que os autores fazem do texto clássico de Bordieu, interessa-nos a crítica que tecem a respeito dos estudos sociológicos que entendem a juventude como um período em que a sociedade concede tempo para os jovens postergarem responsabilidades, como casamento, filhos, trabalho etc., ou seja, a crítica que destinam ao conceito de moratória, proposto por Erikson, na atualidade.

Para Margulis e Urresti (1996), o conceito de moratória implica entender a juventude somente como signo, isto é, como uma construção desengajada de outras condições, desvinculada de condições materiais e históricas que condicionam seu significante.

Endossando essa perspectiva, Sposito (2003) aponta que é necessário, ao tratar do conceito de juventude, tomar cuidado com sua definição, já que, por um lado, trata-se de uma categoria social e histórica e, por outro, diz respeito a uma condição experimentada de maneira singular pelos indivíduos. A autora informa que tal tensão pode ser resolvida com a distinção entre condição juvenil - o modo como a sociedade constitui e atribui significado a esse momento da vida (dimensão histórico-geracional) - de situação juvenil - como tal condição é vivida a partir dos distintos recortes referidos às diferenças sociais, de classe, gênero, raça etc.

Segundo Sposito, um traço predominante da condição juvenil nas últimas décadas é o de descristalização dos modelos de transição (circuito família - escola - trabalho). Se antes, a condição de transição para a vida adulta dava-se por meio da aquisição de responsabilidades e da autonomia econômica, via trabalho e constituição familiar, hoje, com as dificuldades de inserção no mercado de trabalho, boa parte dos jovens deve lidar com outros modos de vivenciar e de se constituir como adultos. Tal faceta da atualidade implica, sobretudo, a dissociação no exercício de algumas funções adultas e a latência que separa a posse de alguns atributos de seu imediato exercício.

Para Santos (2009), “a juventude não é percebida apenas como moratória, mas como um momento marcado pela inserção em múltiplas dimensões da vida pessoal e social” (p. 20). Assim, a experiência juvenil passa a ter sentido por si e não somente como uma preparação para a vida adulta.

Contudo, não se pode esquecer que, muito embora devam se referendar as juventudes como vivências significativas em si, elas fazem parte de uma etapa da vida pela qual todos passam. Assim sendo, o enfoque geracional também se mostra como um eixo importante ao se falar de juventude. De acordo com Margulis e Urresti (1998), não se pode ignorar a facticidad, o modo particular de estar no mundo, de se lançar à temporalidade, de experimentar distâncias e durações. Cada sujeito se insere em uma geração e, 
consequentemente, em uma cultura distinta. Pertencer a uma geração significa, necessariamente, apresentar níveis distintos de sensibilidade, experiência e memória.

É inegável, de acordo com essa visão, que os jovens possuem uma moratória vital, em outras palavras, uma espécie de energia que desperta neles um sentimento de distanciamento da morte, como se vivessem um tempo a mais de vida.

Assumem os autores que, tanto o aspecto energético do corpo, a moratória vital, quanto o aspecto significativo, das juventudes, no plano sociocultural, são facetas importantes e integradas, não existindo separadamente.

Ecoando essa integração proposta pelos autores, Sposito sustenta que

[...] a juventude é vivida como um processo definido a partir de uma inegável singularidade: é a fase da vida em que se inicia a busca dessa autonomia, marcada pela construção de elementos da identidade - pessoal e coletiva - como por uma atitude de experimentação. $(2005$, p. 89$)$

Assim, vemos a construção das identidades de uma forma bastante particular, entrelaçando os aspectos pessoais e coletivos, em uma fase marcada pela experimentação. Dessa perspectiva, alguns autores pensam na constituição das identidades inseridas no contexto atual e em como o jovem hoje realiza experimentações que constituem suas trajetórias.

Para Melucci (2007), a juventude dos dias de hoje é extremamente complexa, visto que os jovens vivenciam uma gama muito ampla de possibilidades que lhes saltam aos olhos. Nas palavras do autor, o jovem percebe esse excesso por meio de: a) uma expansão dos campos cognitivo e emocional, na medida em que tudo pode ser conhecido, tentado; b) há uma grande possibilidade de reversibilidade de escolhas e decisões; c) ocorre a substituição de construtos simbólicos pelo conteúdo material da experiência (tudo pode ser imaginado). Em suas palavras, dessa maneira, a experiência se perde, pois é invadida e ultrapassada pelo apelo simbólico da possibilidade. A experiência se dissolve no imaginário e o teste da realidade, na sua dureza, produz frustração e tédio. "Um tempo de possibilidades excessivas torna-se possibilidades sem tempo, um mero fantasma de duração" (MELUCCI, 2007, p. 15).

Também compreendendo a modernidade recente como complexa, Pais (2000 e 2001) indica a metáfora do labirinto para expressá-la: uma estrutura social da complexidade inteligente, na qual sentimos o prazer de nos perdermos para utilizarmos a razão para encontrar a saída. Assim como Melucci, o autor aponta que os jovens tendem a negar a vigência da realidade substituindo-a por projeções utópicas e, vivendo em estruturas sociais labirínticas, envolvem-se em trajetórias ioiô. 
O conceito de trajetórias ioiô parece-nos bastante acertado para evidenciar como os jovens sentem a sua vida marcada por inconstâncias, flutuações, descontinuidades, reversibilidades e movimentos de vai e vem. Vários fatores contribuem para a constituição dessas trajetórias, os quais podemos, inclusive, aproximar daqueles destacados por Melucci. São eles:

- uma lógica "experimentalista" que o autor denomina como o "culto da sensação multiplicada", isto é, no campo das relações amorosas e do consumo, a vontade insaciável de experimentar coisas, pessoas etc.;

- princípio de reversibilidade nos processos de transição para a vida adulta. É o tempo do eterno retorno, quando se conquista certo status de vida adulta para depois retornar à juventude, por exemplo quando o filho sai de casa para morar sozinho e, depois, volta para a casa dos pais;

- alongamento da juventude devido ao prolongamento das trajetórias escolares e ao retardamento da entrada no mundo do trabalho;

- jovens tanto seguem o princípio do "tempo contínuo" de entrada para a vida adulta quanto em um tempo cíclico, mágico, do domínio da ilusão. É o caso, por exemplo, do envolvimento com "vícios": computador, manias, ídolos e até mesmo o uso de drogas ilícitas;

- para os jovens, o tempo presente ganha ascendência sobre os tempos futuro e passado. O lema dos jovens seria "viver no presente em função do presente";

- os jovens escolhem, muitas vezes, rotas do cotidiano que são de ruptura e de desvio, em caminhos sinuosos, cheios de obstáculos, buscando contrapor-se à rotina da vida adulta;

- o envolvimento com grupos de pares.

A complexidade das trajetórias juvenis na atualidade e a consequente construção de identidades dos jovens nesses percursos condizem com nossa percepção de um funcionamento psíquico e moral complexo que comporta idas e vindas, flutuações e incertezas. Compreender a incerteza e a fluidez que caracteriza as trajetórias juvenis hoje traz indicações importantes para elucidar como o sujeito psicológico jovem atua nos contextos reais, em que a moralidade se insere. 


\subsection{Condição juvenil no Brasil: alguns apontamentos}

Para alargar a compreensão sobre a juventude que trouxemos no item anterior e, destarte, buscar mais indicadores que possam corroborar a compreensão dos processos de integração e regulação de valores e sentimentos que subjazem os projetos de vida dos sujeitos de nossa investigação, partiremos, no presente item deste capítulo, para a abordagem de alguns aspectos concernentes à forma como têm vivenciado sua condição juvenil no Brasil.

Basearemo-nos em estudos que vêm tratando de índices resultantes de grandes pesquisas com jovens brasileiros. Acreditamos que tais estudos foram capazes de traçar perfis e levantaram a discussão a respeito de ser jovem em nosso país nos tempos atuais, trazendo, para o presente estudo, indicações importantes. Não teremos a intenção de levantar todos os dados referentes aos jovens brasileiros, pois são muitas as facetas investigadas por tais estudos, com temáticas inerentes às situações dessa fase da vida. A ideia deste subcapítulo é incorporar, dentre as análises apresentadas, algumas considerações a partir dos dados coletados que estão estreitamente vinculadas à elaboração de projetos de vida no campo da psicologia moral.

Antes de trazermos os aportes de alguns estudos atuais, sentimos a necessidade de resgatar a tematização social da juventude no Brasil em breve histórico que nos introduza a essa temática. A esse respeito, encontramos no trabalho de Abramo (1997) alguns aportes importantes. Segundo a autora, a juventude ganhou relevo em nosso país na década de 1960, quando os jovens de classe média, do ensino secundário e universitários, mobilizaram entidades estudantis e se engajaram em partidos de esquerda para lutar contra o regime autoritário, assim como abraçaram movimentos culturais que questionavam padrões de comportamento - sexuais, morais, na relação com a propriedade e o consumo. Se, por um lado, essa mobilização jovem gerou respostas violentas e a defesa de uma ordem imposta, por outro trouxe certa esperança de renovação para alguns setores descontentes com o sistema. No entanto, como assinala a autora, mesmo para esses setores, essa geração representava uma energia utópica, que não conseguia levar a cabo efetivamente tal transformação. Somente depois de muito tempo essa geração de 60 foi reelaborada de uma forma positiva, como de jovens idealistas, generosos e criativos, que ousaram sonhar e se comprometer com a mudança social.

Ainda segundo Abramo, na década de 1980 a juventude se mostra de uma forma totalmente oposta a essa geração de 60, assumindo um viés patológico. Era uma geração vista como consumista, individualista, conservadora e indiferente aos assuntos públicos, apática. $\mathrm{O}$ 
problema relativo à juventude passa a ser sua incapacidade de resistir ou oferecer alternativas às tendências inscritas no sistema social.

Nos anos 90, a visibilidade social dos jovens muda um pouco em relação à dos jovens dos anos 80. Os jovens passam a chamar a atenção pelas suas presenças nas ruas, envolvidos em diversos tipos de ações individuais e coletivas. No entanto, a maior parte dessas ações continuava sendo relacionada aos traços do individualismo, da fragmentação e, de forma mais acentuada, da violência e do desvio (meninos de rua, arrastões, gangues, galera, atos de vandalismo etc.).

Abramo sugere que a juventude dos anos 90 é

fruto de uma situação anômala, da falência das instituições de socialização, da profunda cisão entre integrados e excluídos, de uma cultura que estimula o hedonismo e leva a um extremo individualismo, os jovens aparecem como vítimas e promotores de uma "dissolução do social". O pânico, aqui, se estrutura em torno da própria possibilidade de uma coesão social qualquer. (1997, p. 32)

Dessa forma, ainda consoante a autora, os jovens incorporam os dilemas e as dificuldades da sociedade em que estão inseridos, sendo vistos como "encarnação de impossibilidades". Isto quer dizer que eles não estão sendo vistos, ouvidos e entendidos como sujeitos que apresentam suas próprias questões, para além dos medos e esperanças dos outros. Eles permanecem, assim, como "semi-invisíveis", apesar da sempre crescente visibilidade que a juventude alcançou na sociedade, principalmente nos meios de comunicação. Dessa ótica, o jovem brasileiro pode ser significado como emblema dos problemas sociais, levandonos a não enxergá-lo e entendê-lo propriamente.

Na conjuntura dos jovens brasileiros dos anos 90, Abramo afirma que é uma geração cuja imagem assusta e ameaça a integridade social. Por um lado, constituem-se como vítimas do processo de exclusão profunda que marca a sociedade, por outro, inserem-se no aprofundamento das tendências de individualismo e hedonismo, comportando-se de forma desregrada e amoral. Essa visão acerca do jovem brasileiro torna-o objeto não apenas de medo, mas também de compaixão e de esforços para salvá-lo da situação em que se encontra. Dificilmente, nessa lógica, esse jovem é capaz de qualquer ação propositiva, como real interlocutor para decifrar os significados dessa abordagem sobre ele.

Esse resgate histórico promovido por Abramo faz-se fundamental para compreender a visibilidade da juventude na sociedade brasileira, mostrando-se ainda bastante atual, já que há uma visão sobre os jovens como "problemas sociais", ora de quem a sociedade tem de se proteger ora a quem ela deve acolher. Segundo Camarano et al. (2004), “os jovens não entram 
na agenda das políticas públicas como 'problemas políticos', como atores passíveis de participação, entendimento e diálogo, permanecendo ainda como “estado de coisas"” (p. 3).

Em estudo sobre a transição da juventude para a vida adulta, Camarano et al. (2004) salientam que a heterogeneidade do grupo populacional jovem no Brasil está associada às diferenças condicionadas pela sua posição social e de sua família, sua origem, raça e sexo.

[...] Os jovens são indivíduos que estão sendo construídos com base nas suas características pessoais e nas informações, experiências e oportunidades propiciadas pela família e pelo contexto social em que vivem, aí incluídas as políticas públicas. Os contextos diferenciados ampliam ou restringem as possibilidades desses jovens e definem vulnerabilidades diferenciadas. (CAMARANO et al., 2004, p. 6)

Sobre as vulnerabilidades, as autoras apontam que constituem uma exposição potencial maior a riscos de diversas naturezas (sociais, econômicas, políticas, culturais, entre outras), que implicam o enfrentamento de diversos desafios. Tais vulnerabilidades estão presentes nas diversas juventudes, em uma fase em que os sujeitos delineiam muitas de suas características a partir, sobretudo, de conflitos e rupturas. É um momento de buscas e definições, no qual, consoante às autoras, os jovens são obrigados a fazer escolhas sem ter, necessariamente, informações e experiências para fazer opções de vida que irão repercutir em seu futuro ${ }^{24}$.

A transição para a vida adulta, no sentido do que expõem Camarano et al. (2004), não pode ser considerada apenas como a passagem da escola para o trabalho, mas como um processo complexo que envolve a formação escolar, a inserção profissional e familiar, articulando um sistema de dispositivos institucionais e processos biográficos de socialização que interferem na vida das pessoas desde a puberdade.

No estudo sobre os jovens brasileiros, as autoras visualizaram essa transição com base nas relações entre escola e trabalho e a sua posição no domicílio, sendo esse último indicador da saída (ou não) da casa dos pais. Sem adentrar nos dados expostos por Camarano et al., verificamos algumas considerações que puderam ser tecidas a partir dos resultados:

- grande parte dos jovens brasileiros apresenta uma transição tradicional para a vida adulta, com a saída da casa dos pais e residência em novo domicílio,

\footnotetext{
${ }^{24}$ Sobre tal tema, é importante situar a atuação de um grupo de estudos denominado "Juventude: Resiliência e Vulnerabilidade" (originalmente consistia no Grupo de Trabalho da Associação Nacional de Pesquisa e Pósgraduação em Psicologia - ANPEPP). Esse grupo tem se dedicado a empreender pesquisas com jovens de baixa renda para verificar fatores de risco que podem vir a prejudicá-los em seu desenvolvimento, assim como trazer indicações para políticas públicas.
} 
tornando-se chefes (com ou sem cônjuge/com ou sem filhos) e tendo deixado a escola e ingressado no mercado de trabalho;

- novas modalidades de transição estão emergindo, caracterizando-se pela continuidade dos estudos entre os chefes e novos padrões de arranjos familiares, como os monoparentais femininos;

- o aumento da escolarização e a difícil inserção no mercado de trabalho exercem impacto importante no retardo da saída da casa dos pais (as autoras levantam a hipótese de que a transição tem ocorrido mesmo na casa dos pais);

- há uma sugestão de que a "independência econômica” pode não se apresentar como condição única e suficiente para a transição para a vida adulta. Nesse sentido, residir com os pais pode revelar uma relação de dependência em duas direções: dos filhos com os pais e também dos pais com os filhos. A dependência pode ser tanto financeira quanto de suporte afetivo.

Para Camarano et al. (2004), os resultados evidenciaram a multiplicidade de situações em que as transições para a vida adulta podem ocorrer. Dessa forma, os processos são marcados por trajetórias nãolineares das fases da vida, ocorrendo também em novos arranjos familiares que não passam necessariamente pela saída da casa dos pais e supondo possibilidades de reversão.

Nesta mesma linha de pensamento, Abramo (2005) defende que houve modificações nos processos de transição para a vida adulta, trazidas em grande parte pelas mudanças no mundo do trabalho e nas possibilidades e padrões de inserção no "mundo adulto". Assim também encontramos em Sposito (2003) a indicação, como pano de fundo, de uma relativa descronologização do percurso das idades, e uma dificuldade de inclusão plena no mercado de trabalho. Dessa forma, a entrada no mundo adulto se faz cada vez mais tarde, estendendo mais o tempo da juventude, segundo etapas variadas e desreguladas, sem uma linearidade padrão.

Em estudo que analisa resultados sobre a juventude no Brasil, Abramo (2005) reconhece que os jovens de nosso país vivem essa etapa no seio da família de origem, contando com sua estrutura (material e afetiva). Como elementos destacados pelos jovens, encontram-se estudo, trabalho e diversão, experiências que variam em forma, grau e qualidade com que são vividos, consoante às desigualdades de idade, gênero e classe.

De acordo com Abramo, uma das distinções que devem ser apontadas está nas atividades dominantes entre adolescentes e jovens. Entre os adolescentes, de 15 a 19 anos, 
predominou o estudo. Para metade desse grupo, o trabalho, como atividade e aspiração, é uma realidade, mas normalmente em condições demasiadamente precárias, "o que reforça a preocupação existente com o dano que tal experiência pode causar no desenvolvimento e trajetória futura dos jovens que assim vivem essa experiência” (p. 67).

Já entre os jovens com mais de 20 anos, o trabalho mostra-se como atividade primordial, enquanto o estudo é usufruído por metade desse grupo. Aqui, o desemprego coloca-se como problemática central.

Um aspecto que se destaca nos resultados encontrados por Abramo é do sentido geral de certa forma compartilhado pelos jovens brasileiros desta geração: um período da vida em que se tem menor responsabilidade que os adultos, principalmente por não se ter formado nova família e, portanto, ter menor carga de encargos financeiros.

Outro traço muito valorizado pelos jovens da amostra refere-se a uma vida alegre e com muito espaço para diversão. Parece à autora que a questão de aproveitar a vida possui mais força do que uma preparação para o futuro. Acrescenta Abramo que

Estudar, ou poder só estudar, é citado por apenas parcela da mostra, e mais fortemente entre aqueles que estão estudando. Talvez porque, também, os sentimentos em relação ao futuro sejam muito ambíguos, sobressaindo dúvidas e riscos, engendrando posturas divididas entre um investimento e cuidado com o futuro e aproveitamento imediato da vida. A entrada no mercado de trabalho não aparece, para a grande maioria dos jovens, como corrosiva dessa "moratória"; o trabalho não aparece como elemento negador desta experiência, mas ao contrário, para muitos deles, como constitutivo desse conjunto. (ABRAMO, 2005, p. 68)

Nesse sentido, a autora expõe que a "moratória" juvenil atual ganha o sentido de uma possibilidade de vivência e de experimentação diferenciada no mundo dos adultos, sem, no entanto, ter a responsabilidade dos adultos. A sexualidade, o estudo, o trabalho e o lazer podem ser vividos com menos compromissos e encargos. Quando não se forma uma família, os vínculos afetivos também são menos definidos (como o ficar), assim como a presença de mais alegria e liberdade nas ações cotidianas.

Por fim, cabe evidenciar, ainda sobre esse estudo, a alta positividade com que os jovens valoram suas vidas, a despeito das diferentes situações e de todos os fatores de dificuldades econômicas e de perspectiva. Abramo supõe que tal positividade decorre da própria possibilidade de viver a juventude como uma experiência positiva.

Sobre os mesmos dados, encontramos a análise de Lassance (2005) que procurou evidenciar a juventude brasileira com base nas diferenças regionais, que se mostram bastante acentuadas no contraste do território do nosso país. Com a intenção de verificar se as 
distâncias entre os jovens das regiões brasileiras eram significativas, o autor buscou as semelhanças e diferenças entre eles.

Lassance averiguou que os jovens de todo país respondem de modo muito semelhante a algumas questões relacionadas às formas como a juventude é vivenciada no Brasil. Os jovens brasileiros, de forma geral, sentem-se satisfeitos com sua saúde física e sexual, bem como apresentam uma visão bastante positiva sobre a sua vida pessoal no futuro e sobre a família. Além disso, o jovem brasileiro vê-se como alguém suscetível a riscos e que, consequentemente, possui responsabilidades e preocupações.

Outro aspecto que predominou nos resultados obtidos na pesquisa com os jovens brasileiros é uma visão frágil sobre a importância política dos processos de representação democrática. Os jovens do Brasil consideram muito pouco a opção de mudar a política nacional.

Ainda como semelhança entre os jovens de nosso país consta a questão do emprego, que é ponderada por eles de uma forma próxima. No entanto, os resultados alertam para a indicação de certo desalento a respeito das chances de se conseguir trabalho e/ou uma acomodação à estratégia de retardar seu ingresso no mercado de trabalho.

As distâncias regionais encontram-se em termos de expectativas. Os jovens de diferentes regiões possuem expectativas distantes relacionadas às melhorias no ambiente em que vivem (bairro) e no mundo. Enquanto nas regiões Norte e Centro-Oeste há um maior pessimismo em relação a essa melhora, há mais otimismo nas regiões Sul, Sudeste e, principalmente, Nordeste.

Há uma grande variação regional quanto a condições de emprego e estratégias para conseguir emprego. Nesse sentido, a disparidade de expectativas diante de um problema considerado nacional pelos jovens indica claramente os problemas do desenvolvimento regional, desigual e combinado, que criam chances bastante peculiares e barreiras difíceis de serem transpostas.

Chama à atenção a avaliação positiva que esses jovens têm a respeito da educação que recebem na escola, que é considerada por eles como uma ponte de acesso ao mundo adulto, apesar da constatação, por grande parte deles, de uma qualidade de ensino precária (a qual praticamente não recebe críticas contundentes desse grupo). Sposito (2005) também constata tal fato, indicando que os jovens consideram a escolarização como uma das possibilidades para se situar melhor no mundo, para além de um ganho imediato com o emprego ou um futuro profissional melhor. 
Ainda sobre a visão do jovem sobre a escola, encontramos em Libório, Coêlho e Castro (2011), em análise de grande coleta de dados com jovens de baixa renda (KOLLER; CERQUEIRA-SANTOS; MORAIS; RIBEIRO, 2005), uma constatação de que os jovens apresentam um nível relativamente baixo de insatisfação com a escola e com os professores. Grande parte dos jovens afirmou querer permanecer na instituição em que estuda e projeta nos estudos a concretização de seus sonhos, planos e suas expectativas de futuro. Devido a esses aspectos, os autores indicam a escola como um espaço de proteção, que apenas não se situa dessa forma, na opinião dos participantes, quando é solicitado o vínculo entre o professor e alunos. Uma parte significativa dos jovens aponta que não confia nos professores e não pode contar com eles.

Sposito (2005) traz a informação de que a expansão da escolaridade e a progressiva retirada da criança e do jovem do mundo do trabalho criaram uma imagem em que a "escolarização faz juventude". No entanto, como nos alerta a autora, tal expansão é recente no Brasil, fazendo com que questionemos a mediação escolar como constituição da juventude.

Os jovens da atualidade não experimentam sua condição juvenil em espaços não escolares e adentram na escola com essas práticas e modos de vida consolidados porque possuem alternativas e desejam preservá-las. Outras agências, além da escola, contribuem para oferecer modelos culturais para a experiência de ser jovem, o que nos leva a pensar a respeito dos múltiplos espaços socializadores.

Ainda para Sposito (2005), os jovens experimentam uma ambiguidade, logo que depositam confiança na escola, em relação ao futuro, mas lhes falta sentido no presente, configurando relações mais difíceis e tensas. Dessa forma, o jovem pode tecer uma relação apenas instrumental com o conhecimento ou se retrair em relação ao seu processo de assimilação.

A autora destaca a importância do mundo do trabalho para os jovens. Em suas palavras, "[...] Sob esse ponto de vista, poderíamos afirmar que no Brasil o 'trabalho também faz juventude' e se torna demasiadamente complexa a construção sociocultural da categoria ‘juventude’ em nosso país sem a sua mediação efetiva e simbólica” (SPOSITO, 2005, p. 124).

A esse respeito, podemos indicar como profícua a análise de Thomé, Telmo e Koller (2011) sobre contexto e opinião dos jovens sobre o trabalho. Analisando uma grande quantidade de dados ${ }^{25}$, as autoras analisaram as opiniões e vivências de jovens trabalhadores e não trabalhadores. Mediante tal análise, possibilitaram a identificação de um quadro de

\footnotetext{
${ }^{25}$ Consiste na mesma amostra do estudo de Libório, Coêlho e Castro (2011), citado nesse mesmo subcapítulo.
} 
fragilidade relacionado ao contexto do mercado de trabalho, já que este se mostra como não favorável aos jovens. Para as autoras, "perde-se de vista que o público juvenil está em processo de formação das suas identidades pessoal e profissional e que o contexto de sua vida particular é influenciado por seu trabalho, bem como o seu trabalho é influenciado por suas vivências pessoais". (THOMÉ; TELMO; KOLLER, 2011, p. 37).

O contexto de trabalho, de acordo com essa investigação, vulnerabiliza o jovem, quando ele se vê diante do trabalho informal, recebe remuneração inferior a um salário mínimo e poucos benefícios, assim como possui dificuldades em economizar o dinheiro recebido, o que o impede ter uma reserva financeira para planos futuros.

Ainda consoante Thomé, Telmo e Koller (2011), ao significarem a palavra "trabalho", os jovens participantes destacaram "produção de algo útil" e "dinheiro", dimensões que podem refletir a busca por um trabalho que construa algo produtivo para o sujeito e a sociedade, sem perder de vista que o trabalho necessita proporcionar condições de sobrevivência para o jovem e para sua família, por meio da remuneração.

Além do trabalho, encontram-se também duas dimensões significativas para os jovens dessa mesma amostra: a família e a religião. Sobre a família, Souza e Oliveira (2011) apontam que é vista pelos jovens como uma "unidade possuidora de recursos e de fatores protetores para enfrentamento de situações de risco" (p. 48). Embora sinalizem as mudanças ocorridas na estrutura familiar brasileira nos últimos anos, mostram que sua função tem se mantido e fortalecido, tornando-se, para os jovens, um valor. Assim, os resultados sinalizaram que, a despeito de, em algumas situações promover risco aos jovens (por exemplo: violência doméstica, uso de drogas ilícitas etc.), a família mantém, aos olhos dos jovens, seu papel de proporcionar segurança, apoio, proteção e limites.

A respeito da religiosidade, Marques, Santos e Dell'Aglio (2011) apresentam essa vertente das respostas coletadas, informando que existem conexões entre a identidade positiva e a religiosidade. Indicam a influência da religiosidade na identidade dos jovens participantes da pesquisa, já que estes se mostram autoconfiantes e com maior conhecimento de si mesmos. No entanto, ressalvam que o envolvimento religioso não pode ser considerado fator protetor de vulnerabilidades, visto que, em certos contextos e frente a características individuais, o impacto da religiosidade no jovem pode ser negativo.

Com base nas análises apresentadas a respeito dos jovens brasileiros, reconhecemos como fundamental, em um estudo sobre esses sujeitos na contemporaneidade, analisar aspectos como trabalho, família e escola, os quais, embora sejam evidentemente tradicionais, assumem novas configurações, principalmente mediante a diversidade não apenas regional, 
mas no tocante a gênero, raça e classe. Embora saibamos que os jovens apresentam singularidades nos modos de vivenciar a condição juvenil, é possível perceber, nessas análises, certas tendências na forma como percebem e se situam na juventude. Por esse motivo, Lassance (2005) considera que se pode afirmar a existência de um "jovem brasileiro" pela aproximação em alguns aspectos substanciais entre os jovens de nosso país, como em seu perfil e em sua autoimagem, mesmo que existam matizes diferenciais relacionadas às expectativas, visões de futuro e estratégias.

As considerações tecidas a respeito do jovem em nosso país oportunizam uma adequação do conceito de projeto de vida à sua realidade, levando em consideração certas tendências reveladas nas investigações que tentaram traçar o seu perfil. No próximo item deste capítulo, abordaremos os conceitos de projeto de vida na perspectiva do que expusemos sobre a juventude e, principalmente, sobre a forma como é vivenciada pelos jovens brasileiros.

\subsection{Projeto de vida e moralidade}

$\mathrm{Na}$ ótica que estamos empreendendo no presente capítulo, buscamos articular uma visão da complexidade do sujeito psicológico, no que tange à moralidade e sua integração à identidade, e uma perspectiva sobre o jovem, objeto de estudo desta investigação. Seguindo tal correlação, partiremos, no presente subcapítulo, para a abordagem sobre projeto de vida e de que forma tal conceito se articula com os aspectos até então abordados.

Como se trata de um conceito novo para o campo da Psicologia Moral, buscaremos, primeiramente, trazer algumas contribuições da filosofia e da antropologia sobre o conceito de projeto. Depois, passaremos a considerações sobre estudos de psicologia que já vêm abordando os projetos de vida na juventude.

\subsubsection{Contribuições de teorias sobre projetos}

Para alicerçar nossa perspectiva sobre projetos de vida, enfocaremos alguns estudos dos campos da antropologia e da filosofia que trazem contribuições sobre o conceito de projeto.

Em primeiro lugar, enfocaremos algumas colocações de Boutinet (1999/2002), em seu livro intitulado Antropologia do projeto, que se mostram pertinentes ao nosso estudo. 
De acordo com Boutinet, a ideia de projeto tem como ponto central a perspectiva de futuro, no que tange à regulação da atividade presente em função daquilo que se almeja alcançar. O futuro, nessa ótica, compromete o presente, como escolha, renúncia ou dedicação. O projeto exige condutas antecipatórias. Em suas palavras,

"antecipar é, em última análise, dar provas de inteligência em relação à
situação presente, ou seja, adotar uma atividade de desvio que permita
melhor reaprender as situações com as quais nos defrontamos, evitar que
essas se imponham a nós de modo coercitivo" (BOUTINET, 1999/2002, p.
70).

Para Boutinet, há fases da vida que são vistas como situações em que existem projetos. Entre essas fases, Boutinet destaca o "projeto adolescente de orientação e de inserção". Citando os estudos de Piaget e Inhelder, o autor enfatiza a utilização do aparelho lógicoformal do jovem, que há pouco fora formado, com o domínio das operações interiorizadas, que pode orientá-lo em relação ao que é abstrato. De acordo com esses estudos, o adolescente tenta, através do projeto, explorar novas relações entre o possível e o real.

O projeto adolescente se configura, segundo o autor, em três perspectivas: escolar, profissional e de vida. O projeto escolar trata-se de um tipo de estudo almejado pelo jovem de acordo com suas opções e habilidades. Ele está relacionado mais às questões de escolarização do que das aspirações individuais. Já o projeto de orientação profissional é realizado a médio prazo, correspondendo a um projeto de inserção socioprofissional. Percebe-se que os estudos chegam a substituir esse projeto temporariamente, garantindo um refúgio, "uma proteção diante do meio pouco envolvente em tempos de crise, em suma, adiando incessantemente o momento de inserção profissional” (BOUTINET, 1999/2002, p. 90). Tanto o projeto escolar quanto o projeto profissional tornam-se uma necessidade cultural e pessoal na atualidade, à medida que os mecanismos de inserção socioprofissional perderam seu automatismo.

O terceiro projeto definido por Boutinet (1999/2002) diz respeito ao projeto de vida, o qual contempla prazo maior para execução e envolve o estilo de vida que o jovem pretende adotar dentro de alguns anos (exemplos citados pelo autor: celibato, vida conjugal, tentativa de casamento, união livre, militância, envolvimento caritativo etc.). Nessa escolha, os jovens tendem a, por escolhas pessoais, não reproduzir os modelos tradicionais, de acordo com uma evolução lenta, porém contínua dos costumes. Os jovens se defrontam com múltiplas referências na escolha de vida, algumas delas permanecendo majoritárias. Sentem, para o autor, a necessidade de conceber um projeto variável, tributário de uma ou de outra dessas referências, mas que questione o modelo tradicional dominante do projeto de vida. Do projeto 
à sua realização, trata-se, evidentemente, de saber se a antecipação será efetivada, transformando esse modelo tradicional ou não. $\mathrm{O}$ projeto de vida, nessa perspectiva, concerne à escolha de um modelo de vida.

De acordo com Boutinet, os três tipos de projetos são parcialmente autônomos e parcialmente imbricados uns aos outros. À luz da complexidade que perfaz o projeto adolescente, escreve o autor

[...] Se o projeto adolescente é hoje em dia valorizado, isso se dá justamente porque nem tudo é evidente, porque a passagem à vida adulta é cada vez mais problemática na solução da continuidade das diferentes faixas etárias e também porque a evolução de nossa sociedade aponta para uma individualização maior dos comportamentos, sem, no entanto, eliminar as imposições que pesam sobre tais comportamentos. [...] o projeto adolescente [...] geralmente obedece a uma injunção contraditória: o ambiente do jovem o incita a saber o que quer fazer mais tarde, a munir-se de um projeto, mas cria imposições tais que impedem a realização de um grande número de projetos adolescentes. (BOUTINET, 1999/2002, p. 91)

Com uma visão próxima a de Boutinet, encontramos no trabalho de Gilberto Velho (1994), também oriundo do campo da antropologia, as inter-relações entre os projetos pessoais e as possibilidades oferecidas pelo contexto em que o jovem atua.

Velho indica que "projeto [...] é a conduta organizada para atingir finalidades específicas" (1994, p. 40). O projeto está, na visão desse autor, imbricado ao campo de possibilidades, que pode ser entendido como uma dimensão sociocultural, um espaço para formulação e implementação dos projetos. As imbricações entre projeto e campo de possibilidades ajudam a análise de trajetórias e biografias enquanto expressão de um quadro sócio-histórico, sem esvaziá-las arbitrariamente de suas peculiaridades e singularidades.

Indicando a existência de um projeto coletivo, Velho (1994) coloca que ele não é vivido igualmente pelos sujeitos que o compartilham. Existem, outrossim, diferenças de interpretação devido a particularidades de status, trajetórias, gênero e geração.

Para Velho,

A multiplicação e a fragmentação de domínios, associadas a variáveis econômicas, políticas, sociológicas e simbólicas, constituem um mundo de indivíduos cuja identidade é colocada permanentemente em cheque e sujeita a alterações drásticas. O trânsito intenso e frequente entre domínios diferenciados implica adaptações constantes dos atores, produtores de e produzidos por escalas de valores e ideologias individualistas constitutivas da vida moderna. (1994, p. 44, grifos do autor)

Desse modo, os projetos individuais sempre interagem com outros dentro de um campo de possibilidades. Não operam, dessa forma, em um vácuo, mas sim a partir de 
premissas e paradigmas culturais compartilhados por universos específicos. Tais projetos são complexos: os sujeitos podem ter projetos diferentes e até contraditórios entre si. A pertinência e a relevância da construção de projetos apenas deve, consoante o autor, ser definida contextualmente.

Velho estabelece que é possível haver mudanças no sujeito, com base na incorporação de projetos pessoais, os quais se distinguem dos existentes como projetos coletivos. Lança mão, para explicar esse fenômeno, do conceito de metamorfose. Pode-se entender, a partir deste, que as trajetórias dos sujeitos ganham consistência com o delineamento mais ou menos elaborado de projetos com objetivos específicos. A viabilidade de suas realizações depende da interação com outros projetos individuais e coletivos, assim como da natureza e da dinâmica do campo de possibilidades.

Os projetos, como as pessoas, mudam. Ou as pessoas mudam através de seus projetos. A transformação individual se dá ao longo do tempo e contextualmente. A heterogeneidade, a globalização e a fragmentação da sociedade moderna introduzem novas dimensões que põem em xeque todas as concepções de identidade social e consistência existencial, em termos amplos. (VELHO, 1994, p. 48)

Desse ponto de vista, Velho indica as imbricações entre projetos individuais e coletivos, entre projeto de vida e campos de possibilidades, ou seja, contextos em que a realização das projeções acerca do futuro poderá ocorrer. Tal apontamento leva-nos a perceber o quanto os projetos são capazes de mudar os sujeitos e de serem mudados por eles.

Assim como no trabalho de Velho (1994), vemos nas considerações de Machado (2004, 2006) uma proposta de compreensão dos projetos que pode colaborar com nossa visão sobre essa temática. Isso porque, em ambas as teorizações, vemos uma observação perspicaz a respeito das transformações que podem acontecer tanto nos projetos quanto nos sujeitos.

Para Machado (2004, 2006), cada ser humano vive a sua vida como um projeto - viver é um contínuo projetar - o que evidencia a necessidade de todo ser humano em buscar algo e, para se manter vivo, estabelecer metas voltadas ao futuro e lançar-se em direção a elas.

De acordo com o autor, quatro são os elementos constitutivos da ideia de projeto, presentes em maior ou menor grau em todos os usos próprios do termo:

1) ter um projeto significa ter metas, ter alvos e se lançar em busca deles, projetar-se em direção a eles;

2) há a referência ao futuro: um projeto é a prefiguração de uma ação a ser realizada futuramente; 
3) pressupõe um futuro aberto, indeterminado, que depende de nossas ações;

4) as realizações prefiguradas em um projeto devem ser realizadas pelo projetante, seja ele uma pessoa, uma equipe, um grupo social ou uma coletividade inteira. Podemos ter projetos juntamente com os outros, mas não pelos outros.

Tais características levam o autor a afirmar que a vida transcorre como um projeto. Nesse sentido, indica que

Desde o nascimento, somos lançados como um jato para a frente (pro jactum), escolhendo metas, constituindo caminhos, articulando trajetórias vitais. [...] Em nosso trajeto, levamos em consideração as balizas que nos orientam no espaço moral, os valores que compõem o cenário de todos os projetos. (2006, p. 60)

A capacidade de projetar pode ser identificada como o traço mais característico da atividade humana. "O modo de ser do ser humano é o permanente pretender ser" $(2004$, p. 8). E, a partir dessa perspectiva, pode-se entender os sujeitos como seres que vivenciam um quadro de valores situados histórica e culturalmente, lançando-se em busca de metas, construindo trajetórias de vida que os caracterizam como pessoas.

Sem projetos, portanto, não existe vida, em sentido humano. Tanto em sentido pessoal quanto em sentido coletivo, a ideia de crise está sempre associada a uma ausência de, ou a uma transformação radical nos projetos que nos mantêm vivos ou nos valores que os sustentam. (MACHADO, 2004, p. 9)

Sendo a capacidade de elaborar projetos o que nos torna verdadeiramente humanos, faz-se necessário destacar que, antes da existência desses projetos, há, segundo Machado, algo que os alimenta. Em sua hipótese, o que leva o sujeito a ter projetos é o fato de ele "ter ilusões", no sentido de que pode imaginar, fantasiar, ter utopias, etc.

Se o que vem antes dos projetos é a ilusão, o que vem depois, nos termos de Machado, é a necessidade de associá-los com procedimentos que visem à implementação das ações em busca das metas antecipadas, bem como de provê-los de avaliação e de trajetórias emergentes, em busca de novas metas. Assim, não basta vontade e improviso, mas são necessárias organização e planejamento das ações. A todo o tempo, é preciso estabelecer metas intermediárias, articular objetivos parciais, conceber indicadores relativos ao cumprimento das metas. 
Além disso, é fundamental verificar que novas metas decorrerão daquelas que foram ou não atingidas. O ser humano realiza permanentemente uma diversidade de projetos, que se articulam tanto simultaneamente quanto de modo sucessivo, configurando uma complexa teia de interesses e ações.

Nesse sentido, é importante destacar que

Mesmo se tratando de projetos de vida, característicos do modo de ser do ser humano, não nascemos determinados para percorrer uma única trajetória de projetos, ou vocacionados para um único tipo de atividade. Movemo-nos permanentemente em um terreno pleno de potencialidades, pleno de apelos que vêm de fora e que devem ser articulados com chamamentos interiores, do fundo do nosso ser. As alternativas, em cada bifurcação da vida, não são aleatórias nem determinadas: escolhemos tão livremente quanto nossa circunstância nos permite e quanto a vocação ditada pelo "fundo insubornável" da pessoa única que somos, nas palavras de Marías. E construímos uma trajetória de projetos absolutamente original, que nos identifica como pessoa. (MACHADO, 2004, p. 16-17, grifo nosso)

Por fim, acreditamos ser pertinente destacar que, para Machado, os projetos individuais ou coletivos são estruturados a partir de uma arquitetura de valores socialmente negociados e acordados, de forma que possam garantir a sua conservação e, ao mesmo tempo, busquem transformações visando ao novo.

As teorias, expostas aqui muito brevemente, trazem indicações de que os projetos articulam-se sobremaneira com o contexto vivenciado por quem os projeta, em um jogo que envolve o individual e o social. Os projetos e as trajetórias deles resultantes não podem, de acordo com tais acepções, serem tomados como formas estáveis, não suscetíveis a mudanças. Pelo contrário, há a abertura para o novo, para a reelaboração de metas, para a concomitância entre projetos, etc.

Apoiando-nos nessa visão, passaremos, no próximo item deste capítulo, à abordagem sobre projetos de vida no campo da Psicologia Moral, tecendo nossas considerações e novos apontamentos sobre esse conceito.

\subsubsection{Projetos de vida no campo da psicologia moral}

Tomando por base o conceito de projeto, conforme vislumbramos no tópico anterior, percebemos que está intimamente relacionado com a constituição do sujeito, em sua complexa construção de identidade, em sua interação com o mundo. A compreensão do conceito de projeto de vida, neste comenos, deve levar em consideração tais apontamentos, 
mas precisa direcionar-se, em sua abordagem pelo viés da psicologia, a aspectos que tocam à constituição do psiquismo humano.

Compreendemos que os projetos de vida comportam diversos aspectos do funcionamento psíquico humano, incluindo a moralidade. Nos projetos de vida, são expressos valores, sentimentos, pensamentos, desejos, ideais, etc. que perfazem a identidade do sujeito e, no caso de nosso estudo, do jovem. De forma a ampliar nossa compreensão sobre os processos de integração e regulação de valores e sentimentos, acreditamos que a análise dos projetos de vida dos jovens pode ser profícua por englobar a moralidade de uma forma complexa, envolvendo aspectos do cotidiano dos jovens e suas projeções para o futuro.

O campo da psicologia vem atribuindo a construção de projetos de vida à adolescência. Para a teoria epistemológica, seria o período no qual se adquiririam as operações formais; para a psicologia moral, seria a época de integração do self à moralidade, bem como da conquista da autonomia no campo moral.

Embora tenhamos ampliado nossas considerações a respeito da juventude, o que justificaria não aderir a essa visão do jovem apenas em sua condição juvenil, ou seja, como etapa de vida, acreditamos ser pertinente trazer algumas visões sobre projetos na lógica de alguns estudos da psicologia. Cremos que tais estudos são importantes por tecerem reflexões bastante inaugurais sobre o conceito de projeto de vida.

A princípio, gostaríamos de trazer a perspectiva piagetiana a respeito dos programas de vida, que acreditamos estar próxima ao conceito de projeto de vida. Ao se debruçar sobre a lógica do adolescente, Inhelder e Piaget (1976) apresentam a ideia de que os sujeitos nessa etapa da vida atingem o pensamento formal e buscam a integração com o mundo, iniciando reflexões sobre o próprio pensamento e partindo para a construção de teorias.

Para os autores, a reflexão permite ao adolescente chegar à projeção, ao campo do possível. Nesse ínterim, fazem-se importantes dois aspectos: o programa de vida e a reforma da sociedade. Tais aspectos revelam a construção de uma identidade inserida no mundo. Em suas palavras:

[...] além da necessidade de participar das ideologias adultas, para ele [o adolescente] é indispensável chegar a uma concepção das coisas que lhe dê a possibilidade de afirmar-se e criar (donde a ligação estreita entre o sistema construído e o programa de vida) e lhe garanta, ao mesmo tempo, que terá mais êxito que seus antecessores (donde as reformas necessárias, onde se misturam da maneira mais íntima as preocupações desinteressadas e as ambições características da juventude). (INHELDER; PIAGET, 1976, p. 254-255) 
Ainda sobre os programas de vida, Inhelder e Piaget (1976) veem nestes uma forma superior de egocentrismo, já que o adolescente, ao pensar no ambiente em que procurará se localizar, pensará suas atividades sociais nesse ambiente social e nos meios para transformálo. Dessa forma, pode ocorrer uma relativa indiferenciação entre seu ponto de vista como sujeito chamado a construir seu programa de vida e o ponto de vista do grupo que ele pretende transformar.

É importante destacar que muitos dos empreendimentos dos adolescentes, segundo os autores, são dotados de uma ambição ingênua de transformação da realidade. Inhelder e Piaget (1976) ressaltam que grande parte dos projetos tem característica transitória e é formulada para que o sujeito busque sua diferenciação dos demais.

Em alguns casos esses tipos de programas de vida têm uma influência real no desenvolvimento ulterior do indivíduo e pode ocorrer que encontremos, em seus papéis de adolescentes, o esboço de algumas ideias que efetivamente desenvolveram mais tarde. Mas em muitos outros casos, os projetos de adolescentes parecem mais uma espécie de jogo superior com funções de compensação, de participação em ambientes realmente inacessíveis, etc. Assim, o adolescente aceita orientações que o satisfazem durante certo tempo, e são em seguida abandonadas. (INHELDER; PIAGET, 1976, p. 256)

Ademais, há uma indicação, por parte dos autores, de que a moralidade, por se situar no campo afetivo, atinge desenvolvimento equivalente às operações formais, chegando ao estádio de autonomia. Inhelder e Piaget (1976) apontam que os adolescentes passam a ter sentimentos pelos seus ideais, assim como constituem sua personalidade ${ }^{26}$. Dessa forma, os programas de vida e a iniciativa renovadora são, nos planos cognitivo e afetivo, essenciais para a construção da personalidade.

O plano de vida é, de acordo com Inhelder e Piaget (1976), uma escala de valores que possibilita organizar os ideais, subordinando-os uns aos outros de acordo com o que considerará permanente. Além disso, constitui autonomia moral, de forma a garantir a ação do adolescente no mesmo plano do adulto.

Sobre projetos de vida, no campo da psicologia moral, faz-se necessário apontar a teoria elaborada por William Damon e demais estudiosos do Stanford Center on Adolescence, sobre o conceito de purpose, que vem sendo empregado no Brasil como projeto vital ${ }^{27}$,

\footnotetext{
${ }^{26}$ Para Inhelder e Piaget (1976), a personalidade constitui-se no "eu” descentralizado. A personalidade é "a submissão do eu a um ideal que encarna, mas que ultrapassa e ao qual se subordina; é a adesão a uma escala de valores, não abstrata, mas relativa a uma obra" (p. 259).

27 No presente estudo, usaremos o termo "projeto de vida", pois vemos que a diferenciação entre este o de "projeto vital" é bastante tênue e nos sentimos mais à vontade com o seu uso.
} 
tradução que compreende tanto o aspecto de uma projeção futura que faz sentido para o sujeito, quanto a importância que assume para a constituição de sua identidade ${ }^{28}$.

Damon (2009) almeja, em suas investigações mais recentes, dedicar-se às formas positivas com as quais os jovens vêm vivenciando a condição da juventude na contemporaneidade.

Esse posicionamento de Damon pode ser explicado porque o autor, em sua trajetória como pesquisador, passou a destacar, em decorrência de trabalhos como de Victor Frankl (1959/1991) e do movimento da psicologia positiva, uma maior ênfase nos aspectos positivos da constituição da identidade, quando os objetivos de vida se unem aos objetivos morais (cf. COLBY; DAMON, 1992). Sobre a juventude, encontra-se na publicação realizada por Damon, Menon e Bronk (2003) uma aposta nos projetos de vida como norte para comportamentos generosos, comprometimento com a moral, realização pessoal e autoestima. Para os autores, esses aspectos positivos dos projetos de vida na juventude oportunizam a emergência de uma identidade moral.

Projeto de vida, consoante Damon, Menon e Bronk (2003), diz respeito a "uma intenção estável e generalizável para realizar algo que é significativo para o self e consequentemente para o mundo além do self' (p. 121, tradução nossa) ${ }^{29}$.

Segundo esses autores, existe uma diferença entre os conceitos de sentido (meaning) e de projeto de vida (purpose), a qual se situa na compreensão de que o projeto de vida relaciona-se a determinados processos psicológicos que não são abarcados pelo conceito de sentido, este último mais genérico e amplo. Assim, por exemplo, o projeto de vida aparece relacionado ao desenvolvimento da identidade, à orientação futura das ações do sujeito, às conquistas, à persistência e à motivação para agir conforme metas e objetivos (DAMON; MENON; BRONK, 2003).

\footnotetext{
28 A tradução de purpose como projeto vital foi apresentada no livro O que o jovem quer da vida? Como pais $e$ professores podem orientar e motivar os adolescentes, publicado em 2009 pela Editora Summus. Na apresentação à edição brasileira, Araújo infere que a melhor tradução para o termo em português corresponde a projeto, esclarecendo que ambos se aproximam no sentido de designar "[...] uma das condições para dar sentido ético à vida das pessoas e à sociedade" (p. 14). No entanto, o termo projeto, por si só, não abarca toda a definição do conceito de purpose proposto por Damon; torna-se necessário, segundo Araújo, especificar a função essencial que tal projeto exerce na vida do sujeito, na medida em que "[...] se torne o centro dos interesses de uma pessoa e seja constituinte de sua identidade" (ARAÚJO, 2009, p. 14). Por esse motivo, na visão do autor, o termo "projeto vital" passa a designar de modo apropriado o conceito que Damon denomina, no inglês, como purpose. Como indicamos na citação n. 27, preferimos o uso da expressão "projeto de vida".

${ }^{29}$ Entendemos a "estabilidade" proposta por Damon e colaboradores como um aspecto concernente ao self, no que diz respeito à construção e à "coerência" de seu sistema de valores. Verificamos que a ideia de plano de vida de Inhelder e Piaget não corresponde à proposta de Damon. Para Inhelder e Piaget, os planos de vida, geralmente, são produtos da tentativa de diferenciação do jovem em relação aos outros, sendo transitórios.
} 
Tendo uma conotação de algo permanente na constituição da identidade do sujeito, embora receba importância a partir da adolescência, o projeto vital reforça-se com sentimentos positivos, como a alegria, nos momentos bons de sua vivência, assim como o dota de resiliência nos momentos difíceis.

Destaca-se, nas pesquisas promovidas por Damon e seus seguidores, o papel do bemestar no engajamento em um projeto de vida. Nas formulações elaboradas por esses autores, encontramos o posicionamento de que este leva à satisfação pessoal, trazendo as pessoas para além de si mesmas e levando-as a se interessarem por uma série de atividades envolventes. Assim, "pessoas com projetos de vida deixam de pensar nelas mesmas, tornando-se, em vez disso, fascinadas pelo trabalho ou pelo problema que têm em mãos" (DAMON, 2009, p. 52). O esforço árduo e frequentemente sem intenção de ganho pessoal parece, de acordo com esse olhar, o caminho mais certo para ser feliz do que a busca da felicidade em si.

O projeto de vida pode ser entendido como um grande objetivo na vida do sujeito, um objetivo que embasa suas decisões e suas ações e, consequentemente, se manifesta no seu comportamento. O projeto de vida é essencial para a vida do sujeito e é de tal forma assumido por ele que se mostra central em sua identidade.

Para Damon (2009), os projetos de vida podem ser complexos e ambiciosos ou modestos e familiares. No entanto, configuram-se como uma razão mais profunda que se apresenta como pano de fundo para os objetivos e os motivos mais imediatos, e que, portanto, justifica as ações, as preocupações e as escolhas dos sujeitos. Damon aponta para a existência de uma estreita relação entre um projeto de vida e os objetivos mais imediatos, a curto prazo, de modo que "[...] onde não existe um projeto de vida maior, objetivos e motivos de curto prazo normalmente levam a lugar nenhum e logo se extinguem em uma atividade inútil" (2009, p. 54).

Ademais, ainda de acordo com Damon (2009), a constituição de um projeto de vida exige que o sujeito conheça a si próprio e ao mundo que o cerca, para que saiba identificar as necessidades, os problemas e os conflitos presentes no meio, ao mesmo tempo em que analisa suas características e suas possibilidades realistas de ação, para assim formular objetivos de longo prazo. Faz-se necessário que o sujeito compreenda de que forma capacidades, crenças, valores e aspirações pessoais podem servir de base para a realização de algo que contribua com a sociedade e com o mundo.

Verificam-se vários desdobramentos da teoria sobre projeto de vida proposta por Damon. Alguns trabalhos já vêm sinalizando a necessidade de mudança de alguns aspectos do 
conceito de projeto vital. Entre esses estudos, destacamos os elaborados por Bundick (2009) e Yeager e Bundick (2009).

Investigando o papel do projeto de vida no bem-estar psicológico na juventude, os autores indicaram como objetivos avançar na construção do engajamento significativo como importante componente de uma boa vida e estabelecer relações entre o engajamento significativo, o projeto de vida na adolescência e o bem-estar psicológico.

Para Bundick (2009), os projetos de vida podem ter dois tipos de objetivos: um cuja principal meta é de beneficiar o mundo além do self; outro que diz respeito a um propósito de beneficiar a si mesmo (a self oriented life goal). Consoante Bundick (2009), a natureza das ações orientadas para o self, ou seja, para cumprir objetivos pessoais, na verdade, poderiam ser estendidas para além do self.

As pessoas procuram sentido para as suas ações em diversos tipos de fontes, que podem influenciar seus objetivos de vida. $\mathrm{O}$ engajamento em ações significativas se refere à forma como cada sujeito elege atividades que se mostram envolventes em todos os domínios de sua vida, de acordo com o que é sentido como importante e em consonância com valores e características de sua identidade. O engajamento, dessa forma, designa-se como uma construção singular que pode estar relacionada ao projeto vital, mas não precisa, necessariamente, estar vinculada a ele.

Esse engajamento significativo pode levar à felicidade, cuja essência é sentida e percebida de forma bastante pessoal. Assim, segundo Bundick, vê-se que é uma felicidade diferente daquela alcançada por ações hedonistas, com fins em si mesmas. Pelo contrário, refere-se a um tipo de felicidade que diz respeito a uma realização das potencialidades de cada pessoa, causando grande sensação de completude. É o que o autor denomina, com base na filosofia aristotélica, como eudemonia.

Partindo de tal análise, Bundick estabelece que "(o projeto de vida) é um objetivo estável e generalizado altamente centralizado, que organiza e motiva as ações, decisões e aspirações cotidianas" (BUNDICK, 2009, p. 43, tradução nossa). Nesse sentido, o projeto vital pode ter qualquer conteúdo - centrado no self ou para além do self - desde que se relacione aos critérios que o definem: a) estabilidade (não ser efêmero); b) ter objetivos de longo prazo e operar pela vida do sujeito, subsumindo múltiplas e diversas metas concretas; c) ser organizador e motivador da vida do sujeito (faz com que se tome decisões, forma objetivos de curto prazo e leva ao engajamento nas atividades). 
Eu considero o projeto de vida visualizando o nível pessoal (por exemplo, como uma variável da personalidade); em outras palavras, eu estou interessado em como uma pessoa pode obter propósito na forma como vive, não apenas se ela acredita que tem ou entende seu projeto vital. Isso implica tanto a identificação de um ou mais projetos de vida quanto uma direção para possuí-los. Para simplificar, eu me refiro a essa variação da personalidade como projeto de vida, embora seja melhor articulá-la com um modo de estar disposto a ter o projeto de vida. Desse modo, minha definição de projeto vital considerará a forma como o sujeito acredita que o estabelecerá para a sua vida, assim como a forma em que se orientará em direção à realização por ter tais objetivos. (BUNDICK, 2009, p. 44, tradução nossa)

Essa definição de projeto de vida pretende-se integrativa, incorporando múltiplas definições para promover uma conceituação que se torne mais inclusiva dos elementos que compõem a identidade moral. Nessa concepção, reforçando a teoria de Damon, tanto os objetivos pessoais quanto aqueles que se voltam para além do si mesmo, atingindo o mundo, são projetos de vida. No entanto, são de fontes diferentes.

De acordo com Bundick, a relação entre o engajamento com significado para o self e o sentimento de bem-estar é mediada pelo projeto de vida. Dessa forma, propõe um modelo mediacional a partir do qual

[...] assim que as pessoas entendem o que é significativo para elas por meio de suas ações, elas se inclinam para formar objetivos (incluindo aqueles que são mais importantes em suas vidas). Mesmo quando os objetivos centrais não estão envolvidos nos engajamentos significativos, essas experiências podem contribuir para a formação de uma coerente hierarquia de objetivos que pode promover mecanismos para implementar objetivos de longo alcance que se estruturam para integrar o projeto de vida. [...] uma vez que esses objetivos são estabelecidos, podem funcionar como uma forma de bem-estar. (BUNDICK, 2009, p. 54)

A teoria de Bundick evidencia que, de acordo com o conteúdo do projeto de vida, pode-se lançar uma projeção que, sem intenção, atinja a sociedade. Grande parte dos projetos voltados ao trabalho pode trazer benefícios para o mundo, mesmo que essa não seja a primeira intenção do sujeito ${ }^{30}$.

Esse autor consegue explicar que as experiências dos engajamentos significativos para os sujeitos oportunizam a elaboração ou reorganização dos projetos vitais. Isso nos parece

\footnotetext{
${ }^{30}$ Vale destacar que a intenção de extrapolar os interesses individuais para além do self, de forma a atingir o mundo, consiste em uma linha tênue, visto que nunca objetivamos contribuir para o mundo sem que estejamos também envolvidos em promover benefícios a nós mesmos. Uma das contribuições dos trabalhos de Damon ao campo da psicologia moral foi a de intensificar esforços para a compreensão de uma moral que se destine não apenas aos outros (other-regarding), mas também a si mesmos (self-regarding). Bundick, em continuação aos trabalhos de Damon, destaca esse aspecto de sua teoria, indicando que as ações do self sempre estão em interação com o mundo e, mesmo sem intencionalidade, o atingem.
} 
uma visão profícua para o entendimento dos projetos vitais, porque nem sempre formulamos, de forma racional, os projetos para depois pensarmos nas atividades em que podemos nos engajar. Às vezes, por ter se envolvido em uma atividade, ela se tornou significativa e corroborou para a construção de um projeto de vida. É um processo que se organiza de forma complexa, tornando-se bastante pessoal e de acordo com a identidade de cada um.

Aproximamo-nos do conceito de projeto de vida proposto pelos autores, pois vemos neste a possibilidade de assinalar as conexões entre moralidade e self, chegando a envolver o sujeito real, com sentimentos, pensamentos, crenças, desejos, objetivos, etc. Além disso, vemos que os trabalhos empreendidos por Damon e colaboradores são legitimados por pesquisas empíricas realizadas em vários países, com grande amostra, o que nos traz a visão de que o campo aberto por tais pesquisadores apresenta oportunidades de avanços nas descobertas sobre a moralidade humana. O conteúdo dos projetos de vida interessa-nos também porque, ao trazer sentido à vida das pessoas, organiza pensamentos, sentimentos e ações, estando relacionado aos seus sistemas de valores.

Contudo, muito embora reconheçamos mérito nas teorias do campo da psicologia moral, acreditamos que elas podem ser ampliadas por visões que abarquem maior complexidade do sujeito, envolvendo suas trajetórias, "idas e vindas". Se nos aproximamos de tais teorias pelo conceito proposto, devemos deixar clara a nossa intenção de enfocá-lo por outro viés, mais condizente com as intenções de nossa investigação.

Assinalando a complexidade que envolve o sujeito e a moralidade, vislumbramos os projetos de vida como elaborações realizadas pelos sujeitos de forma bastante particular e intrinsecamente tecidas com as suas características e da forma como eles veem a si próprios. Além disso, compreendemos a articulação desses projetos individuais ao contexto, que, sendo um campo de possibilidades, como nos informa Velho (1994), articula outros projetos individuais e alguns coletivos.

Identificamos, na construção da identidade moral, um núcleo central que configura os valores, crenças, desejos e objetivos do sujeito, e que o identifica como ser diferente dos outros. No entanto, entendemos que tal identidade está permeável a mudanças, "à melhora que podemos fazer de nós mesmos" (NUCCI, 2004), com base nas experiências realizadas por meio dos projetos de vida, por meio de ações presentes voltadas para o futuro, as quais embasam outras constituições de metas e, consequentemente, novos projetos.

Acreditamos que estudar os projetos de vida, sob essa perspectiva, significa contribuir para o desenvolvimento de pesquisas no campo da psicologia moral. Além disso, pode propiciar uma concepção mais fecunda para entender um pouco mais da complexidade que 
perfaz o funcionamento psíquico dos jovens no tocante à moralidade, estabelecendo critérios compatíveis com suas vivências e as características do mundo contemporâneo.

No próximo capítulo, buscaremos apresentar uma fonte teórica importante para a presente investigação, a Teoria dos Modelos Organizadores do Pensamento (MORENO MARIMÓN et al, 1999), pela qual pretendemos aliar a perspectiva de um estudo funcional do psiquismo humano, mediante a análise dos processos de integração e regulação de valores e sentimentos, e a fecundidade de seu estudo pela perspectiva dos projetos de vida. 


\section{CAPÍTULO III \\ MODELOS ORGANIZADORES DO PENSAMENTO, FUNCIONAMENTO PSÍQUICO E MORALIDADE}

[...] não há uma descontinuidade entre o social e o humano e suas raízes biológicas. $\mathrm{O}$ fenômeno do conhecer é um todo integrado, e todos os seus aspectos estão fundamentados sobre a mesma base. (MATURANA; VARELA, 1987/1995, p. 69)

Para desvendar os processos de integração e regulação de valores e sentimentos nos projetos de vida dos jovens, faz-se necessária uma análise funcional e que comporte a complexidade do sujeito psicológico. Isso porque tais processos se inter-relacionam com outros aspectos que compõem o sistema moral do sujeito.

Buscando seguir por esse viés, vimos como necessária uma abordagem sobre o jovem e como constrói suas identidades e trajetórias, chegando ao conceito de projeto de vida, que compreendemos como uma projeção de futuro, ancorada em vivências do passado e do presente, que comporta desejos, pensamentos, sentimentos, interesses e objetivos do sujeito e que se constitui de forma complexa, envolvendo tanto regularidade, no sentido de que carrega características identitárias do sujeito, quanto transitoriedade, já que está aberto à mudança de pensamento.

Assim, entendendo o projeto de vida como uma unidade complexa, sugerimos que a integração e a regulação de valores e sentimentos que consideramos inerentes a esse conceito deva ser abordada por uma teoria que abra a perspectiva de análise para a incorporação de tal complexidade. Encontramos na Teoria dos Modelos Organizadores do Pensamento, formulada pelas autoras Montserrat Moreno Marimón, Genoveva Sastre Vilarrasa, Aurora Leal e Magali Bovet (MORENO MARIMÓN et al., 1999) um aporte teórico-metodológico que visa a elucidar os processos funcionais que são ativados por trás da organização do pensamento do ser humano frente às situações que se lhe apresentam.

Inscrevendo-se no marco de estudos que optou pelo viés da microgênese (INHELDER; CELLERIER, 1992) e, dessa forma, destinando-se ao estudo funcional do psiquismo humano, a Teoria dos Modelos Organizadores intenta quebrar um paradigma firmado na psicologia, em que se prioriza um único aspecto do pensamento do sujeito: o viés cognitivo. Essa teoria incorpora a análise de um sujeito dotado de pensamentos, sentimentos, crenças, desejos e objetivos, e que está em interação constante com o meio com o qual se relaciona. 
A formulação da Teoria dos Modelos Organizadores corresponde a uma ideia, hoje muito difundida no meio acadêmico, sobre a necessidade do pensamento complexo para compreensão dos fenômenos (MORIN, 2000, 2001; PRIGOGINE; STENGERS, 1984). A via dos novos paradigmas permeou várias áreas do conhecimento, como nos informa Schnitman (1999), culminando em uma mescla de perspectivas que resultou em uma nova visão sobre a Ciência. Em paradigmas anteriores, operava-se pelo princípio de disjunção, cindindo as interações e as relações entre os fenômenos, de redução, estudando um fenômeno apenas por uma via, e abstração, retirando do campo de estudo a realidade concreta e valorizando apenas conceitos para fazer uma leitura do ser humano e do mundo (MORIN, 2001). Nesses paradigmas, a fragmentação do objeto de estudo conduzia sempre à certeza e ao previsível.

$\mathrm{O}$ advento de outro paradigma trouxe à Ciência a possibilidade de incertezas, com a abertura ao novo. "A Ciência, a pesquisa, o desenvolvimento de modelos e práticas de implementação são agora diálogos, não monólogos que podem ser sustentados unilateralmente" (SCHNITMAN, 1999, p. 23). Os novos paradigmas significaram, para a Ciência, um alento para a criação de teorias que buscaram ampliar construtos teóricos que, até então, apenas puderam ser observados por uma única via.

Em psicologia, o marco do construtivismo, a partir de Piaget, trouxe indícios importantes para uma visão de um sujeito ativo sobre suas percepções de mundo. Contudo, como vimos no primeiro capítulo de nosso trabalho, a princípio, a teoria piagetiana esteve marcada, no mais das vezes, por uma ênfase estruturalista, em que se priorizou os aspectos racionais do sujeito. Colaboradores de Piaget, como Barbel Inhelder e Guy Cellérier, passaram a trazer, com base nos próprios anseios do epistemólogo suíço em seus últimos trabalhos, a necessidade de um estudo que incorporasse não apenas os aspectos estruturais, mas também com foco nos procedimentos do pensamento. Para tanto, com tal abertura, viu-se a oportunidade de considerar o sujeito psicológico, na sua inserção nas situações de resolução de problemas, em detrimento do sujeito epistêmico, deslocado da realidade.

Essa perspectiva pôde trazer avanços significativos para o campo da psicologia moral, uma vez que se abriu o espectro para novas possibilidades de articulação entre o self e sua interação com o mundo, na construção de seu pensamento.

Os desenvolvimentos recentes no campo da psicologia e das terapias psicológicas estão relacionados principalmente à compreensão de que o conhecimento sobre o sujeito não está dissociado do conhecimento do sujeito; ou seja, de que não é possível separar aquilo (ou aquele) que é conhecido daquele que conhece; no 
caso da psicologia, o ser humano "observado" do ser humano "observador". (SOAR FILHO, 1998, p. 85, grifos do autor)

Maturana e Varela (1987/1995), ao pesquisarem sobre as bases biológicas do conhecimento humano, contribuíram, seguindo a perspectiva desse novo paradigma, ao caracterizar o ser humano como sistemas "autopoiéticos" ou autoprodutores, que, em sua complexidade, têm por finalidade produzir a "si mesmos". Nessa lógica, não existe separação entre produto e produtor, já que "o ser e o fazer de uma unidade autopoiética são inseparáveis, e esse constitui seu modo específico de organização" (MATURANA; VARELA, 1987/1995, p. 89). Da mesma forma, Von Glasersfeld (1994) postula que o conhecimento não pode ser uma representação do mundo independente do ser humano que o constrói e o aplica cotidianamente. Para o autor, o saber é uma construção operada pelo sujeito em sua experiência, por meio da qual é possível orientar-se no mundo, prever situações e até determiná-las (p. 26).

As consequências dessa visão trazem uma consideração sobre o self como altamente articulado com o meio com o qual convive, passando a ser visto por aspectos relacionais, processuais e contextuais, mais do que como uma estrutura relativamente fixa e permanente.

No bojo de tais articulações da psicologia, vê-se o anseio da Teoria dos Modelos Organizadores do Pensamento (MORENO MARIMÓN et al., 1999) em extrapolar os limites da fragmentação e em desvendar as relações que se estabelecem nos processos psicológicos.

Em psicologia, o descobrimento de constantes é o que permite abordar o estudo da diversidade, que adquire um sentido precisamente graças à sua referência a tais constantes. Uma vez descrita a regularidade, o pensamento volta-se para a diversidade; o imutável deixa de ser o centro de nossos interesses e buscamos as explicações na mudança. A ideia de mudança penetra também a psicologia quando começa a observar o ser humano como um ser que evolui. Mas em toda mudança há algo que permanece, e a conjunção da permanência e da mudança aumenta a complexidade dos novos fenômenos que se vislumbram, surgindo a necessidade de modelos capazes de descrever e interpretar simultaneamente o que permanece e o que muda, isto é, capazes de dar conta da complexidade. (MORENO MARIMÓN et al., 1999, p. 16-17)

Valendo-nos dessas considerações, percebemos a necessidade de utilizar uma teoria que explique e dê conta das variações do pensamento do sujeito e das mudanças que se constituem na complexidade dos procedimentos que a mente humana utiliza para construir e se apropriar do conhecimento. Por esse motivo, elegemos, no presente estudo, a Teoria dos 
Modelos Organizadores, que, inserindo-se na gama de trabalhos que ultrapassa os limites da fragmentação, pode nos oportunizar a percepção da organização do pensamento dos sujeitos participantes por uma via que abarca os aspectos concernentes ao seu psiquismo no diálogo que estabelece com o contexto, de forma processual, propiciando uma análise que "chegue" às relações tecidas pelos processos de integração e de regulação de valores e sentimentos, que subjazem a elaboração dos projetos de vida.

Ao optar pela Teoria dos Modelos Organizadores do Pensamento, procedemos a uma metodologia que, implicando suas bases conceituais, é capaz de levar à visualização dos procedimentos realizados para a elaboração dos projetos de vida, incluindo aqueles relacionados à integração e regulação de valores e sentimentos. Pela abertura proposta pela teoria, não se estabelecem categorias predeterminadas, mas se espera destacar, em uma análise processual dos juízos emitidos pelos sujeitos, como chegaram às suas elaborações.

Neste capítulo, abordaremos tal teoria, tecendo relações, principalmente, com os avanços por ela proporcionados na compreensão do funcionamento psíquico humano e a moralidade, bem como indicando as possibilidades que ela oferece ao campo metodológico.

\subsection{Modelos Organizadores do Pensamento e funcionamento psíquico}

É difícil compreender o funcionamento emocional no ser humano se não conhecemos seu funcionamento cognitivo, já que ambos estão inextricavelmente unidos. Para tanto, necessitamos um modelo explicativo - que necessariamente há de ser funcional - de como procedemos para compreender o que acontece no universo que nos rodeia. (MORENO MARIMÓN; SASTRE, 2010, tradução nossa)

Em uma visão que incorpora a complexidade, estudar o sujeito psicológico significa, necessariamente, abarcar seus sentimentos, pensamentos, crenças, valores e desejos, nas relações que estabelece consigo mesmo e com o mundo. Os processos de integração e regulação de valores e sentimentos organizam e são organizados pelas dimensões que constituem o sujeito psicológico, tramitando pelo sistema moral e ultrapassando seu âmbito de forma a interagir com os demais sistemas que compõe o psiquismo humano.

Na Teoria dos Modelos Organizadores do Pensamento (MORENO MARIMÓN et al., 1999), vê-se uma formulação que procura considerar tal complexidade do funcionamento psicológico, envolvendo tanto as dimensões cognitivas quanto as afetivas e socioculturais. É uma teoria que busca explicar o processo de conhecimento do sujeito sobre o mundo, 
permitindo visualizar o papel das estruturas e dos conteúdos no modo como ele pensa a realidade. Partindo da ideia de que o sujeito constrói modelos da realidade que lhe permitem conhecer uma parte do mundo que o cerca, a teoria dos Modelos Organizadores procura estudar a forma como ele os constrói.

Apostando no sujeito como ativo em seu próprio processo de construção da realidade e no papel da representação do mundo como fundamental para essa construção, as autoras beberam em duas fontes teóricas para chegar à formulação sobre os Modelos Organizadores: as propostas teóricas de Piaget e as proposições dos Modelos Mentais, formuladas, principalmente, por Johnson-Laird.

Traremos, de forma breve, alguns apontamentos sobre essas teorias, na forma como foram incorporados pelas autoras, para que possamos entender, de maneira mais acurada, a proposta teórica dos Modelos Organizadores do Pensamento e de que forma pode representar um avanço para a compreensão sobre o funcionamento psíquico humano.

As obras piagetianas, fontes de estudos das autoras da Teoria dos Modelos Organizadores do Pensamento, forneceram-lhes uma sólida base teórica sobre o funcionamento cognitivo do ser humano. Nessa formulação, a preocupação epistemológica central de Piaget era a de estudar, por meio de uma teoria construtivista e interacionista, como o sujeito passa de um estado de menor conhecimento para outro de maior conhecimento, ou seja, um curso ascendente rumo a uma maior complexidade. Nesse curso, o sujeito passa por estádios $^{31}$ até atingir, em seu processo construtivo, as estruturas operatórias concretas e formais. Nesse ínterim, pode-se classificar a obra piagetiana como centrada nos aspectos estruturalistas do pensamento, como já indicamos algumas vezes em nosso percurso teórico, uma vez que se concentra na perspectiva do sujeito, das suas ações e das mudanças que nele se operam.

Embora reconheçam a importância desses estudos, no que tange às descobertas sobre as estruturas do pensamento, Moreno Marimón e colaboradoras passaram a questionar o fato de que a concentração no sujeito levou Piaget a desconsiderar o meio, dando pouca importância aos aspectos não formais do pensamento, entre os quais se encontra o que denomina “conteúdos" (MORENO MARIMÓN et al., 1999). O estruturalismo de Piaget, a despeito de se constituir como fonte fundamental para a formulação da teoria, foi alvo de críticas das autoras por, essencialmente, considerar o sujeito epistêmico, e não psicológico, desvinculado dos conteúdos do meio. Elas apontam que, ao construir uma teoria que se baseia

\footnotetext{
${ }^{31}$ Os estádios são sensório-motor, pré-operatório, operatório concreto e operatório formal. Não nos deteremos na descrição de cada um deles por não serem o foco do presente trabalho.
} 
na sucessão ou gênese das estruturas, Piaget acabou por evidenciar que existem condutas que não seguem exatamente a mesma linearidade, ou seja, alguns sujeitos possuem dificuldades de aplicar uma mesma estrutura mental, ou até não chegam a conseguir aplicá-la, em situações aparentemente isomorfas. A esse fato, Piaget denominou como "defasagens", para que pudesse manter a mesma ideia de que existem estágios sucessivos no desenvolvimento cognitivo humano.

Moreno Marimón et al. (1999) destacam que essas defasagens, diferentemente do que postulou Piaget, não são uma exceção, mas parecem ser a norma no funcionamento cognitivo, visto que não se pode aplicar a mesma operação em situações diversas, ou seja, o uso de uma operação parece não estar estritamente vinculado a um estágio, mas também aos conteúdos aos quais se aplica.

Arantes (2000a), uma das autoras que seguiu o enfoque dos Modelos Organizadores do Pensamento, sinaliza que Piaget, diante das críticas recebidas e também a partir de suas investigações sobre a causalidade, na década de 60, começou a mudar o enfoque de sua pesquisa, na década de 70, direcionando-a para a compreensão dos aspectos funcionais da inteligência. Nessas pesquisas, Piaget percebeu um papel maior dos objetos (conteúdos) na cognição, considerando-os como importantes para a constituição das estruturas mentais.

Muito embora tenha se voltado a tal estudo, Piaget não adentrou nesse campo tempo suficiente para destrinchar o papel funcional na construção do conhecimento, cabendo aos seus seguidores um maior aprofundamento desse aspecto do funcionamento psíquico humano.

Inhelder e De Caprona (1992), colaboradores de Piaget em seus estudos, mesmo reconhecendo a importância da teoria epistemológica para a compreensão de uma "arquitetura geral do conhecimento", já destacam que se faz necessário não apenas entender o sujeito epistêmico, mas também e principalmente o sujeito psicológico (p. 9). As ideias desses autores têm muito a dizer sobre as críticas e às formulações sobre os Modelos Organizadores do Pensamento, assim como nos levam a notar que a percepção de um sujeito como ser complexo e em interação com os conteúdos de seu contexto faz parte de uma corrente de pensamento que configura a construção de novos paradigmas em psicologia.

As formulações de Inhelder e De Caprona aproximam-se demasiadamente da Teoria dos Modelos Organizadores do Pensamento, já que buscam evidenciar as características do processo interativo entre sujeito e objeto. Para os autores, a noção de esquemas não é suficiente para uma abordagem a partir da resolução de problemas, cujo enfoque recai para conteúdos de situações concretas. Para apreender determinados aspectos do funcionamento psicológico, passaram a recorrer ao conceito de representações. 
A noção de representação, consoante Inhelder e De Caprona, comporta dois aspectos complementares: a semioticidade, abordada sob o ângulo de tratamentos diferentes permitidos pelos diversos modos de representação (gesto, imagem, linguagem), e a possibilidade, para o sujeito, de refletir sobre os fins e os meios aos quais ele se propõe, em outras palavras, a representação do "como fazer", de antecipar a ação para planejar a conduta. "As representações incidem, consequentemente, tanto sobre os caminhos a tomar quanto sobre os resultados a que eles conduzem" (1992, p. 34), o que é fundamental para a formação de instrumentos cognitivos que levam o sujeito a pensar.

Discorrendo sobre o papel funcional das representações, apontam que funcionam em sistemas de conduta diversos e abertos, uma vez que podem ser modificados ou adaptados. Algumas representações podem ser, destarte, móveis e independentes dos sistemas de condutas que incidem sobre elas, enquanto outras, por possuírem comportamento bem determinado dentro do sistema, são integradas, quando pertencentes a programas comportamentais inferidos como condição necessária dos comportamentos observáveis a que elas pertencem. Inhelder e De Caprona (1992) destacam a importância de reconhecer a distinção entre "representações integradas" e "representações móveis" para que se esclareça que "o saber fazer implica representações tanto quanto o saber" (1992, p. 34), e que ambos os tipos de representação corroboram para que o sujeito construa os instrumentos cognitivos utilizados por ele em diferentes sistemas de conduta.

Os autores afirmam que esses instrumentos cognitivos formam os "modelos do sujeito". Em suas palavras:

O sujeito psicológico, em situação de resolução de problema, constrói para si próprio 'modelos ad hoc', locais, que utiliza para organizar o encadeamento de suas ações, assim como para interpretar a situação com a qual está sendo confrontado. Essas formas de organização diferem das estruturas até então preponderantes em psicologia genética. (...) Modelos ad hoc e estruturas ou modelos gerais são organizações subjacentes aos comportamentos. Garantem, assim, a coerência dos conhecimentos elaborados por um sujeito. Contudo, a coerência de procedimento não comporta o caráter de estabilidade da coerência estrutural, uma vez que é, principalmente, consequência de modelos locais, provisórios e transitórios. (1992, p. 35)

É possível asseverar, a partir das ideias de Inhelder e De Caprona, que, na resolução de problemas, tornam-se cruciais para o funcionamento cognitivo tanto a coerência estrutural, formada pela matemática e pela lógica, características do pensamento, quanto os modelos ad hoc, locais, característicos de um saber-fazer múltiplo e multiforme, amplamente vinculados aos contextos e aos conteúdos. 
Tais concepções remetem à adoção de uma perspectiva teórica que tome a cognição humana em seu aspecto funcional, complementarmente aos estudos estruturais elaborados por Piaget. Assumir essa perspectiva significa procurar compreender de uma forma mais próxima o sujeito psicológico, que vive imerso em uma teia de relações objetivas e subjetivas.

Essas ideias, com certeza, possuem estreita relação com as formulações dos Modelos Organizadores do Pensamento, visto que, sob esse novo enfoque, as defasagens consistem, na verdade, na norma do funcionamento psíquico, o que leva Moreno Marimón e colaboradoras a abrirem o leque de análise para considerar não apenas o que se apresenta como regularidade, mas também e, sobretudo, como não regularidade. Outro aspecto importante da teoria de Piaget e das teorias posteriores e complementares à dele (como a de Inhelder e colaboradores) que vem nortear a Teoria dos Modelos Organizadores é o papel do sujeito como organizador da realidade. Esse aspecto construtivista da teoria de Piaget é fundamental para a compreensão do instrumento teórico-metodológico que adotamos para a realização de nossa pesquisa.

Ainda que, no nosso entender, a teoria de Piaget e as reflexões suscitadas por ela tenham sido fundamentais para a formulação da Teoria dos Modelos Organizadores do Pensamento, não foram as únicas fontes para essa construção teórica. Destaca-se também a teoria dos Modelos Mentais, uma contribuição das ciências cognitivas para a Teoria dos Modelos Organizadores do Pensamento.

Muitos foram os trabalhos que trouxeram à luz o conceito de modelo mental, como uma atividade interna do cérebro em estrita relação com o contexto. No entanto, os estudos de Johnson-Laird (1983, 1994), ancorados no campo da linguagem, mostraram-se bastante fecundos para investigações sobre os aspectos representacionais do pensamento, e nortearam as reflexões das autoras da Teoria dos Modelos Organizadores do Pensamento.

Nas pesquisas de Johnson-Laird, cujo objetivo era analisar modelos mentais elaborados a partir de enunciados verbais, o autor obteve resultados que o levaram a expor o problema da insuficiência da lógica formal para determinar a conclusão diante de uma situação concreta que admite múltiplas conclusões. Seus estudos concluíram que o raciocínio humano não se limita a um processo formal ou sintático. Com base nessa afirmação, apontou que o raciocínio não parte de enunciados proposicionais, mas que o sujeito elabora, a partir deles, modelos mentais, "que são uma representação interna de um estado de coisas do mundo exterior" (Johnson-Laird, 1994, p. 201).

Moreno Marimón e colaboradoras (1999) esclarecem o que são, para Johnson-Laird, os modelos mentais. 
Esses modelos mentais constituem uma forma de representação dos conhecimentos por meio dos quais o ser humano constrói a realidade e isso lhe permite, quando realiza um processo de simulação mental, conceber alternativas e verificar hipóteses. O papel da representação, dentro dessa teoria, é fundamental para explicar tanto a elaboração de modelos como sua manipulação pelo pensamento. (p. 37)

O papel da representação na teoria de Johnson-Laird $(1983,1994)$ é tão essencial que ele chega a considerar que o raciocínio consiste na manipulação de tais modelos e que compreender é elaborar modelos do mundo.

A partir do estudo dos modelos mentais que surgem de sua pesquisa, Johnson-Laird conclui que "a estrutura de um modelo mental é isomorfa à estrutura do estado das coisas, percebido ou pensado, que o modelo representa" (1994, p. 202). Ou seja, ao postular que a estrutura dos modelos corresponde à estrutura do que representam, Johnson-Laird busca fora do próprio pensamento os seus elementos estruturantes, caindo em uma perspectiva empirista e reservando ao sujeito apenas o papel de perceber as situações do mundo exterior.

Além disso, ao se concentrar na percepção do sujeito, a teoria de Johnson-Laird traz à tona o caráter provisório e parcial dos modelos mentais. Os modelos mentais não possuem uma experiência anterior, são modelos locais que, por estarem baseados apenas na percepção momentânea, dependem das informações percebidas pelo sujeito no momento da experiência.

Os conhecimentos anteriores, aos quais Johnson-Laird atribui extrema importância na compreensão e interpretação dos enunciados, não estão organizados em forma de modelos; eles estão na memória de longo prazo. Uma vez elaborado um modelo mental a partir da percepção da realidade, o conhecimento adquirido dessa situação passaria a esse tipo de memória.

A teoria dos modelos mentais de Johnson-Laird contribuiu significantemente para os estudos da psicologia cognitiva por dar demasiada importância aos conteúdos em detrimento das teorias cognitivistas elaboradas até então. Seus estudos abriram caminho para diversas pesquisas nesse campo e, apesar de serem passíveis de críticas, como o fato de buscar implicitamente uma estrutura exterior ao pensamento e se basear unicamente na percepção do sujeito, foram extremamente fecundos para análises que partiram de suas experiências.

Apesar de admitirmos os avanços dessas teorias no campo da psicologia cognitiva, não nos adentraremos nessas investigações, pois elas não são o foco de nossa pesquisa. Cabe ressaltar, entretanto, que o estudo dos modelos mentais de Johnson-Laird e de seus seguidores superou uma visão centrada apenas na estrutura do psiquismo humano e acabou por realçar o 
aspecto funcional deste ao investigar o processo de construção de modelos efetuado por cada sujeito a partir de sua percepção de mundo.

Porém, como nos mostra Arantes (2000a), as teorias que abordam os modelos mentais permanecem limitadas e insuficientes para explicar o raciocínio humano, pois são localistas e postulam que as estruturas internas têm origem na percepção. A abstração de elementos da realidade é, na verdade, um processo muito mais complexo do que uma simples percepção. Se dependesse apenas da percepção, poderíamos afirmar que duas pessoas expostas a uma mesma situação formulariam um mesmo modelo mental, o que, decerto, não ocorre na realidade.

A partir dessa constatação, Moreno Marimón e colaboradoras (1999, p. 55) afirmam que tais investigações acabaram por demonstrar que qualquer percepção implica uma interpretação que, por sua vez, estará imbricada no significado que lhe foi conferido pelo sujeito. Para as autoras, o ato de abstrair um elemento da realidade requer um processo cognitivo mais complexo, não apenas dependente da percepção, pois, junto a esse elemento, muitos outros atuam na realidade e são passíveis de serem abstraídos. O que ocorre é que o sujeito seleciona apenas alguns deles.

Mesmo apontando as limitações da teoria dos modelos mentais, Moreno Marimón e colaboradoras (1999) assumem a relevância de tal teoria por descrever aspectos representacionais do pensamento humano e a utilizam como fonte para o desenvolvimento da Teoria dos Modelos Organizadores do Pensamento.

Integrando aspectos da teoria dos modelos mentais e elementos da epistemologia genética de Piaget, as autoras conseguiram elaborar, de uma perspectiva evolutivaconstrutivista, uma teoria que busca uma explicação que considere, concomitantemente, os aspectos estruturais do sujeito e os aspectos externos a ele que configuram os conteúdos presentes na realidade. 


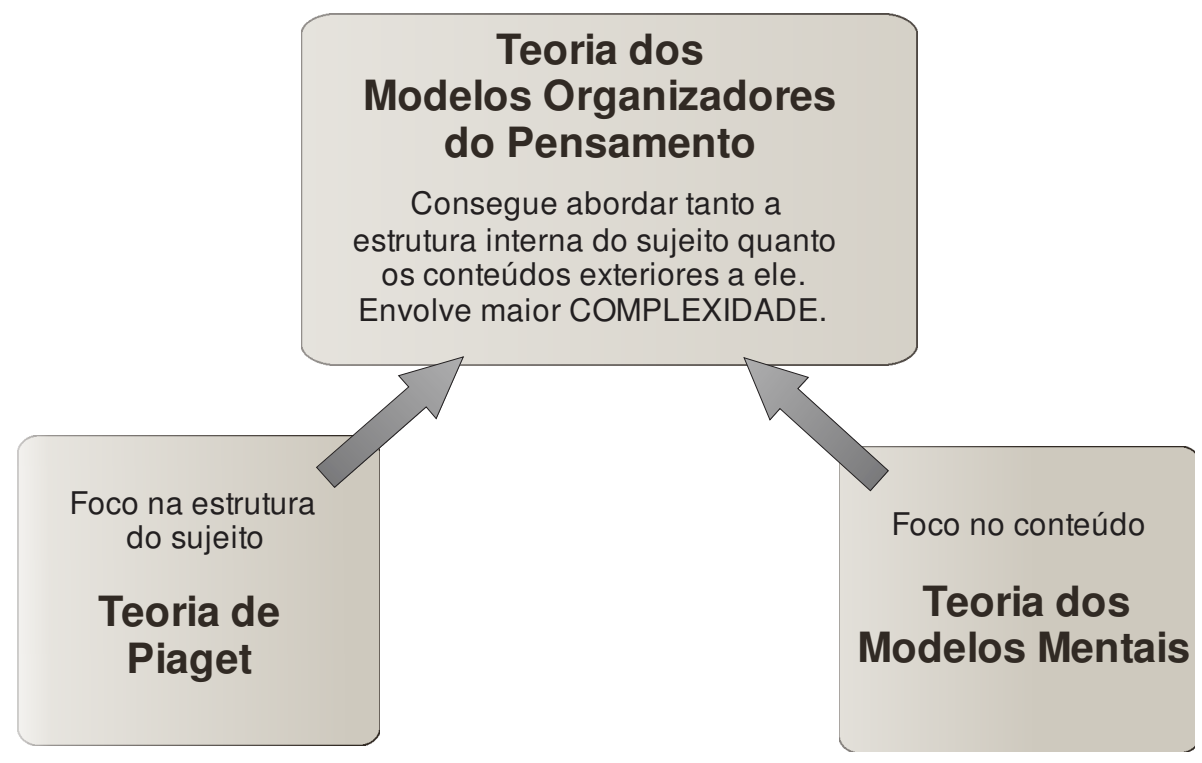

$\mathrm{Na}$ Teoria dos Modelos Organizadores, vimos uma tentativa de abordar, com a configuração que caracteriza os novos paradigmas, os conteúdos que não estiveram presentes na teoria de Piaget, de uma perspectiva que leva em consideração toda a atividade construtora do sujeito, em sua complexidade. Assim, nessa teoria, as autoras propõem que, frente a acontecimentos observáveis, os quais podem ser interpretados de diversas maneiras, cada sujeito seleciona e organiza uma série de elementos, tecendo relações e implicações entre eles, a partir das quais constrói modelos para representar a "realidade".

Importa-nos saber [...] como se comporta o ser humano na construção do que chamamos "realidade", quais são os procedimentos que utiliza e como estes dependem de sua morfologia, de sua constituição anatômica e de seu sistema nervoso, mas também de sua história, de sua cultura, de sua forma de vida, do meio que o rodeia, tanto físico como social, e também da forma como assimila o mundo exterior para fazê-lo digerível pelos seus sistemas de construção da realidade (neurológicos, biológicos, sociais, individuais, emocionais, etc.). (MORENO MARIMÓN; SASTRE, 2010, p. 58 , tradução nossa)

Faz-se importante destacar o termo "realidade" e seu significado para as autoras. Sendo que o modelo organizador compreende a representação da realidade elaborada pelo sujeito, a realidade é uma forma, entre outras possíveis, de "ver o mundo"32. Tal maneira de "ver o mundo" tem muita relação com o paradigma através do qual ele é visto e que, também, está fortemente influenciado pelos interesses individuais ou coletivos de seus autores. Esses

\footnotetext{
${ }^{32}$ Para Moreno Marimón et al. (1999), é necessário diferenciar realidade objetiva de realidade subjetiva. A primeira é aquela que serve de referência para a elaboração de modelos organizadores; a segunda é o que o sujeito compreende da primeira.
} 
paradigmas restringem a percepção da realidade: "somente consideramos real aquilo em que cremos e somente cremos no que somos capazes de imaginar" (MORENO MARIMÓN; SASTRE, 2010, p. 60, tradução nossa).

O entendimento do termo "realidade" para as autoras envolve, necessariamente, uma interpretação do sujeito dos fenômenos observáveis, que está fortemente relacionada com suas estruturas mentais. Assim, sendo as características do sujeito atuantes em seu pensamento, vêse que ele não se limita a copiar a realidade, mas construir "realidades" a partir dos observáveis e da interpretação que faz deles.

$\mathrm{Na}$ elaboração de um modelo organizador, a "realidade" é um produto da relação/interação do sujeito com o contexto.

Para Lemos-de-Souza (2008), a "realidade"

[...] atravessa sujeito e contexto. É pessoal, individual e ao mesmo tempo social e coletiva; não é estática e nem imutável, mas sim dinâmica. Essa dinâmica de transformação se dá no jogo do universo de relações [...]. Entendemos que a realidade objetiva no modelo organizador é produzida e transformada pelo sujeito e que a realidade subjetiva é também transformada pelo contexto. Um modelo organizador é então produzido na relação dialógica entre "realidade" objetiva e subjetiva. (p. 101)

Tendo em consideração esse continuum que envolve o sujeito, com suas particularidades, e os elementos observáveis nos contextos em que convive, nota-se que a elaboração de modelos organizadores, como forma de construção de conhecimentos, consume-se em processos em que estão envolvidos diversos aspectos para chegar a uma forma particular de contemplar tais fenômenos observáveis.

O resultado desses processos conduz a uma organização do pensamento, que proporciona ao sujeito a compreensão dos fenômenos. Tal organização está aberta a processos de "reiteração reconstrutiva", que ocorrem sempre que um contexto proporciona a revisão dos modelos, fazendo com que aumente sua complexidade e a capacidade de perceber fenômenos complexos que antes o sujeito era incapaz de detectar devido à falta de paradigmas que poderiam lhe permitir tal percepção.

Os modelos organizadores, dessa forma, podem ser descritos como

[...] um sistema dinâmico e organizado que construímos a partir dos elementos que selecionamos das situações, circunstâncias, eventos ou fenômenos que observamos ou imaginamos, dos significados que atribuímos a cada um deles e das implicações ou consequências que extraímos de tudo isso. (MORENO MARIMÓN; SASTRE, 2010, p. 70, tradução nossa) 
Para Moreno Marimón e Sastre (2010), cada pessoa realiza uma seleção do que conhece e do que observa, em relação ao contexto, segundo uma série de características constantes em seu funcionamento psíquico. Pode-se chegar a essa construção mental particular de cada sujeito por uma via funcional que revela quais elementos o sujeito selecionou da situação concreta, quais significados atribuiu a esses elementos e de que forma organizou e estabeleceu implicações ou consequências que derivam de toda essa elaboração.

Os modelos organizadores, portanto, são constituídos desses processos que ocorrem simultaneamente, ora rapidamente, no caso de situações cotidianas que exigem respostas rápidas, ora de forma lenta e gradual, como em situações difíceis em que temos que refletir muito para chegar a uma resposta ou em teorias científicas. Quando elaborados de forma rápida, os modelos organizadores pautar-se-ão na apresentação de um mínimo de plausibilidade de acordo com o contexto, com alguns elementos selecionados que parecem, ao sujeito, mais significativos e evidentes, na medida em que permitam atribuição de significados, gerando-lhe um todo coerente. No caso dos modelos organizadores elaborados de forma lenta, a postura do sujeito será de analisar todos os elementos que conseguir abstrair da situação, repassar todas as possibilidades de interpretação que é capaz de realizar, considerando o que é mais plausível e submetendo-o à comprovação.

Em todos esses processos de elaboração de modelos organizadores, é preciso considerar que o sujeito, ao representar o mundo por meio de construções mentais, leva em consideração seus sentimentos. Os modelos organizadores são, nesse ínterim, construções que estão embasadas em sentimentos, conhecimentos e ações. E, por estarem fundados nesse tipo de construções, possuem um caráter funcional.

Os modelos organizadores têm um caráter funcional, já que nos permitem descrever como procedemos no momento de pensar, julgar, extrair conclusões e decidir como atuar. Descrevem as características gerais de nosso funcionamento mental no momento de construir realidades. Por isso, é de extremo interesse, tanto para a psicologia quanto para a vida cotidiana, conhecer suas características. (MORENO MARIMÓN; SASTRE, 2010, p. 73, tradução nossa)

São três componentes básicos dos modelos organizadores que ocorrem simultaneamente e de forma integrada: a abstração e seleção de elementos da situação; a atribuição de significados aos elementos considerados relevantes; e o estabelecimento de relações e/ou implicações entre os elementos abstraídos e seus significados. Para maior compreensão sobre a construção dos modelos organizadores, descreveremos cada um desses processos separadamente, embora ressaltemos a importância de considerá-los imbricados. 
Ao elaborar um modelo organizador, o sujeito interpreta fatos e objetos que lhes são perceptíveis na situação. Os resultados dessa interpretação são os elementos, que procedem de percepções, das ações (tanto físicas quanto mentais) e do conhecimento em geral que o sujeito possui sobre certa situação, assim como das inferências que realiza, levando em conta todos esses aspectos (MORENO MARIMÓN et al., 1999, p. 78).

No processo de abstração e seleção dos elementos da realidade, o sujeito não retém todos os existentes, ou seja, não copia toda a realidade, mas considera relevantes aqueles que lhes são significativos e ignora aqueles que lhe parecem impertinentes, consoante seus paradigmas. De acordo com Moreno Marimón e Sastre (2010), os seres humanos não poderiam considerar todos os elementos presentes em uma situação concreta, nem lhes atribuir tudo o que conhecem a respeito da situação, pois isso seria antieconômico e, consequentemente, inviável (p. 71). A seleção de elementos do contexto é feita de forma que o sujeito relacione-os espontaneamente entre si para lhes garantir coerência. Tal sistema de relações garante coerência interna ao sujeito, trazendo-lhe a sensação de que ele é coerente com o mundo externo. As autoras nos informam que essas relações não são observáveis, mas produtos das inferências e de interlocuções mentais que o sujeito realiza. Podem ser estabelecidos diversos tipos de relações entre os elementos (por exemplo, de proximidade espacial, de causalidade, emocional, temporal, lógica, etc.), dependendo unicamente do ponto de vista em que posicionamos nosso pensamento. Portanto, uma relação nunca é "objetiva", mas produto da atividade mental do sujeito, que envolve a interpretação que ele dá a determinadas percepções.

Entre os elementos retidos pelo sujeito como significativos, há inferências ou invenção de elementos, em função da necessidade de compreensão da situação observada. Faz-se importante sublinhar que tanto os elementos que realmente figuram na realidade quanto outros imaginados possuem o mesmo status e têm, para o sujeito que constrói o modelo organizador, o mesmo valor. Essas inferências e invenções são necessárias para garantir a coerência do sistema de relações organizado por ele.

Ao mesmo tempo em que o sujeito abstrai elementos da situação, retirados do contexto, inferidos ou inventados, envolve-se no processo de atribuição de significados para cada elemento. Isso porque, para o sujeito, o elemento só existe se lhe atribui significado, caso contrário faria parte daqueles tidos por "insignificantes" e que não atuam para contribuir para a coerência do modelo. O significado, dessa forma, é fundamental para a existência dos elementos presentes no modelo e é o que faz com que se atribua uma interpretação ou outra para cada elemento. $\mathrm{Na}$ dimensão do significado, está explícito o caráter afetivo-cognitivo, 
uma vez que só se atribui significado àquilo para o que se atribui um interesse ou um valor. Tal atribuição de valor está, também, intrinsecamente relacionada às crenças ou convicções, ou seja, o paradigma que guia o sujeito.

Diversos sujeitos, diante de um único elemento, em uma mesma situação, podem atribuir a ele diferentes significados, do mesmo modo que um único sujeito pode atribuir diferentes significados a uma mesma situação de acordo com o momento em que se encontra. Dessa forma, podemos verificar que muitos de nossos sistemas de pensamento evoluem, modificando os modelos organizadores que elaboramos sobre as situações, de acordo com o enfrentamento de contextos que oportunizam novos elementos e com os ganhos de complexidade que passamos a verificar em nossas estruturas mentais. Muito embora isso ocorra com vários modelos organizadores do pensamento, outros podem manter-se estáveis, caso não haja experiências que proporcionem novos elementos e/ou atribuição de significados a eles.

A organização de um modelo, na relação entre elementos significados pelo sujeito diante do contexto, é fundamental para que ele tenha coerência interna. Tal coerência não pode ser tida como de caráter universal; pelo contrário, é subjetiva, individual e não necessariamente compartilhada por outras pessoas. O nível de relações estabelecidas pelo sujeito está estreitamente relacionado com suas capacidades mentais e com suas possibilidades de avanços, assim como com suas concepções éticas e sociais, experiências pessoais e sentimentos.

Do processo organizador do modelo, que envolve as relações entre elementos e seus significados, acontecem as implicações, que remetem à função de explicar, ordenar e/ou resolver a situação enfrentada pelo sujeito. Desse modo, as implicações são fonte de ações e retratam o modelo e sua complexidade.

Os modelos organizadores não cumprem só a função de servir de base para a explicação de alguns fatos; servem também de ponto de partida para a ação, já que esta não tem como base a realidade, mas o que cada um acredita que é a realidade; dessa forma, nossas convicções guiam nossos atos mais que os fatos objetivos, o que equivale a dizer que construímos modelos de realidade. (MORENO MARIMÓN et al., 1999, p. 91)

A ação ocorre, destarte, em consequência do modelo organizador que é construído em cada situação particular e em decorrência das implicações que derivam dele. Em outras palavras, os modelos organizadores servem de explicação para ações. Além disso, as ações 
podem mudar os modelos organizadores, pois provocam novas "realidades", permitindo que o sujeito se situe em outras perspectivas.

Sobre as implicações, é importante indicar que ocorrem conjuntamente aos processos de abstração e significação dos elementos. As implicações ou consequências são derivadas dos significados atribuídos aos elementos, ao mesmo tempo em que vão permitir ou não a seleção de outros elementos. De acordo com Arantes (2003), a atribuição de significados, condição necessária para que um elemento seja considerado pertinente em um modelo organizador, pressupõe uma série de implicações que derivam do significado.

Desse modo, é possível asseverar que, uma vez que as implicações estabelecidas pelos sujeitos durante a elaboração de um modelo organizador dependem dos significados atribuídos aos elementos considerados relevantes, frente a uma mesma realidade, o sujeito pode estabelecer variadas relações, o que o leva a ter diferentes pontos de vista sobre um mesmo fato. No entanto, apesar de ser possível obter diferentes pontos de vista sobre o mesmo fato, a possibilidade de ordenamento dos elementos que compõem o modelo organizador, cuja função está em dar coerência interna a eles, não é infinita, visto que deve ter certo grau de compatibilidade com o real (MORENO MARIMÓN et al., 1999, p. 364). A realidade objetiva atua, pois, como regulador da elaboração dos modelos organizadores.

Segundo Moreno Marimón e Sastre (2010), os aspectos funcionais do modelo organizador não são conscientes, tal como ocorre com a elaboração do pensamento e dos sentimentos. $\mathrm{O}$ funcionamento psíquico, assim, permanece oculto à consciência na medida em que a tomada de consciência dos processos de pensamento sempre acontece posteriormente e requer uma profunda reflexão sobre a reflexão.

Para as autoras, a construção de modelos é inevitável, já que sem eles não haveria pensamento. O referente do pensamento (tanto do 'cotidiano' quanto do ‘científico') não é a realidade exterior, mas os modelos organizadores que construímos a partir deles, de nossas inferências, de nossas crenças e de nosso estado cognitivo-emocional. A inteligência, nessa ótica, consiste em estabelecer relações entre elementos, agrupando-os em modelos e relacionando diferentes modelos entre si, formando redes cada vez mais complexas e submetidas continuamente a mudanças.

Os modelos mais simples servem de elementos para que se construam outros mais complexos que servem, a sua vez, de base para outros modelos, relacionados entre si, de tal maneira que podem adquirir cada vez maior complexidade. O emaranhado de organizações, significados e implicações que decorre disso faz possível uma adaptação ao meio, isto é, uma transformação mental do meio, simplificado e esquematizado, que se 
converte em compreensível e manejável pelo sujeito, ao custo de simplificar tudo o que nos rodeia. $\mathrm{O}$ sujeito se adapta ao meio adaptando o meio às suas possibilidades de organização. (MORENO MARIMÓN; SASTRE, 2010, p. 83, tradução nossa)

O caráter funcional e dinâmico dos modelos organizadores explica a interação do sujeito com o meio através da experiência e se manifesta no processo constante de evolução que implica a conservação e a mudança. Os modelos estão em constante transformação. Isso porque, em um primeiro momento, o sujeito se serve de modelos antigos para explicar a realidade, mas verifica que tais analogias não dão conta de explicar novos elementos que se lhe apresentam, o que ocasiona a formulação de novos modelos.

No que tange à transformação, faz-se necessário indicar o papel dos sentimentos. Na elaboração de um modelo organizador, os sentimentos formam parte primordial no processo de abstração e atribuição de significados aos elementos. Os sentimentos estão presentes em todo ato cognitivo (MORENO MARIMÓN; SASTRE, 2010, p. 85). Como os significados estão na interpretação do sujeito sobre a realidade, eles são "flutuantes" ou transitórios de acordo com os momentos "cognitivo-emocionais" pelos quais o sujeito passa. Em uma situação conflitiva, o sujeito passa por momentos muito diferentes, o que o leva a mudar os significados atribuídos aos elementos ou até a abstrair elementos diferentes em uma mesma situação. Essa forma de mudar o pensamento leva-nos a verificar que, ao mesmo tempo em que a organização do modelo solicita uma coerência interna, ela está aberta à falta de constância. "Se rompemos com a ideia de que o pensamento 'deve ser' consistente consigo mesmo, podemos apreciar a falta de constância e a variabilidade que o caracteriza, que de outra forma seríamos incapazes de perceber" (MORENO MARIMÓN; SASTRE, 2010, p. 86, tradução nossa).

Ao visualizar o funcionamento psicológico como dinâmico, garantindo tanto a coerência interna do sujeito quanto as transformações e falta de constância do pensamento que se dão na relação entre essa coerência e a forma como interpreta o meio, a Teoria dos Modelos Organizadores avança na compreensão sobre o funcionamento psíquico e suporta nossa articulação entre a moralidade e os projetos de vida dos jovens, no que se refere aos processos de regulação e integração de valores e sentimentos. No próximo item, apresentaremos os avanços que tal teoria apresenta para o campo da moralidade e para a perspectiva, dentro dos estudos nessa área, dos projetos de vida. 


\subsection{Modelos Organizadores do Pensamento: contribuições e perspectivas para o estudo da moralidade}

Embora tenha iniciado suas investigações no campo da Física (MORENO MARIMÓN et al., 1999), a Teoria dos Modelos Organizadores do Pensamento mostrou-se fecunda para avanços no campo da moralidade, uma vez que incorpora uma perspectiva funcional, levando em consideração o sujeito psicológico e a complexidade que envolve seus aspectos cognitivos, afetivos, físicos e sociais.

Uma série de investigações vem sendo desenvolvida no Brasil e também no exterior, especialmente na Espanha, com conteúdos acerca de questões morais. Tais pesquisas introduzem a metodologia e a perspectiva teórica dos modelos organizadores do pensamento no estudo da moralidade humana, tecendo discussões a partir de considerações sobre a moralidade e dos aspectos envolvidos em sua construção como a afetividade, o conhecimento social e a cultura.

Segundo levantamento feito por Vasconcelos, Arantes, Lemos-de-Souza, Trevisol e Belloto (2010), os estudos sobre a moralidade na perspectiva dos modelos organizadores podem ser organizados em três grupos: (a) pesquisas que se dedicam a investigar o papel organizativo dos estados emocionais e dos sentimentos nas relações entre juízos e ações morais (ARANTES, 2000, 2003; ARANTES; SASTRE, 2003; MARTINS, 2003; AFFONSO, 2008); (b) estudos que estão voltados para a complexidade dos juízos morais elaborados em função dos conteúdos envolvidos em conflitos, numa perspectiva psicogenética ou não (LEMOS-DE-SOUZA, 2008; LEMOS-DE-SOUZA; VASCONCELOS, 2003; PÁVON, 2002; SASTRE; MORENO MARIMÓN, 2000; SASTRE, MORENO MARIMÓN; FERNÁNDEZ, 1994; PÁTARO, 2007; SASTRE; TIMON HERRERO, 2003; PUPO, 2007; STACH-HAERTEL, 2009); (c) investigações sobre as mudanças de modelos em função de diferentes idades a partir de problemas morais ou de conhecimento social (SASTRE; MORENO MARIMÓN; PÁVON, 2001; TREVISOL, 2002; VASCONCELOS; BELLOTO; ENDO, 2007; MARTINS, 2008). Abordaremos alguns desses estudos nos próximos parágrafos, de forma a explicitar os avanços proporcionados por essa teoria em relação à moralidade.

As indicações do primeiro grupo (a) incidem sobre o papel organizativo dos sentimentos no funcionamento psíquico. Um dos estudos que se destacam nesse grupo é o de Arantes (2000a, 2003). Nesta pesquisa, 90 professores(as) brasileiros(as) foram divididos em três grupos e cada um deles foi levado a experienciar diferentes estados emocionais, antes de serem solicitados a resolver um conflito moral que envolvia a utilização de drogas por um 
aluno dentro da escola. Um grupo experienciou sentimentos "positivos", como alegria, felicidade e/ou satisfação pessoal; outro grupo experienciou sentimentos "negativos", como tristeza, frustração e/ou insatisfação pessoal; e o terceiro grupo foi chamado de "neutro" porque os sujeitos não foram induzidos a experienciar nenhum tipo de sentimentos.

Os resultados gerais mostraram que os(as) professores(as) do grupo "positivo" tenderam a organizar seus pensamentos com modelos organizadores mais complexos e defenderam a ideia de que a professora deveria se envolver diretamente na ajuda ao estudante usuário de drogas. Por outro lado, professores(as) do grupo "negativo" tenderam a elaborar modelos organizadores menos complexos e defenderam o princípio de que a professora não tinha que se envolver nesse tipo de problema de seus alunos. O grupo "neutro" se colocou exatamente entre os dois outros grupos. Como conclusão geral, Arantes observou que o estado emocional dos sujeitos influencia a organização de seus pensamentos quando solicitados a resolver conflitos morais.

Outro estudo que se destaca nesse grupo é o de Affonso (2008). O objetivo deste focava-se em investigar a influência dos estados emocionais na organização do pensamento dos sujeitos frente a um conflito hipotético de natureza moral. A autora, primeiramente, propiciou uma dinâmica com os grupos de sujeitos que perfizeram a pesquisa, com o objetivo de possibilitar que os mesmos fossem imersos em estados emocionais específicos. Tal como o fez Arantes (2000a), Affonso dividiu os sujeitos em dois grupos: o primeiro vivenciou sentimentos positivos, enquanto o segundo sentimentos negativos. Após a dinâmica inicial de indução de um estado emocional, os sujeitos foram solicitados a se posicionar, por escrito, diante de um conflito moral relacionado à violência e às questões de gênero. Nesse conflito, a questão central era a oposição do marido quanto à saída da companheira da esfera doméstica e cuidado com os filhos, para o retorno aos estudos, mercado de trabalho e outras atividades voltadas para a esfera pública.

A análise dos dados permitiu a Affonso perceber que existe diversidade na forma como os sujeitos percebem os conflitos, dependendo de seu estado emocional. Enquanto o grupo positivo apresentou uma tendência para encarar o marido que se recusa a deixar a esposa voltar a estudar como uma pessoa boa, preocupada com o bem-estar dos filhos e a segurança da família, deixando de lado o fato de esse marido ter agredido a mulher, o grupo negativo o viu como uma pessoa problemática e egoísta, incapaz de respeitar as pessoas, enfatizando a agressão para justificar suas respostas. No grupo positivo, houve uma tendência para buscar soluções a partir do diálogo e da negociação, de forma a atender as necessidades de todos na família. No grupo negativo, em contrapartida, os sujeitos tenderam a salientar 
soluções mais radicais e extremas, como a separação do casal ou até mesmo o revide da agressão.

Além disso, a autora percebeu também a influência exercida pela dimensão do gênero nas respostas dos sujeitos. Entre os sujeitos do grupo positivo, o grupo feminino, em sua maioria, buscou soluções conciliatórias que envolviam algumas concessões e que almejavam convencer o marido a "permitir" o retorno aos estudos, deixando implícito que o comando das ações familiares estava nas mãos do homem. Já no grupo masculino, houve uma maior tendência para a sugestão de soluções que buscassem o auxílio na organização da rotina dos cuidados com a casa e filhos de modo que a mulher pudesse dar conta de tudo. Entre os sujeitos do grupo negativo, as mulheres, grosso modo, sugeriram a separação do casal, enquanto os homens não buscaram essa alternativa; pelo contrário, mobilizaram ora ações para "convencer" a mulher de que o retorno aos estudos traria muitos problemas para a casa e para os filhos, ora insinuavam a pura e simples proibição, sem argumentos. A agressão do marido, para os sujeitos do sexo masculino do grupo negativo, não foi abstraída como um elemento significativo da situação.

Considerando essa análise, a autora chegou à conclusão de que os estados emocionais e o gênero influem, sobremaneira, na organização psíquica dos sujeitos, levando-os a formar diversas representações das ações.

O segundo grupo de trabalhos (b) que utilizam o instrumento teórico-metodológico dos Modelos Organizadores do Pensamento caracteriza-se por evidenciar a complexidade dos juízos morais elaborados em função de um conflito apresentado. Alguns desses estudos buscam, assim como os do primeiro grupo, tecer relações com variáveis, como sexo, idade e local de residência, com a intenção de discutir questões relacionadas a gênero, psicogênese e cultura.

Para evidenciar as contribuições desse grupo de investigações, destacamos o trabalho de Lemos-de-Souza (2008), que buscou investigar os modelos organizadores do pensamento aplicados por 400 jovens de 15 a 21 anos frente a um conflito moral e interpessoal em um ambiente escolar, a partir de uma perspectiva de gênero. $O$ autor apresentou aos sujeitos participantes da pesquisa uma situação de homofobia envolvendo dois protagonistas: em uma das histórias os personagens eram meninos e, em outra, eram meninas. Após a leitura do texto referente ao conflito, os sujeitos foram solicitados a responder questões referentes aos sentimentos e pensamentos de cada um dos protagonistas, além de serem solicitados a dissertar, também, a respeito do que cada personagem deveria fazer nessa situação. 
Os resultados da pesquisa revelaram uma grande variabilidade na forma como a representação de gênero ocorre entre jovens em uma determinada situação, abrindo espaço para a pluralidade de gênero, isto é, feminilidades e masculinidades. $\mathrm{O}$ autor descobriu que as variáveis sexo dos participantes e estado onde nasceram (Mato Grosso e São Paulo) foram aspectos importantes para essa variabilidade entre os modelos. Com relação à variável sexo, o autor constatou que os jovens lançam mão de representações sobre as diferenças de gênero que se cristalizam em determinados aspectos e rompem com estereótipos em outros. Isso quer dizer que, quando eles constroem modelos a partir de seu próprio sexo como referência, tendem a criar modelos que fogem do estereótipo, mas, quando têm de interpretar o real a partir de outra referência de gênero, partem de crenças e estereótipos frequentes na cultura de gênero da sociedade em que vivem.

A variante relacionada ao estado em que moram os sujeitos participantes possibilitou a Lemos-de-Souza (2008) concluir que os sujeitos do estado de São Paulo aplicaram uma maior variabilidade de modelos, o que indica que as possibilidades de representações do gênero dos participantes desse estado tendem a ser amplas, buscando fugir dos estereótipos de uma única forma de lidar com a situação problema. Os sujeitos do estado do Mato Grosso tenderam a aplicar apenas dois tipos de modelos, tanto para um personagem quanto para outro, desvelando uma maior tendência à rigidez no modo de representar o gênero diante da situação de conflito interpessoal que envolve a homofobia.

O autor aponta, a partir de suas conclusões, que as representações de gênero têm papel relevante no modo como os jovens resolvem conflitos interpessoais, marcando a produção de estereótipos nas relações sociais entre homens e entre mulheres na escola.

Outro trabalho, de Vasconcelos, Bellotto e Endo (2007), merece destaque nesse grupo. Esse estudo objetivou compreender o fenômeno da indisciplina, considerando a sua complexidade. Dessa forma, para realizar uma pesquisa qualitativa do problema, os autores buscaram no referencial da teoria dos modelos organizadores uma forma de identificar as significações abstraídas por alunos de $2^{\mathrm{a}}$ e $4^{\mathrm{a}}$ séries do Ensino Fundamental ao abordar o tema.

Como instrumento de pesquisa, os autores utilizaram entrevista semidiretiva e a apresentação de dois conflitos hipotéticos relacionados a situações de indisciplina em sala de aula. Tais conflitos foram direcionados a duas situações específicas: o primeiro descrevia um(a) aluno(a) jogando um apagador na cabeça de outro(a) aluno(a), sendo que toda a situação fora observada por um(a) terceiro(a) aluno(a); o segundo dizia respeito a uma 
situação de um(a) aluno(a) jogando um apagador nas costas do(a) professor(a), sendo que toda a situação fora observada por um(a) terceiro(a) aluno(a).

Após a apresentação de cada um dos conflitos, os participantes foram solicitados a responder perguntas a respeito do que o personagem que observou a situação pensou e sentiu sobre o acontecimento e o que poderia fazer diante da situação. A análise e interpretação dos modelos revelaram, segundo os autores, que os modelos abstraídos por ambos os grupos $\left(2^{\mathrm{a}} \mathrm{e}\right.$ $4^{\mathrm{a}}$ séries) refletiram a diversidade e a regularidade presentes nos raciocínios elaborados para resolver os conflitos apresentados. Além disso, pela variedade de modelos organizadores identificados, foi possível aos autores perceber a importância dos conteúdos socioculturais na construção de argumentos relacionados aos julgamentos morais.

Buscando também compreender as representações mentais consoante às variáveis socioculturais, Arantes, Sastre e González (2007) procuraram analisar as representações mentais de adolescentes sobre um episódio de violência contra a mulher. Nessa análise, as autoras apoiaram-se na Teoria dos Modelos Organizadores do Pensamento para identificar diferentes estratégias de resolução de conflito e sua relação com os vínculos cognitivos/afetivos projetados na relação entre os protagonistas, de forma a atender à proposta de realizar uma análise qualitativa das opiniões de cada participante, respeitando sua idiossincrasia, bem como detectando semelhanças e diferenças entre os sujeitos da amostra.

Para tal análise, as autoras propuseram-se a investigar as possíveis influências das variáveis idade, sexo e cultura (brasileira e espanhola), utilizando, como instrumento uma situação na qual uma adolescente relatava, além de aspectos relacionados à sua vida (estudos, família, etc.), um conflito vivido entre ela e o namorado, o qual envolvia um episódio de violência física e insultos. Nesse instrumento, as autoras não inseriram valorações de ordem moral, apenas o relato do conflito.

Com base na leitura desse texto, os sujeitos foram solicitados a responder questões sobre os conselhos que dariam ao(à) protagonista da história e o que fariam, sentiriam e pensariam se estivessem na mesma situação. As respostas às questões levaram Arantes, Sastre e González a identificarem cinco diferentes modelos organizadores do pensamento, que refletem maneiras e níveis distintos de posicionar-se diante da violência contra a mulher. Esses modelos organizadores do pensamento puderam ser inseridos em dois grupos maiores de respostas por suas semelhanças: no primeiro grupo, os sujeitos abstraíram a violência como significativa e a colocaram em evidência já no momento de expor as estratégias de ação, estabelecendo, entre os personagens uma relação de oposição e sugerindo, como forma de resolver o conflito, a ruptura da relação; os sujeitos do segundo grupo não abstraíram o 
elemento da violência contra a mulher, mas se detiveram na problemática interna do agressor e estabeleceram, entre os protagonistas, uma relação de complementariedade cognitivo/afetiva, defendendo soluções conservadoras para o conflito, tais como a separação do casal.

A análise comparativa por idade, sexo e cultura permitiu a Arantes, Sastre e González (2007) concluir, por um lado, que os fatores advindos dessas variáveis influenciam as representações mentais dos adolescentes, mas, por outro lado, não podem ser tomados como os únicos válidos para explicar os obstáculos que dificultam o reconhecimento da violência no momento de elaborar formas de atuar sobre ela. As autoras indicam, ainda, que os resultados mostraram a riqueza e a diversidade das representações subjetivas com que cada indivíduo, em função de sua história pessoal, posiciona-se frente a essa violência.

Em relação ao terceiro grupo (c), a Teoria dos Modelos Organizadores do Pensamento é utilizada como instrumento para verificação de mudanças de modelos em função das idades dos sujeitos, a partir de problemas morais ou de conhecimento social.

Nesse grupo, destacamos a pesquisa efetuada por Trevisol (2002) que teve como objetivo investigar como alunos de diferentes idades e pertencentes a diferentes contextos socioculturais apreendem, organizam e julgam os seus direitos, mais especificamente o direito à educação e à proteção ao trabalho. Apoiado no referencial teórico dos Modelos Organizadores do Pensamento, o qual permite perceber o que é concebido por cada sujeito como sendo a realidade e que se configura como pauta para ações, explicações e teorias, o estudo se baseou em uma amostra composta de alunos na faixa etária entre 8 e 14 anos: 60 deles oriundos de escolas localizadas no Oeste catarinense e outros 60 advindos de uma escola localizada em Coimbra (Portugal). O instrumento utilizado para a coleta de dados foi uma história, envolvendo uma situação-problema, que teve como foco os direitos das crianças. Após a apresentação da história, os sujeitos foram entrevistados de forma individual para identificar o que pensavam e como representavam o cenário em discussão.

$\mathrm{Na}$ análise dos dados, a autora destacou as respostas cujo conteúdo dizia respeito à compreensão dos alunos sobre o direito à proteção ao trabalho. Identificou-se, nessas respostas, a posição unânime de discordância com relação ao trabalho infantil. Por meio de diferentes modelos organizadores do pensamento, evidenciou-se a organização dos dados, de significados e de implicações entre os elementos que compunham a história e outros que transcendiam esse contexto. Um ponto marcante para a autora circunscreveu-se à compreensão dos alunos portugueses, na qual se evidenciou uma manifestação explícita de indignação da situação do trabalho infantil e a convicção de que é papel do Estado garantir os 
direitos para todas as crianças, contrariamente ao que foi apreendido, de certa forma, da análise das representações dos alunos brasileiros. Os alunos portugueses, nas palavras de Trevisol (2002), atribuíram ênfase também ao papel dos pais como os mantenedores das condições de vida da família, o que resolveria o caso da exposição da criança ao trabalho. Para a autora, as diferenças de apreensão dos conteúdos entre os alunos participantes da pesquisa se devem, entre outros fatores, ao lugar de análise, de significação e de julgamento que os sujeitos se colocam para efetuar a leitura da realidade.

Outro trabalho de destaque nesse grupo é o de Martins (2008), o qual se centrou no papel da cultura na organização do pensamento, por meio da análise dos julgamentos e explicações emitidas pelos sujeitos participantes da pesquisa a respeito dos conteúdos de natureza cultural, que incluem questões de gênero e violência. A autora pretendeu analisar o quanto tais questões estão presentes em nossa cultura, sendo legitimadas e naturalizadas, exercendo forte influência na organização do pensamento.

Para tanto, Martins envolveu, em sua amostra, 240 sujeitos, sendo 120 do sexo feminino e 120 do sexo masculino, para favorecer a análise sob a perspectiva de gênero; e sendo 120 universitários e 120 adultos que cursaram até o Ensino Fundamental, já que, de acordo com a autora, a escola constitui-se em espaços de práticas culturais e pode exercer influência na organização do pensamento. Esses sujeitos, após lerem um conflito cujo conteúdo girava em torno das questões de gênero e violência contra a mulher, foram solicitados a responder algumas questões a respeito de como pensam sobre a situação e de como os personagens e o próprio sujeito, se estivesse na situação, deveriam se portar diante do conflito.

Martins analisou as respostas, organizando-as em modelos organizadores do pensamento (cinco no total). E, depois de tratar dos resultados estatisticamente, chegou à conclusão de que o conceito de gênero, como uma construção essencialmente cultural, é internalizado pelas práticas sociais e pela socialização discriminatória e diferenciada oferecida às crianças do sexo feminino e masculino. Essa internalização cultural apresenta nítidos reflexos na organização do pensamento. Além dessa conclusão fundamental, a autora conseguiu depreender de seus dados uma influência do nível de escolaridade dos sujeitos em sua organização do pensamento, visto que os adultos que cursaram até o Ensino Fundamental priorizaram respostas que favoreceram a reprodução de práticas culturais preconceituosas, estereotipadas e discriminatórias em relação à mulher, enquanto que os universitários tenderam a apresentar respostas em que defenderam os direitos da mulher. A partir de seus dados, Martins percebeu certa naturalização da violência, bem como uma maior flexibilidade 
de julgamentos entre mulheres e universitários, o que lhe suscitou a ideia de que esses sujeitos levam em consideração, frente a um determinado contexto, um maior número de variáveis.

A análise dos trabalhos com o referencial teórico-metodológico da Teoria dos Modelos Organizadores apresenta alguns avanços para o campo da moralidade, que indicaremos com base nos trabalhos de Vasconcelos, Belloto e Endo (2007) e de Vasconcelos, Arantes, Lemos-de-Souza, Trevisol e Belloto (2010).

Em primeiro lugar, a Teoria dos Modelos Organizadores do Pensamento, por contemplar o dinamismo do psiquismo humano, consegue expressar a organização entre elementos, significados e suas implicações, sendo capaz de compreender a forma como os sujeitos elaboram a sua representação mental diante de conflitos de conteúdos morais.

Além desse aspecto, acentua-se o fato de que essa teoria consegue conjugar estruturas e conteúdos, permitindo uma compreensão mais abrangente da complexidade que envolve o modo como o sujeito pensa a realidade. Já que apenas recursos operatórios não são suficientes para explicar o juízo moral, nessa perspectiva os aspectos socioculturais, valores, sentimentos, princípios e regras mostraram-se mais fecundos para abordar o raciocínio humano, logo que influem na abstração e significação de elementos da realidade. Nesse sentido, analisar de que forma os conteúdos da realidade são incorporados e organizados pelos sujeitos em seus modelos, tal como fizeram as pesquisas que abordamos, mostra-se um caminho fecundo para os estudos sobre a moralidade humana.

A Teoria dos Modelos Organizadores do Pensamento mostra-se profícua para observar a diversidade de modelos de realidade e a regularidade entre esses modelos. Uma vez que aposta na complexidade inerente à elaboração de modelos sobre o real, incorporando os aspectos subjetivos de construção de uma interpretação sobre o contexto, essa teoria rompe com a linearidade e o estruturalismo propostos por muitos trabalhos em psicologia, estabelecendo o estudo funcional que visa a contemplar o psiquismo de cada sujeito, que necessariamente é diferente de outros. Ao mesmo tempo em que é capaz de observar essa diversidade, a teoria abre-se para um marco geral da regulação do real para a construção de modelos organizadores, já que eles devem apresentar certa plausibilidade com as situações. Assim, o papel do contexto e da cultura faz-se fortemente marcado nas construções individuais, gerando regularidade entre os modelos, ou seja, determinando certas "tendências" de pensamento entre sujeitos de uma mesma cultura.

Outro aspecto importante da adoção da Teoria dos Modelos Organizadores como aporte teórico-metodológico para o estudo da moralidade, e que tem estrita relação com os anteriores, repousa no fato de que esse instrumento constitui em grande avanço da 
metodologia, já que, ao incorporar conflitos morais próximos da realidade dos sujeitos, não imprime a necessidade de caracterizar os dados sob a égide de categorias prévias. Muito pelo contrário, proporciona uma abertura para verificar a diversidade e a complexidade dos dados coletados para a investigação. Sobre esse aspecto, concordamos com Arantes (2000b) ao enfatizar que

do ponto de vista metodológico, o que nos atrai nessa teoria, e que constitui um grande avanço conceitual, é o fato de não trabalharmos com categorias predeterminadas de modelos organizadores. Eles são extraídos a partir das respostas dos sujeitos e não por inferências prévias do pesquisador. Isso significa que os modelos organizadores encontrados não se repetem necessariamente em outras situações e com outra amostra. (p. 144)

Essa teoria, como se vê, não está à procura de inserir o sujeito em uma categoria predeterminada. Pelo contrário, ela almeja perceber as categorias que emanam das respostas dos sujeitos, possibilitando apontar as regularidades, isto é, o que as respostas têm em comum, ou seja, quais as similaridades dos modelos de realidades aplicados pelos sujeitos, quanto às nãoregularidades, o que elas têm de singular e o que caracteriza a diversidade de pensamentos possíveis mediante a realidade.

Para além dessas contribuições, gostaríamos de citar outras duas vertentes de análise dentro da perspectiva da Teoria dos Modelos Organizadores do Pensamento que, em nossa opinião, podem significar avanços para o estudo da moralidade humana.

A primeira diz respeito ao estudo dos processos regulatórios exercidos pelos valores e sentimentos nos contextos de conteúdo moral. Em nosso estudo anterior (PINHEIRO, $2009)^{33}$, conforme citamos no primeiro capítulo de nosso quadro teórico, utilizamo-nos do instrumento teórico-metodológico da Teoria dos Modelos Organizadores do Pensamento para analisar, por uma via funcional, as respostas dos jovens referentes ao valor de generosidade e aos sentimentos morais de culpa e vergonha. Devido à abordagem das respostas por esse instrumento, que não determina categorias prévias, mas considera os elementos abstraídos e significados pelos sujeitos, bem como suas implicações, foi possível verificar o papel de

\footnotetext{
${ }^{33}$ Embora não tenha sido citado no artigo elaborado por Vasconcelos e colaboradores (2010), tal trabalho ofereceu a possibilidade de avanços em relação à aplicação da Teoria dos Modelos Organizadores do Pensamento, pois integrou o estudo do papel regulatório dos sentimentos morais e um elemento apresentado no conflito moral (a generosidade), assim como avançou na percepção da integração e centralidade exercida pelos valores e sentimentos na análise que contou com a leitura de todo o protocolo (e não das questões separadamente). Acreditamos que esse trabalho não poderia ser enquadrado em uma das vertentes expostas pelos autores, mas compreende duas delas, (a) e (b), já que se propôs a investigar sobre o papel organizativo dos sentimentos na mesma medida em que analisou a forma como cada sujeito se posicionou frente a um conteúdo moral na situação hipotética.
} 
regulação exercido pelos valores e sentimentos, bem como a centralidade e integração que estes assumiram na elaboração dos modelos organizadores. Isso significa que, por meio dessa teoria, é possível avançar no estudo das relações que são tecidas nos processos funcionais que envolvem valores, sentimentos, crenças, pensamentos, desejos, etc. Além disso, por propiciar a visualização dessas relações, a análise por meio da teoria dos modelos organizadores permite-nos identificar as integrações entre os valores e sentimentos e a centralidade que eles assumem para o sujeito diante de um contexto.

A segunda vertente diz respeito aos projetos de vida. Consoante o que expusemos no capítulo anterior, nossa ideia de projeto de vida incorpora uma projeção de futuro, que abarca tanto as características do sujeito quanto o caráter de transitoriedade dos projetos. Por se tratarem de uma projeção futura, mas embasada em elementos da vivência do sujeito e de suas particularidades, os projetos contêm aspectos pertinentes à sua identidade. Por estarem intrinsecamente relacionados com conteúdos do contexto, os projetos englobam aspectos sociais, culturais e interpessoais. A Teoria dos Modelos Organizadores do Pensamento, na medida em que engloba estruturas e conteúdos, pode, em nossa consideração, ser profícua para uma melhor compreensão dos projetos de vida.

A análise envolvendo projetos de vida e modelos organizadores do pensamento é nova e apenas foi abordada por alguns trabalhos no Brasil: PÁTARO (2011), ULLER (2012); ARANTES (2012) ${ }^{3435}$, chegando a alguns resultados expressivos no campo da psicologia moral. Citaremos dois desses trabalhos, de forma a trazer indicações sobre descobertas importantes da conjunção entre tais teorias.

Pátaro (2011) objetivou analisar a função psíquica dos sentimentos e das emoções na construção dos projetos de vida dos jovens. Partindo do referencial da Teoria dos Modelos Organizadores do Pensamento e do conceito de projeto de vida (purpose), a pesquisa foi realizada com entrevistas semiestruturadas ${ }^{36}$ com um total de 30 jovens (15 do sexo

\footnotetext{
${ }^{34}$ Essa investigação está inserida no corpo do trabalho de Livre-Docência em vias de defesa pela $\operatorname{Prof}^{\mathrm{a}} \operatorname{Dr}^{\mathrm{a}}$ Valéria Amorim Arantes (em fase de elaboração). Foi financiada pelo Conselho Nacional de Desenvolvimento Científico e Tecnológico (CNPQ) e pela Fundação de Amparo à Pesquisa do Estado de São Paulo (Fapesp).

${ }^{35}$ Embora não tenha analisado os dados pelo referencial da Teoria dos Modelos Organizadores do Pensamento, acreditamos ser importante destacar duas pesquisas que se debruçaram sobre os projetos de vida na juventude. Tratam-se dos trabalhos do Prof. Dr. Ulisses Araújo, "Valores e projetos vitais dos jovens brasileiros" (2012), uma pesquisa financiada pelo Conselho Nacional de Desenvolvimento Científico e Tecnológico (CNPQ) e pela Fundação de Amparo à Pesquisa do Estado de São Paulo (Fapesp), e de Ana Maria Klein, "Projetos de vida e escola: a percepção de estudantes do Ensino Médio sobre a contribuição das experiências escolares aos seus projetos de vida" (2011), uma investigação desenvolvida para obtenção do título de doutora em Educação pela Universidade de São Paulo (USP).

${ }^{36} \mathrm{O}$ referencial utilizado pela autora para a construção do instrumento de pesquisa foi a entrevista elaborada pelo Stanford Center of Adolescence (cf. DAMON, 2009).
} 
masculino e 15 do sexo feminino), entre 15 e 17 anos, estudantes de uma escola pública de Ensino Médio do interior do estado do Paraná.

Verificando os modelos organizadores aplicados pelos sujeitos participantes, a autora identificou a influência dos sentimentos e das emoções no engajamento dos jovens em projetos de vida. Tal influência, segundo Pátaro, pôde ser constatada por alguns aspectos. Primeiramente, na configuração dos sentimentos e das emoções no raciocínio que se mostra intimamente relacionada com o engajamento do jovem em seu projeto de vida. Os projetos de vida, portanto, parecem depender, em grande parte, de como os jovens compreendem e lidam com seus sentimentos e emoções, assim como os sentimentos e emoções das pessoas com quem convivem.

Em segundo lugar, Pátaro (2011) indica que os sentimentos e emoções embasam as relações pessoais, configurando-se como um aspecto de grande relevância no raciocínio dos participantes que se engajaram em projetos de vida. A importância das relações interpessoais veicula-se, segundo a autora, à integração entre os âmbitos público e privado.

Mais um aspecto que determina a influência dos sentimentos nos projetos de vida está no bem-estar pessoal e na autorrealização. Para Pátaro, os sentimentos de satisfação e de realização pessoal, assim como outros sentimentos positivos vinculados ao self, mostram-se relevantes para a compreensão dos projetos de vida. Além disso, há a presença de valores nos projetos, que são evidenciados pelos sentimentos. Entre esses valores, a autora destaca os valores morais altruístas, que compareceram às respostas vinculadas a um maior engajamento com os projetos de vida.

A autora enfatiza o papel dos sentimentos para a percepção por parte dos jovens de seus conflitos, obstáculos e dificuldades vivenciadas, demonstrando incômodo com a situação e vontade de superação. A falta de sentimentos veiculada a esses aspectos influenciou uma postura passiva por parte dos participantes.

Arantes (2012) teve por objetivo analisar que papel os sentimentos e emoções dos jovens exercem na organização de seus projetos de vida (purposes). Com uma amostra de 240 jovens estudantes do Ensino Médio do Estado de São Paulo, a autora aplicou um questionário escrito e aberto com treze questões referentes a: a) aspectos do self, da vida do jovem e de sua relação com o mundo; b) mudanças sugeridas pelo sujeito para mudar a realidade, bem como ações que ele realiza para tanto; c) projeções futuras do jovem, em um futuro próximo (5 anos) e em um futuro distante (40 anos); d) dimensão dos projetos de vida dos jovens e de seus sentimentos. 
O processo de análise, com base no instrumento teórico-metodológico da Teoria dos Modelos Organizadores do Pensamento, contou com a identificação dos elementos abstraídos, dos significados atribuídos e das relações/implicações estabelecidas por cada sujeito. Depois, buscando abordar os conteúdos mais interessantes para a análise, passou-se a verificar semelhanças e diferenças entre as respostas dos jovens, de acordo com os aspectos levantados no primeiro passo. Por fim, chegou à identificação de seis modelos organizadores do pensamento, que refletem diferentes configurações de sentimentos e valores nos projetos de vida (com suas multidimensões) dos jovens participantes.

As descobertas de Arantes (2012) ilustram que o modo como os sentimentos e emoções comparecem ao raciocínio dos sujeitos está intimamente relacionado ao engajamento dos jovens em seus projetos de vida. Para a autora, os projetos de vida parecem depender, em grande parte, da forma como os jovens compreendem e lidam com seus próprios sentimentos e emoções, assim como os sentimentos e emoções de pessoas de seu convívio. Destacam-se, na análise de Arantes, quatro aspectos:

a) o senso de satisfação e de realização pessoal, devido ao engajamento em projetos de vida, e o incômodo ou desconforto com a necessidade de melhorias no mundo, quando o sujeito apresenta a intenção de fazer a diferença. Os significados atribuídos pelos jovens a esses sentimentos, bem como as relações (e/ou integração) que estabelecem entre estes e outros elementos abstraídos e retidos como significativos, parecem à autora como fatores que pode impulsioná-los (ou não) à ação - e não aceitação, aspecto fundamental para a construção de projetos de vida.

b) os sentimentos e emoções que embasam as relações interpessoais apresentam grande relevância no raciocínio dos participantes. Os significados, implicações e/ou relações que o jovem atribui à sua relação com outras pessoas aparecem como fundamento para os elementos constituintes de seu projeto de vida, integrando os âmbitos público e privado e levando em consideração os interesses e objetivos pessoais, bem como os sentimentos e emoções do sujeito no julgamento e ações morais.

c) as relações afetivas mostram-se significativas no papel que o sujeito atribui ao bem-estar do outro, na medida em que podem estar vinculados à generosidade e à solidariedade, gerando condutas altruístas. No entanto, o engajamento em projetos de vida vai além das preocupações altruístas, mas pressupõe organizações nas 
quais comparecem sentimentos e emoções que, além de se fundamentar no bemestar do outro, também se relacionam ao seu próprio bem-estar.

d) o engajamento em projetos de vida está relacionado aos valores éticos, regulados por sentimentos e emoções, que integram a identidade dos jovens e servem de base para os seus projetos. É evidente a vinculação entre os valores e a dimensão afetiva.

As proposições assinaladas por Pátaro (2011) e Arantes (2012) sugerem a importância que os vínculos afetivos assumem no processo de construção dos projetos de vida. Ao defenderem a importância das relações interpessoais no desenvolvimento moral do ser humano, passam a destinar espaço para uma abordagem do ser humano em sua complexidade. Os projetos de vida, em sua concepção, podem se constituir como elementos importantes no processo de desenvolvimento dos jovens, possibilitando um sentido ético à sua vida, o engajamento em objetivos que sejam significativos a si e ao mundo, bem como a satisfação em suas ações, escolhas e planos.

A incorporação de uma análise de dados realizada com base nos modelos organizadores do pensamento aproximou as autoras dos processos mentais e do continuum entre pensar, sentir e agir. Tal referencial permitiu-lhes adentrar a complexidade da dinâmica do funcionamento psíquico, possibilitando um olhar para as regularidades e também para a diversidade e as singularidades do pensamento humano.

A perspectiva de aliar o estudo dos processos de integração e regulação de valores e sentimentos às propostas dos projetos de vida e da Teoria dos Modelos Organizadores do Pensamento parece-nos uma via fecunda de análise, já que compreende uma maior possibilidade de analisar a complexidade que perfaz o psiquismo humano, inclusive no tocante à moralidade.

No próximo capítulo, traçaremos o percurso que guiou metodologicamente a presente pesquisa, explicitando a influência das bases teóricas por nós apresentadas. 


\section{CAPÍTULO IV PLANO DE INVESTIGAÇÃO}

No delineamento do presente plano de investigação, consideramos os pressupostos teóricos envolvidos na formulação de nosso problema de pesquisa. Dessa forma, alicerçamonos em uma visão do funcionamento psicológico pela via da complexidade, que nos permite observar os processos funcionais de regulação e integração de valores e sentimentos que constituem base para juízos em contextos que envolvem conteúdos morais. A contribuição desse construto teórico embasa-se, sobretudo, na corrente que vem intentando quebrar um paradigma centrado apenas na cognição, para incorporar, em suas análises, uma perspectiva cognitivo-afetiva-social que visa à integração da moral ao self.

Outra vertente que apoia a construção desta investigação encontra-se nos projetos de vida, pautados em uma concepção que considera os percursos e trajetórias dos jovens. Ao mesmo tempo em que se vê como necessária a indicação de que tais projetos de vida contêm aspectos concernentes às identidades dos sujeitos, fundados em seus paradigmas, percebe-se o caráter de transitoriedade de tais projetos, de acordo com o momento de vida, o contexto e as questões culturais.

É necessário considerar que a via de complexidade que se pretende abarcar, partindo de tais pressupostos, não se esgota com uma investigação, mas consegue ampliar um construto teórico na medida em que várias pesquisas, de forma interdisciplinar, são capazes de abordar o mesmo fenômeno. Dessa forma, não pretendemos dar conta da complexidade do objeto em estudo, porém contribuir para a análise das relações que levam à sua compreensão, o que corresponde a dar um passo para o entendimento das relações entre os processos de integração e regulação e os projetos de vida dos jovens.

Para tanto, a Teoria dos Modelos Organizadores do Pensamento (MORENO MARIMÓN et al., 1999) apresenta-se como outra contribuição importante. Partindo de seus princípios, que trazem indicações a respeito da elaboração pelo sujeito de modelos de "realidade", utilizamos tal teoria como instrumento teórico-metodológico para investigar, de maneira funcional, os processos de regulação e integração de valores e sentimentos do sujeito diante da formulação de seus projetos de vida e de um conflito envolvendo esse conteúdo.

Ao utilizar a Teoria dos Modelos Organizadores do Pensamento, procederemos a uma análise fina e minuciosa, que buscará empreender nossas considerações para além da constatação de sentimentos e valores presentes nos projetos de vida dos jovens, mas se envolverá na forma como são elaborados, nas relações tecidas entre os processos que regulam 
e integram a afetividade ao self.

A metodologia empregada pela presente investigação, embora esteja alicerçada em tais pressupostos, seguiu um percurso individual, da pesquisadora, já que envolveu não apenas construtos teóricos, mas uma percepção e intuição bastante subjetivas. Consideramos, de acordo com a teoria dos Modelos Organizadores do Pensamento, o pesquisador como um sujeito que também constrói conhecimento sobre o real e sobre si mesmo. "As relações entre elementos e significados que o pesquisador produz, baseado em dada situação, constituem um processo fundamentado na interação com seu objeto de conhecimento" (VASCONCELOS et al., 2010).

Nos próximos itens deste capítulo, apresentaremos tal percurso, buscando explicitar as escolhas teóricas e metodológicas de nossa pesquisa.

\subsection{Problematização e objetivos da pesquisa}

A escolha da temática da presente pesquisa, que se refere aos processos de regulação e integração entre valores e sentimentos nos projetos de vida dos jovens, provém de um percurso de pesquisa que envolve a pesquisadora e seus modelos de "realidade", ou seja, aquilo que abstrai, significa e compreende dos contextos em que atua, de acordo com suas vivências, construtos teóricos e inserção cultural.

Para além da trajetória científica que fundamentou a escolha de tal temática, há de se destacar que a moralidade na juventude tem sido um aspecto de reflexão em nossa história profissional. A atuação em uma escola particular da periferia de São Paulo levou-nos a empreender estudos sobre o jovem e seus projetos de vida, notadamente pelas questões relacionadas à moralidade, já que percebíamos que deviam ser temas trabalhados naquela instituição pelo fato de que se proporcionava pouca reflexão aos educandos a esse respeito.

Ademais, investigando a moralidade, pelo viés da psicologia moral e, mais especificamente, com a Teoria dos Modelos Organizadores do Pensamento (MORENO MARIMÓN et al., 1999), pudemos seguir um caminho que foi, ao longo dos trabalhos desenvolvidos, ganhando complexidade e partindo para um enfoque sobre o tema aqui abordado.

De forma a transformar tal objeto em problema de pesquisa, aprofundamo-nos em três vertentes de estudo que, complementares, poderiam, em nossa visão, contribuir para a sua elaboração.

Em primeiro lugar, verificamos a temática da moralidade no tocante à regulação e 
integração entre valores e sentimentos. Buscando nos aprofundar no sentido desses termos, seguimos para a compreensão do sujeito psicológico (cf. ARAÚJO, 1998) e dos processos funcionais que atuam por detrás de seus juízos e ações morais. Compreendemos a regulação e a integração entre valores e sentimentos como processos que são inerentes ao funcionamento psíquico humano, quando estudado por uma via que considera o sujeito como ser que age, pensa e sente.

Nota-se que alguns estudos (DE LA TAILLE, 2002; ARAÚJO, 1998, 2003a) incidem sobre o papel regulatório dos sentimentos morais, enfatizando sua atuação nos sistemas que compõem o sujeito psicológico, influenciando juízos e ações morais. Ainda encontramos em alguns estudos (DAMON, 1995; ARAÚJO, 2003a) a indicação de que os valores posicionamse no sistema moral dos sujeitos como centrais ou periféricos, em consonância com a carga afetiva que recebem.

Além desses estudos, encontram-se outros que incidem sobre a concepção de identidade moral (BLASI, 1995, 2004; DAMON, 1992), trazendo uma vertente que indica a moralidade como integrada ao self. Essa integração dá-se com a centralidade que a moralidade ocupa na identidade do sujeito, ao mesmo tempo em que indica que, no sistema moral de cada um, há a necessidade de integração entre valores, compondo um modo como o sujeito tende a pensar e agir moralmente. Alguns estudos vêm a contribuir com o posicionamento de que tal integração deve levar em consideração os conteúdos do contexto e as relações interpessoais (NISAN, 2004; BENHABIB, 1992; NUCCI, 2001, 2004; TURIEL, 2002) e os processos não conscientes de formulação de juízos e ações morais (LAPSLEY; NARVAEZ, 2004). Ainda no que se refere à integração, cabe posicionar a teoria de Moreno Marimón e Sastre (2010) que indica que os sentimentos devem ser vistos como "complexos de sentimentos", logo que não podem ser entendidos de forma isolada, pois envolvem diversos sentimentos de acordo com os conteúdos das situações. Essa teoria contribui para pensarmos que sentimentos e, em nossa hipótese, valores estão sempre integrados na elaboração de juízos e ações morais.

Seguindo, em grande parte, os avanços proporcionados por esses trabalhos, empreendemos, anteriormente, uma investigação que buscou entender a regulação exercida pelos sentimentos morais de culpa e vergonha em relação ao valor de generosidade (PINHEIRO, 2009). Além da constatação do papel regulatório de tais sentimentos, percebemos o comparecimento do valor de amizade que se mostrou integrado à generosidade. Em grande parte das respostas emitidas pelos jovens participantes em que a generosidade era indicada como pertinente ao conflito apresentado, os sujeitos trouxeram também a indicação 
da amizade. Quanto maior o vínculo entre tais valores, maior foi o rechaço de alternativas não generosas em relação aos personagens da situação hipotética analisada pelos participantes. E, nas respostas em que a amizade não era abstraída de forma significativa, não houve o comparecimento da generosidade.

Tais indicações puderam nos trazer uma perspectiva de que os valores se integram aos processos funcionais de elaboração de juízos e ações morais, exercendo papel, juntamente com os sentimentos, de reguladores morais. Na medida em que um valor se integra a outro, ambos exercem maior influência sobre a elaboração de formas de pensar e atuar diante de um conflito moral.

Procurando aprofundar as indicações desse trabalho, como outra vertente para o presente estudo, vimos nos projetos de vida elaborados pelos jovens um caminho profícuo para uma ampliação das descobertas efetuadas, uma vez que em sua elaboração estão envolvidos valores e sentimentos que são mobilizados de acordo com a rotina vivenciada, com ações passadas e também com as projeções de futuro.

Uma vez que os projetos de vida analisados na presente pesquisa referem-se a construtos realizados por jovens, partimos de alguns estudos sobre a juventude, no campo da sociologia, que contribuíram para uma visão que vai além da consideração da condição juvenil, como o modo que a sociedade atribui significado a esse momento da vida, para abordar também a situação juvenil, que se refere à forma como tal condição é vivida (SPOSITO, 2003, 2005). Nessa perspectiva, de forma a contribuir para nosso entendimento sobre os projetos de vida dos jovens, encontra-se uma abordagem significativa sobre a constituição de identidades juvenis que engloba as trajetórias vivenciadas, que se apresentam como repletas de possibilidades e reversibilidades (MELUCCI, 2007, PAIS, 2000, 2001). As trajetórias dos jovens brasileiros, investigadas em alguns trabalhos (CAMARANO et al., 2004; ABRAMO, 2005; LASSANCE, 2005; SPOSITO, 2005; THOMÉ; TELMO; KOLLER, 2011; LIBÓRIO; COÊLHO; CASTRO, 2011), revelaram aspectos importantes como inserção profissional, família, visão sobre futuro, religião e escola. Na consideração de tais aspectos, elucidaram-se trajetórias nãolineares seguidas pelos jovens, bem como vulnerabilidades e pontos de fortalecimento ou resiliência para enfrentamento de dificuldades.

Instituídos dessas considerações, partimos para uma análise sobre projetos de vida e, de forma a ampliarmos nossa visão, utilizamo-nos de estudos filosóficos ou antropológicos sobre o conceito de projeto. Dessa forma, verificamos que o termo projeto pode ser compreendido em uma intersecção com campos de possibilidades, isto é, contextos em que as projeções sobre o futuro podem acontecer (VELHO, 1994), além de se constituir como uma 
complexa teia de interesses e ações, estruturada por uma arquitetura de valores que são acordados socialmente para manter sua conservação ao mesmo tempo em que buscam transformações visando ao novo (MACHADO, 2004). Nessas considerações sobre projetos, observamos o caráter de mutabilidade e de transformação. Os projetos mudam de acordo com aspectos pessoais e coletivos, assim como as pessoas mudam por meio de seus projetos.

Com as indicações sobre juventude e projetos, voltamos nosso olhar à abordagem da psicologia sobre projeto de vida. Percebemos que tais estudos mostram-se preocupados em aplicar tal conceito a uma condição da juventude (INHELDER; PIAGET, 1976) e como objetivos almejados pelos jovens por lhes serem significativos e por trazerem uma perspectiva de contribuição com o mundo (DAMON, 2003, 2009). Aproximamo-nos de tais teorias pelo conceito proposto, mas, pela perspectiva dos estudos sociológicos, filosóficos e antropológicos, fomos influenciados a amplificar suas considerações, apontando o caráter de complexidade e de mutabilidade dos projetos de vida.

Dessa forma, chegamos a um conceito de projeto de vida como uma projeção de futuro, que comporta desejos, pensamentos, sentimentos, interesses e objetivos do sujeito e que se constitui de forma complexa, envolvendo comprometimento com o self, no sentido de que carrega regularidades, características pessoais e paradigmas construídos e consolidados em vivências, e, ao mesmo tempo, transitoriedade, pois está aberto às mudanças de pensamento, suscetíveis a juízos e ações sobre o real, que trazem elementos e significados novos às suas elaborações.

Tratar da complexidade que envolve os projetos de vida e os processos de regulação e integração de valores e sentimentos que os organizam exige de nossa investigação a adoção de uma última vertente que possa corroborar uma análise funcional, sem tomar como ponto de partida categorias predeterminadas. Dessa forma, a Teoria dos Modelos Organizadores do Pensamento (MORENO MARIMÓN et al., 1999) tornou-se um referencial fundamental para a compreensão desses processos no funcionamento psíquico dos jovens ao elaborar seus projetos de vida.

Os trabalhos que utilizam tal instrumento teórico-metodológico no campo da moralidade têm se baseado na resolução de conflitos como oportunidade ímpar para investigar os processos que subjazem os juízos elaborados a partir de conteúdos de cunho moral (ARANTES, 2000a; AFFONSO, 2007; LEMOS-DE-SOUZA, 2008; VASCONCELOS; BELLOTO; ENDO, 2007; TREVISOL, 2007; PÁTARO, 2007; STACH-HAERTEL, 2009, entre outros). O estudo dos modelos organizadores sobre os projetos de vida é, nesse ínterim, um caminho novo, que apenas foi trilhado por poucas pesquisas no Brasil (PÁTARO, 2011; 
ULLER, 2012; ARANTES, 2012). Pensamos, então, em aliar uma vertente já consolidada nessa área de estudos, a partir da resolução de conflitos, a essa nova perspectiva. A análise dos modelos organizadores diante desses dois instrumentos pode ser profícua, em nosso entender, para avanços nas descobertas sobre a moralidade.

Com base nessas considerações, nosso problema de pesquisa se configura da seguinte forma: diante de questões referentes aos seus projetos de vida e a um conflito moral cujo conteúdo apresenta essa temática, como se dão os processos de integração e regulação de valores e sentimentos nas elaborações realizadas por jovens?

A partir desse problema, delimitamos alguns objetivos específicos, a seguir, os quais nos auxiliam no seu esclarecimento:

- Identificar os Modelos Organizadores do Pensamento relacionados aos projetos de vida dos jovens e aqueles elaborados por eles diante de uma situação de conflito moral, estabelecendo relações entre a integração de valores e a possível regulação exercida por tal integração e pelos sentimentos;

- Identificar e analisar se existe ou não um continuum entre os processos de integração e regulação de valores nas duas situações: de explicitação dos projetos de vida pelos jovens e nas elaborações diante de um conflito moral formuladas por eles.

- A partir dos resultados revelados pela presente pesquisa, bem como das discussões que teceremos sobre eles, trazer indicações, apontamentos e reflexões para o campo da educação moral, visando ao desenvolvimento de práticas pedagógicas que levem os jovens a construírem projetos de vida que lhes sejam significativos e que visem à sua inserção ética na sociedade.

\subsection{Participantes}

A escolha dos participantes da presente pesquisa deu-se em um processo longo, que envolveu critérios relacionados aos objetivos traçados e às possibilidades de coleta de dados.

Como se trata de um estudo que almeja enfocar os processos de regulação e integração entre valores e sentimentos nos projetos de vida na juventude, participaram dessa investigação 200 jovens, com idade entre 15 e 19 anos, alunos e alunas de Ensino Médio de escolas públicas. 
Para enriquecer os dados obtidos, participaram jovens de cada uma das cinco macrorregiões do Brasil $^{37}$. Com isso, a amostra de cada região foi proporcional ao seu percentual na distribuição da população juvenil brasileira. Em cada região, os dados foram coletados em dois tipos de municípios: metrópoles e capitais regionais.

Para definir as cidades participantes desta pesquisa, adotamos o conceito de metrópole, caracterizado por uma população com mais de 1 milhão de habitantes, e o conceito de capitais regionais. Neste segundo caso, de acordo com os dados do IBGE de 2007, existem 39 municípios que atendem a denominação de capitais regionais $\mathrm{C}$, caracterizadas por população de até 250 mil habitantes.

Optamos por uma metrópole e uma capital regional $\mathrm{C}$ de cada um das cinco regiões brasileiras, de acordo com as facilidades de contato e custos de viagens. As cidades onde foram realizadas as coletas constam na tabela a seguir.

Tabela 1: Regiões e cidades em que foram coletados os dados

\begin{tabular}{ccc}
\hline Região & Metrópole & Capital regional C \\
\hline Norte & Belém $(\mathrm{PA})$ & Macapá $(\mathrm{AM})$ \\
Nordeste & Fortaleza $(\mathrm{CE})$ & Sobral $(\mathrm{CE})$ \\
Centro- Oeste & Goiânia $(\mathrm{GO})$ & Dourados $(\mathrm{MS})$ \\
Sudeste & São Paulo $(\mathrm{SP})$ & Rio Claro $(\mathrm{SP})$ \\
Sul & Curitiba $(\mathrm{PR})$ & Ponta Grossa $(\mathrm{PR})$ \\
\hline
\end{tabular}

A fim de manter proporcionalidade na composição do grupo de participantes, levamos em consideração a variável sexo ${ }^{38}$. De forma a exemplificar a sua distribuição, apresentamos o quadro a seguir:

\footnotetext{
${ }^{37}$ Nosso objetivo não foi o de comparar jovens de cada uma das regiões brasileiras. Entendemos que, pelo caráter qualitativo da presente pesquisa e pelo número de participantes, não é possível tecer tais considerações.

${ }^{38}$ Não é objetivo do presente estudo traçar comparações entre sujeitos dos sexos feminino e masculino.
} 
Tabela 2: Distribuição dos sujeitos nas regiões e cidades em que foram coletados os dados

\begin{tabular}{|c|c|c|c|c|}
\hline Região & Cidade & Gênero & Núm. parti & Total região \\
\hline \multirow{4}{*}{ Norte } & Belém & Masculino & 4 & \multirow{4}{*}{16} \\
\hline & & Feminino & 4 & \\
\hline & Macapá & Masculino & 4 & \\
\hline & & Feminino & 4 & \\
\hline \multirow{4}{*}{ Nordeste } & Fortaleza & Masculino & 12 & \multirow{4}{*}{48} \\
\hline & & Feminino & 12 & \\
\hline & Sobral & Masculino & 12 & \\
\hline & & Feminino & 12 & \\
\hline \multirow{4}{*}{ Centro-Oeste } & Goiânia & Masculino & 6 & \multirow{4}{*}{24} \\
\hline & & Feminino & 6 & \\
\hline & Dourados & Masculino & 6 & \\
\hline & & Feminino & 6 & \\
\hline \multirow{4}{*}{ Sudeste } & São Paulo & Masculino & 16 & \multirow{4}{*}{64} \\
\hline & & Feminino & 16 & \\
\hline & Rio Claro & Masculino & 16 & \\
\hline & & Feminino & 16 & \\
\hline \multirow{4}{*}{ Sul } & Curitiba & Masculino & 12 & \multirow{4}{*}{48} \\
\hline & & Feminino & 12 & \\
\hline & \multirow[t]{2}{*}{ Ponta Grossa } & Masculino & 12 & \\
\hline & & Feminino & 12 & \\
\hline & & Total & 200 & 200 \\
\hline
\end{tabular}

Sobre a escolha desses estudantes, faz-se necessário apontar dois aspectos fundamentais para a formação do grupo de participantes. Em primeiro lugar, a presente pesquisa vincula-se a outras investigações, conduzidas pelo Prof. Dr. Ulisses Ferreira Araújo $^{39}$ e pela Prof ${ }^{a}$ Dr $^{a}$ Valéria Amorim Arantes ${ }^{40}$. Com interesse em destacar os valores e projetos de vida de jovens brasileiros, a pesquisa do Prof. Dr. Ulisses Ferreira Araújo analisou os dados de uma forma quantitativa, com respostas de 3.500 estudantes do Ensino Médio das cinco regiões brasileiras ao questionário proposto. Após levantamento dos sujeitos, partiu-se para uma segunda fase, de caráter qualitativo, em que foram selecionados jovens que responderam ao questionário anterior. Essa segunda investigação, coordenada pela $\operatorname{Prof}^{\mathrm{a}} \operatorname{Dr}^{\mathrm{a}}$ Valéria Amorim Arantes, procurou manter a coleta de dados em algumas cidades brasileiras, abarcando as cinco regiões demográficas. A coleta dessa segunda pesquisa serviu-nos de base

\footnotetext{
${ }^{39}$ Refere-se à pesquisa "Valores e projetos vitais de jovens brasileiros" (2011), financiada pelo Conselho Nacional de Desenvolvimento Científico e Tecnológico (CNPq) e pela Fundação de Amparo à Pesquisa do Estado de São Paulo (Fapesp).

${ }^{40}$ Trata-se da pesquisa "O papel dos sentimentos e emoções nos projetos de vida (purpose) dos jovens de cinco regiões brasileiras" (2011), financiada pela Fundação de Amparo à Pesquisa do Estado de São Paulo (Fapesp) e pelo Conselho Nacional de Desenvolvimento Científico e Tecnológico (CNPq).
} 
para a constituição de nosso grupo de participantes.

Em segundo lugar, os sujeitos participantes foram escolhidos pela facilidade de contato com as instituições. O contato realizado pelos pesquisadores anteriormente facilitou novo contato com as escolas, seus diretores, coordenadores ou secretários municipais.

Diante do grupo de alunos que havia realizado a pesquisa quantitativa, cada escola selecionou os estudantes que estavam na instituição quando a pesquisadora esteve presente, de forma aleatória, mas balanceando o número de respondentes de acordo com o sexo. A participação dos jovens foi voluntária. Alguns questionários foram desprezados por falta de informações pessoais, respostas nulas ou incompletas.

\subsection{Construção dos instrumentos de pesquisa}

Tendo como objetivo investigar sobre os processos de regulação e de integração entre valores e sentimentos subjacentes à elaboração dos projetos de vida dos jovens participantes de nossa investigação, buscamos dois enfoques para a elaboração dos instrumentos de pesquisa.

O primeiro deles centrou-se na formulação de um questionário sobre o projeto de vida. Buscamos, para tanto, nos estudos que desenvolvemos em nosso quadro teórico uma vertente que embasasse tal formulação. Entender o projeto de vida de cada jovem significa, para nós, avançar em uma perspectiva que admite a complexidade e o dinamismo do pensamento humano. O projeto de vida, conforme esboçamos anteriormente, constitui-se na projeção de um percurso, que comporta "idas e vindas", ao mesmo tempo em que sinaliza características e paradigmas do self. Por ter caráter de projeção futura, o projeto de vida tem como base experiências passadas e ações presentes, permitindo uma análise processual, e não focada em "fotografias estanques" (DAMON, 2009) $)^{41}$.

Assim sendo, uma referência importante para interpelar os projetos de vida dos jovens participantes da presente investigação foi o questionário formulado pelo Stanford Center on Adolescence $^{42}$. Tal instrumento, consolidado internacionalmente, apresenta como característica uma multidimensionalidade no sentido de que busca identificar alguns aspectos do self dos jovens participantes, investiga mudanças que eles gostariam que ocorressem no

\footnotetext{
${ }^{41}$ Enfatizamos que tal processo corresponde ao pensamento do sujeito diante da coleta de dados. Podem acontecer alterações na forma como o sujeito elabora seu projeto de vida, as quais poderiam ser analisadas em um estudo longitudinal, o que não é o caso do presente trabalho.

${ }^{42}$ Grupo de pesquisa do Prof. William Damon e colaboradores.
} 
mundo (buscando identificar seu mundo ideal), analisa as suas projeções futuras e tenta identificar os projetos de vida dos entrevistados.

Partindo dessa referência, passamos a tentar adaptá-la à pesquisa em nosso país, por meio de estudos pilotos. Como a intenção de nosso trabalho estava em estudar a funcionalidade dos processos de regulação e integração entre valores e sentimentos nos projetos de vida dos jovens, vimos como necessário abrir o caminho para a complexidade do pensamento dos sujeitos participantes. Nos estudos pilotos, três ao total, muitas respostas ficaram limitadas e se restringiam aos elementos destacados no início do questionário ${ }^{43}$, além de não evidenciarem os sentimentos, cuja importância para o presente estudo é central. Então, fizemos adaptações que permitissem: a) respostas amplas, em que os sujeitos pudessem expressar o que e o quanto quisessem; b) a articulação com os sentimentos, induzindo-os a pensarem na afetividade; c) um enfoque maior na questão dos projetos vitais, com perguntas diretas sobre as projeções futuras dos jovens.

Chegamos, então, a 13 perguntas que abordavam diferentes aspectos da vida dos sujeitos e suas projeções para a vida futura, buscando verificar o papel dos sentimentos e dos valores nos processos regulatórios e integratórios que articularam seus projetos de vida. Tais perguntas foram feitas em forma de questionário escrito e aberto.

Apresentamos o questionário na íntegra a seguir:

1. Conte-me um pouco sobre você e sua vida, destacando como se sente em seu dia a dia.

2. Quais são as três coisas mais importantes para você? Enumere por ordem de importância (do mais importante para o menos importante).

3. Como você se sente em relação a cada uma dessas coisas? Explique com detalhes.

4. Como cada uma dessas coisas se tornaram importantes para você?

\section{Quais as dificuldades enfrentadas por você com relação a essas coisas importantes?}

\footnotetext{
${ }^{43}$ Isso porque, no questionário original, solicitava-se ao jovem que indicasse três "coisas" que lhes fossem mais importantes. Depois, ao longo de toda entrevista, o jovem devia voltar-se novamente ao que havia elegido a princípio.
} 
6. O que você gostaria que fosse diferente no mundo e o que faz para concretizar tal mudança?

7. Como você se sente com relação a essa mudança?

8. Imagine como será a sua vida daqui a cinco anos e diga o que será importante para você nessa ocasião.

9. Como você acha que se sentirá daqui a cinco anos?

10. Agora, imagine-se com 40 anos. Como você acha que será a sua vida? O que você acha que estará fazendo? O que você acha que será importante para você?

\section{Como você acha que se sentirá aos 40 anos?}

\section{O que é para você um projeto de vida? Que projeto você tem para sua vida?}

\section{Caso você tenha um projeto, como se sente em relação a ele?}

Tal questionário aberto mostrou-se mais rico para a compreensão a respeito dos processos de regulação e de integração de valores e de sentimentos, pois permitiu aos sujeitos a revelação, ao longo de suas respostas, de seus valores e de seus sentimentos, assim como a forma como se integravam e regulavam o comparecimento de outros elementos e significados em suas elaborações. Isso porque, se o jovem indicava a família, por exemplo, como a coisa mais importante de sua vida, depois podia ir referendando tal elemento, mostrando-o como um valor, na integração com outros valores como a gratidão, a responsabilidade, etc., ou, pelo contrário, podia apresentar elementos contraditórios, como foco em atividades hedonistas ou de consumo, que não fortaleciam esse elemento destacado inicialmente.

Embora a opção por esse questionário escrito e aberto tenha significado "ganhos" em relação a respostas mais diretas e pontuais, entendemos que tal instrumento poderia ser ainda mais abrangente se fosse uma entrevista oral, uma vez que, diante do exposto pelo jovem, poder-se-ia voltar a determinadas informações e fazer novos questionamentos, assim como o fez Pátaro (2011). Além disso, por se tratar de um questionário aplicado em um determinado momento, muito embora solicite ao jovem a recuperação de um processo em relação às suas projeções futuras, configura-se na percepção sobre o projeto de vida elaborada em um momento rápido de reflexão, sem dar a oportunidade ao jovem de voltar ao que informou, 
repensar suas estratégias, trazer novas indicações, etc. Admitimos, ademais, que alguns fatores podem ter influenciado os jovens ao responder ao questionário, como problemas físicos (de saúde, por exemplo), estados emocionais, desinteresse, entre muitos outros. Se fosse possível voltar a esses jovens em outros momentos, certamente evidenciaríamos diferenças em suas respostas e poderíamos indagá-los a seu respeito.

Outro aspecto importante diz respeito a uma possível redução de questões desse instrumento, logo que, muito embora tenhamos feito vários estudos piloto e, consequentemente, diversas mudanças e adaptações das questões, pudemos perceber, na análise das respostas, que as primeiras perguntas ainda poderiam ser condensadas, de forma a não se tornarem repetitivas.

Apesar de identificarmos tais falhas no instrumento aplicado, posicionamo-nos em seu favor, visto que contemplou os objetivos propostos na presente investigação. Ademais, devido ao número de participantes de nosso estudo e à diversidade de locais de coleta de dados, seria impossível realizar entrevistas orais ou mais questionários que contemplassem os aspectos que levantamos.

O segundo enfoque para a construção dos instrumentos de pesquisa recaiu sobre a resolução de conflitos. Vemos que, no campo da psicologia moral, com a perspectiva de uma análise que esteja cingida à funcionalidade do psiquismo humano, muitos trabalhos vêm utilizando conflitos hipotéticos como forma de identificar os juízos formulados pelo sujeito diante de uma situação de cunho moral (ARANTES, 2000a; PUPO, 2007; AFFONSO, 2008; MARTINS, 2003, 2008; LEMOS-DE-SOUZA, 2008; TREVISOL, 2007; ARANTES; SASTRE; GONZÁLEZ, 2007; PINHEIRO, 2009; entre outros).

Essa perspectiva, em relação à metodologia, denota que a resolução de conflitos proporciona um estudo pela via funcional. Os conflitos trazem, mesmo que de forma hipotética, os contextos em que os sujeitos podem atuar realmente, incorporando, de uma só vez e de forma extremamente complexa, pensamentos, sentimentos, desejos, crenças, valores, etc.

A resolução de problemas é, para nós, uma ocasião para estudar os processos funcionais que intervêm quando o sujeito aplica os seus conhecimentos em contextos particulares, quer dizer, no momento em que aplica as suas estruturas na assimilação de "universos de problemas" que encontra na sua atividade adaptativa. (INHELDER; DE CAPRONA, 1992, p. 19) 
O papel da resolução de problemas, nessa ótica, está em verificar como o sujeito organiza seu pensamento mediante os conteúdos das situações. Para Inhelder e De Caprona (1992), diante de um problema, o sujeito organiza conteúdos, atribui significações e "representa para si" finalidades e certas etapas da resolução, elaborando procedimentos de codificação (p. 57).

Entendemos que a resolução de problemas, indicada pelos autores, está intimamente relacionada com os conflitos, na área de psicologia moral, por exigirem do sujeito a elaboração de juízos e ações regulados pela interpretação que faz dos conteúdos da "realidade".

O conflito moral, segundo Oliveira e Costa (1995), tem como núcleo não apenas direitos e deveres, mas também necessidades e valores do eu e do outro. Os conteúdos do conflito com conteúdo moral são percebidos pelo sujeito de acordo com a forma como elabora seu pensamento, levando em consideração tanto aspectos psíquicos quanto sociais.

Com a proposta de seguir tais indicações, mas contemplando o presente objeto de estudo, elaboramos um conflito moral com conteúdo relacionado a um projeto de vida vivenciado por um(a) protagonista fictício(a). Tal instrumento contou com uma breve história em que o(a) jovem consegue uma vaga em um estágio na área em que deseja atuar, em uma grande empresa. A mãe desse(a) jovem lhe solicita que não aceite a oportunidade, porque ela precisava de ajuda para tomar conta dos irmãos e necessitava trabalhar o dia todo.

A temática desse conflito foi elaborada para que pudéssemos tecer relações entre as respostas obtidas nos dois instrumentos elaborados. Assim, o sujeito participante necessitou posicionar-se de forma diferenciada em relação a cada instrumento. Quando elaborou respostas sobre o seu projeto de vida, conseguiu levar à esfera de reflexão aquilo que se mostrava mais importante nas vivências passadas, nas ações atuais e em suas projeções sobre o futuro. Quando entrou em contato com o conflito, por meio de sua leitura, pôde interpretar uma situação com o conteúdo de um projeto de vida de um personagem fíctício, o que o fez “opinar" sobre as suas atitudes, sem que estivesse vivenciando o conflito na realidade ${ }^{44}$. A elaboração de respostas sobre o conflito envolveu tomar a perspectiva do protagonista da situação apresentada, levando o jovem a posicionar-se sem o receio de se expor.

\footnotetext{
${ }^{44}$ Sobre esse aspecto, é importante indicar que, muito embora tenhamos nos alicerçado em perspectivas dos jovens, a partir de encontros com estudantes do Ensino Médio e de pesquisas sobre juventude, o conflito apresentado não será capaz de promover o envolvimento de todos os participantes em sua temática. Alguns jovens podem sentir-se distantes do que foi proposto.
} 
Seguem abaixo as duas versões do conflito, pois este foi apresentado nas versões masculina e feminina, de forma a se aproximar do contexto do(a) jovem participante, facilitando seu envolvimento com a história.

\section{Versão masculina}

Meu nome é Maurício. Tenho 17 anos e estudo na Escola Estadual João Teixeira Alves, que fica na periferia da minha cidade. Estou no $2^{\circ}$ ano do Ensino Médio e acho que consigo ir bem na escola.

Faço curso técnico em mecatrônica e meu grande sonho é trabalhar na Petrobrás.

No meu curso, ofereceram vagas de estágio em uma grande empresa. Eu fiz os testes e passei! Fiquei muito feliz porque pensei que seria uma grande oportunidade de dar o primeiro passo para o meu futuro profissional.

Eu conseguiria conciliar a escola e o emprego, só teria mesmo de deixar o curso profissionalizante que falta um ano para terminar. Mas acho que a experiência na empresa me ajudaria bastante a aprender.

A minha mãe me pediu para não aceitar o estágio, porque ela arranjou um emprego em uma fábrica e só poderá chegar em casa bem tarde da noite. Como eu tenho dois irmãos pequenos, ela precisará que eu fique em casa tomando conta deles.

\section{Versão feminina}

Meu nome é Milena. Tenho 17 anos e estudo na Escola Estadual João Teixeira Alves, que fica na periferia da minha cidade. Estou no $2^{\circ}$ ano do Ensino Médio e acho que consigo ir bem na escola.

Faço curso técnico em tecnologia da informação e meu grande sonho é trabalhar em uma grande empresa, desenvolvendo conteúdos para sites.

No meu curso, ofereceram vagas de estágio em uma grande empresa. Eu fiz os testes e passei! Fiquei muito feliz porque pensei que seria uma grande oportunidade de dar o primeiro passo para o meu futuro profissional.

Eu conseguiria conciliar a escola e o emprego, só teria mesmo de deixar o curso profissionalizante que falta um ano para terminar. Mas acho que a experiência na empresa me ajudaria bastante a aprender.

A minha mãe me pediu para não aceitar o estágio, porque ela arranjou um emprego em uma fábrica e só poderá chegar em casa bem tarde da noite. Como eu tenho dois 
irmãos pequenos, ela precisará que eu fique em casa tomando conta deles.

Esse conflito foi gerado a partir de encontros com jovens estudantes do $1^{\circ}$ e $3^{\circ}$ anos do Ensino Médio de uma escola particular da Zona Sul de São Paulo. Nos encontros, dois com cada grupo, houve uma roda de discussão a respeito dos projetos de vida. No primeiro encontro, nos apresentamos e solicitamos que os jovens também o fizessem. Posteriormente, pedimos que eles relatassem sobre suas projeções para o futuro e o que faziam no presente. Como percebemos que os jovens não se sentiram à vontade em um primeiro momento, voltamos às duas turmas e novamente solicitamos o relato, voltando ao que haviam sugerido no primeiro debate.

Nesses encontros, os jovens manifestaram como elementos importantes a família, o trabalho, as amizades e o lazer. Muitos deles citaram o trabalho dos pais, primeiras inserções no mercado de trabalho, a importância da família como base e apoio para as conquistas e a vontade de ajudar financeiramente os pais. Além disso, alguns jovens citaram as "baladas" como aspectos muito frequentes em suas rotinas e como momentos importantes de socialização.

Aliado às descobertas desses encontros, partimos para leituras a respeito da juventude em nosso país, o que referendou tais elementos. Assim, o conflito foi elaborado com uma história baseada na fala de um dos jovens, que consistia no desejo de realizar um estágio em uma grande empresa, a Petrobrás, aliado a outro elemento que foi levantado por grande parte dos jovens, o vínculo familiar. Com base em experiências anteriores, acreditamos que, juntamente a esses elementos, outros valores poderiam estar envolvidos, como a responsabilidade, a generosidade, a gratidão, a lealdade, entre outros.

É importante ressaltar que, para a elaboração desse instrumento, necessitamos de quatro estudos piloto, de forma a eliminar possíveis erros de compreensão por parte dos participantes, assim como ter uma atenção focada para a não emissão de juízos de valor previamente, que pudessem interferir nas suas respostas.

Após a leitura desse conflito, os sujeitos foram solicitados a responder, de forma aberta, a três questões:

1. Se você vivesse o conflito de Maurício/Milena, como você o resolveria? Explique detalhadamente. Explique, também, como você se sentiria com essa resolução. 
2. Imagine que o conflito de Maurício/ Milena tenha sido vivido por você e que, na ocasião, você tivesse aceitado o emprego e decidido não atender ao pedido de sua mãe. Como você se sentiria? Explique detalhadamente sua resposta.

3. Imagine, agora, que, nessa mesma situação, você tenha decidido abrir mão da oportunidade do estágio para atender ao pedido de sua mãe. O que você sentiria? Explique com detalhes a sua resposta.

Pode-se verificar que as três questões giram em torno da resolução do conflito, exigindo que os jovens escrevessem com detalhes e expusessem seus sentimentos. $\mathrm{O}$ que diferencia as questões 2 e 3 é a apresentação de um posicionamento já realizado pelo(a) protagonista da situação. Assim, exigia-se dos sujeitos a confirmação dos elementos abstraídos e dos significados atribuídos na primeira questão, juntamente aos sentimentos que, em nosso entender, poderiam regular as relações entre eles.

A intenção, com essas três questões, era de obter um panorama em que o sujeito "confirmasse" ou "refutasse" os sentimentos e valores apresentados, dando-nos indicações a respeito da centralidade da sua organização e integração, bem como do seu papel regulatório.

Com a elaboração dos dois instrumentos, pensamos em uma análise que, envolvendo um conteúdo que diz respeito a projetos de vida (do próprio sujeito e da interpretação de um conflito hipotético), possa evidenciar valores e sentimentos, em seus processos de regulação e integração, de duas formas diferentes.

Além disso, no percurso de construção dos instrumentos, procuramos evidenciar a complexidade dos juízos elaborados pelos sujeitos, considerando os múltiplos aspectos presentes em seu psiquismo. $\mathrm{O}$ fato de construir dois instrumentos com a intenção de perceber se existe ou não um continuum entre os processos tecidos em um e em outro vem ao encontro da vontade de ampliar, ainda mais, o espectro para compreensão da complexidade envolvida nas elaborações dos jovens.

\subsection{Procedimentos para coleta dos dados}

Para proceder com a coleta dos dados, primeiramente realizamos o contato com as escolas públicas que haviam participado da pesquisa do Prof. Dr. Ulisses Ferreira Araújo. Apesar das dificuldades de contato, conseguimos agendar datas para as coletas em cada cidade prevista. 
Nesse contato, enviamos ao diretor ou coordenador, por email, um documento com informações sobre a investigação e solicitação da participação dos alunos e alunas. Após consentimento, passamos os nomes dos jovens que já tinham participado da primeira fase e solicitamos que verificassem se ainda permaneciam na escola. Com todos os dados acertados, pedimos ao nosso contato que conversasse com os estudantes, explicando sobre a coleta.

Em algumas localidades, os contatos foram facilitados pelo fato de haver pessoas conhecidas que trabalhavam em cargos mais elevados das Secretarias de Educação. Essas pessoas ajudavam-nos a entrar em contato com a escola, estavam presentes na data da coleta, incentivando-a. Por outro lado, em algumas cidades não obtivemos esse apoio, tendo que fazer a coleta com muita insegurança se seríamos bem recebidos ou não.

Organizamos os dois questionários (do projeto de vida e do conflito moral) em um instrumento virtual do site SurveyMonkey (com acesso pelo endereço eletrônico www.surveymonkey.com). O propósito de utilizar tal instrumento foi o de facilitar a posterior transcrição, uma vez que, ao preencher os campos com suas respostas (com quantos caracteres quisessem), estas seriam salvas no site.

Apesar dessa facilidade, nossa coleta necessitava que a escola participante tivesse computadores conectados à internet, o que foi uma das grandes dificuldades que encontramos. Em muitas das escolas, inclusive de grandes metrópoles, como São Paulo, não havia computadores ou eles não estavam conectados à internet. Em alguns locais, como Macapá, não há internet banda larga, o que dificultou a coleta de informações.

Como alternativa a esses problemas, criamos um documento em Power Point com os mesmos questionários. Isso resolveu, em parte, o problema de não conseguir coletar os dados em uma localidade. No entanto, perdemos muitos questionários, pois, nesse documento, o sujeito poderia pular páginas (o que não acontecia no site). As respostas emitidas com o documento desse plano alternativo foram depois copiadas para o site pela pesquisadora.

Muito embora todo o questionário estivesse no site, vimos como fundamental a presença da pesquisadora no acompanhamento da coleta de dados para orientar os jovens e esclarecer suas dúvidas (além de lidar com os problemas relacionados ao site e ao uso da internet). Portanto, foi necessário um cronograma de viagens aos locais de coleta ${ }^{45}$, além de planejamento em relação à logística, acomodação, etc.

\footnotetext{
${ }^{45}$ Como a presente pesquisa vincula-se a outras duas, citadas anteriormente, outros pesquisadores, Livia Moreiras e Waldir Uller (a quem somos gratos), coletaram uma parte dos dados.
} 
Nas datas agendadas com cada escola, programamo-nos para chegar com antecedência a fim de preparar os computadores. A coleta foi feita nos laboratórios de informática das escolas, geralmente com a presença do professor de informática além da pesquisadora.

A princípio, explicamos aos jovens sobre a pesquisa, quais eram os objetivos e que a participação deles era muito importante. Incentivamos os jovens a escrever com sinceridade e expondo suas respostas com detalhes. Também pedimos que prestassem atenção às solicitações de respostas relacionadas à afetividade. Cada jovem teve acesso a um link que, uma vez aberto, gerava um questionário pronto para ser respondido. Nas primeiras páginas, havia informações a respeito da pesquisa e a solicitação de participação. O sujeito assinalava se desejava ou não participar da pesquisa, a qual era totalmente voluntária ${ }^{46}$.

Depois de passarem pelas páginas iniciais e se identificarem, os sujeitos chegavam ao questionário sobre os projetos de vida (questionário "projeto de vida) e, logo após, o conflito e as questões sobre ele (questionário "conflito moral"). Cada questão era apresentada em uma página, com espaço para que os jovens escrevessem à vontade. Esse método permitiu que todas as perguntas fossem respondidas, logo que somente se poderia passar a outra página quando fosse respondida a atual.

O sujeito apenas poderia passar à página seguinte após ter respondido a anterior. No entanto, poderia voltar às questões que já havia respondido, reformulando-as caso desejasse. Assim que o sujeito terminava de responder a todo o questionário, este era salvo pelo site, em seus arquivos.

\subsection{Procedimentos de análise dos dados}

Os procedimentos de análise dos dados foram embasados no instrumento teóricometodológico da Teoria dos Modelos Organizadores do Pensamento (MORENO MARIMÓN et al., 1999) e nos avanços por ele produzido no campo da psicologia moral. A análise buscou perfazer a complexidade das respostas obtidas, verificando a diversidade de pensamentos e sentimentos dos participantes ao mesmo tempo em que buscou analisar as suas regularidades.

Para proceder com tal análise, o ponto de partida foi a elaboração de protocolos com os questionários arquivados no site SurveyMonkey. De forma a obter uma visualização de

\footnotetext{
${ }^{46}$ Os procedimentos éticos foram tomados segundo as normas éticas estipuladas pela Resolução 196/96 do Conselho Nacional de Saúde para pesquisa com seres humanos e de acordo com as determinações do Estatuto da Criança e do Adolescente.
} 
todas as respostas dos sujeitos em uma mesma lauda, organizamos as perguntas e respostas em caixas de texto, seguindo sua sequência.

De posse dos protocolos com as respostas sobre os conflitos morais e sobre os projetos de vida dos sujeitos participantes, procedemos às várias leituras, excluindo as respostas em que não era possível o trabalho de análise, seja pelos participantes não terem respondido algumas questões, seja por uma inadequação de idade ou, simplesmente, por um ajuste ao número de participantes. Seguimos, como demais trabalhos que se utilizaram de tal aporte teórico-metodológico (VASCONCELOS et al., 2010), uma leitura coletiva do material, em que a pesquisadora e a orientadora discutiram cada resposta dada e de que forma se articulava no conjunto do protocolo.

A análise dos dois instrumentos foi orientada pela definição dos modelos organizadores, destacando seus componentes: os elementos abstraídos e retidos como significativos; os significados atribuídos aos elementos e as implicações e/ou relações entre elementos e significados. Cabe ressaltar que, mediante o que nos aponta a Teoria dos Modelos Organizadores do Pensamento, não trabalhamos com categorias prévias, mas buscamos enveredar pela organização do pensamento dos jovens, contemplando a análise das exceções e das respostas que caracterizam a maioria dos participantes (ARANTES; SASTRE; GONZÁLEZ, 2007).

Utilizamos uma estratégia para análise dos dados já promovida em nossa pesquisa anterior (PINHEIRO, 2009). No processo de análise desse trabalho, com uma amplitude muito menor, consideramos todas as respostas de uma só vez, buscando compreender os elementos abstraídos e significados, bem como as relações e implicações entre eles no conjunto do que foi respondido por cada participante. Assim, foi-nos possível verificar como, ao longo do questionário, o sujeito foi se posicionando frente aos elementos destacados e que significados lhes atribuiu, chegando a uma compreensão das relações por ele tecidas em um todo. Com tal estratégia, conseguimos analisar a dinâmica de pensamento do sujeito, observando se reforçava os valores ou sentimentos aos quais atribuía significados ou se era contraditório, apresentando outros elementos e significados.

Seguindo esse processo, primeiramente enfocamos as respostas referentes aos projetos de vida. Assim, analisamos as 13 respostas emitidas por cada participante, destacando, em uma ficha: os elementos abstraídos, os significados que lhes foram atribuídos e as relações/implicações. Durante esse processo, procuramos descobrir como os participantes organizaram os conteúdos para a construção das respostas. Após esse trabalho fino de análise, reparamos em algumas tendências de organização do pensamento e passamos a agrupá-las, de 
forma a extrair seu modelo organizador. É importante destacar que, devido à grande quantidade de questões, que exigiam o posicionamento do sujeito em várias frentes, mas que se articulavam em um todo complexo - o projeto de vida -, o processo de agrupamento dos protocolos, buscando evidenciar a regularidade de pensamento dos jovens, levou em maior consideração os elementos que receberam maior significação, incorporando-se na teia de articulações, relações e implicações do modelo. Isso quer dizer que os modelos organizadores do pensamento referentes aos projetos de vida, pela sua complexidade, foram extraídos pelos elementos e significados centrais e por toda a lógica pela qual enveredava sua organização. Os demais elementos e significados, que não compunham tal organização, foram descritos na apresentação dos modelos, evidenciando seu papel secundário e não organizativo do projeto de vida ${ }^{47}$.

Após essa análise, passamos a descrever os modelos organizadores, buscando evidenciar de que forma os sujeitos abstraíram, significaram e teceram relações entre os elementos e seus significados. Devido à complexidade de cada modelo organizador, não pudemos nos restringir a identificar os elementos, os significados atribuídos e as implicações e/ou relações. Preferimos, embora saibamos da necessidade de destacar cada fase da análise dos modelos, organizá-los em seu continuum, identificando as inter-relações entre elementos, significados e implicações/ relações entre eles, perfazendo a dinâmica do pensamento dos jovens. Dentro de um mesmo modelo, pelas diferenças de elementos abstraídos e de atribuição de significados, verificamos que, muito embora resultassem em uma mesma "lógica" de pensamento, alguns protocolos precisariam ser descritos de forma separada, o que resultou em submodelos.

Seguida à descrição dos modelos e submodelos organizadores, procedemos com uma análise dos processos de integração e regulação entre eles, no tocante às relações entre elementos centrais abstraídos, sentimentos indicados e relações/implicações entre elementos e sentimentos. De forma a descobrir as tendências de organização dos modelos organizadores, além dessa análise, passamos à distribuição dos participantes nos modelos e sub-modelos organizadores.

Terminada a análise e descrição dos modelos organizadores referentes ao "questionário projeto de vida", passamos ao mesmo processo com as respostas em relação ao “questionário conflito moral". Nessa etapa, como havia apenas três questões, sentimos maior

\footnotetext{
${ }^{47}$ Dessa forma, dentro de um mesmo modelo organizador, alguns sujeitos chegaram a destacar e a atribuir significado a elementos que outros não fizeram. Acreditamos que, pelo fato de tais elementos não interferirem na organização do modelo, com os demais elementos atuando de forma mais "forte" e com mais significados, pudemos agrupar tais sujeitos na mesma "lógica" de pensamento dos demais.
} 
facilidade de percepção dos elementos abstraídos, dos significados atribuídos e das relações/implicações entre eles. No entanto, é necessário ressaltar que os modelos organizadores extraídos dessa análise também se mostraram complexos, exigindo uma análise fina e criteriosa.

Assim como fizemos com os projetos de vida, após análise e descrição dos modelos, partimos para a comparação entre os seus elementos e sentimentos, assim como as implicações/relações entre eles. Também buscamos descobrir as tendências de organização desses modelos organizadores e passamos, dessa maneira, a explicitar o número de jovens que aplicou cada um deles.

Ao final dos dois processos, procedemos com uma análise dos processos de integração e regulação de valores e sentimentos entre os modelos organizadores referentes ao projeto de vida e ao conflito. Primeiramente, buscamos estabelecer um cruzamento dos dados referentes à aplicação de modelos nas duas esferas e, depois, passamos a uma descrição detalhada de cinco sujeitos, para elucidação de tal cruzamento entre modelos. 


\section{CAPÍtULO V \\ APRESENTAÇÃO DOS MODELOS ORGANIZADORES REFERENTES AOS PROJETOS DE VIDA}

\subsection{Considerações sobre a apresentação dos modelos organizadores do pensamento referentes ao projeto de vida dos jovens}

Tendo por objetivo verificar os processos de integração de valores e sentimentos que subjazem os raciocínios dos jovens na elaboração de seus projetos de vida, procedemos à análise das respostas emitidas pelos participantes às treze questões formuladas com base em: a) rotina (ações presentes); b) valores (o que lhe é mais importante); c) dificuldades, perspectivas e engajamento em ações que visam a mudar o mundo; d) projeções sobre um futuro próximo (cinco anos) ou distante (40 anos); e) definição de seu projeto de vida.

Para a compreensão de tais processos, não bastou à nossa análise a percepção de quais valores e sentimentos compareceram às respostas dos jovens, mas de que forma se articularam na elaboração de seu raciocínio. Desse modo, sem desconsiderar as estruturas e os conteúdos presentes na organização do pensamento, destinamos nosso empenho para elucidar a dinâmica que a sustenta.

Dado o caráter processual dos objetivos que permeiam a presente investigação, adotamos a Teoria dos Modelos Organizadores do Pensamento (MORENO MARIMÓN et al. 1999) que, por contemplar a formulação de modelos de "realidade" pelo ser humano, leva em consideração a complexidade que perfaz seu psiquismo, permitindo a averiguação da atuação e da implicação de diferentes aspectos para a sua organização frente a conteúdos do meio.

Os projetos de vida, na medida em que são formulações realizadas pelos sujeitos, em um processo que leva em consideração elementos vivenciados ou imaginados pelo sujeito em relação ao passado, ao presente e às projeções sobre o futuro, alicerçam-se em valores e sentimentos, nos processos que estes tecem para a sua organização. Os projetos não apenas elucidam valores e sentimentos, mas são, outrossim, construídos por base nos processos que envolvem a integração e a regulação entre eles.

A complexidade inerente à elaboração de um projeto de vida está calcada na multiplicidade de relações e organizações que podem dar-se no raciocínio do jovem. A partir dos dados obtidos (no nosso caso, as respostas referentes às questões sobre o projeto de vida dos jovens), a Teoria dos Modelos Organizadores do Pensamento dá-nos a oportunidade de desvendar os processos que se promovem por detrás dos julgamentos dos participantes. Com 
o uso desse referencial, não postulamos categorias prévias, mas deixamos emergir, das respostas encontradas, o raciocínio do sujeito, por meio dos elementos que ele abstrai da realidade, dos significados que lhe atribui e das relações e/ou implicações que formula entre tais aspectos.

A Teoria dos Modelos Organizadores do Pensamento torna possível uma análise que foque o olhar tanto para os conteúdos quanto para as dinâmicas do pensamento humano, envolvendo esses dois aspectos em um continuum que ressignifica as respostas dos sujeitos, proporcionado a compreensão da representação que eles fazem de determinado fenômeno. Isso porque, ao evidenciar os elementos que são abstraídos pelo jovem ao responder sobre os seus projetos, podem-se observar pensamentos, sentimentos, emoções, desejos, angústias relacionados a valores, contravalores, relações interpessoais, vínculos, entre outros, os quais são significados de diversas formas pelos sujeitos. Além do mais, de acordo com o que apontamos em nosso capítulo sobre essa teoria, os elementos abstraídos e significados nem sempre comparecem na realidade, podendo ser imaginados ou inventados por quem aplica o modelo organizador, resultando em ainda maior diversidade de julgamentos.

Obtivemos grande volume de dados oriundos da coleta das treze respostas referentes ao questionário sobre projeto de vida, as quais se caracterizaram pela grande diversidade de elementos, significados e suas relações/implicações. O desafio de analisar os procedimentos para elaboração do modelo organizador de cada participante, com foco em seus processos de integração e regulação de valores e sentimentos, esteve centrado no fato de que cada um apresentou singularidades em suas respostas, mostrando que, a despeito de podermos encontrar regularidades entre raciocínios, a diversidade de juízos traz indicações importantes para a constituição do projeto de vida como uma organização extremamente particular.

Procurando desvendar tal organização, no que cinge aos processos integratórios e regulatórios dos valores e sentimentos, optamos por analisar todas as respostas conjuntamente, as quais posicionamos em um mesmo protocolo. Por entender que a abstração e significação de elementos coocorrem com as implicações e as relações estabelecidas entre eles e que, por serem atividades concomitantes do funcionamento psíquico, expressam formas de pensar e sentir do sujeito quando defronte a uma realidade, nossa análise priorizou esse continuum, procurando indícios e estabelecendo, em várias leituras e releituras das respostas de cada sujeito, a dinâmica de seu pensar, sem desprezar os conteúdos que apareceram ao longo do questionário. Prevaleceu uma análise microgenética, qualitativa e "fina" com as várias leituras dos protocolos em busca da "linha de pensamento" de cada sujeito. 
Para chegarmos à extração de cada modelo e submodelo, procedemos a um levantamento dos elementos centrais, significados e relações/implicações estabelecidas por cada jovem para organização de seu pensamento. Esse levantamento conduziu ao agrupamento dos protocolos (sempre que possível), indicando uma tendência de raciocínio entre os jovens participantes e nos permitindo verificar certas regularidades. Assim, dentro do que postulamos como modelo organizador, detivemo-nos à organização central dos elementos, significados e suas relações/implicações. Dada a grande quantidade de protocolos e variabilidade de respostas que fazia emergir grande número de elementos que não possuíam significados e relações que os integrassem com os demais, nossa opção foi por destacar os elementos e significados mais presentes, organizando-os em um núcleo central que referendou a explicitação do modelo organizador. Na descrição de cada modelo, contudo, apresentamos alguns desses elementos periféricos, mesmo que tenham sido abstraídos e significados por apenas uma parte dos sujeitos, de forma a evidenciar as nãoregularidades que caracterizam o pensamento humano, que, em nossa percepção, mostram a riqueza de julgamentos dos sujeitos participantes.

Devido à grande diversidade e complexidade das respostas, alguns modelos organizadores do pensamento foram divididos em submodelos para que nos aproximássemos, ainda mais, das peculiaridades dos elementos abstraídos, dos significados atribuídos a eles, bem como das implicações/relações entre eles.

Em cada descrição dos modelos organizadores, procuramos detalhar ao máximo, procurando abranger grande parte dos aspectos apresentados pelos sujeitos. Vale ressaltar que os modelos organizadores extraídos, muito embora tenham elementos comuns, no tocante à dinâmica do pensamento e aos conteúdos, os quais permitem um agrupamento dos protocolos, apresentam também elementos singulares, próprios de cada sujeito. Tentaremos, na medida do possível, apontar tais elementos, priorizando uma análise que dá voz à diversidade de julgamentos, mas tendo ciência de que, por causa do grande número de respostas, não poderemos indicar todos esses elementos para não tornar a descrição cansativa ao leitor.

Devido à complexidade que corresponde aos modelos organizadores concernentes aos projetos de vida dos participantes de nossa investigação, vimos como necessária a abordagem que extrapola, algumas vezes, a descrição dos elementos abstraídos, dos significados atribuídos e das relações/implicações entre eles. Cremos que, no corpo da descrição dos modelos, ganhe importância o destaque das características das respostas, do nível de complexidade pela organização das relações entre elementos e seus significados, assim como de detalhes que incidem sobre nuances do pensamento dos sujeitos. Tendo ciência de que tal 
amplitude pode vir a desfocar a descrição do modelo organizador no que tange às implicações/relações tecidas entre elementos abstraídos e significados atribuídos, voltaremos, ao final de cada descrição, a uma tabela que procurará explicitar o raciocínio dos sujeitos em seus projetos de vida, em torno de seu núcleo central ${ }^{48}$.

De forma a elucidar cada modelo organizador aplicado pelos jovens de nossa amostra, utilizamo-nos de muitos exemplos oriundos dos vários questionários ${ }^{49}$, com a intenção de trazer ao leitor aquilo que julgamos de mais rico em nossa investigação: a voz dos jovens. Decidimos não apresentar um único sujeito como exemplo para cada modelo, em virtude da intenção de mostrar a diversidade que compõe os agrupamentos.

Por fim, é importante destacar que três respostas não puderam ser agrupadas às demais por, apesar de apresentarem os mesmos elementos atribuídos como significativos, não terem lhes conferido o mesmo significado, gerando outros tipos de implicações. Optamos por manter essas respostas no item "outras dinâmicas de organização do pensamento" como uma tentativa de confirmar a nossa opção por trazer à luz a diversidade de juízos que constou em nossa amostra.

\subsection{Descrição dos modelos organizadores relativos ao questionário sobre projeto de vida.}

a) Modelo organizador 1 - Projeções frágeis

Número de sujeitos que aplicaram o modelo: 56

Os sujeitos que aplicaram o modelo organizador 1 não se remeteram a projetos de vida ou o fizeram de forma vaga e esvaziada de significados, não trazendo clareza do que almejam para o seu futuro.

\footnotetext{
${ }^{48} \mathrm{O}$ instrumento tabela não se mostra como uma melhor forma de visualizar o dinamismo que compõe o pensamento do jovem, mas, devido às várias intersecções que existem entre elementos e seus significados, sentimentos e seus significados e implicações/relações que resultam de todo esse processo, seria muito difícil compor um esquema mais próximo da sua complexidade.

49 Como os exemplos foram retirados das escritas dos jovens, procuramos fazer correções "leves", principalmente de ortografia, de forma a não alterar o significado de suas respostas. Acreditamos que tais correções sejam importantes para não desviar o foco do trabalho que se encontra no significado das respostas e não no domínio de linguagem escrita dos participantes. Outro aspecto importante sobre os exemplos está na apresentação de grupos de respostas de um mesmo participante, com o qual intentaremos apresentar a dinâmica de seu raciocínio. De forma a não prejudicar a leitura e de não torná-la cansativa, não traremos as perguntas, apenas as respostas, que, em nosso entender, já evidenciarão o assunto tratado pelo jovem.
} 
As respostas que perfazem esse modelo são, no geral, pouco elaboradas e contraditórias. Os elementos abstraídos que organizam o pensamento desses sujeitos ora mostravam pouca força para nortear as respostas dos sujeitos, ora eram tão fortes que inibiam qualquer possibilidade de projeção futura.

Devido à diversidade de elementos abstraídos, que ocasionaram diferentes dinâmicas do pensar, subdividimos o presente modelo organizador em três grupos: o submodelo 1a, em que os valores de trabalho e família eram destacados de forma branda e pouco elaborada; o submodelo 1b, no qual uma experiência negativa na história dos sujeitos os leva a projeções frágeis e contraditórias; e o submodelo 1c, cujo elemento organizador central (Deus) encontra-se fortemente vinculado a todas as elaborações sobre o futuro dos sujeitos, levandoos a não realizarem projeções sobre si mesmos.

Vale ressaltar que, nesse modelo, os sentimentos apontados pelos sujeitos são, no mais das vezes, o sentir-se "bem" ou "normal", diante das situações vividas ou projetadas. Alguns sujeitos desse grupo indicam cansaço, tédio ou tristeza aos 40 anos. O sentimento de felicidade não compareceu às respostas, com exceção de alguns sujeitos do submodelo 1a que trouxeram esse aspecto de maneira vaga e desprovida de significados.

\section{Submodelo 1a}

\section{Número de sujeitos que aplicaram o submodelo: 52}

O submodelo 1a caracteriza-se por respostas, em geral, curtas e contraditórias. Nessas respostas, foi possível identificar dois elementos abstraídos pelos sujeitos que, em nossa visão, organizaram as suas respostas: a família e o trabalho.

Poder-se-ia afirmar que a família e o trabalho são valores para os sujeitos; no entanto, tais valores não comparecem com carga grande de significados, o que acarreta em relações/ implicações, de certa forma, incipientes. É um submodelo carente de complexidade, em que as respostas emitidas pelos sujeitos nos parecem esvaziadas de significados.

"Q1 - Me sinto bem no meu dia a dia, muito bem"/ "Q2 - 1 a escola, 2 jogar bola, 3 sair com os amigos"/ "Q3 - Eu me sinto satisfeito bastante"/ "Q4 - porque é o que eu mais gosto da vida"/ "Q5 - nenhuma”. (Sujeito 112, 15 anos, masculino, Rio Claro, SP) 
"Q1 - Eu sou uma pessoa calma, frequento muito a escola, sincera e etc."/ "Q2 - 1 - minha família, 2 - acabar com a fome, 3 - todas as pessoas sejam felizes."/ "Q3 - útil para todos"/ "Q4 - com a realidade do dia a dia"/ "Q5 - de não ter condições para ajudar financeiramente”. (Sujeito 28, 17 anos, masculino, Fortaleza, CE)

Sobre os valores destacados, percebe-se que os sujeitos que aplicaram esse submodelo, em grande parte, tentam fazer projeções de trabalho e família para o futuro. Contudo, tais projeções são frágeis e, muitas vezes, esbarram em uma idealização desses elementos.

“Q11 - Uma pessoa feliz porque o sonho de uma mulher é ter sua própria família e um casamento maravilhoso."/ "Q12 - Um projeto de vida é quando você já tem tudo planejado como vai ser sua vida. Meu projeto de vida é me formar em uma boa faculdade e ter uma família com pelo menos 4 filhos." "Q13 - minha relação é que eu vou ter tudo que eu quero e o que eu sonho.” (Sujeito 123, 16 anos, feminino, São Paulo, SP)

"Q8 - Eu espero que eu seja muito feliz com um emprego maravilhoso, uma família muito bonita e feliz, isso será muito importante pra mim."/ "Q9 - Uma pessoa realizada, uma pessoa feliz que correu atrás de seus objetivos." "Q10 - Ter uma família unida com filhos maravilhosos com o gostinho de ter cumprido a minha missão.” (Sujeito 38, 17 anos, masculino, Sobral, CE)

Pareceu-nos que os sujeitos que aplicaram o submodelo 1a projetam um futuro "normal", como se fosse o próprio "curso da vida", como se a vida os levasse a seu "destino", que é um "lugar-comum" - casar, ter filhos, ter emprego. Muitos desses sujeitos indicam que estarão cansados, velhos ou aposentados quando estiverem com 40 anos.

"Q8 - minha casa, minha mulher, meu filho, uma vida sossegada."/ "Q9 - não sei, só passando pela experiência pra saber."/ Q10 - não tenho a mínima ideia, quando eu estiver com 40 anos, mas sempre vai ser importante pra mim é minha família.” (Sujeito 102, 18 anos, masculino, São Paulo, SP)

"Q8 - se eu estiver viva até lá, eu estarei cursando a faculdade e tendo a minha casa."/ "Q9 - vou me sentir ótima, vou estar cumprindo os meus desejos"/ "Q10 - Vou estar muito velha, 
não sei como será, trabalhando com certeza, Deus e minha família.” (Sujeito 183, feminino, 17 anos, Curitiba, PR)

"Q10 - o mais importante a família claro. Mas minha vida vai ser mais focada na minha família. Vou estar em casa com minha mulher e meus filhos, sentado no sofá assistindo TV. $O$ que será mais importante é minha família.” (Sujeito 116, 16 anos, masculino, Rio Claro, SP).

Muitos sujeitos apontam que se esforçarão para atingir projetos, mas carecem de ações e significados que apontem tais ações. Por exemplo, sobre o trabalho, apontam que será importante no futuro, mas não indicam qual profissão desejam seguir. Alguns demonstram incerteza sobre o futuro, apontando, inclusive, que não saberão se estarão vivos.

"Q8 - Quem sou eu para dizer sobre o futuro? o futuro só pertence a Deus."/ "Q9 - Não tenho a mínima ideia, nem sei se vou estar vivo." (Sujeito 155, 19 anos, masculino, Curitiba, PR)

Na questão seis, quando se perguntava ao sujeito o que ele gostaria que fosse diferente no mundo, todos os que aplicaram o submodelo 1a responderam de forma contraditória aos valores expressados como organizadores ao longo de todo questionário. Alguns sujeitos apontaram a violência; outros, a falta de respeito com a natureza; outros, a falta de respeito entre os seres humanos.

"Q6 - A violência... cada um fazendo a sua parte o mundo pode se tornar melhor!"/ "Q7 me sinto triste porque sei que nem todo mundo quer fazer a diferença e querendo ou não se todos juntos não colaborarmos isso nunca ira acontecer." (Sujeito 47, 17 anos, feminino, Fortaleza, CE)

Alguns sujeitos desse grupo chegam a expor que não possuem projeto de vida ou, então, mostram extremas dúvidas sobre seus projetos.

“Q12 - Um projeto de vida pra mim é: programar o futuro. Mas se preocupar com o futuro não é algo muito bom, viver o presente e fazer com que não se arrependa é algo vital. Não tenho, vou começar a pensar no futuro quando perceber que está na hora, sou jovem, e eu só 
tenho que estudar e ser feliz."/ "Q13 - Não tenho projeto." (Sujeito 97, 16 anos, masculino, São Paulo, SP)

"Q12 - pra mim o projeto de vida pode ser o que você quer para si profissionalmente. E o meu projeto de vida é me formar em nutricionismo ou então ser uma roqueira, compor minhas próprias musicas.” (Sujeito 52, 17 anos, feminino, Fortaleza, CE)

Sobre os sentimentos, poucos são mobilizados. Quando comparecem, ora dizem respeito a se sentir "bem" com a rotina, ora apontam que se sentem "normal".

"Q3 - Me sinto normal, como se fosse algo importante, do começo da minha vida até o fim dela."/ "Q10 - Minha vida será normal, como todas as famílias, vou ter casa, emprego, carro, filhos. O mais importante será a família." (Sujeito 97, 16 anos, masculino, São Paulo, $\mathrm{SP})$

A felicidade comparece em algumas respostas como um elemento que também organiza o pensamento do sujeito, embora não de forma central. A felicidade não se apresenta com significados, ou seja, os sujeitos a mobilizam como algo em si, sem relação com outros aspectos da vida, como a realização profissional e pessoal. É uma felicidade "esvaziada" de sentido.

“Q12 - projeto de vida é aquilo planejado desde cedo para seu futuro, seu próprio bem; eu planejo ter uma família, minha casa própria, uma vida sem preocupações, e ser feliz." (Sujeito 158, 16 anos, masculino, Curitiba, PR)

“Q12 - Planos para o futuro. Ser feliz.” (Sujeito 114, 15 anos, masculino, Rio Claro, SP)

É importante apontar que alguns sujeitos que aplicaram o submodelo 1a mobilizaram os elementos Deus e amigos, principalmente no início do questionário. No entanto, tais elementos não receberam significados, tampouco compareceram em boa parte das respostas. Isso nos leva a compreender que não são elementos organizadores centrais para esses jovens. 
De forma breve, podemos indicar que o submodelo 1a organiza-se, dinamicamente ${ }^{50} \mathrm{e}$ em seu núcleo central, da seguinte forma:

Tabela 3: Relações/implicações entre elementos centrais, sentimentos e seus significados no submodelo 1a.

\begin{tabular}{|c|c|c|c|}
\hline & & Significados & Relações/implicações \\
\hline \multirow[t]{2}{*}{$\begin{array}{l}\text { Elementos } \\
\text { centrais }\end{array}$} & Trabalho & $\begin{array}{l}\text { Curso "natural” da vida; } \\
\text { idealização; incerteza. }\end{array}$ & \multirow{3}{*}{$\begin{array}{l}\text { Projeção frágil dos } \\
\text { elementos trabalho } \\
\text { família e dos sentimentos } \\
\text { (bem-estar e normal) pelos } \\
\text { significados que recebem: } \\
\text { naturalidade de progressão } \\
\text { da vida, idealização e } \\
\text { incerteza. }\end{array}$} \\
\hline & Família & $\begin{array}{l}\text { Curso "natural" da vida; } \\
\text { idealização; incerteza. }\end{array}$ & \\
\hline Sentimentos & $\begin{array}{l}\text { Bem-estar } \\
\text { "Normal" }\end{array}$ & $\begin{array}{l}\text { Desejável; esperado para o } \\
\text { futuro. }\end{array}$ & \\
\hline
\end{tabular}

\section{Submodelo 1b}

\section{Número de sujeitos que aplicaram o submodelo: 2}

O submodelo $1 b$ traz respostas com uma maior gama de significados atribuídos aos elementos organizadores centrais, que também são o trabalho e a família. No entanto, assim como no submodelo 1a, esses elementos têm significados contraditórios ao longo do questionário, resultando em implicações e/ou relações estabelecidas entre eles de forma incipiente.

A contradição presente em todo o questionário foi por nós percebida como originada de um elemento organizador central: uma experiência negativa marcante na história de vida dos dois sujeitos que aplicaram esse submodelo.

“Q1 - Não faço muito no meu dia a dia, normalmente só vou para a escola de manhã e fico em casa o resto do dia. Gostaria de fazer mais, mas não faço... Perdi recentemente um

\footnotetext{
${ }^{50}$ Embora se trate de uma tabela, entendemos que as relações entre seus componentes é dinâmica e implica intersecções, resultando na complexidade da elaboração realizada pelo jovem. O objetivo de apresentar tal tabela encontra-se na facilitação de compreensão, para o leitor, das relações/implicações estabelecidas entre os elementos centrais, os sentimentos e seus significados.
} 
parente muito íntimo e estou passando por uma fase muito difícil da minha vida." (Sujeito 130, 15 anos, feminino, São Paulo, SP)

"Q1 - Moro com minha família, tenho 5 irmãs e 1 irmão. Sou a mais nova de casa. Eu já engravidei, mas bem no começo eu perdi meu filho, não sei exatamente o porque eu o perdi, perdi ele com 2 para 3 semanas de gravidez, eu acho que eu perdi ele, porque eu estava muito nervosa, no começo, quando eu soube que eu estava grávida. No começo foi realmente difícil para mim, eu só ficava pensando na reação do meu pai, em ele receber esta notícia, seria muito difícil dele aceitar, não deixava eu ficar com nenhum menino, imagine eu dando de que eu estava grávida, ele iria surtar, sendo que eu sou a mais nova de casa, e a minha irmã mais velha tem 30 anos nem tem filho, nem é casada, todos os meus irmãos são solteiros(as), eu estava muito decidida em ter meu filho, mas infelizmente eu perdi ele, agora eu só preciso ir ao médico pra fazer uma limpagem em mim, mais isto foi um alerta de Deus, em que eu não conseguiria criar meu filho nesta idade. [...]" (Sujeito 131, 15 anos, feminino, São Paulo, SP)

A força desse elemento faz com que grande parte das respostas desses sujeitos sejam norteadas por ele, inibindo, também, ações voltadas para o futuro. As projeções que os sujeitos fazem sobre o futuro são contraditórias, influenciadas pelas experiências negativas.

“Q8 - Será importante eu já estar cursando um ensino superior, trabalhando e tentando levar minha vida da melhor forma possível."/ "Q9 - Acho que a gente começa a ver o mundo mais como ele é por fora e não com uma mente tão fechada como a dos adolescentes."/ "Q12 - Para mim são as coisas que você pretende fazer no seu futuro. Eu pretendo viajar primeiro para o exterior assim que possível para tentar algo fora.” (Sujeito 130, 15 anos, feminino, São Paulo, SP)

“Q8 - Trabalhadora, mas não um trabalho popular em que as mulheres trabalham, quero ser jogadora de futebol, quero ter filho já nesta idade, ter minha casa pra morar, não quero mais morar com meus pais, quero ter minha própria casa, isso é importante pra mim./ "Q10 - Já vou ter minha família, vou ser uma pessoa mais decidida e ter minhas próprias vontades. Minha vida será com barreiras, como todas as pessoas enfrentam. Acho que estarei trabalhando, só não sei de que. Minha dedicação será muito importante para mim.” (Sujeito 131, 15 anos, feminino, São Paulo, SP) 
Como é possível verificar nos exemplos acima, embora haja uma indicação de um futuro, mesmo que de forma contraditória, os sujeitos que aplicaram o submodelo $1 \mathrm{~b}$ não trazem força em seus projetos, não tendo claros os significados atribuídos aos valores de família e trabalho. Desejam trabalhar, mas não se sabe qual a profissão ou o que desejam fazer no futuro.

Além disso, o mesmo aspecto de estar cansado, desejando, no futuro, uma vida comum e idealizada aparece.

“Q10 - Será ruim, pois as pessoas das quais eu mais amo estarão com pouco tempo de vida. Espero que seja uma vida estável, sem dificuldades muito grandes, pois dificuldades sempre temos ao longo da vida toda, com certeza ainda estarei trabalhando. E será importante estar com as pessoas que eu gosto, pessoas que eu gosto fazendo o que gosto”. (Sujeito 130, 15 anos, feminino, São Paulo, SP)

As observações desses sujeitos sobre o que gostariam que fosse diferente no mundo são coerentes com as experiências negativas vividas por eles. No entanto, a força desses acontecimentos em suas vidas não os leva a apontar ações para reverter a situação. Pelo contrário, parecem ser aspectos "desmotivadores” ou norteadores para uma vida comum.

"Q6 - Acho que as pessoas deviam se conscientizar de que a vida tem muito mais valor do que elas podem ver, e pensar que o que não tem valor a elas tem valor aos outros. Para concretizar procuro não incentivar a violência."/ "Q7 - Vejo que não faz muita diferença o que penso e sim que as pessoas no mundo pensam do jeito delas cada uma e não estão dispostas a mudar por tão pouco." (Sujeito 130, 15 anos, feminino, São Paulo, SP)

"Q6 - A educação das pessoas, respeito com as pessoas, saber lidar com as diferenças."/ “Q7 - Mais tranquila.” (Sujeito 131, 15 anos, feminino, São Paulo, SP)

Nas duas respostas que perfazem esse submodelo não encontramos muitas referências aos sentimentos. Os sujeitos destacam, inclusive, falta de afetividade e uma visão negativa do mundo. 
“Q3 - 1. Minha família eu não tenho muito afeto, não converso muito com ninguém, não converso com meu pai, só faço as coisas que ele pede, minha mãe também não converso muito não. Minhas irmãs eu converso só um pouco, não tenho muita afetividade com eles, fico mais na minha, guardo as coisas mais pra mim [...]”.(Sujeito 131, 15 anos, feminino, São Paulo, SP)

"Q11 - Velha e com pouco tempo de vida mesmo sabendo que com 40 anos não estarei tão velha assim, mas esse é o meu pensamento agora." (Sujeito 130, 15 anos, feminino, São Paulo, SP)

A felicidade não é contemplada nessas respostas, tampouco a realização pessoal e a satisfação em relação ao projeto de vida.

De forma a explicitar o núcleo central que organiza esse submodelo, apresentamos a tabela abaixo, procurando indicar as relações/implicações entre elementos centrais, sentimentos e seus significados.

Tabela 4: Relações/implicações entre elementos centrais, sentimentos e seus significados no submodelo 1 b.

\begin{tabular}{|c|c|c|c|}
\hline & & Significados & Relações/implicações \\
\hline \multirow[t]{3}{*}{$\begin{array}{l}\text { Elementos } \\
\text { centrais }\end{array}$} & Trabalho & $\begin{array}{l}\text { Curso "natural" da vida; } \\
\text { idealização; }\end{array}$ & \multirow{4}{*}{$\begin{array}{l}\text { Projeção frágil dos } \\
\text { elementos trabalho } \\
\text { família, influenciada por } \\
\text { uma experiência negativa. } \\
\text { A falta de sentimentos } \\
\text { contribui para uma visão } \\
\text { negativa, com planos } \\
\text { frágeis ou meramente } \\
\text { idealizados no futuro. }\end{array}$} \\
\hline & Família & $\begin{array}{l}\text { Curso "natural" da vida; } \\
\text { idealização. }\end{array}$ & \\
\hline & $\begin{array}{l}\text { Experiência } \\
\text { negativa }\end{array}$ & $\begin{array}{l}\text { Fase difícil; provoca um } \\
\text { visão negativa do futuro. }\end{array}$ & \\
\hline Sentimentos & ------ & 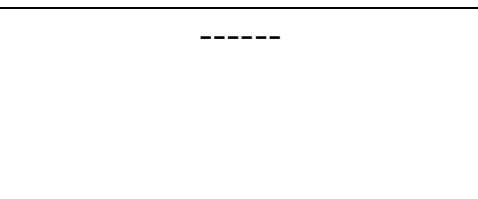 & \\
\hline
\end{tabular}




\section{Submodelo 1c}

\section{Número de sujeitos que aplicaram o submodelo: 2}

O elemento organizador central do submodelo 1c é Deus e a religiosidade dos sujeitos. Tal elemento está presente em todas as respostas dos dois sujeitos que aplicaram esse modelo organizador, influenciando a abstração de elementos da realidade, bem como os significados atribuídos a esses elementos e as relações/implicações estabelecidas entre eles.

"Q4 - A partir do momento que conheci a verdade, aprendi a ter boa moral e ter bons princípios e principalmente o que Jeová deseja de nós e quantas maravilhosas e inúmeras coisas que Ele fez e nos proveu, as coisas amorosas que deixou para nos ensinar (como a Bíblia) e o grande e maior exemplo que seu filho Jesus nos deixou me fazem sempre refletir e ver o quanto tenho para agradecê-lo, e fazer sua vontade é o mínimo que posso fazer pra começar. Uma das coisas que ele nos incentiva a fazer é amar a Ele e ao próximo, ter amor fraternal com nossos parentes e muitas outras coisas e acho importantíssimo colocar tais coisas (como fazer a vontade de Deus) como primordiais em minha vida." (Sujeito 140, 15 anos, feminino, Rio Claro, SP)

A força desse elemento é deveras grande, levando os sujeitos que aplicaram o submodelo 1c a projetar sua vida futura em torno da adoração a Deus e do seguimento dos preceitos da religião escolhida. Essa projeção impede os sujeitos de pensarem em suas próprias vidas, como se a crença em Deus pudesse "garantir" seu futuro.

“Q8 - Não faço ideia de como será, já que o futuro é incerto e não sabemos como será, mas se o governo perfeito que desejo já estiver 'imperando' será importante mostrar a outros que tudo aquilo que falamos é verdade e que a partir daquele momento poderemos ter paz." (Sujeito 140, 15 anos, feminino, Rio Claro, SP)

"Q10 - minha vida vai ser muito bem aventurada, vou estar trabalhando pro meu Deus, o meu bem estar com o meu Deus.” (Sujeito 24, 15 anos, masculino, Fortaleza, CE) 
A respeito do projeto de vida, os dois sujeitos não apresentam clareza sobre o que desejam fazer no futuro. Assumem que estão construindo seus projetos ou que ainda não estão pensando a respeito disso.

“Q12 - [...] Não pensei ainda em que quero trabalhar, mas sei que desejo fazer algo que possa me ajudar a 'viver'... mas sei também que desejo continuar a me preocupar com os outros e sempre ajudar se estiver ao meu alcance."/ "Q13 - Como já disse com relação sobre que profissão vou escolher ser eu não sei ainda, mas não me preocupo com isso, eu acho sim importante ter que trabalhar mas quando for a hora certa eu me preocuparei com isso e farei planos para conseguir fazer algo que talvez eu goste.” (Sujeito 140, 15 anos, feminino, Rio Claro, SP)

"Q12 - Construir algo de que vai me ajudar no meu crescer, eu ainda estou construindo."/ “Q13 - caminhando muito bem.” (Sujeito 24, 15 anos, masculino, Fortaleza, CE)

Quando indagados sobre o que gostariam que fosse diferente no mundo, esses sujeitos novamente recorrem às crenças e às ações circunscritas a seus preceitos religiosos. Percebe-se a motivação a essas mudanças e uma verdadeira crença de que tais modificações irão acontecer, inclusive pelas ações dos próprios sujeitos.

"Q6 - gostaria que as pessoas fossem perfeitas e buscassem colocar em suas vidas algo realmente importante, que revessemos nossos entes queridos falecidos, que a fome e as guerras acabassem e fôssemos governados por um só governante. Eu acredito que no futuro isso acontecerá e para que isso aconteça e muitas pessoas estejam incluídas eu participo de uma obra de muita importância que é anunciar o reino de Deus [...]"/ "Q7 - Extremamente feliz e muito ansiosa para que essas coisas aconteçam, eu tenho certeza de que vão acontecer!!” (Sujeito 140, 15 anos, feminino, Rio Claro, SP)

"Q6 - eu queria que não tivesse brigas, drogas, e prostituição, o que faço pra concretizar tal mudança eu prego a palavra do meu senhor Jesus."/ "Q7 - me sinto motivado a fazer mais e mais." (Sujeito 24, 15 anos, masculino, Fortaleza, CE)

Os sentimentos mobilizados por esses sujeitos, em geral, correspondem aos do submodelo 1a, ou seja, remetem a sentir-se bem com a rotina vivenciada. As exceções 
encontram-se na questão sete, como se pode observar nos exemplos acima. Nessa questão, os sujeitos indicaram como se sentem em relação à mudança pretendida no mundo.

Um desses sujeitos aponta cansaço ao final da vida, assim como tédio ou tristeza; o outro não apresenta sentimentos nessa projeção. Não comparece, em relação às projeções de futuro, a felicidade.

"Q10 - Muito chata e um tédio, se eu chegar aos 40 anos espero continuar fazendo o mesmo que hoje (pelo menos) falar das promessas divinas de Jeová a outros com mais denodo e expectativa do que antes."/ "Q11 - Talvez um pouco triste e cansada pela idade mas ansiosa e sempre na expectativa de um mundo melhor." (Sujeito 140, 15 anos, feminino, Rio Claro, $\mathrm{SP})$

Elucidando o núcleo central desse submodelo organizador, apresentamos a tabela abaixo.

Tabela 5: Relações/implicações entre elementos centrais, sentimentos e seus significados no submodelo 1c.

\begin{tabular}{|c|c|c|c|}
\hline \multirow[b]{2}{*}{$\begin{array}{l}\text { Elementos } \\
\text { centrais }\end{array}$} & \multirow[b]{2}{*}{ Deus } & Significados & \multirow{2}{*}{\begin{tabular}{l}
\multicolumn{3}{c}{ Relações/implicações } \\
Projeção frágil devido à \\
força da crença religiosa, \\
que inibe o sujeito a \\
pensar em $\quad$ outros \\
elementos. Sentimentos
\end{tabular}} \\
\hline & & $\begin{array}{lcr}\text { Garantirá } & \text { o futuro; } \\
\text { necessita } & \text { que } & \text { sua } \\
\text { "palavra" } & \text { seja difundida; } \\
\text { promove } & \text { mudanças no } \\
\text { mundo. } & \end{array}$ & \\
\hline \multirow[t]{3}{*}{ Sentimentos } & $\begin{array}{l}\text { Bem-estar } \\
\text { Normal }\end{array}$ & Rotina; crenças em Deus. & \multirow{3}{*}{$\begin{array}{l}\text { são fracamente } \\
\text { mobilizados, acarretando } \\
\text { em um "empobrecimento" } \\
\text { das projeções sobre o } \\
\text { futuro. }\end{array}$} \\
\hline & $\begin{array}{l}\text { Felicidade } \\
\text { Realização }\end{array}$ & $\begin{array}{l}\text { Concretização de } \\
\text { mudanças feitas por Deus. }\end{array}$ & \\
\hline & $\begin{array}{l}\text { Cansaço* } \\
\text { Tédio* } \\
\text { Tristeza* }\end{array}$ & $\begin{array}{l}\text { Decorrente da idade*; } \\
\text { Pelo fato de permanecer } \\
\text { fazendo o que faz hoje.* }\end{array}$ & \\
\hline
\end{tabular}

* Em algumas respostas. 


\section{b) Modelo organizador 2 - Consumo e estabilidade financeira}

\section{Número de sujeitos que aplicaram o modelo: 12}

Os sujeitos que aplicaram o modelo organizador 2 apresentaram como elemento organizador central o trabalho, o qual foi significado como meio para obtenção de dinheiro, estabilidade financeira e consumo de bens. Esse modelo, o qual não necessitou de subagrupamentos, traz fortemente a questão financeira em grande parte das respostas emitidas pelos sujeitos. A força desse elemento norteia os projetos de vida apresentados, que giram em torno da obtenção de dinheiro e bens para uma vida confortável e estável.

“Q3 - [...] Em relação ao trabalho, apesar de estar começando agora, acho que é uma coisa muito importante para meu crescimento financeiro, que é o que eu mais desejo." (Sujeito 136, 16 anos, feminino, São Paulo, SP)

"Q1 - trabalho em uma loja, estudo de manhã, meio corrido, mas dou conta..."/ "Q2 família, futuro, crescimento financeiro"/ "Q3 - em família tudo certo, futuro estou correndo atrás e o financeiro acho que isso eu consigo com muito trabalho." (Sujeito 199, 15 anos, feminino, Ponta Grossa, PR)

Outro elemento abstraído pelos sujeitos que aplicaram o modelo 2 foi a família. Contudo, tal elemento não recebeu significados atuantes para a construção do modelo organizador. Podemos, assim, afirmar que esse valor não foi mobilizado como um elemento organizador central para esses jovens. Interessante se faz observar que, em algumas respostas, a família foi significada por meio do elemento trabalho como garantia para aquisição de dinheiro e bens ou de uma forma ideal, pensada como uma companhia ou como necessitando de cuidados.

"Q3 - A família é a base de tudo, pois se você não tiver uma boa base familiar, poderá não corresponder com o mercado de trabalho no dia-a-dia.[...]" (Sujeito 109, 15 anos, masculino, Rio Claro, SP) 
O elemento estudo/escola comparece em algumas respostas como um meio para atingir o trabalho e, consequentemente, o sucesso financeiro e de consumo.

"Q3 - [...] o estudo é o meio de se conseguir tudo que queremos e é por meio do trabalho que conseguimos nosso sustento e as coisas que desejamos ter." (Sujeito 193, 16 anos, feminino, Ponta Grossa, PR)

Os projetos de vida são compostos, de acordo com o que apresentam os sujeitos que aplicaram o modelo organizador 2 , dos valores de trabalho e família, sendo que o elemento trabalho atua como central e é significado como meio para atingir a possibilidade de ganhar dinheiro e adquirir bens de consumo.

"Q8 - Ter meus familiares ainda presentes em minha vida, ter um bom emprego, para que eu não necessite depender dos outros, e também conseguir conquistar o meu sonho desde pequeno, o mais rápido possível, que é comprar meu carro, com meu dinheiro." (Sujeito 173, 15 anos, Masculino, Ponta Grossa, PR)

Referindo-se a esse projeto ao longo de todo o questionário, os sujeitos apontam como ação principal o trabalho. Os que ainda não trabalham indicam a necessidade de trabalhar para atingir seus desejos.

"Q1 - eu sou DJ, gosto muito do que faço estudo e trabalho de balconista em outro local. Meu dia-a-dia é muito corrido."/ "Q4 - primeiramente, quando nasci eles já foram importante para mim, ser DJ tornou quando eu comecei a ganhar dinheiro." (Sujeito 99, 17 anos, masculino, São Paulo, SP)

"Q1 - Sou um cara pacífico que não gosto de me estressar, sou de uma família de classe baixa, mas não ligo pra isso, pois sou feliz e nada importa assim também as vezes é o meu dia-a-dia."/ "Q2 - 1. Ter minha família 2. Minha namorada 3. Conseguir um emprego."/ "Q3 - eu me sinto bem, porque tudo está como é pra ser, menos o fato de que eu ainda não tenho emprego." (Sujeito 23, 15 anos, masculino, Fortaleza, CE)

Um aspecto que chama atenção nesse modelo organizador é a presença, no futuro mais distante (40 anos), de sentimentos como cansaço e de preocupações em ficar velho ou com 
dificuldades de saúde. Juntamente a isso, nota-se a vontade, de uma parte desses jovens, de dedicar-se, nessa etapa, a descansar e a curtir a vida, por meio de viagens e passeios.

"Q10 - acho que será bom, vou estar na minha casa acordando tarde, o importante será ver meus filhos ou netos bem."/ "Q11 - acho que será cansado.” (Sujeito 99, 17 anos, masculino, São Paulo, SP)

“Q10 - Minha vida não mudará, a maior mudança que pode ocorrer é o desgaste do corpo e com isso aparecimento de doenças. Nessa idade o importante é curtir o que resta da vida, com a família e amigos."/ "Q11 - Dificuldade e falta de capacidade física e motora." (Sujeito 109, 15 anos, masculino, Rio Claro, SP)

A despeito dessas projeções do futuro em que aparecem sentimentos de cansaço e desgaste físico, são recorrentes os sentimentos de bem-estar, realização e satisfação ao longo dos questionários, mas, principalmente, nas respostas referentes à rotina. Isso também ocorre em relação à felicidade. Todos esses sentimentos, de acordo com a nossa leitura, são expressos pelos sujeitos, levando em consideração o elemento organizador central: o trabalho como via para atingir o dinheiro/consumo. Ou seja, os sujeitos se mostram felizes ou realizados estritamente pelas conquistas financeiras.

"Q9 - feliz, bem empregado e com meu sonho realizado." (Sujeito 173, 15 anos, masculino, Ponta Grossa/PR)

"Q11 - Se eu conseguir realizar meus objetivos de vida, com certeza me sentirei muito feliz e realizada.” (Sujeito 136, 16 anos, feminino, São Paulo, SP)

A grande maioria dos sujeitos que aplicaram o modelo 2 não possui coerência entre as ações para o seu projeto de vida e os problemas que percebem no mundo. Enquanto as ações estão voltadas para um projeto concernente ao trabalho, na questão seis, cuja pergunta referese ao que gostaria que fosse diferente no mundo, esses sujeitos indicam outros aspectos que lhes chamam a atenção, por exemplo, a violência, a destruição da natureza, o desrespeito entre as pessoas. Ao apontar esses aspectos, não exprimem as ações possíveis que poderiam realizar para mudar a realidade observada. 
"Q6 - a violência, pois isso é o que prejudica mais e o que eu tento fazer para mudar é ser legal com todos, isso inclui respeito pelo próximo."/ "Q7 - eu me sinto muito menos despreocupado ao sair para atividades.” (Sujeito 19, 17 anos, masculino, Fortaleza, CE)

Apenas dois sujeitos referem-se à desigualdade social; no entanto, o fazem de forma vaga, sem posicionar suas ações a respeito do problema.

"Q6 - que cada pessoa tivesse o que pretende ter, que ninguém fosse melhor que ninguém, porque todos nós quando morremos vamos para o mesmo lugar (terra)."/ "Q7 - me sentiria muito bem em passar do lado de outras pessoas e não ver diferença entre elas nem melhor nem pior.” (Sujeito 99, 17 anos, masculino, São Paulo, SP)

Quatro sujeitos que aplicaram o modelo organizador 2 citaram o elemento Deus, no início da entrevista. Contudo, tal elemento apareceu destituído de significados, não comparecendo nas respostas às últimas perguntas. Em nossa análise, percebemos que não se constitui como um elemento organizador central para esse grupo.

Vejamos, abaixo, uma tabela que procura exprimir as relações entre os elementos centrais, sentimentos e significados do modelo 2.

Tabela 6: Relações/implicações entre elementos centrais, sentimentos e seus significados no submodelo 2.

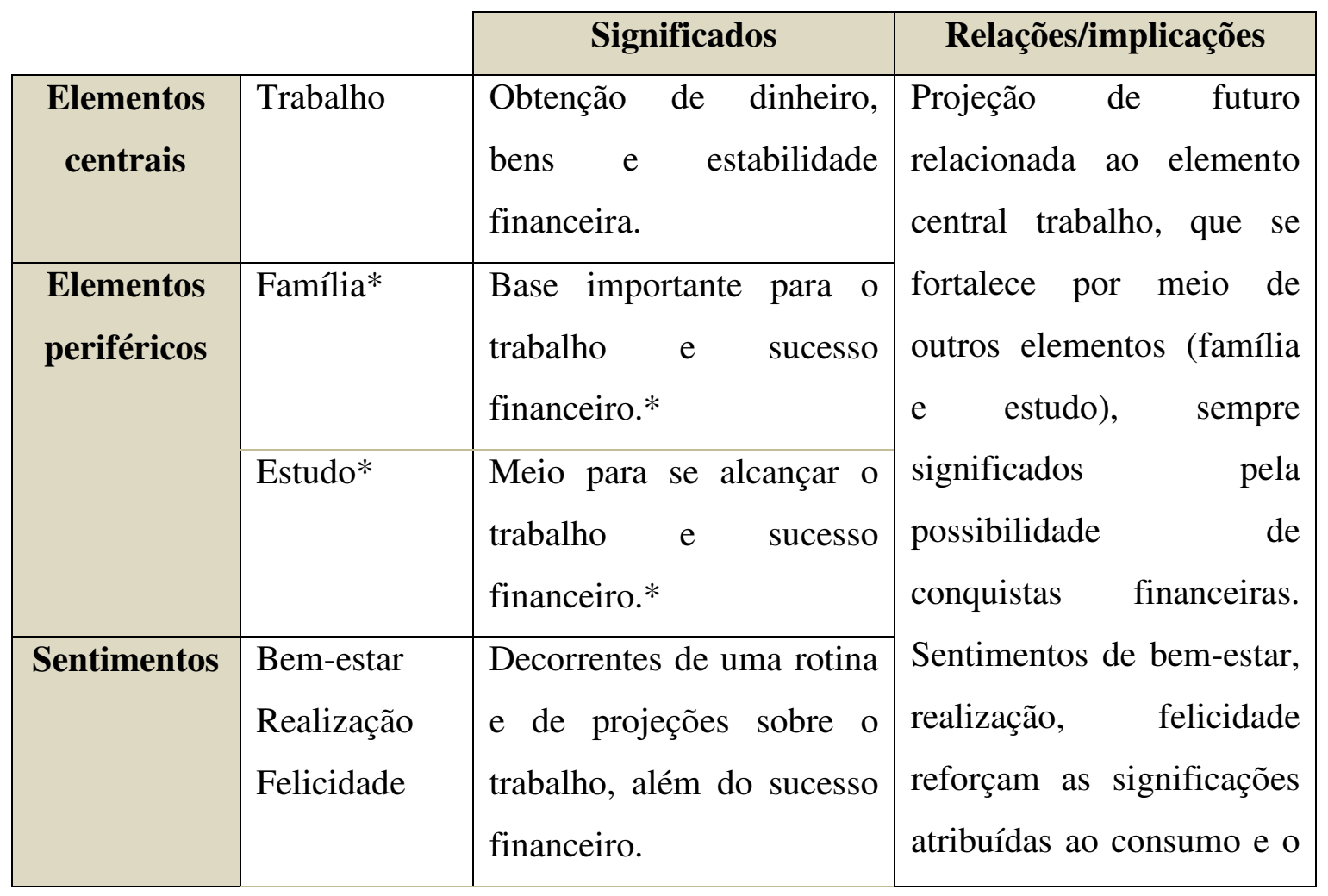




\begin{tabular}{|l|l|lrr|}
\hline Cansaço & Decorrente do tempo de & cansaço & provém & da \\
& trabalho; debilidade física; & perspectiva & de & ter \\
& necessidade de descansar e & trabalhado & muito & para \\
& curtir a vida. & alcançar os objetivos. & \\
\hline
\end{tabular}

* Em algumas respostas.

c) Modelo organizador 3 - Relações interpessoais/vínculos

\section{Número de sujeitos que aplicaram o modelo: 16}

O elemento organizador central do modelo 3 consiste nas relações interpessoais e vínculos estabelecidos pelos sujeitos. Em grande parte das respostas emitidas, encontram-se referências às relações familiares, de amizade ou namoro como aspectos importantes que norteiam as rotinas e projetos dos sujeitos.

“Q3 - [...] Minha família é minha base, sei que sempre poderei contar com ela. Meus irmãos e minha mãe são tudo o que tenho, além do que aprendo na escola. Porque tudo o que levaremos desta vida é o amor e sabedoria conquistados aqui." (Sujeito 179, 15 anos, feminino, Curitiba, PR)

"Q4 - Minha família se torna importante na minha vida, a partir do momento em que sempre que preciso estão ali para me darem força e me ajudarem, seja nos momentos bons ou ruins. Meus estudos sei que no futuro vou precisar, seja para arrumar uma boa profissão como para estabilizar a minha vida e cumprir meus objetivos. Já meu namorado com ele descobri a coisa mais importante que é saber dar valor a cada momento que passamos juntos, e também nas coisas mais simples da vida. Me fez mudar, crescer e saber a importância que posso ter para as pessoas.” (Sujeito 122, 17 anos, feminino, São Paulo, SP)

O elemento trabalho foi abstraído pelos sujeitos que aplicaram o modelo organizador 3. Todavia, tal valor comparece de forma periférica, como um dos aspectos que comporão o futuro desses sujeitos. Ele é significado, em nosso entender, como um passaporte para uma vida estável e estruturada para que o sujeito possa conviver bem com seus próximos. 
Outros valores abstraídos como significativos foram a família e a amizade. Os significados atribuídos a esses valores são os de apoio, confiança, boa convivência, divertimento, isto é, aspectos relacionados aos vínculos e relações interpessoais.

"Q8 - Tudo família, pessoas confiáveis e amizades verdadeiras.”/ "Q10 - espero estar trabalhando, com uma vida estável com uma família e o mais importante estar feliz."/ "Q12 - [...] Eu quero ter uma família alguém que eu possa confiar, ter uma vida estável com um bom emprego.” (Sujeito 154, 19 anos, masculino, Curitiba, Paraná)

Dando ênfase às relações interpessoais, as projeções para o futuro envolvem vínculos na família e a estabilidade de um emprego. Possuem, no mais, uma característica marcante que é a vontade de aproveitar a vida ao lado de quem se gosta.

"Q8 - Eu me imagino daqui a cinco anos em um bom emprego, com um bom salário, uma vida boa, e as pessoas que eu amo em minha volta. E a coisa mais importante seria eu estar feliz."/ "Q10 - Eu me imagino com 40 anos em um bom emprego, ganhando um bom salário, com uma boa casa, casado e com filhos. Com certeza, ainda estarei jogando bola. E a coisa mais importante seria eu estar feliz e ter a pessoas que eu amo por perto." (Sujeito 167, 16 anos, masculino, Ponta Grossa, PR)

"Q8 - Nossa, acho que vou estar formada na faculdade, com um bom emprego, com minha família e amigos ao meu lado. Vou estar noiva pronta para casar com um homem muito especial e que me faça muito feliz!"/ "Q10 - Eu acho que minha vida vai ser bem agitada, vou ser uma pessoa alegre, fazer exercícios, brincar com as pessoas, contar piadas, etc... Eu vou estar trabalhando em uma grande empresa, vou ter meu marido, filhos, minha casinha e até netinhos. Eu acho que as importâncias não vão mudar muito, acho que minha família vai ser prioridade em tudo!" (Sujeito 121, 16 anos, feminino, São Paulo, SP)

Um aspecto que é comum a todas as respostas do modelo 3 repousa no fato de que todos os sujeitos expressam uma rotina sem ações visando ao futuro. Em alguns protocolos, encontramos a descrição de uma rotina tediosa; em outros, um cotidiano comum, reforçado pela ideia de apreciação dos vínculos familiares e/ou de amizade. 
"Q1 - o meu dia a dia de semana é... acordar cedo, ir a escola, estudar, depois vou para casa, ajudo minha mãe a limpar casa (por enquanto não tenho trabalho), eu entro na internet, e saio para ver se eu tenho lição para fazer ou revisar e assisto novela e vou dormir... geralmente é isso que eu faço. Eu me sinto muito feliz por ter amigos e família por perto.” (Sujeito 143, 15 anos, feminino, Rio Claro, SP)

"Q1 - Meu dia-a-dia é meio ruim porque não tem nada para fazer. Minha vida mesmo é escola, casa e igreja." (Sujeito 137, 15 anos, feminino, Rio Claro, SP)

Quando indagados sobre o que gostariam que fosse diferente no mundo, os sujeitos cujas respostas foram agrupadas no modelo organizador 3 relatam percepções sobre o comportamento humano, desejando que as pessoas vivessem em paz, sem conflitos, e que houvesse mais união e solidariedade. Aspectos como respeito ao outro, pensar no coletivo e em formas de ajuda aos outros foram recorrentes em todos os relatos dos sujeitos desse grupo. O posicionamento desses jovens diante da problemática levantada é o de pensar em suas próprias atitudes, com vistas a mudar, ao menos, um pouco a situação vigente. Embora exponham, em grande parte das respostas, uma ação pessoal para resolução do problema, os participantes desse grupo parecem pensar que suas atitudes pouco podem mudar a realidade e se colocam como: a) esperançosos por uma mudança; b) com apontamentos sobre como se sentiriam se ela acontecesse; c) indicando sentimentos negativos, sem esperanças de que tal modificação possa ocorrer.

"Q6 - Gostaria que as pessoas se amassem mais, que deixassem de ser menos egoístas e passassem a pensar em prol do coletivo. Uma pessoa apenas não conseguiria tal façanha, mas com certeza com a união de um grupo o ideal de um mundo melhor pudesse se concretizar, atualmente não faço nada, mas pretendo ingressar em algum projeto social assim que possível."/ "Q7 - Esperançoso para que um dia isso realmente ocorra.” (Sujeito 68, 16 anos, masculino, Goiânia, GO)

"Q6 - Se o mercado de trabalho fosse menos competitivo, acredito que teria tempo livre para ficar com minha família, pois gastaria menos tempo estudando. Sempre tento aproveitar ao máximo o tempo que passo com meus pais e minhas irmãs. Queria poder voltar no tempo para mudar minha maneira de pensar, pois acredito que se tivesse estudado mais no passado, hoje as coisas seriam mais fáceis. Gostaria que as pessoas fossem honestas e não se 
aproveitassem da bondade de outras pessoas para alcançar seus objetivos. Procuro me afastar de pessoas de má índole."/ "Q7 - Me sinto bem, pois sei que essa fase vai passar e quando isso acontecer vou poder aproveitar ao máximo a companhia da minha família. Infelizmente, não posso voltar no tempo, mas posso tentar mudar essa situação me esforçando ao máximo para reverter essa situação. Sou feliz, por ter a meu lado pessoas honestas e amorosas.” (Sujeito 14, 16 anos, feminino, Macapá, AP)

Sobre os sentimentos destacados pelos sujeitos que aplicaram o modelo organizador 3 , é notória a presença do amor, o qual, em nosso entender, é fruto das relações existentes, imaginadas ou projetadas nas respostas. Tal sentimento é citado explicitamente por grande parte desses jovens, tanto quando se referem às suas rotinas como quando fazem referência ao futuro.

O sentimento de amor relaciona-se aos elementos família, namorado(a) e/ou amigos (apenas uma citação). Quando relacionado à família, o amor comparece como algo imprescindível da relação parental; recebido e ofertado pelo jovem, é fonte da sua gratidão pelos pais. Ao projetar esse sentimento no futuro, a família citada é a construída na vida adulta (muitas vezes com o(a) namorado(a) citado(a) como presente na rotina). $\mathrm{O}$ amor, aqui, é mobilizado como um aspecto da relação familiar com vistas à felicidade.

“Q3 - Deus: Pra mim é tudo, sem ele nós não somos nada. Família: As pessoas que eu mais amo nessa vida. Futebol: esporte favorito, desde que nasci o futebol faz parte da minha vida."/ "Q4 - [...] a minha família se tornou importante pra mim quando eu vi que eles sempre me apoiaram e sempre me deram todo o amor possível [...]"/ "Q8 - Eu me imagino daqui a cinco anos em um bom emprego, com um bom salário, uma vida boa, e as pessoas que eu amo em minha volta. E a coisa mais importante seria eu estar feliz." (Sujeito 167, 16 anos, masculino, Ponta Grossa, PR)

"Q8 - Ter uma pessoa aо meu lado, que me ajude, que me aconselhe, que possa me amar."/ “Q9 - Muito feliz.” (Sujeito 137, 15 anos, feminino, Rio Claro, São Paulo)

Além do sentimento de amor, os sentimentos de felicidade e realização comparecem com grande força no modelo organizador 3. A felicidade não apenas é mobilizada como um sentimento, mas também como um valor, já que os sujeitos a apontam como algo que 
gostariam de ter em suas vidas futuras. Ela está intimamente atrelada aos vínculos e às relações interpessoais projetadas pelos jovens (familiares ou de amizade).

A realização ou satisfação pessoal mostram-se presentes quando os sujeitos indicam seus sonhos e desejos realizados no futuro, no tocante também das relações interpessoais.

“Q10 - Minha vida será ótima, e isso só depende de mim. Poderei estar fazendo um churrasco com meus irmãos neste mesmo horário daqui a 40 anos..."/ "Q11 - Feliz e realizada." (Sujeito 179, 15 anos, feminino, Curitiba, PR)

"Q10 - vou sem duvida estar velha, mas espero não precisar trabalhar, espero que minha família esteja comigo."/ "Q11 - não quero me sentir cansada nem acabada e sim feliz e satisfeita por realizar meu sonho."/ "Q12 - algo planejado para o seu futuro, o meu é ser alguém bem-sucedida e ser feliz em volta de pessoas que eu amo." (Sujeito 143, 15 anos, feminino, Rio Claro, SP)

Por fim, cabe indicar que o elemento Deus foi abstraído por uma parcela pequena do grupo de sujeitos que aplicaram o modelo organizador 3. Os jovens que abstraíram esse elemento como significativo, atribuíram poucos significados a ele, apenas quando relatam sobre o que é mais importante em seu cotidiano. Não há projeções futuras relacionadas a Deus, o que implica, conseguintemente, em concluirmos que esse valor não é central para esses sujeitos.

A seguir, representamos o núcleo central que configura o modelo organizador 3 , com seus elementos centrais, sentimentos, significados e relações/implicações. 
Tabela 7: Relações/implicações entre elementos centrais, sentimentos e seus significados no submodelo 3.

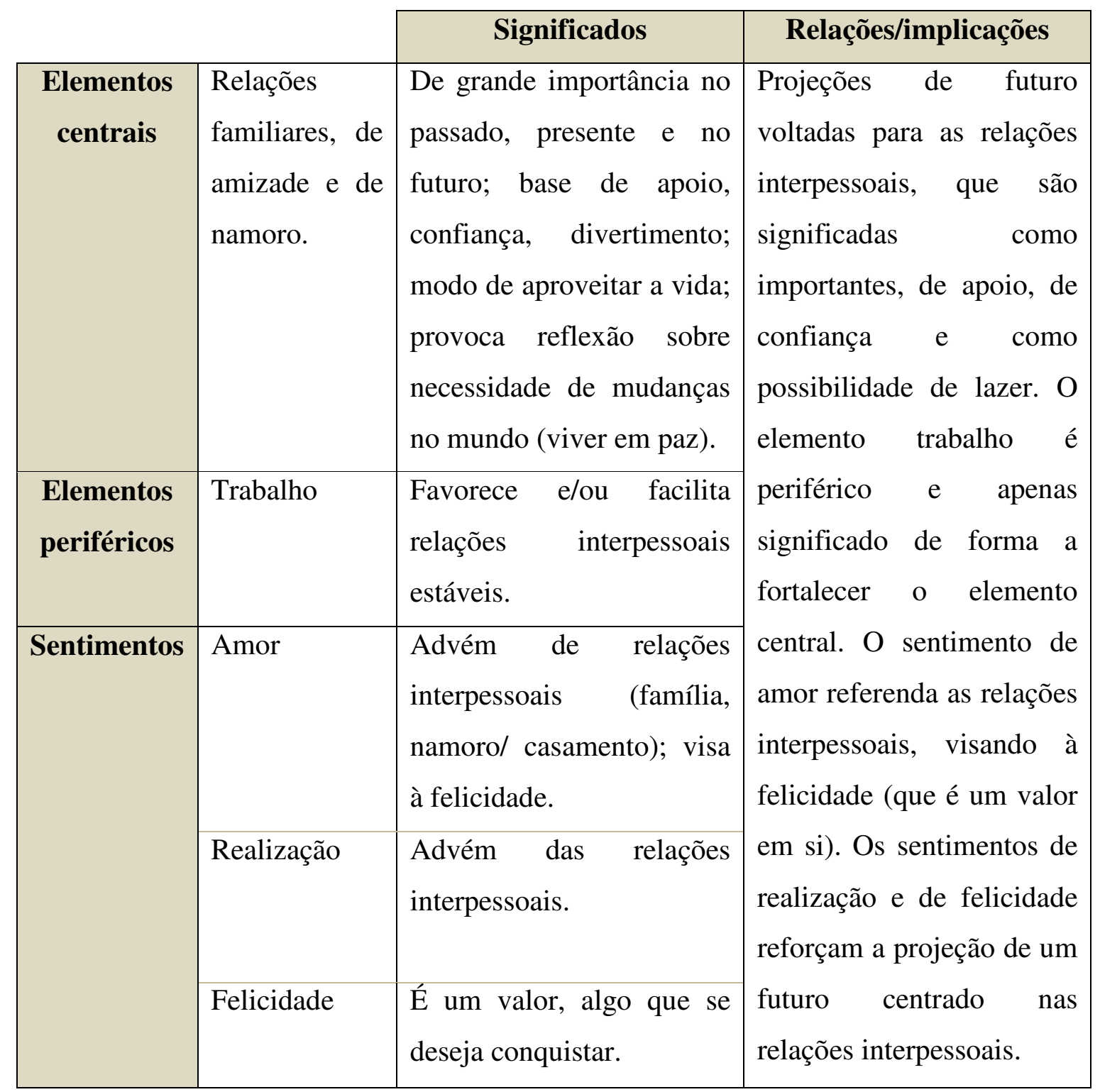

d) Modelo organizador 4 - Idealização do trabalho e da família

Número de sujeitos que aplicaram o modelo: 51

No modelo organizador 4, comparecem os valores de trabalho e família. Tais valores aparecem de forma coerente nas respostas, com uma melhor elaboração dos elementos abstraídos, os significados atribuídos pelos sujeitos e as implicações/relações entre eles. 
Muito embora dotados de uma maior complexidade, as respostas apresentam uma mesma dinâmica de pensamento, a partir da qual foi possível realizar o seu agrupamento.

É importante apontar que os elementos trabalho e família são significados como projeções de futuro pelos sujeitos do modelo 4, mas não envolvem as suas ações. Esses elementos comparecem de uma forma idealizada, como se a vida os levasse a eles, sem necessitar de comprometimento em suas atitudes presentes e futuras.

Deus foi um elemento foi abstraído por parte desses sujeitos, o que nos direcionou para a divisão desse modelo organizador em dois submodelos. No submodelo 4a, o trabalho e a família foram apresentados como elementos idealizados pelos sujeitos que almejam conquistá-los, mas não se referem a maneiras como fazê-lo. O submodelo $4 \mathrm{~b}$ traz as mesmas indicações a respeito do trabalho e da família, e também fortemente o elemento Deus, que direciona esses outros aspectos das projeções futuras desses jovens.

Os sentimentos de bem-estar, de realização e de felicidade estão presentes nas respostas dos sujeitos que aplicaram o modelo 4. Esses sentimentos estão intimamente relacionados com as projeções dos valores trabalho e família.

\section{Submodelo 4a}

\section{Número de sujeitos que aplicaram o submodelo: 46}

O submodelo 4a caracteriza-se por trazer dois elementos organizadores constantes nas respostas dos sujeitos: o trabalho e a família. É possível asseverar que esses elementos são valores para os jovens, visto que estão constantemente valorados de forma positiva ao longo dos protocolos.

Entendemos que o trabalho e a família foram apresentados pelos sujeitos que aplicaram o submodelo $4 \mathrm{a}$ como elementos muito importantes em suas vidas futuras. Contudo, tais elementos foram explicados de uma forma, em nossa concepção, "idealizada" e carente de maiores significações.

Ao dissertar sobre o trabalho, grande parte dos sujeitos desse grupo não cita a área em que deseja atuar, tampouco revela seus gostos e preferências acerca da profissão.

\section{“Q8 - Trabalhar na profissão na qual me formei para exercer e tentar o melhor para vencer} na vida, ou seja, ter uma boa condição de vida e talvez até constituir uma família."/ "Q10 - 
A vida de um pai de família bem-sucedido tentando dar aquilo que nunca teve aos filhos, é claro que educando-os apropriadamente para não desviarem do caminho certo, e lentamente caminhando para sua aposentadoria futura tendo como importantes a família, o trabalho e a própria saúde e bem-estar pessoal."/ "Q12 - [...] Meu projeto é: concluir meus estudos e me formar na profissão que escolher e exercê-la com o intuito de acumular capital e ter uma aposentadoria tranquila, além de constituir uma família." (Sujeito 74, 16 anos, masculino, Dourados, MS)

"Q8 - será importante estar cursando faculdade, ter uma boa condição de vida, e estar bem posicionada na vida amorosa."/ "Q10 - acho que será boa, estarei desenvolvendo minha profissão, ter uma família bem estruturada."/ "Q12 - [...] planejar um casamento, um bom emprego, uma família, filhos, etc. Exatamente este." (Sujeito 77, 16 anos, feminino, Goiânia, GO)

Alguns sujeitos (poucas ocorrências) chegam a apontar uma profissão, mas o fazem com pouca relevância no contexto geral dos protocolos. Alguns significados são atribuídos ao trabalho como sustento da família e a possibilidade de descanso e vida tranquila após os 40 anos. Tais acepções ocorrem nas respostas de uma parcela pequena dos sujeitos que aplicaram o submodelo 4a e, quando assim compareciam, não eram recorrentes em todo o questionário.

"Q8 - Acredito que as mesmas coisas que são importantes hoje, pois julgo a importância das coisas em minha vida visando não somente o agora."/ "Q9 - Provavelmente estarei frequentando a faculdade ainda (pois pretendo fazer medicina que é bastante extenso o estudo), estarei me sentindo uma pessoa realizada com os estudos e as demais coisas." "Q10 - Será importante a família que estará constituída por mim, meu trabalho, entre essas coisas."/ "Q12 - [...] Meu projeto de vida talvez não se difira muito do comum, pois quero terminar a escola, fazer um curso superior, me casar e ter filhos.” (Sujeito 88, 15 anos, feminino, Dourados, MS)

O elemento família também é abstraído e comparece fortemente às respostas emitidas pelos jovens que abstraíram o submodelo 4a. Assim como o trabalho, a família recebe poucos significados, os quais, como pudemos constatar, giram em torno de uma instituição idealizada. Além dessa idealização, alguns sujeitos conseguem ampliar um pouco mais a rede de significações sobre a família, chegando a indicar o sustento e a educação dos filhos. 
Cremos, contudo, que os sentidos atribuídos à família aproximam-se mais de uma visão idealizada do que em efetivas ações.

"Q8 - bom, daqui a cinco anos me imagino trabalhando, tendo minha casa mesmo que seja de aluguel no início, com minha família."/ "Q10 - um pouco mais corrida, estarei trabalhando ainda cuidando da minha casa e família, minha família e meu emprego."/ "Q12 - [...] eu pretendo acabar o Ensino Médio e entrar para uma faculdade de enfermagem, medicina, algo do tipo. Trabalhar no começo, alugar uma casa, mas em breve comprar a minha casa e claro construir minha família.” (Sujeito 133, 17 anos, feminino, São Paulo, SP)

“Q8 - Daqui a cinco anos, serão importantes para mim: minha família e amigos, minha faculdade, meu emprego (ou não) e a minha saúde e felicidade."/ "Q10 - Quando eu tiver 40 anos, planejo ser uma profissional realizada, com um emprego garantido, uma família bem estruturada: com meus filhos estudando e me dando muito orgulho e um marido atencioso. Como sempre o mais importante será a família e amigos e minha felicidade e saúde." (Sujeito 186, 15 anos, feminino, Curitiba, PR)

Nota-se que tais valores, trabalho e família, são fortes para os sujeitos, mas não contam com o seu envolvimento e ações no cotidiano. A rotina é descrita pelos jovens sem menção a planos futuros, sinalizando uma falta de envolvimento em seus projetos de vida.

"Q1 - vou pra escola de manhã, depois de tarde trabalho das duas às sete e assisto novela. Me sinto muito bem na escola, pois eu vejo meus amigos, brinco e aprendo. E na hora de trabalhar eu gosto, pois eu ganho meu dinheiro e compro as minhas coisas, sem depender dos meus pais pra comprarem. E também entro na internet para conversar com meus amigos e ver as notícias.” (Sujeito 141, 15 anos, feminino, Rio Claro, SP)

"Q1 - Sou uma pessoa muito alegre, divertida, gosto de fazer os outros sorrirem, mesmo quando eu mesma não quero sorrir. Sou ativa e comunicativa, me dou bem com todos que convivo. Às vezes me sinto sozinha, mas logo passa, pois sei que tenho minha família e pessoas que eu posso contar sempre.” (Sujeito 81, 16 anos, feminino, Goiânia, GO)

Quando fazem referência ao estudo em suas rotinas como algo importante em suas vidas, uma parcela dos sujeitos que aplicaram o submodelo 4 a (por volta de metade dessa 
amostra) o apontam como um meio para o emprego, como se devessem segui-lo para uma titulação esperada pelo mundo do trabalho. Apenas um sujeito aponta a necessidade de conhecer para ampliar seus horizontes.

“Q3 - [...] Creio que meus estudos me tornarão 'alguém', me levando a um trabalho que me satisfaça mais em outros aspectos do que somente no financeiro." (Sujeito 88, 15 anos, feminino, Dourados, MS)

Dessa forma, o trabalho e a família não surgem como uma realização pessoal, mas como um "futuro comum", que, uma vez que não é refletido/projetado pelos sujeitos em seu cotidiano, emerge como uma perspectiva aceitável, como um "curso da vida".

"Q12 - Planejar seu futuro, sua vida. Não penso muito em detalhes de como será minha vida, quero fazer uma faculdade, viajar, e depois deixar que a vida me ajude." (Sujeito 147, 15 anos, feminino, Rio Claro, SP)

"Q11 - de saúde, acho que bem, mas conforme a idade poderei ter problemas, mas nada tão sério. Também acho que vivendo com muita "normalidade" como as pessoas de bem com a vida vivem.” (Sujeito 132, 15 anos, feminino, São Paulo)

No submodelo 4a, alguns sujeitos (poucas ocorrências) não apresentam sentimentos ou o fazem de forma negativa, mesmo tendo valorado positivamente o trabalho e a família.

"Q8 - Daqui a cinco anos eu tenho certeza que eu vou dar muito valor principalmente a minha família e a um bom emprego."/ "Q9 - mais responsável e até mais chato."/ "Q10 um bom emprego, não com tanta disposição pra novas aventuras."/ "Q11 - cansado, indisposto e com sabedoria que vou adquirir com o decorrer dos tempos." (Sujeito 108, 15 anos, masculino, Rio Claro, SP)

Grande parte dos jovens que aplicaram esse submodelo, em contrapartida, mobilizou sentimentos como realização, bem-estar e felicidade. Esses sentimentos são apresentados como muito fortes para alguns deles, enquanto causam dúvidas para outros. De qualquer forma, estão relacionados à idealização que os sujeitos fazem do futuro em relação ao trabalho e à família. 
" $Q 9$ - se minha vida continuar do jeito que está e melhorar um pouco mais, acredito que serei muito feliz." "Q11 - Feliz da vida por ter chegado lá, pois no mundo em que vivemos sempre temos que agradecer a Deus por mais um dia, principalmente a cada ano que passa." (Sujeito 51, 16 anos, feminino, Fortaleza, CE)

"Q9 - Me sentirei uma pessoa realizada, pois plantarei para colher no meu futuro."/ "Q10 Com certeza, serei uma mulher de muita experiência. Minha vida será muito feliz. [...]"/ "Q11 - Me sentirei muito realizada, pois com certeza os meus objetivos alcançarei e desfrutarei do melhor.” (Sujeito 60, 17 anos, feminino, Sobral, CE)

Observando com mais atenção o sentimento de felicidade, percebe-se que não é apresentado com tanta força para os sujeitos e que, nesse submodelo, não consiste em um valor. A felicidade é percebida, por grande maioria dos jovens, como um dos aspectos resultantes do trabalho e da família. Ela não é valorada, em si, como um projeto futuro, mas como consequência das suas ações.

"Q11 - Me sentiria uma pessoa nova, que tem muita vida pela frente, pois não pretendo morrer cedo. Me sentiria feliz por tudo o que fiz até chegar a esta idade, e mais feliz ainda pelas coisas que vou fazer ainda.” (Sujeito 16, 15 anos, feminino, Macapá, AP)

"Q11 - O melhor homem do mundo, uma sensação de extrema felicidade e bem-estar pessoal uma vez que tudo deu como planejado.” (Sujeito 74, 16 anos, masculino, Dourados, MS)

Outro sentimento que se destaca nas respostas emitidas pelos sujeitos que aplicaram o submodelo 4a é a confiança em seu projeto de vida, bem como certa determinação para realizá-lo. Alguns chegam a apontar que têm obrigação de executá-lo. Isso nos parece curioso, já que não mobilizam ações ao longo do protocolo visando ao futuro. É uma confiança que não se "sustenta", talvez pelo aspecto de idealização presente nessas respostas.

"Q13 - Estou confiante, pois acho que tenho capacidade de realizar todos os meus objetivos, tenho certeza de que vou conseguir realizá-los.” (Sujeito 13, 16 anos, feminino, Macapá, AP) 
“Q13 - Sinto que estou caminhando bem e que vou realizar esse projeto.” (Sujeito 82, 17 anos, feminino, Goiânia, GO)

Chama a atenção no submodelo $4 \mathrm{a}$ o fato de que, quando questionados sobre o que desejam que mude no mundo, os sujeitos desse grupo apresentam respostas sem coerência, fazendo referência a aspectos como poluição, desmatamento, corrupção, falta de união entre as pessoas, entre tantos outros. Os jovens não se colocaram como agentes para a mudança sugestionada, apenas indicam ora ações pontuais e individuais, ora a necessidade de ações mais amplas, de toda a sociedade.

“Q6 - nossos governantes, pois eles são grandes responsáveis para a melhoria do mundo que posso fazer? E todos podem escolher os melhores governantes para o nosso mundo."/ "Q7 que poderia melhorar em tudo principalmente na saúde, pois vemos por aí pessoas morrendo em corredores de hospitais sem assistência médica." (Sujeito 22, 18 anos, masculino, Fortaleza, CE)

Parte dos jovens desse submodelo (cerca de metade dos protocolos desse grupo) mobilizou o elemento Deus no início do questionário. Ao relatar sobre esse elemento, os sujeitos lançam mão do senso comum e de preceitos religiosos que nos parecem algo que vem "de fora para dentro", sem ser assimilado por eles. Deus comparece, principalmente, quando discorrem sobre o seu cotidiano e o que é mais importante em seu dia a dia. Tal elemento se dissipa nas demais respostas dos sujeitos, essencialmente as que trazem argumentações sobre o futuro.

“Q2 - $1^{o}$ Deus $2^{o}$ família $3^{o}$ estudos."/ "Q3 - me sinto ótima, pois preciso de todas elas, para ser feliz e me dar bem na vida."/ "Q4 - sempre foi importante, porque sem Deus eu não existiria [...]”. (Sujeito 144, 17 anos, feminino, Rio Claro, SP)

"Q2 - 1. um buscar a Deus 2. Minha família 3 - jogar bola.”/ "Q3 - muito bem!! Porque apesar de eu não ser um menino merecedor eu reconheço que tem pessoas que me amam." (Sujeito 91, 18 anos, masculino, São Paulo, SP)

Lançamos mão da tabela a seguir para tentar explicitar a organização do núcleo central do pensamento dos jovens diante de seus projetos de vida no submodelo 4a. 
Tabela 8: Relações/implicações entre elementos centrais, sentimentos e seus significados no submodelo 4a.

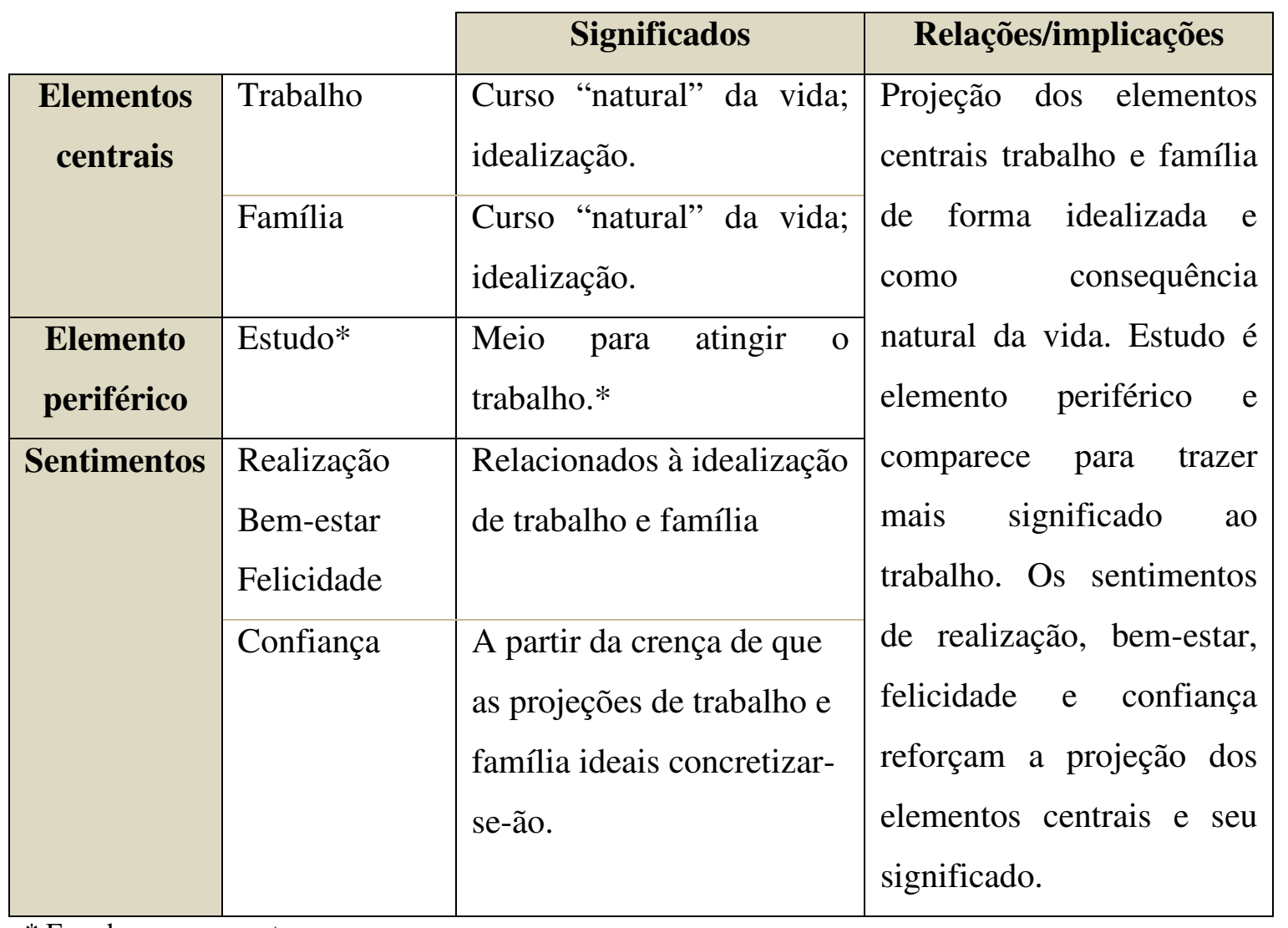

* Em algumas respostas.

\section{Submodelo 4b}

\section{Número de sujeitos que aplicaram o submodelo: 5}

O submodelo $4 \mathrm{~b}$ traz elementos organizadores centrais semelhantes ao submodelo $4 \mathrm{a}$ : o trabalho e a família. Contudo, tais valores, apesar de serem organizadores do pensamento desses sujeitos, também são organizados por um valor hierarquicamente superior: Deus.

Assim, vemos que o valor Deus é mais forte e coerente no discurso dos jovens desse grupo do que o trabalho e a família, os quais recebem poucos significados. Desde o início do questionário, os sujeitos apontam Deus como um aspecto muito importante em suas rotinas e projeções de futuro. O trabalho e a família comparecem a esse submodelo organizador por meio desse valor.

Deus é significado pelos sujeitos por preceitos religiosos aos quais é perceptível que estão submetidos. Além do mais, estabelece-se uma relação próxima entre a divindade e a 
religião, em que eles se colocam como atuantes. É clara certa posição de dever em relação a Deus: é necessário "segui-lo", por uma imposição social ou da família. A prática da religião é extremamente valorada por esses jovens, como uma atividade diferenciada em seus cotidianos, em que sentem prazer. Parece-nos que a vida desses jovens gira em torno da igreja e dos pensamentos relacionados à religião.

"Q1 - Me sinto contente e alegre por mais um dia de vida que o senhor Jesus me deu, e por uma família linda que eu tenho incluindo meu namorado, vou na igreja umas 4 vezes por semana e sou uma menina muito feliz. Gosto de sair, e me divertir com os amigos da igreja e estar ao lado das pessoas que gostam de mim, meus pais me amam muito e querem o melhor para mim por isso eles conversam e ajudam bastante. Desejo pra todo mundo serem pessoas humildes e que valorizem o que têm, e a procurar uma igreja para visitarem porque é muito importante em nossa vida hoje aceitar Jesus como nosso único e suficiente salvador. Agradeço por estar fazendo essa pesquisa.” (Sujeito 148, 15 anos, feminino, Rio Claro, SP)

Significando a família como uma instituição idealizada, tal como ocorreu no submodelo $4 \mathrm{a}$, os sujeitos apontam como importante ter um relacionamento estável e com filhos. Alguns jovens chegam a indicar como relevante a educação e formação dos filhos. Sobre o trabalho, a força do elemento Deus se sobressai, levando esses sujeitos a apontar que, no futuro, se dedicarão ao trabalho na igreja. $\mathrm{O}$ trabalho sugerido por eles diz respeito a ser missionário, "pregar a palavra do Senhor", ser cantor(a) na igreja, ou seja, funções de divulgação e enaltecimento da divindade em que acreditam. Não percebemos, nos presentes protocolos, uma mobilização para ajudar aos outros por meio da religião.

Alguns sujeitos chegam a insinuar certa vontade de seguir uma profissão ou de ter um trabalho paralelo ao da igreja. Entretanto, esse caminho está repleto de dúvidas e não recebe muitos significados ao longo das respostas.

"Q8 - Imagino que eu estarei casada e com certeza o que vai ser importante para mim vai ser minha família na presença de Deus."/ "Q10 - Estarei velha já, creio q será mais tranquila minha vida. Estarei trabalhando na obra de Deus. Agradar ao Senhor ainda."/ “Q12 - Um plano de vida. Penso em trabalhar, fazer faculdade, me formar e ter meu próprio negócio, e tudo para a Glória de Deus.” (Sujeito 84, 17 anos, feminino, Dourados, MS) 
"Q8 - Daqui a cinco anos, estarei provavelmente nos últimos anos da faculdade, falando outro idioma, estarei noiva, e pregando o evangelho.[...]"/ "Q10 - Com quarenta anos, já me imagino casada com dois filhos, vivendo em uma comunidade de aliança, realizada profissionalmente com uma vida estável e tranquila. Estarei sendo mãe, esposa, trabalhadora, e com certeza, uma grande missionária Ruah.[...]"/ "Q12 - [...] Meu mapa ainda não está pronto, toda manhã muda algo, mas meus pontos principais já estão definidos: RUAH, VIDA PESSOAL (FAMÍLIA), PROFISSIONAL.” (Sujeito 85, 16 anos, Feminino, Dourados, MS)

Parece-nos que os sujeitos que aplicaram o submodelo 4 b não têm clareza das ações que deveriam tomar para envolver-se em seus projetos de vida. Ao relatar sobre suas rotinas, esses jovens trazem, em sua grande maioria, uma descrição de vida “comum”, sem pontuar a respeito do que fazem visando ao futuro.

"Q1 - meu dia é bem comprido eu estudo, fico à tarde escutando musica, estudando, aí trabalho, por enquanto para comprar roupas porque eu amo roupas... tenho um dia muito feliz, tenho um namorado lindo que me ama, sou muito divertida, tenho problemas, mas temos que seguir adiante mesmo com esses obstáculos, tendo fé em Deus, seguindo uma vida correta ou tentando ninguém é perfeito, tenho irmãos lindos, uma vó que eu amo muito, eu acho que é isso. Estou me preparando para me mudar para Curitiba, então são essas coisas novas, mas tenho que enfrentar...” (Sujeito 190, 16 anos, feminino, Ponta Grossa, PR)

“Q1 - tenho 16 anos, estou no Ensino Médio, estudo pela manhã e faço estágio à tarde. Meu dia é bastante corrido, só nos finais de semana que é mais tranquilo, quando vou à igreja, o que gosto muito e faz muito bem pra minha vida." (Sujeito 197, 16 anos, feminino, Ponta Grossa, PR)

Quando indagados sobre o que gostariam que fosse diferente no mundo, todos os jovens desse submodelo indicam que as pessoas deveriam mudar suas atitudes e crenças. Todos se posicionam como atuantes nessa mudança, afirmando que fazem a sua parte "pregando o evangelho", isto é, divulgando os preceitos religiosos em que creem. Eles relatam sentimentos de bem-estar durante a prática da atividade religiosa, muito embora reconheçam que não é uma tarefa fácil e desprovida de obstáculos. 
"Q6 - eu acho que as pessoas deviam mudar suas atitudes. Hoje em dia as pessoas são muito egoístas, orgulhosas. Eu acho que toda maldade que tem no mundo é por isso, tentaria colocar juízo na cabeça desse povo, ensinando a eles a verdade e a vida. Jesus é a única salvação."/ "Q7 - melhor porque saberia que tanta maldade não existiria mais, eu sei que isso é impossível o mal ainda anda por aí, mas se a maioria fosse bom teríamos um mundo melhor.” (Sujeito 190, 16 anos, feminino, Ponta Grossa, PR)

"Q6 - Gostaria que houvesse mais respeito com o próximo, pois o respeito acarreta muitas coisas, como a admiração que mais tarde se torna amor. Para concretizar essa mudança, faço uma ação simples, que não é muito aceita, mas creio que um dia todos irão concordar. Prego sobre um Deus de amor, que ama, acima dos erros, que já nos salvou, que nos envia força, que nos leva à vida em comunidade. Creio que levando este Deus, as pessoas passarão a aprender a lidar com a vida do próximo. Se amar, e respeitando mais."/ "Q7 - Me sinto segura em relação ao que quero, da mudança que quero levar ao mundo, mas me sinto insegura quando penso sobre como as pessoas irão lidar com o meu pensamento." (Sujeito 85, 16 anos, feminino, Dourados, MS)

No submodelo 4b, comparecem os sentimentos de realização, bem-estar e felicidade, relacionados ao futuro e à conquista dos objetivos de trabalhar na igreja (e também em outro emprego, como apontam alguns) e ter uma família. Não houve ocorrência da felicidade como valor, desprovida das significações dos valores de trabalho e família.

"Q9 - Se eu conseguir realizar tudo que eu quero, acho que estarei feliz."/ "Q11 - Se tiver conseguido fazer tudo que planejei me sentirei uma pessoa feliz e realizada." (Sujeito 197, 16 anos, feminino, Ponta Grossa, PR)

"Q9 - Realizada no que faço, como se sinto hoje!”/ "Q11 - Literalmente realizada, pois tudo aquilo que eu busco, consegui encontrar aos meus 40 anos.” (Sujeito 85, 16 anos, Feminino, Dourados, MS)

Grande parte dos sujeitos que aplicou esse submodelo relata confiança em realizar seus projetos de vida, assim como ocorreu no submodelo 4a, mesmo não apresentando ações que os levem a concretizá-los. 
"Q13 - Objetiva, não quero desistir de nenhum mesmo que minha vida talvez não seja muito boa, mas lutar pelos meus direitos eu vou e sempre confiando em Deus para tudo." (Sujeito 190, 16 anos, feminino, Ponta Grossa, PR)

Abaixo, apresentamos os elementos centrais, os sentimentos, os significados a eles atribuídos e as relações/implicações que organizam o submodelo $4 \mathrm{~b}$.

Tabela 9: Relações/implicações entre elementos centrais, sentimentos e seus significados no submodelo 4b.

\begin{tabular}{|c|c|c|c|}
\hline & & Significados & Relações/implicações \\
\hline \multirow[t]{4}{*}{$\begin{array}{l}\text { Elementos } \\
\text { centrais }\end{array}$} & Deus & $\begin{array}{l}\text { Importante; religião a ser } \\
\text { seguida. }\end{array}$ & \multirow{5}{*}{$\begin{array}{l}\text { Projeção de um futuro } \\
\text { voltada para a religião e } \\
\text { para o trabalho na igreja. } \\
\text { Família é significada } \\
\text { como possibilidade de } \\
\text { relacionamento estável e } \\
\text { com filhos. Sentimentos } \\
\text { de realização, bem-estar, } \\
\text { felicidade e confiança } \\
\text { reforçam projeção } \\
\text { relacionada à religião, ao } \\
\text { trabalho religioso e à } \\
\text { família. }\end{array}$} \\
\hline & $\begin{array}{l}\text { Trabalho } \\
\text { religioso }\end{array}$ & $\begin{array}{l}\text { Dedicação ao trabalho na } \\
\text { igreja no futuro. }\end{array}$ & \\
\hline & Trabalho* & $\begin{array}{l}\text { Incerteza sobre futuro } \\
\text { profissional*. }\end{array}$ & \\
\hline & Família & $\begin{array}{l}\text { Relacionamento estável, } \\
\text { com filhos. }\end{array}$ & \\
\hline Sentimentos & $\begin{array}{l}\text { Realização } \\
\text { Bem-estar } \\
\text { Felicidade } \\
\text { Confiança }\end{array}$ & $\begin{array}{l}\text { Decorrente do trabalho a } \\
\text { ser desenvolvido na igreja } \\
\text { e da família a ser } \\
\text { constituída. }\end{array}$ & \\
\hline
\end{tabular}

* Algumas respostas.

e) Modelo organizador 5 - Trabalho e família

Número de sujeitos que aplicaram o modelo: 26

Assim como o modelo anterior, o modelo 5 envolve a abstração de dois elementos organizadores centrais: o trabalho e a família. Contudo, contrariamente ao modelo 4, tem-se, no modelo 5, uma maior elaboração por parte dos jovens, o que os leva a tecer considerações 
acerca de suas ações e a obter uma maior clareza a respeito de suas projeções futuras que abarcam tais elementos. Em vez de uma visão idealizada do trabalho e da família, esses sujeitos trazem indicações práticas e conscientes sobre formas de atingir seus objetivos em relação aos elementos destacados.

Parte dos sujeitos que aplicaram o modelo 5 trouxeram um outro elemento fortemente abstraído: o fato de serem mães. Isso nos levou a dividir o modelo 5 em dois submodelos, de forma a abranger a diversidade encontrada, não minimizando aspectos que, muito embora tivessem sido pouco aplicados, mostram-se de suma importância para os sujeitos.

O submodelo 5a consiste em uma compreensão mais elaborada do trabalho, apontando formas de conquistá-lo e com uma maior ciência da área em que se deseja atuar. Ademais, o trabalho é significado, nesse submodelo, como uma forma de ajudar a família por meio de uma vida estável financeiramente. Já a família é significada como necessitada de cuidados e da responsabilidade dos sujeitos. O submodelo $5 \mathrm{~b}$ é uma versão próxima do submodelo $5 \mathrm{a}$, mas que traz também outro elemento organizador central: o fato de ser mãe. Tal elemento aprofunda as questões de responsabilidade para com os filhos.

Em relação aos sentimentos, tem-se a presença muito clara de bem-estar, felicidade e realização por poder atingir, por meio do trabalho, realização pessoal e das pessoas com que se conviverá e com que tecem laços afetivos.

\section{Submodelo 5a}

Número de sujeitos que aplicaram o submodelo: 14

Os jovens cujas respostas foram agrupadas no submodelo 5a trouxeram como elementos organizadores centrais o trabalho e a família. Norteando grande parte das respostas desses sujeitos, esses elementos receberam maior carga de significados, trazendo mais complexidade nas implicações e relações estabelecidas por eles.

É fundamental destacar que, nesse submodelo, ocorre maior coerência em grande parte dos protocolos, com a sinalização dos mesmos elementos do princípio do questionário ao seu fim. Isso demonstra a força que os elementos trabalho e família adquiriram para os jovens desse grupo.

No submodelo 5a, o trabalho é significado como muito importante e uma meta real para os sujeitos. Grande parte deles possui clareza da área em que pretendem atuar; outra 
parcela não indica sua futura profissão, mas estabelece, assim como os outros, as etapas para exercê-la: terminar o Ensino Médio, cursar uma faculdade, estudar para adquirir conhecimentos para a área, etc.

"Q3 - [...] A meu FUTURO estou bastante preocupada, pois desejo fazer medicina, quero ser pediatra gosto muito de crianças ;) e uma faculdade dessas é muito cara, então quero me esforçar ao máximo para conseguir passar em uma Federal. Por isso minha preocupação. [...]"/ "Q4 - [...] meu futuro eu comecei a achar importante quando comecei a 8 a série e vi que as coisas não são tão simples como a gente acha que são quando somos crianças."/ "Q5 - assim sabe só queria ter mais condições financeiras para poder estudar numa escola melhor para pode me preparar para conseguir passar na faculdade que tanto desejo."/ "Q8 - imagino que eu esteja na faculdade de medicina fazendo as coisas que eu gosto, estando bem financeiramente; importante vai ser eu concluir minha faculdade." (Sujeito 145, 15 anos, feminino, Rio Claro, SP)

A coerência apresentada nas respostas do submodelo 5a pode ser percebida quando, explicitamente, os sujeitos apontam seu projeto de vida e também no envolvimento e nas ações relatadas nas questões sobre suas rotinas.

"Q3 - Sinto que estou no caminho certo, estudando e futuramente fazendo a faculdade que desejo para chegar à profissão que eu quero."/ "Q8 - Eu acho que estarei cursando uma faculdade e trabalhando para ajudar em casa e pagar a faculdade, na minha opinião os estudos serão muito importante para conseguir um bom emprego."/ "Q12 - [...] meu projeto é no futuro ingressar na carreira de engenharia civil." (Sujeito 163, 16 anos, masculino, Curitiba, PR)

O trabalho também ganha outro significado que é o de, por meio do dinheiro recebido, ajudar ou sustentar a família. Isso quer dizer que a família é significada pelos sujeitos com mediação do elemento trabalho. Na maior parte das respostas desse grupo, encontramos a mobilização do sujeito em retribuir à sua família tudo o que fizeram para educá-lo, ou seja, comparece o sentimento de gratidão. Outro significado também presente é o de perceber as dificuldades financeiras da família e desejar mudar esse quadro tanto para si quanto para os pais e demais familiares. 
“Q4 - Desde os meus 4 anos, quando decidi ser médico e aos 8 anos conheci um lado sofrido na minha família e desde aí tenho esse objetivo de querer ser rico para poder tirá-los da miséria e assim tem sido tão importante para mim trazer uma boa qualidade de vida para meus avós, minha mãe e meu irmão. [...]"/ "Q8 - Bom daqui a cinco anos estarei fazendo faculdade de medicina, um momento muito bom e com certeza minha vida será mais calma, pois além de não precisar trabalhar mais eu estarei fazendo o que gosto, usarei a minha poupança do meu dinheiro que tenho guardado pra isso pra me manter na faculdade e, ao sair de lá, é quase certeza que terei um emprego na certa."/ "Q10 - Então com 40 anos já terei minha vida realizada, meu emprego, minha casa, minha família de boa qualidade de vida e nesse ano estarei me casando, pois só com 40 eu vou me casar e isso, de certa forma, será importante para mim.” (Sujeito 67, 16 anos, masculino, Goiânia, GO)

Além de visar a uma retribuição, por meio de ajuda financeira aos familiares que cuidaram dos jovens em sua infância, encontramos, em grande parte das respostas emitidas pelos sujeitos que aplicaram o submodelo 5a, a vontade de constituir família e garantir uma vida confortável e estável a ela, assim como poder educar apropriadamente os filhos. Atribuímos a esses elementos o valor de responsabilidade como central para esses jovens.

“Q8 - em primeiro lugar seria importante minha família 'casamento', formar uma família e ainda continuar estudando para poder ter um ótimo emprego e poder sustentá-la e dar tudo para meus filhos o que meus pais não puderam me dar."/ "Q10 - seria boa, estaria trabalhando ainda, sustentando uma família e com certeza iria ter meu próprio negócio, pois tenho sonho de abrir minha própria empresa futuramente." "Q12 - sonhos, ter minha própria empresa, fazer uma faculdade, ter uma família, e dar um pouco mais de conforto aos meus pais mais tarde.” (Sujeito 174, 17 anos, masculino, Ponta Grossa, PR)

“Q3 - [...] No futuro, penso no que vai ser importante para mim e para a minha família, me formar, trabalhar, formar uma família, em relação ao trabalho não gostaria de ganhar muito, mas sim uma quantia razoável em que em cima dela dê para conseguir comprar minhas coisas e também para minha família e etc.[...]"/ "Q10 - Já com 40 anos me imagino trabalhando com a minha casa, meu carro e o mais importante minha família. Imagino um mundo em paz com escolas para todos, comida para todos. Me imagino podendo ir nas reuniões de escola dos meus filhos, podendo acompanhar seu crescimento. Ser abraçado pela esposa e ouvir 'Feliz dia dos pais, papai' isso seria muito importante, pois poderei ter uma 
maior autoridade para ajudar muitos e o mundo." (Sujeito 104, 15 anos, masculino, São Paulo, SP)

Os sentimentos apontados pelos jovens do submodelo 5a relacionam-se ao bem-estar, à realização, à satisfação e à felicidade. Tais sentimentos estão associados à concretização do projeto de vida dos sujeitos que é, por meio do trabalho, cuidar da família. Em muitos protocolos, apresenta-se, também, uma sensação de experiência, maturidade e responsabilidade diante da situação vivenciada.

“Q9 - Mais madura, certa do que estarei, espero não estar realizada, mas sentindo que estou no caminho certo para isso./ "Não tão velha, bonita, finalmente realizada, mas ainda tendo sonhos para realizar." (Sujeito 61, 16 anos, feminino, Sobral, CE)

“Q8 - Espero que eu esteja cursando minha faculdade de publicidade, que eu possa ajudar minha família que eu tenha me tornado uma pessoa de bem e mais madura. [...]"/ "Q9 Mais responsável, independente, madura."/ "Q11 - Feliz eu espero, mais experiente." (Sujeito 80, 16 anos, feminino, Goiânia, GO)

O orgulho e a gratidão são outros sentimentos que comparecem em algumas respostas desse grupo. Muito embora haja poucas ocorrências desses sentimentos, consideramos pertinente indicá-los na análise, tanto para dar vez à diversidade de pensamentos, como para ressaltar a dinâmica do pensamento desse submodelo, uma vez que, embora não sejam sentimentos explicitados por todos os sujeitos, é possível perceber que se aproximam das formas de pensar de grande parte deles.

"Q9 - Feliz, por estar onde estarei."/ “Q10 - Com certeza ainda serei um profissional, e já terei conquistado minha família, e isso será importante."/ "Q11 - Orgulhoso por ser o que serei, pois pretendo ser um excelente juiz.” (Sujeito 7, 16 anos, masculino, Macapá, AP)

"Q8 - Me vejo uma pessoa bem de vida, formada, com uma profissão e com orgulho de ter acreditado em mim e nos que me ajudaram, passando para os outros e aprendendo com eles, as experiências da vida." " $Q 9$ - Com muito orgulho de mim, por não ter desistido da vida por coisas menos importantes e muito agradecido por aqueles que acreditaram em mim." (Sujeito 32, 18 anos, masculino, Sobral, CE) 
O sentimento de felicidade refere-se mais a uma realização pessoal e não está fortemente mobilizado pelos sujeitos desse submodelo. Talvez o peso da responsabilidade futura não seja compatível com a sensação de uma felicidade "em si", o que discutiremos mais a frente. Nesses protocolos, não houve ocorrências da felicidade como um valor por si só, ou seja, quando os sujeitos valoram o fato de serem felizes.

“Q11 - Feliz, mas com muita coisa para fazer.” (Sujeito 103, 15 anos, masculino, São Paulo, SP)

"Q9 - Não sei... feliz, estudando morando em uma boa casa não sei direito como será."/ " $Q$ 11 - bem se tudo der certo serei feliz porque estarei bem de vida com uma bela família e pessoa bem-sucedida financeiramente." (Sujeito 69, 16 anos, masculino, Goiânia, GO)

Apesar de apresentarem coerência em seu discurso ao longo do questionário, quando indagados sobre o que gostariam que fosse diferente no mundo, os sujeitos trazem respostas que não se relacionam às problemáticas levantadas ao longo do protocolo. As respostas são díspares, relacionando-se à desigualdade social, ao preconceito, à violência, à poluição... Uma parte dos sujeitos se coloca como tomando uma ação individual para a realização do problema, enquanto outra parte aponta qual seria a resolução por outros.

"Q6 - A desigualdade. Faço com que isso não aconteça em diversos lugares que seria o caso: supermercado, praças, eventos e em vários outros locais."/ "Q7 - Me sinto com o dever cumprido e que estou no caminho certo." (Sujeito 39, 19 anos, masculino, Sobral, CE)

"Q6 - A educação. Mais investimentos!”/ "Q7 - Se houvesse essa mudança, com certeza muito feliz.” (Sujeito 4, 18 anos, masculino, Belém, PA)

Metade dos jovens que aplicaram o submodelo 5a citou o elemento Deus. Aqui, também se encontra uma indicação de Deus como um aspecto importante da vida dos sujeitos, que o significam a partir de preceitos religiosos provavelmente aprendidos em igrejas ou na família. Quando começam a dissertar sobre o futuro, a grande maioria dos sujeitos do submodelo 5a não retoma o elemento Deus em suas respostas. As poucas ocorrências que o trazem no futuro, também o fazem com certo senso comum. 
"Q2 - 1. Deus 2. Família 3. Amigos."/ "Q3 - Me sinto bem, cada dia que passa vejo as maravilhas que Deus pode me proporcionar mesmo eu sendo uma pecadora.[...]"/ "Q10 meus filhos, meu marido, meus pais e acima de tudo Deus sempre! [...]” (Sujeito 56, 17 anos, feminino, Sobral, CE)

Representamos, na tabela a seguir, o núcleo central que organiza os projetos de vida elaborados pelos jovens que aplicaram o submodelo 5a.

Tabela 10: Relações/implicações entre elementos centrais, sentimentos e seus significados no submodelo 5a.

\begin{tabular}{|c|c|c|c|}
\hline & & Significados & Relações/implicações \\
\hline \multirow[t]{2}{*}{$\begin{array}{c}\text { Elementos } \\
\text { centrais }\end{array}$} & Trabalho & $\begin{array}{l}\text { Meta real, com ações e } \\
\text { ciência de um percurso a } \\
\text { ser traçado; } \\
\text { responsabilidade para com } \\
\text { o sustento da família. }\end{array}$ & \multirow{5}{*}{$\begin{array}{l}\text { Projeção dos elementos } \\
\text { trabalho e família de } \\
\text { forma integrada, já que o } \\
\text { trabalho é significado } \\
\text { como uma meta real para } \\
\text { proporcionar cuidados } \\
\text { para com a família. } \\
\text { Sentimentos positivos } \\
\text { reforçam as projeções que } \\
\text { trazem os elementos } \\
\text { trabalho e família. }\end{array}$} \\
\hline & Família & $\begin{array}{l}\text { Retribuição à educação } \\
\text { recebida; desejo de } \\
\text { constituir família e } \\
\text { percepção de que ela } \\
\text { requer responsabilidade. }\end{array}$ & \\
\hline \multirow[t]{3}{*}{ Sentimentos } & $\begin{array}{l}\text { Bem-estar } \\
\text { Realização } \\
\text { Satisfação }\end{array}$ & $\begin{array}{l}\text { Decorrente do trabalho e } \\
\text { da família. }\end{array}$ & \\
\hline & Orgulho * & $\begin{array}{l}\text { Advém do sucesso obtido } \\
\text { na vida.* }\end{array}$ & \\
\hline & Gratidão* & $\begin{array}{l}\text { Advém da percepção } \\
\text { sobre os esforços da } \\
\text { família em educá-lo(a). }\end{array}$ & \\
\hline
\end{tabular}

* Em algumas respostas. 


\section{Submodelo 5b}

\section{Número de sujeitos que aplicaram o submodelo: 3}

Como nos submodelos anteriores, no submodelo $5 \mathrm{~b}$ os elementos organizadores centrais são o trabalho e a família. O aspecto que o diferencia é outro elemento importante que acaba por nortear todo o discurso elaborado ao longo das questões: o fato de serem mães. Essa forte experiência em suas vidas traz uma perspectiva muito parecida do que encontramos no submodelo 5a, mas com ainda mais ênfase na responsabilidade sobre a vida do(a) filho(a), tanto em termos financeiros quanto de educação e formação.

Com muita coerência entre as respostas, as jovens que aplicaram o submodelo $5 b$ relatam em seu cotidiano a preocupação que têm para com o futuro assim como suas ações, no sentido de que almejam conseguir superar a situação em que vivem para conseguir garantir uma boa vida a si mesmas e ao(à) filho(a). Talvez por vivenciarem uma situação difícil e de grandes mudanças em suas vidas, essas jovens tratam de suas vidas de uma forma mais realista e com maior consciência sobre elas. Chama a atenção a solidão em que vivem.

“Q1 - Bom, eu tenho 21 anos, no momento só estudo, tenho uma filha de 4 anos, ela fica em uma creche pública, fico em casa, às vezes trabalho de diarista, moro com minha mãe e irmão mais novo que eu. No meu dia a dia, me sinto um pouco só, porque meu irmão trabalha e minha mãe também, fico sozinha o dia todo. Fico em casa arrumando coisas para fazer, ou quando tenho trabalho e deveres do colégio daí ocupo um pouco a minha cabeça... Esse é o meu dia a dia." "Q2 - 1. Terminar meus estudos e fazer uma faculdade. 2. Ter um trabalho que dê para sustentar minha família. 3. Ter minha própria casa..."/ "Q3 - Me sinto às vezes incapaz de correr atrás dos meus objetivos, porque não trabalho, no momento quem sustenta a casa é minha mãe, por isso quero terminar os estudos e fazer uma faculdade, porque se não, nunca que vou poder ter um trabalho bom que dê para sustentar minha família, levar uma vida boa e um dia poder ter minha própria casa.” (Sujeito 180, 21 anos, feminino, Curitiba, PR)

"Q1 - [...] conheci um menino que é com quem vivo hoje e tenho uma filha. Eu vivo feliz, mas tem horas que parece que existe algo que me faz falta... Hoje em dia eu sou assim de casa para a escola, tenho amigos, não gosto de ficar grudada com amigos e também não sinto 
falta de sair... Amo ficar em casa, e sozinha."/ "Q2 - 1. Deus. 2. Minha filha. 3. Amar minha família e por ela ser amada." (Sujeito 181, 17 anos, feminino, Curitiba, PR)

Sobre o trabalho, essas jovens trazem um forte significado a respeito da necessidade de trabalhar para conseguir atingir seus objetivos de sustentar e educar seus(uas) filhos(as). $\mathrm{O}$ fato de trabalhar é o que importa, sem, necessariamente, haver uma área ou profissão de desejo. Em um único protocolo, encontramos questionamentos acerca da profissão. O que se mostrou um valor para elas é ter um bom emprego, que possa propiciar renda para uma vida confortável.

Estão claras para essas jovens as etapas que deverão conquistar para chegar ao mercado de trabalho. Elas apontam suas ações e também uma maior consciência sobre como podem alcançar seus sonhos.

A despeito de trazerem o elemento trabalho com força, percebe-se que ele é um meio para chegar à família, ou melhor, ao(à) filho(a), além de ser uma conquista e motivo de orgulho para essas jovens pela superação de seu status quo.

“Q8 - Bom daqui a cinco anos espero ter minha casa própria, minha faculdade quase concluída, com minha filha e meu marido mais unidos, o que vai ser importante é eu poder dizer que eu consegui chegar lá e provar às pessoas ao meu redor que eu sou capaz de fazer tudo isso."/ "Q10 - Imagino uma vida confortável, cuidando dos meus filhos e netos acho e ajudando cada um deles a se realizarem igual eu, ver que consegui prosseguir, me criar, me formar e ver minha filha criada com uma boa formação e com filho, acho. E isso vai me deixar irradiante."/ "Q12 - [...] Meu projeto de vida é me formar em medicina ou pedagogia, ter minha casa própria, dar uma vida boa e confortável e um futuro educacional excelente pra minha filha. Esse é o meu projeto." (Sujeito 182, 18 anos, feminino, Curitiba, PR)

A família valorada por essas jovens concerne aos(às) seus(uas) filhos(as) e, ao máximo, ao companheiro ou a um possível relacionamento. Nas projeções, a figura do(a) filho(a) é recorrente e aparece com muita força, trazendo um ser que precisa de cuidados e que é, ao mesmo tempo, fonte de realização para essas mães.

“Q8 - Daqui a cinco anos quero estar na minha própria casa, com um bom emprego, pois será importante pra minha filha ter um futuro garantido."/ "Q10 - Eu acho que estarei bem num bom emprego ou aposentada já, com o futuro da minha filha garantido, ela podendo 
fazer uma faculdade, levando uma vida boa, não sei mas poderia ter mais filhos, me casar novamente e ter netos. O mais importante para mim é isso, entrar num bom emprego e poder ter uma vida boa, pra quando chegar o futuro, não precisar ficar quebrando a cabeça."/ "Q12 - [...] Terminar meus estudos, fazer uma faculdade e trabalhar na área que pretendo, $e$ dar para minha filha um futuro melhor." (Sujeito 180, 21 anos, feminino, Curitiba, PR)

Os sentimentos presentes nas respostas das jovens que aplicaram o submodelo $5 \mathrm{~b}$ ao projetar seus futuros são de bem-estar, realização e felicidade. Tais sentimentos se explicitam na referência ao sonho de criar bem o(a) filho(a) e chegar a uma vida estável e harmoniosa. A felicidade não é tida como um valor em si.

"Q9 - uma pessoa feliz de ver as coisas que eu consegui, de ter estudado, mesmo com as dificuldades que me apareceram."/ "Q11 - Feliz, passar um filminho em minha cabeça, e eu poder dizer que aquilo valeu a pena." (Sujeito 181, 17 anos, feminino, Curitiba, PR)

"Q9 - uma pessoa renovada e quase realizada."/ "Q11 - super bem.” (Sujeito 182, 18 anos, feminino, Curitiba, PR)

São presentes também, nos protocolos, alguns sentimentos como insegurança e insatisfação com a vida presente e com as projeções para o futuro.

"Q13 - um pouco assustada, pois nada ocorreu como planejado, as coisas foram meio atropeladas (filha com 16 anos) e isso me ajudou em quase todas as questões só me prejudicou nos meus estudos e tenho medo de não conseguir dar parabéns para mim se eu vou conseguir concluir meu projeto." (Sujeito 182, 18 anos, feminino, Curitiba, PR)

Mesmo apresentando muita coerência em suas respostas, quando indagadas sobre o que gostariam que fosse diferente no mundo, as jovens desse grupo trouxeram outros assuntos diversos da problemática vivenciada por elas ou não responderam. As ações para realizar a mudança ou são indicadas como aspectos individuais ou não são apresentadas.

“Q6 - A desigualdade, eu não posso mudar o mundo, mas posso fazer a minha vez, tratando todos de igual para igual e melhor ainda, quando aceitam eu falo que Deus quer que seja assim, mas infelizmente muitos o deixaram de lado."/ "Q7 - Eu me sinto uma pessoa um 
pouco mais correta, ao saber que o que eu faço me deixa bem comigo mesma." (Sujeito 181, 17 anos, feminino, Curitiba, PR)

“Q6 - muitas coisas.”/ "Q7 - não houve.” (Sujeito 182, 18 anos, feminino, Curitiba, PR)

Uma das jovens que aplicaram o submodelo $5 \mathrm{~b}$ traz o elemento Deus em suas respostas. No entanto, tal elemento comparece apenas em poucos momentos, principalmente no início do questionário, e não parece nortear o seu pensamento. É significado por meio de preceitos religiosos de conhecimento da jovem.

"Q2 - 1. Deus 2. Minha filha 3. Amar minha família e por ela ser amada."/ "Q3 - Em relação a Deus, Ele que me deu a vida e é Ele quem a mantém, e me dá força para superar certos obstáculos que a vida nos mostra." (Sujeito 181, 17 anos, feminino, Curitiba, PR)

Na tabela, relacionaremos os elementos centrais, os sentimentos, os significados que lhes foram atribuídos e as relações/implicações que organizam esse submodelo.

Tabela 11: Relações/implicações entre elementos centrais, sentimentos e seus significados no submodelo 5b.

\begin{tabular}{|c|c|c|c|}
\hline & & Significados & Relações/implicações \\
\hline $\begin{array}{c}\text { Elementos } \\
\text { centrais }\end{array}$ & Filho (a) & $\begin{array}{l}\text { Mobiliza } \\
\text { promove o senso de } \\
\text { responsabilidade. } \\
\text { Garante de sustento e } \\
\text { educação para o filho; } \\
\text { motivo de orgulho; } \\
\text { garante estabilidade na } \\
\text { vida. }\end{array}$ & \multirow{2}{*}{$\begin{array}{l}\text { Projeção de futuro } \\
\text { centrada no elemento } \\
\text { "filho(a)", que se integra } \\
\text { ao elemento trabalho, que } \\
\text { é significado como } \\
\text { sustento e educação do } \\
\text { filho, além de superação e } \\
\text { oportunidade de uma vida } \\
\text { estável. Os sentimentos } \\
\text { positivos reforçam essa } \\
\text { projeção, enquanto os } \\
\text { negativos indicam } \\
\text { insegurança e insatisfação }\end{array}$} \\
\hline Sentimentos & $\begin{array}{l}\text { Bem-estar } \\
\text { Realização } \\
\text { Felicidade } \\
\text { Insegurança } \\
\text { Insatisfação }\end{array}$ & $\begin{array}{l}\text { Advém da maternidade e } \\
\text { da estabilidade da vida } \\
\text { futura. } \\
\text { Provocados pela gravidez } \\
\text { indesejada e seus }\end{array}$ & \\
\hline
\end{tabular}




\begin{tabular}{|l|l|l|}
\hline & desdobramentos. & pela gravidez inesperada. \\
\hline
\end{tabular}

\section{f) Modelo organizador 6 - Trabalho}

\section{Número de sujeitos que aplicaram o modelo: 22}

O modelo organizador 6 traz o trabalho como elemento organizador central. Para os jovens que aplicaram esse modelo, o trabalho é um valor forte, que se apresenta desde as questões sobre a rotina até as projeções sobre o futuro.

Recebendo diversas significações ao longo dos protocolos, o trabalho mostra-se como o que há de mais importante na vida desses sujeitos e acaba sobressaindo-se a outros valores que compareceram nos modelos anteriores, como a família e as relações interpessoais. Mesmo tendo abstraído um único elemento organizador central, os jovens desse grupo apresentam, em sua grande maioria, respostas elaboradas com grande carga de significações, ganhando em complexidade.

Pelas diferentes formas como o trabalho foi significado nesse modelo organizador, fizemos uma subdivisão, agrupando-o em dois submodelos organizadores. No submodelo 6a, o trabalho é significado como o aspecto mais importante da vida dos jovens e o que eles almejam alcançar, com muito esforço, no futuro. O submodelo $6 \mathrm{~b}$ corresponde a uma elaboração que coloca o trabalho como realização pessoal, isto é, sentir-se bem e realizado por fazer algo de que se gosta, além de trazê-lo como reconhecimento da sociedade pelos benefícios gerados pelas funções desempenhadas pelos sujeitos.

Os sentimentos destacados pelos sujeitos desse modelo organizador são os de bemestar, realização e felicidade, os quais ocorrem nas projeções de uma vida inserida no mundo do trabalho a partir dos significados que se atribuíram a esse elemento ao longo das respostas. Não há registros de respostas em que a felicidade é um valor, ou seja, algo que os sujeitos desejam, sem estar relacionada a outros aspectos destacados. 


\section{Submodelo 6a}

\section{Número de sujeitos que aplicaram o submodelo: 14}

No submodelo 6a, impera o trabalho como elemento organizador central do discurso dos sujeitos, que o apresentam de forma muito positiva e relevante ao longo de todo o questionário. Sendo um valor para os sujeitos, o trabalho comparece em grande parte dos relatos sobre os seus cotidianos, seja por já exercerem efetivamente um cargo ou um trabalho autônomo, seja por terem esse objetivo e já tomarem ações voltadas para esse fim.

"Q1 - Meu dia normalmente começa pela manhã quando estou na escola, de tarde faço curso de inglês e informática. Inglês dia de terça e quinta e informática dia de segunda, quarta e sexta e na maioria das vezes na parte da noite ajudo minha mãe, pois ela exerce a profissão de manicure e quando não estou ajudando ela estou estudando pra alguma prova, eu me sinto muito bem no meu dia-a-dia fazendo o que eu gosto."/ "Q2 - 1. Estudar pra ser alguém na vida 2. Fazer faculdade (fisioterapia) 3. Conseguir realizar todos os meus objetivos." (Sujeito 54, 16 anos, feminino, Sobral, CE)

O trabalho é significado como algo que depende do esforço pessoal dos jovens, que, no mais das vezes, reconhecem as etapas necessárias para consegui-lo e em que área desejam atuar. Um dos elementos abstraídos e intimamente relacionado com o trabalho é o estudo. Esse elemento é compreendido pelos sujeitos como um caminho para o mundo do trabalho e a possibilidade de ser bem-sucedido nessa trajetória.

A família e os amigos, quando comparecem nesses protocolos, recebem o significado de dar apoio e motivação para essa empreitada. Tais elementos não estão presentes nas projeções de futuro desses sujeitos.

"Q3 - A minha família é a coisa mais importante pra mim porque é ela que muitas vezes me traz motivação e vontade de me superar cada vez mais, os estudos vêm logo depois, pois é através dele que eu sei que vou conseguir realizar todos os meus sonhos. Os meus amigos também são uma coisa importante. Eles muitas vezes me dão apoio e me aconselham a não desistir do que realmente quero."/ "Q12 - [...] Tenho o objetivo de concluir o Ensino Médio, passar no vestibular, entrar na universidade, fazer o curso de odontologia e logo em seguida 
especialização e enfim o que mais quero é me formar." (Sujeito 53, 17 anos, feminino, Sobral, CE)

O trabalho também é significado por alguns sujeitos como meio para ter estabilidade financeira, independência e fazer o que se gosta. Assim, o trabalho é apresentado como uma realização pessoal, não só pela profissão exercida, mas também pelo fato de terem lutado ao longo da vida para conquistá-lo. Ao fim da vida, esses jovens esperam reconhecer todo o esforço que tiveram e se sentirem vencedores.

“Q2 - 1. Os estudos 2. O trabalho, 3. A dança!"/ "Q3 - eu quero estudar muito para poder fazer faculdade e poder ser alguém melhor ainda na vida! Gosto muito de trabalhar pois gosto de ser independente! A dança é quase tudo na vida, pois é onde eu passo o maior tempo me divertindo!"/ "Q8 - o meu trabalho! Pois quero seguir como prof. de dança!" (Sujeito 18, 16 anos, masculino, Fortaleza, CE)

"Q3 - uma profissional capacitada para o mercado de trabalho e fazendo o que eu gosto de fazer, e poder ser reconhecida pelo que estudei muitos anos." (Sujeito 83, 18 anos, feminino, Dourados, MS)

Alguns jovens que aplicaram o submodelo 6a projetam uma grande carga de trabalho e um consequente cansaço futuro pelos anos de dedicação, chegando a indicar aposentadoria e um tempo merecido de descanso. A carga de trabalho é expressa como necessária para a conquista de estabilidade e reconhecimento.

"Q10 - Minha vida será cansativa, trabalhando muito, chegar a me aposentar com muito reconhecimento." (Sujeito 20, 15 anos, masculino, Fortaleza, CE)

"Q12 - [...] Terminar o Ensino Médio e fazer faculdade de software. Quando terminar, trabalharei em uma empresa tipo Microsoft ou Google. Depois vou me aposentar e viajar o mundo.” (Sujeito 128, 15 anos, feminino, São Paulo, SP)

A grande maioria dos sujeitos desse grupo apresentou sentimentos relacionados às suas conquistas projetadas no futuro. Os sentimentos de bem-estar, realização pessoal e felicidade foram os mais destacados, em uma vinculação clara ao fato de os sujeitos se 
sentirem "vencedores", por terem se esforçado no estudo e no trabalho ao longo da vida. Nenhum dos jovens apontou a necessidade de ser feliz, valorando esse sentimento em si, sem estar relacionado a algum aspecto levantado ao longo dos protocolos.

"Q11 - Com certeza me sentirei uma pessoa vencedora, uma pessoa que lutou muito e conseguiu realizar tudo que sempre quis e sonhou." (Sujeito 53, 17 anos, feminino, Sobral, $\mathrm{CE})$

“Q11 - Me sentirei bem, realizado, feliz de tudo que fiz e poderá fazer." (Sujeito 106, 15 anos, masculino, Rio Claro, SP)

Ainda que possuam muita coerência em seus discursos, enfocando o elemento trabalho, grande parte dos jovens que elaboraram suas respostas de acordo com o submodelo 6a não percebe a problemática destacada por eles como um aspecto que deveria ser diferente no mundo. Na questão seis, quando questionados a respeito do que gostariam que mudasse no mundo, a maioria deles salienta pontos como problemas estruturais do nosso país (educação, corrupção), desigualdade social, poluição, entre outros. Os sujeitos não se posicionam como ativos para a realização da mudança pretendida ou, então, evidenciam ações individuais frágeis.

"Q6 - ajudar o meio ambiente principalmente a floresta amazônica. Para fazer a minha parte eu não jogo lixo na rua."/ "Q7 - eu ia me sentir muito feliz se isso acontecesse de verdade." (Sujeito 21, 16 anos, masculino, Fortaleza, CE)

"Q6 - desigualdade social, melhorar as condições de vida."/ "Q7 - bem pois seria um avanço em nosso ambiente social.” (Sujeito 192, 18 anos, feminino, Ponta Grossa, PR)

Apenas três sujeitos evidenciaram o elemento Deus em suas respostas sobre a sua vida atual, que estão no início do questionário. Nessas respostas, Deus é significado a partir do senso comum. No discurso voltado para o futuro, esse elemento desaparece.

“Q2 - Deus, minha família e o planeta."/ "Q3 - eu me sinto feliz, pois eu amo todas essas pessoas que eu citei anteriormente e também por participar dessa nova geração mundial.” (Sujeito 21, 16 anos, masculino, Fortaleza, CE) 
Com o intuito de representar as relações/implicações estabelecidas entre elementos centrais, sentimentos e suas significações, apresentamos a tabela abaixo.

Tabela 12: Relações/implicações entre elementos centrais, sentimentos e seus significados no submodelo 6a.

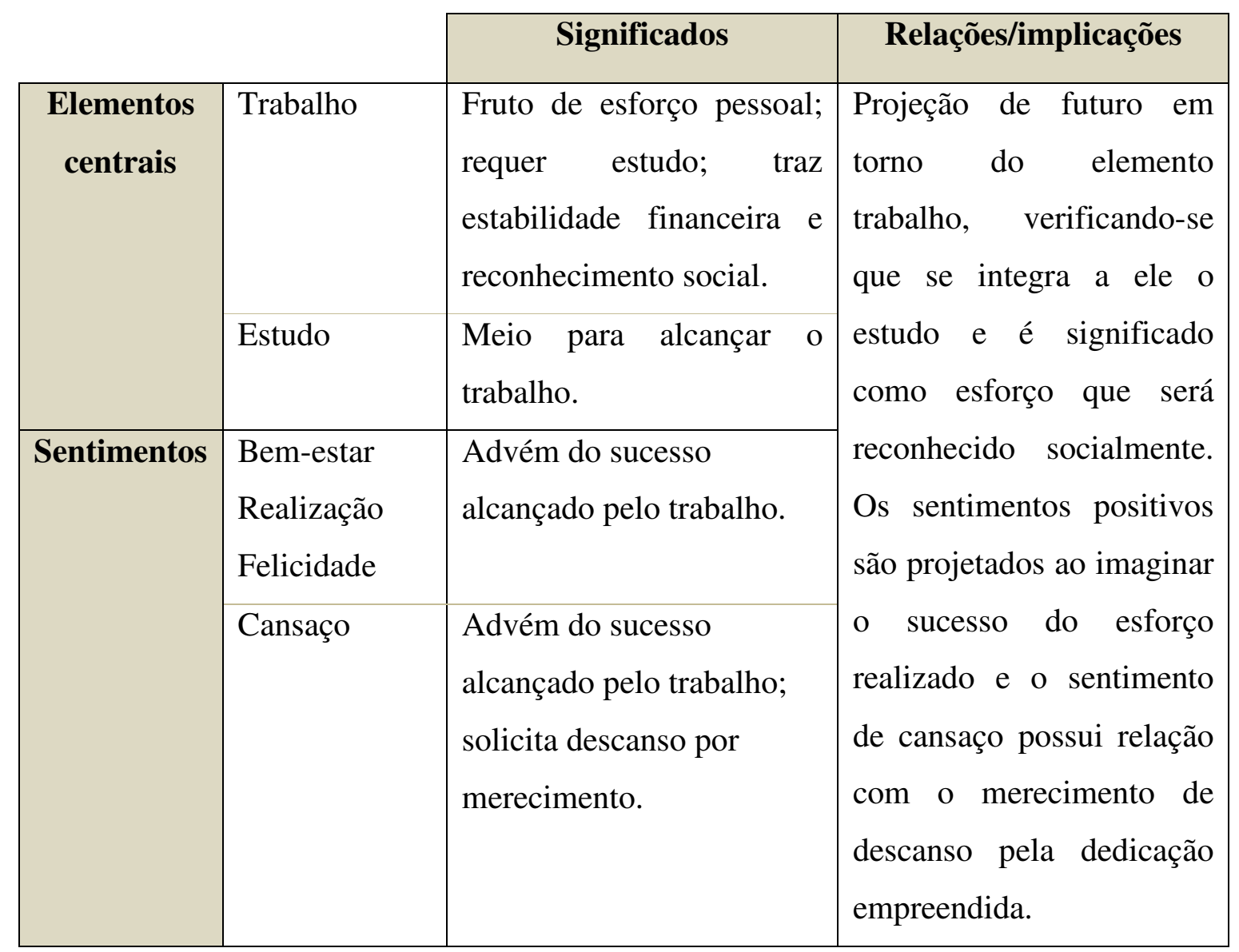

\section{Submodelo 6b}

\section{Número de sujeitos que aplicaram o submodelo: 8}

Bem como no submodelo 6a, no submodelo $6 \mathrm{~b}$ tem-se como elemento organizador central o trabalho, que é valorado pelos jovens que o aplicaram de uma forma extremamente positiva. Aqui, todavia, esse elemento recebe outros significados, resultando em outras implicações no discurso dos sujeitos.

No submodelo $6 b$, é perceptível um maior número de significados atribuídos ao trabalho, os quais conferem consistência às respostas e coerência entre elas. Esse elemento é 
mencionado no decorrer de todo o questionário com muita força e propriedade, envolvendo também outros elementos, os quais são explicados por seu viés.

Em todas as respostas, nota-se que o sujeito tem clareza de suas ações para conquistar o que deseja: contribuir para a sociedade por meio de seu trabalho e ser reconhecido por isso. Para chegar a esse objetivo, esses jovens enumeram as ações que têm tomado ou que preveem em seu futuro próximo ou a longo prazo. Eles reconhecem a necessidade de esforço e determinação solicitados para cumprirem seus projetos de vida.

"Q1 - Bom eu acordo cedo apesar de vir para a escola de carro. Todos os dias com exceção de sexta-feira eu tenho curso. Inglês e Informática. É bem cansativo, mas eu sei que será útil para o meu futuro, por isso procuro dar o melhor de mim sempre." "Q8 - Meu trabalho. Por isso agora eu estudo e dou o melhor de mim. Sei que lá na frente com todo esse esforço vou conseguir me destacar no mercado de trabalho."/ "Q12 - [...] Meu projeto de vida é terminar os estudos, fazer intercâmbio de 1 ano para aperfeiçoar o Inglês e depois fazer uma faculdade de Jornalismo fora do Brasil ou aqui mesmo.” (Sujeito 126, feminino, 15 anos, São Paulo, SP)

Em grande parte dos protocolos, uma das ações fundamentais para se alcançar o mundo do trabalho é o estudo, não apenas na escola, mas em atividades procuradas pelos jovens para contemplar o que entende como necessidades para a concretização de seus projetos de vida. Apenas um dos sujeitos que aplicou o submodelo $6 \mathrm{~b}$ ultrapassa essa forma de ver o estudo, pois o valoriza em si. Porém, nesse caso, o estudo se constituirá na fonte de trabalho desse sujeito.

"Q1 - [...] o que mais gosto de fazer é estudar física e matemática. [...]"/ "Q3 - Física: é algo que amo fazer por mais difícil que seja, é o que me move."/ "Q8 - Daqui a cinco anos estarei fazendo universidade de física bacharelado, estudando piano e me aprimorando no violino. Estarei mais amadurecida em relação à vida. Mais importante será terminar a faculdade, trabalho."/ Q12 - Me aprimorar em minha área física, fazendo mestrado e doutorado. Continuar tocando.” (Sujeito 189, feminino, 15 anos, Ponta Grossa, PR)

Todos os sujeitos que aplicaram o submodelo 6b sabem qual profissão desejam seguir e em que área querem atuar. Fica clara, em seus protocolos, a vontade de contribuir com o mundo, exercendo uma profissão que condiz com seus estilos de vida e personalidades. Esse 
aspecto é muito importante nessas respostas, uma vez que o trabalho não é significado pelo viés de um fazer "comum", um "curso da vida", mas pensado como uma forma de realização pessoal por se fazer o que se gosta e também por meio de um reconhecimento da sociedade a respeito de algum benefício propiciado por esse trabalho.

“Q8 - Bom meu desejo é estar exercendo a profissão que acho que tenho vocação, fazendo o que eu gosto. Quem sabe estarei viajando pelo mundo ou até mesmo pelo Brasil conhecendo novos lugares, apreciando a natureza que é o que tem de mais belo nesse mundo."/ "Q9 [...] Quero ser bióloga, descobrir uma espécie, ter meu nome reconhecido não para o mundo inteiro, mas pra que pelo menos saibam que fui importante um dia. [...]" (Sujeito 63, 17 anos, feminino, Sobral, CE)

“Q13 - todo mundo tem seu projeto, o meu é mais seguindo no rumo da música, eu sei o que eu quero fazer da minha vida é ser músico, eu sinto prazer em tocar, cantar, ver o público cantando a música junto, isso me traz muita alegria." (Sujeito 89, 15 anos, masculino, São Paulo, SP)

Nesse grupo, encontramos nas respostas a consciência dos gostos pessoais e também do que realmente se sabe fazer. Os jovens que aplicaram o submodelo $6 \mathrm{~b}$ não se explicam com visões idealizadas da realidade, muito embora pensem "alto" a respeito de seus projetos de vida. Explicando melhor, diferentemente dos modelos anteriores, as respostas desse submodelo são, no geral, concernentes a realizações nem sempre tangíveis à grande maioria da população, devido ao fato de que não dependem apenas de talento e esforço, mas também de sorte. Por exemplo, para descobrir uma espécie com o seu nome, a bióloga não precisa apenas ser talentosa e conhecer diversas espécies, mas também ter a sorte de encontrá-la. Os sujeitos parecem não perceber essa dificuldade, possuindo uma visão sonhadora (e não idealizada) da realidade, apesar de conscientes sobre ela.

“Q10 - Primeiro que achar não leva a nada. Eu tenho que ter certeza, mesmo que nessa vida tudo seja uma surpresa, tenho uma ideia claríssima do que quero para mim aos 40. Pode parecer engraçado e mesquinho, mas estarei famoso. Trabalharei com grandes pessoas e meu nome será visto por aí. Verdade que será estressante e cansativo, pois estarei trabalhando muito. Não penso em casar, mas penso numa companhia. Uma boa casa, meu ateliê e minhas obras no tapete vermelho. É assim que vai ser."/ "Q12 - [...] Meu projeto de 
vida eu tenho guardado há algum tempo em minha cabeça, e continuará lá, nunca menor, ele só cresce a cada dia. Meu projeto é ser um artista da moda, vestir pessoas importantes, falar ao mundo, mostrar ao mundo minhas ideias." (Sujeito 170, 16 anos, masculino, Ponta Grossa, PR)

A família é um elemento que comparece com menos força nas respostas advindas dos questionários desses jovens. Ao ser mencionada em seus cotidianos, a família, na maioria das vezes, é entendida como um apoio e motivação aos estudos e ao trabalho. Nas projeções sobre o futuro, em alguns protocolos, encontramos a indicação de famílias não tradicionais, o que não aconteceu nos demais modelos; em outros, a constituição de uma família com quem se convive.

"Q3 - A minha família é primordial para minha vida, pois é o que realmente me fortalece e me dá condições de lutar na vida, já cursar Direito é o meu grande objetivo de vida desde tenra idade, já meu pai é meu modelo de profissional. [...]”/ "Q8 - Na ocasião seria ter um emprego de grande importância na sociedade."/ "Q10 - Eu acho que minha vida será muito boa, pois eu estarei exercendo a minha profissão, a minha vocação. Eu acho que deverei estar como advogado ou juiz; o que deverá ser importante vai ser a família que terei construído."/ "Q12 - [...] Meu projeto de vida é ser advogado por um tempo, depois passar em concurso e me formar juiz, construir algumas empresas no ramo imobiliário, me casar só depois e exercer um papel importante na sociedade." (Sujeito 6, 17 anos, masculino, Macapá, AP)

“Q12 - [...] Não necessariamente casar, pois é uma coisa que está deixando de ser primordial na vida de qualquer mulher. Ter meus filhos, pelo menos dois, e um homem que me entenda e que me aceite assim como sou, que possamos nos entender e ver nos olhos um do outro o que está se passando pela mente de cada um e que eu possa fazer o mesmo por ele." (Sujeito 63, 17 anos, feminino, Sobral, CE)

São notórios os sentimentos apontados pelos sujeitos que aplicaram o submodelo 6b. Muitos mencionam felicidade, realização, satisfação, bem-estar relacionados à concretização de seus sonhos e, parece-nos, a uma sensação de "completude", como se, uma vez realizado o projeto de vida, nada mais faltaria a esses sujeitos. Nesse submodelo, não há respostas que se 
refiram ao desejo de ser feliz, sem que isso esteja relacionado à realização por meio do trabalho e reconhecimento social.

"Q11 - muita alegria, pois eu acho que já teria alcançado o meu sonho, e as pessoas que eu amo do meu lado, estaria muito feliz, acho que, se eu tiver minha família do meu lado e tiver uma carreira no mundo da música, seria muito feliz, não faltaria mais nada.” (Sujeito 89, 15 anos, masculino, São Paulo, SP)

"Q9 - Eu acho que eu serei bastante realizado e completo com a minha vida."/ "Q11 - Um homem realizado, feliz, completo e preparado para enfrentar o que vier pela frente." (Sujeito 6, 17 anos, masculino, Macapá, AP)

Alguns sujeitos que elaboraram seu discurso de acordo com o agrupamento que propusemos como submodelo 6b reportaram ao elemento Deus. Esse elemento compareceu com força nas primeiras respostas do questionário, quando os sujeitos indicaram o que era mais importante para eles e também como era o seu cotidiano. Para além de usarem o senso comum e ensinamentos aprendidos na igreja, esses sujeitos questionam a religião e a colocam como uma escolha pessoal e refletida. Embora tragam significados diferenciados acerca desse elemento, em vista do que encontramos nos modelos anteriores, os jovens não o preservam ao longo de suas respostas, deixando com que a força do elemento trabalho norteie as questões que dizem respeito ao futuro.

"Q2 - 1. Deus 2. Família 3. Amigos"/ "Q3 - 1. Deus, eu apesar, de é claro não conhecê-lo, sou uma pessoa que tem muita fé e, apesar dos obstáculos, eu continuo firme nesta fé que me deixa capaz de acreditar em mim mesmo, essa força divinal me dá sempre a esperança de acreditar que sou capaz de realizar o que eu quiser. [...]"/ "Q3 - 1. Deus, eu fui ensinado desde pequeno que existe uma força superior que interfere em nossas vidas e comanda tudo, eu apenas tive a escolha de aceitar essa realidade ou criar a que eu quisesse, escolhi a que me pareceu mais real, que mais me agrada e satisfaz.” (Sujeito 73, 15 anos, masculino, Dourados, MS)

“Q2 - 1. Deus 2. Meu sucesso pessoal 3. Criatividade."/ "Q3 - 1. Deus - Acho importante ter um lado especial, pois acredito no sobrenatural, sempre existirão coisas inexplicáveis para a ciência, então creio que só pode ser Deus. Sei que sou errado e que não sigo seus 
mandamentos como deveria, mas o amo acima de tudo.[...]” (Sujeito 170, 16 anos, masculino, Ponta Grossa, PR)

A seguir, apresentamos, na tabela as relações/implicações que puderam ser tecidas pelos participantes que aplicaram o submodelo $6 \mathrm{~b}$, diante dos elementos abstraídos e dos significados a eles atribuídos.

Tabela 13: Relações/implicações entre elementos centrais, sentimentos e seus significados no submodelo 6b.

\begin{tabular}{|c|c|c|c|}
\hline & & Significados & Relações/implicações \\
\hline \multirow[t]{2}{*}{$\begin{array}{l}\text { Elementos } \\
\text { centrais }\end{array}$} & Trabalho & $\begin{array}{l}\text { Fruto do esforço pessoal; } \\
\text { requer estudo; contribui } \\
\text { para a sociedade; } \\
\text { realização pessoal; traz } \\
\text { reconhecimento social. }\end{array}$ & \multirow{5}{*}{$\begin{array}{l}\text { Projeção de futuro em } \\
\text { torno do elemento } \\
\text { trabalho, em integração } \\
\text { com o estudo, como fonte } \\
\text { de realização pessoal e de } \\
\text { reconhecimento social. A } \\
\text { família é um elemento } \\
\text { periférico, } \\
\text { significada apenas como } \\
\text { motivação aos elementos } \\
\text { principais. Os sentimentos } \\
\text { positivos reforçam a } \\
\text { mobilização dos elementos } \\
\text { trabalho e estudo. }\end{array}$} \\
\hline & Estudo & $\begin{array}{l}\text { Meio para alcançar o } \\
\text { trabalho; } \\
\text { conherece } \\
\text { alcançar o projeto de vida. }\end{array}$ & \\
\hline \multirow[t]{2}{*}{$\begin{array}{l}\text { Elementos } \\
\text { periféricos }\end{array}$} & Família & $\begin{array}{l}\text { Apoio e motivação aos } \\
\text { estudos e trabalho. }\end{array}$ & \\
\hline & Deus* & $\begin{array}{l}\text { Escolha refletida de uma } \\
\text { crença religiosa.* }\end{array}$ & \\
\hline Sentimentos & $\begin{array}{l}\text { Bem-estar } \\
\text { Realização } \\
\text { Satisfação } \\
\text { Felicidade }\end{array}$ & $\begin{array}{l}\text { Sensação de } \\
\text { “completude”, relacionada } \\
\text { à realização pessoal e } \\
\text { reconhecimento social do } \\
\text { trabalho. }\end{array}$ & \\
\hline
\end{tabular}

\footnotetext{
* Em algumas respostas.
} 


\section{g) Modelo organizador 7 - Intenção de atingir o outro}

\section{Número de sujeitos que aplicaram o modelo: 14}

O grupo de jovens que aplicou o modelo organizador 7 mobilizou um elemento organizador central diferente dos demais modelos apresentados: a vontade de atingir o outro por meio de suas ações. Esse elemento é visto de forma muito positiva por eles e provém, claramente, de suas histórias de vida, vivências cotidianas e desejos para o futuro.

Tal elemento comparece ao longo de todas as respostas desses protocolos, recebendo muitas significações que trazem ao modelo organizador uma grande elaboração e complexidade. Outrossim, garante extrema coerência no pensamento desses jovens pela força com que comparece em todo o questionário.

Há outros elementos que são abstraídos e retidos como significativos pelos sujeitos, que recebem diversas acepções ao longo de seus discursos. Destacam-se, entre esses elementos, o trabalho, a família e Deus/religião. Um dos significados recebidos por esses elementos passa pelo viés dessa vontade de atingir o outro. Os jovens compreendem que podem ajudar o outro, partindo de uma ou mais instâncias. Tal vontade de ser útil a outro ou poder ajudá-lo não comparece desprovida de integração: ela significa e recebe significados de outros elementos, ganhando um sentido único de acordo com os projetos de vida de cada um deles.

Devido a diferentes integrações com outros elementos, dividimos o presente modelo organizador em dois submodelos. O submodelo 7a traz o anseio de atingir o outro por meio da família ou da religião, enquanto no submodelo $7 \mathrm{~b}$ tal desejo é expresso pelo trabalho.

Também são perceptíveis os sentimentos de bem-estar, realização, satisfação e felicidade, relativos às projeções futuras de transcender sua vida pessoal por meio dos projetos que se almeja realizar. Os sujeitos referem-se a esses sentimentos como uma satisfação em realizar o bem para os outros. Não obstante termos encontrado esses sentimentos em todos os sujeitos que aplicaram o modelo 7, percebemos que, no submodelo 7b, há também a atribuição do sentimento de felicidade aos outros que recebem a ajuda e apoio por meio do trabalho realizado por eles. 


\section{Submodelo 7a}

\section{Número de sujeitos que aplicaram o submodelo: 5}

O elemento organizador central do submodelo 7a é a vontade de ajudar o outro. Tal elemento é valorado de forma positiva pelos jovens que elaboraram esse submodelo e está presente, com força, em todas as respostas emitidas.

Esse elemento é significado como um desejo de atingir o outro, de forma a proporcionar-lhe bem-estar, relacionando-se a outros elementos. Ele mostra-se fortemente mobilizado desde os relatos sobre as vivências cotidianas até as projeções de suas vidas futuras. Ora é integrado à religião, por meio de ações religiosas, como missões, ora é integrado à família (apenas uma ocorrência), quando o jovem planeja a adoção para ajudar uma criança carente.

“Q1 - [...] levo um dia a dia tranquilo, pela manhã ajudo meus pais na lanchonete, à tarde estudo, à noite vou à igreja (uma das coisas que mais gosto e mais faço). Na igreja trabalho com crianças do bairro ensinando sobre Jesus e falo sobre coisas do cotidiano (drogas, violência, estudo, respeito, etc). Sou feliz! O mundo vive dizendo que ser pobre, favelado, estudante de escola pública é sinônimo de infelicidade, mas não concordo, pois sou satisfeita com que tenho!"/ "Q2 - 1. Jesus 2. Família e estudos 3. Meu próximo.”/ "Q3 - [...] Meu próximo: considero pessoas mais importantes que coisas (coisas são necessárias, mas não são tudo).”, "Q10 - 57 anos... muito tempo... meio século de vida... não estarei aposentada! Rs, estarei trabalhando numa creche com crianças de rua (um de meus sonhos). A história que construí, o legado que deixarei...” (Sujeito 10, 17 anos, feminino, Belém, PA)

O submodelo 7a mostra-se extremamente coerente, do início ao fim dos protocolos. Um aspecto que chama a atenção a esse respeito é o fato de os sujeitos registrarem, quando solicitados a escrever sobre o que gostariam que fosse diferente no mundo, respostas condizentes com a vontade de ajudar os outros, apresentando-se como agentes para tanto.

"Q6- gostaria que o amor não se esfriasse (como temos visto nos noticiários). Como trabalho com crianças, busco mostrar a elas que o amor é mais importante.” (Sujeito 10, 17 anos, feminino, Belém, PA) 
O elemento Deus e, consequentemente, a religião comparece em todos os protocolos. Nesse submodelo, esse elemento ganha outros significados até então não existentes nos modelos anteriores. A fé em Deus e o compromisso com a religião são aspectos que transformaram as vidas desses sujeitos, levando-os a pensar nos outros e a fazer bem a eles, assim como promovendo mudanças em suas próprias vidas e na maneira de enxergar a realidade. Os sujeitos não se utilizam de senso comum ou preceitos assimilados para relatar sobre a sua fé.

“Q1 - [...] depois vou fazer minhas atividades religiosas, que para mim têm a maior importância, me sinto extremamente feliz com projetos sociais que faço, sou uma pessoa alegre e brincalhona, gosto muito de ajudar o próximo, sempre ser prestativa.[...]"/ "Q3 Bom minha vida na igreja é uma coisa que adotei há pouco tempo, mas é meu maior prazer, ajudar, acolher, ser feliz.[...]”/ "Q4 - A fé mudou minha vida, aprendi muitas coisas, aprendi a viver, amar e olhar o mundo de hoje com outros olhos, também ter um Deus, influencia muito nos estudos, em respeitar seu colega, respeitar seu professor, estudar, pensar em coisas boas.[...]” (Sujeito 125, 15 anos, feminino, São Paulo, SP)

Quando relatam sobre suas rotinas, parte dos sujeitos desse grupo aponta ações relacionadas à religião, como percebemos nos exemplos acima. Outra parte, embora apresente a religião como fator muito importante em suas vidas e como forte projeção no futuro, indica ações voltadas ao estudo e ao trabalho, que são outros elementos citados por todos os sujeitos do submodelo $7 \mathrm{a}$.

“Q1 - [...] estou cursando o segundo ano do Ensino Médio, e trabalhando na DCCO por meio período pelo programa jovem aprendiz. Moro com a minha mãe. Por ela trabalhar o dia todo e eu estudar e trabalhar, meu convívio com ela é apenas à noite, e finais de semana. Apesar de ter o dia-a-dia um pouco corrido, gosto disso porque assim tenho uma preparação para o futuro, e também cursando um profissionalizante.” (Sujeito 79, 16 anos, feminino, Goiânia, GO)

O elemento trabalho é abstraído por todos os sujeitos desse grupo, mas não está associado à vontade de ajudar os outros. Ele é importante, mas não possui tantos significados atribuídos pelo sujeito. Concorrendo com a vontade de ajudar, é algo que não a impede, mas 
também não a reforça. São elementos independentes nas projeções de futuro elaboradas pelos jovens.

Todos os sujeitos que aplicaram o submodelo 7a mostram-se dedicados ao trabalho, conhecendo os meios necessários para alcançá-lo. Parte dos sujeitos, inclusive, cita a área em que deseja atuar, sendo que todos se referem à importância desse trabalho para uma vida digna em sociedade. Entretanto, esse elemento não se mostra suficiente para que os jovens se sintam realizados em seus projetos de vida, o que faz com que mobilizem ações voluntárias, missões religiosas, etc.

"Q8 - pretendo estar concluindo a faculdade (fisioterapia). Será importante estar trabalhando nesta área."/ "Q12 - [...] concluir o curso de fisioterapia viajar para RS, trabalhar, ser voluntária na creche, formar família." (Sujeito 10, 17 anos, feminino, Belém, PA)

"Q9 - Realizada profissionalmente com a carreira que pretendo, e sabendo ajudar mais e ajudando como sempre fiz."/ "Q10 - Creio que, se depender de mim, estarei estável, ajudando na melhoria de um país (pois tenho muita vontade de fazer parte de uma ONG para crianças carentes). Importante para me será o mundo em que meus filhos estarão vivendo, e a conscientização do que é importante na vida para eles e para o mundo.” (Sujeito 79, 16 anos, feminino, Goiânia, GO)

Muito embora possamos perceber a vontade de fazer o bem para o outro, é visível que esses sujeitos, apesar de apontarem ações a respeito desse projeto de vida, não citam estratégias, causas e consequências reais de seus atos, o que nos leva a inferir que possuem uma visão sonhadora e distante a respeito das formas de ajudar o outro.

A família é outro elemento abstraído e retido como significativo por parte desses jovens. Em uma das respostas desse grupo, encontramos o desejo de ajudar o outro por meio da família. O jovem em questão aponta o desejo de adotar uma criança carente. Nossa percepção acerca dessa resposta é de uma semelhança da dinâmica de pensamento em relação aos que desejam atuar em ONGs ou em outras formas de voluntariado. Tal semelhança nos fez inserir esse protocolo no submodelo $7 \mathrm{a}$, a despeito dessa diferença em seu conteúdo.

“Q10 - Eu provavelmente já serei mãe, já terei adotado um filho (um menino negro entre 4 e 6 anos), estarei casada há 35 anos e ainda vou estar na igreja, talvez como missionária. 
Também terei um ótimo cargo numa rádio."/ "Q12 - Fazer minha faculdade, me formar e ser independente, casar, ter dois filhos, sendo um deles adotado, e fazer muitas missões religiosas.” (Sujeito 134, 18 anos, feminino, São Paulo, SP)

Nas outras respostas agrupadas como submodelo 7a, há poucas referências à família, levando-nos a entender que esse valor não se posiciona como central para esses jovens. As referências à família são pontuais e próximas de uma instituição idealizada, tal como encontramos no submodelo 4a. Assim como o elemento trabalho, a família parece coocorrer com os outros elementos e não se integrar a eles.

"Q10 - Puxa, com 40 anos vou estar uma mulher vivida, vou ter passado por várias experiências, vou estar me sentindo vivida mesmo, espero estar casada, com filhos, e isso será importante."/ “Q12 - Eu tenho sonhos, eu tenho metas, quero fazer uma faculdade, ter um emprego digno, ter uma boa família, ter casa, filhos e poder educá-los para o mundo, quero continuar ajudando sempre as pessoas com que caminho.” (Sujeito 125, 15 anos, feminino, São Paulo, SP)

Os sentimentos revelados pelos jovens que aplicaram o submodelo 7a são os de felicidade e realização, estreitamente vinculados à projeção de futuro. Observamos que os sujeitos entendem que possuem uma "missão" a realizar e projetam tais sentimentos com o seu cumprimento. É como se tivessem obstáculos e barreiras que precisam ser superados para a ocorrência dos sentimentos de realização e felicidade.

"Q11 - Com o espírito de que lutei e venci, quebrando cada barreira com pessoas importantes na minha vida, ao meu lado.” (Sujeito 79, 16 anos, feminino, Goiânia, GO)

“Q9 - Me sentirei uma pessoa feliz, sei que vou passar por muitas coisas, e muitas coisas vão acontecer, mas que tenho força e fé para superar a tudo isso. Espero ter concretizado tudo que sonhei agora com meus 15 anos.” (Sujeito 125, 15 anos, feminino, São Paulo, SP)

A tabela abaixo busca apresentar os elementos centrais e periféricos, os sentimentos, significados e relações/implicações estabelecidas entre eles, os quais compõem o núcleo central que constitui o submodelo $7 \mathrm{a}$. 
Tabela 14: Relações/implicações entre elementos centrais, sentimentos e seus significados no submodelo 7a.

\begin{tabular}{|c|c|c|c|}
\hline & & Significados & Relações/implicações \\
\hline \multirow[t]{2}{*}{$\begin{array}{l}\text { Elementos } \\
\text { centrais }\end{array}$} & "Outro(s)",51 & $\begin{array}{l}\text { Necessita de ajuda e } \\
\text { provoca o desejo de } \\
\text { ajudar, de cumprir uma } \\
\text { missão, de desenvolver } \\
\text { uma atividade religiosa. }\end{array}$ & \multirow{5}{*}{$\begin{array}{l}\text { Projeção de futuro que } \\
\text { visa a ajudar o outro, por } \\
\text { meio de ações solidárias e } \\
\text { missões religiosas. A } \\
\text { religião integra-se a esse } \\
\text { elemento, alimentando-o. } \\
\text { Trabalho e família são } \\
\text { elementos periféricos que } \\
\text { não se integram aos } \\
\text { centrais. Os sentimentos } \\
\text { de realização e felicidade } \\
\text { corroboram a sensação de } \\
\text { conquistar o que foi }\end{array}$} \\
\hline & Deus & $\begin{array}{l}\text { Transforma a vida do } \\
\text { sujeito pela fé em Deus e o } \\
\text { compromisso com a } \\
\text { religião; alimenta a } \\
\text { vontade de ajudar o outro. }\end{array}$ & \\
\hline \multirow[t]{2}{*}{$\begin{array}{l}\text { Elementos } \\
\text { periféricos }\end{array}$} & Trabalho & $\begin{array}{l}\text { Importante; realização } \\
\text { pessoal. }\end{array}$ & \\
\hline & Família & Idealização.* & \\
\hline Sentimentos & $\begin{array}{l}\text { Realização } \\
\text { Felicidade }\end{array}$ & $\begin{array}{l}\text { Sensação de "completude" } \\
\text { ao ajudar o outro. }\end{array}$ & \\
\hline
\end{tabular}

* Há uma exceção em que a família é significada como possibilidade de ajudar a outro (adoção).

\section{Submodelo $7 b$}

\section{Número de sujeitos que aplicaram o submodelo: 9}

No submodelo $7 \mathrm{~b}$, encontramos uma vontade de atingir o outro atuando como um elemento organizador central de todo o discurso elaborado pelos jovens que o abstraíram. Pela presença atuante desse elemento e pela forma como é significado positivamente no decorrer de todo o protocolo, entendemos que está fortemente vinculado a outros elementos e sentimentos expressos pelos sujeitos.

\footnotetext{
${ }^{51}$ Nos submodelos $7 \mathrm{a}$ e $7 \mathrm{~b}$, os sujeitos abstraem o elemento outras pessoas (que seria a sociedade em si), significando-o como a quem gostariam de ajudar ou atingir por meio do trabalho. Indicamos que o termo "outros" poderia representar esse elemento.
} 
O presente submodelo traz grande coerência e elaboração nas respostas, com uma ampla gama de complexidade entre os elementos, significados atribuídos a eles e as implicações dessas relações. As respostas elaboradas retomam os elementos apresentados, tecendo coerentemente o pensamento desses sujeitos e apresentando-os de uma forma única e peculiar, própria de cada um deles. Assim, os sujeitos, muito embora mostrem uma dinâmica do pensar semelhante, em que consta uma vontade e uma necessidade de atingir o outro, deixam bem claros os conteúdos em que atuam, a partir dos quais traçam seus projetos de vida.

A vontade de atingir o outro está integrada estreitamente com o trabalho, isto é, por meio das ações movidas pelo trabalho desempenhado. Aqui, os jovens retratam uma transcendência de seus objetivos pessoais por meio de suas ações no trabalho, o que nos leva a entender que o emprego, em si, traz a possibilidade de pensar no outro como forma de beneficiá-lo. É, de certa forma, um dever daquele que trabalha, ser útil e benéfico para a sociedade e, mais detidamente, para aqueles que serão atingidos por tais ações.

Por meio do trabalho, os jovens almejam fazer o bem aos outros, dentro daquilo que esperam desempenhar. Então, está clara, para todos esses sujeitos, a área em que desejam trabalhar e a sua importância para o mundo e a sociedade. Entre as profissões destacadas por esses jovens, temos: bombeiro, médico, advogado, enfermeiro, jornalista e jogador de futebol.

“Q12 - [...] Eu já tenho o meu projeto de vida. Eu pretendo ser bombeiro, e a razão de eu querer ser um bombeiro é porque eu quero poder ajudar as pessoas quero salvar vidas e arriscar minha vida pela da pessoa, porque um bombeiro tem de ser corajoso, não pode falhar nunca e nem desistir em algum incêndio e afogamento, um bombeiro tem que estar sempre pronto pra o que vier e honrar o seu trabalho." (Sujeito 115, 16 anos, masculino, Rio Claro, SP)

“Q8 - [...] E estarei me formando em Enfermagem e, com certeza, já estarei trabalhando em algum hospital ou posto de saúde, ajudando a salvar e cuidar das vidas de inúmeras pessoas que por ali passarão. [...]” (Sujeito 62, 16 anos, feminino, Sobral, CE)

O trabalho não é apenas significado por essa vontade de colaboração com o outro, mas também por outros aspectos, alguns deles presentes em modelos anteriores, como o reconhecimento da sociedade a respeito das ações realizadas, a autorrealização pessoal ao se 
fazer o que se gosta e o orgulho por todo o esforço dedicado nos anos de estudo. Os sujeitos reconhecem os estudos e as ações necessárias para se destacar no mercado de trabalho.

"Q1 - [...] Faço curso de manhã que é curso profissionalizante. Esse ano vou tentar o vestibular, quero passar em medicina.[...]”/ "Q8 - Eu estarei na faculdade e o importante para mim vai ser eu me formar e fazer minha especialização e ter um bom emprego."/ "Q12 - O meu projeto de vida é estudar, conseguir passar no meu curso de medicina, ter uma carreira como médica e ajudar muitas pessoas. Para mim, um projeto de vida é você saber o que quer e correr atrás para alcançar o que se deseja." (Sujeito 9, 17 anos, feminino, Belém, PA)

Todos os sujeitos que aplicaram o submodelo $7 \mathrm{~b}$ citaram ações e envolvimento com o trabalho, principalmente com os estudos, que, para eles, é fundamental para alcançar o que desejam.

“Q1 - Bem, eu, como a maioria dos adolescentes, tenho vários planos e sonhos, um deles é cursar jornalismo e pra isso estou me preparando e muito. Passo a maior parte do tempo estudando ou dançando uma das coisas que mais amo. [...]”" (Sujeito 33, 17 anos, masculino, Sobral, CE)

"Q1 - eu jogo futebol, acordo todos os dias bem cedo menos no domingo que é o principal dia que eu descanso, geralmente acordo 7:30, tomo café e vou treinar. 8:00 chego no clube, o treino começa ás 8:30 e termina 11:30, eu geralmente descanso à tarde venho para o colégio de noite. Eu gosto dessa rotina, apesar de ser cansativa para minha idade. Aos 15 anos, pessoas que não praticam esportes apenas estudam. Eu, no meu dia, me sinto bem, às vezes cansado, chateado, mas eu gosto então, feliz." (Sujeito 161, 15 anos, masculino, Curitiba, PR)

Além do elemento trabalho, que, em nosso entender, constitui-se também como um valor para os jovens desse grupo, comparece o elemento família, a partir do qual não percebemos a integração com a vontade de ajudar. A família comparece em todos os protocolos, relacionada a uma gratidão à formação e educação recebidas ao longo de suas vidas, assim como à vontade de constituir uma família e criar/educar os filhos de acordo com os preceitos em que se acredita. 
“Q10 - Acredito que aos 40 anos, já estarei casada e terei minha própria família, já terei realizado boa parte dos meus planos, estarei exercendo minha profissão. Daí em diante, creio que os meus sonhos serão os sonhos dos meus filhos, ou seja, eu tentarei empenhá-los naquilo que eles querem para a vida, assim como a minha mãe fez comigo, estarei incentivando-os a lutar pelo que querem. As coisas importantes continuarão as mesmas, na mesma ordem, sendo que agora, terei acrescentado os projetos dos meus filhos." (Sujeito 62, 16 anos, feminino, Sobral, CE)

Parece-nos que a força de alguns acontecimentos na vida desses sujeitos, bem como o incentivo por parte de algumas pessoas, levou esses jovens a realizar projeções voltadas a um trabalho com vistas a atingir a sociedade e à responsabilidade em relação à família.

“Q2 - 1. Família 2. Ética 3. Estudo."/ "Q3 - Família, a primeira estrutura de como ser uma boa pessoa, ética, conceitos básicos, de ser uma pessoa influente na sociedade para conviver nela apesar de tantos horrores. [...]"/ "Q8 - daqui a cinco anos, a vontade de ajudar $e$ defender as pessoas vai ser maior que a vontade de ter status."/ "Q10 - uma vida na qual vou ter orgulho de ser quem eu sou, vou ter bens, mas o meu bem maior é saber que fiz coisas boas pelas pessoas, acho que ter família estruturada acima de tudo.[...]"/ "Q12 - [...] meu projeto de vida tranquila é poder proporcionar uma vida melhor as pessoas que amo." (Sujeito 78, 18 anos, feminino, Goiânia, GO)

"Q2 - 3. Minha querida mãe que já faleceu faz 3 meses eu nunca me dei bem com ela, minha mãe sempre bebeu muito e sempre brigou com meu pai e me batia muito, aí meu pai separou dela e fomos morar eи теи pai е теи irmão, mesmo ela tendo me maltratado, eu sempre gostei dela. Ela é minha mãe, a pessoa mais importante em nossa vida.[...]"/ "Q3 - Tipo tendo meu pai e meu irmão mais novo ao meu lado, eu me sinto muito bem, mas eu sinto falta da minha mãe [...]. Minha mãe, ela tinha qualidades boas, ia despertar essas qualidades boas, mas ela não sabia despertar essas qualidades. Todos que ficavam perto dela sentiam raiva, ódio dela, mas ela foi minha mãe, eu nunca senti raiva dela, sempre tentei fazer o máximo possível para ter ajudá-la, mas foi tarde demais..."/ "Q10 - Minha vida vai ser muito corrida, né? Já vou estar trabalhando, vou ter que cuidar da minha família, ensinar coisas boas para meus filhos e sempre ajudar os desamparados e ser feliz com o resto das oportunidades que servirem para mim."/ Q11 - [...] vou tentar fazer todos felizes, 
principalmente minha família e amigos, e não posso esquecer do meu pai que sempre cuidou de mim. Aos 40 anos, eu vou ter que retribuir tudo o que ele me fez e, mais ainda, porque ele foi um ótimo pai pra mim, nunca me abandonou e sempre esteve do meu lado." (Sujeito 115, 16 anos, masculino, Rio Claro, SP)

A coerência presente no submodelo $7 \mathrm{~b}$ é reforçada pelo fato de que os jovens que o aplicaram apontam problemas no mundo, que desejariam que fossem mudados, relacionados aos elementos abstraídos e significados por eles em suas respostas. Eles se colocam como atuantes em relação à problemática realçada e preveem, em suas profissões, uma possível solução ou a sua diminuição.

"Q6 - Muitas coisas, primeiro o preconceito e a intolerância, porque esta é sem dúvida um dos principais problemas que todo o mundo enfrenta hoje. Acredito que a voz pode ser tão poderosa, então faço desta minha arma contra a intolerância."/ "Q10 - Acho que serei um profissional de sucesso, um benfeitor em relação à vida humana. Estaria fazendo o que mais amo (escrever), e o que seria mais importante para mim seria o próximo."/ "Q12 - Planejarse para o futuro. Cursar jornalismo, ter uma editora e uma ONG." (Sujeito 33, 17 anos, masculino, Sobral, CE)

"Q6 - No mundo, existe muita destruição, muitas guerras, muita corrupção e muita pobreza. Na minha opinião, isso tudo teria que mudar. Eu participo de projetos voltados para crianças carentes de baixa renda."/ "Q8 - Me formar em direito."/ "Q10 - a minha vida será mais bem sucedida. Eu estarei lutando pelos direitos dos cidadãos.” (Sujeito 5, 17 anos, masculino, Macapá, AP)

Parte dos jovens que aplicaram esse submodelo mobilizaram o elemento Deus cujos significados voltaram-se para ensinamentos que eles utilizaram para elaborar seus projetos vitais. Esse elemento comparece ao longo das respostas, integrando-se aos demais e garantindo maior força a eles.

"Q3 - bem, eu não sou cristão como a maioria das pessoas. Eu sou pagão e isso me incomoda. [...] Aprendi uma coisa na religião que estou estudando... Amar a todos, bem isso aprendemos em qualquer lugar, mas usamos? Bem, digo que nem todos e isso é muito importante para mim [...]"/ "Q8 - [...] acho que estaria em uma carreira militar tentando 
fazer algo para ser lembrado e acho que já teria começado a construção de uma casa própria e teria uma namorada que eu pudesse amar e ser amado e respeitá-la e ser respeitado, pudesse conversar sobre várias coisas.[...]"/ "Q10 - pretendo que minha vida seja animada com meus filhos e que eu ainda esteja em minha carreira militar ou fazendo algo que ajude as pessoas em meu país. Não posso dizer que sou patriota, mas posso dizer que quero de certa forma mudar o mundo para melhor. Acho que o que seria importante para mim: meu casamento, minhas tradições pagãs, meus filhos [...]” (Sujeito 71, 17 anos, masculino, Dourados, MS)

Sobre os sentimentos, pode-se afirmar que estão fortemente associados à concretização do projeto de vida, o qual envolve não só o próprio sujeito quanto os outros. Os sentimentos de realização e felicidade são apontados pelos jovens não apenas a respeito de si mesmos, mas também em relação aos que serão atingidos por meio do trabalho.

"Q11 - feliz... com um mundo melhor porque ate lá acho que pelo menos o local onde eu viveria estará mudado por mim e pelas pessoas que pensam igual a mim.” (Sujeito 71, 17 anos, masculino, Dourados, MS)

“Q9 - mais feliz por ter coisas que eu sempre quis e ajudar várias pessoas.” (Sujeito 161, 15 anos, masculino, Curitiba/ PR)

O núcleo central do submodelo $7 \mathrm{~b}$ pode ser representado na tabela abaixo, em que constam seus elementos, sentimentos, significados e relações/implicações entre eles. 
Tabela 15: Relações/implicações entre elementos centrais, sentimentos e seus significados no submodelo 7 b.

\begin{tabular}{|c|c|c|c|}
\hline & & Significados & Relações/implicações \\
\hline \multirow[t]{3}{*}{$\begin{array}{c}\text { Elementos } \\
\text { centrais }\end{array}$} & "Outro(s)" & $\begin{array}{l}\text { Provoca o desejo de ajudar } \\
\text { por meio do trabalho. }\end{array}$ & \multirow{7}{*}{$\begin{array}{l}\text { Projeção de futuro que } \\
\text { visa a atingir a sociedade } \\
\text { por meio do trabalho, que } \\
\text { também é significado } \\
\text { como realização pessoal e } \\
\text { reconhecimento social. A } \\
\text { família não se integra a } \\
\text { esses dois elementos, } \\
\text { porém recebe significados } \\
\text { de retribuição (reforçado } \\
\text { pelo sentimento de } \\
\text { gratidão) e de vontade de } \\
\text { constituir família/ educar } \\
\text { filhos. Os elementos } \\
\text { estudo e } \\
\text { comparecem integrados } \\
\text { aos elementos centrais, } \\
\text { reforçando-os, assim como } \\
\text { o fazem os sentimentos de } \\
\text { realização e felicidade. }\end{array}$} \\
\hline & Trabalho & $\begin{array}{l}\text { Forma pela qual podemos } \\
\text { ajudar o outro, contribuir } \\
\text { para a sociedade; Leva à } \\
\text { realização pessoal e } \\
\text { reconhecimento social; } \\
\text { Solicita envolvimento com } \\
\text { estudos. }\end{array}$ & \\
\hline & Família & $\begin{array}{l}\text { Instituição a ser construída } \\
\text { como retribuição pela } \\
\text { educação recebida; } \\
\text { merecedora de uma } \\
\text { educação condizente com } \\
\text { seus valores. }\end{array}$ & \\
\hline \multirow[t]{2}{*}{$\begin{array}{l}\text { Elementos } \\
\text { periféricos }\end{array}$} & Estudo & $\begin{array}{l}\text { Meio para se alcançar uma } \\
\text { profissão. }\end{array}$ & \\
\hline & Deus* & $\begin{array}{ll}\text { Preceitos } & \text { religiosos } \\
\text { fortalecem } & \text { elementos } \\
\text { centrais.* } & \end{array}$ & \\
\hline \multirow[t]{2}{*}{ Sentimentos } & $\begin{array}{l}\text { Realização } \\
\text { Felicidade }\end{array}$ & $\begin{array}{l}\text { Relacionam-se ao } \\
\text { trabalho, família e na } \\
\text { percepção de que outros } \\
\text { também mobilizarão esses } \\
\text { sentimentos. }\end{array}$ & \\
\hline & Gratidão & $\begin{array}{l}\text { Advém da família da qual } \\
\text { pertence. }\end{array}$ & \\
\hline
\end{tabular}

* Em algumas respostas 


\section{h) Outras dinâmicas de organização do pensamento}

\section{Número de sujeitos que aplicaram o modelo: 3}

Conforme apontamos anteriormente, nossa investigação buscou realizar uma análise minuciosa das respostas obtidas e, a partir, delas, extrair as regularidades para a elaboração dos modelos organizadores do pensamento. Tais regularidades foram encontradas nos conteúdos que orientavam os sujeitos em suas representações da realidade, isto é, nos elementos abstraídos e significados por eles, e, principalmente, nas dinâmicas de pensamento que atuavam nas relações e/ou implicações entre os elementos e seus significados.

Embora saibamos da importância desses agrupamentos para os fins dessa investigação, pretende-se também fazer emergir as nãoregularidades, expondo o quão complexo é o psiquismo humano.

Seguindo essa consideração, em nossa análise, após a leitura e releitura exaustiva dos protocolos, notamos que três deles não puderam ser agrupados nos modelos organizadores descritos anteriormente, tanto no que tange aos elementos organizadores centrais abstraídos e significados quanto no que se refere às dinâmicas do pensar. Como almejamos dar ênfase às nãoregularidades ao invés de subtraí-las, descreveremos tais protocolos a seguir.

\section{Outras dinâmicas de organização do pensamento 1}

\section{Número de sujeitos que aplicaram o modelo: 2}

Dos três protocolos que compõem o item "outras dinâmicas de organização do pensamento", agrupamos dois pela dinâmica de pensamento, que corresponde a uma reflexão interior, que acompanha esses jovens do início do questionário, quando abarcam suas rotinas diárias, até o seu fim, quando dissertam a respeito de seus projetos de vida. Essa reflexão é valorizada pelo sujeito como uma forma de autoconhecimento para uma vida mais harmoniosa. Em um dos sujeitos, vemos essa reflexão como uma forma negativa, enquanto na outra uma visão bem positiva.

"Q3 - [...] A paz comigo mesmo eu não tenho, pois minha mente é uma bagunça..."/ "Q4 - A paz interior eu não tenho e aprendi que isso é muito importante para que uma pessoa seja 
feliz e tenha harmonia."/ "Q9 - Insatisfeito por ter aproveitado bem a minha juventude." (Sujeito 72, 15 anos, masculino, Dourados, MS)

"Q3 - Divido o ser em partes. O corpo físico o que sente o mundo, que sofre as ações externas. O corpo inteligível, no caso o intelecto. Então, com os esportes, mantenho o corpo físico e com o resto das atividades, como ler, escrever ou fazer música, mantenho a saúde da alma."/ "Q4 - Com o tempo, por mais que tenha sido curto até agora. Analisei as minhas necessidades como ser humano, as pesei, as analisei e então selecionei o que me faria feliz pela maior parte do tempo.” (Sujeito 90, 16 anos, masculino, São Paulo, SP)

A atividade de reflexão realizada por esses jovens leva-os a pensar em sua felicidade e no que é realmente importante para eles. Assim, juntamente à reflexão vemos que outros elementos foram abstraídos, a partir dessa dinâmica, configurando-se como fortes para as suas projeções de futuro. A reflexão torna esses protocolos coerentes e elaborados de forma complexa na maior parte das respostas emitidas.

Um dos sujeitos, por meio do ato de refletir, percebe suas dificuldades presentes em relação à instabilidade e dependência financeira em sua vida atual e projeta seu futuro, voltando-se para a profissão de escritor, de forma que possa realizar sua vontade de ter reconhecimento social e independência.

"Q1 - Muitas pessoas acham que eu não tenho problema, e que vivo uma vida perfeita; mas por dentro eu me sinto como uma bomba-relógio que apenas num toque será destruído. Às vezes, eu sinto que vou desaparecer, como se eu não tivesse alma ou coisa parecida. Sou triste e podre por dentro, por fora uso uma máscara que me deixa 'poderoso' e 'protegido'.”/ “Q3 - Eu não tenho dinheiro - sinto falta disso, pois minha família é dependente financeira de outras pessoas, e eu tenho vontade de comprar um livro ou algo pessoal, bem egoísta mesmo, mas quando caio na real, eu vejo o quanto somos hospedeiros."/ "Q8 - Trabalho e com meus livros publicados. O importante pra mim será escrever os meus próprios romances..."/ "Q10 - Minha vida será uma turbulência e estarei conhecido mundialmente. Estarei escrevendo e coordenando os meus livros para filme. Bem talvez, quase impossível, pensando em uma família..."/ "Q12 - [...] escrever, escrever, escrever até morrer..."/ "Q13 Egoísta e feliz...” (Sujeito 72, 15 anos, masculino, Dourados, MS) 
O outro sujeito, em compensação, usa a reflexão sobre o seu dia a dia, sem apontar questões relativas a problemas vivenciados. É uma reflexão como busca de uma vida melhor. As projeções desse sujeito vão no sentido de ter uma vida "confortável", sem muitas significações a respeito do que deseja fazer em seu futuro.

“Q1 - Procuro não contar o tempo. E nem olhar para seu rosto. Não gosto da cara do tédio. Então o ocupo quase que cem por cento. Sempre buscando um certo equilíbrio. Tento exercer o positivismo a todo o segundo, tentando olhar para as coisas como se acabasse de chegar ao solo terrestre. E assim estou sempre mirando algo de interessante nas coisas. Pratico alguns esportes e faço música e medito. E assim a vida vai."/ "Q8 - Seria importante já ter iniciado o ensino superior. E estar empregado, fazendo algo que goste."/ "Q10 - Provavelmente viajando. Se for como planejo.” (Sujeito 90, 16 anos, masculino, São Paulo, SP)

Como é possível perceber nos excertos acima, os sujeitos não se envolvem com os seus projetos em seus cotidianos, por meio de ações que busquem atingi-los. Ademais, quando questionados sobre o que desejariam que fosse diferente no mundo, apontam questões para as quais apresentam "soluções” frágeis.

“Q6 - Gostaria que não houvesse preconceito contra as pessoas 'diferentes', negros, índios entre outros. Faço protestos em qualquer trabalho escolar, expondo bem claro as minhas ideias...” (Sujeito 72, 15 anos, masculino, Dourados, MS)

"Q6 - Que o olhar capitalista fosse ao menos razoavelmente cegado por um tempo. A modo de mostrar aos jovens tudo que existe por detrás das marcas e mídias. Dar a eles, ao menos a escolha de uma vida rica e saudável. Sei que sou muito pequeno, e sozinho o máximo que posso conseguir, é contar isso a vocês.” (Sujeito 90, 16 anos, masculino, São Paulo, SP)

Em relação aos sentimentos, destacam-se a felicidade, bem-estar e a realização, vinculadas ao fato de se atingir os objetivos propostos, bem como acompanhadas de um sentimento de inquietude e/ou insatisfação.

"Q9 - Se conseguir o que pretendo, me sentirei confortável. Mas como todo homem. Ainda estarei inquieto."/ "Q11 - Ainda inquieto. Um senhor, sorridente e inquieto. rsrs.” (Sujeito 90, 16 anos, masculino, São Paulo, SP) 
“Q11 - Realizado.”/ "Q13 - Egoísta e feliz...” (Sujeito 72, 15 anos, masculino, Dourados, MS)

Vejamos, abaixo, a tabela que exprime as relações/implicações entre elementos, sentimentos e seus significados nesse modelo organizador.

Tabela 16: Relações/implicações entre elementos centrais, sentimentos e seus significados no modelo "Outras dinâmicas de organização do pensamento 1".

\begin{tabular}{|c|c|c|c|}
\hline & & Significados & Relações/implicações \\
\hline \multirow[t]{2}{*}{$\begin{array}{c}\text { Elementos } \\
\text { centrais }\end{array}$} & $\begin{array}{l}\text { Rotina e } \\
\text { necessidades }\end{array}$ & $\begin{array}{l}\text { Promove } \\
\text { autoconhecimento } \\
\text { (reflexão); importante para } \\
\text { uma vida harmoniosa; } \\
\text { busca de uma vida melhor. }\end{array}$ & \multirow{4}{*}{$\begin{array}{l}\text { Projeção frágil relacionada } \\
\text { ao trabalho, como } \\
\text { realização pessoal, devido } \\
\text { ao posicionamento do } \\
\text { elemento rotina } \\
\text { necessidades do sujeito no } \\
\text { presente, que são } \\
\text { significados } \\
\text { importantes. } \\
\text { sentimentos positivos } \\
\text { estão relacionados à } \\
\text { concretização dos } \\
\text { objetivos, } \\
\text { comparecem outros, de } \\
\text { inquietude e insatisfação, } \\
\text { promovidos pelo ato de } \\
\text { refletir. }\end{array}$} \\
\hline & Trabalho & Realização pessoal. & \\
\hline \multirow[t]{2}{*}{ Sentimentos } & $\begin{array}{l}\text { Bem-estar } \\
\text { Felicidade } \\
\text { Realização }\end{array}$ & $\begin{array}{l}\text { Advém da concretização } \\
\text { dos objetivos de vida. }\end{array}$ & \\
\hline & $\begin{array}{l}\text { Inquietude } \\
\text { Insatisfação }\end{array}$ & Provocados pela reflexão. & \\
\hline
\end{tabular}




\section{Outra dinâmica de organização do pensamento 2}

Número de sujeitos que aplicaram o modelo: 1

Outro protocolo que não pôde ser agrupado aos demais modelos organizadores extraídos das respostas emitidas pelos sujeitos de nossa amostra foi o do único jovem que elegeu como elemento organizador central a atuação política.

Comparecendo com força, principalmente nas primeiras respostas do questionário cujas perguntas solicitavam dissertar sobre as rotinas e sobre o que é importante para o sujeito, esse elemento foi significado pelo sujeito principalmente como um trabalho que traz satisfação pessoal, sendo valorado de forma muito positiva. Tal elemento, em nossa perspectiva, originou-se devido às vivências que esse jovem possui em sua escola. Importante (e curioso) se faz notar que tal elemento vai perdendo força ao longo do questionário, nas projeções sobre o futuro.

A família é outro elemento abstraído por esse sujeito e comparece em grande parte das respostas emitidas. O sujeito apenas enfoca a sua importância, sem atribuir significados a ela.

"Q1 - Eu sou uma pessoa extrovertida, moro com meus pais e vivo praticamente pra minha escola, faço parte da rádio escola e do grêmio estudantil e gosto muito do que faço."/ "Q2 1. Meus pais 2. Minha formação 3. Trabalhos que desenvolvo em minha escola e em meu bairro."/ "Q3 - me sinto bem por fazer coisas boas, que fazem meus pais e minha família sentirem orgulho de mim."/ "Q4 - se tornou importante, pelo fato de me sentir bem, fazendo coisas boas, e isso se torna quase que um vício."/ "Q8 - não consigo imaginar, porque eu não tenho planos pro futuro, mas pode ter certeza, a minha família sempre foi e sempre será muito importante pra mim."/ "Q10 - eu quero uma vida bem calma, acho que devo esta me envolvendo em assuntos sociais, e minha família será o mais importante."/ "Q12 - [...] e o meu projeto de vida, é me formar, ser independente e ter essa boa colocação.” (Sujeito 8, 17 anos, masculino, Macapá, AP)

O sujeito que aplicou esse modelo organizador apenas aponta o benefício de sua atuação política quando questionado sobre o que deseja que mude no mundo em que vive. Nessa resposta, aponta que pode trazer uma maior consciência política aos outros. 
"Q6 - eu gostaria que a corrupção não existisse mais, e eu tento politizar todos que vivem ao meu redor, para que tenham uma consciência política e não se corrompam também."/ "Q7 me sinto muito bem, afinal estou fazendo a minha parte." (Sujeito 8, 17 anos, masculino, Macapá, AP)

Embora mobilizados fortemente no início do questionário, o sentimento de bem-estar por fazer algo que julga como bom para si mesmo e para a sociedade desaparece nas projeções futuras desse jovem.

"Q9 - não faço a mínima ideia."/ "Q11 - acho que vou me sentir um pouco cansado, eu estou com 18 anos e já me sinto.” (Sujeito 8, 17 anos, masculino, Macapá, AP)

Abaixo, segue tabela que procura evidenciar os elementos, sentimentos, significados e suas relações/ implicações nesse modelo organizador.

Tabela 17: Relações/implicações entre elementos centrais, sentimentos e seus significados no modelo “Outras dinâmicas de organização do pensamento 2".

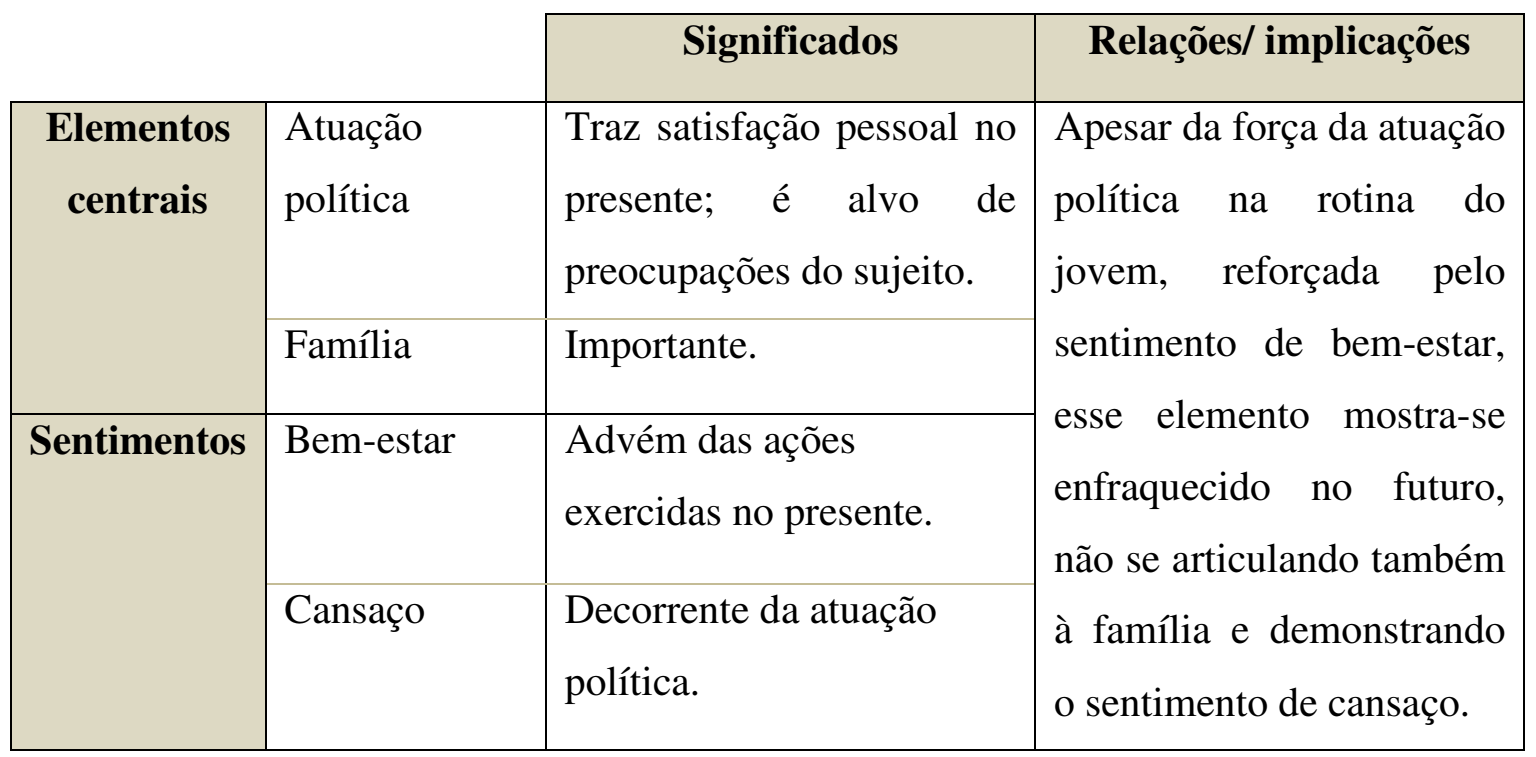




\section{CAPÍTULO VI \\ APRESENTAÇÃO E ANÁLISE DOS RESULTADOS REFERENTES AOS PROJETOS DE VIDA}

\subsection{Considerações sobre a apresentação dos dados e a análise dos resultados relativos ao projeto de vida dos jovens}

Nossa pesquisa, consoante ao que expusemos em nossas indicações acerca da metodologia empregada, tem o enfoque voltado para uma análise qualitativa dos dados, em que, sem o apoio de categorias prévias, fizemos as leituras dos protocolos, buscando uma regularidade entre eles que possa ser traduzida como uma representação da realidade efetuada pelos sujeitos, ou seja, um modelo organizador do pensamento, sem desprezar elementos que, por se constituírem como nãoregularidades, reforçam a complexidade e a individualidade do funcionamento psíquico humano. Tal enfoque, em nossa visão, pode ser complementado por uma análise também quantitativa, de forma a mostrar tendências de organização do pensamento humano e, em nosso caso, as que giram em torno dos projetos de vida dos jovens brasileiros.

Nesse continuum entre a análise qualitativa e a quantitativa, almeja-se tratar da problemática levantada pelo presente trabalho de uma forma mais ampla, sem distorcer nenhuma das duas análises, tampouco dar a uma delas mais valor do que outra, mas, pelo contrário, tratá-las de forma complementar. Acreditamos na riqueza de tal abordagem, por tentar traduzir a complexidade que perfaz o pensamento dos sujeitos participantes de nossa investigação.

No presente capítulo, nos dedicaremos mais especificamente a apresentar os modelos organizadores que descrevemos no capítulo anterior, referentes ao projeto de vida dos jovens brasileiros, no tocante a dois aspectos importantes para a presente investigação: a) os elementos destacados e significados nos modelos organizadores do pensamento abstraídos pelos sujeitos de nossa amostra, bem como as relações destes com os sentimentos apresentados; b) o número de sujeitos que os aplicaram.

Tal apresentação dar-se-á por meio de tabelas e gráficos, para uma melhor apreensão por parte do leitor sobre os dados obtidos em nossa pesquisa. Antes, porém, acreditamos ser pertinente retomar, de forma muito breve, as características de cada modelo e submodelo organizador do pensamento. Essa apresentação sucinta, em nosso entender, facilitará ao leitor a compreensão das tabelas e gráficos a seguir. 
Após cada tabela e gráfico apresentados, destrincharemos uma análise dos resultados encontrados, à luz de nosso embasamento teórico e de hipóteses que levantamos a partir de nosso problema de pesquisa.

\subsection{Descrição sumária dos modelos e submodelos}

\section{Modelo organizador 1 - Projeções frágeis}

Submodelo Mobilização dos elementos organizadores centrais trabalho e família, de

1a forma frágil e carente de significados. Futuro projetado como "normal", um curso "natural" da vida. Modelo carente de coerência e sem envolvimento e ações para com o projeto de vida. Sentimentos de bemestar ou "normal".

Submodelo Mobilização dos elementos organizadores centrais trabalho e família, 1b com uma maior atribuição de significados, os quais compareceram de forma contraditória. Presença de uma experiência negativa que marca a vida desses sujeitos e os impede de projetar seus futuros. Praticamente não há referência a sentimentos.

Submodelo Mobilização do elemento organizador central Deus. Tal elemento leva os 1c sujeitos a projetar suas vidas em torno da adoração a Deus e do seguimento dos preceitos da religião escolhida $\mathrm{O}$ sentimento apontado é o de bem-estar.

\section{Modelo organizador 2 - Consumo e estabilidade financeira}

Mobilização do elemento organizador central trabalho, significado como possibilidade de consumo e estabilidade financeira no futuro. Os elementos família e estudo compareceram fragilmente: a família significada de forma idealizada ou como meio para a conquista desse trabalho; o estudo como meio de se atingir o mercado de trabalho. A ação voltada para o projeto de vida é o trabalho. Os sentimentos que comparecem nesse modelo organizador ora são os de bem-estar, realização e felicidade, ora são os de cansaço. 


\section{Modelo organizador 3 - Relações interpessoais/vínculos}

Mobilização dos vínculos e relações interpessoas como elementos organizadores centrais. Tais elementos foram significados em relação a três elementos organizadores: a família, os amigos e o trabalho. Os sujeitos fazem projeções relacionadas à boa convivência e à estabilidade no trabalho. Embora não citem ações voltadas ao futuro, apresentam coerência ao dissertar sobre o que gostariam que fosse diferente no mundo. $\mathrm{O}$ sentimento de amor comparece fortemente, assim como a felicidade, a realização e satisfação. A felicidade comparece, também, como um valor projetado no futuro.

\section{Modelo organizador 4 - Idealização do trabalho e da família}

Submodelo Mobilização dos elementos organizadores centrais trabalho e família, 4a que são significados de forma idealizada. Esses elementos são fortemente indicados pelos sujeitos, mas não contam com suas ações e envolvimento, tampouco com uma projeção mais elaborada no futuro. Sentimentos que comparecem nesse submodelo: realização, bem-estar e felicidade. Os sujeitos apresentam confiança em seus projetos de vida.

Submodelo Mobilização dos elementos organizadores centrais Deus, trabalho e 4b família. Deus é compreendido pelos sujeitos como um ser a quem se deve obediência. Enquanto a família é significada de uma forma idealizada, o trabalho recebe como significado um meio de realizar ações na igreja. Comparecem os sentimentos de realização, bem-estar e felicidade. 
Modelo organizador 5 - Trabalho e família

Submodelo Mobilização dos elementos organizadores centrais trabalho e família, 5a com carga maior de significados e complexidade. O trabalho é significado como uma meta real para os sujeitos visando a sustentar uma família (valor de responsabilidade). Sentimentos mobilizados de bemestar, realização e satisfação, orgulho, gratidão e felicidade.

Submodelo Mobilização dos elementos organizadores centrais trabalho e família, 5b significados por meio de outro elemento importante: o fato de ser mãe. Significados semelhantes ao do submodelo $4 \mathrm{c}$, mas com mais ênfase na responsabilidade sobre a família. Apresentam-se os sentimentos de bemestar, realização e felicidade.

Modelo organizador 6 - Trabalho

Submodelo Mobilização do elemento organizador central trabalho, significado como 6a algo que depende do esforço pessoal dos jovens e que lhes dá prazer, realização pessoal. A família e o estudo são elementos indicados como meios para se atingir tal projeto de vida. Os sentimentos apresentados são de realização, bem-estar e felicidade, além de cansaço.

Submodelo Mobilização do elemento organizador central trabalho, o qual recebe 6b grande carga de significados, conferindo maior complexidade às respostas. Além de ser uma meta real para os sujeitos e dependente do esforço pessoal, o trabalho é significado como uma contribuição para a sociedade, visando a um reconhecimento social e a uma realização pessoal consoante os gostos e desejos de cada um. Sentimentos de felicidade, realização, satisfação e sensação de completude. 


\section{Modelo organizador 7 - Intenção de atingir o outro}

Submodelo Mobilização do elemento organizador central outro, que é significado, 7a com muita elaboração e complexidade, como uma forte vontade de ajudar a sociedade, por meio da religião e voluntariado. O trabalho é um elemento periférico, sendo significado como importante. Há ações e envolvimento com os projetos de vida. Comparecimento dos sentimentos de felicidade e realização.

Submodelo Mobilização do elemento organizador central outro, integrado com o 7b elemento organizador central trabalho, com vasta gama de significados atribuídos que conferem complexidade e coerência entre as respostas emitidas. Outros significados atribuídos ao trabalho são a realização pessoal e o reconhecimento social. A família é outro elemento organizador que comparece significada por meio da gratidão pela educação recebida e pela vontade de constituir família e se ter responsabilidade sobre ela. Há ações e envolvimento com os projetos de vida. Os sentimentos presentes são de realização e felicidade, não só sentidos pelos sujeitos em relação aos projetos de vida, mas também por quem recebe o ato generoso.

\subsection{Processos de integração e regulação de valores e sentimentos nos modelos e submodelos organizadores aplicados pelos participantes da pesquisa em relação aos seus projetos de vida}

Iniciaremos a discussão de nossos resultados referentes aos projetos de vida dos jovens, procurando interpretar as relações entre os elementos e sentimentos que compareceram aos modelos organizadores do pensamento, bem como a forma como foram relacionados/implicados os valores e sentimentos em cada configuração psíquica.

É muito importante destacar que os projetos de vida, como assinalamos em nosso quadro teórico, constituem-se na projeção de um percurso, que tem espaço para idas e vindas, assim como se baseia na construção de identidades morais por meio de experiências, crenças e representação de elementos contextuais. Dessa forma, estamos analisando processos dinâmicos do funcionamento psíquico que envolvem complexidade e que estão sujeitos a 
mudanças, mesmo que estejam comprometidos com uma identidade, com um self que possui características próprias, responsáveis pela sua diferenciação dos demais. Acreditamos que temos em mãos um material que nos possibilita desenvolver uma análise com a pretensão de desvelar os processos de integração e de regulação de valores e sentimentos que subjazem a elaboração dos projetos de vida dos participantes de nossa investigação.

Nesse momento de nossa análise, verificaremos a forma como tais processos se dão nas projeções para o futuro feitas pelos jovens. Faz-se necessário destacar que buscamos, a partir do presente instrumento, indicações a respeito de como os jovens pensam sobre si mesmos. Esse processo leva o sujeito a abstrair elementos sobre sua vida, ancorados em experiências passadas, vivências presentes e possibilidades futuras, sem que possuam conteúdo de um conflito moral hipotético sobre o qual possam destacar e significar elementos. Em nosso entender, nesse processo o sujeito passa, com mais cuidado, por todos os elementos que consegue abstrair, incluindo aqueles que inventa, atribuindo-lhes significado e tecendo relações/implicações entre eles. Devido ao caráter de posicionamento sobre a própria vida, pensar em um projeto significa refletir, o que engloba idas e vindas, constatação de hipóteses e elaborações com grande carga de complexidade.

Nesse item de nosso capítulo, analisaremos os processos de integração e de regulação exercidos pelos valores e sentimentos apresentados pelos jovens na elaboração de seus modelos organizadores referentes aos seus projetos de vida. Para tanto, apresentaremos, a seguir, uma tabela que traz os principais elementos e sentimentos destacados nos modelos, assim como as relações e/ou implicações entre eles. Essa tabela consistirá em um modelo "simplificado" daquelas que criamos em cada modelo organizador, com o objetivo de nos centrar nas relações/implicações entre os elementos centrais e sentimentos. Devemos estar cientes, na leitura dessa tabela, de que cada elemento e cada sentimento receberam um ou mais significados, que se inter-relacionaram, implicando na complexidade que perfez a aplicação de cada modelo organizador. 
Tabela 18: Elementos, sentimentos e relações/implicações entre valores e sentimentos destacados nos modelos e submodelos organizadores aplicados pelos jovens participantes da pesquisa em relação aos seus projetos de vida. ${ }^{52}$

\begin{tabular}{|c|c|c|c|c|}
\hline$\frac{\frac{0}{0}}{\frac{0}{0}}$ & 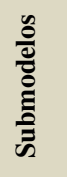 & $\begin{array}{l}\text { Elementos } \\
\text { centrais }\end{array}$ & Sentimentos & $\begin{array}{l}\text { Relações/implicações entre } \\
\text { elementos e sentimentos }\end{array}$ \\
\hline \multirow{3}{*}{1} & 1a & $\begin{array}{l}\text { Trabalho e } \\
\text { família. }\end{array}$ & $\begin{array}{l}\text { "Bem-estar", } \\
\text { "normal". }\end{array}$ & $\begin{array}{l}\text { Sentimentos de "bem-estar" e } \\
\text { "normal" são relacionados aos } \\
\text { elementos de forma branda, } \\
\text { mostrando que não são valores } \\
\text { centrais. }\end{array}$ \\
\hline & $1 b$ & $\begin{array}{l}\text { Experiência } \\
\text { negativa, trabalho } \\
\text { e família. }\end{array}$ & ------------- & $\begin{array}{l}\text { Marca de experiência negativa traz } \\
\text { elementos que aparecem de forma } \\
\text { contraditória e sem a integração } \\
\text { com os sentimentos. }\end{array}$ \\
\hline & 1c & Deus. & "Bem-estar". & $\begin{array}{l}\text { O "bem-estar" se relaciona ao fato } \\
\text { de possuir uma crença, que atua } \\
\text { para a formulação frágil de projetos } \\
\text { de vida. }\end{array}$ \\
\hline 2 & & Trabalho. & $\begin{array}{l}\text { "Bem-estar", } \\
\text { realização, felicidade } \\
\text { e cansaço. }\end{array}$ & $\begin{array}{l}\text { Os sentimentos de "bem-estar", } \\
\text { realização e felicidade relacionam- } \\
\text { se ao trabalho significado como } \\
\text { possibilidade de consumo. O } \\
\text { cansaço comparece em relação aos } \\
\text { anos de trabalho necessários para } \\
\text { tal conquista. }\end{array}$ \\
\hline 3 & & $\begin{array}{c}\text { Relações } \\
\text { interpessoais. }\end{array}$ & $\begin{array}{l}\text { "Bem-estar", } \\
\text { felicidade, realização } \\
\text { e amor. }\end{array}$ & $\begin{array}{l}\text { "Bem-estar", felicidade, realização } \\
\text { são sentimentos apontados em } \\
\text { referência às relações interpessoais } \\
\text { conquistadas por meio do trabalho, } \\
\text { da família e de amizades. O amor é } \\
\text { fortemente mobilizado em vistas } \\
\text { dessas relações. Ser feliz é um } \\
\text { valor em si. }\end{array}$ \\
\hline \multirow[t]{2}{*}{4} & $4 \mathbf{a}$ & $\begin{array}{l}\text { Trabalho e } \\
\text { família. }\end{array}$ & $\begin{array}{l}\text { “Bem-estar", } \\
\text { realização, felicidade } \\
\text { e confiança. }\end{array}$ & $\begin{array}{l}\text { Visão idealizada do trabalho e da } \\
\text { família integrada aos sentimentos } \\
\text { de "bem-estar", } \\
\text { felicidade e confiança. }\end{array}$ \\
\hline & $4 b$ & $\begin{array}{l}\text { Deus, trabalho e } \\
\text { família. }\end{array}$ & $\begin{array}{l}\text { "Bem-estar", } \\
\text { realização, felicidade } \\
\text { e confiança. }\end{array}$ & $\begin{array}{l}\text { Visão idealizada do trabalho e da } \\
\text { família, com o trabalho voltado } \\
\text { para a igreja pela presença forte do } \\
\text { elemento "Deus" e pelos }\end{array}$ \\
\hline
\end{tabular}

${ }^{52}$ Os elementos apresentados nessa tabela são os que se posicionaram de forma central na elaboração dos modelos e submodelos organizadores. Os sentimentos são aqueles mobilizados por todos os sujeitos que os aplicaram. Assim, elementos periféricos e sentimentos que não foram expostos por todos os participantes, não foram aqui apresentados, por tentarmos estabelecer, no presente momento desse estudo, algumas considerações sobre as tendências de organização do pensamento dos jovens na elaboração de seus projetos de vida. 


\begin{tabular}{|c|c|c|c|c|}
\hline & & & & sentimentos positivos. \\
\hline \multirow[b]{2}{*}{5} & $5 \mathbf{a}$ & $\begin{array}{l}\text { Trabalho e } \\
\text { família. }\end{array}$ & $\begin{array}{l}\text { "Bem-estar", } \\
\text { realização, } \\
\text { satisfação } \\
\text { e felicidade. }\end{array}$ & $\begin{array}{l}\text { Os sentimentos são relacionados ao } \\
\text { trabalho e à responsabilidade que o } \\
\text { sujeito demonstra em relação à } \\
\text { família. }\end{array}$ \\
\hline & $5 \mathbf{b}$ & $\begin{array}{l}\text { Trabalho e } \\
\text { família, na figura } \\
\text { do(a) filho(a). }\end{array}$ & $\begin{array}{l}\text { "Bem-estar", } \\
\text { realização, } \\
\text { felicidade, } \\
\text { insegurança, } \\
\text { insatisfação. }\end{array}$ & $\begin{array}{l}\text { Os sentimentos positivos são } \\
\text { relacionados ao trabalho e à } \\
\text { responsabilidade que o sujeito } \\
\text { demonstra em relação à família, } \\
\text { principalmente ao(à) filho(a). } \\
\text { Apresentam-se sentimentos } \\
\text { negativos ao se referir à gravidez } \\
\text { inesperada. }\end{array}$ \\
\hline \multirow[t]{2}{*}{6} & $\mathbf{6 a}$ & $\begin{array}{l}\text { Trabalho e } \\
\text { estudo. }\end{array}$ & $\begin{array}{l}\text { Realização, "bem- } \\
\text { estar" e felicidade, } \\
\text { cansaço. }\end{array}$ & $\begin{array}{l}\text { Sentimentos de realização, "bem- } \\
\text { estar" e felicidade relacionados ao } \\
\text { trabalho como realização pessoal. } \\
\text { O estudo está intimamente } \\
\text { relacionado a esse elemento. } \\
\text { Cansaço refere-se aos anos de } \\
\text { trabalho. }\end{array}$ \\
\hline & $\mathbf{6 b}$ & $\begin{array}{c}\text { Trabalho e } \\
\text { estudo. }\end{array}$ & $\begin{array}{l}\text { Felicidade, "bem- } \\
\text { estar", realização, } \\
\text { satisfação. }\end{array}$ & $\begin{array}{l}\text { Sensação de completude por meio } \\
\text { dos sentimentos de felicidade, } \\
\text { "bem-estar", realização e satisfação } \\
\text { relacionados ao trabalho como } \\
\text { realização } \\
\text { reconhecimento social. }\end{array}$ \\
\hline 7 & $7 \mathbf{a}$ & "Outros" e Deus. & $\begin{array}{l}\text { Felicidade e } \\
\text { realização. }\end{array}$ & $\begin{array}{l}\text { Sentimentos de } \text { felicidade } \\
\text { realização voltados ao fato de } \\
\text { ajudar os outros por meio da } \\
\text { religião e do voluntariado. }\end{array}$ \\
\hline & $7 \mathbf{b}$ & $\begin{array}{l}\text { Trabalho, } \\
\text { "outros" e } \\
\text { família. }\end{array}$ & $\begin{array}{l}\text { Realização, } \\
\text { felicidade. }\end{array}$ & $\begin{array}{l}\text { O trabalho é valorado como } \\
\text { realização } \\
\text { reconhecimento social, além de ser } \\
\text { visto como meio de atingir } \\
\text { beneficamente o outro. } \\
\text { responsabilidade comparece em } \\
\text { relação à família, pela qual } \\
\text { apresenta gratidão. Os sentimentos } \\
\text { referem-se a si próprios e aos que } \\
\text { são beneficiados por suas ações. }\end{array}$ \\
\hline
\end{tabular}

A tabela acima nos traz aportes importantes para nossa análise, pois oportuniza tanto a visualização dos elementos e sentimentos destacados quanto das relações e implicações entre eles na elaboração dos projetos de vida dos participantes da presente investigação.

No continuum que envolve os três aspectos destacados na tabela, elementos centrais, sentimentos e relações/implicações, percebe-se a complexidade inerente à elaboração dos 
projetos de vida pelos jovens, uma vez que a rede de significados estabelecida traz indicações importantes para a análise dos processos de integração e de regulação de valores e sentimentos.

Um primeiro ponto que gostaríamos de destacar é que os elementos centrais abstraídos pelos jovens são, quando enlevados por sentimentos positivos ${ }^{53}$, valores. Lembrando-nos da concepção de Piaget (1932) e, depois ampliada por Araújo (2003), os valores emergem das trocas afetivas que o sujeito realiza com o exterior, com objetos, com pessoas e/ou com relações. Para os autores, os valores são construídos pelos sujeitos e se organizam em seu sistema moral, podendo posicionar-se de forma central ou periférica (DAMON, 1995; ARAÚJO, 1998, 2003a). Além disso, como verificamos, os projetos de vida são constituídos por valores (MACHADO, 2006) dentro de um campo de possibilidades (VELHO, 1994), considerando o histórico de vida, o engajamento nas ações presentes (DAMON, 2009; BUNDICK, 2009) e as expectativas de futuro. Os valores que os jovens apresentam mediante a abstração e significação de elementos centrais em seus projetos de vida foram, em grande parte, trabalho e família. Alguns valores, Deus, Relações interpessoais (além da família), Estudo e Vontade de atingir o outro ("Outro"), também se organizaram de forma central, mas não para uma grande porcentagem de participantes. Outros elementos, que se mostraram mais periféricos também se constituíram como valores, mas não receberam a mesma carga afetiva daqueles que citamos (e, portanto, não compareceram à presente tabela).

O que salta aos olhos em uma primeira leitura dessa tabela é o fato de terem sido mobilizados praticamente os mesmos elementos centrais (valores) e sentimentos nos modelos organizadores aplicados. O comparecimento do trabalho em praticamente todas as respostas nos mostra o desejo de se inserir (ou permanecer, em muitos casos) no mercado, mostrando que os jovens estudantes que participaram da presente investigação preocupam-se, sobretudo, com modos de subsistência para si e para a família em um futuro próximo e distante, em detrimento de aspectos hedonistas, como divertir-se com amigos e "curtir a vida". Vê-se que o trabalho foi significado de diversas formas pelos sujeitos, desde um "passaporte" para o consumo até a realização pessoal, profissional e que beneficia a outrem, englobando não apenas o âmbito público (ao qual ele se destina), mas também ao pessoal, em uma visão que também incorpora o outro concreto (BENHABIB, 1992). A presença desse elemento com tamanha força vem ao encontro de estudos da sociologia (SPOSITO, 2003, 2005; ABRAMO,

\footnotetext{
${ }^{53}$ Por esse motivo, no modelo 1 , com exceção do modelo 1c (em que os sujeitos projetam valores positivos sobre Deus), percebemos que trabalho e família, embora sejam elementos centrais, não podem ser considerados valores, uma vez que não recebem carga afetiva positiva ou, se a recebem, ela é feita de forma extremamente branda.
} 
2005) e da psicologia (THOMÉ; TELMO; KOLLER, 2011) que indicam a importância do trabalho e da inserção profissional para os jovens de nosso país. Nesse sentido, podemos comprovar que o "trabalho faz juventude" (SPOSITO, 2003), ao menos para os jovens que participaram de nossa investigação.

O elemento estudo, embora compareça em grande parte das respostas, posiciona-se como central em apenas um modelo organizador e estando estritamente relacionado ao trabalho. O estudo mostra-se, para os participantes, como um meio para atingir o trabalho e, nesse sentido, é um valor que ganha proporções hierarquicamente inferiores a ele, funcionando como um "meio" para se atingir a um fim.

A família também se faz presente de maneira bastante elevada nos modelos organizadores, algumas vezes como uma idealização, mostrando o objetivo de constituir uma família; outras vezes, como fonte de responsabilidade do sujeito. De qualquer forma, verificamos que a família mostra-se como apoio a esse jovem, levando-o a valorizá-la. A família posiciona-se como fundamental para seu pleno desenvolvimento, o que pôde também ser verificado no estudo de Souza e Oliveira (2011) para quem a família exerce o papel de proteção perante situações de risco, embora possam existir, no seio familiar, aspectos que podem expor os jovens a essas situações.

Deus é um elemento que aparece em muitas respostas nos modelos organizadores, mas foi considerado, nessa análise, como um elemento em destaque apenas quando recebeu significações e, nas suas relações com os demais elementos, contribuiu para a organização do modelo. Dessa forma, observa-se que Deus e a religião, que correspondem às crenças e à fé dos jovens, puderam ser compreendidos de diferentes maneiras, as quais propiciaram formas variadas de organização dos modelos. O poder da religião de levar o jovem à autoconfiança e à transformação positiva de si mesmo é um papel destacado por Marques, Santos e Dell'Aglio (2011), contudo, como nos informam as autoras, a fé também pode gerar um impacto negativo sobre os projetos de vida dos jovens, fazendo com que eles restrinjam suas projeções apenas a esse aspecto. Nesse sentido, percebemos que a formulação de modelos em que o valor da religião posicionou-se como central, pôde estabelecer força para a elaboração do projeto de vida ou ocasionou seu "esvaziamento".

Dois elementos compareceram de forma central em apenas dois modelos organizadores. As relações interpessoais foram significadas de forma central no modelo 3, indicando a importância, para os sujeitos, dos vínculos familiares, de amizade e de namoro/casamento. Esse elemento veio desprovido de integração com outros elementos centrais. Já o elemento "outros", que diz respeito a uma vontade de ajudar/atingir o outro por 
meio de ações solidárias ou do trabalho, compareceu fortemente vinculado à religião (Deus) e ao trabalho e família.

Quanto aos sentimentos, vê-se a presença dos sentimentos positivos de bem-estar, realização e felicidade, de forma geral. Tais sentimentos parecem regular o comparecimento dos elementos em destaque nos modelos organizadores, trazendo um reforço positivo das escolhas, projetos e objetivos futuros. Apenas foram percebidos dois sentimentos negativos, os quais também atuam como reguladores da organização do pensamento dos jovens. $\mathrm{O}$ cansaço relaciona-se com o trabalho, quando os sujeitos significam esse elemento como fonte de esforço e dedicação ao longo da vida. A insegurança e a insatisfação comparecem no significado atribuído às jovens que tiveram uma gravidez não planejada.

Gostaríamos de ressaltar que, se são praticamente os mesmos elementos e sentimentos mobilizados por praticamente todos os modelos organizadores, sua diferença reside nas implicações e relações estabelecidas entre eles. Nessa pesquisa, compreendemos que não é suficiente saber quais são os valores e sentimentos apontados pelos jovens brasileiros, mas sim tentar revelar como eles integram e regulam seus valores e sentimentos em seus projetos de vida.

Nesse sentido, os dados revelam interessantes apontamentos em relação às tendências de organização psíquica dos jovens sobre os seus projetos de vida. Ressaltamos que, em nenhum momento, gostaríamos de sinalizar que um modelo caracteriza-se como melhor do que o outro. O nosso papel não está no julgamento sobre o que os jovens responderam. Pelo contrário, acreditamos na riqueza dos dados que corresponde às particularidades de cada jovem participante e julgamos interessante destacar as diversas maneiras de organizar os projetos de vida, envolvendo valores e sentimentos.

No modelo 1, verificam-se projeções frágeis sobre o futuro. No entanto, tais projeções não se dão de forma equivalente nos três submodelos. O submodelo 1a é organizado em torno dos elementos trabalho e família, os quais comparecem de forma evidentemente branda. $\mathrm{O}$ sentimento de bem-estar comparece nessa mesma intensidade, mas chama a atenção o fato de os sujeitos afirmarem que se sentem "normais" diante de seus projetos de vida. Assim, acreditamos que esses jovens não apresentam valores de fato, uma vez que não destinam sentimentos positivos ou o fazem de maneira extremamente branda aos elementos destacados.

Já o submodelo $1 b$ indica a força de uma experiência negativa na organização psíquica dos sujeitos, que apenas citaram os elementos trabalho e família de uma forma contraditória. Os sentimentos não compareceram nesse submodelo, indicando dois aspectos importantes para a elaboração dos projetos de vida: a) a necessidade da afetividade para tal formulação; b) 
a força de uma experiência muito negativa acarreta um posicionamento pessimista que inibe tal elaboração.

No submodelo 1c, temos algo, grosso modo, semelhante: a crença em Deus é um elemento muito forte e aparece de forma isolada, fazendo com que os sujeitos não apresentem outros desejos e objetivos. O sentimento de bem-estar está relacionado a essa crença, projetando-a como um valor e reforçando essa visão unilateral apresentada pelos jovens que aplicaram esse submodelo.

Nota-se que, no modelo 1, apenas um dos elementos destacados constitui-se em um valor que recebe projeção de sentimentos positivos. Contudo, tal valor, regulado pelo sentimento de bem-estar, mostra-se como um obstáculo para que os sujeitos teçam projeções futuras.

Se no modelo 1 tínhamos a não integração de valores e sentimentos, no modelo 2 vemos uma grande integração dos sentimentos de bem-estar, realização e felicidade ao elemento trabalho. Sendo significado pelos jovens como uma possibilidade de consumo e de estabilidade financeira, esse elemento é um valor por receber carga afetiva, ainda que não seja um valor moral. O trabalho também recebe a integração com o sentimento de cansaço, relacionado aos anos de esforço e dedicação que esse valor solicita. Tal integração mostra certo enfraquecimento desse valor, como se adicionasse um aspecto negativo a ele, tornandoo não tão central para esses sujeitos.

O modelo 3 é atípico na amostra por trazer como elemento central as relações interpessoais, integrando-se aos sentimentos de bem-estar, realização e amor. Os sujeitos que aplicaram o modelo 3 concebem que o trabalho, a família e as amizades proporcionarão vínculos e felicidade no futuro. As relações interpessoais são valores para esses jovens, já que recebem carga afetiva positiva. Destacam-se, nesse modelo, dois aspectos importantes: o fato de a felicidade ser um valor em si, ou seja, há uma projeção de sentimentos positivos acerca do ser feliz, sem apontar os procedimentos para se alcançar tal felicidade; o amor comparece fortemente vinculado às relações interpessoais. A integração entre as relações interpessoais e a felicidade assegura a centralidade do primeiro na organização psíquica dos sujeitos, regulando o não comparecimento de outros valores e também sendo regulados pelos sentimentos, em especial o amor, que comparece, em sua complexidade, direcionado para evidenciar os vínculos e se mostrando diferente de acordo com o vínculo construído (familiar, de amizade, de namoro). 
Nos modelos 4, 5 e 6, apresentam-se, essencialmente, o trabalho e a família como elementos centrais. Todavia, percebem-se diferenças significativas entre esses modelos e seus respectivos submodelos.

O modelo 4 subdivide-se em dois grupos, com elaboração praticamente semelhante. Nos dois submodelos (4a e 4b), são mobilizados os elementos trabalho e família, sendo regulados pelos sentimentos de bem-estar, realização e felicidade. Embora haja tal regulação, é notório que não há integração dos valores trabalho e família, que aparecem como entidades em separado, de uma forma idealizada. O que diferencia o submodelo $4 \mathrm{~b}$ é a presença forte do elemento Deus, abordado positivamente com sentimentos pelos jovens que organizaram seus raciocínios de acordo com esse submodelo. Tal valor integra-se ao trabalho, de forma a levar os sujeitos a pensar em trabalhar na igreja. Essa se constitui na única integração entre valores nesse modelo. Devido à quase inexistente integração de valores no modelo 4 , inferimos que eles se posicionam de forma periférica no sistema moral desses sujeitos.

Contrariamente ao modelo 4, no modelo 5 vemos uma grande integração entre o trabalho e a família, que são valorados positivamente pelos jovens. Entendemos essa integração com a observação de que o trabalho fornecerá aos sujeitos possibilidade de arcar com responsabilidades em relação à família (ajuda nos gastos, apoio financeiro, etc.). Essa integração recebe forte carga afetiva não apenas dos sentimentos de bem-estar, realização e felicidade, mas também orgulho, satisfação e gratidão. Chama a atenção o modelo $5 b$ no qual uma experiência de vida - ter um filho - orienta os sujeitos a demonstrarem forte vinculação entre o trabalho e a família, intensificando a responsabilidade pela última, principalmente no tocante ao(à) filho(a). Devido à gama de integrações e regulações percebidas nesse modelos, é possível observar sua complexidade e a possibilidade desses sujeitos de atuar nos contextos, inclusive os de conteúdo moral.

O modelo 6 também é composto de grande complexidade trazendo o trabalho como elemento central, o qual se integra ao elemento estudo. No submodelo 6a, o trabalho é significado como uma realização pessoal, recebendo a carga afetiva positiva dos sentimentos de realização, bem-estar e felicidade. O estudo é visto como um meio para chegar ao trabalho. Tem-se, no submodelo 6b, o trabalho, também integrado ao estudo, significado não apenas como realização pessoal, mas como reconhecimento social. Essa diferença nos submodelos traduz-se, sobremaneira, na regulação exercida por alguns sentimentos: enquanto no submodelo 6a vemos o sentimento de cansaço atribuído aos anos de trabalho, no submodelo 6b há o sentimento de completude, de realização plena. Atribuímos essa diferença na forma de significar o trabalho como uma realização apenas pessoal ou atingindo outrem. Parece-nos 
que o trabalho no submodelo $6 \mathrm{~b}$ organiza-se de forma mais central no sistema moral dos sujeitos porque extrapola os desejos, necessidades e objetivos do self.

Por fim, no modelo 7, observa-se, na abstração de elementos, um forte desejo de atingir o outro com o projeto de vida. Há diferenças significativas nos dois submodelos, cuja complexidade se encontra nas formas de integração e regulação de valores e sentimentos. $\mathrm{O}$ submodelo 7a traz como valores centrais o "outro" e Deus, intimamente integrados, já que os jovens mostram vontade de ajudar outras pessoas por meio da religião. O papel da crença, nesse submodelo, é muito diferente dos modelos anteriores, chamando-nos à atenção sobre a complexidade que perfaz a organização das crenças. Os sentimentos de felicidade e realização regulam essa integração.

O submodelo $7 \mathrm{~b}$, em nosso entender, consegue aliar muitos dos valores destacados nos modelos anteriores, tecendo uma complexa integração e regulação entre eles e os sentimentos. Como valores, verificamos o trabalho e a família que são integrados pela responsabilidade que o sujeito sente em relação a essa última. O trabalho também se integra a uma vontade de atingir o outro, pois essa ação corresponderia a uma função de sua atividade, mas igualmente benéfica no sentido de ajuda a pessoas que extrapolam seus vínculos familiares. É muito interessante observar a regulação e integração dos sentimentos nesse submodelo: eles são entendidos pelos jovens do submodelo $7 \mathrm{~b}$ como referentes às próprias conquistas no trabalho e na família, e também à forma como os beneficiados se sentirão com tais ações.

A análise da integração e regulação por sentimentos e valores, realizada nos parágrafos anteriores, demonstra a complexidade que perfaz o psiquismo humano e as diferenças existentes nas formas de processar os valores e sentimentos nos projetos de vida. Com a presença de praticamente os mesmos elementos e sentimentos nos modelos organizadores extraídos das respostas dos jovens de nossa amostra, pudemos verificar que o sujeito, ao construir seu projeto de vida diante de uma "realidade", abstrai elementos dentro de um rol culturalmente construído, mas o faz de forma bastante particular, de acordo com suas vivências e crenças, em comprometimento com o que lhe caracteriza como self (BLASI, 1995, 2004; NISAN, 2004). As possibilidades de articulação entre os elementos e os sentimentos garantem a complexidade na elaboração das projeções sobre o futuro, trazendo ao sujeito o espaço de criação que perfaz e consolida a sua identidade.

Tais possibilidades de articulação também dizem respeito ao modo como cada elemento é significado, propiciando diferentes relações/implicações. Verifica-se que, em grande parte dos protocolos, os elementos receberam vários significados que os constituíram de uma forma única, particular. O trabalho, por exemplo, pôde ser significado das seguintes 
maneiras: de uma forma idealizada; como realização pessoal; como forma de se responsabilizar pela família; como reconhecimento social. Em alguns protocolos, o sujeito significou esse elemento de uma dessas formas, mas, em muitos deles, aliou-o a diversos significados. Assim, deve-se pensar, a partir do que expusemos, que os valores não podem ser entendidos sempre da mesma forma, visto que possuem diversas implicações que os subsidiam.

Os significados atribuídos aos valores também se articularam, na dinâmica de organização do pensamento, a outros valores e aos sentimentos, garantindo coerência ao raciocínio do jovem. Estamos de acordo com Moreno Marimón e Sastre (2010) quando anunciam que sentimentos, pensamentos e operações mentais devem ser entendidos como aspectos integrados, como sistemas que atuam dentro de um conjunto que lhes confira sentido, e nunca de forma isolada. Tal articulação entre valores e sentimentos, que entendemos por integração, fortaleceu, na análise que fazemos de nossos resultados, o comparecimento dos valores e sua centralidade na elaboração de projetos de vida.

Percebe-se que os valores trabalho e família foram mobilizados de forma integrada em muitas dinâmicas de organização do pensamento (submodelos 4a e 4b, 5a e 5b, 7b), recebendo carga afetiva positiva de sentimentos como bem-estar, realização e felicidade. No entanto, embora estivessem em integração, regulados por sentimentos positivos, e se posicionando como centrais, isso não compreendeu, necessariamente, que ganhassem em complexidade de significados e articulações tecidas entre eles. Nos submodelos $4 \mathrm{a}$ e $4 \mathrm{~b}$, a integração entre trabalho e família não apresenta muitos significados, permanecendo como uma "idealização" de algo que acontecerá no futuro. No entanto, nos submodelos 5a, 5b e 7b, há um forte vínculo entre eles, já que os jovens conseguem perceber que um elemento depende de outro(s) em seus projetos de vida. Essa interdependência ocorreu, nos submodelos 5a e 5b, nas relações tecidas entre o trabalho como potencial para estabilidade financeira e possibilidade de auxiliar a família, compreendida como quem necessita de ajuda e cuidados. Já no submodelo $7 b$, a integração ocorre fortemente como uma regulação para a centralidade dos elementos/valores trabalho/família/“outros". Possuindo as mesmas relações de significados dos submodelos $5 \mathrm{a}$ e $5 \mathrm{~b}$, aqui os sujeitos estabeleceram ainda outras articulações com a vontade de ajudar, por meio do trabalho, outras pessoas (sociedade) e retribuir à família a educação oferecida na infância.

O trabalho também se mostrou integrado a outro valor, o estudo. Nos submodelos 6 a e $6 \mathrm{~b}$, esses elementos, embora de níveis de centralidade diferentes, visto que o trabalho ocupa posição hierarquicamente superior ao estudo na organização do pensamento desses sujeitos, 
recebem carga afetiva de sentimentos positivos e articulam-se em torno da possibilidade da conquista de realização pessoal e, no submodelo $6 \mathrm{~b}$, de reconhecimento social. $\mathrm{O}$ comparecimento do sentimento de cansaço, significado como uma projeção sobre o estado emocional do sujeito ao longo de anos de dedicação, acaba por restringir algumas relações entre os elementos, trazendo significado do trabalho apenas para o nível pessoal e não coletivo. O submodelo $6 \mathrm{~b}$, em contrapartida, tem a integração do trabalho e do estudo, com alto nível de articulação e de carga afetiva, resultando em uma sensação de "completude" e coerência, no envolvimento entre as esferas do pessoal, na realização e satisfação por atuar na profissão, e do social, por chegar, por meio do trabalho, ao uso de seu "saber-fazer" às pessoas, que o reconheceriam.

Outro elemento que se mostra integrado nos modelos organizadores extraídos das respostas dos jovens participantes de nossa investigação é Deus. Interessante se faz perceber as nuances de integração desse valor a outros e aos sentimentos, bem como as articulações tecidas pelos significados que lhes foram atribuídos. Em primeiro lugar, o comparecimento do elemento Deus não garantiu a elaboração fortemente articulada pelos sujeitos, o que pode ser comprovado ao verificar o submodelo 1c, em que os jovens inibem demais projeções, ancoradas em outros valores, devido à falta de relações estabelecidas com outros elementos. No submodelo $4 \mathrm{~b}$, verifica-se que a religião articula-se ao trabalho, referendada por sentimentos positivos, postulando aos sujeitos um trabalho na igreja, como perpetuação da crença. Essa articulação entre os valores e sentimentos não culmina na integração do terceiro elemento, família, na medida em que esta se mantém "isolada" e sendo significada apenas de uma forma idealizada. A rede de relações estabelecida entre os dois valores e os sentimentos não chega ao terceiro, deixando-o enfraquecido e carente de coerência. O submodelo 7a, contudo, traz os elementos Deus e "outros" fortemente integrados e mobilizados, recebendo forte carga afetiva e se posicionando de forma central na organização do raciocínio do jovem.

Os modelos que não articularam a integração entre valores, também apresentaram alto grau de complexidade, principalmente pelos significados atribuídos e pela regulação realizada pelos sentimentos, conferindo coerência à dinâmica do raciocínio dos sujeitos que os aplicaram. Contudo, tais modelos (modelos 2 e 3) ainda poderiam ganhar em nível de articulação com a integração de outros elementos. Curiosamente, esses modelos restringem-se a ganhos "pessoais": possibilidade de consumo e de estar com família, amigos, namorado/marido (diversão, apoio, etc.).

A força da carga afetiva influencia, sobremaneira, a regulação para comparecimento de valores, hajam visto os submodelos $1 \mathrm{a}, 1 \mathrm{~b}$ e $1 \mathrm{c}$, em que as projeções sobre o futuro 
demonstram-se frágeis, sem a integração de valores que possam constituí-las. Em todos os outros modelos e submodelos, a atuação dos sentimentos positivos contribui para a integração e regulação entre os valores e sentimentos, constituindo uma verdadeira rede de significações que confere coerência ao pensamento do sujeito. Os submodelos 1a, 1b e 1c, pelo contrário, apresentam incoerência e muitos elementos contraditórios.

Por todo o exposto, vemos que a complexidade de um modelo não está na quantidade de elementos abstraídos, mas na centralidade que ocupam devido à rede de significações que estabelecem sobre os elementos e sentimentos integrados, garantindo coerência à dinâmica de organização do pensamento.

Dessa forma, cremos que, ao elaborar um projeto de vida, o sujeito aplicou, mediante sua interpretação dos elementos da realidade e de sua imaginação, um complexo emaranhado de valores e sentimentos (MORENO MARIMÓN; SASTRE, 2010) que se articularam de forma bastante peculiar, permitindo ao sujeito corresponder com os conteúdos do meio em que vive e se relaciona, ao mesmo tempo em que leva em consideração pensamentos, crenças, sentimentos, valores, desejos, que, até então, foram frutos de um processo de vida que contou com experiências diversas, incluindo aquelas no campo da moralidade.

\subsection{Apresentação e análise quantitativa dos resultados referentes aos modelos organizadores aplicados pelos sujeitos participantes da pesquisa em relação aos seus projetos de vida}

Passaremos, no presente item de nosso capítulo dedicado à apresentação dos resultados acerca dos projetos de vida dos jovens participantes de nossa investigação, a apresentar e discutir dados referentes a uma análise quantitativa em relação aos modelos organizadores do pensamento.

Usaremos, para tanto, tabelas e gráficos que elucidarão os resultados de acordo com o número total de participantes de nossa investigação, distribuídos nos modelos e submodelos organizadores do pensamento.

Abaixo, apresentamos os resultados referentes à distribuição dos sujeitos nos modelos e submodelos extraídos das respostas referentes ao projeto de vida. 
Tabela 19: Distribuição dos sujeitos em modelos e submodelos referentes à elaboração do projeto de vida

\begin{tabular}{|c|c|c|c|}
\hline $\begin{array}{c}\text { Modelos } \\
\text { Organizadores }\end{array}$ & $\begin{array}{c}\text { Sub } \\
\text { modelo }\end{array}$ & $\mathbf{n}$ & $\%$ \\
\hline \multirow[t]{4}{*}{ Modelo 1} & & 56 & 28,0 \\
\hline & $1 \mathrm{~A}$ & 52 & 26,0 \\
\hline & 1B & 02 & 1,0 \\
\hline & $1 \mathrm{C}$ & 02 & 1,0 \\
\hline Modelo 2 & & 12 & 6,0 \\
\hline Modelo 3 & & 16 & 8,0 \\
\hline \multirow[t]{3}{*}{ Modelo 4} & & 51 & 25,5 \\
\hline & $4 \mathrm{~A}$ & 46 & 23,0 \\
\hline & $4 B$ & 05 & 2,5 \\
\hline \multirow[t]{3}{*}{ Modelo 5} & & 26 & 13,0 \\
\hline & $5 \mathrm{~A}$ & 23 & 11,5 \\
\hline & $5 B$ & 03 & 1,5 \\
\hline \multirow[t]{3}{*}{ Modelo 6} & & 22 & 11,0 \\
\hline & $6 \mathrm{~A}$ & 14 & 7,0 \\
\hline & $6 \mathrm{~B}$ & 08 & 4,0 \\
\hline \multirow[t]{3}{*}{ Modelo 7} & & 14 & 7,0 \\
\hline & $7 \mathrm{~A}$ & 05 & 2,5 \\
\hline & $7 B$ & 09 & 4,5 \\
\hline \multirow[t]{4}{*}{ Outros } & & 03 & 1,5 \\
\hline & 1 & 02 & 1,0 \\
\hline & 2 & 01 & 0,5 \\
\hline & Total: & 200 & 100,0 \\
\hline
\end{tabular}


Em uma análise apoiada pela leitura da tabela anterior, percebemos que:

- O submodelo 1a, em que se verifica a abstração dos elementos trabalho e família com pouca integração e regulação tanto entre si como pelos sentimentos de bem-estar e "normal", culminando na elaboração frágil de projetos de vida, apresenta a maior porcentagem entre os modelos organizadores aplicados $(26 \%$ do total de participantes);

- Trazendo os mesmos elementos do submodelo 1a, o submodelo 4a também foi aplicado por grande parcela da amostra, $23 \%$ do total. Lembramos que, nesse submodelo, os sujeitos indicavam o trabalho e a família de uma forma idealizada e com integração frágil entre esses valores.

- Outros modelos ou submodelos que receberam porcentual mais significativo na amostra são o modelo 3 (com 8\% da amostra), o submodelo 5a (com 11,5\% da amostra) e o submodelo 6a (com 7\% da amostra). Esses modelos traziam o trabalho como consumo, o trabalho integrado à responsabilidade para com a família e o trabalho como realização pessoal, respectivamente.

- O item "outros" é composto por dois modelos organizadores: um deles foi aplicado por dois sujeitos que apresentaram um forte apelo à reflexão e o outro foi elaborado por apenas um sujeito que apresentou uma leve propensão para a atuação política.

- Em grande parte dos modelos, o número de respostas compôs percentuais baixos, o que confirma a nossa opção por dar vez às singularidades dos raciocínios dos jovens que se envolveram em nossa pesquisa.

A distribuição dos participantes nos modelos organizadores possibilitou-nos a verificação de algumas semelhanças e regularidades que se fazem relevantes para a nossa análise. Entre essas regularidades, embora tenhamos intenção de discutir os resultados posteriormente, podemos já indicar que chama a atenção a quantidade de jovens que elaborou os submodelos 1a e 4a, com dinâmicas de pensamento que envolveram pouca integração entre os elementos trabalho e família, constituindo-os como valores periféricos, no caso do submodelo 1a, por serem regulados por sentimentos brandos, ou como valores centrais, no caso do submodelo 4a, pela regulação exercida pelos sentimentos de bem-estar, realização e felicidade.

De uma forma geral, percebemos que os modelos compõem-se de um submodelo com o número maior e outro(s) com números menores. Isso se deu, essencialmente, por 
significados e atribuições diferentes aos elementos destacados, bem como a presença de outro elemento que, em sua integração com os demais, regulou a organização dos valores no modelo organizador. É o caso, por exemplo, do elemento Deus, cujos significados atribuídos trouxeram diferentes formas de organização do pensamento dos jovens, aproximando-os e distanciando-os das elaborações de outros modelos.

Ao destacar os submodelos, dentro de um grupo de respostas que se centravam em uma mesma organização do pensamento, demos relevo às diferenças entre as relações/implicações estabelecidas envolvendo elementos, sentimentos e seus significados. Alguns desses submodelos não apresentaram números expressivos de respostas $(1 \mathrm{~b}, 1 \mathrm{c}, 4 \mathrm{~b}$, 7a, "outras dinâmicas"), contudo acreditamos que foram articulados de maneira diversa de outros submodelos, acarretando outras relações/implicações que, a despeito de se mostrarem "próximas", constituíam diferenças significativas perante outros raciocínios.

Assim, a verificação do número de sujeitos que aplicou cada modelo organizador pôde, para além de dar destaque às tendências de pensamento, ou seja, às regularidades presentes nos raciocínios dos jovens, vislumbrar também as singularidades que se manifestam na elaboração de seus projetos de vida. Tal enfoque verifica-se da descrição e análise inclusive de modelos que não puderam ser agrupados com outros, como fizemos com o item “outras dinâmicas de organização do pensamento 1 e 2", que consiste em modelos organizadores aplicados apenas por 2 sujeitos (“outras dinâmicas de organização do pensamento 1") e por 1 sujeito (“outras dinâmicas de organização do pensamento 2").

Como os submodelos têm, de certa forma, semelhanças entre si, nos processos de integração e a regulação de valores e sentimentos para a elaboração dos projetos de vida, acreditamos ser pertinente, para a presente análise, apresentar os dados dos modelos organizadores aplicados pelo total de sujeitos de nossa investigação. 
Gráfico 1: Distribuição dos sujeitos nos Modelos Organizadores referentes à elaboração do projeto de vida

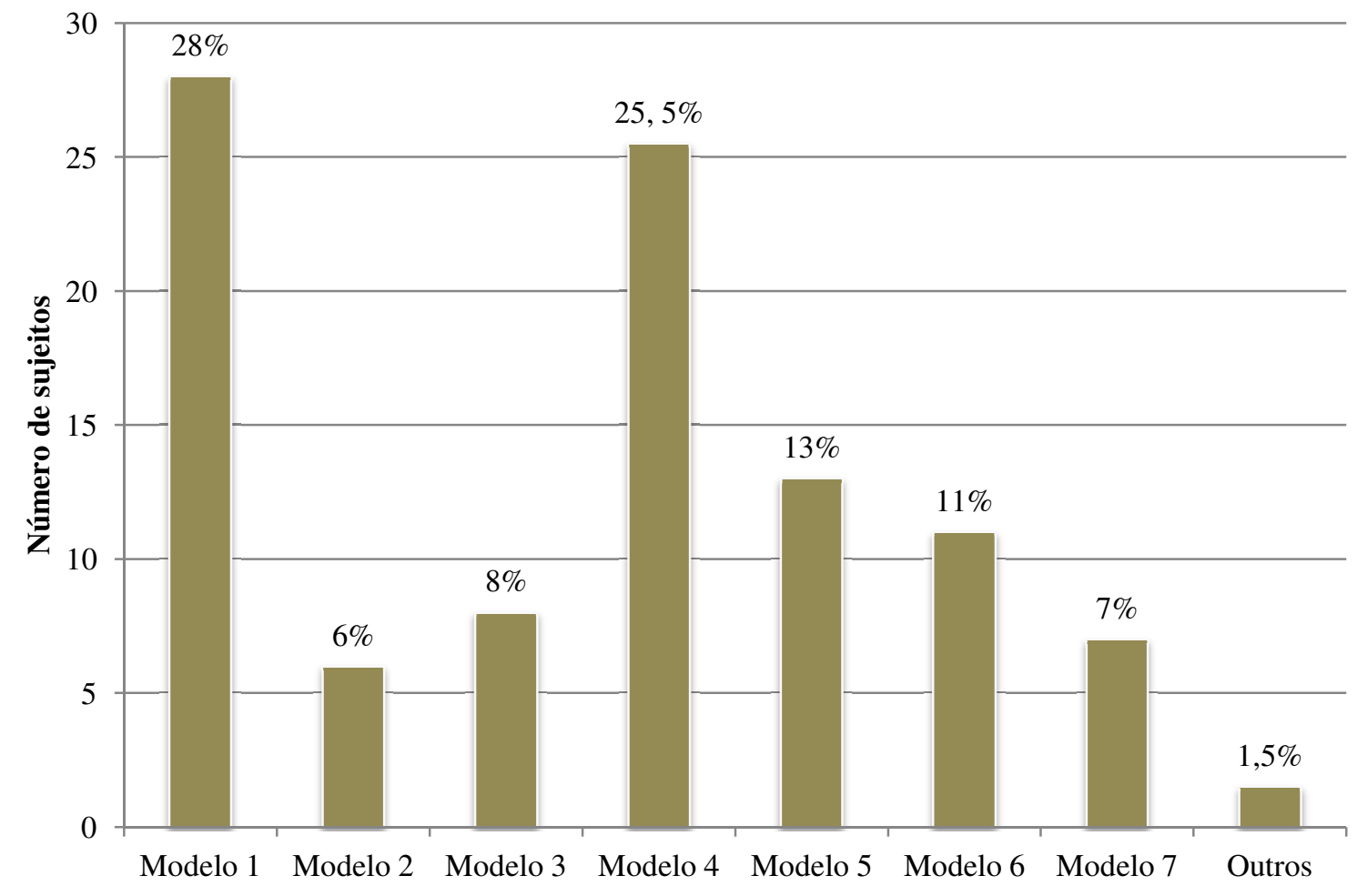

Ao analisarmos a distribuição dos sujeitos nos modelos organizadores do pensamento aplicados, pudemos perceber que:

- Grande parte dos sujeitos aplicou os modelos 1 e 4 , sendo que $28 \%$ dos sujeitos aplicaram o modelo 1, em que efetivaram projeções futuras frágeis, e 25,5\% aplicaram o modelo 4, cuja elaboração pouco integrou os valores de trabalho e família, trazendo uma idealização desses elementos.

- Os modelos 5 e 6 trazem um percentual próximo, $13 \%$ e 11\%, respectivamente. Nesses modelos, o trabalho apresenta-se como um elemento central, sendo constituído como um valor, pela carga afetiva que recebe. No modelo 5, ele integra-se à responsabilidade para com a família e, no modelo 6, ao estudo, com o objetivo de obter realização pessoal ou reconhecimento social.

- O modelo 7, em que se verifica uma maior preocupação com o outro no projeto de vida dos jovens, foi aplicado por $7 \%$ da amostra.

- Com número de sujeitos próximos ao modelo 7, há os modelos 2 e 3, com $6 \%$ e $8 \%$ da amostra total, respectivamente. Tais modelos voltaram-se para o trabalho significado como consumo e para as relações interpessoais. 
- O item "outras dinâmicas de organização do pensamento" contém apenas três respostas, equivalendo a $1,5 \%$ da amostra total.

Novamente, pela força dos submodelos 1a e 4a, os modelos aplicados por um número expressivo de jovens foram os modelos 1 e 4, com $28 \%$ e 25,5\% do total de participantes, respectivamente. Percebe-se que os demais modelos, com exceção das outras dinâmicas do pensamento, aplicado apenas por três sujeitos, trouxeram percentuais próximos, entre $6 \%$ e $13 \%$ da amostra. Interpretamos tais dados pelo fato de termos, nos modelos 1 e 4, um pensamento centrado em elementos culturalmente veiculados (trabalho e família), sem necessariamente ser embasado ou possuir um embasamento tênue em articulações entre eles e demais elementos do contexto, sentimentos e valores do sujeito na elaboração do projeto de vida. Os demais modelos organizadores, que também trazem esses elementos, passam a integrá-los a outros, juntamente a sentimentos, tecendo elaborações que contam com maior especificidade, sendo, dessa forma, compartilhadas por um grupo menor de sujeitos.

Além dessa interpretação, de forma a atingir os objetivos de nossa pesquisa, vemos como importante refletir sobre esses dados pelo viés dos processos de integração e de regulação de valores e sentimentos. Pela nossa leitura, apenas um modelo, o modelo 1, apresentou processos bastante simplificados de regulação, não mostrando, pelas respostas emitidas, integração entre valores e sentimentos. Nesse modelo, os elementos foram explicitados de forma contraditória e os sentimentos compareceram de forma branda, o que fez com que os sujeitos elaborassem projetos de vida com incoerência.

Todos os demais modelos articularam valores e sentimentos em processos de integração e regulação, mesmo que em níveis de complexidade diferentes, chegando à formulação de um projeto de vida. Podemos confirmar tal assertiva pelo fato de comparecerem elementos centrais que se posicionaram como valores, por receberem trocas afetivas com sentimentos de bem-estar, realização e felicidade, por exemplo, além de demonstrarem integração entre os valores e os sentimentos.

De forma a visualizar os resultados obtidos por esse prisma, acreditamos ser importante criar "categorias de modelos" que possam evidenciar os resultados à luz do objetivo principal de nossa pesquisa, que é o de analisar os processos de integração e regulação de valores e sentimentos nos projetos de vida dos jovens. A utilização de categorias de modelos organizadores consiste no agrupamento de formas de raciocínio semelhantes dadas pelo modo como os elementos, os significados e as relações/implicações configuraramse nos modelos - segundo critérios pertinentes ao contexto da investigação proposta. Tal 
procedimento vem se mostrando relevante para a análise dos dados em diferentes pesquisas que se referendam na Teoria dos Modelos Organizadores do Pensamento (ARANTES, 2000; MARTINS, 2003; LEMOS-DE-SOUZA, 2008; PÁTARO, 2011; PINHEIRO, 2009, entre outros). A organização dos dados, segundo essas categorias, possibilita uma análise mais apurada das regularidades presentes no raciocínio dos participantes da investigação, à medida que, a partir das semelhanças presentes nos modelos organizadores, permite a visualização das formas de pensamento a partir de uma perspectiva mais ampla. As categorias de modelos organizadores, em nossa concepção, poderão contribuir para nossa análise.

Abaixo, esboçamos em uma tabela e em um gráfico a distribuição dos sujeitos nos dois grupos de modelos: frágil integração entre valores e sentimentos, que compreendeu o modelo 1, e com maior articulação entre os processos de integração/regulação entre valores e sentimentos (modelos 2, 3, 4, 5, 6, 7 e outros).

Tabela 20: Distribuição dos sujeitos nas categorias de modelos em relação aos processos de integração/regulação de valores e sentimentos na elaboração dos projetos de vida.

\begin{tabular}{ccc}
\hline $\begin{array}{c}\text { Categorias de } \\
\text { modelos }\end{array}$ & $\mathbf{n}$ & $\%$ \\
\hline $\begin{array}{c}\text { Processos frágeis } \\
\text { de integração/ } \\
\text { regulação entre } \\
\text { valores e } \\
\text { sentimentos } \\
\text { (modelo 1) }\end{array}$ & $\mathbf{5 6}$ & $\mathbf{2 8 , 0}$ \\
& & \\
\hline $\begin{array}{c}\text { Articulação de } \\
\text { processos de } \\
\text { integração/ } \\
\text { regulação entre } \\
\text { valores e } \\
\text { sentimentos }\end{array}$ & & \\
(modelos 2, 3, 4, 5, 6, & \\
7 e outros) & & \\
\hline Total & $\mathbf{7 2 , 0}$ \\
\hline
\end{tabular}


Gráfico 2: Categorias de modelos em relação aos processos de integração/regulação de valores e sentimentos nos projetos de vida

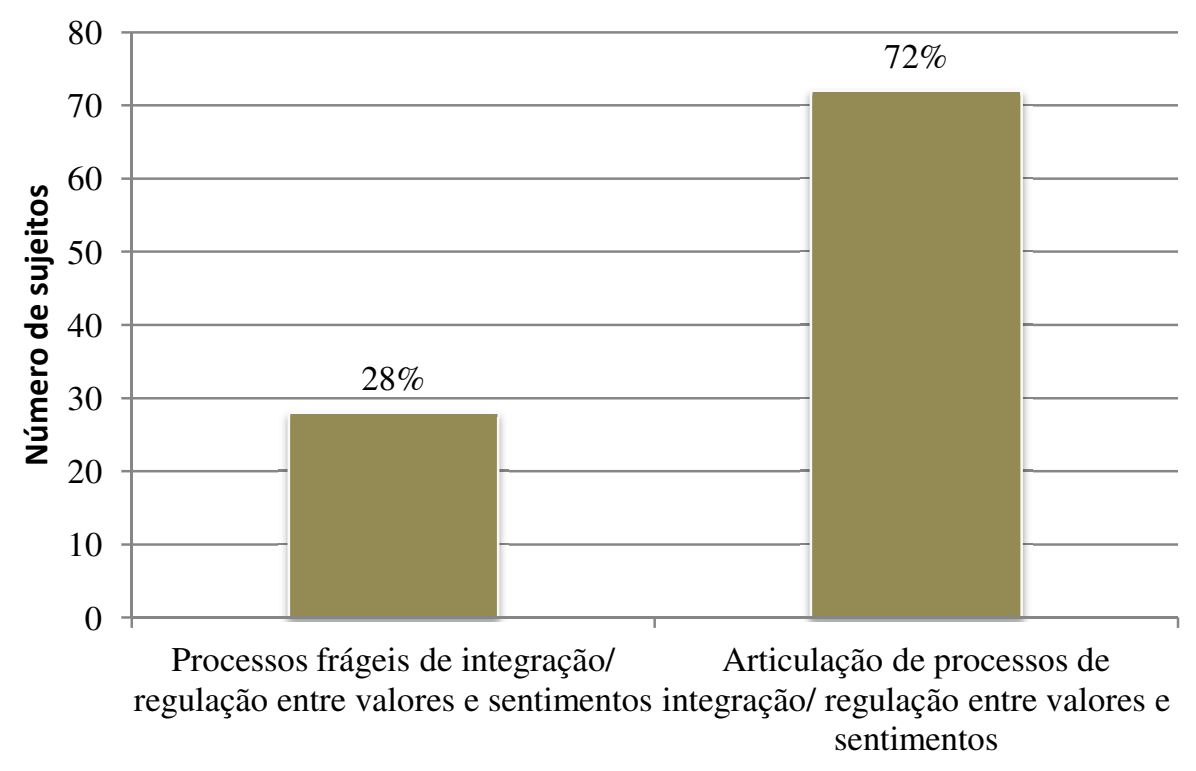

Percebe-se, com o exposto acima, que grande parte dos sujeitos (72\% dos participantes), mediante a intenção de elaborar um projeto de vida, consegue, na formulação de seus raciocínios, articular processos de integração de valores e sentimentos, fazendo com que tais processos regulem a abstração, significação e elaboração de relações e implicações sobre os elementos que correspondem às suas vivências passadas, às ações presentes e às projeções de futuro.

É importante destacar que, embora reconheçamos que os jovens, em sua grande maioria, mostre que seus projetos estão ancorados em uma arquitetura de valores (MACHADO, 2006), há diferenças no nível de complexidade das dinâmicas de organização do pensamento que corresponde à rede de significações tecidas para uma maior coerência entre cada elemento, valor e sentimento mobilizados. Assim sendo, podemos verificar que os modelos organizadores podem ser agrupados em três níveis distintos de complexidade:

Grupo A - Baixa integração entre valores e sentimentos, respostas contraditórias, projeto de vida frágil, ausência ou pouca mobilização de sentimentos (modelo 1);

Grupo B - Mobilização de um ou dois valores, pouca ou inexistente integração entre valores, projeto de vida elaborado, coerência entre grande parte das respostas, regulação por sentimentos (modelos 2, 3 e 4, outras dinâmicas);

Grupo C - Mobilização entre dois ou mais valores, integração e regulação entre valores e sentimentos, projeto de vida elaborado e com grande coerência (modelos 5, 6 e 7). 
De forma a visualizar o agrupamento consoante essas categorias referentes à complexidade dos projetos de vida, chegamos ao seguinte resultado:

Tabela 21: Distribuição dos sujeitos nas categorias de modelos em relação aos processos de integração/regulação de valores e sentimentos em níveis de complexidade na elaboração dos projetos de vida.

\begin{tabular}{ccc}
\hline $\begin{array}{c}\text { Categorias de } \\
\text { modelos }\end{array}$ & $\mathbf{n}$ & $\%$ \\
\hline $\begin{array}{c}\text { Grupo A } \\
\text { (modelo 1) }\end{array}$ & $\mathbf{5 6}$ & $\mathbf{2 8 , 0}$ \\
\hline $\begin{array}{c}\text { Grupo B } \\
\text { (modelos 2, 3, 4 e } \\
\text { outras dinâmicas) }\end{array}$ & $\mathbf{8 2}$ & $\mathbf{4 1 , 0}$ \\
\hline $\begin{array}{c}\text { Grupo C } \\
\text { (modelos 5, 6 e 7) }\end{array}$ & $\mathbf{6 2}$ & $\mathbf{3 1 , 0}$ \\
\hline Total & $\mathbf{2 0 0}$ & $\mathbf{1 0 0 , 0}$
\end{tabular}

Gráfico 3: Categorias de modelos em relação aos processos de integração/ regulação de valores e sentimentos em níveis de complexidade na elaboração dos projetos de vida.

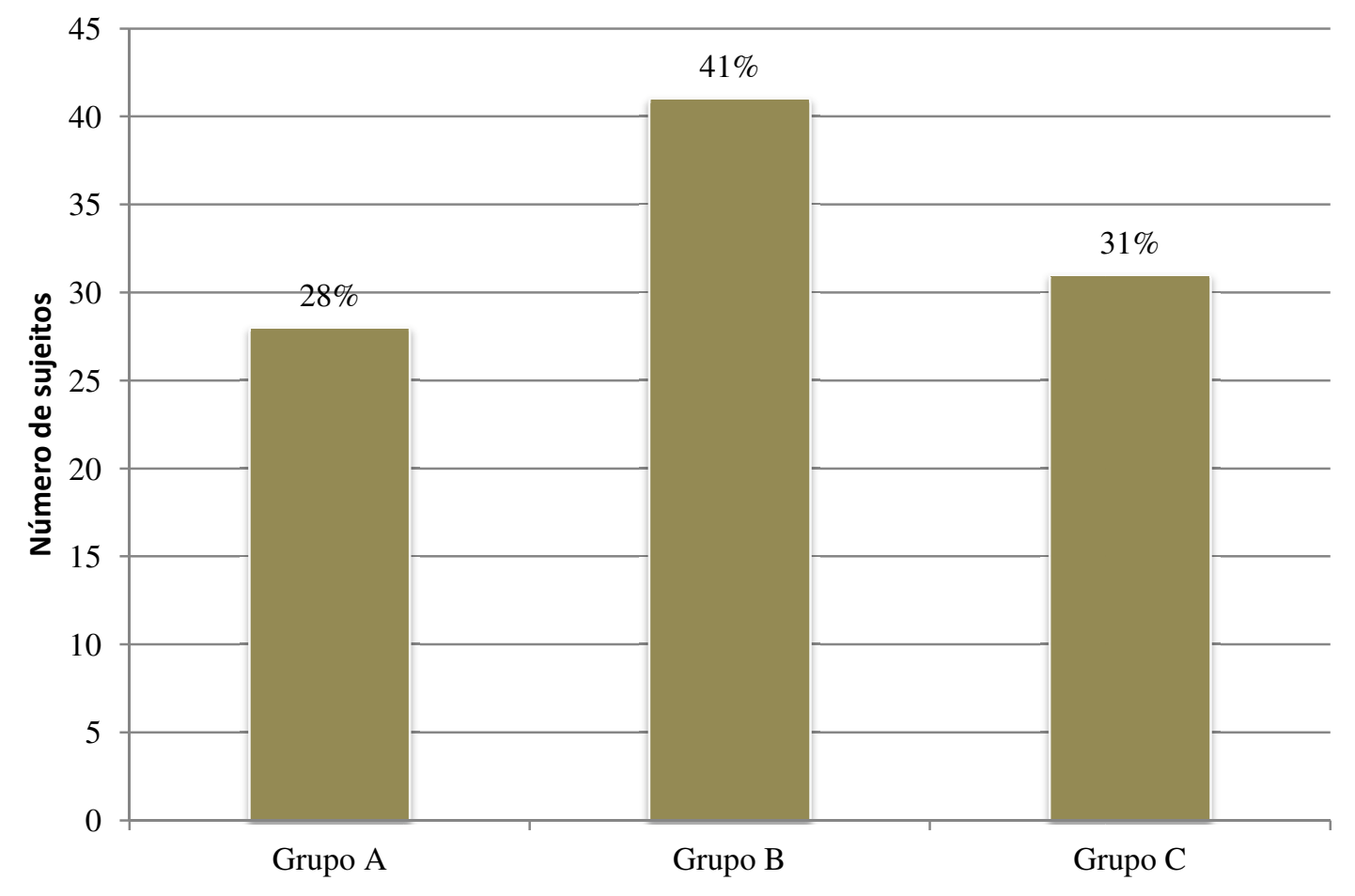

Como podemos observar, $41 \%$ (82 sujeitos) dos jovens participantes dessa pesquisa organizam seu pensamento sobre seus projetos de vida procedendo com integração frágil ou inexistente entre valores e regulação por sentimentos. Já conseguem estabelecer significados 
aos elementos abstraídos, assim como promover a regulação entre sentimentos para o comparecimento de valores. No entanto, suas elaborações ainda poderiam receber maior complexidade na articulação entre os valores e sentimentos.

O grupo $\mathrm{C}$, que contém modelos em que houve maior integração e regulação de valores e sentimentos, trazendo maior gama de significações entre os elementos abstraídos, chegando a relações/implicações mais complexas, correspondeu a 31\% (62 jovens) dos participantes. Em número bastante próximo, 28\% dos jovens (56 protocolos) aplicou modelos em que abstraíram elementos que não se evidenciaram como valores (com exceção do valor Deus, no submodelo 1c), pela falta de carga afetiva e significações atribuídas, levando-os a elaborar projeções frágeis e contraditórias.

Deixaremos para discutir esses resultados mais à frente. 


\section{CAPÍTULO VII}

\section{APRESENTAÇÃO DOS MODELOS ORGANIZADORES REFERENTES AO CONFLITO MORAL}

\subsection{Considerações sobre a apresentação dos modelos organizadores do pensamento referentes ao conflito moral}

Como enfocamos em nossa descrição a respeito dos instrumentos utilizados na presente investigação, além das questões relativas ao projeto de vida, apresentamos aos jovens de nossa amostra um conflito moral envolvendo decisões de um(a) jovem fictício(a) acerca da possibilidade de ingressar em um estágio a despeito do pedido de ajuda feito pela mãe para que não aceitasse a oportunidade. Após tal conflito, os participantes responderam a três questões, conforme indicamos anteriormente, para que pudéssemos analisar como se dão os processos de integração e de regulação de valores e sentimentos na formulação de juízos morais, envolvendo esse conteúdo.

As respostas a essas três questões possibilitaram uma visão sobre como os sujeitos participantes de nossa pesquisa se posicionaram frente ao conflito, indicando os valores e os sentimentos mobilizados. Atenderam, em sua maioria, à nossa expectativa de perceber, nessa segunda etapa da investigação, diferentes juízos diante de uma situação de conflito moral. Vale ressaltar, como pontuamos anteriormente, que tal conflito tinha por base o projeto de vida do personagem, o qual era relacionado ao trabalho. Explicando melhor, nossa intenção era a de perceber os pensamentos e sentimentos dos sujeitos na resolução do conflito envolvendo o conteúdo de um projeto de vida.

Para a análise das respostas dos sujeitos, realizamos a leitura das três questões conjuntamente, de forma a obter um panorama mais amplo das representações apresentadas, bem como a perceber um continuиm entre os valores e sentimentos destacados nas três respostas. Tal tipo de análise já foi feito por nós anteriormente (PINHEIRO, 2009) com resultados animadores a respeito da generosidade.

Novamente, nos decidimos por uma análise pelo viés da Teoria dos Modelos Organizadores do Pensamento (MORENO MARIMÓN et al., 1999), uma vez que pretendíamos observar, sem o apoio de categorias prévias, os elementos abstraídos, os significados atribuídos a esses elementos e as implicações/relações estabelecidas entre eles. As várias leituras dos protocolos nos levaram a observar as regularidades existentes entre as 
respostas dos jovens de nossa pesquisa e possibilitaram efetuar agrupamentos dos modelos organizadores do pensamento aplicados, sem deixar de ressaltar, como nos possibilita esse instrumento teórico-metodológico, as não regularidades. Vale destacar que tal instrumento nos permitiu considerar, também nessa análise, não apenas os conteúdos indicados pelos jovens, mas também, e principalmente, suas dinâmicas de pensamento.

É importante salientar que, como se tratam de respostas a um conflito moral, esse instrumento solicitou um posicionamento frente à situação, na incorporação do papel vivenciado pelo personagem fictício. Ao ter que se posicionar como o personagem, o sujeito necessitou avaliar uma situação dada, abstraindo elementos, significando-os e tecendo relações e/ou implicações entre eles. A elaboração de um raciocínio diante de uma situação que envolve um conteúdo sobre projeto de vida difere daquela que exige a elaboração do próprio projeto de vida do sujeito, visto que, embora exija a escrita do jovem sobre o conflito, ao trazer, de antemão, elementos da situação, permite a elaboração de um juízo mais ágil, sem recorrer a muita reflexão sobre os próprios valores.

Embora se tenha, nessa segunda etapa do estudo, um número menor de respostas a serem analisadas, obtivemos grande complexidade nos discursos elaborados pelos jovens, o que nos levou à extração não apenas de modelos organizadores, mas também de submodelos, cujas descrições puderam trazer à luz um pouco da diversidade de juízos encontrada.

Na descrição de cada modelo e submodelo, procuramos dar o máximo de indicações ao leitor a respeito da forma como organizaram suas respostas, incluindo exemplos elucidativos dessa organização ${ }^{54}$. Como fizemos a análise das três questões conjuntamente, os exemplos apresentados se constituem das respostas de um mesmo sujeito.

Vale ressaltar que, devido ao fato de termos a intenção de observar se existe ou não continuum entre os processos de integração e regulação de valores e sentimentos na elaboração dos projetos de vida e na formulação de juízos frente ao conflito moral, a ordem de apresentação desses modelos visa a estabelecer vínculos entre as análises e não diz respeito a uma hierarquia entre os modelos apresentados.

Por fim, faz-se mister apontar que seis sujeitos participantes de nossa investigação emitiram respostas sobre as quais não pudemos verificar os elementos abstraídos, os significados atribuídos a esses elementos e as relações/ implicações entre eles. Tais respostas mostraram-se confusas, contraditórias e extremamente escassas em conteúdos.

\footnotetext{
${ }^{54}$ Fizemos, também nessas respostas, correções de linguagem nos exemplos que ilustram cada modelo e submodelo, principalmente nas questões de ortografia, procurando manter, ao máximo, a sintaxe utilizada pelo sujeito e sua lógica de argumentação.
} 


\subsection{Descrição dos Modelos Organizadores do Pensamento referentes ao conflito moral}

a) Modelo A - Opção pelo estágio

Número de sujeitos que aplicaram o modelo: 43

No modelo A, os sujeitos abstraíram fortemente o elemento estágio/trabalho, não dando indicações de que poderiam ajudar a mãe a cuidar dos irmãos.

Os sujeitos que aplicaram esse modelo mobilizaram sentimentos de bem-estar pela escolha do emprego. Quando indagados sobre como se sentiriam caso não aceitassem essa oportunidade, relatam, no mais das vezes, que se sentiriam mal, tristes ou magoados.

No decorrer da análise, percebemos uma diferença na forma como significaram o pedido de ajuda da mãe, o que nos fez dividir o presente modelo em três submodelos. No submodelo $\mathrm{A} 1$, os sujeitos não dão indicações de que se preocupam com a mãe ou com os irmãos, desprezando esses elementos em prol da realização de seus objetivos. Outro grupo, do submodelo A2, demonstra fracamente uma tristeza ou um sentir-se mal pelo fato de não ajudar a mãe a cuidar dos irmãos, mas demonstra um forte sentimento negativo caso não aceite o emprego. Por fim, o submodelo A3 mostra-se semelhante ao A2 no que tange aos sentimentos, mas aponta que a mãe entenderia a situação e lhe atribui uma "culpa" caso não aceitem o estágio.

\section{Submodelo A1}

Número de sujeitos que aplicaram o submodelo: 16

O submodelo A1 é caracterizado pela abstração do elemento estágio, como um organizador central, que é significado como um grande objetivo de vida dos sujeitos que o aplicaram. Devido à grande vontade de aceitar o emprego na área de seu interesse, os sujeitos não demonstram anseio de ajudar a mãe e os irmãos, tampouco se sentem preocupados com eles. 
Diante do pedido de ajuda à família, os sujeitos não se sentem responsáveis pela situação, deixando-a nas mãos da mãe ou dos irmãos. Eles delegam essa responsabilidade claramente, centrando-se apenas em seu próprio objetivo.

Entende-se que o trabalho, por meio do elemento estágio abstraído pelos sujeitos, mostra-se como um valor para esses jovens, pela forma como é visualizado por eles, em detrimento da generosidade ou da responsabilidade para com a família.

Em relação aos sentimentos, percebe-se que se apresentam fortemente relacionados ao fato de aceitar o estágio. Notavelmente, não comparecem às respostas à questão um, que solicitava ao sujeito a sua resolução do conflito. Apenas, foram mencionados nas respostas às questões dois e três, quando deviam manifestá-los frente a uma decisão do protagonista. Nestas respostas, os sujeitos mostram que se sentem muito bem ao se vislumbrarem no trabalho, enquanto demonstram sentimentos extremamente negativos, como a tristeza e o malestar, quando se imaginam ajudando a mãe e recusando o estágio. Poucos sujeitos manifestam que se sentiriam mal pelo fato de não ajudar a mãe, mas esse sentimento é mobilizado de forma deveras branda e, em nosso entender, pouco significativa no contexto das respostas emitidas.

Ao estabelecer relações entre os elementos abstraídos e retidos como significativos, bem como os seus significados, os sujeitos tomam a nítida posição de seguir com os seus objetivos relacionados ao trabalho, sem se importar com o pedido de ajuda de suas mães e sem mobilizar sentimentos morais em relação ao fato de não manifestarem ajuda.

A seguir, trazemos dois exemplos para ilustrar o submodelo A1.

"Q1 - eu aceitaria o serviço para requerer conhecimento e meus irmãos teriam que saber fazer as coisas sozinho, pois eu precisaria ser independente para ter meus objetivos concluídos.

Q2 - mal, mas ao mesmo tempo realizada, pois fui atrás dos meus objetivos.

Q3 - mal, pois joguei fora uma grande oportunidade."

(Sujeito 83, 18 anos, feminino, Dourados, MS)

“Q1 - Eu iria para o estágio, minha mãe arrumaria uma babá que cuidasse dos meus irmãos, porque é realmente meu sonho e, se apareceu a oportunidade do primeiro passo, não posso desperdiçá-la.

Q2 - Me sentiria bem por estar lutando pelo sonho em relação ao meu futuro. 
Q3 - Me sentiria muito mal, pois estaria perdendo um ótima oportunidade de começar a realizar meu sonho."

(Sujeito 166, 17 anos, masculino, Ponta Grossa/ PR)

A tabela abaixo, assim como fizemos com as elaborações sobre os projetos de vida ${ }^{55}$, explicita os elementos centrais, os sentimentos, os significados atribuídos a eles e as relações/implicações que organizam esse submodelo organizador.

Tabela 22: Relações/implicações entre elementos centrais, sentimentos e seus significados no submodelo A1.

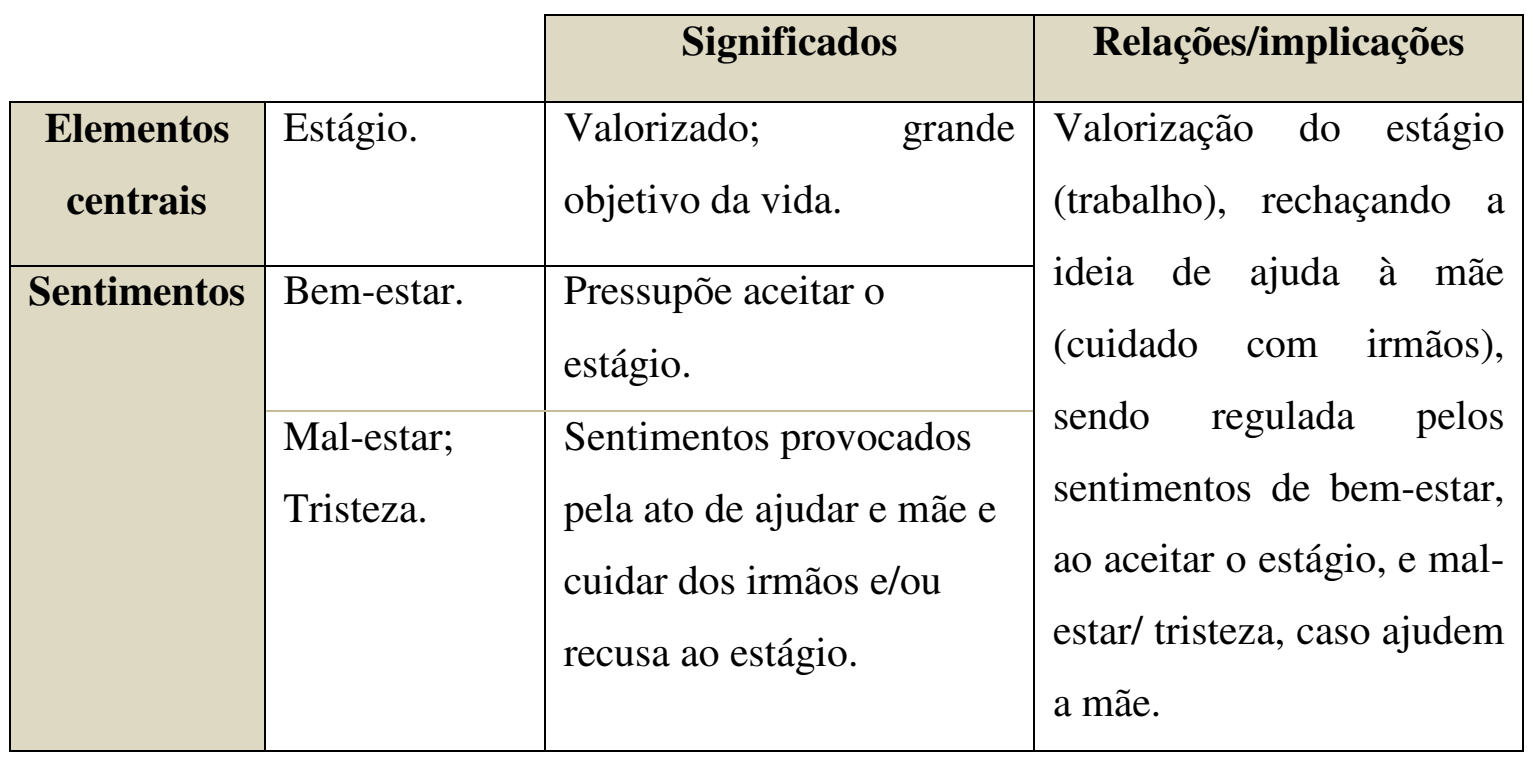

\section{Submodelo A2}

\section{Número de sujeitos que aplicaram o submodelo: 6}

Assim como no submodelo A1, o submodelo A2 foi aplicado pelos sujeitos que elegeram, entre os elementos presentes na situação de conflito moral apresentada, o estágio como elemento organizador central. Tal elemento levou esses sujeitos, pela força com que foi mobilizado, a não trazer de maneira mais efetiva a figura da mãe, que pede ajuda, e dos irmãos.

\footnotetext{
${ }^{55}$ Procuramos desenvolver o mesmo estilo de tabela para que essa análise siga da mesma forma que a anterior, sobre os projetos de vida. Compreendemos que não há tantas informações, em comparação com os modelos referentes aos projetos de vida, no entanto pensamos ser importante elucidar as dinâmicas de organização do pensamento dos jovens que aplicaram cada modelo e submodelo, de forma a torná-las mais claras.
} 
No entanto, diferentemente do submodelo anterior, neste há uma pequena preocupação com a situação da família e não apenas o enfoque na oportunidade de estágio. Tal preocupação não se evidencia fortemente nas respostas emitidas, já que não recebe muitos significados ao longo do discurso dos jovens.

Quanto aos sentimentos, é importante destacar que comparecem logo à primeira questão, quando o sujeito deve informar como resolveria o conflito e como se sentiria com essa resolução. Nas respostas à primeira questão, os sentimentos são expressos de acordo com o posicionamento dos sujeitos, o qual diz respeito ao aceite do estágio para seguir com o seu objetivo de alcançar o trabalho em sua área. Os sujeitos demonstram sentirem-se mal ora por entender que não ajudariam a mãe, ora por pensar que não poderiam aceitar o estágio.

Nas respostas às questões dois e três, verifica-se que, quando os sujeitos trazem a figura da mãe, apresentam sentimentos negativos, como tristeza e mal-estar, por não ajudarem diante do pedido. Esses sentimentos, todavia, são expressos de forma branda e logo contraditos por outros sentimentos, estes positivos, como felicidade e bem-estar, que são fortemente mobilizados em relação ao estágio.

Outro aspecto que deve ser destacado no submodelo A2 é que, muito embora se sintam mal ou infelizes quando se imaginam recusando o estágio, esses sujeitos não demonstram revolta em relação à situação ou à mãe. É uma posição de aceitação do fato, o que nos indica que o trabalho é importante para esses jovens, mas não tão fortemente mobilizado a ponto de fazê-los esquecer totalmente de suas famílias.

Diante do exposto, podemos inferir que, na abstração de elementos e na significação que lhes foi conferida, os jovens que aplicaram o submodelo A2 demonstram forte vínculo ao estágio, como parte de seus objetivos em relação ao trabalho, o que os faz ter uma preocupação frágil, mas existente, em relação à mãe e aos irmãos.

Nos dois exemplos abaixo, podemos visualizar mais detidamente como os jovens aplicaram esse submodelo.

"Q1 - eu aceitaria o estágio porque a experiência me ajudaria a crescer de vida, e me sentiria bem.

Q2 - eu me sentiria um pouco mal, mas eu explicava a ela que era muito melhor pra mim e pra ela.

Q3 - eu me sentiria mal, mas eu ia entender o que ela queria."

(Sujeito 24, 15 anos, masculino, Fortaleza, CE) 
"Q1 - me sentiria muito mal, pois não teria oportunidade de fazer o estágio que iria significar muito a mim e minha carreira.

Q2 - mal por não ter atendido ao pedido da minha mãe, mas também contente por ter aceitado o emprego que me ajudaria no meu trabalho.

Q3 - me sentiria mal por não conseguir o estágio, mas não estaria brigado com minha mãe pela situação do pedido.”

(Sujeito 117, 15 anos, masculino, Rio Claro, SP)

Vejamos a tabela abaixo que traz as relações/implicações entre os elementos, sentimentos e significados do submodelo A2.

Tabela 23: Relações/implicações entre elementos centrais, sentimentos e seus significados no submodelo A2.

\begin{tabular}{|c|c|c|c|}
\hline & & Significados & Relações/implicações \\
\hline $\begin{array}{l}\text { Elementos } \\
\text { centrais }\end{array}$ & Estágio. & $\begin{array}{l}\text { Valorizado; objetivo de } \\
\text { vida. }\end{array}$ & $\begin{array}{l}\text { Valorização do estágio } \\
\text { (trabalho), regulada por }\end{array}$ \\
\hline $\begin{array}{l}\text { Elementos } \\
\text { periféricos }\end{array}$ & Mãe e irmãos. & $\begin{array}{l}\text { Trazem preocupações com } \\
\text { situação familiar. }\end{array}$ & $\begin{array}{l}\text { sentimentos de bem-estar } \\
\text { e felicidade, com }\end{array}$ \\
\hline Sentimentos & $\begin{array}{l}\text { Bem-estar; } \\
\text { Felicidade. }\end{array}$ & $\begin{array}{l}\text { Advém da aceitação do } \\
\text { estágio. }\end{array}$ & $\begin{array}{lr}\text { preocupação } & \text { branda } \\
\text { (sentimentos } & \text { negativos) }\end{array}$ \\
\hline & $\begin{array}{l}\text { Mal-estar; } \\
\text { Infelicidade. }\end{array}$ & $\begin{array}{l}\text { Provocados por não ajudar } \\
\text { a mãe / irmãos. }\end{array}$ & $\begin{array}{l}\text { em relação à mãe e } \\
\text { irmãos. Postura de } \\
\text { aceitação da decisão da } \\
\text { mãe para não aceitar o } \\
\text { estágio. }\end{array}$ \\
\hline
\end{tabular}




\section{Submodelo A3}

\section{Número de sujeitos que aplicaram o submodelo: 22}

Bem como nos submodelos anteriores, no submodelo A3 o elemento organizador central é o estágio, que foi abstraído pelos sujeitos e significado como um objetivo fortemente mobilizado por eles.

Em consequência da centralidade assumida por esse elemento no submodelo A3 e da forma como atuou na dinâmica de pensamento desses jovens, outro elemento foi abstraído de forma bastante presente: a mãe. Esse elemento recebeu como significado a indicação de que é dever da mãe cuidar da situação e entender as suas escolhas para que eles possam seguir seus objetivos voltados para o trabalho.

O diálogo está bastante presente nesse submodelo, especialmente nas respostas à primeira questão, quando os sujeitos tinham que exprimir a forma como resolveriam o conflito. Nessas respostas, encontra-se uma mobilização para uma conversa com a mãe, com a intenção de convencê-la de que a sua escolha é o melhor para eles. Não se observa nesse diálogo a vontade de compartilhar com a família as responsabilidades, mas um posicionamento voltado para indicar os deveres da mãe e/ou convencê-la de que ela deve compreender a escolha por ingressar no estágio.

Os sentimentos comparecem principalmente nas respostas às questões dois e três. $\mathrm{Na}$ questão dois, em que os jovens deviam descrever como se sentiriam caso aceitassem o estágio e não ajudassem a mãe, eles se referem à culpa, mal-estar, tristeza, entre outros sentimentos negativos. A despeito de esses sentimentos comparecerem de forma convincente, eles não são suficientes para fazer com que os jovens que aplicaram o submodelo A3 pensem em desistir de sua escolha para ajudar a mãe. Pelo contrário, eles voltam a retomar seu objetivo, informando que a mãe iria entendê-los, com o apoio, em alguns casos, de sentimentos positivos, como bem-estar e felicidade.

$\mathrm{Na}$ última questão, cujas respostas voltaram-se para os sentimentos dos sujeitos caso tivessem ajudado a mãe e não aceitado o estágio, os sentimentos expressos são de mal-estar, tristeza e arrependimento. Os sujeitos mostram inconformismo ou revolta frente à situação.

Pode-se verificar que as relações entre os elementos abstraídos e os significados atribuídos a eles nos leva a verificar que os jovens do submodelo A3 apostam no estágio como parte de seus objetivos em relação ao trabalho e sentem a necessidade de dialogar com a 
mãe para que ela entenda a situação, assim como de acreditar que é dever dela tanto compreender quanto resolver seus problemas sozinha.

Os exemplos a seguir foram selecionados para ilustrar o submodelo A3.

"Q1 - bem diria a minha mãe que olhasse meus irmãos porque era uma chance pra eu melhorar na minha vida, para me tornar uma pessoa realizada, para eu correr atrás do meu futuro! E pediria pra ela me entender.

Q2 - me sentiria mal, mas eu estava correndo atrás do futuro e ela com certeza iria me entender.

Q3 - eu iria atrás de outras oportunidades, não ia ficar parada, pois parada a gente não consegue nada!"

(Sujeito 50, 16 anos, feminino, Fortaleza, CE)

"Q1 - Aceitaria o estágio. Temos que agarrar as oportunidades com força. Não é querer ser egoísta, sei que é difícil deixar a família na mão, mas, quando se trata do nosso futuro, só nós mesmos podemos cuidar dele. Os irmãos poderiam muito bem ir para uma escola integral, e sem querer ser egoísta de novo, acho que quem teria que mudar de planos seria a mãe. Ela fez filhos e precisa cuidar deles e de seus futuros. Eu até ajudaria em casa com parte do salário, e por que não deixar as crianças na casa de um familiar ou vizinhos, pagando um pouco por isso? Não me sentiria mal em relação a aceitar o emprego e deixar minha família em segundo plano. Tenho que cuidar de mim primeiro, infelizmente. E tudo tem solução, trabalhando se encontra uma.

Q2 - Me sentiria um pouco mal no começo, mas se minha mãe for realmente preocupada comigo, entenderia. Depois de alguns dias, estaria bem e feliz com a minha decisão. Tentaria ajudar minha mãe me ajudando primeiro.

Q3 - Muito mal e arrependido por perder a oportunidade. Derrotado por não poder seguir meus próprios passos porque os outros me impediram."

(Sujeito 170, 16 anos, masculino, Ponta Grossa, PR)

$\mathrm{Na}$ tabela a seguir, podemos observar a configuração do núcleo central do submodelo organizador A3, pelos elementos, sentimentos, significados e relações/implicações estabelecidos. 
Tabela 24: Relações/implicações entre elementos centrais, sentimentos e seus significados no submodelo A3.

\begin{tabular}{|c|c|c|c|}
\hline & Significados & Relações/ implicações \\
\hline $\begin{array}{c}\text { Elementos } \\
\text { centrais }\end{array}$ & Papel da mãe. & $\begin{array}{l}\text { Valorizado; grande } \\
\text { objetivo da vida. } \\
\text { Cuidar dos filhos. }\end{array}$ & $\begin{array}{l}\text { Valorização do estágio } \\
\text { (trabalho) e percepção do } \\
\text { dever da mãe de cuidar dos }\end{array}$ \\
\hline Sentimentos & $\begin{array}{l}\text { Inconformismo; } \\
\text { Arrependimento. }\end{array}$ & $\begin{array}{l}\text { Advém da recusa em } \\
\text { ajudar a mãe e da } \\
\text { recusa pelo estágio. } \\
\text { Advém do fato de não } \\
\text { aceitar a oportunidade } \\
\text { de estágio. } \\
\text { Ao perceber que a mãe } \\
\text { compreendeu a } \\
\text { situação.* }\end{array}$ & $\begin{array}{l}\text { filhos, o que os faz tentar o } \\
\text { diálogo para que ela } \\
\text { compreenda a situação. Os } \\
\text { sentimentos negativos } \\
\text { relacionam-se com o fato de } \\
\text { não ajudar a mãe e de } \\
\text { recusar a oportunidade de } \\
\text { estágio. } \\
\text { positivos } \\
\text { comparecem quando mãe } \\
\text { entende a posição do } \\
\text { sujeito. }\end{array}$ \\
\hline
\end{tabular}

* Em algumas respostas.

b) Modelo B - Opção pelo estágio e culpa em contrariar mãe

Número de sujeitos que aplicaram o modelo: 10

O modelo B, assim como o modelo A, traz as respostas dos sujeitos que abstraíram fortemente a opção pelo estágio. Porém, nesse modelo, tem-se uma preocupação pelo fato de ter contrariado a mãe com essa escolha.

Ao mesmo tempo em que estão presentes sentimentos positivos, como de bem-estar, por seguir com o objetivo de chegar ao mundo do trabalho, também estão presentes, de forma incisiva, sentimentos negativos ao pensar na mãe e no fato de ela não estar feliz com a situação. Entre esses sentimentos negativos, destaca-se a culpa.

Devido à culpa mobilizada pelos jovens que aplicaram o modelo $\mathrm{B}$, tem-se a presença do diálogo como forma de explicar à mãe sobre sua escolha. Diferentemente do submodelo 
A3, esse diálogo não é compreendido como passaporte para que a mãe cumpra o seu dever de entender a situação. Pelo contrário, ele serve, em nossa visão, para aliviar os sentimentos negativos em relação ao fato de não ajudar a família. Há uma diferença na forma como os sujeitos desse modelo significaram esse diálogo, o que nos fez dividi-lo em dois submodelos: o submodelo B1 traz o diálogo apenas para explicar à mãe a situação e o submodelo B2 usa o diálogo como forma de confortá-la.

\section{Submodelo B1}

\section{Número de sujeitos que aplicaram o submodelo: 5}

Trazendo a opção por realizar o estágio, os sujeitos que aplicaram o submodelo B1 o elegeram como elemento organizador central de seus juízos perante o conflito moral apresentado. Tal opção norteia as respostas desses sujeitos, fazendo com que eles estejam, em todo o seu discurso, voltados para ela.

Outro elemento presente de forma significativa é a mãe, que é vista, por esses jovens, como triste e contrariada pela decisão que tomaram. Devido à forma como significaram o papel da mãe nesse submodelo, sentem a necessidade de estabelecer um diálogo com ela para explicar sobre suas escolhas. Esse diálogo, muitas vezes, é direcionado para explicar a importância do aceite do estágio para o futuro do sujeito. Em alguns casos, também se volta para pedir desculpas à mãe.

Sobre os sentimentos, é notória a presença de bem-estar por fazer a opção pelo trabalho, mas, acima disso, estão presentes sentimentos negativos, como a culpa e o mal-estar por contrariar a mãe. Parece-nos que o diálogo comparece a esse submodelo como uma forma de amainar a culpa sentida por esses jovens.

$\mathrm{Na}$ terceira questão, quando se perguntava aos sujeitos como se sentiriam caso não aceitassem o estágio, vemos um reforço ao fato de terem escolhido o estágio pelos sentimentos de culpa e inconformismo, fortemente mobilizados ao imaginarem-se longe da opção escolhida.

Entre os elementos abstraídos e os significados que lhes foram atribuídos, vemos que os sujeitos, diante da situação de conflito moral apresentada, fazem a escolha pelo estágio, mas sentem culpa ou mal-estar por terem contrariado a mãe, o que, todavia, não os leva a 
mudar de opção, mas escolher o diálogo como forma de amenizar esses sentimentos negativos.

Temos, abaixo, dois exemplos que visam a explicitar o que descrevemos acerca do submodelo B1.

“Q1 - iria conversar bem com os pais. Pois é uma oportunidade boa e não é sempre que iria ter outra. Eu iria me sentir bem, pois iria resolver um problema e me dar bem no futuro.

Q2 - me sentiria mal, pois a mãe ficaria triste e teria que achar alguém para ficar com os irmãos, mas a profissão é boa e ajudará muito no futuro.

Q3 - que iria perder muito tempo, pois teria que atender os irmãos e demoraria mais para ter uma profissão boa."

(Sujeito 169, 16 anos, masculino, Ponta Grossa, PR)

"Q1 - Veria bem o que iria escolher, mas no caso da Milena deveria sim aceitar o estágio não por falta de profissionalismo, mas sim porque ela vai aprender coisas novas e seria melhor para o seu futuro.

Q2 - Por ela ter uma certa idade, acho que cada um tem suas decisões, pediria desculpas para a minha mãe, mas tendo sua consciência do que estaria fazendo.

Q3 - Me sentiria meio culpada sabendo que não tomei atitude pra escolher o que queria pra mim."

(Sujeito 135, 16 anos, feminino, São Paulo, SP)

A seguir, retrataremos a organização desse submodelo, explicitando os elementos centrais, os sentimentos, os significados atribuídos a eles, bem como as suas relações/implicações. 
Tabela 25: Relações/implicações entre elementos centrais, sentimentos e seus significados no submodelo B1.

\begin{tabular}{|c|c|c|c|}
\hline & & Significados & Relações/implicações \\
\hline \multirow[t]{3}{*}{$\begin{array}{c}\text { Elementos } \\
\text { centrais }\end{array}$} & Estágio. & $\begin{array}{l}\text { Valorizado; objetivo } \\
\text { de vida. }\end{array}$ & \multirow{3}{*}{$\begin{array}{l}\text { Valorização do estágio } \\
\text { (trabalho) e visão da mãe } \\
\text { como contrariada e triste } \\
\text { pela decisão do filho, o que } \\
\text { solicita o diálogo para } \\
\text { amenizar a } \quad \text { situação. } \\
\text { Sentimentos de culpa e mal- } \\
\text { estar comparecem }\end{array}$} \\
\hline & Mãe. & $\begin{array}{l}\text { Merecedora } \\
\text { explicações por meio } \\
\text { do diálogo. }\end{array}$ & \\
\hline & $\begin{array}{l}\text { Sentimentos da } \\
\text { mãe. }\end{array}$ & Triste, contrariada. & \\
\hline \multirow[t]{4}{*}{ Sentimentos } & $\begin{array}{l}\text { Culpa; mal- } \\
\text { estar; tristeza. }\end{array}$ & $\begin{array}{l}\text { Advém do fato de não } \\
\text { ajudar a mãe e de abrir } \\
\text { mão do estágio. }\end{array}$ & \multirow{4}{*}{$\begin{array}{l}\text { regulando o fato de } \\
\text { contrariar a mãe } \\
\text { juntamente com } \\
\text { inconformismo, de não } \\
\text { aceitar o estágio. O bem- } \\
\text { estar é brando e se refere ao } \\
\text { aceite do trabalho. }\end{array}$} \\
\hline & $\begin{array}{l}\text { Culpa; mal- } \\
\text { estar. }\end{array}$ & $\begin{array}{l}\text { Advém do fato de } \\
\text { contrariar a mãe e não } \\
\text { aceitar o estágio. }\end{array}$ & \\
\hline & Inconformismo. & $\begin{array}{l}\text { Advém do fato de não } \\
\text { aceitar estágio. }\end{array}$ & \\
\hline & Bem-estar. & $\begin{array}{l}\text { Advém do fato de } \\
\text { aceitar estágio. }\end{array}$ & \\
\hline
\end{tabular}

\section{Submodelo B2}

\section{Número de sujeitos que aplicaram o submodelo: 5}

Assim como no submodelo B1, no submodelo B2 os sujeitos claramente trazem a opção pelo estágio como elemento organizador central que interfere no modo de compreender e emitir juízos sobre a situação de conflito moral apresentada. Esse elemento é fortemente mobilizado ao longo das três questões respondidas.

Aqui, também se encontra a abstração do elemento mãe, porém, diferentemente do submodelo anterior, significado não só como alguém que iria se contrariar perante a sua decisão. A mãe, no submodelo B2, pode ser observada como mais atuante na situação, no 
sentido de que possui um maior vínculo com os sujeitos que o aplicaram. Tal vínculo implica maior atenção por parte desses jovens sobre a forma como irão resolver o conflito.

Em vista desse vínculo e da forma como significaram a mãe na situação apresentada, os jovens do submodelo B2 buscam o diálogo, de maneira a explicar a sua opção e a importância que ela assume para o seu objetivo de ingressar na área de sua escolha. Nesse diálogo também comparece a necessidade de confortar essa mãe e ter a certeza de sua aceitação do fato para prosseguir com a escolha.

Embora tenhamos o sentimento de bem-estar por seguir a opção de aceitar o estágio, é visível a força dos sentimentos de culpa e tristeza caso a mãe não compreenda a situação, o que reforça o que explicamos acerca do vínculo existente entre mãe e filho que foi significado por esses jovens.

Quando questionados sobre como se sentiriam caso não aceitassem o estágio, esses sujeitos sentem-se mal, insatisfeitos, tristes ou arrependidos, retomando a força que o elemento estágio tem para eles nesse submodelo organizador. Alguns sujeitos chegam a informar que compreenderiam a mãe por essa escolha, mas não manifestam sentimentos positivos a respeito disso, outros chegam a culpá-la por não compreender a situação e os obrigarem a cuidar dos irmãos.

Assim, entendemos que, na abstração e significação dos elementos presentes no conflito apresentados a esses jovens, as relações estabelecidas por eles dizem respeito a uma opção por ingressar no estágio, acompanhada por fortes sentimentos negativos atribuídos ao fato de deixarem a mãe triste. Para de fato conseguirem fazer essa escolha, esses sujeitos elegem o diálogo como forma de confortar a mãe e/ou buscar seu apoio a essa decisão, sem, destarte, promoverem uma quebra do vínculo que têm com ela.

Nas respostas a seguir, encontramos exemplos que podem elucidar o que apresentamos a respeito do submodelo $\mathrm{B} 2$.

"Q1 - Buscaria meu sonho, porque devemos nos sentir felizes com o que fazemos. Me sentiria confusa, mas seguiria o que me fizesse feliz.

Q2 - Tentaria confortá-la dizendo que eu fiz o que me fazia feliz e o que eu acredito que faço bem. Me sentiria triste por talvez ter decepcionado ela e tentaria provar que esse foi o melhor caminho para mim.

Q3 - Me sentiria insatisfeita, mas tentaria me adaptar e me dedicar mais, talvez fosse infeliz por deixar meu sonho sem ter vivido ele."

(Sujeito 189, 15 anos, feminino, Ponta Grossa, PR) 
“Q1 - faria o estágio para me capacitar e tentaria entrar num acordo com minha mãe, pois cuidar dos meus irmãos não me acrescentaria em muita coisa, mas o estágio sim.

Q2 - Se eu tivesse me entendido com ela, me sentiria bem, pois não teria com que me preocupar, mas caso minha mãe não tivesse entendido e mesmo assim eu ter aceitado a proposta com certeza me sentiria culpada e com a consciência pesada. E, consequentemente, não iria bem no estágio.

Q3 - dependendo da situação, arrependida e talvez culparia minha mãe por ter perdido uma oportunidade de ser alguém na vida.”

(Sujeito 84, 17 anos, feminino, Dourados, MS)

A tabela a seguir explicita as relações/implicações entre os elementos centrais, os sentimentos e os significados a eles atribuídos, os quais organizam o submodelo B2.

Tabela 26: Relações/implicações entre elementos centrais, sentimentos e seus significados no submodelo B2.

\begin{tabular}{|c|c|c|c|}
\hline & & Significados & Relações/ implicações \\
\hline $\begin{array}{l}\text { Elementos } \\
\text { centrais }\end{array}$ & Estágio. & $\begin{array}{l}\text { Valorizado; objetivo } \\
\text { de vida. }\end{array}$ & $\begin{array}{l}\text { Valorização do estágio } \\
\text { (trabalho) e visão da mãe }\end{array}$ \\
\hline $\begin{array}{l}\text { Elementos } \\
\text { periféricos }\end{array}$ & $\begin{array}{l}\text { Sentimentos da } \\
\text { mãe. }\end{array}$ & $\begin{array}{l}\text { Possui vínculos com o } \\
\text { sujeito; merecedora de } \\
\text { conforto e explicação } \\
\text { pelo diálogo; apenas } \\
\text { com seu } \\
\text { consentimento poderá } \\
\text { haver o aceite do } \\
\text { estágio. } \\
\text { Contrariada. }\end{array}$ & $\begin{array}{l}\text { como contrariada e que } \\
\text { merece conforto } \\
\text { explicação por meio do } \\
\text { diálogo. Apenas aceitaria o } \\
\text { estágio com } \\
\text { consentimento da mãe, o } \\
\text { que é regulado pelos } \\
\text { sentimentos de culpa e } \\
\text { tristeza. Caso não aceite o } \\
\text { estágio, apresenta }\end{array}$ \\
\hline Sentimentos & Culpa; tristeza. & $\begin{array}{l}\text { Advém do fato de a } \\
\text { mãe não compreender } \\
\text { a situação. }\end{array}$ & $\begin{array}{l}\text { sentimentos negativos e } \\
\text { projeta de forma branda } \\
\text { sentimentos positivos em }\end{array}$ \\
\hline
\end{tabular}




\begin{tabular}{|l|l|l|l|}
\hline & $\begin{array}{l}\text { Mal-estar; } \\
\text { insatisfação; } \\
\text { tristeza, } \\
\text { arrependimento. }\end{array}$ & $\begin{array}{l}\text { Advém do fato de não } \\
\text { aceitar o estágio. }\end{array}$ & relação ao aceite. \\
\cline { 2 - 4 } & Bem-estar. & $\begin{array}{l}\text { Advém do fato de } \\
\text { aceitar estágio. }\end{array}$ & \\
\hline
\end{tabular}

c) Modelo C - Opção pelo estágio como ajuda à família

Número de sujeitos que aplicaram o modelo: 7

Elegendo a opção pelo estágio como elemento organizador central, os sujeitos que aplicaram o modelo $\mathrm{C}$ significaram essa escolha como um aspecto importante do conflito moral apresentado e que faz parte de seus sonhos e projetos.

Tal elemento norteia a resolução apresentada nos protocolos e recebe um significado diferente do que foi apresentado nos modelos A e B. Nesse modelo, encontramos a opção pelo estágio como um aspecto importante para a família. Segundo esses jovens, o estágio é necessário para que tenham uma remuneração que possa ajudar imediatamente ou a longo prazo a família. A intenção desses sujeitos é a de ajudar a família, não pelo que foi solicitado pela mãe (o que parece que eles não abstraem da situação apresentada), mas pelo retorno financeiro desse trabalho.

Os sentimentos comparecem, principalmente, às questões dois e três, quando se indaga diretamente sobre eles caso tivessem a resolução de ajudar a mãe ou, pelo contrário, se concluíssem ajudá-la e abrir mão do estágio. Nas respostas à questão dois, encontram-se sentimentos negativos, como mal-estar, culpa e tristeza, os quais são logo contraditos pela afirmação de que isso era para o bem da família, o que traz bem-estar.

Já na questão três, vê-se a presença de sentimentos negativos por não ter seguido com os planos de aceitar o estágio e alcançar o objetivo de ingressar no mercado de trabalho. Em algumas respostas, há um esboço de bem-estar pelo fato de a mãe estar feliz, o qual se mostra bastante enfraquecido.

Temos, no modelo $\mathrm{C}$, a partir das relações entre os elementos abstraídos e significados que lhes foram atribuídos, uma eleição do estágio como algo importante para realização pessoal dos sujeitos, bem como imaginado por eles como algo positivo para a família. 
Os exemplos a seguir são trazidos na intenção de elucidar o modelo C.

“Q1 - bem complicado, mas acho que eu faria de tudo, para realizar o estagio, e não desistiria tão facilmente.

Q2 - me sentiria um pouco mal, mas, se eu estivesse fazendo isso, seria por uma boa causa, pois só queria fazer o estágio para proporcionar uma vida melhor para eles.

Q3 - me sentiria muito mal, pois estaria abrindo mão de um sonho.”

(Sujeito 144, 17 anos, feminino, Rio Claro, SP)

"Q1 - bom, eu no caso de Milena, me sentiria muito indecisa, pois ela tem um dever a cumprir, mas também tem sua mãe para ajudar e, na minha opinião, realizaria meu sonho pra mim, não só pensando em mim, mas também no futuro da minha mãe. Eu me sentiria indecisa demais, mas seguiria meu coração.

Q2 - eu me sentiria culpada, mas ao mesmo tempo realizada, mas seria mais realizada por no futuro eu poder dar um futuro melhor pra ela.

Q3 - triste demais, porque no futuro não poderia dar um futuro melhor pra ela."

(Sujeito 54, 16 anos, feminino, Sobral, CE)

Abaixo, apresentamos a tabela com as relações/implicações estabelecidas entre elementos centrais, sentimentos e significados do modelo C.

Tabela 27: Relações/implicações entre elementos centrais, sentimentos e seus significados no modelo C.

\begin{tabular}{|c|c|c|c|}
\hline & & Significados & Relações/implicações \\
\hline \multirow[t]{2}{*}{$\begin{array}{c}\text { Elementos } \\
\text { centrais }\end{array}$} & Estágio. & $\begin{array}{l}\text { Valorizado } r \\
\text { ingresso no mercado } \\
\text { de trabalho; importante } \\
\text { para a família } \\
\text { (remuneração). }\end{array}$ & \multirow{3}{*}{$\begin{array}{l}\text { Valorização do estágio } \\
\text { como realização pessoal e } \\
\text { como forma de ajudar a } \\
\text { família financeiramente. Os } \\
\text { sentimentos negativos } \\
\text { comparecem em relação ao } \\
\text { não aceite do estágio e o } \\
\text { bem-estar refere-se ao } \\
\text { pensamento de que o }\end{array}$} \\
\hline & Família. & $\begin{array}{l}\text { Necessita de ajuda } \\
\text { financeira. }\end{array}$ & \\
\hline Sentimentos & $\begin{array}{l}\text { Mal-estar, culpa, } \\
\text { tristeza. }\end{array}$ & $\begin{array}{l}\text { Advém do fato de não } \\
\text { aceitar o estágio. }\end{array}$ & \\
\hline
\end{tabular}




\begin{tabular}{|l|l|l|l|l|}
\hline & Bem-estar. & $\begin{array}{l}\text { Advém do fato de } \\
\text { aceitar o estágio. }\end{array}$ & $\begin{array}{l}\text { estágio é bom para a } \\
\text { família. }\end{array}$ & \\
\hline
\end{tabular}

d) Modelo D

Número de sujeitos que aplicaram o modelo: 22

No modelo D, foi abstraído como elemento organizador central o curso que o personagem da situação de conflito moral realizava e do qual teria que abrir mão no caso de aceitar o estágio. Chamou-nos a atenção a abstração desse elemento de forma tão central, porque o conflito não o enfocava, mas trazia de forma mais enfática a dúvida entre ajudar a mãe ou ingressar no estágio.

Em nossa interpretação, o curso é visto por esses jovens como possibilidade de estudar para conseguir uma oportunidade melhor de trabalho. É uma ação voltada exclusivamente para o futuro.

Alguns jovens enfocam o curso exclusivamente pela importância de estudar, enquanto outros acrescentam a esse significado a oportunidade de ajudar a família. Por essa diferença na forma como significaram o elemento curso, dividimos esse modelo nos submodelos D1 e D2.

Estão presentes os sentimentos de bem-estar por concluírem o curso e, no caso do submodelo D2, por ajudarem a família. No entanto, também é possível verificar sentimentos negativos vinculados ao fato de não aceitarem o estágio. Apesar de comparecerem de forma mais branda, estes últimos expressam que os sujeitos gostariam de aproveitar a oportunidade de ingresso no mercado de trabalho, embora julguem o mais adequado permanecer no curso para melhores chances futuras. 


\section{Submodelo D1}

\section{Número de sujeitos que aplicaram o submodelo: 12}

Os sujeitos que aplicaram o submodelo D1 elegeram o curso como elemento organizador central de suas respostas concernentes ao conflito moral apresentado. Muito embora esse elemento não estivesse presente com grande enfoque na situação fictícia, ele foi abstraído fortemente por esses jovens e significado como oportunidade de estudo, vislumbrando a futura vida profissional.

Percebe-se que o estudo se constitui em um valor para esses jovens, uma vez que eles deixam de abordar o conflito proposto para enveredar para seu enfoque.

Ao optar pelo curso, esses jovens teriam a oportunidade de englobar, também em suas respostas, a ajuda à família. Entretanto, eles não o fazem, restringindo-se apenas ao fato da importância de estudar.

Sobre os sentimentos esboçados, comparece um mal-estar brandamente mobilizado por não realizar o estágio, o qual logo é refutado por um bem-estar pela oportunidade de concluir o curso. $\mathrm{O}$ fato de não atender a mãe também é fonte de mal-estar para grande parte dos jovens. Contudo, os sentimentos não nos parecem fortemente evocados, como se qualquer resolução acarretasse um tipo de sentimento, o qual logo seria mudado, como se todas as possibilidades pudessem agradar aos jovens.

Assim, entre os elementos abstraídos e significados atribuídos, pode-se chegar à seguinte formulação: os sujeitos optam por concluir o curso e se sentem bem diante de tal escolha, mas admitem, apesar de demonstrarem mal-estar, outras possibilidades de resolução do conflito, como aceitar o estágio.

As respostas abaixo vêm a ilustrar o submodelo D1.

“Q1 - Com certeza, não aceitaria o estágio. Em primeiro lugar pra mim, estudar é o essencial. Me sentiria chateada em não aceitar, mas pensaria no meu curso, que é algo que gosto e que também irá me ajudar na vida profissional.

Q2 - Apesar de não atender ao pedido, eu me sentiria bem, pois também seria algo bom pra mim.

Q3 - Também me sentiria bem, pois acredito que tanto um quanto o outro são bons."

(Sujeito 136, 16 anos, feminino, São Paulo, SP) 
“Q1 - Optaria por terminar meu curso profissionalizante e, mais tarde, procuraria emprego. Se não preciso muito do dinheiro em determinado tempo de minha vida precocemente, escolheria obter conhecimentos.

Q2 - Me sentiria um pouco ruim por não poder ajudar minha mãe desta forma, mas com certeza estaria a ajudando de outra maneira.

Q3 - Um pouco frustrada talvez, porém acreditaria em uma nova oportunidade mais a frente.”

(Sujeito 88, 15 anos, feminino, Dourados, MS)

As relações e/ou implicações estabelecidas entre elementos, sentimentos e seus significados do submodelo D1 podem ser expressas da seguinte forma.

Tabela 28: Relações/implicações entre elementos centrais, sentimentos e seus significados no submodelo D1.

\begin{tabular}{|c|c|c|c|}
\hline & & Significados & Relações/ implicações \\
\hline $\begin{array}{l}\text { Elementos } \\
\text { centrais }\end{array}$ & Curso. & $\begin{array}{l}\text { Valorizado pela } \\
\text { oportunidade de } \\
\text { estudo, em relação ao } \\
\text { futuro profissional. }\end{array}$ & $\begin{array}{l}\text { Valorização do curso como } \\
\text { chance de estudar e garantir } \\
\text { melhor profissão no futuro. } \\
\text { Sentimentos positivos e }\end{array}$ \\
\hline $\begin{array}{l}\text { Elementos } \\
\text { periféricos }\end{array}$ & Mãe. & Solicita ajuda. & $\begin{array}{l}\text { negativos são brandos em } \\
\text { relação a não aceitar o }\end{array}$ \\
\hline Sentimentos & Bem-estar. & $\begin{array}{l}\text { Advém do fato de não } \\
\text { aceitar o estágio; não } \\
\text { atender ao pedido da } \\
\text { mãe. } \\
\text { Advém da } \\
\text { possibilidade de } \\
\text { concluir o curso }\end{array}$ & $\begin{array}{l}\text { estágio, a não atender à mãe } \\
\text { ou concluir o curso. }\end{array}$ \\
\hline
\end{tabular}




\section{Submodelo D2}

\section{Número de sujeitos que aplicaram o submodelo: 10}

Assim como no submodelo D1, o elemento organizador central abstraído pelos sujeitos no submodelo D2 é o curso, a despeito desse elemento não ter comparecido com centralidade no conflito moral apresentado aos jovens participantes de nossa pesquisa.

Tal elemento norteia o conjunto de respostas, sendo significado como possibilidade de estudo para melhores chances profissionais no futuro. O estudo mostra-se um valor para esses jovens que acreditam que, por meio dele, podem ser bem-sucedidos futuramente.

Juntamente a esse elemento, aparece com bastante ênfase a ajuda à mãe e a ajuda à família. Os sujeitos aliam o fato de desejarem concluir o curso com a vontade de auxiliar a mãe diante de seu pedido. Eles também se manifestam a favor de tomar ações que não se voltem a magoar a mãe ou preocupá-la, alguns inclusive indicando que gostariam de retribuir o que ela já fez por eles.

Em relação aos sentimentos, percebe-se que os sujeitos se sentem mal ou tristes por não aceitarem o estágio, já que este seria na área em que querem ingressar. Os sentimentos de bem-estar e felicidade, todavia, se posicionam mais fortemente em favor da escolha do curso e da ajuda oferecida à família.

Essa perspectiva é bastante coerente e comparece em todas as respostas, especialmente na emitida à terceira questão. Os jovens apontam que se sentiriam tristes por não poderem aceitar o trabalho, mas felizes por concluir o curso e ter melhores possibilidades futuras de emprego, bem como não magoar a mãe e ajudá-la a cuidar dos irmãos. Tal presença de sentimentos reforça posicionamentos das questões anteriores.

Dessa forma, chegamos à conclusão de que, para os jovens que emitiram respostas de acordo com o submodelo D2, o curso e, concomitantemente, a ajuda à mãe são elementos importantes. Eles gostariam de aceitar o estágio, mas ponderam suas escolhas e elegem os elementos com vistas a garantir um futuro melhor estruturado no campo do trabalho.

De forma a elucidar o submodelo D2, apresentamos os dois exemplos a seguir. 
“Q1 - Não aceitaria o estágio porque, se eu parasse o curso, talvez não conseguisse um emprego fixo naquela empresa por não ter o curso completo. Me sentiria muito triste porque estágios em grandes empresas nessa área são muito difíceis de conseguir, mas apesar disso me sentiria feliz por poder completar o curso e minha mãe iria se sentir despreocupada, porque meus irmãos não ficariam sozinhos em casa.

Q2 - Me sentiria ao mesmo tempo feliz e triste. Me sentiria feliz por poder ter um emprego em uma área que gosto. Me sentiria triste por ter magoado minha mãe e por não poder terminar o curso, podendo dificultar minha fixação no mercado de trabalho.

Q3 - Me sentiria ao mesmo tempo feliz e triste. Me sentiria triste por não poder ter um emprego em uma área que gosto. Me sentiria feliz por não ter magoado minha mãe e por poder terminar o curso, podendo facilitar minha fixação no mercado de trabalho."

(Sujeito 128, 15 anos, feminino, São Paulo, SP)

"Q1 - Já que no momento eu não poderia fazer o estágio eu tentaria concluir o curso técnico e deixaria essa vontade para um momento que fosse possível. O estágio seria uma coisa muito importante, mas o curso técnico também traria benefícios pro meu futuro. No momento, sentiria uma certa frustração por não conseguir o que tanto queria naquele momento mas logo veria que no futuro poderiam surgir outras oportunidades.

Q2 - Acho que dificilmente isso aconteceria, mas, se por acaso acontecesse, eu mesmo fazendo uma coisa importante para mim ficaria com a consciência pesada por não ter atendido ao pedido e necessidade da minha mãe, tentaria outra forma de resolver o problema e, por mais que estivesse gostando do estágio, se não conseguisse resolver desistiria dele. Q3 - Estaria desistindo de uma coisa que era importante pra mim, por isso me sentiria mal, mas por outro lado estaria com a consciência tranquila por ter aceitado ajudar minha mãe ficando com meus irmãos. Durante um bom tempo eu ficaria pensando na oportunidade que eu havia perdido, mas acho que, com o decorrer do tempo, eu ia acabar me acostumando."

(Sujeito 53, 17 anos, feminino, Sobral, CE)

$\mathrm{Na}$ tabela a seguir, constam as relações/implicações estabelecidas entre elementos centrais, sentimentos e significados que lhes foram atribuídos no submodelo D2. 
Tabela 29: Relações/implicações entre elementos centrais, sentimentos e seus significados no submodelo D2.

\begin{tabular}{|c|c|c|c|}
\hline & & Significados & Relações/implicações \\
\hline \multirow[t]{2}{*}{$\begin{array}{l}\text { Elementos } \\
\text { centrais }\end{array}$} & Curso. & $\begin{array}{l}\text { Valorizado pela } \\
\text { oportunidade de } \\
\text { estudo, em relação ao } \\
\text { futuro profissional; } \\
\text { possibilidade de acatar } \\
\text { pedido da mãe e ajudar } \\
\text { família. }\end{array}$ & \multirow{5}{*}{$\begin{array}{l}\text { Valorização do curso como } \\
\text { chance de estudar e garantir } \\
\text { melhor profissão no futuro, } \\
\text { bem como ajudar a mãe, } \\
\text { para não magoá-la. } \\
\text { Apresentam-se mal-estar e } \\
\text { tristeza em relação a não } \\
\text { aceitar o estágio e não } \\
\text { atender ao pedido da mãe; } \\
\text { bem-estar e felicidade em } \\
\text { concluir o curso e ajudar a } \\
\text { mãe e a família. }\end{array}$} \\
\hline & Mãe. & $\begin{array}{l}\text { Não pode ser } \\
\text { magoada; necessita } \\
\text { retribuição pelo que } \\
\text { fez no passado*. }\end{array}$ & \\
\hline $\begin{array}{l}\text { Elementos } \\
\text { periféricos }\end{array}$ & Estágio. & $\begin{array}{l}\text { Área em que querem } \\
\text { trabalhar. }\end{array}$ & \\
\hline \multirow[t]{2}{*}{ Sentimentos } & $\begin{array}{l}\text { Mal-estar; } \\
\text { tristeza. }\end{array}$ & $\begin{array}{l}\text { Advém do fato de não } \\
\text { aceitar o estágio; não } \\
\text { atender ao pedido da } \\
\text { mãe. }\end{array}$ & \\
\hline & $\begin{array}{l}\text { Bem-estar; } \\
\text { felicidade. }\end{array}$ & $\begin{array}{l}\text { Advém da } \\
\text { oportunidade de } \\
\text { concluir o curso; de } \\
\text { ajudar a mãe e a } \\
\text { família. }\end{array}$ & \\
\hline
\end{tabular}

\footnotetext{
* Em algumas respostas.
} 
e) Modelo E - Dever de ajudar a mãe

\section{Número de sujeitos que aplicaram o modelo: 20}

O modelo E traz como elemento organizador central a ajuda à família. Essa ajuda é significada pelos jovens que o aplicaram como uma obrigação ou um dever relacionado à figura da mãe.

Os sujeitos manifestam a vontade de aceitar o estágio, mas refletem sobre seu dever como filhos e acatam ao pedido da mãe.

Devido à forma como os sentimentos foram mobilizados por esse grupo de jovens, separamos os protocolos em dois submodelos organizadores. No submodelo E1, os sujeitos, embora tristes pelo fato de não optarem pelo estágio, sentem-se muito bem e felizes por auxiliar a mãe e, consequentemente, ajudar a família. Em contrapartida, no submodelo E2, encontram-se sentimentos negativos em relação a essa obediência, como mal-estar, tristeza, arrependimento e inconformismo.

\section{Submodelo E1}

\section{Número de sujeitos que aplicaram o submodelo: 14}

A ajuda à mãe é o elemento organizador central do submodelo E1. Os sujeitos significam essa ajuda indicando a importância da família e, em algumas respostas, a possibilidade de aproveitar o tempo para estudar mais e concluir o curso técnico.

Mais fortemente evocado, porém, é o significado de uma certa obrigação em ajudar a mãe. Os jovens dão indicações de que querem ajudar a mãe para não magoá-la, o que nos informa que o vínculo com ela é um valor que recebe bastante carga afetiva positiva por eles. Há também a ideia de que a mãe é sábia e sempre os aconselha de forma orientá-los no que lhes seja melhor.

O elemento estágio não é desprezado por esse grupo de sujeitos, que o interpretam como uma oportunidade real de ingressar na área em que gostariam de atuar. Contudo, tal elemento não se posiciona como central nesse submodelo organizador, estando menos valorado que o respeito ao pedido da mãe. 
A respeito dos sentimentos, percebe-se que, ao tratar do fato de não aceitar o estágio, os jovens sentem mal-estar e tristeza. Eles expressam, entretanto, fortes sentimentos positivos, como bem-estar e felicidade, ao ajudarem a mãe.

No processo de abstração e significação dos elementos, nota-se que os jovens que aplicaram o submodelo E1 têm como foco a ajuda à mãe e sentem-se muito bem por auxiliála. Eles gostariam de aceitar o estágio, mas esse dever em relação à mãe é mais forte e os leva a decidir por ajudá-la.

Nas respostas a seguir, temos exemplos do submodelo E1.

“Q1 - Acho que ajudaria minha mãe não aceitando o estágio. Outras oportunidades estão por vim mais para frente. Por enquanto, eu terminaria o curso, ganhava experiência e depois sim eu conseguiria talvez um estágio bem melhor do que o anterior. Eu me sentiria triste sim por ter perdido uma grande oportunidade, mas outras virão!

Q2 - Eu me sentiria muito mal sabendo que não obedeci minha mãe e deixei os meus irmãos menores sozinhos ou até com pessoas desconhecidas.

Q3 - Me sentiria muito triste, mas muito bem por ter atendido ao pedido da minha mãe e seguido o conselho dela porque o melhor estará por vim pra mim!”

(Sujeito 121, 16 anos, feminino, São Paulo, SP)

"Q1 - Me sentiria dividida entre meu sonho e minha família, mas minha família é muito mais importante para mim do que meus sonhos.

Q2 - Muito mau, porque sempre obedeci minha mãe. Não teria sentido me tornar uma pessoa bem sucedida com minha mãe desapontada comigo.

Q3 - Me sentiria com dever cumprido. Ficaria um pouco mal, mas minha mãe é mais importante pra mim."

(Sujeito 123, 16 anos, feminino, São Paulo, SP)

$\mathrm{Na}$ tabela, apresentamos as relações/implicações entre os elementos, sentimentos e significados articulados no submodelo E1. 
Tabela 30: Relações/implicações entre elementos centrais, sentimentos e seus significados no submodelo E1.

\begin{tabular}{|c|c|c|c|}
\hline & & Significados & Relações/implicações \\
\hline $\begin{array}{l}\text { Elementos } \\
\text { centrais }\end{array}$ & Mãe. & $\begin{array}{l}\text { Necessita de ajuda; } \\
\text { sábia; emite conselhos } \\
\text { que beneficiam o(a) } \\
\text { filho(a). }\end{array}$ & \multirow{4}{*}{$\begin{array}{l}\text { A mãe necessita de ajuda e } \\
\text { possui sabedoria, por isso } \\
\text { existe o dever do sujeito em } \\
\text { acatar com o pedido da } \\
\text { mãe. Há sentimentos } \\
\text { positivos que reforçam essa } \\
\text { escolha. O } \\
\text { comparece de } \\
\text { secundária forma } \\
\text { sentimentos } \\
\text { brandos. }\end{array}$} \\
\hline $\begin{array}{l}\text { Elementos } \\
\text { periféricos }\end{array}$ & Estágio. & $\begin{array}{l}\text { Oportunidade de } \\
\text { ingressar no mercado } \\
\text { de trabalho. }\end{array}$ & \\
\hline \multirow[t]{2}{*}{ Sentimentos } & $\begin{array}{l}\text { Mal-estar; } \\
\text { tristeza. }\end{array}$ & $\begin{array}{l}\text { Advém do fato de não } \\
\text { aceitar o estágio; não } \\
\text { atender ao pedido da } \\
\text { mãe. }\end{array}$ & \\
\hline & $\begin{array}{l}\text { Bem-estar; } \\
\text { felicidade. }\end{array}$ & $\begin{array}{l}\text { Advém do fato de } \\
\text { ajudar a mãe. }\end{array}$ & \\
\hline
\end{tabular}

\section{Submodelo E2}

\section{Número de sujeitos que aplicaram o submodelo: 6}

O submodelo $\mathrm{E} 2$ traz como elemento organizador central a ajuda à mãe, assim como o submodelo E1. Essa ajuda é significada como algo fundamental para a mãe, que é uma pessoa importante para os sujeitos que aplicaram esse submodelo.

A mãe é vista como uma pessoa que tem obrigações para com a família e que precisa trabalhar para sustentá-la. Os sujeitos articulam essa ideia da necessidade de emprego da mãe em comparação com a sua própria necessidade e pendem por acatar o pedido dela feito a eles de cuidar dos irmãos.

Os jovens sentem uma "pressão" da situação e no dever de atender à solicitação da mãe. Contrariamente ao submodelo anterior, constitui-se em uma forma de se posicionar frente ao dever de ajudá-la que contesta e que não aceita passivamente o ocorrido. 
Os sujeitos revelam a importância que o elemento estágio assume para eles. Entendendo o estágio como um passo fundamental para suas projeções de trabalho futuro, esses jovens refletem sobre as duas possibilidades, de aceitá-lo ou não, e pendem em atender à mãe, pois não gostariam de contrariá-la, assim como inferir na rotina e nas despesas da família.

Importante notar que esses jovens não discutem sobre a necessidade de ajudar a mãe a tomar conta dos irmãos, mas revelam estar preocupados com a obrigação dessa mãe de trabalhar para sustentar a família. Entre o trabalho da mãe e o estágio oferecido, percebem que é mais vantajoso que a mãe esteja trabalhando.

Os sentimentos revelam e são revelados pelos elementos abstraídos por esses sujeitos. Como se sentem diante de uma "pressão" da situação, apontam infelicidade, desilusão, malestar e culpa por terem que atender ao pedido da mãe e não ingressar no estágio. Parece-nos que o fato de ter ajudado a mãe causa sentimentos negativos nesses jovens.

Além desses sentimentos, os sujeitos indicam também certo conformismo com a situação, mostrando-se desiludidos e tristes, mas sem reação ao atender ao pedido da mãe.

As relações estabelecidas entre os elementos abstraídos e os significados que lhes foram atribuídos nos levam a considerar que o submodelo E2 é composto de uma ajuda a mãe e, necessariamente, a ajuda à família, que não são bem recebidos pelos sujeitos, cujos sentimentos negativos revelam a vontade de ingressar no estágio.

Como exemplos para o que exploramos acima, apresentamos dois conjuntos de respostas.

"Q1 - mas a mãe de Milena tem que trabalhar para dar um futuro mais estável a ela e seus irmãos, sendo que, se a Milena for fazer o estágio, não receberá nada em troca em relação à verba e infelizmente, no mundo em que vivemos, não conseguiríamos viver sem um capital, isso é normal no Brasil, pois se houvesse um local para o irmão de Milena ficar, se o nosso querido governo oferecesse essa estabilidade, será que a Milena não poderia realizar seu sonho e a sua mãe também poderia trabalhar? Mas, enfim, ela se afastará cada vez mais do seu sonho, sendo que ela estava tão próxima a ele.

Q2 - não consigo nem explicar muito bem, pois com certeza eu teria atendido pelo pedido de minha mãe, mas com certeza não me sentiria feliz com a minha decisão, pois teria me afastado de um sonho que estava tão perto.

Q3 - me sentiria desiludida pelo meu sonho.”

(Sujeito 139, 15 anos, feminino, Rio Claro, SP) 
“Q1 - Eu não aceitaria o estágio, porque acho que minha mãe deveria trabalhar sim. Me sentiria vazio, triste, desiludido, mas iria mostrar a ela que era isso mesmo que eu queria. Q2 - Pressionado. Eu não gostaria de contrariar minha mãe, pelo que ela já fez por mim na vida, e que eu teria ainda muito tempo para viver a minha vida...

Q3 - Injustiçado. Porque nós precisamos do dinheiro e ela parece não estar nem aí, e ia acabar conformado porque gastar para uma pessoa cuidar não resolveria nada o nosso problema."

(Sujeito 72, 15 anos, masculino, Dourados, MS)

Apresentamos, a seguir, os elementos, sentimentos, significados e relações/implicações do submodelo E2.

Tabela 31: Relações/implicações entre elementos centrais, sentimentos e seus significados no submodelo E2.

\begin{tabular}{|c|c|c|c|}
\hline & Significados & Relações/implicações \\
\hline $\begin{array}{l}\text { Elementos } \\
\text { centrais }\end{array}$ & Mãe. & $\begin{array}{l}\text { Importante; tem } \\
\text { obrigações para com a } \\
\text { família. }\end{array}$ & $\begin{array}{l}\text { A mãe tem obrigações } \\
\text { perante a família e, por isso, } \\
\text { trabalha. Entre o trabalho da }\end{array}$ \\
\hline \multirow[t]{2}{*}{$\begin{array}{l}\text { Elementos } \\
\text { periféricos }\end{array}$} & Trabalho da mãe & $\begin{array}{l}\text { Oferecerá } \\
\text { remuneração } \\
\text { vantajosa }\end{array}$ & \multirow{3}{*}{$\begin{array}{l}\text { mãe e o do sujeito, há } \\
\text { reflexão, pesando a } \\
\text { remuneração da mãe. O } \\
\text { estágio é valorizado como } \\
\text { passo importante para o } \\
\text { futuro, mas comparado ao } \\
\text { emprego da mãe. Mostram- } \\
\text { se sentimentos negativos } \\
\text { em relação a acatar o } \\
\text { pedido da mãe. }\end{array}$} \\
\hline & $\begin{array}{l}\text { Remuneração do } \\
\text { estágio }\end{array}$ & $\begin{array}{l}\text { Fundamental para o } \\
\text { futuro profissional;. } \\
\text { Inferior ao emprego da } \\
\text { mãe. }\end{array}$ & \\
\hline Sentimentos & $\begin{array}{l}\text { Infelicidade; } \\
\text { desilusão; mal- } \\
\text { estar; culpa. }\end{array}$ & $\begin{array}{l}\text { Advém do fato de não } \\
\text { aceitar o estágio; de } \\
\text { não atender ao pedido } \\
\text { da mãe. }\end{array}$ & \\
\hline
\end{tabular}




\section{f) Modelo F - Ajuda à mãe e à família}

\section{Número de sujeitos que aplicaram o modelo: 29}

No modelo $\mathrm{F}$, os sujeitos claramente abstraem como elemento organizador central a ajuda à mãe. Tal elemento é significado pela firme não aceitação do estágio e pela visualização das necessidades da família. A intenção desses jovens é não deixar a família e cuidar dos irmãos, tanto para que a mãe não fique preocupada quanto para que eles também se sintam tranquilos com a situação. Assim, dão indicações de que não aceitariam o estágio, assumindo responsabilidade em relação à família. Esses jovens relegam seus objetivos em prol da família, enfocando o bem-estar dela.

Outro elemento que foi significado apenas por parte dos sujeitos que aplicaram o modelo $\mathrm{F}$ foi o fato de que desejam retribuir à mãe o que ela já fez por eles (cuidados, educação, etc.). Frente à presença desse significado em um grupo de jovens, decidimos dividir o modelo $\mathrm{F}$ em dois submodelos. O submodelo F1, em que tal significação não comparece; o submodelo F2 que a traz de forma contundente.

Quanto aos sentimentos, pode-se vislumbrar que o fato de não atender à mãe e à família levaria esses sujeitos a sentimentos extremamente negativos como a culpa, forte malestar e tristeza. Um termo frequentemente utilizado por eles é egoísmo.

Ao se imaginarem ajudando a família, esses jovens sentem-se muito bem, felizes e realizados por tal escolha, o que reforça o elemento central destacado.

\section{Submodelo F1}

\section{Número de sujeitos que aplicaram o submodelo: 18}

Elegendo como elemento organizador central a ajuda à mãe, os sujeitos que aplicaram o submodelo F1 o significam como uma necessidade de não magoá-la, assim como de não “dar as costas" à família em um momento em que precisa de auxílio. Os jovens desse submodelo sentem-se responsáveis pelos seus pais e irmãos.

Outros significados que foram atribuídos a esse elemento, são a importância que a mãe dá ao emprego que conseguiu e a característica do vínculo entre mãe e filho, que imprime um significado de ajuda mútua e constante na família. 
Alguns dos sujeitos cujas respostas foram agrupadas no submodelo F1 mencionaram o curso como aspecto fundamental para o futuro profissional. No entanto, esse elemento não foi eleito como central e norteador do discurso desses jovens.

Sobre o estágio, os sujeitos não se mostram indiferentes. Pelo contrário, manifestam vontade de aceitá-lo, porém ponderam sobre suas escolhas e ajudar a família sobressai-se mediante suas reflexões.

Os jovens apresentam sentimentos positivos, estreitamente articulados à ajuda à mãe. Em outras palavras, sentem-se felizes e realizados pela escolha tomada. Ademais, mobilizam fortemente sentimentos negativos, como culpa, infelicidade e mal-estar quando se imaginam contrariando o desejo de auxiliar a família na situação apresentada. Muitos desses jovens apontam que, se não atendessem à mãe, seriam egoístas.

Quando questionados sobre como se sentiriam caso não aceitassem o estágio para ajudar a mãe, os sujeitos informam que estariam tristes por perderem a oportunidade, mas conformados com a situação. Tais sentimentos são enfraquecidos pelo fato de que logo esboçam felicidade e realização por poder ajudar a mãe nesse momento em que ela precisa.

No processo de abstração e significação dos elementos, esses jovens apontam o desejo de atender à mãe com o objetivo de ajudar a família, pela qual se imaginam responsáveis. Embora se sintam mal por perderem oportunidades, sentem-se felizes e realizados por ajudar.

Nas respostas abaixo, acreditamos poder elucidar o submodelo F1.

"Q1 - Eu recusaria o estágio, mesmo sabendo que uma oportunidade como essa é quase única, continuaria com meu curso e cuidaria dos meus irmãos, uma vez que eu me sentiria triste recusando o estágio, mas por outro lado me sentiria feliz por estar ajudando minha mãe.

Q2 - Me sentiria feliz de um lado por estar trabalhando com algo que eu gosto e que poderá ajudar em meu futuro, mas por outro lado sinto grande remorso por saber que estou fazendo algo que me deixa feliz e que acaba magoando minha mãe, pois, no momento que ela mais precisou de mim, eu deixei-a.

Q3 - Feliz por estar ajudando minha mãe, pois seria muito difícil para arrumar alguém confiável para ficar com meus irmãos. O meu futuro poderia esperar um pouco, mesmo tendo em mente que oportunidades como essa que eu perdi poderão não voltar mais.”

(Sujeito 73, 15 anos, masculino, Dourados, MS) 
“Q1 - Eu ficaria com meus irmãos, pois sei o quanto esse emprego é importante para minha mãe. Apesar de querer muito aceitar a proposta de estágio, sei que outras propostas iguais ou melhores que esta surgirão em minha vida. Ficarei triste por um tempo, mas saberei que essa foi a decisão certa a tomar.

Q2 - O sentimento de culpa me inundaria e eu não conseguiria continuar no estágio. Afinal, no momento em que minha mãe realmente precisou de mim, eu não pude ajudá-la porque fui egoísta e não quis enxergar que este emprego era muito importante para minha mãe.

Q3 - Ficaria triste durante um tempo, no entanto, saberia que tomei a decisão certa. Acho que meu estágio não é tão importante quando comparado ao emprego de minha mãe."

(Sujeito 14, 16 anos, feminino, Macapá, AP)

A seguir, demonstramos na tabela as relações/implicações entre elementos, sentimentos e seus significados no submodelo F1.

Tabela 32: Relações/implicações entre elementos centrais, sentimentos e seus significados no submodelo F1.

\begin{tabular}{|c|c|c|c|}
\hline & & Significados & Relações/implicações \\
\hline \multirow[t]{3}{*}{$\begin{array}{l}\text { Elementos } \\
\text { centrais }\end{array}$} & Mãe. & $\begin{array}{l}\text { Não é merecedora de } \\
\text { mágoa. Merece ajuda. }\end{array}$ & \multirow{6}{*}{$\begin{array}{l}\text { Ajuda à mãe, como forma } \\
\text { de cuidar da família, pela } \\
\text { qual sentem } \\
\text { responsáveis. Os elementos } \\
\text { estágio e curso são } \\
\text { mobilizados como } \\
\text { importantes, mas ficam em } \\
\text { um segundo plano, em } \\
\text { relação à família. Os } \\
\text { sentimentos positivos } \\
\text { negativos reforçam escolha } \\
\text { em ajudar a família. }\end{array}$} \\
\hline & Emprego da mãe & Importante. & \\
\hline & Família. & $\begin{array}{ll}\text { Fonte } & \text { de } \\
\text { responsabilidade } & \text { do } \\
\text { sujeito. } & \end{array}$ & \\
\hline \multirow[t]{2}{*}{$\begin{array}{l}\text { Elementos } \\
\text { periféricos }\end{array}$} & $\begin{array}{l}\text { Conflito } \\
\text { apresentado. }\end{array}$ & $\begin{array}{l}\text { Provoca muitas } \\
\text { dúvidas no filho entre } \\
\text { atender seu desejo ou a } \\
\text { necessidade da mãe. }\end{array}$ & \\
\hline & Curso. & $\begin{array}{l}\text { Importante para } \mathrm{o} \\
\text { futuro profissional. }\end{array}$ & \\
\hline Sentimentos & $\begin{array}{l}\text { Felicidade; } \\
\text { realização. }\end{array}$ & $\begin{array}{l}\text { Advém do fato de } \\
\text { ajudar a mãe e cuidar } \\
\text { da família. }\end{array}$ & \\
\hline
\end{tabular}




\begin{tabular}{|l|l|l|l|}
\hline $\begin{array}{l}\text { Culpa, } \\
\text { infelicidade } \\
\text { mal-estar. }\end{array}$ & $\begin{array}{l}\text { Advém do fato de não } \\
\text { ajudar a família. }\end{array}$ \\
$\begin{array}{l}\text { Tristeza } \\
\text { (brando) }\end{array}$ & $\begin{array}{l}\text { Advém do fato de não } \\
\text { aceitar o estágio. }\end{array}$ & \\
\hline
\end{tabular}

\section{Submodelo F2}

\section{Número de sujeitos que aplicaram o submodelo: 11}

Assim como no submodelo F1, no submodelo F2 o elemento organizador central abstraído foi a ajuda à mãe, de acordo com a percepção que esses jovens têm a respeito de sua responsabilidade em relação às suas famílias. Eles desejam ajudar a tomar conta dos irmãos, preocupando-se com o bem-estar de seus familiares.

A figura da mãe é significada como alguém que sempre deu apoio e tomou muitas ações positivas em prol desses sujeitos. Assim, eles se veem com a chance de retribuir um pouco do que já receberam dela ao longo de suas vidas.

O estágio é abstraído como uma oportunidade importante de trabalho, que colaboraria para o futuro. Contudo, os sujeitos que aplicaram o submodelo F2 não se voltam ao seu aceite para enfocar o vínculo familiar. Eles assumem uma postura de conformismo com a situação, pensando que outras oportunidades estão por vir, ainda mais por eles serem tão jovens.

No submodelo F2, os sentimentos estão correlacionados aos elementos abstraídos, no sentido de que realimentam as escolhas tomadas pelos sujeitos. Apesar de se sentirem mal e tristes por não aceitarem o estágio, os sujeitos sentem-se muito bem e responsáveis por ajudarem a mãe. Eles relatam uma sensação de "dever cumprido", como se tivessem feito uma escolha acertada.

Ao se imaginar não atendendo à solicitação da mãe, esses jovens revelam sentimentos negativos muito fortes, como culpa, desprezo por si mesmos, infelicidade e extremo malestar, indicando a centralidade que o elemento ajuda à mãe ocupa em sua organização psíquica frente à situação de conflito moral apresentada.

$\mathrm{Na}$ questão três, ao serem indagados a respeito de quais seriam seus sentimentos se tivessem aceitado ajudar a mãe, os jovens apostam em sentimentos iniciais negativos em relação à oportunidade perdida, os quais logo são rechaçados por sentimentos positivos 
vinculados ao fato de terem feito, em suas opiniões, o correto diante do conflito. Há certo conformismo com a situação e a indicação de que, no futuro, outras oportunidades aparecerão.

Assim sendo, podemos inferir que, na abstração e seleção de elementos, os sujeitos que aplicaram o submodelo F2 elegem ajudar a mãe, porque se sentem responsáveis pela família e porque desejam retribuir o que julgam que ela fez por eles. Ao ajudar a família se sentem bem, mas não deixam de registrar sua vontade de ingressar no estágio.

Os conjuntos de respostas a seguir foram selecionados de forma a aclarar o que expusemos acerca do submodelo F2.

“Q1 - Eu pensaria sinceramente no bem estar da minha família, poxa, minha mãe precisa de mim, sustenta a mim e aos meus irmãos, portanto, ela merece meu apoio. Outras oportunidades surgirão. Eu ficaria bastante feliz no começo, mas com o tempo eu aceitaria, foi o melhor para todos, pelo menos, por enquanto.

Q2 - Eu me sentiria culpada e horrível por dentro. Mãe é tudo, e eu deveria sim, ter aceito o pedido dela, mesmo que pudesse me prejudicar num futuro profissional.

Q3 - No começo ficaria triste, e pensando em tudo que perdi por não ter aceito a proposta. Mas depois esse sentimento de raiva mista de tristeza, passaria.”

(Sujeito 81, 16 anos, feminino. Goiânia, GO)

"Q1 - Ficaria entre a razão e a emoção. A emoção de ter um emprego em uma grande fábrica onde teria uma ótima experiência profissional, mas ficaria com o pedido da minha mãe, porque sei que, ajudando, faria isso de muito bom grado, e não me arrependeria.

Q2 - Me sentiria muito mal, com muito orgulho no coração, por não ter ajudado aquela pessoa que sempre me ajudou em tudo na minha vida. Não me sentiria feliz, ficaria angustiado em deixar minha família para trás.

Q3 - Sentiria muito feliz estaria retribuindo tudo aquilo que ela fez por mim. E saberia que bem mais na frente algo melhor iria aparecer para mim."

(Sujeito 30, 16 anos, masculino, Sobral, CE)

$\mathrm{Na}$ tabela a seguir, apontamos os elementos, sentimentos, significados atribuídos e as relações/implicações referentes a eles no submodelo F2. 
Tabela 33: Relações/implicações entre elementos centrais, sentimentos e seus significados no submodelo F2.

\begin{tabular}{|c|c|c|c|}
\hline & & Significados & Relações/implicações \\
\hline \multirow[t]{2}{*}{$\begin{array}{l}\text { Elementos } \\
\text { centrais }\end{array}$} & Mãe. & $\begin{array}{l}\text { Pessoa que sempre deu } \\
\text { apoio e atuou de forma } \\
\text { positiva em relação ao } \\
\text { sujeito; merece } \\
\text { retribuição. }\end{array}$ & \multirow{6}{*}{$\begin{array}{l}\text { Ajuda à mãe, como forma } \\
\text { de retribuir seu apoio e } \\
\text { cuidar da família, pela qual } \\
\text { se sentem responsáveis. } \\
\text { Sentem desejo de ingressar } \\
\text { no estágio, mas deixam esse } \\
\text { elemento em segundo } \\
\text { plano. Os sentimentos } \\
\text { positivos e negativos } \\
\text { reforçam escolha em ajudar } \\
\text { a família. }\end{array}$} \\
\hline & Família. & $\begin{array}{l}\text { Fonte de } \\
\text { responsabilidade do } \\
\text { sujeito; apresenta } \\
\text { preocupação com seu } \\
\text { bem-estar. }\end{array}$ & \\
\hline $\begin{array}{l}\text { Elementos } \\
\text { periféricos }\end{array}$ & Estágio. & $\begin{array}{l}\text { Oportunidade de } \\
\text { trabalho que } \\
\text { colaboraria para } \\
\text { futuro; impedimento } \\
\text { para atender a } \\
\text { necessidade da família. }\end{array}$ & \\
\hline \multirow[t]{3}{*}{ Sentimentos } & $\begin{array}{l}\text { Felicidade; } \\
\text { realização. }\end{array}$ & $\begin{array}{l}\text { Advém do fato de } \\
\text { ajudar a mãe e cuidar } \\
\text { da família. }\end{array}$ & \\
\hline & $\begin{array}{l}\text { Culpa; desprezo } \\
\text { por si mesmos; } \\
\text { infelicidade; } \\
\text { intenso mal- } \\
\text { estar. }\end{array}$ & $\begin{array}{l}\text { Advém do fato de não } \\
\text { atender ao pedido da } \\
\text { mãe; não ajudar a } \\
\text { família. }\end{array}$ & \\
\hline & $\begin{array}{l}\text { Mal-estar; } \\
\text { Tristeza } \\
\text { (brando) }\end{array}$ & $\begin{array}{l}\text { Advém do fato de não } \\
\text { aceitar o estágio. }\end{array}$ & \\
\hline
\end{tabular}




\section{g) Modelo G - Conciliação de interesses}

\section{Número de sujeitos que aplicaram o modelo: 62}

Pode-se afirmar que, no modelo G, os sujeitos abstraíram como elemento organizador central uma resolução do problema que beneficiasse não apenas a si mesmos, mas também a família.

Esse elemento é significado com uma solução prática do problema, envolvendo tanto o aceite ao estágio quanto a ajuda à família. São exemplos para essas soluções: contratar uma babá para cuidar dos irmãos, buscar dividir-se entre emprego e auxílio à família, com reorganização de horários, procurar um familiar ou vizinho para ficar com as crianças, entre outros.

Tais soluções têm o significado, para esses jovens, de realização de seus sonhos, sem deixar de atender ao pedido da mãe. Assim sendo, assumem responsabilidade em relação à família.

Como houve diferenças em um dos significados atribuídos a esse elemento, dividimos o modelo organizador $\mathrm{G}$ em dois submodelos: o submodelo G1 e o submodelo G2.

No submodelo G1, essa resolução se dá em forma de buscar meios de conseguir amparar a família para que os sujeitos se sintam livres para o estágio. É uma forma de conseguir conciliar ambas as necessidades, mas com vistas, principalmente, ao interesse próprio. $\mathrm{O}$ benefício à família é importante, mas secundário para esses sujeitos.

Já no submodelo G2, tem-se uma resolução que almeja a conciliação dos interesses da mãe e deles próprios. Os jovens que aplicaram esse submodelo não apenas pensam em realizar seu desejo de ingressar no estágio, mas explicitamente refletem sobre o bem-estar da família e o atendimento às suas necessidades.

Em relação aos sentimentos, comparecem bem-estar, felicidade e realização ao obter uma resolução que almeja ora alcançar os interesses próprios, não deixando de ajudar a família, ora atingir os objetivos de ambos os lados, em verdadeira conciliação de interesses.

Apenas há sentimentos negativos quando o sujeito se imagina contrariando as soluções propostas. Projetam, nas questões em que isso é solicitado, sentimentos como mal-estar, infelicidade e insatisfação por não atenderem aos objetivos de aceitar o estágio ou atender ao pedido da mãe. 


\section{Submodelo G1}

\section{Número de sujeitos que aplicaram o submodelo: 38}

O submodelo G1 traz como elemento organizador central uma resolução do conflito que satisfaça o interesse próprio do sujeito, sem menosprezar, também, o pedido da mãe. É uma tentativa de conciliação que, muito embora tenha como foco "arrumar" a situação para o possível ingresso no estágio, também beneficia, indiretamente, a família.

Os jovens mostram-se responsáveis em relação à situação familiar, tendo em vista o fato de que se preocupam em como ajudá-la mediante o pedido da mãe.

Está claro que, para esses sujeitos, tanto o emprego quanto a família são valorados positivamente de forma bastante acentuada. Contudo, dentre esses dois aspectos, fica nítido que o estágio se mostra mais fortemente abstraído por eles, uma vez que acaba orientando as soluções como uma forma de se atingir esse objetivo.

É interessante observar como os jovens desse submodelo tentam, por meio de alternativas práticas, conciliar o estágio com a ajuda à família, mesmo priorizando o primeiro em detrimento da segunda. Como soluções apresentadas, podemos citar: a contração de uma babá ou conseguir um familiar ou vizinho para ficar com os irmãos, procurar um emprego com tempo menor de trabalho para conciliar com o cuidado às crianças, entre outros.

Os sujeitos que aplicaram o submodelo G1, além de se preocuparem com os cuidados com a família, também revelam, em sua maioria, a preocupação de não magoar ou desapontar a mãe.

Quanto aos sentimentos, percebe-se, claramente, bem-estar, felicidade e tranquilidade por terem ajustado a situação, conciliando cuidados com a família e a dedicação à carreira profissional futura.

Esses sentimentos apenas não comparecem quando as questões requerem que os jovens se imaginem contrariando o auxílio à mãe ou abrindo mão do estágio. Nesses casos, os sentimentos desvelados são mal-estar, tristeza, culpa, arrependimento e infelicidade, o que comprova a forma como valoram a conciliação entre os interesses próprios e a vontade de ajudar a família. Sobre esses sentimentos, vê-se uma maior mobilização daqueles negativos quando relacionados ao trabalho.

Geralmente, os jovens desse submodelo mostram sentimentos negativos de forma mais intensa quando se imaginam não aceitando o estágio. Atribuímos a menor carga desses 
sentimentos à ajuda à família porque entendemos que esses sujeitos estão tranquilos no tocante a isso, já que realizaram ações em prol de resolverem essa situação.

Nas relações estabelecidas entre os elementos abstraídos e os significados que lhes foram atribuídos, nota-se que, no submodelo G1, os jovens desejam resolver a situação em busca de realizar seu objetivo de ingressar no estágio, buscando soluções para também ajudar a família, de forma que não deixem de ter sua responsabilidade sobre ela e também não desapontem a mãe.

Nos exemplos abaixo, encontramos dois grupos de respostas eleitos para melhor visualizar o que expusemos acima.

"Q1 - Tentaria conciliar as duas coisas, não largar o estágio, ajudar sua mãe, ajeitando-se com dois horários, pra ela não perder essa boa oportunidade.

Q2 - Me sentiria mal, pois queria aceitar o estágio, mais tinha que cuidar dos meus irmãos e aceitar um emprego na fábrica, mas daria um jeito de conciliar as duas coisas.

Q3 - Ficaria triste, mais arrumaria alguém pra olhar as crianças com dinheiro do estágio, mas não largaria a oportunidade, pois amanhã iria me arrepender.”

(Sujeito 125, 15 anos, feminino, São Paulo, SP)

"Q1 - No caso dele, era traçar um meio de conseguir um amigo ou até mesmo arranjar uma babá para que ele pudesse fazer o seu curso e, com o dinheiro do estágio, pagaria a babá, ajudava sua mãe e depositava $20 \%$ do seu salário. Assim, ele conseguiria administrar sua casa e ao mesmo tempo ajudar sua mãe.

Q2 - Muito mal, pois estaria entrando em discórdia com minha mãe e eu já passei por isso. Foi assim, fazendo um planejamento de vida que consegui mudar a situação. Inicialmente, eu estava mal, mas de alguma forma eu poderia mudar aquilo. Pensando nesse plano, tudo se encaixou perfeitamente.

Q3 - Bem, neste caso eu me sentiria arrependido, mas superaria logo e continuava meu curso e meus estudos normalmente. Quem sabe não apareceria uma oportunidade melhor."

(Sujeito 67, 16 anos, masculino, Goiânia, GO)

A tabela a seguir busca explicitar as relações/implicações estabelecidas entre elementos, sentimentos e os significados atribuídos a eles no submodelo G1. 
Tabela 34: Relações/implicações entre elementos centrais, sentimentos e seus significados no submodelo G1.

\begin{tabular}{|c|c|c|c|}
\hline & Significados & Relações/implicações \\
\hline \multirow[t]{3}{*}{$\begin{array}{c}\text { Elementos } \\
\text { centrais }\end{array}$} & Estágio. & $\begin{array}{l}\text { Oportunidade } \\
\text { importante para futuro } \\
\text { profissional. }\end{array}$ & \multirow{5}{*}{$\begin{array}{l}\text { Conciliação dos elementos } \\
\text { estágio e família por meio } \\
\text { de estratégias diversas, } \\
\text { pesando tanto } \\
\text { oportunidade para o sujeito } \\
\text { quanto a responsabilidade } \\
\text { em relação à família. } \\
\text { Sentimentos negativos e } \\
\text { positivos referem-se à } \\
\text { conciliação de interesses. }\end{array}$} \\
\hline & Mãe. & $\begin{array}{l}\text { Não merece ficar } \\
\text { magoada; precisa de } \\
\text { ajuda. }\end{array}$ & \\
\hline & Família. & $\begin{array}{ll}\text { Fonte } & \text { de } \\
\text { responsabilidade do } \\
\text { sujeito. }\end{array}$ & \\
\hline \multirow[t]{2}{*}{ Sentimentos } & $\begin{array}{l}\text { Bem-estar; } \\
\text { felicidade; } \\
\text { tranquilidade. }\end{array}$ & $\begin{array}{l}\text { Advém da conciliação } \\
\text { de cuidados com a } \\
\text { família e dedicação à } \\
\text { carreira. }\end{array}$ & \\
\hline & $\begin{array}{l}\text { Mal-estar; } \\
\text { tristeza; culpa; } \\
\text { arrependimento; } \\
\text { infelicidade. }\end{array}$ & $\begin{array}{l}\text { Não conseguir } \\
\text { conciliar os interesses } \\
\text { próprios e da família. }\end{array}$ & \\
\hline
\end{tabular}

\section{Submodelo G2}

\section{Número de sujeitos que aplicaram o submodelo: 24}

Elegendo como elemento organizador central a conciliação entre trabalho e família, os sujeitos que aplicaram o submodelo G2 demonstram a valoração positiva que efetuam acerca desses dois aspectos de suas vidas.

No submodelo G2, os sujeitos significam essa conciliação como algo que possa beneficiar não apenas a si próprios, mas à família também. Eles se preocupam em atingir seus objetivos em relação ao estágio, que é entendido como uma oportunidade de chegar ao mundo do trabalho, e trazem, na mesma proporção, uma preocupação com o bem-estar e os cuidados 
que são necessários para que a família fique bem. É, em nosso entender, uma conciliação equilibrada de interesses.

Assim como no submodelo G1, os jovens desse submodelo apresentam alternativas práticas para que possam tanto aceitar o estágio quanto ajudar a mãe. Entre essas soluções, encontramos a reorganização de horários, a procura por pessoas de confiança ou instituições escolares para cuidar dos irmãos, etc. Chama-nos a atenção, todavia, o fato de os sujeitos sempre se mostrarem preocupados com a família.

Outro aspecto importante a ser destacado no submodelo G2 é a vontade de não desagradar ou aborrecer a mãe. Devido a esse aspecto, encontra-se uma visão de que, caso não seja possível atender a essa oportunidade de estágio, outras aparecerão, já que o sujeito é jovem e, pela sua capacidade, poderá passar em outras provas. Demonstram autoconfiança em si mesmos e visão otimista de futuro.

Os sentimentos de bem-estar, felicidade e tranquilidade estão presentes em grande parte das respostas, especialmente às emitidas nas questões um e dois. Os jovens mostram-se felizes, satisfeitos e tranquilos com sua escolha de conciliar tanto os seus interesses quanto os da família.

Há sentimentos negativos, de mal-estar e tristeza, quando o sujeito percebe que não conseguirá atingir o seu objetivo de conciliar a situação, pendendo para um lado ou outro.

$\mathrm{Na}$ questão três, vemos uma maior aceitação ou conformismo, caso não se consiga aceitar o estágio. Os sujeitos mostram-se tristes, mas relatam sentir-se bem por ajudar a família, conformando-se com a situação e procurando outras oportunidades que tragam a possibilidade de ajustar a situação sem deixar os cuidados com a família de lado.

Podemos inferir, por fim, que os jovens que aplicaram o submodelo G2, em sua abstração e significação dos elementos, buscam conciliar a situação, visando tanto beneficiar a si próprios, com o aceite do estágio, quanto a sua família. Tal resolução acarreta o seu bemestar e, em seu entender, o dos familiares.

Temos, a seguir, dois grupos de respostas que buscam exemplificar o submodelo G2.

“Q1 - Eu, com certeza, aceitaria o estágio e procuraria uma creche ou alguém para ficar com meus irmãos.

Q2 - Eu tentaria outra solução, não deixaria minha mãe tomar conta de tudo sozinha. Acho que eu me colocaria no lugar dela e tentaria perceber o que ela estava sentindo. 
Q3 - Eu iria me sentir péssima, pois o estágio iria ser um grande passo pro meu futuro profissional e deixar que aquela oportunidade escapasse assim, eu iria ficar chateada, mas talvez um pouco conformada já que estaria ajudando a minha mãe.”

(Sujeito 58, 15 anos, feminino, Sobral, CE)

“Q1 - Iria arrumar uma pessoa de confiança para ficar com meus irmãos, assim eu poderia trabalhar, fazendo o que eu mais gosto e minha mãe também. Iria me sentir agradável um pouco, mas um pouco preocupada por ter que deixar meus irmãos com outra pessoa.

Q2 - Me sentiria mal porque minha mãe não iria trabalhar e ia ficar magoada comigo.

Q3 - Iria ficar magoada, mas a segurança dos meus irmãos é importante também. E mais para frente procuraria outro emprego.”

(Sujeito 151, 15 anos, feminino, Rio Claro, SP)

Vejamos, na tabela abaixo, os elementos, sentimentos, significados a eles atribuídos e as relações/implicações estabelecidas entre eles no submodelo G2.

Tabela 35: Relações/implicações entre elementos centrais, sentimentos e seus significados no submodelo G2.

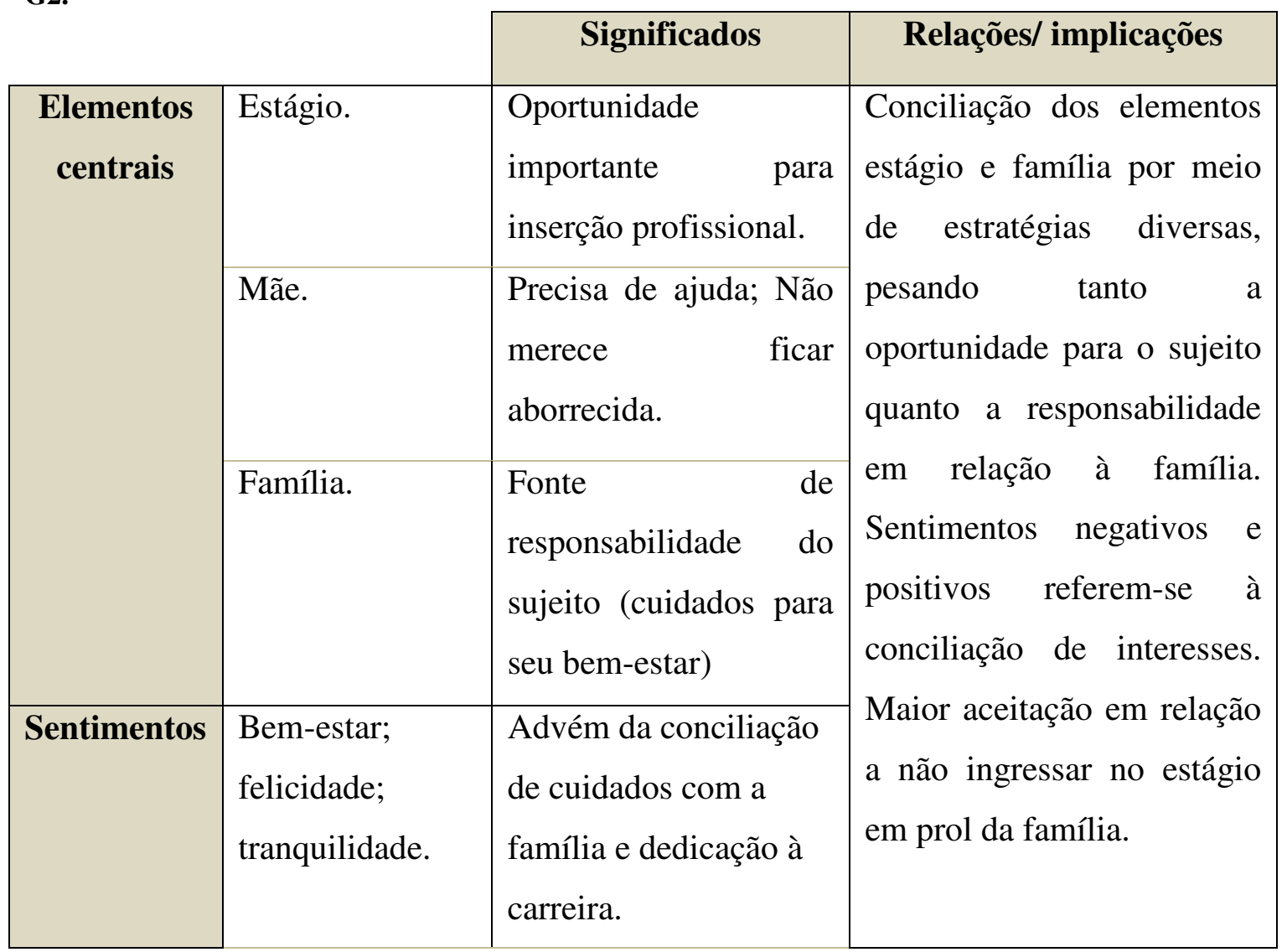




\begin{tabular}{|l|l|l|}
\hline Mal-estar; & Advém do fato de não \\
tristeza. & conseguir conciliar os \\
& $\begin{array}{l}\text { interesses próprios e } \\
\text { da família. }\end{array}$
\end{tabular} \mid




\section{CAPÍTULO VIII}

\section{APRESENTAÇÃo E ANÁLISE dOS RESULTADOS REFERENTES AO CONFLITO MORAL}

\subsection{Considerações sobre a apresentação e a análise dos resultados relativos ao conflito moral}

No presente item de nossa investigação, dedicaremo-nos a apresentar os resultados referentes ao questionário sobre o conflito moral envolvendo o projeto de vida de um personagem.

É importante ressaltar que, a respeito das respostas emitidas sobre a situação de conflito moral, também priorizamos uma descrição qualitativa dos dados coletados, buscando, em uma análise minuciosa, compreender tanto os conteúdos destacados quanto as dinâmicas de pensamento evocadas pelos jovens. Novamente, utilizamos como instrumento teóricometodológico a Teoria dos Modelos Organizadores do Pensamento (MORENO MARIMÓN et al., 1999) que nos possibilitou, sem o apoio de categorias prévias, compreender os elementos abstraídos e retidos como significativos, seus significados e a implicação/relação entre eles. Com tal instrumento, foi possível resgatar os valores e sentimentos dos jovens em seu posicionamento frente ao conflito moral.

Assim como fizemos anteriormente, aqui também acreditamos ser oportuno complementar a análise qualitativa com a quantitativa, para enriquecer e ampliar nossa perspectiva em relação aos resultados encontrados. Nesse continuum entre as duas análises, poderemos verificar tendências de organização de pensamento dos jovens participantes de nossa investigação quando estão mobilizados a pensar em uma situação contextualmente localizada.

Enveredaremos o presente capítulo para apresentar os modelos organizadores que descrevemos mais detidamente no item anterior, enfocando dois aspectos. O primeiro seguirá numa análise dos resultados referentes à integração entre elementos e sentimentos presentes nos modelos organizadores. O segundo deter-se-á no número de sujeitos que aplicaram cada modelo e submodelo organizador. Ambos os itens serão abordados por meio de gráficos e tabelas, com o intuito de facilitar ao leitor a compreensão dos resultados que obtivemos nessa etapa da pesquisa. 
Assim como fizemos anteriormente, consideramos pertinente retomar os modelos organizadores e seus submodelos brevemente, de forma a facilitar as considerações por parte do leitor a respeito dos resultados.

Após cada gráfico e tabela, tecemos algumas considerações acerca do que analisamos a respeito dos resultados.

\subsection{Descrição sumária dos modelos e submodelos referentes às questões sobre o conflito moral}

\section{Modelo organizador A - Opção pelo estágio}

Submodelo Os sujeitos optam pelo estágio, sem se importar com a família. Sentem-

A1 se bem e felizes com sua escolha e com sentimentos negativos caso contrariem essa opção.

Submodelo Sujeitos optam por estágio, mas possuem preocupação branda em

A2 relação à mãe e à família. Sentem-se mal quando se imaginam não ajudando a mãe, mas muito piores quando não aceitam o estágio.

Submodelo Os jovens apostam no estágio e sentem a necessidade de dialogar com a A3 mãe para que ela entenda a situação, assim como de acreditar que é dever dela tanto compreender quanto resolver seus problemas sozinha. Os sentimentos apresentados são de mal-estar, culpa e tristeza por não ajudar a mãe, mas de felicidade e bem-estar por aceitarem o estágio.

\section{Modelo organizador B - Opção pelo estágio e culpa em contrariar mãe}

Submodelo Os jovens fazem a escolha pelo estágio, o que lhes causa leve bem-estar,

B1 mas sentem culpa ou mal-estar por terem contrariado a mãe, o que não chega a levá-los a mudar de opção, mas escolher o diálogo como forma de amenizar esses sentimentos negativos.

Submodelo Opção pelo estágio, acompanhada por fortes sentimentos negativos,

B2 como culpa e tristeza, atribuídos ao fato de deixarem a mãe triste. Para de fato conseguirem fazer essa escolha, esses sujeitos elegem o diálogo como forma de confortar a mãe e/ ou buscar seu apoio a essa decisão, sem promoverem uma quebra do vínculo que têm com ela. 


\section{Modelo organizador C - Opção do estágio para ajudar a família}

Os sujeitos elegem o estágio como algo importante para realização pessoal dos sujeitos, bem como imaginado por eles como algo positivo para a família. Os sujeitos sentem-se bem e felizes com relação a sua escolha. Mostram-se tristes, culpados ou infelizes caso não aceitem o estágio.

\section{Modelo organizador D - Opção pelo curso}

Submodelo Os sujeitos optam por concluir o curso e apresentam sentimentos

D1 positivos como bem-estar e felicidade diante de tal escolha, mas aceitam, apesar de apresentarem mal-estar, outras possibilidades de resolução do conflito, como ingressar no estágio.

Submodelo Os elementos curso e ajuda à mãe são destacados como importantes para D2 esses sujeitos. Eles gostariam de aceitar o estágio e mostram sentimentos negativos pelo fato de não o aceitarem, mas ponderam suas escolhas e elegem terminar o curso e ajudar a mãe, com vistas a garantir um futuro pessoal melhor estruturado no campo do trabalho. Sentem-se bem e felizes diante dessa escolha.

\section{Modelo organizador E-Dever de ajudar a mãe}

Submodelo Os jovens optam por ajudar a mãe e sentem-se muito bem por obedecê-

E1 la. Eles gostariam de aceitar o estágio, demonstrando sentimentos negativos, como mal-estar e tristeza, mas a obediência à mãe é fortalecida por sentimentos positivos, o que os leva a se decidir por ajudá-la.

Submodelo Os sujeitos revelam opção por auxiliar a mãe, indicando, contudo,

E2 sentimentos negativos que revelam a vontade de ingressar no estágio em vez de ajudar a família. Sua decisão se pauta na remuneração obtida em cada emprego (trabalho da mãe e estágio). 


\section{Modelo organizador F - Ajuda à mãe e à família}

Submodelo Os sujeitos demonstram o desejo de atender à mãe com o objetivo de F1 ajudar a família, pela qual se imaginam responsáveis. Embora se sintam mal por perderem oportunidades, sentem-se felizes e realizados por ajudar.

Submodelo Os jovens elegem ajudar a mãe, porque se sentem responsáveis pela F2 família e porque desejam retribuir o que julgam que ela fez por eles. Ao ajudar a família, sentem-se muito bem, mas não deixam de registrar sua vontade de ingressar no estágio, apresentando de forma branda sentimentos negativos.

\section{Modelo organizador G - Conciliação de interesses}

Submodelo Os jovens buscam soluções para poder ingressar no estágio. Apresentam

G1 formas práticas de ajudar a família, de forma que não deixem de ter sua responsabilidade sobre ela e também não desapontem a mãe, sem, entretanto, deixar de lutar pelo estágio. Demonstram sentimentos de felicidade, bem-estar e tranquilidade por terem resolvido a situação. Os sentimentos negativos, como culpa, tristeza e mal-estar comparecem quando os sujeitos se imaginam contrariando a resolução posta.

Submodelo Os sujeitos buscam conciliar a situação, visando tanto beneficiar a si G2 próprios, com o aceite do estágio, quanto a sua família. Tal resolução acarreta o seu bem-estar e, em seu entender, o dos familiares. Os sentimentos negativos de culpa, tristeza e mal-estar estão presentes quando os sujeitos se imaginam contrariando sua solução a respeito da situação. 


\subsection{Processos de integração e regulação de valores e sentimentos nos modelos e submodelos organizadores aplicados pelos sujeitos participantes da pesquisa em relação ao conflito moral}

Assim como na análise que fizemos dos resultados concernentes aos projetos de vida, julgamos importante apresentar a configuração dos valores e sentimentos na resolução de um conflito envolvendo como conteúdo o projeto de vida de um personagem. Nossa intenção é perceber se houve integração e regulação entre valores e sentimentos também diante desse instrumento.

Devemos ressaltar que a análise das respostas em relação ao conflito moral permitiu verificar os elementos abstraídos e significados pelos sujeitos de uma forma diferente da anterior, pois compreendia elementos que constavam em uma situação, o que era um fator regulador para o seu comparecimento nas respostas. Diferentemente das respostas sobre os projetos de vida, em que o sujeito necessitava pensar, de forma ampla, sobre a sua vida, lembrando elementos e inventando outros, na elaboração de respostas sobre o conflito, o jovem tinha uma gama de elementos aos quais poderia atribuir significados, tecendo as relações/ implicações que julgava pertinentes.

Diante do conflito, os sujeitos tomaram uma decisão, colocando-se no lugar de um protagonista fictício, o que evidencia a contextualização de uma experiência de vida, relacionada ao conteúdo de um projeto de vida. Percebe-se que, a despeito de ser uma história de outra pessoa (fictícia) que exigia tomar um papel que não é o seu, o conflito solicitou aos jovens uma dinâmica de organização de seu pensamento de uma forma mais rápida, com menos elementos à disposição para elaboração de seu juízo moral. O conflito proporciona a configuração de representações que integram elementos pertinentes ao self (no comprometimento que possuem com sua identidade moral) e os dispostos no contexto (LAPSLEY; NARVAEZ, 2004). Cremos que, ao responder acerca do conflito proposto, os participantes puderam enfrentar uma situação de uma forma que se aproxima de contextos que pode vivenciar em sua rotina.

É importante destacar que, mesmo com tal possibilidade, o uso de um conflito hipotético pode aproximar-se de uns, mas se afastar de outros, no sentido de que: a) o sujeito pode ter vivenciado uma situação semelhante, ou a entende devido à vivência de alguém próximo, ou a compreende por já ter pensado/imaginado uma experiência desse tipo; b) o sujeito não se sente envolvido por tal situação, pela falta de vivências ou de oportunidades de pensar sobre o assunto. Embora, no percurso desse trabalho, tenhamos verificado, com muita 
atenção, se o conflito proposto atendia a um projeto de vida possível para os jovens, é muito provável que não tenha se aproximado de todos os participantes de nossa investigação.

Postas essas considerações e seguindo com o objetivo de analisar a integração e a regulação de valores e sentimentos, a seguir apresentamos uma tabela que contém os elementos destacados pelos sujeitos, os sentimentos revelados com a resolução do conflito, bem como as relações/implicações estabelecidas entre eles. Essa tabela consistirá em uma forma resumida daquelas que apresentamos na descrição dos modelos organizadores para que possamos identificar os processos de integração e regulação de valores e sentimentos nas dinâmicas de organização do pensamento dos jovens dessa pesquisa.

Tabela 36: Elementos, sentimentos e relações/implicações entre valores e sentimentos nos modelos e submodelos organizadores aplicados pelos jovens participantes da pesquisa em relação ao conflito moral.

\begin{tabular}{|c|c|c|c|c|c|c|}
\hline & 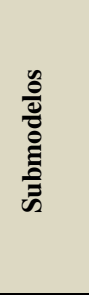 & $\begin{array}{l}\text { Centralidade } \\
\text { dos } \\
\text { elementos no } \\
\text { modelo }\end{array}$ & $\begin{array}{l}\text { Elementos } \\
\text { abstraídos na } \\
\text { resolução do } \\
\text { conflito }\end{array}$ & $\begin{array}{l}\text { Sentimentos } \\
\text { relacionados à } \\
\text { resolução do } \\
\text { conflito }\end{array}$ & $\begin{array}{c}\text { Sentimentos } \\
\text { relacionados ao } \\
\text { fato de } \\
\text { contrariarem } \\
\text { resolução do } \\
\text { conflito }\end{array}$ & $\begin{array}{c}\text { Relações/ } \\
\text { implicações entre } \\
\text { elementos e } \\
\text { sentimentos }\end{array}$ \\
\hline \multirow{2}{*}{\multicolumn{2}{|c|}{$\mathbf{A}$}} & $\begin{array}{l}\text { Elementos } \\
\text { centrais }\end{array}$ & Estágio & Bem-estar & $\begin{array}{l}\text { Mal-estar e } \\
\text { tristeza }\end{array}$ & \multirow{2}{*}{$\begin{array}{l}\text { Estágio é um valor, } \\
\text { que recebe carga } \\
\text { afetiva de } \\
\text { sentimentos } \\
\text { positivos e } \\
\text { negativos. }\end{array}$} \\
\hline & & $\begin{array}{l}\text { Elementos } \\
\text { periféricos }\end{array}$ & ---- & $\begin{array}{l}---- \\
\end{array}$ & ----- & \\
\hline \multirow{2}{*}{\multicolumn{2}{|c|}{ A2 }} & $\begin{array}{l}\text { Elementos } \\
\text { centrais }\end{array}$ & Estágio & Bem-estar & $\begin{array}{c}\text { Mal-estar e/ou } \\
\text { tristeza }\end{array}$ & \multirow{2}{*}{$\begin{array}{c}\text { Estágio é um valor, } \\
\text { recebendo } \\
\text { sentimentos } \\
\text { positivos e } \\
\text { negativos. A mãe/ } \\
\text { família é elemento } \\
\text { periférico, recebendo } \\
\text { sentimentos } \\
\text { negativos brandos. }\end{array}$} \\
\hline & & $\begin{array}{l}\text { Elementos } \\
\text { periféricos }\end{array}$ & Mãe/ família & $\begin{array}{l}\text { Mal-estar e } \\
\text { tristeza } \\
\text { (brandos) }\end{array}$ & ---- & \\
\hline \multirow{2}{*}{\multicolumn{2}{|c|}{ A3 }} & $\begin{array}{c}\text { Elementos } \\
\text { centrais }\end{array}$ & Estágio & $\begin{array}{l}\text { Bem-estar e } \\
\text { felicidade }\end{array}$ & $\begin{array}{c}\text { Mal-estar, } \\
\text { tristeza e/ ou } \\
\text { arrependimento }\end{array}$ & \multirow{2}{*}{$\begin{array}{l}\text { Estágio é um valor, } \\
\text { recebendo } \\
\text { sentimentos } \\
\text { positivos e } \\
\text { negativos. Mãe é um } \\
\text { elemento periférico, } \\
\text { que, por mobilizar } \\
\text { sentimentos } \\
\text { negativos, leva os } \\
\text { sujeitos a dialogarem }\end{array}$} \\
\hline & & $\begin{array}{l}\text { Elementos } \\
\text { periféricos }\end{array}$ & Papel da mãe & $\begin{array}{l}\text { Mal-estar, culpa } \\
\text { e tristeza }\end{array}$ & ---- & \\
\hline
\end{tabular}




\begin{tabular}{|c|c|c|c|c|c|c|}
\hline & & & & & & $\begin{array}{l}\text { com a mãe } \\
\text { (convencimento de } \\
\text { que ela deve } \\
\text { entender). }\end{array}$ \\
\hline \multirow[t]{2}{*}{ B 1} & \multirow[t]{2}{*}{ B1 } & $\begin{array}{c}\text { Elementos } \\
\text { centrais }\end{array}$ & Estágio & $\begin{array}{l}\text { Bem-estar } \\
\text { (brando) }\end{array}$ & $\begin{array}{c}\text { Culpa e/ou } \\
\text { inconformismo }\end{array}$ & \multirow[b]{2}{*}{$\begin{array}{c}\text { Estágio é um valor, } \\
\text { que recebe } \\
\text { sentimentos } \\
\text { negativos e, de } \\
\text { forma branda, } \\
\text { positivos. A mãe } \\
\text { mobiliza sentimentos } \\
\text { negativos, o que leva } \\
\text { os sujeitos a } \\
\text { tentarem o diálogo } \\
\text { para amenizar a } \\
\text { situação. }\end{array}$} \\
\hline & & $\begin{array}{l}\text { Elementos } \\
\text { periféricos }\end{array}$ & $\begin{array}{c}\text { Mãe } \\
\text { Sentimentos da } \\
\text { mãe }\end{array}$ & $\begin{array}{l}\text { Culpa e mal- } \\
\quad \text { estar }\end{array}$ & ---- & \\
\hline & \multirow[t]{2}{*}{ B2 } & $\begin{array}{l}\text { Elementos } \\
\text { centrais }\end{array}$ & Estágio & $\begin{array}{l}\text { Bem-estar } \\
\text { (brando) }\end{array}$ & $\begin{array}{c}\text { Mal-estar, } \\
\text { insatisfação, } \\
\text { tristeza e/ou } \\
\text { arrependimento }\end{array}$ & \multirow{2}{*}{$\begin{array}{c}\text { Estágio é um valor, } \\
\text { que recebe } \\
\text { sentimentos } \\
\text { negativos e, de } \\
\text { forma branda, } \\
\text { positivos. A mãe } \\
\text { mobiliza fortes } \\
\text { sentimentos } \\
\text { negativos, o que leva } \\
\text { os sujeitos a } \\
\text { tentarem o diálogo } \\
\text { para confortá-la e } \\
\text { buscar seu apoio. } \\
\end{array}$} \\
\hline & & $\begin{array}{l}\text { Elementos } \\
\text { periféricos }\end{array}$ & $\begin{array}{c}\text { Mãe } \\
\text { Sentimentos da } \\
\text { mãe }\end{array}$ & $\begin{array}{l}\text { Culpa, mal-estar } \\
\text { e tristeza }\end{array}$ & $\begin{array}{l}\text { Revolta/ culpam } \\
\text { a mãe }\end{array}$ & \\
\hline \multirow[t]{2}{*}{$\mathbf{C}$} & & $\begin{array}{l}\text { Elementos } \\
\text { centrais }\end{array}$ & $\begin{array}{c}\text { Estágio } \\
\text { Mãe/ família }\end{array}$ & $\begin{array}{l}\text { Bem-estar e } \\
\text { felicidade }\end{array}$ & $\begin{array}{c}\text { Tristeza, culpa } \\
\text { e/ ou } \\
\text { arrependimento }\end{array}$ & \multirow{2}{*}{$\begin{array}{l}\text { Estágio é um valor } \\
\text { central que se integra } \\
\text { à família, juntamente } \\
\text { a sentimentos } \\
\text { positivos e } \\
\text { negativos, por ser } \\
\text { algo que os sujeitos } \\
\text { imaginam como } \\
\text { necessário para a } \\
\text { família. }\end{array}$} \\
\hline & & $\begin{array}{l}\text { Elementos } \\
\text { periféricos }\end{array}$ & ---- & ---- & ---- & \\
\hline \multirow[b]{2}{*}{$\mathbf{D}$} & \multirow[t]{2}{*}{ D1 } & $\begin{array}{l}\text { Elementos } \\
\text { centrais }\end{array}$ & Curso & Bem-estar & $\begin{array}{c}\text { Sentimentos } \\
\text { negativos } \\
\text { brandos }\end{array}$ & \multirow{2}{*}{$\begin{array}{l}\text { Curso é valorizado, } \\
\text { recebendo carga } \\
\text { afetiva, mesmo que } \\
\text { branda. Estágio e } \\
\text { mãe são elementos } \\
\text { periféricos, } \\
\text { relacionados a } \\
\text { sentimentos brandos, } \\
\text { o que faz o sujeito } \\
\text { aceitar outras } \\
\text { possibilidades de }\end{array}$} \\
\hline & & $\begin{array}{l}\text { Elementos } \\
\text { periféricos }\end{array}$ & $\begin{array}{l}\text { Estágio } \\
\text { Mãe }\end{array}$ & $\begin{array}{l}\text { Mal-estar } \\
\text { (brando) }\end{array}$ & $\begin{array}{l}\text { Sentimentos } \\
\text { positivos } \\
\text { brandos ou } \\
\text { inexistentes }\end{array}$ & \\
\hline
\end{tabular}




\begin{tabular}{|c|c|c|c|c|c|c|}
\hline & & & & & & $\begin{array}{l}\text { resoluçãa do } \\
\text { conflito. }\end{array}$ \\
\hline & \multirow[b]{2}{*}{ D2 } & $\begin{array}{c}\text { Elementos } \\
\text { centrais }\end{array}$ & $\begin{array}{l}\text { Curso } \\
\text { Mãe }\end{array}$ & $\begin{array}{l}\text { Bem-estar e } \\
\text { felicidade }\end{array}$ & $\begin{array}{c}\text { Culpa, tristeza e/ } \\
\text { ou mal-estar }\end{array}$ & \multirow[b]{2}{*}{$\begin{array}{l}\text { Curso é elemento } \\
\text { central, juntamente } \\
\text { com atender ao } \\
\text { pedido da mãe, os } \\
\text { quais recebem } \\
\text { sentimentos } \\
\text { positivos e } \\
\text { negativos. Estágio é } \\
\text { elemento periférico, } \\
\text { que recebe } \\
\text { sentimentos brandos }\end{array}$} \\
\hline & & $\begin{array}{l}\text { Elementos } \\
\text { periféricos }\end{array}$ & Estágio & $\begin{array}{l}\text { Mal-estar e } \\
\text { tristeza } \\
\text { (brandos) }\end{array}$ & ---- & \\
\hline \multirow{4}{*}{$\mathbf{E}$} & \multirow{2}{*}{ E1 } & $\begin{array}{c}\text { Elementos } \\
\text { centrais }\end{array}$ & Mãe & $\begin{array}{l}\text { Bem-estar e } \\
\text { felicidade }\end{array}$ & Mal-estar & \multirow[b]{2}{*}{$\begin{array}{c}\text { Mãe é um valor } \\
\text { central, que se } \\
\text { relaciona a } \\
\text { sentimentos } \\
\text { positivos e } \\
\text { negativos. O estágio } \\
\text { posiciona-se de } \\
\text { forma periférica, } \\
\text { com poucos } \\
\text { sentimentos } \\
\text { relacionados. }\end{array}$} \\
\hline & & $\begin{array}{l}\text { Elementos } \\
\text { periféricos }\end{array}$ & Estágio & $\begin{array}{l}\text { Mal-estar e } \\
\text { tristeza }\end{array}$ & ---- & \\
\hline & \multirow[t]{2}{*}{ E2 } & $\begin{array}{l}\text { Elementos } \\
\text { centrais }\end{array}$ & Mãe & $\begin{array}{l}\text { Mal-estar, } \\
\text { tristeza e culpa }\end{array}$ & $\begin{array}{l}\text { Desilusão e } \\
\text { tristeza (em } \\
\text { relação a abrir } \\
\text { mão do estágio) }\end{array}$ & \multirow{2}{*}{$\begin{array}{c}\text { Mãe é elemento } \\
\text { central, significados } \\
\text { como um dever } \\
\text { sentido pelo sujeito } \\
\text { pelo fato de refletir } \\
\text { sobre as vantagens e } \\
\text { desvantagens de } \\
\text { aceitar o estágio } \\
\text { (remuneração). Há } \\
\text { projeção de } \\
\text { sentimentos } \\
\text { negativos. }\end{array}$} \\
\hline & & $\begin{array}{l}\text { Elementos } \\
\text { periféricos }\end{array}$ & $\begin{array}{c}\text { Estágio } \\
\text { Trabalho da mãe } \\
\text { Remuneração do } \\
\text { estágio }\end{array}$ & ---- & ---- & \\
\hline \multirow{3}{*}{$\mathbf{F}$} & \multirow[t]{2}{*}{ F1 } & $\begin{array}{l}\text { Elementos } \\
\text { centrais }\end{array}$ & $\begin{array}{c}\text { Mãe } \\
\text { Família } \\
\text { Trabalho da mãe }\end{array}$ & $\begin{array}{l}\text { Felicidade e } \\
\text { realização }\end{array}$ & $\begin{array}{l}\text { Tristeza, culpa e } \\
\text { mal-estar }\end{array}$ & \multirow{2}{*}{$\begin{array}{l}\text { Mãe (família) é um } \\
\text { elemento central, } \\
\text { valorado com a } \\
\text { carga afetiva } \\
\text { projetada pelo } \\
\text { sujeito, que se sente } \\
\text { responsável por ele. } \\
\text { Estágio mostra-se } \\
\text { periférico, já que } \\
\text { recebe sentimentos } \\
\text { negativos brandos. }\end{array}$} \\
\hline & & $\begin{array}{l}\text { Elementos } \\
\text { periféricos }\end{array}$ & Estágio & $\begin{array}{l}\text { Mal-estar } \\
\text { (brando) }\end{array}$ & ---- & \\
\hline & & $\begin{array}{c}\text { Elementos } \\
\text { centrais }\end{array}$ & Mãe/família & $\begin{array}{l}\text { Felicidade e } \\
\text { realização }\end{array}$ & $\begin{array}{c}\text { Tristeza, culpa e } \\
\text { mal-estar }\end{array}$ & $\begin{array}{l}\text { Mãe (família) é um } \\
\text { elemento central, }\end{array}$ \\
\hline
\end{tabular}




\begin{tabular}{|c|c|c|c|c|c|c|}
\hline & F2 & $\begin{array}{l}\text { Elementos } \\
\text { periféricos }\end{array}$ & Estágio & $\begin{array}{c}\text { Mal-estar e } \\
\text { tristeza (brando) }\end{array}$ & ---- & $\begin{array}{l}\text { valorado com a } \\
\text { carga afetiva } \\
\text { projetada pelo } \\
\text { sujeito, que se sente } \\
\text { responsável por ele e } \\
\text { deseja retribuir o que } \\
\text { mãe já lhe fez. } \\
\text { Estágio mostra-se } \\
\text { periférico, já que } \\
\text { recebe sentimentos } \\
\text { negativos brandos. }\end{array}$ \\
\hline & \multirow[t]{2}{*}{ G1 } & $\begin{array}{l}\text { Elementos } \\
\text { centrais }\end{array}$ & $\begin{array}{c}\text { Estágio } \\
\text { Mãe/família }\end{array}$ & $\begin{array}{c}\text { Felicidade, bem- } \\
\text { estar e } \\
\text { tranquilidade }\end{array}$ & $\begin{array}{l}\text { Mal-estar, culpa } \\
\text { e tristeza }\end{array}$ & \multirow{2}{*}{$\begin{array}{l}\text { Estágio e mãe } \\
\text { (família) são } \\
\text { elementos centrais } \\
\text { que se integram pela } \\
\text { conciliação de } \\
\text { interesses pensada } \\
\text { pelo sujeito e sobre a } \\
\text { qual são projetados } \\
\text { sentimentos } \\
\text { positivos e } \\
\text { negativos. Tais } \\
\text { sentimentos } \\
\text { remetem-se mais ao } \\
\text { estágio. }\end{array}$} \\
\hline $\mathbf{G}$ & & $\begin{array}{l}\text { Elementos } \\
\text { periféricos }\end{array}$ & ---- & ---- & ---- & \\
\hline & \multirow{2}{*}{ G2 } & $\begin{array}{l}\text { Elementos } \\
\text { centrais }\end{array}$ & $\begin{array}{c}\text { Estágio } \\
\text { Mãe/família }\end{array}$ & $\begin{array}{l}\text { Tranquilidade, } \\
\text { felicidade e bem- } \\
\text { estar do sujeito e } \\
\text { da família }\end{array}$ & $\begin{array}{l}\text { Mal-estar, culpa } \\
\text { e tristeza }\end{array}$ & \multirow{2}{*}{$\begin{array}{l}\text { Estágio e mãe } \\
\text { (família) são } \\
\text { elementos centrais } \\
\text { que se integram pela } \\
\text { conciliação de } \\
\text { interesses pensada } \\
\text { pelo sujeito e sobre a } \\
\text { qual são projetados } \\
\text { sentimentos } \\
\text { positivos e } \\
\text { negativos. Tais } \\
\text { sentimentos } \\
\text { remetem-se ao } \\
\text { próprio bem-estar e } \\
\text { ao da família. }\end{array}$} \\
\hline & & $\begin{array}{l}\text { Elementos } \\
\text { periféricos }\end{array}$ & ---- & ---- & ---- & \\
\hline
\end{tabular}

A tabela acima evidencia a abstração, a significação de elementos $\mathrm{e}$ as relações/implicações estabelecidas pelos jovens na elaboração de seus modelos organizadores diante de um conflito moral cujo conteúdo versava sobre um projeto de vida de um personagem fictício. Nesse conflito, conforme esboçamos em nosso plano de investigação, o protagonista consegue uma vaga de estágio que almejava em uma empresa, mas a mãe lhe 
pede para que não aceite para ajudá-la a cuidar de seus irmãos. Perante esse conflito, o sujeito precisou organizar seu pensamento mediante conteúdos da situação (INHELDER; DE CAPRONA, 1992). Com a análise pautada no instrumento teórico-metodológico da Teoria dos Modelos Organizadores do Pensamento (MORENO MARIMÓN et al., 1999), verificouse como os jovens participantes de nossa investigação elaboraram tal organização, por meio da forma como abstraíram, significaram e relacionaram elementos presentes na situação hipotética exposta, em conjunto com uma gama de conhecimentos e criações que puderam inferir sobre eles.

Como o conflito girava em torno do estágio (trabalho) e da mãe (pedido de ajuda), o que se percebe, em uma primeira leitura da tabela, é o destaque aos mesmos elementos: estágio e mãe/ família, com exceção do modelo D que traz como elemento central o curso. Contudo, assim como esboçamos na análise dos elementos destacados nos projetos de vida dos jovens, o que traz singularidade a cada modelo e submodelo organizador está na configuração desses elementos, da centralidade que eles assumem, da integração que têm entre si e dos papéis regulatórios que os determinam.

No modelo A, verifica-se o estágio como elemento central que é altamente valorado pelos sujeitos. Esse elemento recebe grande carga afetiva de sentimentos de bem-estar, fazendo com que não compareçam elementos periféricos (submodelo A1) ou, quando comparecem (submodelos A2 e A3), mostram-se relacionados à figura da mãe e da família, mas mobilizados de forma branda, recebendo sentimentos negativos fracamente articulados. Somente no submodelo A3 vemos um maior sentimento de mal-estar e culpa relacionado ao elemento periférico. Todavia, a força existente nos sentimentos positivos ao se pensar em realizar o desejo de aceitar o estágio e os fortes sentimentos negativos expressos por não atender a essa oportunidade, quando essa possibilidade é colocada, reforçam o posicionamento do estágio como elemento central e, podemos dizer, valor para esses sujeitos. As relações e/ou implicações estabelecidas, portanto, estão centradas no estágio, que é extremamente valorado pelo sujeito. Tal valoração, pela carga afetiva que recebe, afasta a projeção de sentimentos sobre outros elementos e a sua abstração e atribuição de significados.

Assim como no modelo A, o elemento central destacado pelo modelo B é o estágio. Esse elemento, entretanto, recebe sentimentos positivos brandos de bem-estar por essa escolha, os quais possibilitam o comparecimento da mãe como elemento periférico. Sobre a mãe, os sujeitos que aplicaram o modelo B diferem em sua forma de entendê-la. Enquanto os sujeitos do submodelo B1 sentem apenas culpa, mal-estar e tristeza por não ajudá-la ou tristeza e arrependimento por não aceitar o estágio, os que aplicaram o submodelo B2 
acrescentam a esses sentimentos a culpa da mãe, revoltando-se contra ela, como se ela constituísse o empecilho para a realização do estágio.

Já o modelo C mostra-se bastante peculiar. Nesse modelo, os sujeitos não perceberam os elementos mãe/família e estágio como antagônicos. Para eles, ambos são elementos centrais e a opção pelo estágio significa ajudar a família futuramente. Os sentimentos que se integram e regulam esse posicionamento central dos elementos são os de bem-estar, caso consigam realizar o estágio, e tristeza, culpa e arrependimento, caso contrário. Assim, têm-se como relações/ implicações que o estágio é uma opção percebida pelos jovens como uma possibilidade de ajudar a família.

O modelo D também surpreende pelo fato de os sujeitos terem abstraído como elemento central o curso que é mencionado no conflito como um dos aspectos de formação, aliados à forma como o sujeito estava vivendo antes de passar pela situação exposta. Ambos os submodelos elegem o curso como elemento central. Porém, há diferenças na forma como foram organizados. O submodelo D1 traz o curso como elemento central isoladamente, elaborando o estágio e a mãe como elementos periféricos. Em relação ao curso, esses jovens sentem bem-estar, mas sentimentos negativos brandos caso não consigam realizá-lo. Em relação à mãe e ao estágio, apenas mobilizam sentimentos de mal-estar enfraquecidos por não terem conseguido ajudar a família ou aceitar o emprego. No submodelo D2, a mãe aparece como um elemento central, juntamente com o curso, pois os sujeitos entendem que fazer o curso pode beneficiá-los e também à mãe que terá alguém para ajudar-lhe com os demais filhos. Em relação a esses elementos, os jovens mostram-se bem e felizes e, quando são questionados a respeito de como se sentiriam caso agissem contrariamente, mostram culpa, tristeza e mal-estar. Como elemento periférico, os sujeitos que aplicaram o submodelo D2 evidenciam o estágio, a partir de sentimentos negativos bastante brandos.

O modelo organizador E tem como elemento central a mãe e, consequentemente, a ajuda que os sujeitos lhe prestariam. No entanto, esse elemento é significado diferentemente em cada submodelo, recebendo carga afetiva também diversa. Se no submodelo E1, há a evidência de um bem-estar por ajudar a mãe, e mal-estar relacionado à hipótese de não fazêlo, tendo o estágio como elemento periférico, o qual recebe sentimentos brandos, no submodelo E2 a ajuda à mãe é significada como uma obrigação, levando esses jovens a se sentirem mal e culpados caso não ajudem a família e fazendo com que posicionem o estágio também como um elemento central, fonte de sentimentos negativos e de desilusão por se verem como impossibilitados a fazer tal escolha. 
No modelo F, vê-se a mãe/ família como elemento central. Os sujeitos que aplicaram esse modelo sentem-se responsáveis pela família e mostram fortes sentimentos positivos ao ajudá-la. Quando se imaginam contrariando essa escolha, evidenciam sentimentos negativos, em especial a culpa. A diferença entre os submodelos (F1 e F2) está na gratidão e vontade de retribuir à mãe a educação, apoio e dedicação recebidos (apenas no submodelo F2). Os sujeitos que aplicaram o modelo $\mathrm{F}$ mobilizam o elemento estágio como periférico, indicando sentimentos negativos brandos pelo fato de deixarem essa oportunidade.

Posicionando como centrais o estágio e a família, os jovens que aplicaram o modelo $\mathrm{G}$ valoraram ambos os elementos, buscando ações para conseguir efetuar o estágio, sem deixar os familiares sem ajuda. Por terem traçados tais soluções, os jovens apresentam sentimentos de bem-estar, felicidade e tranquilidade, bem como mal-estar, culpa e tristeza quando se imaginam não realizando o estágio e não ajudando a família. O que diferencia os submodelos G1 e G2 está na forma como os sujeitos percebem o sentimento de bem-estar. Enquanto no submodelo G1, os sujeitos pensam em seu próprio bem-estar, no submodelo G2 priorizam também o da família.

Um aspecto que merece ser destacado sobre a integração e regulação entre valores e sentimentos está na forma como esses processos se dão para a mobilização de elementos centrais, que podem posicionar-se como valores para os jovens participantes, de acordo com as trocas afetivas que estabelece. Pode-se perceber que todos os elementos centrais que organizaram o raciocínio dos jovens nos modelos que apresentamos receberam projeções de sentimentos quando se imaginaram tomando posições a favor e contra sua forma de resolver o conflito, o que nos leva a inferir que são valores para esses jovens. A força dos sentimentos positivos e negativos projetada sobre eles mostrou-se importante para regular o seu comparecimento e a sua centralidade na construção do pensamento diante do conflito moral. Elementos que foram mobilizados de forma periférica receberam pouca ou nenhuma troca afetiva, o que os levou a se posicionar como valores não tão centrais para os participantes.

Sobre os sentimentos, vê-se que eles apresentam ainda maior força quando se relacionam ao fato de contrariar a forma de resolver a situação como haviam programado. Nesse caso, quando os sentimentos negativos posicionavam-se de maneira acentuada, os elementos/valores receberam força para sua centralidade no modelo organizador. Assim, observamos a existência de sentimentos que foram além do "mal-estar", que, como vimos nessas respostas referentes ao conflito e àquelas referentes aos projetos de vida, mostrou-se brando, em oposição à sensação de bem-estar. Os sentimentos de culpa, tristeza, arrependimento e insatisfação puderam ser notados em grande parte dos modelos e 
submodelos, trazendo uma maior indicação de que os valores mobilizados posicionaram-se de forma central para a organização do pensamento dos sujeitos.

Outro ponto de destaque que pode ser evidenciado na tabela que apresentamos está na integração dos elementos e sentimentos. Os elementos, na medida em que receberam carga afetiva para se constituírem como valores, puderam integrar-se ou não a outros valores, de acordo com as relações/ implicações estabelecidas pelos jovens a partir da abstração e significação dos elementos e sentimentos da situação. Deste modo, vê-se que uma parcela dos jovens entendeu os elementos estágio, curso e família como díspares (submodelos A1, A2, A3, B1, B2, D1, E1, F1 e F2), fazendo com que um dos elementos recebesse maior carga de sentimentos, valorando-os em detrimento de outros, que ora não compareceram ora se posicionaram como periféricos. No entanto, em uma parte dos modelos e submodelos, os sujeitos articularam elementos, valorando-os de forma a posicionarem-nos como centrais na organização de seus raciocínios (modelo C, submodelos D2, G1 e G2). Nessas dinâmicas de organização do pensamento dos sujeitos, os elementos não se mostraram antagônicos, mas contingentes na resolução do conflito moral. Faz-se importante destacar que, quando mais do que um elemento foi abstraído como organizador central, recebendo significados e projeção de sentimentos, houve uma maior tendência a priorizar o bem-estar pessoal na mesma medida em que se intentou chegar ao bem-estar da mãe e da família.

Percebe-se, com essas considerações acerca das implicações existentes entre os elementos e os sentimentos, que a forma como os jovens elaboraram a situação de conflito moral mostrou-se bastante singular, integrando valores e sentimentos. Sobre a integração e regulação entre valores e sentimentos, apresentamos a seguir um gráfico ilustrativo a respeito dos elementos destacados nos modelos organizadores do pensamento, abstraídos a partir do conflito moral apresentado. 
Gráfico 4: Representação da integração/regulação entre valores e sentimentos nos modelos organizadores do pensamento referentes ao conflito moral.

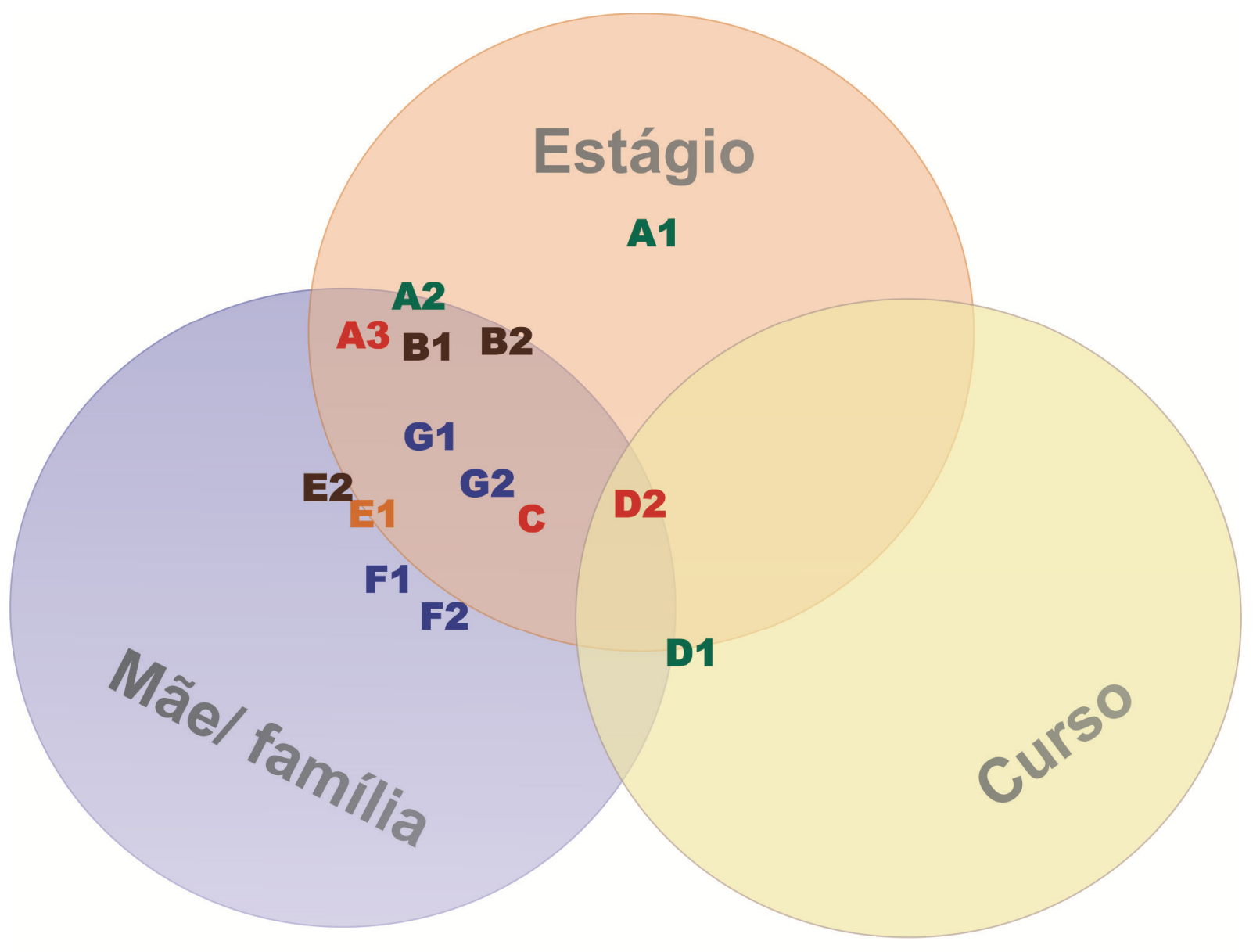

\section{Legenda}

$\square$ Sentimentos brandos de bem-estar pela opção e de mal-estar caso não a realize.

Bem-estar brando ou inexistente e fortes sentimentos de culpa, tristeza e mal-estar pela decisão tomada.

Forte bem-estar e felicidade pela escolha e brandos sentimentos negativos de mal-estar e tristeza caso não a efetue.

$\square$ Bem-estar e/ ou felicidade pela decisão e de culpa, tristeza e arrependimento quando se imaginam realizando ações contrárias.

Fortes sentimentos de felicidade e realização pela opção e fortes sentimentos negativos de tristeza, culpa e mal-estar quando se imaginam agindo contrariamente a ela. 
Com esse gráfico, tivemos a intenção de ilustrar a integração entre valores e entre sentimentos e a regulação exercida por ela. Teceremos algumas considerações a respeito dessa forma de apresentação dos valores e sentimentos nos modelos organizadores do pensamento.

Em primeiro lugar, essa imagem não pretende ser uma concepção estática da forma como os sujeitos mobilizaram valores e sentimentos diante da situação de conflito moral. Ela consiste na representação de um momento determinado de organização psíquica, altamente vinculado ao contexto apresentado.

Sobre o gráfico, vemos três elementos destacados pelos jovens em suas respostas, com espaços de intersecção entre eles, visando a representar sua possível integração. Podemos afirmar que esses elementos mostraram-se como valores para os sujeitos, uma vez que receberam carga afetiva positiva ou negativa (quando pensaram em contradizê-los). Os modelos organizadores foram posicionados nessa ilustração de acordo com os valores indicados, ficando nas zonas de intersecção quando existia alguma integração entre eles. Quanto maior a integração, exprimimos maior centralidade entre os círculos representativos dos valores. Além disso, de acordo com os sentimentos os modelos receberam uma cor que representava a intensidade da carga afetiva, consoante expusemos na legenda.

O que podemos perceber é que grande parte dos modelos apresenta-se na intersecção entre família e estágio. Apenas um modelo organizador não buscou integração entre valores, posicionando-se de forma mais afastada das zonas de intersecção: o submodelo A1. Os demais modelos, de certa forma, demonstraram a existência de mais do que um valor, mesmo que o posicionando perifericamente. É importante destacar que o modelo A1, e os submodelos A2 e D1, que apresentaram fraca integração, foram os modelos que mobilizaram sentimentos mais brandos.

A maior integração de valores aconteceu entre família e estágio, havendo apenas um submodelo, D2, que se posicionou na integração entre esses elementos e o curso. Alguns modelos tenderam a mobilizar a família como central, mostrando menos força do estágio (submodelos E1, E2, F2, F1), enquanto outros priorizaram o estágio em detrimento da família (A2, A3, B1, B2). Apenas encontramos uma forte integração entre os valores de família e estágio nos submodelos G1 e G2 e no modelo C.

Em relação aos sentimentos, verificamos que, quanto menos os valores se tornam integrados, mais brandos eles se mostram, parecendo-nos que a carga afetiva é mais forte quando os valores se integram. Tal apontamento referenda um aspecto que destacamos já na análise da integração e da regulação de valores e sentimentos em relação aos projetos de vida: os valores e os sentimentos são aplicados pelos sujeitos de forma articulada e complexa, e 
nunca de maneira isolada (MORENO MARIMÓN; SASTRE, 2010; PINHEIRO, 2009). No entanto, diferentemente do que observamos na análise dos projetos de vida, em que os sujeitos organizaram seus modelos contando com vários elementos oriundos de experiências passadas, ações presentes e projeções futuras, os quais envolviam maior necessidade de análise de variáveis e idas e vindas em sua elaboração, na análise das respostas ao conflito, a articulação, via processos de integração e regulação de valores e sentimentos, pôde ser constatada na aplicação de modelos referentes a um contexto "real", que exigia o posicionamento de valores pessoais de forma mais rápida, em relação a conteúdos do contexto (LAPSLEY; NARVAEZ, 2004). Os processos de integração e regulação de valores e sentimentos diante do contexto que envolvia um projeto de vida mostraram-se altamente articulados, envolvendo valores que constituem a identidade moral dos sujeitos, nas relações que estabelecem entre si e com os sentimentos e guiando, dentro de um espectro de conteúdos expostos na situação (e outros imaginados pelo jovem), a forma como organizaram seu raciocínio.

\subsection{Apresentação e análise dos resultados quantitativos referentes aos modelos organizadores aplicados pelos sujeitos participantes da pesquisa em relação ao conflito moral}

Neste item do presente capítulo, apresentaremos e discutiremos os resultados referentes a uma análise quantitativa, com o objetivo de complementar a análise até então efetuada sobre a integração e regulação de valores e sentimentos.

Assim como fizemos com os resultados apresentados acerca dos projetos de vida, utilizaremos gráficos e tabelas para explicitar a distribuição dos participantes de nossa pesquisa nos modelos e submodelos organizadores do pensamento.

Na tabela a seguir, apresentamos os resultados referentes à distribuição dos sujeitos nos modelos e submodelos extraídos das respostas sobre o conflito moral. 
Tabela 37: Distribuição dos sujeitos em modelos e submodelos aplicados em relação ao conflito moral

\begin{tabular}{|c|c|c|c|}
\hline $\begin{array}{c}\text { Modelos } \\
\text { organizadores }\end{array}$ & $\begin{array}{c}\text { Sub } \\
\text { modelo }\end{array}$ & $\mathbf{n}$ & $\%$ \\
\hline \multirow[t]{4}{*}{ Modelo A } & & 44 & 22,0 \\
\hline & A1 & 16 & 8,0 \\
\hline & $\mathrm{A} 2$ & 06 & 3,0 \\
\hline & A3 & 22 & 11,0 \\
\hline \multirow[t]{3}{*}{ Modelo B } & & 10 & 5,0 \\
\hline & B1 & 5 & 2,5 \\
\hline & B2 & 5 & 2,5 \\
\hline Modelo C & & 7 & 3,5 \\
\hline \multirow[t]{3}{*}{ Modelo D } & & 22 & 11,0 \\
\hline & D1 & 12 & 6,0 \\
\hline & D2 & 10 & 5,0 \\
\hline Modelo E & & 20 & 10,0 \\
\hline
\end{tabular}

\begin{tabular}{cccc} 
& E1 & 14 & 7,0 \\
& E2 & 06 & 3,0 \\
\hline Modelo F & & $\mathbf{2 9}$ & $\mathbf{1 4 , 5}$ \\
& F1 & 18 & 9,0 \\
& F2 & 11 & 5,5 \\
\hline Modelo G & & $\mathbf{6 2}$ & $\mathbf{3 1 , 0}$ \\
& G1 & 38 & 19,0 \\
& G2 & 24 & 12,0 \\
\hline Não respondeu & & $\mathbf{0 6}$ & $\mathbf{3 , 0}$ \\
\hline & Total: & $\mathbf{2 0 0}$ & $\mathbf{1 0 0 , 0}$ \\
\hline
\end{tabular}


De acordo com os resultados apresentados, podemos tecer algumas considerações:

- O modelo organizador $\mathrm{G}$ tem os submodelos com o maior número de respostas: o submodelo G1, com 38 (perfazendo 19\% dos participantes), e o submodelo G2, com 24 (12\% do total de jovens). Nesses submodelos, verificamos a solução do conflito por meio de uma conciliação entre o estágio e a ajuda à família, dos interesses pessoais e familiares.

- Outros submodelos receberam números de respostas significativos. O submodelo A3, com 22 sujeitos (11\% dos participantes), em que o estágio foi valorado de forma central e a mãe/ família posicionou-se como um valor periférico. E o submodelo F1, com 18 jovens (com 9\% dos participantes) que priorizaram a ajuda à mãe, pelo fato de se sentirem responsáveis pela família.

- Os submodelos A1, D1, D2, E1 e F2 foram aplicados por uma média de 10 a 16 jovens. No submodelo A1, que apontava o estágio como elemento organizador central, houve 16 respostas (8\% do total de jovens). Os submodelos D1 e D2, que apresentavam como elemento central o curso, distinguindo-se pelo fato de lhe integrarem ou não a família, receberam 12 e 10 respostas, respectivamente $6 \%$ e $5 \%$ dos participantes. O submodelo E1, cujas respostas centraram-se na ajuda à mãe, como um dever a ser cumprido pelos jovens, foi elaborado por 14 jovens (7\% do total de sujeitos) e o submodelo F2, o qual também se referia a uma ajuda à família, mas pela responsabilidade que se tem por ela e pela retribuição que se deseja dar à mãe, foi aplicado por 11 participantes (5,5\% do total de jovens).

- O modelo $\mathrm{C}$ e os submodelos A2, B1, b2 e E2 receberam os menores percentuais dentre os jovens participantes dessa investigação. Percebendo o estágio como aspecto fundamental para a família, o modelo $\mathrm{C}$ foi aplicado por 7 jovens $(3,5 \%$ dos participantes). O submodelo A2 foi elaborado por 6 sujeitos (3\% das respostas), trazendo o estágio como elemento central, mas uma leve preocupação com a mãe e com a família. Perfazendo o mesmo percentual, observa-se o submodelo E2, que trazia o dever de ajudar a mãe, embora considerasse importante o estágio, o que lhe provocava sentimentos negativos. No modelo B, subdividido em dois submodelos que posicionaram o estágio como central, mas, devido à culpa em relação à mãe, intentam um diálogo, no sentido de garantir sua aprovação (submodelo B1) e de confortá-la 
(submodelo B2), verifica-se que 10 jovens o aplicaram: 5 respostas elaboradas no submodelo B1 e 5 repostas elaboradas no submodelo B2 (2,5\% do total de participantes, em cada submodelo).

- Seis sujeitos não corresponderam à comanda solicitada, deixando questões em branco ou incompletas. Tivemos que manter tais protocolos, pois as respostas desses mesmos jovens foram utilizadas na análise sobre seus projetos de vida.

Com tal análise, foi possível verificar algumas tendências de aplicação dos modelos e submodelos organizadores, que nos apontam na direção de algumas regularidades de organização do raciocínio dos jovens participantes de nossa pesquisa. Há de se destacar o grande número de jovens que, diante de uma situação em que o projeto de vida de um personagem está em jogo, opta por tentar conciliar interesses, priorizando não apenas seu bem-estar, mas também o de sua família (submodelos G1 e G2). Isso significa que os participantes, diante de uma situação de conflito, tendem a buscar soluções que não apenas venham ao encontro dos seus sonhos e desejos, mas que beneficiem também outras pessoas de seu âmbito pessoal.

Outra tendência esteve na aplicação do submodelo A3, que trouxe o elemento estágio de forma bastante contundente, apresentando uma preocupação branda em relação à mãe e à família. Essa tendência, em nosso entender, foi também aplicada de forma próxima em outros modelos (A2, B1, B2), a despeito de eles apresentarem outras relações/implicações entre os elementos abstraídos e significados. Assim, mostra-se de suma importância para os jovens que elaboraram esses submodelos o elemento estágio, compreendido como uma forma de inserção no mercado de trabalho, o que comprova pesquisas que demonstraram que o trabalho se mostra como um forte valor na juventude brasileira (SPOSITO, 2003, 2005; ABRAMO, 2005; THOMÉ; TELMO; KOLLER, 2011).

Muito embora se apresente com um número não tão baixo, priorizar a família, em detrimento do estágio, foi aplicado por percentual de sujeitos (submodelos E1, E2, F1 e F2) menor do que nos outros modelos organizadores. Isso nos traz a indicação de que, mesmo tendo a família como um valor importante, uma vez que, mesmo se configurando como um valor periférico em grande parte das dinâmicas de organização do pensamento, o trabalho, por meio do estágio, mostrou-se um valor mais central para uma boa parcela dos jovens que participaram da presente investigação.

Apesar de tais tendências, a análise da distribuição dos jovens nos modelos e submodelos permite enfatizar também as singularidades, pois evidencia diferenças pequenas 
entre submodelos, no que tange à atribuição de significados e/ou ao estabelecimento de relações/implicações, sem desconsiderá-las, embora tenham sido aplicadas por um número baixo de participantes. Além disso, com a análise evidenciaram-se outros elementos e outras relações que, até então, não haviam sido pensados por nós na elaboração do instrumento (pelo menos com a carga de intensidade que receberam nas respostas emitidas), como a indicação da relevância do curso e a estreita relação do estágio como supridor das necessidades da família. Nesse aspecto, a utilização do instrumento teórico-metodológico da Teoria dos Modelos Organizadores do Pensamento (MORENO MARIMÓN et al., 1999) pôde nos auxiliar ao imprimir chances de posicionar, como de igual valor, as representações dos sujeitos, sejam elas advindas de elementos da realidade, imaginadas ou projetadas pelo sujeito. Cada pessoa pode ter uma interpretação da situação, de acordo com os modelos que organizam a realidade para si, em um conjunto que abarca pensamentos, sentimentos, crenças, objetivos, entre vários outros aspectos.

Complementando essa análise que envolve os modelos e submodelos, julgamos pertinente apresentar os resultados relacionados à aplicação dos modelos, pois, a despeito de eles se subdividirem devido a diferenças na significação dos elementos, contaram com elementos e implicações próximas, caracterizando processos psicológicos de organização dos modelos também, de certa forma, semelhantes.

O gráfico a seguir pretende abarcar a distribuição dos sujeitos nos modelos organizadores do pensamento referentes ao conflito moral. 
Gráfico 5: Distribuição dos sujeitos nos modelos organizadores referentes ao conflito moral.

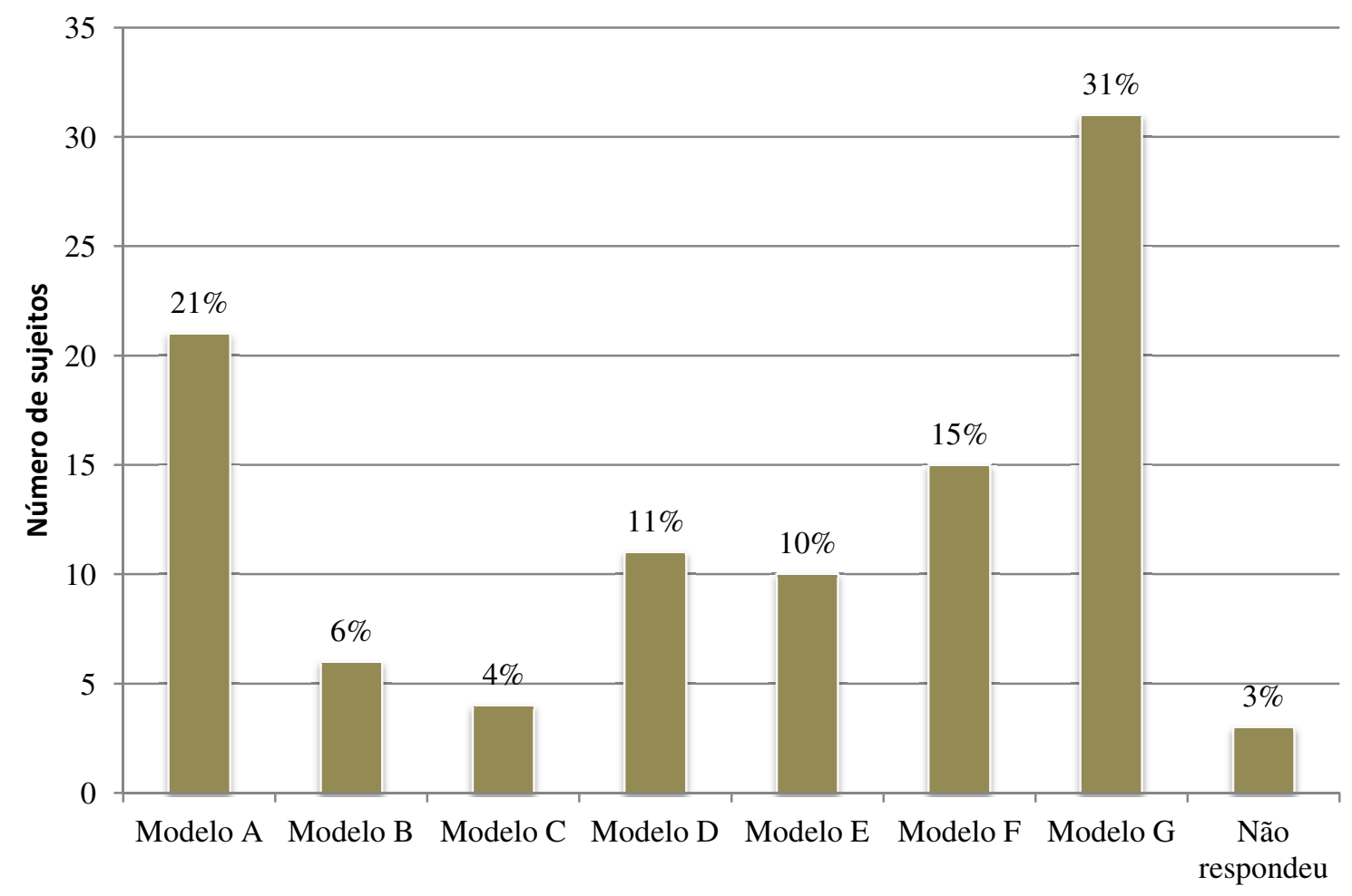

A análise desse gráfico permite-nos verificar que o maior número de sujeitos concentra-se nos modelos A (com $21 \%$ da amostra) e no modelo $\mathrm{G}$ (com $31 \%$ da amostra), o que nos leva a compreender que o estágio é significado como um valor importante para esses jovens, já que ele comparece como prioridade, extinguindo outros valores ou tornando-os bastante periféricos (modelo A), o que sinaliza a respeito da importância do trabalho para esses jovens, ou fazem com que o sujeito procure soluções para realizar tanto seu desejo pessoal quanto atender a família (modelo G).

$\mathrm{O}$ modelo $\mathrm{C}$ recebeu o menor número de respostas (4\% da amostra) que mostravam uma visão de que o estágio iria beneficiar a família. O modelo B também foi aplicado por um número menor de sujeitos (6\% da amostra), que registraram a importância do estágio, mas sentiram-se culpados e tristes em contrariar a mãe.

Os modelos D, E e F tiveram um número próximo de sujeitos que os aplicaram (11\%, $10 \%$ e $15 \%$ da amostra, respectivamente). Nesses modelos, a ajuda à mãe é mais manifestada, embora se tenha presente o elemento estágio, oscilando como uma forma mais central até mais periférica. A ajuda à mãe obteve significados diferentes: aliar a ajuda à família com o curso; acatar um dever de ajudar a mãe; e ajudar à mãe e à família. 
É nítida a relevância dos processos de integração e regulação de valores e sentimentos para a elaboração de modelos organizadores frente ao conflito moral que envolveu o projeto de vida do personagem fictício. Notou-se que tais processos comparecem e organizam todos os modelos aplicados pelos jovens, com enfoques bastante singulares, de acordo com as características de cada sujeito, da sua constituição moral (BLASI, 1993, 2004) e da forma como puderam perceber a situação a partir de construtos anteriores para aplicação em contextos reais (LAPSLEY; NARVAEZ, 2004).

Contudo, percebe-se que a teia de relações aplicada em cada modelo diferiu-se por graus de complexidade, no tocante à abstração, significação e estabelecimento de implicações entre os elementos. Em alguns modelos, foi constatada uma maior integração entre os elementos destacados, os quais receberam carga afetiva que os posicionou como valores para os participantes, em outros modelos os sentimentos estiveram integrados e regulando o comparecimento de um valor em detrimento de outros.

O que pudemos compreender sobre tais processos nos modelos organizadores aplicados pelos jovens dessa investigação é que uma maior integração entre os elementos abstraídos, culminando em uma maior atribuição de significados e levando a uma maior projeção afetiva, resultou em modelos que organizaram o pensamento dos jovens para uma visão que prioriza o seu próprio projeto de vida, o qual se mostrou, pela força do próprio conteúdo do contexto, centrado no trabalho, ao mesmo tempo em que tornou relevantes as necessidades do outro, no caso, a família.

Assim, podemos inferir que os processos de integração e regulação de valores e sentimentos, quando se dão em um nível de complexidade que envolve uma maior gama de componentes fortalece, diante de uma situação moral, juízos que priorizam tanto aspectos concernentes à sociedade e aos seus princípios morais, quanto àqueles que dizem respeito aos outros, como seres que necessitam de apoio e cuidados (NISAN, 2004; BENHABIB, 1992); que evidenciam escolhas pautadas no bem-estar próprio e no bem-estar alheio (DAMON, 1992, 1995, 2009; BUNDICK, 2009).

De forma a evidenciar tais níveis de complexidade, mediante nosso esforço de enfocar os processos de integração e regulação de valores e sentimentos, recorreremos novamente às "categorias de modelos", as quais, conforme explicamos anteriormente, servem-nos como apoio para desvelar os resultados de acordo com os objetivos traçados em nossa pesquisa, referendando, de uma forma mais ampla, as regularidades que se colocaram na organização do pensamento dos jovens participantes deste trabalho. 
Agrupamos os modelos organizadores, distinguindo-os de acordo com o nível de articulação dos processos de integração e regulação de valores e sentimentos. No primeiro grupo (modelos A, B, D, E e F), um valor é posicionado como central, recebendo maior carga afetiva, em detrimento de outros valores (quando compareceram) ${ }^{56}$. No segundo grupo (modelos $\mathrm{C}$ e $\mathrm{G}$ ), dois valores ocupam a centralidade da organização psíquica dos jovens, recebendo ambos os sentimentos positivos, como reforço de suas escolhas, e os negativos, caso contrariem as ações previstas.

Tabela 38: Distribuição dos sujeitos nas categorias de modelos em relação aos processos de integração/regulação de valores e sentimentos diante do conflito moral.

\begin{tabular}{ccc}
\hline $\begin{array}{c}\text { Categorias de } \\
\text { modelos }\end{array}$ & n & $\%$ \\
\hline $\begin{array}{c}\text { Articulação de } \\
\text { processo de }\end{array}$ & & \\
$\begin{array}{c}\text { integração/regula } \\
\text { ção entre um } \\
\text { valor central e } \\
\text { sentimentos } \\
\text { (modelos A, B, D, E e }\end{array}$ & & \\
F) & & \\
& & \\
\hline $\begin{array}{c}\text { Articulação de } \\
\text { processos de } \\
\text { integração/regula } \\
\text { ção entre valores } \\
\text { centrais e } \\
\text { sentimentos }\end{array}$ & & \\
(modelos C e G) & & \\
\hline Total & & \\
\hline (m) & & \\
\hline
\end{tabular}

\footnotetext{
${ }^{56}$ Justificamos a inclusão nessa categoria dos submodelos D2 e E2, pois entendemos que, embora haja mais do que um elemento central abstraído e significado pelos sujeitos, nem todos os que serviram para organizar o raciocínio dos jovens puderam ser qualificados como valores. No submodelo D2, o curso mostra-se como um valor central, em detrimento da mãe/família, que são destacados pelo sujeito como uma forma de contiguidade ao valor central (já que estará no curso, poderá auxiliar a mãe, tomando conta dos irmãos). O submodelo E2 traz o estágio como valor e um sentimento de dever para com a mãe. Os sentimentos negativos projetados por esses jovens evocam essa ajuda, ou seja, o sujeito auxilia a família contra a sua vontade (a família não é um valor central para esses jovens).

${ }^{57}$ Lembramos que foi necessário desconsiderar seis protocolos que apresentaram respostas evasivas, muito curtas ou nulas do total de respostas obtidas para análise (200 sujeitos).
} 
Gráfico 6: Categorias de modelos em relação aos processos de integração/ regulação de valores e sentimentos diante do conflito moral

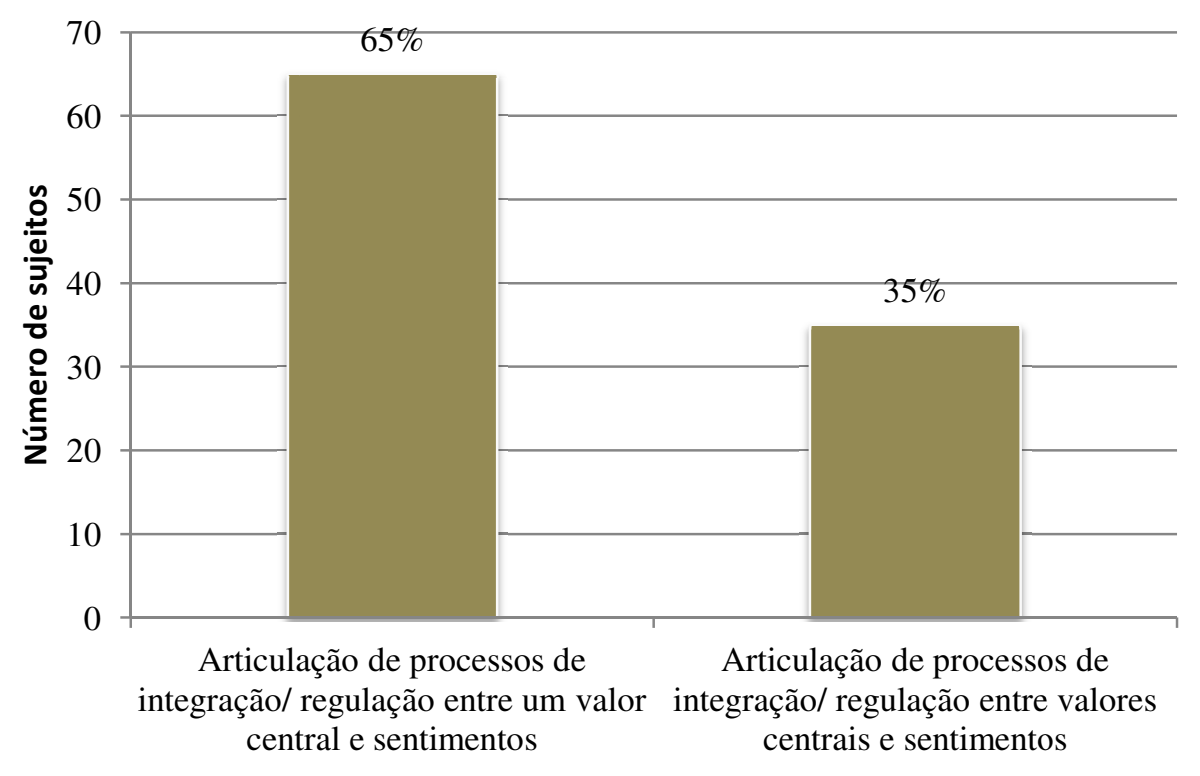

Antes de discutirmos os resultados acima, cremos ser fundamental ponderar que, nas respostas obtidas em relação ao conflito moral, não obtivemos pouca articulação dos processos de integração/regulação de valores e sentimentos. Isso porque todas as respostas foram construídas com base em um ou mais elementos abstraídos do contexto (ou imaginados pelo sujeito, dando-lhes a mesma importância daqueles que constavam na situação apresentada), nas significações que lhes foram atribuídas e nas relações/implicações estabelecidas no conjunto que perfez cada dinâmica do raciocínio empregada. Como se trata de outro instrumento, que requis dos jovens uma elaboração diferente daquela proposta pelas questões relacionadas aos seus projetos de vida, estão em jogo, na análise dos resultados, outros aspectos concernentes aos processos de integração e de regulação de valores e sentimentos. Considerando que os jovens tiveram a oportunidade de se posicionar frente a uma situação que evocava, dentro de um contexto do projeto de vida de um personagem, uma moral voltada para a conquista de objetivos pessoais e/ou o auxílio a uma pessoa próxima (a mãe), a análise de tais processos agora se volta para a complexidade tecida entre os elementos abstraídos, e destes quais perfizeram valores para os jovens, e os sentimentos que lhes foram projetados.

Postas essas considerações, verificamos que houve uma maior centralidade de valores, incorporando ambas as perspectivas (a do sujeito e a da família), no segundo grupo, que, representado pelos modelos $\mathrm{C}$ e $\mathrm{G}$, obteve $35 \%$ das respostas emitidas pelos participantes de nossa investigação. Uma maior parte dos sujeitos (65\% do total de jovens) aplicou modelos 
em que articulou processos de integração e regulação de valores e sentimentos, centralizando um valor em detrimento de outros e, conseguintemente, localizando a perspectiva de forma mais próxima de si ou da família.

Os processos de integração e regulação puderam organizar modelos que elucidaram valores e sentimentos que: a) visavam ao próprio projeto de vida como um valor, na projeção mais forte/central de sentimentos a respeito do estágio (inserção no mercado de trabalho); b) intentavam dar apoio total à família, na projeção mais forte/central de sentimentos a respeito do auxílio à mãe e ao cuidado com a família; c) estabeleceram uma integração entre os objetivos de seus projetos de vida (aceitação do estágio) e dos cuidados à família.

Desse modo, percebemos a possibilidade de outro agrupamento, em três categorias que não correspondem estritamente aos níveis de complexidade dos processos de integração e regulação de valores e sentimentos, mas trazem indícios sobre os mesmos, na medida em que expõem a interlocução os valores destacados e a centralidade que estes e os sentimentos ocupam nas dinâmicas de organização do pensamento dos jovens diante do conflito moral apresentado. São elas:

Grupo A - Valor central estágio/curso, ausência ou presença de outros valores como periféricos (baixa integração entre valores), projeção de sentimentos positivos e negativos mais forte sobre o valor central e baixa ou inexistente sobre os valores periféricos (modelos A, B e D);

Grupo B - Valor central família/mãe, ausência ou presença de outros valores como periféricos (baixa integração entre valores), projeção de sentimentos positivos e negativos mais forte sobre o valor central e baixa ou inexistente sobre os valores periféricos (modelos $\mathrm{E}^{58}$ e F);

Grupo C - Mobilização entre dois valores: estágio e família (mãe), conciliando os dois pontos de vista (do sujeito e da família), integração e regulação entre valores e sentimentos de forma central (modelos C e G).

A distribuição dos sujeitos nessas categorias pode ser mais bem observada com a tabela e gráfico expostos a seguir:

\footnotetext{
${ }^{58} \mathrm{O}$ sub-modelo E2, nesse sentido, torna-se um pouco ambíguo, pois se refere ao elemento estágio como central, mas se sente no dever de auxiliar a mãe. Não entendemos que, em tal submodelo, exista a integração de dois valores. O estágio é um valor para os jovens que aplicaram esse submodelo, mas, pela "força da situação", ao avaliar suas escolhas, eles decidem ajudar a mãe. Decidimos manter esse submodelo nesse agrupamento, embora saibamos que a mãe não é um valor para esses jovens, porque na dinâmica que organiza seus raciocínios vemos uma aproximação com o submodelo E1 e o modelo F.
} 
Tabela 39: Distribuição dos sujeitos nas categorias de modelos em relação aos processos de integração/regulação de valores e sentimentos em diferentes articulações diante do conflito moral.

\begin{tabular}{ccc}
\hline $\begin{array}{c}\text { Categorias de } \\
\text { modelos }\end{array}$ & N & $\%$ \\
\hline $\begin{array}{c}\text { Grupo A } \\
\text { (modelos A, B e D) }\end{array}$ & $\mathbf{7 6}$ & $\mathbf{4 0 , 0}$ \\
\hline $\begin{array}{c}\text { Grupo B } \\
\text { (modelos E e F) }\end{array}$ & 49 & $\mathbf{2 5 , 0}$ \\
\hline $\begin{array}{c}\text { Grupo C } \\
\text { (modelos C e G) }\end{array}$ & $\mathbf{6 9}$ & $\mathbf{3 5 , 0}$ \\
\hline Total & $\mathbf{1 9 4}$ & $\mathbf{1 0 0 , 0}$
\end{tabular}

Gráfico 7: Categorias de modelos em relação aos processos de integração/regulação de valores e sentimentos em diferentes articulações diante do conflito moral.

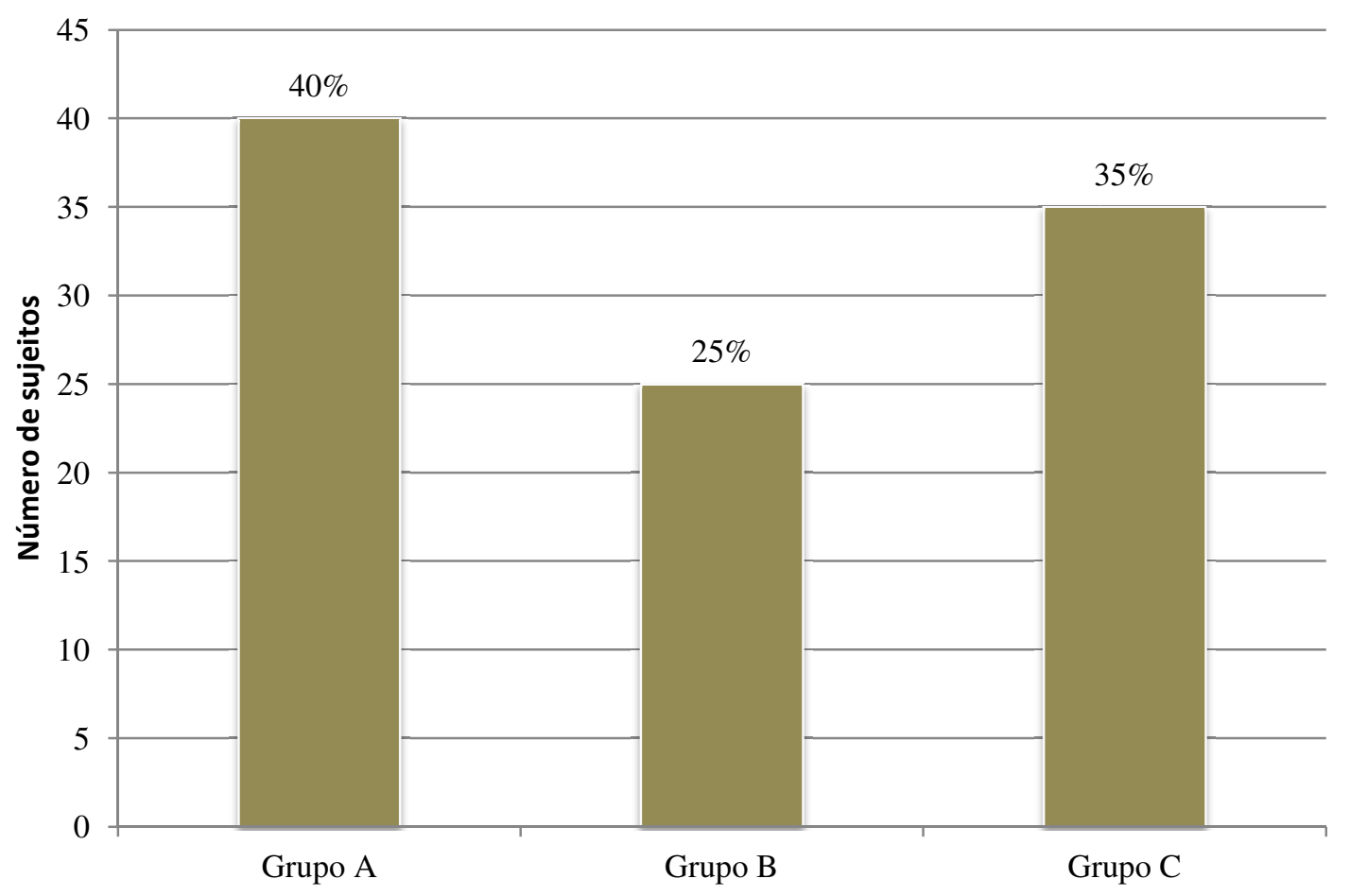

A apresentação dos resultados mediante o agrupamento nas categorias acima indicadas traz interessantes apontamentos para nossa análise dos processos de integração e regulação de valores e sentimentos.

Observa-se, a princípio, que os percentuais são equilibrados, girando em torno de $25 \%$ a 40\%, não havendo, portanto, disparidades que indiquem tendências dos jovens a traçar, 
diante de um conflito em que está em jogo um projeto de vida, valores mais próximos de uma satisfação pessoal ou de um pensamento voltado exclusivamente ao outro.

No entanto, faz-se necessário destacar que a maior parcela dos jovens (76 sujeitos, em um total de $40 \%$ dos participantes) voltou-se para cumprir com anseios que valorizam a inserção no mercado de trabalho, por meio do aceite ao estágio, mesmo que isso significasse a mobilização de valores periféricos (ajuda à família), por meio de sentimentos negativos brandos ou até um pouco mais fortes (como a culpa, que leva uma parte desses sujeitos a buscarem a aceitação da mãe por meio do diálogo).

Outra parcela significativa (69 sujeitos, em um total de $35 \%$ dos jovens) valorizou igualmente o projeto de vida relacionado ao trabalho (aceite do estágio), mas considerou igualmente importante a ajuda à mãe e os cuidados para com a família, conciliando seus interesses pessoais e os das pessoas de sua convivência.

Um número um pouco menor de sujeitos (49 jovens, em um total de $25 \%$ dos participantes) elegeu a família, por meio da ajuda à mãe, como valor central, apresentando ou não outros valores periféricos (estágio) para os quais se projetaram sentimentos negativos mais brandos. Para esses jovens, a família, que recebeu carga afetiva intensa, é mais importante do que seus planos pessoais e suas projeções para o futuro.

Embora saibamos que os resultados oriundos dessa análise, pelo fato de terem sido fruto de um instrumento que partiu da resolução de um conflito, não possam ser comparados aos da análise anterior, cremos que trazem indícios importantes que complementam alguns aspectos destacados anteriormente. Dessa forma, em nosso próximo capítulo, nos destinaremos a discutir sobre os resultados encontrados nas duas análises para verificar se existe um continuиm entre os processos de integração e regulação de valores e sentimentos na elaboração dos projetos de vida e diante de um conflito moral que contém esse conteúdo. 


\section{CAPÍTULO IX \\ DISCUSSÃO DOS RESULTADOS EM RELAÇÃO AOS PROCESSOS DE INTEGRAÇÃO E REGULAÇÃO DE VALORES E SENTIMENTOS NA ELABORAÇÃO DOS PROJETOS DE VIDA E DIANTE DO CONFLITO MORAL}

O principal objetivo desta investigação concentra-se na verificação sobre como se dão os processos de integração e regulação de valores e sentimentos na elaboração dos projetos de vida e na resolução de um conflito moral por jovens. Nos capítulos cinco, seis, sete e oito, dedicamo-nos a descrever os modelos organizadores elaborados pelos participantes e a apresentar os resultados concernentes aos dois instrumentos aplicados.

Neste capítulo, aprofundaremos a discussão sobre os resultados apresentados, resgatando aspectos que julgamos interessantes para a compreensão sobre os processos de integração e regulação de valores e sentimentos, tanto na formulação de projetos de vida quanto na resolução de um conflito que tinha como conteúdo o projeto de vida de um personagem. De forma geral, também discutiremos sobre os resultados, procurando indícios sobre a existência ou não de um continuum entre tais processos no campo da elaboração dos projetos e em um contexto específico com esse conteúdo.

Como já arguimos em capítulos anteriores, e de forma mais aguçada em nosso plano de investigação, os instrumentos aplicados advêm de fontes distintas e possuem objetivos diferentes em relação à forma como o sujeito formula seu pensamento. Para a elaboração de seus próprios projetos de vida, os jovens precisaram, mediante um grupo de 13 questões, refletir sobre suas experiências passadas, sobre suas ações presentes e suas projeções futuras. Os elementos abstraídos pelos participantes encontraram-se nesse esforço de articulação, que, necessariamente, englobou o encadeamento de ideias, de forma a compor um "todo lógico". Para garantir a "coerência" da elaboração do projeto de vida, supõe-se que cada jovem passou por uma série de construções, "idas e vindas", em um processo de organização do pensamento bastante complexo. Formular um projeto de vida consiste em uma atividade que, além de assumir importância para o jovem, acarreta o envolvimento de várias dimensões do self e da sua inter-relação com o mundo.

A resolução de conflitos morais já se coloca de uma forma diferente para os sujeitos que necessitam pensar "dentro de um contexto", posicionando-se no lugar do protagonista e tomando decisões mais rápidas, com elementos cerceados pela própria situação. Embora consista em um processo a ser realizado prontamente, os juízos elaborados pelos sujeitos 
diante de conflitos morais também são absolutamente complexos, uma vez que mobilizam processos que, mesmo com menor chance de revisões e de articulações de ideias, englobam as diversas facetas do self e da sua relação com o meio.

Em ambas as situações, do nosso ponto de vista, acontecem processos funcionais, altamente vinculados aos aspectos concernentes à identidade do sujeito e aos conteúdos das situações. Entre tais processos, estão os de integração e regulação de valores e sentimentos, os quais, a despeito de ocorrerem diferentemente de acordo com a forma como se solicita a elaboração por parte do sujeito, necessariamente coocorrem para a articulação, com base em conjuntos de valores e sentimentos, dos elementos abstraídos, dos significados que lhes são atribuídos e das relações e/ ou implicações que são realizadas sobre tudo isso.

Assim, muito embora tenhamos duas solicitações de organização do pensamento diferentes - o projeto de vida e a resolução de um conflito moral com esse conteúdo -, apresenta-se também, em nossa hipótese, um ponto em comum entre elas: sempre que se organiza um pensamento ocorrem processos de integração e regulação entre valores e sentimentos. Sobre essa divergência/similitude, repousa nosso anseio de perceber se tais processos guardam um continuum que os leva a serem aplicados em situações diversas ou se estão estritamente associados aos conteúdos do meio.

Não desejamos indicar que tais processos se dão de forma estática, mesmo porque isso contrariaria o percurso até o momento traçado. Nossa intenção é de verificar se existem tendências de aplicação desses processos, uma vez que, na organização do pensamento, dentro do campo da moralidade, eles serviriam de base para novas formulações, mediante outros contextos e, assim, novos processos para novos posicionamentos frente às situações encontradas.

Percorreremos, neste capítulo, um caminho diverso do que apresentamos nos itens anteriores. Passaremos a trazer, em um âmbito mais geral, os principais resultados das análises realizadas, traçando paralelos referentes aos processos de integração e regulação de valores e sentimentos na elaboração dos projetos de vida e na resolução do conflito moral. Depois, correlacionaremos os modelos aplicados pelos jovens, de forma a verificar se existe ou não um continuum entre os processos diante de cada instrumento. Por fim, exploraremos as respostas de quatro jovens, buscando aprofundar e exemplificar a discussão realizada de forma mais ampla. 


\subsection{Processos de integração e regulação de valores e sentimentos na elaboração dos projetos de vida e diante de um conflito moral}

O estudo dos processos de integração e regulação de valores e sentimentos revela-se por uma via funcional, uma vez que são mobilizados na organização do pensamento dos sujeitos na medida em que estes necessitam compreender/atuar nas diversas situações que vivenciam cotidianamente.

Nos dois contextos específicos, em que foi solicitada ao jovem participante de nossa pesquisa a elaboração a respeito de um projeto de vida, houve uma série de procedimentos que o levaram a formular juízos, ancorados em seus valores e sentimentos. Como são intrinsecamente mobilizados na organização dos raciocínios dos sujeitos, os processos de integração e regulação de valores e sentimentos puderam, juntamente a outros processos que envolvem outras dimensões do psiquismo humano, arquitetar as maneiras como cada sujeito realizou suas projeções e como se posicionou mediante a resolução de um conflito com conteúdo de um projeto de vida de um personagem. No entanto, como se tratam de duas solicitações diferentes, a despeito de se referendarem a uma mesma temática (o projeto de vida), levaram os jovens participantes a mobilizarem procedimentos diversos para organização de seu pensamento.

Os processos de integração e regulação de valores e sentimentos compõem-se de um todo articulado. Compreendem um complexo que traz a vinculação dos valores e dos sentimentos por meio dos diversos significados que lhes são atribuídos, conferindo-lhes relações e implicações. Na elaboração de juízos, atuam, de acordo com os elementos da situação e aspectos concernentes ao self, processos regulatórios que integram valores e sentimentos, fortalecendo-os e levando-os a rechaçar outras hipóteses.

Ainda que vislumbremos tais processos em sua complexidade, cremos ser pertinente "destrinchá-los", a fim de tecer considerações sobre os resultados encontrados nas formulações advindas a partir de cada instrumento. Assim, traremos nossa discussão organizada em algumas etapas. Esperamos que, à luz dessa fragmentação, possamos evidenciar o todo que perfez as inter-relações entre os valores e sentimentos nas dinâmicas de organização do pensamento dos jovens em referência aos projetos de vida.

Iniciaremos com os valores mobilizados em cada uma das solicitações ao sujeito - de elaboração de seus projetos de vida e diante de um conflito moral com esse conteúdo -, os quais podem ser explicitados na tabela a seguir. 
Tabela 40: Valores mobilizados na elaboração dos projetos de vida e diante do conflito moral.

\begin{tabular}{cc}
\hline Projeto de vida & Conflito moral \\
\hline Trabalho & Estágio \\
Família & Mãe/família \\
Estudo & Curso \\
Deus & \\
"Outros",59 & \\
\hline
\end{tabular}

Estamos de acordo com a proposição de que valores são resultados de uma projeção afetiva positiva sobre objetos e/ou pessoas e/ou relações e/ou sobre si mesmos (PIAGET, 1932; ARAÚJO, 2007). Portanto, consideramos que, embora o que expusemos acima não esteja circunscrito a valores morais (justiça, generosidade, honestidade etc.), alguns elementos foram mobilizados a partir de projeções de sentimentos positivos, fazendo com que se tornassem valorados perante os jovens de nossa investigação.

Além de sentimentos positivos, esses valores receberam significados que puderam tecer uma rede de relações, formando um todo articulado. Nessa articulação, foi possível presenciar, em grande parte dos modelos organizadores do pensamento, a integração entre valores, a qual oportunizou maior complexidade às formulações dos participantes.

Foi possível verificar que os valores relacionaram-se, mediante os significados atribuídos, de diferentes formas de acordo com o contexto apresentado. Na tabela a seguir, indicamos as integrações de valores a partir de cada instrumento e os significados que lhes foram atribuídos, gerando redes de significação.

\footnotetext{
59 Lembramos que "outros" significa uma preocupação/vontade de ajudar outras pessoas, além do círculo familiar do sujeito.
} 
Tabela 41: Integração de valores e suas significações na elaboração dos projetos de vida e no conflito moral

\begin{tabular}{|c|c|c|c|}
\hline \multicolumn{2}{|r|}{ Projeto de vida } & \multicolumn{2}{|r|}{ Conflito moral } \\
\hline $\begin{array}{c}\text { Valores } \\
\text { integrados }\end{array}$ & Significados & $\begin{array}{c}\text { Valores } \\
\text { integrados }\end{array}$ & Significados \\
\hline $\begin{array}{l}\text { Trabalho e } \\
\text { família }\end{array}$ & $\begin{array}{l}\text { Idealização do trabalho e } \\
\text { da família. } \\
\text { Responsabilidade do } \\
\text { sujeito em relação à } \\
\text { família. } \\
\text { Gratidão em relação à } \\
\text { família }\end{array}$ & $\begin{array}{l}\text { Estágio e } \\
\text { família }\end{array}$ & $\begin{array}{l}\text { Estágio é necessário para } \\
\text { ajuda financeira à família. } \\
\text { Conciliação de interesses } \\
\text { entre sujeito e família. }\end{array}$ \\
\hline $\begin{array}{l}\text { Trabalho e } \\
\text { estudo }\end{array}$ & $\begin{array}{l}\text { Estudo abre as portas para } \\
\text { o mercado de trabalho. } \\
\text { Realização pessoal e } \\
\text { reconhecimento social por } \\
\text { meio do trabalho e do } \\
\text { estudo. }\end{array}$ & $\begin{array}{l}\text { Curso e } \\
\text { família. }\end{array}$ & $\begin{array}{l}\text { Curso será importante para o } \\
\text { futuro do jovem ao mesmo } \\
\text { tempo em que permite mais } \\
\text { tempo para ajudar mãe } \\
\text { (cuidar dos irmãos). }\end{array}$ \\
\hline $\begin{array}{l}\text { Deus, } \\
\text { trabalho e } \\
\text { família }\end{array}$ & $\begin{array}{c}\text { Visão idealizada do } \\
\text { trabalho e da família. } \\
\text { Trabalho relacionado à } \\
\text { igreja. }\end{array}$ & & \\
\hline $\begin{array}{l}\text { "Outros"e } \\
\text { Deus }\end{array}$ & $\begin{array}{l}\text { Ajudar os outros por meio } \\
\text { da religião e voluntariado. }\end{array}$ & & \\
\hline $\begin{array}{l}\text { Trabalho, } \\
\text { "outros" e } \\
\text { família }\end{array}$ & $\begin{array}{l}\text { Trabalho objetiva atingir } \\
\text { beneficamente o "outro", a } \\
\text { sociedade. } \\
\text { Responsabilidade do } \\
\text { sujeito em relação à } \\
\text { família. } \\
\text { Gratidão em relação à } \\
\text { família. }\end{array}$ & & \\
\hline
\end{tabular}

A integração entre os valores foi realizada pelos significados a eles atribuídos, na teia de relações tecida pelos jovens. Quando as relações estabelecidas entre os valores e seus significados constituiu um todo articulado e coerente para o sujeito, os elementos posicionaram-se de uma forma central na elaboração do projeto de vida ou na resolução do conflito moral. Podemos inferir, a partir dessas considerações, que, ao mesmo tempo em que garantiram tal centralidade, essa integração regulou o não comparecimento de outras dinâmicas, relacionadas a outros elementos, que não se fizeram tão significativos para os jovens, não recebendo trocas afetivas positivas que os levassem ao status de valores no modelo organizador.

Pode-se constatar que a integração de valores ocorreu tanto na elaboração dos projetos de vida quanto diante do conflito moral. Contudo, verificando a coluna que diz respeito à 
elaboração dos projetos de vida, vê-se que os sujeitos integraram uma maior gama de valores em relação à coluna que traz a integração realizada na resolução do conflito moral. Isso se deve, essencialmente, pelo caráter de cada instrumento. A formulação de um projeto de vida, como já evidenciamos, está aberta a toda sorte de vivências passadas, ações presentes e projeções futuras. A regulação exercida pelos conteúdos da realidade, assim, dá-se de forma menos pontual que em um conflito localizado. No conflito moral, os elementos estão determinados e, embora haja espaço para a imaginação e a criação dos sujeitos, há uma restrição maior em relação ao que pode ser abstraído e significado.

Um aspecto que nos chama a atenção é que, mesmo frente a uma grande possibilidade de integração de valores, principalmente na elaboração dos projetos de vida, houve uma maior articulação do trabalho, família e estudo. Tal integração pode ser explicada por uma influência cultural (TURIEL, 2002; NUCCI, 2001, 2004) que se mostra significativa para a centralidade de valores como trabalho (SPOSITO, 2003, 2005; ABRAMO, 2005; THOMÉ; TELMO; KOLLER, 2011), estudo (SPOSITO, 2005) e família (SOUZA; OLIVEIRA, 2011), que são indicados pelos jovens como fatores importantes para suas vidas.

Faz-se necessário apontar que, como o conflito girava em torno de uma situação em que um personagem tem uma projeção de futuro voltada para o trabalho (estágio em uma grande empresa) e esbarra no pedido da mãe para que não aceite, fica clara a possibilidade de integração entre esses dois elementos, posicionados como valores para os jovens. Os processos de integração que aliam esses dois valores diferem em parte daqueles que são tecidos na elaboração do projeto de vida. Enquanto o significado de responsabilidade em relação à família comparece frente aos dois instrumentos, também se apresentam outros significados, como uma idealização desses elementos e a conciliação de interesses, mostrando que tais processos não se deram de forma completamente equivalente nas duas solicitações.

O estudo/curso é um valor que se integra a outros valores. Contudo, se nas respostas que formularam os projetos de vida esse valor esteve em inter-relação com o trabalho, significado como um "meio" para se chegar/inserir no mercado, naquelas que se voltaram à resolução do conflito, tal valor demonstrou interlocução também com a família, significando uma possibilidade de conseguir tempo para ajudar a mãe a cuidar dos irmãos.

A integração de outros valores, "Deus" e "outros", inclusive com os valores de trabalho e família, pôde apenas comparecer mediante a solicitação de elaboração do projeto de vida, já que foi possível aos jovens alicerçarem-se em suas vivências e projeções futuras. É importante destacar que tais valores, quando integrados a outros, possibilitaram visões bastante diferentes, dando aos valores de trabalho e família outras conotações. A única 
integração que agregou três valores, trabalho, família e "outros", foi a que mais recebeu significados e permitiu o estabelecimento de relações com uma gama maior de complexidade.

Devemos chamar a atenção, também, para o fato de que a integração de valores, tal como sinalizamos na tabela anterior, não ocorreu em todos os modelos organizadores do pensamento. Assim, diante dos dois instrumentos, houve respostas que elegeram apenas valores periféricos, sem integrá-los (por exemplo, o submodelo 1a), ou somente um valor central (por exemplo, os modelos 3, 4 e A1). Verifica-se que a centralidade assumida pelos valores em integração apresenta-se devido ao fortalecimento que eles ganharam nos significados atribuídos às suas articulações.

Além da integração dos valores como um aspecto regulador da organização do pensamento, vemos também como crucial a integração entre os sentimentos e as relações estabelecidas entre eles e os conjuntos de valores. Os sentimentos que compareceram às respostas referentes à elaboração do projeto de vida e à resolução do conflito moral foram pouco diversificados, como podemos analisar a seguir.

Tabela 42: Sentimentos mobilizados na elaboração dos projetos de vida e diante do conflito moral

\begin{tabular}{|c|c|c|}
\cline { 2 - 3 } \multicolumn{1}{c|}{} & Projeto de vida & Conflito moral \\
\hline \multirow{3}{*}{ Sentimentos } & Bem-estar & Bem-estar \\
positivos & Realização & Realização \\
& Felicidade & Tranquilidade \\
& Satisfação & Felicidade \\
\hline \multirow{3}{*}{ Sentimentos } & Amor & Mal-estar \\
negativos & Insegurança & Tristeza \\
& Insatisfação & Culpa \\
& Cansaço & Inconformismo \\
& & Insatisfação \\
& & Desilusão \\
& & Arrependimento \\
\hline
\end{tabular}

Verificamos, com a relação de sentimentos mobilizados em cada situação, que os jovens indicaram sentimentos positivos e negativos em seus modelos organizadores correspondentes à temática dos projetos de vida. É evidente a presença, principalmente, dos 
sentimentos positivos de bem-estar, realização e felicidade. O único sentimento positivo que difere nos dois instrumentos é o amor, que comparece a apenas um modelo organizador referente ao projeto de vida (modelo 3, que apresentou as relações interpessoais como valor). Os sentimentos positivos apresentaram-se de forma a posicionar os elementos abstraídos e significados como valores e a reforçar sua integração.

Se os sentimentos positivos mostraram-se de forma mais homogênea, o mesmo não se pode dizer dos sentimentos negativos. Na elaboração dos projetos de vida, poucas foram as referências a esses sentimentos, tendo os sujeitos restringido o seu comparecimento a apenas alguns modelos: insegurança e insatisfação, no submodelo $5 \mathrm{~b}$, ao se referirem à gravidez sem planejamento; e o cansaço, no modelo 2 e no submodelo 6a, ao projetarem os anos de trabalho e de esforço. Já na resolução de conflito, tais sentimentos mostraram-se mais diversificados e atuantes na elaboração dos modelos organizadores. Pode-se entender que os sujeitos mobilizaram mais sentimentos dessa natureza porque se imaginaram contrariando valores que lhes pareceram importantes.

Nas tabelas a seguir, buscamos uma relação entre a integração dos valores e dos sentimentos nos modelos organizadores aplicados nos projetos de vida e na resolução do conflito moral.

Tabela 43: Integração de valores e de sentimentos positivos e negativos na elaboração dos projetos de vida

\begin{tabular}{|c|c|c|}
\hline Valores integrados & Sentimentos positivos & Sentimentos negativos \\
\hline Trabalho e família & $\begin{array}{l}\text { Bem-estar, realização, } \\
\text { felicidade, satisfação. }\end{array}$ & Insegurança, insatisfação. \\
\hline Trabalho e estudo & $\begin{array}{l}\text { Bem-estar, realização, } \\
\text { felicidade, satisfação. }\end{array}$ & Cansaço. \\
\hline Deus, trabalho e família & $\begin{array}{l}\text { Bem-estar, realização, } \\
\text { felicidade, satisfação. }\end{array}$ & $\begin{array}{ll}--- \\
\end{array}$ \\
\hline "Outros" e Deus & Felicidade e realização. & ---- \\
\hline $\begin{array}{c}\text { Trabalho, “outros" e } \\
\text { família }\end{array}$ & Felicidade e realização. & ---- \\
\hline
\end{tabular}


Tabela 44: Integração de valores e de sentimentos positivos e negativos diante do conflito moral

\begin{tabular}{|c|c|c|}
\hline Valores integrados & Sentimentos positivos & Sentimentos negativos \\
\hline Estágio e família & $\begin{array}{c}\text { Bem-estar, realização, } \\
\text { felicidade, tranquilidade. }\end{array}$ & $\begin{array}{c}\text { Mal-estar, tristeza, } \\
\text { arrependimento, culpa, } \\
\text { inconformismo, } \\
\text { insatisfação, desilusão. }\end{array}$ \\
\hline Curso e família. & Bem-estar e felicidade. & Mal-estar, tristeza e culpa. \\
\hline
\end{tabular}

A partir do exposto, podemos verificar que cada conjunto de valores integrados recebeu carga afetiva positiva, que os referendou propiciando sua organização central na dinâmica de organização de pensamento dos jovens. Pátaro (2011) e Arantes (2012) informam que os sentimentos possuem papel significativo para a elaboração de projetos de vida e ressaltam que os sentimentos de bem-estar e autorrealização são para eles determinantes, assim como outros sentimentos positivos vinculados ao self. Tal como as autoras, foi possível averiguar, em nossa investigação, o papel desses sentimentos para o engajamento dos jovens nos seus projetos de vida.

Os sentimentos negativos foram muito importantes para as elaborações voltadas ao conflito moral, uma vez que regularam a integração dos valores que organizou suas dinâmicas de pensamento. Ao se sentirem contrários aos seus valores, os jovens manifestaram sentimentos mais fortes como culpa, arrependimento e tristeza, demonstrando que, de fato, os valores integrados posicionam-se de forma central em seu sistema moral. Esse papel regulador dos sentimentos já havia sido exposto por pesquisas empíricas, notadamente acerca dos sentimentos de vergonha e de culpa (ARAÚJO, 1998, 2003a; DE LA TAILLE, 2002; PINHEIRO, 2009).

Ainda sobre os sentimentos, gostaríamos de destacar que eles não compareceram de forma isolada, mas em conjuntos, perfazendo um complexo que também recebeu significados articulados àqueles emitidos em relação à integração de valores. Na formulação do projeto de vida, nota-se, basicamente, a presença do grupo de sentimentos positivos composto por bemestar, realização, satisfação e felicidade. A integração desses sentimentos leva-nos a entender uma projeção afetiva altamente positiva, centrada na autorrealização do jovem, ao se imaginar bem-sucedido no futuro próximo ou distante. Os sentimentos negativos nos projetos de vida 
não se configuraram em complexos, permanecendo de forma mais branda e relacionada a aspectos periféricos.

Diante do conflito moral, também foi possível observar conjuntos de sentimentos positivos voltados à autorrealização de projetos pessoais e de ajuda à família. Não obstante, também compareceram outros conjuntos, de sentimentos negativos (mal-estar, tristeza, culpa, etc.), que sinalizaram para uma forte carga afetiva referente à realização de atitudes contrárias aos valores integrados e destacados pelos jovens. Esse complexo de sentimentos negativos foi determinado por um senso de agir contra seus valores e ter que "carregar" o fardo de tal posicionamento.

Por meio do corpo de significados referentes a cada sentimento, vê-se que não se pode considerar um sentimento em uma visão unilateral, com apenas uma implicação, visto que, em cada situação em que é mobilizado, pode receber significados diferentes, inclusive envolvendo outros sentimentos. Por esse motivo, como nos colocam Moreno Marimón e Sastre (2010) é mais correto utilizar o termo "complexo de sentimentos", na medida em que, dentro de um conjunto que lhes confira sentido, um sentimento agrega outros que formam sistemas, configurando variações de acordo com características do grupo de sentimentos articulado.

Os sentimentos positivos e os sentimentos negativos, em nossa investigação, configuraram complexos que, de maneira simultânea, foram aplicados regulando a integração de valores e sendo por ela regulados. Nesse ínterim, mostra-se fundamental destacar que, além da composição dos sentimentos, os complexos remataram pensamentos, no tocante às significações que lhes foram atribuídas, assim como as articuladas às mobilizadas pelos valores. O todo composto pelos complexos de sentimentos e valores pôde ser expresso, na presente pesquisa, como um tecido intra e interconectado, que abarcou, de acordo com a coerência enredada pelo sujeito, sentimentos, pensamentos e valores, em uma rede que lhe conferiu significado pelas relações/implicações estabelecidas.

Percebe-se, desta forma, que os processos de integração de valores e sentimentos constituem-se em um complexo aplicado com matizes diferentes de acordo com as situações e o que elas evocam, bem como na forma como são incorporados ao self, do lugar que ocupam no sistema de valores do sujeito. Assim, ficou claro que, embora tenham se instaurado com uma integração de valores e sentimentos "próxima", mesmo porque se tratava de uma temática semelhante e tenha acontecido uma tendência de articulação entre valores e sentimentos, os processos evocados em uma ou outra situação referendaram tecituras com 
matizes diferentes, com a incorporação de complexos de sentimentos diversos e redes de relações nos significados atribuídos bastante voltadas aos contextos em questão.

\subsection{Discussão dos resultados sobre a distribuição dos sujeitos nos modelos organizadores do pensamento na elaboração dos projetos de vida e diante do conflito moral}

O enfoque das diferenças e contiguidades entre os processos de integração e regulação de valores e sentimentos, efetuado no item anterior deste capítulo, permite que reconheçamos tendências de articulação dos complexos de valores e sentimentos em situações com temáticas próximas, embora elucide que tais processos sempre ganharão nuances de acordo com a interlocução estabelecida entre valores e sentimentos por meio dos significados atribuídos e das relações/implicações realizadas pelo sujeito, de forma a obter, de acordo com tais procedimentos, a organização de seu pensamento.

A seguir, apresentaremos a distribuição dos sujeitos nos modelos organizadores do pensamento diante da elaboração de seus projetos de vida e na resolução do conflito com essa temática. Pretendemos, dessa forma, verificar se houve um continuum entre os processos de integração e regulação de valores e sentimentos coadunados em cada uma das solicitações aos jovens de nossa pesquisa. 
Tabela 45: Distribuição dos sujeitos nos modelos e submodelos organizadores elaborados nos projetos de vida e na resolução do conflito moral

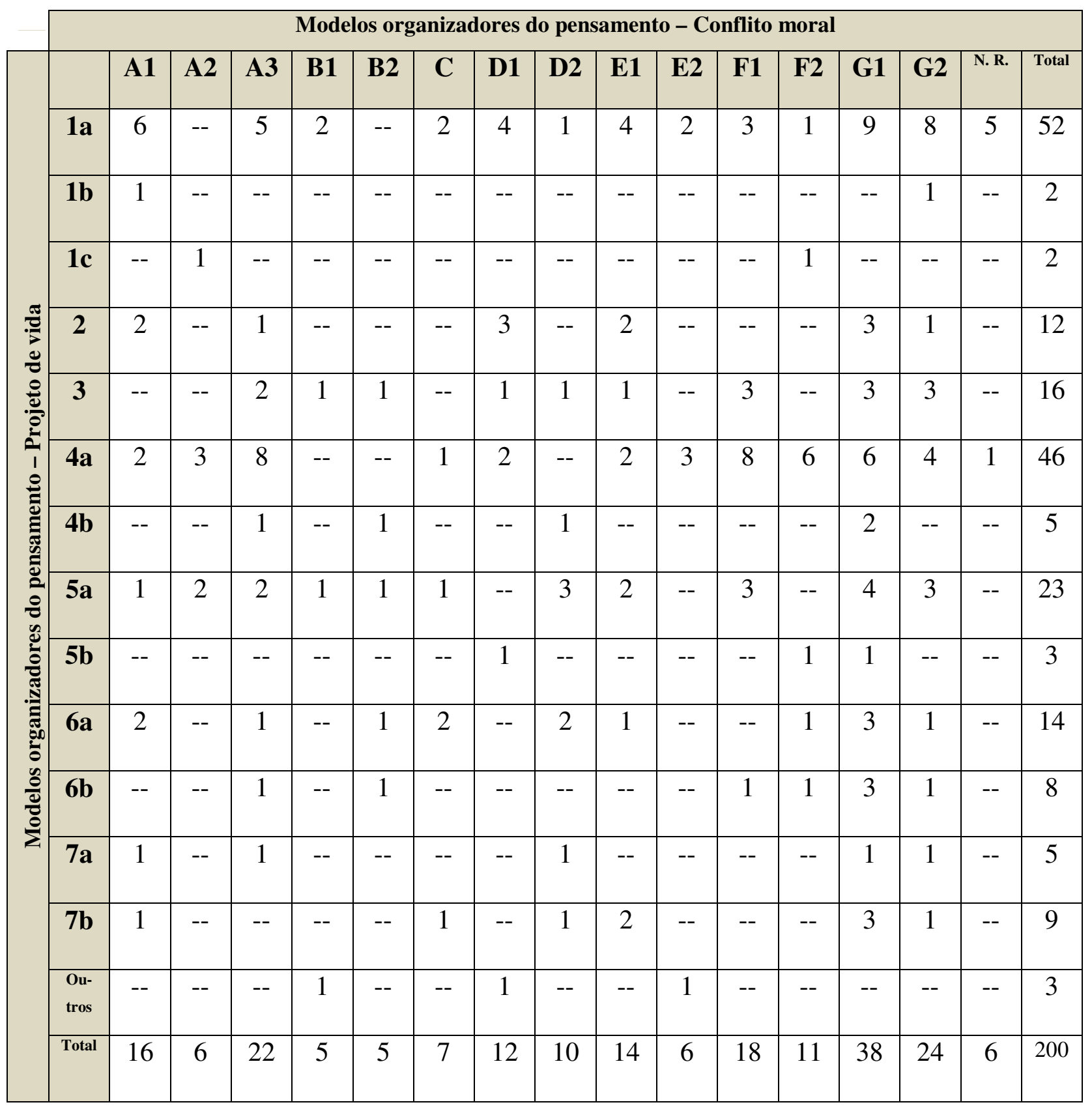

A leitura dessa tabela indica, a priori, que não existe uma continuidade entre a elaboração dos projetos de vida e a resolução do conflito moral com esse conteúdo, pois percebemos que os sujeitos que aplicaram modelos diante de um instrumento, distribuíram-se em vários modelos e submodelos elaborados frente ao conflito moral.

Todavia, alguns detalhes dessa tabela chamam a atenção para possíveis tendências relacionadas à organização do raciocínio dos participantes na aplicação dos modelos organizadores via processos de integração e regulação de valores e sentimentos. 
Os submodelos mais elaborados, nos projetos de vida, foram 1a e 4a. Nesses submodelos, encontra-se uma projeção frágil, com valores periféricos de família e trabalho, e um projeto de vida em que se visualiza o trabalho e a família de forma idealizada. Os sujeitos que aplicaram o submodelo 1a distribuíram-se igualmente nos modelos e submodelos da resolução de conflito, apresentando um número levemente maior na aplicação dos submodelos G1 e G2 que apresentavam uma tentativa de conciliação de interesses.

Os jovens que elaboraram o submodelo 4a também se mostraram distribuídos nos modelos e submodelos da resolução do conflito. Contudo, verifica-se que não aplicaram os submodelos B1 e B2, que indicava a culpa do sujeito em não ajudar a mãe, buscando o diálogo como forma de garantir sua aprovação ou confortá-la. Além disso, proporcionalmente ao número de jovens do submodelo 4a, os submodelos G1 e G2 foram pouco elaborados por eles.

Outros dois aspectos que merecem destaque são as relações entre os modelos aplicados pelos jovens dos submodelos $6 \mathrm{~b}$ e $7 \mathrm{~b}$. Os jovens do submodelo $6 \mathrm{~b}$, em que se priorizava o trabalho como fonte de realização pessoal e reconhecimento social, surpreendentemente elegeram, diante do conflito moral, soluções voltadas à família ou à conciliação de interesses entre o sujeito (trabalho) e família. Já o submodelo 7b, que trazia os valores família, trabalho e "outros", indicando a possibilidade do trabalho beneficiar a sociedade e o círculo familiar, correlacionou-se a modelos que se voltaram a cumprir um dever perante a mãe, a aceitar o estágio como forma de ajudar a família e a conciliar interesses. Apenas um sujeito desse submodelo elaborou o submodelo A1, em que elegia apenas o estágio.

Com a intenção de ampliar a discussão sobre tais tendências, analisaremos os resultados com foco nos modelos organizadores. 
Tabela 46: Distribuição dos sujeitos nos modelos organizadores elaborados nos projetos de vida e na resolução do conflito moral.

\begin{tabular}{|c|c|c|c|c|c|c|c|c|c|c|}
\hline & \multicolumn{10}{|c|}{ Modelos organizadores do pensamento - Conflito moral } \\
\hline \multirow{10}{*}{ 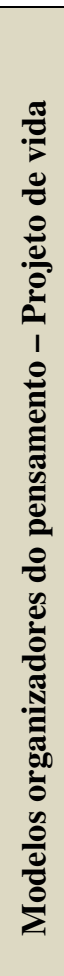 } & & $\mathbf{A}$ & $\mathbf{B}$ & $\mathbf{C}$ & $\mathbf{D}$ & $\mathbf{E}$ & $\mathbf{F}$ & $\mathbf{G}$ & N. R. & Total \\
\hline & 1 & 13 & 2 & 2 & 5 & 6 & 5 & 18 & 5 & 56 \\
\hline & 2 & 3 & -- & -- & 3 & 2 & -- & 4 & -- & 12 \\
\hline & 3 & 2 & 2 & -- & 2 & 1 & 3 & 6 & -- & 16 \\
\hline & 4 & 14 & 1 & 1 & 3 & 5 & 14 & 12 & 1 & 51 \\
\hline & 5 & 5 & 2 & 1 & 4 & 2 & 4 & 8 & -- & 26 \\
\hline & 6 & 4 & 2 & 2 & 2 & 1 & 3 & 8 & -- & 22 \\
\hline & 7 & 3 & -- & 1 & 2 & 2 & -- & 6 & -- & 14 \\
\hline & Outros & -- & 1 & -- & 1 & 1 & -- & - & -- & 3 \\
\hline & Total & 44 & 10 & 7 & 22 & 20 & 29 & 62 & 6 & 200 \\
\hline
\end{tabular}

Gráfico 8: Distribuição dos sujeitos nos modelos organizadores elaborados nos projetos de vida e na resolução do conflito moral.

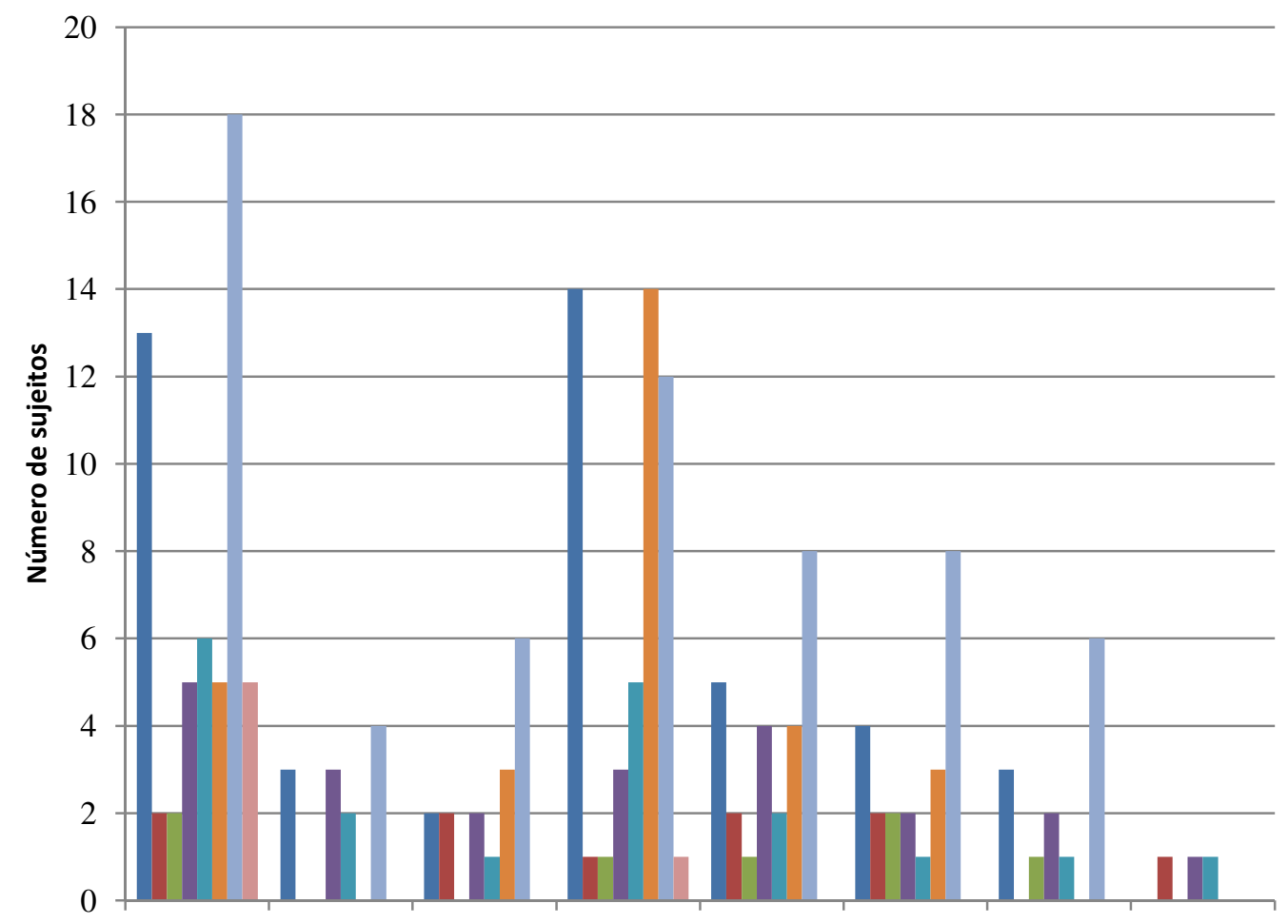

- Modelo A

Modelo B

Modelo C

- Modelo D

Modelo E

Modelo F

Modelo G

Não resp.

Modelo 1 Modelo 2 Modelo 3 Modelo 4 Modelo 5 Modelo 6 Modelo 7 Outros 
A tabela e o gráfico expostos anteriormente fazem-nos observar que grande parte dos participantes aplicou o modelo $G$ na resolução do conflito, independentemente do modelo organizador elaborado sobre seus projetos de vida. Os 62 jovens que o aplicaram distribuíram-se nos modelos organizadores referentes aos projetos de vida, estando, grosso modo, em número superior à elaboração de outros elementos. Com exceção do modelo 4, em todos os outros vemos o modelo $\mathrm{G}$ sendo aplicado em número bastante superior aos demais modelos.

No modelo 1, que apresentou projeções bastante frágeis sobre o futuro, percebe-se que um número significativo de sujeitos (18 jovens) aplicou o modelo $G$, relacionado à conciliação de interesses. Tal resultado destaca-se pelo fato de vislumbrarmos no modelo $G$ um grande nível de complexidade, no envolvimento da perspectiva do self e dos outros. Vê-se que não houve continuum entre a aplicação dos modelos nos projetos de vida e diante do conflito moral para esses participantes. A partir de tal constatação, pode-se considerar que, muito embora esses jovens possam tecer formulações frágeis sobre os projetos de vida, frente a uma situação que envolva essa temática, eles se colocam firmemente em seu propósito, sem desconsiderar a perspectiva do outro.

Ainda sobre o modelo 1, percebe-se que houve um número significativo de jovens que aplicou o modelo A (13 sujeitos), cujas respostas concentravam-se na perspectiva de aceitar o estágio com nenhuma ou pouca consideração pelo pedido da mãe. Como os sentimentos apresentados nos modelos 1 e A são brandos, pode-se observar que esses sujeitos mantiveram o nível de elaboração frágil nas dinâmicas de organização de seu pensamento. A mesma continuidade também pode ser observada no item "não respondeu" (cinco jovens do modelo 1), em que os jovens emitiram respostas curtas e incompletas. Nesse caso, notamos que não desejaram ou não conseguiram, frente às duas solicitações, elaborar respostas mais completas, incorporando significados aos elementos abstraídos que resultaram em relações/implicações bastante tênues e fragilizadas.

Os jovens que elaboraram o modelo 2, a qual correspondia à valoração do trabalho significado, principalmente, como possibilidade de consumo e estabilidade financeira, aplicaram de forma mais equilibrada os modelos A, D, E e G (entre duas e quatro respostas em cada um desses modelos). Assim, embora tentassem conciliar interesses próprios e os da família ao aplicarem o modelo G, esses jovens tenderam a aplicar modelos em que priorizaram o estágio e o estudo, apenas voltando-se à família quando sentiram dever em relação a ajudá-la. Os modelos $\mathrm{B}$, cujo sentimento de culpa levava o jovem a tentar diálogo 
com mãe, $\mathrm{C}$, do estágio como auxílio à família, e F, que valorava a família propriamente, não foram aplicados por esses jovens.

Sobre os participantes que aplicaram o modelo 3, no qual emitiram respostas voltadas às relações interpessoais, depreendemos que organizaram seus raciocínios, distribuindo-se nos modelos A, B, D, E e F (entre um e três respondentes em cada modelo), mas com um número um pouco superior na aplicação do modelo $G$, da conciliação entre interesses pessoais e familiares (com seis participantes dos que aplicaram o modelo 3). Importante se faz citar que nenhum jovem que elaborou o modelo 3 voltou-se à compreensão do estágio como possibilidade de ajudar a família (modelo C).

Observando as relações entre o modelo 4 e a organização do pensamento desses jovens diante do conflito moral, chama-nos à atenção certa tendência à manutenção dos processos de integração e regulação de valores e sentimentos. Ao aplicar o modelo 4, os jovens estabeleceram integração entre os valores de família e trabalho, significando-os de uma forma idealizada, com o apoio de sentimentos positivos de bem-estar, realização e felicidade. A rede de significações estabelecida entre os valores e sentimentos, contudo, mostrou-se branda, acarretando uma projeção não tão sólida. Esses mesmos jovens tenderam a aplicar os modelos A e F (14 formulações em cada, correspondendo a 28 participantes do modelo 4), em que ou priorizaram o estágio, sem se voltar à família, ou se voltaram totalmente à família, sem priorizar o estágio. A força da aplicação desses modelos faz-nos inferir que os valores de trabalho e família, para esses jovens, não se mostrou tão central em seu sistema moral.

Um número significativo de jovens do modelo 4 (12 sujeitos), contrariamente a tal tendência, apresentaram dinâmicas de pensamento que se direcionaram para conciliar a vontade de aderir ao estágio concomitantemente ao fato de ajudar a família (modelo G). Além disso, os demais sujeitos distribuíram-se em número menor de respostas nos demais modelos organizadores: B, C, D e E (entre um e cinco para cada modelo).

Os jovens que aplicaram os modelos 5 e 6, na construção de seus projetos de vida, mostraram distribuição próxima na organização de seu pensamento diante do conflito moral. Os sujeitos de ambos os modelos tenderam a elaborar, de forma mais efetiva, o modelo $\mathrm{G}$, conciliando o interesse pelo estágio e a necessidade da família (oito respondentes de cada modelo). No modelo 5, em que o jovem percebia a integração do valor trabalho à família por meio da responsabilidade que sentia em relação a esta, destaca-se a aplicação dos modelos A, em que deram prioridade ao estágio, do modelo D, no qual também se voltavam ao estágio, mas, pelo sentimento de culpa, tentavam o diálogo com a mãe, e do modelo $\mathrm{F}$, em que se enfatiza a família como valor. Já no modelo 6, nota-se que os jovens distribuíram-se quase 
uniformemente entre os modelos A, B, C, D, E e F, com uma a quatro aplicações em cada modelo.

O modelo 7, por fim, traz alguns resultados importantes para a presente análise. Tratase de um modelo em que, além dos valores de trabalho, família e Deus, traz também, de forma efetiva, a preocupação com o outro. Os jovens que elaboraram esse modelo mostraram uma tendência à aplicação do modelo $\mathrm{G}$, em que fincam seus ideais de aceitação do estágio, sem deixar de se preocupar com a família (seis sujeitos do total de respondentes do modelo 7). No entanto, apesar de terem elaborado projetos de vida voltados ao outro, por meio do voluntariado e do trabalho, uma parcela (três jovens) aplicou o modelo A, destacando o trabalho, sem referência à família. Outras elaborações estiveram centradas nos modelos C, com o estágio como forma de auxílio à família (uma aplicação), D, cujo valor central voltouse ao curso, tendo a família prioridade ou não nessa escolha (dois participantes), e E, em que o jovem sentia o dever de ajudar a família (duas elaborações). Os jovens que aplicaram o modelo 7 não o fizeram com o modelo B (diálogo com mãe para aplacar a culpa frente a aceitação do estágio) e F (ajuda à mãe/família, sem eleição do estágio como importante).

A análise de tais resultados leva-nos a algumas considerações importantes para o presente trabalho, pois conduzem nosso olhar para a complexidade inerente aos processos de integração e regulação entre valores e sentimentos.

Primeiramente, há de se verificar que não se constatam os mesmos processos de integração e regulação entre valores e sentimentos diante das duas solicitações: na elaboração do projeto de vida e na resolução do conflito moral. Mesmo existindo certa relação entre tais "situações", visto que tratavam de uma temática equivalente, verifica-se que exigiam formas de organização diferentes de raciocínio pelos jovens. Os contextos mostraram-se fortemente implicados nos processos de formulação dos modelos, levando os jovens a integrarem valores e sentimentos centrados na interlocução dos conteúdos de cada situação. Assim, ao tecerem seus projetos de vida, abstraíram, significaram e teceram relações/implicações consoantes suas vivências, experiências passadas e projeções futuras; ao se posicionarem diante do conflito moral, organizaram seu pensamento mediante abstração e significação de elementos existentes ou imaginados na situação, ocasionando relações/ implicações entre eles.

Para alguns jovens participantes de nossa investigação, foi possível proceder à integração e regulação de valores e sentimentos "próximos" nas duas situações. Contudo, a rede de relações e implicações estabelecidas, mediante os significados atribuídos não pôde ser a mesma, de acordo com a compreensão sobre os conteúdos expostos na situação. Dessa forma, pôde-se verificar, por exemplo, que sujeitos que aplicaram o modelo 4, em que 
posicionaram família e trabalho como centrais e integrados, embora os tenham significado brandamente como idealizados em seus futuros, voltaram-se, em grande parte, para a aplicação dos modelos A, F e G, priorizando o estágio, a família ou a conciliação do interesse de ambos. Contudo, na aplicação desses modelos, integraram os valores de forma diferente do que fizeram em seus projetos de vida, chegando a outras redes de relações pela configuração de outros complexos de valores e de sentimentos.

Outro ponto fundamental da análise dos processos que envolveram a formulação dos modelos na elaboração dos projetos de vida e diante do conflito moral com esse conteúdo esteve calcado na própria complexidade inerente ao instrumento. Ainda que solicitasse uma tarefa complexa ao sujeito, a resolução do conflito mostrou-se mais tangível aos jovens, visto que lhes solicitava a abstração e significação de elementos expostos em uma "realidade" (embora pudesse incorporar outros imaginados pelo sujeito, mas sempre dentro da regulação exercida pelo "real"). Deessa perspectiva, pôde-se constatar que, mesmo quem elaborou projeções frágeis (modelo 1), conseguiu, frente ao conflito moral, tecer maiores redes de relações mediante complexos de valores e sentimentos interconectados nos processos que subjazeram a organização de seu pensamento, incluindo perspectivas que lançaram mão de maior complexidade, como a percepção do interesse próprio, self-regarding, e de um outro, other-regarding (DAMON, 1995), no modelo G. O conflito moral, no que diz respeito a representar uma "realidade", mesmo que esta não esteja próxima das vivências do sujeito, possibilita uma maior visão sobre o outro, uma vez que ele já se encontra implicado na situação apresentada. Com isso, verifica-se que a elaboração do projeto de vida envolve uma dinâmica que exige uma maior incursão sobre si mesmo, estando "implícita", no mais das vezes, a contiguidade das ações para além do self (BUNDICK, 2009).

Contudo, mesmo estando mais explícita a relação com o outro (o outro concreto, nos termos de Benhabib, 1992) no conflito moral, nem sempre ele é abstraído e significado como importante para a organização da dinâmica do pensamento do jovem, incluindo aqueles que, em seus projetos de vida, se voltaram para o outro, seja por meio do voluntariado e da religião, seja por meio do trabalho. Isso se torna visível ao observarmos que sujeitos que elaboraram o modelo 7 aplicaram o modelo $\mathrm{A}$, desconsiderando de suas respostas a ajuda à mãe e à família.

O que pesa de toda essa discussão é a complexidade inerente aos processos de integração e regulação de valores e sentimentos, dado que o continuum entre tais processos nas duas situações, que levam à organização do pensamento em cada uma delas, pode não parecer tão evidente, como se houvesse, por exemplo, uma tendência de o sujeito que 
formulou projeções frágeis viesse também a emitir juízos morais com pouca integração de valores e sentimentos. Essa análise demonstrou que a moralidade abarca teias de relações compostas por implicados processos de integração e regulação, compondo-se de uma complexidade que deriva da inter-relação das dimensões que compreendem o self e os conteúdos do meio (relações interpessoais, físicas e socioculturais). Restringir-se a correspondências unívocas entre modelos significaria reduzir um conteúdo que, na realidade, mostra-se de uma grande complexidade.

Se as relações entre os modelos não podem ser alvo de comprovação de tendências de organização do pensamento, logo que se tratam de conteúdos fomentadores de dinâmicas diferentes do raciocínio, tal análise nos leva a indicar a força dos conteúdos (NUCCI, 2001, 2004) para a execução de procedimentos que se utilizem de complexos de sentimentos e valores. Contudo, não podemos deixar de assinalar que o sujeito, enquanto ser constituído por uma identidade moral, não elabora modelos apenas a partir das situações, mas parte de outros já construídos em outras vivências para as suas elaborações (MORENO MARIMÓN; SASTRE, 2010; LAPSLEY; NARVAEZ, 2004). O que caracteriza a identidade moral é o compromisso que o sujeito tem para com o self (BLASI, 1995, 2004). Pode-se considerar, destarte, que esse compromisso advém de uma constituição do sistema moral que leva o sujeito a se posicionar perante as situações, levando em conta os valores que lhes são centrais (DAMON, 1995; ARAÚJO, 2007) e os elementos que, a partir e pela regulação desses complexos de valores (incluindo aqueles derivados de crenças, objetivos, desejos, projeções, etc.) e de sentimentos, comparecem à elaboração dos modelos sobre a "realidade". Em nossa concepção, o sujeito deve perceber um nível de "coerência" em seus juízos e ações morais, dentro de um espectro do que julga bom para si mesmo e, consequentemente, para a convivência social (PUIG, 1996, 2007).

Devido à complexidade da relação entre o self e os conteúdos do meio, que envolve, necessariamente, processos de integração e regulação de valores e sentimentos para a organização das dinâmicas do pensamento, averiguar o continuum entre os processos tecidos em cada modelo organizador elaborado diante de solicitações diferentes, significaria perceber esse nível de "coerência" do sujeito nos seus juízos morais. Contudo, tal "coerência" apenas pode ser tecida pelo sujeito, em processos conscientes ou não, que envolvem múltiplas dimensões do psiquismo humano, não estando, necessariamente, exposta na elaboração de juízos ou ações morais. Isso explica porque certos comportamentos parecem incoerentes para uns, mas, no campo de relações estabelecidas pelo sujeito, podem lhes parecer totalmente "coerentes" com sua identidade moral. 
A forma de tentarmos nos aproximar desse continuum entre os processos que se mostram inerentes à elaboração de modelos organizadores encontra-se em uma análise mais fina, buscando nas redes de significados atribuídos aos complexos de valores e sentimentos um sentido que guia as formulações das dinâmicas de pensamento dos jovens no tocante aos projetos de vida.

\subsection{Articulação de processos de integração e regulação de valores e sentimentos na elaboração dos projetos de vida e diante do conflito moral}

Tendo exposto que os processos de integração e regulação de valores e sentimentos ocorrem diferenciadamente mediante as solicitações de organização do pensamento, que envolvem conteúdos e formas de significação e elaboração de relações diversas, mas que prescindem de um continuum que permite ao sujeito embasar suas considerações a partir de outras já tomadas frente a contextos "próximos" e que o constituem como self, percebemos que adentrar nessa rede de significações/relações/implicações torna-se tarefa delicada, visto que é formulada de maneira bastante subjetiva, em uma rede de articulações que faz sentido, muitas vezes, apenas para o próprio sujeito. Entretanto, muito embora saibamos das dificuldades de tal tarefa, parece-nos acertado buscar um maior conhecimento sobre as relações entre a integração e regulação exercida pelos complexos de valores e sentimentos em uma análise fina que considera a particularidade de cada sujeito.

Por não se possível realizar uma análise tão minuciosa do continuum que perfaz os processos de integração e regulação de valores e sentimentos que subjazeram a organização do pensamento de todos os participantes de nossa investigação, elegemos as elaborações de cinco jovens, envolvendo a formulação de seus projetos de vida e diante do conflito moral com esse conteúdo. Esses participantes foram escolhidos por apresentarem processos diferenciados de integração e regulação de valores e sentimentos, trazendo indícios de tendências que compareceram na análise que fizemos anteriormente.

\section{Sujeito 59, feminino, 16 anos, Sobral, CE (aplicou os submodelos 1a e G2)}

O sujeito 59 apresentou uma integração frágil entre elementos em seu projeto de vida e, pela escassez de sentimentos positivos, não os trouxe como valores centrais. Foram apresentados os elementos Deus, família e estudo/trabalho ao longo do protocolo, mas sempre 
com poucos e contraditórios significados atribuídos, o que levou a relações/implicações não tão articuladas.

Ao relatar sobre seu dia a dia, a jovem destaca que mora com a mãe e a tia e se sente bem pela família que tem. Os aspectos que considera mais importantes no presente são Deus, família e seus sonhos, os quais postula terem recebido status de importância por influência da mãe, apesar de não estabelecerem trocas afetivas positivas. A jovem deseja que o mundo mudasse em termos de segurança e paz, o que não apresenta relação com suas ações cotidianas. Ela se vê com o papel de conscientizar as pessoas.

Sobre o futuro mais próximo, o sujeito 59 deseja cursar uma faculdade de veterinária e trabalhar na área. Em um futuro distante, quer estar realizada profissionalmente, casada e com filhos, projetando o sentimento de felicidade. No entanto, quando indica seu projeto de vida, aponta que consiste em construir uma família bem estruturada (não há a indicação de "Deus").

Consideramos que a projeção dessa jovem mostra-se frágil por não manter, ao longo de suas respostas, os elementos e sentimentos com atribuição de significados que lhes garanta uma densa articulação.

Posicionando-se frente ao conflito moral, essa jovem busca manter seus planos em relação ao futuro, sem desconsiderar o pedido da mãe. Sua resposta à primeira questão foi: "eu tentaria resolver da melhor forma possível. Eu tentaria conciliar as duas coisas, de forma que ninguém saísse prejudicado”. A jovem demonstra mal-estar quando se imagina não ajudando a mãe e também caso não aceite o estágio. Contudo, é enfática a indicar que se importa até mais com a mãe do que consigo mesma: "eu me sentiria menos mal (se não aceitasse o trabalho), pois eu estaria ajudando a pessoa que mais amo na Terra".

Percebe-se que, mesmo não apresentando uma rede de relações com grande gama de significados em seu projeto de vida, a jovem indica elementos como família e estudo/trabalho que, no conflito, mostram-se com maior "força" devido aos significados atribuídos e aos sentimentos projetados. A dificuldade em expor a elaboração voltada à família e ao estudo/trabalho fragilizou a exposição de seu projeto de vida, trazendo-o de forma desconectada e, por vezes, contraditória. Contudo, se nos orientarmos pelo conflito moral, percebe-se que esses elementos são valores integrados pela jovem, juntamente a um forte sentimento de mal-estar apresentado caso não atue de acordo com eles, rechaçando outras possibilidades de organizar seu pensamento. 


\section{Sujeito 163, masculino, 16 anos, Curitiba, PR (aplicou os submodelos 5a e A2)}

Nas respostas às questões sobre projeto de vida, o sujeito 163 apresenta dois elementos de forma central, a família e o estudo/trabalho, os quais são fonte de projeção de sentimentos positivos como felicidade e realização, e, portanto, podem ser considerados valores. Tais elementos mostram-se integrados, principalmente, pelo significado em comum que lhes é atribuído: o trabalho, por meio do estudo, ajudará o jovem a cuidar/ser responsável pela sua família.

Esse jovem descreve seu cotidiano de forma sucinta, indicando ações referentes à sua realidade: acordar, almoçar, jogar futebol, tomar banho e ir para o colégio. Como aspectos importantes de sua vida, indica a família, os estudos e o futuro, mostrando preocupação com o percurso que deverá trilhar para a conquista dos seus objetivos. Ele indica que começou a trabalhar, mas não traz outras explicações sobre esse fato.

Sobre as mudanças que deseja ver no mundo, relata o problema das drogas e violência, porém não determina ações efetivas que tem realizado para uma possível transformação do status quo.

Ao se posicionar sobre o futuro próximo, imagina-se cursando uma faculdade e trabalhando para ajudar em casa. Ele refere-se aos estudos como aspecto fundamental para a conquista de um bom emprego. Para o futuro distante, já se vê como engenheiro civil, exercendo a profissão, casado e com um filho. Prioriza o fato de poder dar "um futuro melhor para meu filho". Cita o sentimento de realização e felicidade em relação a essas conquistas.

Colocando-se sobre o conflito, o jovem mostra-se como impossibilitado de ajudar a mãe. Segundo ele, "quando temos uma meta, virão dificuldades como estas, mas depois passarão". Apresenta o sentimento de tristeza em relação ao fato de ter que passar "por cima" da vontade da mãe.

Quando se imagina contrariando o pedido da mãe, o sujeito informa que se sentiria "um pouco triste", contudo "feliz, pois saberia que eu estaria ingressando em um futuro melhor". São sentimentos ambíguos, que evidenciam, na verdade, uma maior valoração do estágio em detrimento da ajuda à mãe. Isso se confirma na última questão, ao se definir como "triste" caso não aceitasse o emprego, já que "seria uma chance perdida que tive".

Os processos de integração e regulação de valores e sentimentos que subjazeram a elaboração do projeto de vida foram articulados, para esse sujeito, de forma a evidenciar os complexos de valores, família e estudo/trabalho, e sentimentos, realização e felicidade, de uma forma diferente daquela tomada diante do conflito moral. Na resolução da situação, o 
jovem revela o trabalho como valor central, posicionando a família de forma periférica, já que alude a poucos sentimentos que regulam seu comparecimento no modelo abstraído.

Embora, a princípio, pareçam elaborações de pensamento distantes entre si, há coerência do sujeito, visto que a família à qual ele se refere em seu projeto não corresponde exatamente à família que o criou e o educou, mas àquela que ele formará e para a qual destinará sua responsabilidade. Assim, o estudo/ trabalho mostra-se como um valor central para esse jovem, sendo mobilizado nas duas situações com praticamente os mesmos significados atribuídos. Todavia, a família é significada de forma diferente em cada situação, alterando-se como um valor central ou periférico para esse jovem.

\section{Sujeito 91, masculino, 18 anos, São Paulo, SP (aplicou os submodelos 4a e F1)}

$\mathrm{Na}$ elaboração de seu projeto de vida, o sujeito 91 prioriza dois aspectos de forma idealizada: a família e o trabalho, os quais se constituem como valores pela projeção de sentimentos de realização pessoal.

O jovem tece críticas ao seu cotidiano, visto que não tem uma mãe presente apenas o pai. No entanto, elogia esse pai por fazer mais do que ele, como filho, merece. Por esse motivo, prefere ficar fora de casa; assim, não precisa pensar que, mesmo sendo "malcriado", recebe de tudo do pai. Diverte-se jogando futebol e namorando.

Sobre os aspectos que julga importantes para a sua vida, estão Deus, a família e jogar futebol, indicando o bem-estar que sente em relação a eles. Informa que tem dificuldades em manter um bom relacionamento com sua família e, como mudança no mundo, posiciona-se contra a violência e a baixa qualidade da educação, sem indicar ações pessoais para efetivá-la.

Em um futuro próximo, destaca desejar uma família com melhores relações que a sua, mostrando o sentimento de realização. Imagina, em um futuro distante, sua dedicação à sua família e ao trabalho (não se coloca sobre qual seria). Sobre seu projeto de vida, aponta certo receio: "eu nem penso MUITO nisso porque eu tenho medo de planejar algo e me decepcionar lá na frente". Depois, revela que quer ter uma boa família, ter um bom emprego e ter uma boa vida, sentindo-se realizado diante dessa projeção.

Entendemos que esse jovem apresenta a família e o trabalho como valores, mas não chega a integrá-los pela via da significação que lhes atribui. Apenas cita tais elementos como importantes, de uma forma idealizada, projetando-lhes o sentimento de realização.

Frente ao conflito moral, esse sujeito volta-se totalmente à família, desprezando a oportunidade de trabalho. "Eu abriria mão de tudo para ficar com minha família, até mesmo 
do futebol que eu amo. Eu me sentiria não muito bem por perder uma oportunidade de emprego, mas me sentiria melhor ainda por ganhar boas reflexões de não ser ambicioso".

Quando precisou se posicionar como aceitando o emprego, o jovem esboça mal-estar, e, diante da possibilidade de ajudar a família, traz a indicação de um forte bem-estar. É interessante notar que, ao se colocar como o protagonista, o sujeito insere a sua "própria história" na situação: "bem, muito bem, porque na minha concepção minha mãe, no caso meu pai, é tudo para mim!”.

Vê-se, portanto, que os valores de família e trabalho realmente não possuem muita integração para esse jovem que os vê de forma idealizada em seu projeto de vida. A família, como pudemos notar nas respostas ao conflito moral, é um valor que se coloca hierarquicamente superior ao trabalho, recebendo grande carga afetiva, o que condiz com toda a mobilização que o sujeito faz no início do seu protocolo ao dissertar sobre o pai.

\section{Sujeito 50, feminino, 16 anos, Fortaleza, CE (aplicou os submodelos 6a e A3)}

O projeto de vida do sujeito 50 traz referências, principalmente, ao trabalho, que se constitui como um valor, recebendo alguns significados e a projeção de sentimentos positivos de bem-estar e realização.

A jovem refere-se a si mesma como calma e alegre, indicando gostar da sua vida e da sua família. Seus prazeres estão na leitura, escrita, dança e conversas, o que lhe causa o sentimento de realização. Ao citar o que lhe é importante, ela indica seus pais, porque lhe criaram, os estudos e o trabalho, que são as vias para "ser alguém na vida" e "ser independente". A jovem não faz referências a dificuldades em sua rotina e se preocupa com a violência, mas não dá a conhecer seu papel na mudança que seria necessária no mundo.

Imagina-se, em um futuro próximo, fazendo faculdade e trabalhando em uma empresa de "alto porte". Refere-se ao sentimento de realização diante dessa projeção. Quando se posiciona frente a um futuro mais distante, faz referência a continuar trabalhando. Nesse momento, chega a indicar "se eu tiver filhos eles vão se tornar importantes", mas, ao apresentar seu projeto de vida, conclui que "é me tornar importante no meu trabalho".

A jovem, a despeito de indicar a família como importante no início do protocolo, volta-se ao trabalho, extremamente valorado pelos sentimentos de bem-estar e realização, e pelos significados que lhes são atribuídos.

Na resolução do conflito, essa jovem também se posiciona favorecendo o trabalho em detrimento da família. "Diria a minha mãe que olhasse meus irmãos porque era uma chance 
para eu melhorar na minha vida, para me tornar uma pessoa realizada, para eu correr atrás do meu futuro! E pediria para ela me entender".

A jovem indica o sentimento de mal-estar caso não aceite o emprego e, frente à possibilidade de não aceitá-lo nem chega a indicar sentimentos: "eu iria atrás de outras oportunidades, não ia ficar parada, pois parada a gente não consegue nada!”.

Assim, percebe-se que as respostas dessa jovem trazem a indicação de que o trabalho é um valor, não integrado a outros, mas regulado por grande carga afetiva e por uma rede de significações que lhe foram atribuídas.

\section{Sujeito 115, masculino, 16 anos, Rio Claro, SP (aplicou os submodelos 7b e G1)}

O projeto de vida do sujeito 115 apresenta grande gama de elementos, significados e, consequentemente, uma teia de relações que evidencia bastante complexidade. Esse sujeito aponta como elementos centrais a preocupação com o outro, o trabalho e a família, que são valorados pela regulação de sentimentos positivos de felicidade e realização.

$\mathrm{O}$ jovem indica que se sente muito bem em seu dia a dia, embora tenha passado por situações difíceis. Ele cita que gosta de ver as pessoas felizes e de ajudá-las sempre que possível. Ao revelar o que lhe é importante atualmente, traz a família, na figura do pai, que o ajudou em todas as situações e com quem tem uma ótima relação, do irmão mais novo, sobre quem apresenta cuidados e que sempre o alegra quando precisa, e da mãe, que faleceu devido à ingestão excessiva de bebidas alcoólicas, com quem o sujeito não tinha uma boa relação (a mãe o maltratava, agredindo-o fisicamente), apesar de demonstrar amor por ela.

Ainda sobre a família, o jovem mostra se sentir bem ao lado do pai e do irmão, mas se reporta à falta da mãe como um aspecto negativo de sua vida. Ele mora com os tios, com quem, apesar de ser feliz, não se sente seguro. Deseja que o pai encontre outra mulher, que seja feliz e que eles tenham um novo lar novamente. Também comenta que tentou ajudar a mãe, mas não conseguiu: "sempre tentei fazer o máximo possível para ajudá-la, mas foi tarde demais...".

O jovem se incomoda com o uso de drogas, cigarros e bebidas e gostaria que isso fosse diferente no mundo, já que sua mãe faleceu devido ao uso dessas substâncias. Ele informa que fumou maconha, mas que parou e faz disso um alerta para várias pessoas.

Em um futuro próximo, esse sujeito planeja ser bombeiro, desempenhando seu papel de ajuda às pessoas. Pensando mais à frente, imagina-se trabalhando e cuidando da família que formará e da que o amparou na infância e juventude. É importante destacar que ele se vê 
sendo feliz e também observando os outros felizes à sua volta: "vou tentar fazer todos felizes, principalmente minha família e amigos. E não posso me esquecer do meu pai que sempre cuidou de mim. Aos 40 anos, eu vou ter que retribuir tudo o que ele me fez e mais ainda [...]”.

Seu projeto de vida parece bem definido: "eu pretendo ser bombeiro, e a razão de eu querer ser um bombeiro é porque eu quero poder ajudar as pessoas. Eu quero salvar vidas e arriscar minha vida pela da pessoa [...]”. Essa perspectiva leva-o a sentir-se realizado e a imaginar que será recompensado pelo que fez em sua vida.

Esse jovem, diante da situação moral, busca conciliar o seu interesse e o da família, ou seja, não pretende desistir do seu projeto, mas não deixa de lado a solicitação de ajuda. Devemos destacar que ele se coloca na situação apresentada, projetando-se no lugar do protagonista: "Eu escolheria o que seria melhor para mim e escutaria meu pai, porque, quando eu quero uma coisa, eu vou até o fim para conquistar aquilo. E ser bombeiro é um sonho meu. Claro que na situação o Maurício está tendo mais oportunidades, mas eu também terei e vou ter de saber aproveitar as oportunidades da minha vida".

Ao se colocar contra a ação de ajudar a mãe ou de aceitar o estágio, são mobilizados sentimentos positivos, indicando uma aceitação dos fatos e a luta para conquistar os objetivos, a despeito das dificuldades. Além disso, há uma visão importante sobre os sentimentos do outro: "Ficaria melhor porque ela estaria feliz com a minha decisão".

Como é possível verificar, os valores mobilizados pelo jovem formataram uma implicada teia de relações que recebeu o reforço positivo, regulando seu fortalecimento perante outras possíveis configurações. O jovem valoriza o trabalho, como meio de ajudar os outros, como realização pessoal e forma de reconhecimento social. O trabalho também é uma forma de garantir a possibilidade de estabilidade junto à família, tanto a que será formada, pela qual sente responsabilidade, quanto a que o criou, pela qual sente gratidão. A resolução do conflito veio a confirmar o posicionamento de sempre ajudar o outro, tendo-o como valor, ao mesmo tempo em que se valoriza o próprio sonho. A integração dos complexos de valores e sentimentos, nas respostas emitidas por esse sujeito, sugerem seu fortalecimento na constituição da identidade moral desse jovem.

Nos cinco exemplos que apresentamos, fica evidente que cada solicitação de posicionamento do jovem, na elaboração de seu projeto de vida e frente a um conflito moral com esse conteúdo, faz com que mobilize processos de integração de complexos de valores e sentimentos, que, ao se fortalecerem para a formulação do seu pensamento, exercem papel regulatório ao não permitir o comparecimento de outros valores e sentimentos. Tais processos 
indicam procedimentos únicos frente às diferentes solicitações, sendo tecidos na organização do pensamento de uma forma particular que envolve a interação do sujeito, sua constituição moral e sua representação acerca dos conteúdos do meio.

Cada exemplo pôde elucidar possibilidades de organização do pensamento frente às solicitações com o conteúdo do projeto de vida. Visualizar os dois momentos dessa organização permitiu estabelecer relações que não puderam ser tecidas na análise mais geral das tendências de aplicação dos modelos. Destarte, o que parecia, em um olhar mais abrangente, a aplicação de modelos com processos de integração e regulação de valores muito díspares, em uma análise mais detida pôde ser visto em uma rede de relações entre os complexos de valores e sentimentos, envolvendo as duas aplicações, de acordo com elementos apresentados que trouxeram indicações sobre sua constituição moral.

Assim, diante de cada situação e da forma como se requereu o processamento dos complexos de valores e sentimentos, cada jovem organizou seu pensamento imprimindo um continuum que guardou semelhanças frente à diversidade de conteúdos apresentados. Desse modo, se um sujeito mobilizou processos de integração e regulação de valores e sentimentos na elaboração de seu projeto de vida, não necessitou, estritamente, aplicar modelos, na resolução do conflito, que integrassem os mesmos complexos de valores e sentimentos. Entretanto, embora se mostrassem processos diferenciados, mantiveram a centralidade dos valores construída pelos jovens em suas vivências e possibilidades de organização do raciocínio feitas anteriormente. 


\section{CAPÍTULO X CONSIDERAÇÕES FINAIS}

O percurso delineado pela presente pesquisa foi traçado no sentido de angariar possibilidades de visualização do fenômeno relacionado à elaboração de projetos de vida na juventude, no que tange aos processos de integração e regulação de valores e sentimentos que a subjazem. Entendendo tal fenômeno em sua complexidade, vimos como necessária a articulação entre bases teóricas que pudessem nos trazer subsídios para uma maior compreensão dos resultados obtidos.

Um primeiro eixo importante para o embasamento de nosso estudo esteve centrado nos conceitos de regulação e integração de valores e sentimentos. Relacionamos tais conceitos a processos funcionais que apenas podem ser analisados pelo viés de estudo do sujeito psicológico (INHELDER; DE CAPRONA, 1992), incorporando, em sua organização psíquica, a moralidade (ARAÚJO, 1998, 2003a). A perspectiva de estudar a integração da moralidade ao self (COLBY; DAMON, 1992; DAMON, 1995; BLASI, 1992, 1995, 2004, entre outros) mostrou-se fecunda, uma vez que possibilitou verificar que a moral perfaz um dos aspectos do psiquismo humano, permitindo, também, que se possa vislumbrar a interlocução do sujeito, em suas dimensões de consciência e nãoconsciência (LAPSLEY; NARVAEZ, 2004), com os conteúdos do contexto (NUCCI, 2001, 2004), envolvendo as relações interpessoais (BENHABIB, 1992; NISAN, 2004).

Os conceitos de integração e regulação, nessa perspectiva, dizem respeito a processos funcionais articulados à organização psíquica dos sujeitos, sendo mobilizados de acordo com as diversas interelações entre as dimensões que a compõem em interlocução com os conteúdos do meio. A regulação moral, em termos funcionais (PUIG, 1996, 2007; ARAÚJO, 1998, 2003a), elucida o comparecimento e a construção de valores, podendo ser exercida por sentimentos (ARAÚJO, 1998, 2003a; DE LA TAILLE, 2002; BARRET, 1995) e também pela própria integração dos valores e sentimentos (PINHEIRO, 2009). A ideia de integração e regulação encontra eco no trabalho de Moreno Marimón e Sastre (2010), em que as autoras consignam a existência de complexos de sentimentos aplicados de acordo com o contexto vivenciado.

Além do suporte das teorias do campo da Psicologia Moral, outro eixo que fundamentou o presente trabalho concentrou-se na definição do conceito de projeto de vida, a partir da discussão promovida por trabalhos sobre juventude das áreas de Sociologia e Psicologia. Mediante estudos que ressaltaram a diversidade da constituição de identidades 
juvenis (SPOSITO, 2003, 2005; MELUCCI, 2007; PAIS, 2000, 2001) e outros que trouxeram tendências relacionadas ao jovem brasileiro (ABRAMO, 1997, 2005; CAMARANO et al. 2004; SPOSITO, 2003, 2005; LASSANCE, 2005; THOMÉ; TELMO; KOLLER, 2011; SOUZA; OLIVEIRA, 2011; MARQUES; SANTOS; DELL'AGLIO, 2011), foi-nos possível obter maior conhecimento sobre os participantes de nossa investigação, seus valores e possibilidades de vivências de sua condição na sociedade, assim como subsídios para a compreensão do conceito de projeto de vida na juventude.

Além da perspectiva sobre juventude, a construção do conceito de projeto de vida recebeu inspiração dos estudos sobre "projeto" (BOUTINET, 1999/2002; VELHO, 1994; MACHADO, 2004, 2006) e, principalmente, da proposta de Damon e colaboradores (DAMON; MENON; BRONK, 2003; DAMON, 2009; BUNDICK, 2009). Nas relações estabelecidas a partir dessas três vertentes, chegamos a uma ideia de projeto de vida como uma projeção de futuro, ancorada em vivências do passado e do presente, que comporta desejos, pensamentos, sentimentos, interesses e objetivos do sujeito e que se constitui de forma complexa, envolvendo regularidade, no sentido de que carrega tanto características constantes do psiquismo do sujeito, quanto transitoriedade, uma vez que se mostra aberta às mudanças de pensamento.

Incorporando as indicações formuladas nos dois primeiros eixos, buscamos o aporte da Teoria dos Modelos Organizadores do Pensamento (MORENO MARIMÓN et al., 1999) que visa a elucidar os processos funcionais ativados por trás da organização do pensamento do ser humano frente aos contextos vivenciados. Ao visualizar como os sujeitos formulam representações sobre a realidade, essa teoria intenta revelar seus pensamentos, sentimentos, desejos, crenças e objetivos diante de situações vivenciadas, isto é, em contato com conteúdos do meio. Por trazer tal possibilidade, a teoria oferece uma abordagem da funcionalidade dos projetos de vida, evidenciando, entre outros, os processos de integração e regulação de valores e sentimentos.

O caminho percorrido na articulação das teorias apresentadas proporcionou-nos a consolidação do objeto de pesquisa. Foi possível observar que, a despeito de encontrarmos teorias que embasem nosso estudo, as relações estabelecidas entre valores e sentimentos, assim como a forma de sua organização, são conteúdos pouco investigados e que merecem aprofundamento que intentamos realizar, mas que ainda necessitarão de enfoques de outras pesquisas.

A complexidade dos processos de integração e regulação de valores e sentimentos propiciou a construção de instrumentos e formas de análise que levaram à obtenção de muitos 
resultados, o que tornava possíveis diversas linhas de discussão. No entanto, ao posicionarmos nossa intenção de elaborar um estudo funcional das projeções realizadas pelos jovens, delimitamos nosso foco para os processos que compareceram detrás das postulações emitidas, buscando averiguar o jogo de relações estabelecido entre valores e sentimentos na interlocução das características do self com os conteúdos das situações vivenciadas pelo jovem.

Assim, os resultados obtidos em nossa investigação não pretendem ser conclusivos, mas instigar a abertura de novas frentes de trabalho no campo da Psicologia Moral. Eles serão discutidos nos tópicos a seguir de forma a apresentar nossas considerações, revisando construtos teóricos e metodológicos, resumindo os principais resultados e trazendo indicações, a partir deles, que cumprem os objetivos propostos.

$\mathrm{Na}$ primeira parte, responderemos às questões de pesquisa relacionadas aos processos de integração e de regulação de valores e sentimentos, baseando-nos tanto nos resultados encontrados quanto no referencial teórico, e aduzindo alguns avanços que consideramos importantes a partir dos problemas colocados. Na segunda parte, trataremos da articulação dos principais resultados encontrados com as possibilidades de trabalho na escola, na perspectiva de uma educação moral que vise à construção de projetos de vida pelos jovens e sua consequente inserção ética na sociedade.

\subsection{Processos de integração e regulação de valores e sentimentos diante de conteúdos relacionados aos projetos de vida: diversidade e regularidade na organização do pensamento dos jovens participantes}

Ao longo deste trabalho, buscamos nos direcionar ao seu objetivo central:

Diante de questões referentes aos seus projetos de vida e a um conflito moral cujo conteúdo apresenta essa temática, como se dão os processos de integração e regulação de valores e sentimentos na elaboração dos jovens?

Cingimos, portanto, ao conceito de integração e regulação de valores e sentimentos, uma vez que nosso objetivo central circunscreveu a compreensão sobre como se dão tais processos na elaboração de projetos de vida por jovens e na resolução de um conflito moral com esse conteúdo. Embora estivéssemos cerceados pela delimitação de tal objetivo, a análise 
foi capaz de contemplar, pela complexidade do estudo, alguns indícios importantes em relação à constituição moral e à elaboração de juízos mediante situações morais.

Antes de adentrarmos a discussão dos resultados, respondendo ao principal questionamento de nosso estudo, entendemos ser pertinente explicar o teor de tal problemática, o que elucidará nossos posicionamentos posteriores.

A investigação empreendida pelo viés funcional acarreta, na elaboração do pensamento, perceber uma rede de relações tecida pelas dimensões constituintes do psiquismo humano (sendo elas conscientes ou não) que a organiza mediante a interlocução com os contextos. Nesse complexo de relações, estão implicados processos que levam a integrar ou rechaçar elementos, via regulações estabelecidas entre os sistemas. Os processos de integração e regulação de valores e sentimentos, em nossa concepção, estão entre esses processos que corroboram a organização psíquica do ser humano, diante de conteúdos de natureza moral que os mobilizem. Assim, entendemos tais processos como constituintes da organização psíquica, ocorrendo em todas as situações que envolvem a moralidade.

Embora concebamos a existência desses processos em toda a organização do pensamento diante da "realidade", percebemos que eles variam de acordo com: a) os conteúdos do meio e como são representados pelo sujeito; b) a demanda da situação (se exige uma organização rápida, de menor reflexão, ou se está envolvida em uma configuração em que o sujeito pode refletir mais, servindo-se de mais elementos e lhes atribuindo mais significados).

Tomando por base tais variações, elegemos dois instrumentos que pudessem, a partir da mesma temática - os projetos de vida -, mobilizar formas diferentes de articular tais processos, utilizando, a princípio, valores e sentimentos que se aproximassem. Dessa forma, conseguiríamos perceber as relações tecidas por esses sentimentos e valores em dois momentos de organização do pensamento, chegando a uma visão da diversidade que compõe tais processos diante de cada contexto e da regularidade de articulação que traz indicações sobre a identidade moral de cada sujeito.

Ao elaborar o projeto de vida, respondendo as 13 questões propostas, o jovem precisou relatar seu cotidiano, informando o que lhe é mais importante e resgatando, nas vivências passadas, como se tornou importante e quais dificuldades foram enfrentadas. Além disso, refletiu sobre as mudanças que considera necessárias no mundo e projetou seu futuro, de uma forma próxima (daqui a cinco anos) e distante (com 40 anos). Por fim, o jovem resumiu, brevemente, seu projeto de vida. Em todas essas etapas, foi solicitado a apresentar seus sentimentos. 
Consideramos que tal elaboração requereu do jovem uma reflexão ampla, com a abstração de muitos elementos (vivenciados ou imaginados), do presente, do passado e do futuro, que foram significados em uma densa rede de relações, estabelecendo certa coerência. Por envolver todos esses aspectos, em grande amplitude, formular o projeto de vida mostra-se uma atividade que comporta muitos pensamentos, influenciados por outras dimensões do psiquismo humano (valores, sentimentos, crenças etc.), implicando em conferência de abstração de elementos, acréscimo ou decréscimo de significações e alterações nas relações e/ou implicações estabelecidas, de forma que o projeto se mostre como um "todo coerente" ao sujeito.

$\mathrm{Na}$ resolução do conflito moral, em contrapartida, os jovens leram uma situação hipotética voltada ao projeto de vida de um protagonista. A pequena história girava em torno de um(a) jovem que gostaria de ingressar em um estágio, pois seu sonho era trabalhar em uma grande empresa. Quando consegue a vaga, a mãe solicita que não a aceite para ajudá-la a cuidar dos irmãos. Os participantes responderam a três questões, posicionando-se frente ao conflito e indicando seus sentimentos.

Conquanto esteja centrada em conteúdos relacionados ao projeto de vida, a situação exposta aos jovens trouxe alguns elementos já demarcados referentes às vivências de um personagem. Portanto, ao responder as questões propostas, os participantes necessitaram enfocar aquele contexto específico, organizando seu pensamento a partir do que compreenderam da situação. Diferentemente da elaboração de um projeto de vida, posicionarse sobre uma situação com esse conteúdo, mas referente a uma outra pessoa, exigia do jovem a concentração em alguns elementos e possibilitava a imaginação de outros, mas sempre centrada nas inferências realizadas pelo sujeito em relação ao "real".

A referência a uma situação determinada levou os jovens a mobilizar e a tecer relações entre elementos restritos. Além disso, pelo caráter de resolução de um conflito específico, solicitava-se uma organização mais "rápida" do raciocínio, sem a necessidade de checar elementos, voltar às significações ou retomar a rede de relações estabelecidas. Tratando-se de uma quantidade de elementos e significados menor, em comparação à elaboração do projeto de vida, embora se apresente grande complexidade nas relações/implicações realizadas, há uma maior chance de o sujeito garantir "coerência" ao seu pensamento.

Por se tratarem de dois instrumentos diferentes, embora voltados à mesma temática, pudemos vislumbrar resultados também variados, apresentando-nos uma multiplicidade de juízos relacionada aos projetos de vida. Assim sendo, podemos chegar a uma primeira resposta ao objetivo central de nossa investigação: os processos de integração e regulação de 
valores e sentimentos ocorrem de maneira diversa de acordo com o contexto elou solicitação de organização do pensamento.

A riqueza dos resultados repousa, justamente, nessa variabilidade que compreendeu tendências de organização do pensamento, exprimindo regularidades na aplicação dos modelos organizadores do pensamento, porém, ao mesmo tempo, evidenciando a singularidade que compôs cada um deles. A discussão desses resultados, em nosso entender, deve evidenciar a díade ${ }^{60}$ que envolve regularidade/singularidade na organização dos raciocínios por cada jovem, implicando tendências de aplicação de processos de integração e regulação de valores e sentimentos diante dos contextos que lhes são apresentados. Tais tendências, que entendemos como regularidades, estão estreitamente relacionadas com as singularidades também existentes nessa organização, uma vez que a força de tais tendências esbarra na maleabilidade necessária para tratar de conteúdos pertinentes a um contexto. $\mathrm{Na}$ díade regularidade/singularidade elaboram-se juízos que consideram tanto aspectos concernentes àquilo que constitui a identidade do sujeito quanto aqueles relacionados ao contexto.

De forma a evidenciar tais relações, no sentido de obter uma reflexão mais apurada sobre nosso objetivo central, dedicaremo-nos a discutir os principais resultados obtidos nas duas frentes de análise, sobre os projetos de vida e a resolução do conflito moral, e nas indicações sobre um possível continuum entre os processos elaborados nas duas situações. Para iniciar essa discussão, teremos como suporte o seguinte objetivo específico:

Identificar e analisar os modelos organizadores do pensamento relacionados aos projetos de vida dos jovens e aqueles elaborados por eles diante de uma situação de conflito moral, estabelecendo relações entre a integração de valores e a possível regulação exercida por tal integração e pelos sentimentos.

Esse objetivo específico, na medida em que traz a necessidade de identificação dos modelos organizadores do pensamento, aproxima-nos da proficuidade do instrumento teóricometodológico para a compreensão da funcionalidade dos projetos de vida. A Teoria dos

${ }^{60}$ O termo "díade" vem do grego (dyás, dyádos), significando um par (FERREIRA, 2004) no qual a individualidade de cada um é eliminada em detrimento da unidade desse par no seio da qual se organizam centros tipos de ligações. Essa palavra vem sendo empregada em teorias de áreas distintas para evidenciar grande simbiose entre dois elementos. Na música, a díade corresponde a um acorde ou intervalo formado por duas notas, tocadas simultaneamente. Cada nota conserva o seu som, mas, tocadas conjuntamente, perfazem um som distinto. Entendemos a regularidade e a singularidade dos processos de integração e regulação de valores e sentimentos como uma díade, por serem aspectos que se mostram intimamente implicados na organização do pensamento. 
Modelos Organizadores do Pensamento (MORENO MARIMÓN et al., 1999), por tratar da forma como o ser humano constrói realidades a partir do que observa e interpreta do contexto, realça a possibilidade de verificar como ele realiza uma seleção do que conhece e observa, segundo características constantes em seu funcionamento psíquico. Assim, condiz com o estudo da funcionalidade dos projetos de vida, por meio da análise dos processos de integração e regulação de valores e sentimentos, uma vez que consegue vislumbrar, na organização do pensamento, como eles são mobilizados e articulados, além de incorporar sentimentos, conhecimentos e ações, possibilitando uma visão mais ampla do funcionamento psíquico.

Ao identificarmos os modelos organizadores aplicados na elaboração do projeto de vida e na resolução do conflito com esse conteúdo, buscamos verificar como o jovem articulou elementos, do contexto e imaginados por ele, e seus sentimentos, atribuiu significados e estabeleceu, entre eles, relações e/ou implicações. Isso significa que, sem utilizarmos categorias prévias, intentamos verificar como cada jovem teceu processos que levaram à organização de seu pensamento.

A verificação dos resultados advinda da análise dos modelos organizadores do pensamento levou-nos a algumas discussões importantes para os objetivos de nossa investigação. Exporemos tais discussões emanadas dos resultados obtidos nas duas frentes de análise dos modelos organizadores, propiciando o aprofundamento teórico necessário às nossas formulações.

A análise das respostas emitidas pelos jovens participantes às questões referentes aos seus projetos de vida pela via dos modelos organizadores do pensamento oportunizou conferir a complexidade imanente a tal elaboração. Conforme esboçamos anteriormente, a extração dos modelos organizadores foi feita em um esforço de contemplar regularidades no que diz respeito à forma de organização do pensamento pelo grupo de sujeitos, sem desprezar as singularidades que compuseram os projetos de vida, visto que cada protocolo mostrou-se único, tendo em comum a lógica impressa nas relações/implicações tecidas pelos jovens. Ao adotar esse instrumento teórico-metodológico, estávamos abertos a essas dimensões e, embora tenhamos fixado o olhar para os processos de integração e regulação de valores e sentimentos, vimos emergir dados que apontaram contribuições importantes, ainda que não esperadas, para a compreensão do fenômeno.

$\mathrm{Na}$ análise das respostas referentes ao projeto de vida, extraímos sete modelos organizadores, com base nos elementos abstraídos, significados que lhes foram atribuídos e as relações e/ou implicações estabelecidas entre eles, considerando, também, o papel dos 
sentimentos em sua organização. Dentro de alguns modelos organizadores, houve diferenças entre elementos abstraídos e significados atribuídos, o que nos levou a dividi-los em submodelos, evidenciando nosso posicionamento de revelar as particularidades da organização de raciocínio dos participantes. Isso também pôde ser comprovado na descrição de modelos que constaram como "outras dinâmicas de organização do pensamento", em que apresentamos formas de formular os projetos de vida que não encontraram semelhanças com os demais agrupamentos.

Ao descrever os modelos organizadores, buscamos evidenciar a riqueza das dinâmicas de organização do pensamento dos jovens, utilizando exemplos para explicar as relações que constituíram o todo lógico que perfez os seus raciocínios. Nessa descrição, foi possível observar a complexidade das articulações entre elementos e sentimentos abstraídos e seus significados, gerando uma teia de relações/implicações.

As redes de relações/implicações tornaram possível verificar os valores dos jovens, visto que, ao mobilizarem e expressarem sentimentos positivos sobre elementos abstraídos (PIAGET, 1956; ARAÚJO, 1998, 2003a), demonstraram que foram valorados positivamente por eles. Ademais, foi possível verificar as relações entre esses valores, os sentimentos e a forma como foram significados, o que nos trouxe uma visão sobre a centralidade (ARAÚJO, 2003a; DAMON, 1995) que ocuparam na elaboração do projeto de vida.

A análise com base nos modelos organizadores do pensamento possibilitou-nos checar todos os valores apresentados pelos jovens, assim como perceber, pela sua inserção em um complexo que envolveu elementos, sentimentos e significações, a importância assumida na organização do seu raciocínio. Assim, verificamos desde projeções frágeis, que traziam elementos sem valorá-los ou valorando-os de forma muito branda, até valores posicionados de forma central nos projetos de vida. Nos modelos organizadores aplicados pelos participantes, ainda pudemos observar sentimentos e de que forma foram projetados sobre esses valores, colaborando para a construção de significados e, consequentemente, para o enredamento que constituiu cada projeto de vida elaborado.

A Teoria dos Modelos Organizadores do Pensamento (MORENO MARIMÓN et al., 1999) tornou possível essa análise funcional, permitindo não apenas vislumbrar quais valores e sentimentos foram mobilizados, mas, principalmente, como foram elaborados dentro do conjunto que constitui cada modelo organizador. Evidenciando a complexidade que compôs a organização do pensamento de cada participante, essa teoria pôde constatar, inclusive, as fragilidades e contradições dos modelos, garantindo a compreensão das coerências/incoerências produzidas por eles. 
Cremos que a análise realizada, por meio desse instrumento teórico-metodológico conseguiu superar uma visão simplista a respeito dos juízos emitidos pelos jovens, incorporando sentimentos, crenças, pensamentos, objetivos e desejos, bem como aspectos relacionados ao âmbito público, trazendo indicações sobre a atuação do jovem no mundo do trabalho e nas relações deste com a sociedade, e ao âmbito privado, nas colocações sobre família, relações interpessoais e cuidado com os próximos (ao outro generalizado e ao outro concreto, segundo Benhabib, 1992), sem emitir juízos de valor sobre as projeções dos jovens.

Nesse aspecto, vemos diferenças entre a análise com os modelos organizadores e a postulada por Damon e colaboradores (DAMON; MENON; BRONK, 2003; DAMON, 2009), que admite categorias preestabelecidas na avaliação dos projetos de vida dos jovens. As indicações desses autores são válidas e foram profícuas para nosso estudo, na medida em que trouxeram a perspectiva de análise das projeções dos jovens e ofereceram base para a criação do instrumento de nossa pesquisa. No entanto, afastamo-nos em sua forma de análise por não permitirem observar a funcionalidade dos projetos de vida.

Ainda sobre a teoria de Damon e colaboradores, gostaríamos de destacar que busca um enfoque diferente do que empreendemos na presente investigação. Em seu percurso acadêmico, Damon, em parceria com Colby (COLBY; DAMON, 1992), esteve centrado em compreender como as pessoas unem seus objetivos de vida a causas morais, perscrutando a correlação entre moralidade e self. De acordo com tal estudo, pessoas de "moral exemplar" pouco duvidam das decisões que tomam em assuntos morais, tampouco pesam as consequências de seus atos. A unidade entre moral e self pode, na análise dos autores, ser comprovada quando escolhas morais são feitas com grande certeza; assim, os objetivos de vida se apresentam como componentes importantes para tal unidade.

A teoria proposta por Damon e colaboradores sobre o projeto de vida (em inglês, purpose) está relacionada à intersecção entre moralidade e self, dentro do espectro que define os objetivos de vida. Tal teoria visa a estudar o engajamento do jovem em um propósito ou objetivo, na medida em que este se mostra no âmbito da moral ou não.

Em nossa investigação, não estamos analisando em que medida o jovem está engajado ou não em conteúdos morais, mas pretendíamos verificar a funcionalidade de suas projeções, logo que seus valores e sentimentos se relacionam a processos que, em integração, exercem papel regulatório. Abrindo o leque de possibilidades em relação aos projetos de vida, consideramos todas as projeções, entendendo-as como dimensões inerentes ao ser humano (MACHADO, 2004, 2006), mas sem desprezar o fato de que alguns jovens podem se voltar a objetivos relacionados à moral (DAMON, 1995; COLBY; DAMON, 1992). 
Nessa abertura de perspectiva, no processo de análise dos projetos de vida, levantamos os valores e sentimentos de cada modelo organizador, buscando observar as relações estabelecidas entre eles. Nos modelos organizadores aplicados pelos jovens participantes, observamos a presença dos elementos trabalho, estudo, família, Deus, relações interpessoais e "outros",61, que compareceram de forma isolada ou integrados e que se mostraram como valores ou não nos projetos de vida.

O fato de obtermos praticamente os mesmos elementos, que puderam ser mobilizados como valores, chamou-nos a atenção, pois havia outras possibilidades que poderiam ser articuladas pelos jovens. Sobre esse aspecto, pudemos observar que os participantes, ao construírem seus projetos de vida diante de uma "realidade", abstraíram elementos dentro de um rol culturalmente construído, mas o fazendo de forma altamente particular, de acordo com suas vivências e crenças, em comprometimento com o que lhe caracteriza como self (BLASI, 1995, 2004; NISAN, 2004). A Teoria dos Modelos Organizadores do Pensamento (MORENO MARIMÓN et al., 1999) ajuda-nos a refletir sobre tal colocação uma vez que postula os conteúdos do contexto como reguladores para a abstração e significação de elementos. Pensar sobre o futuro restringe a organização do pensamento para elementos passíveis de comporem uma projeção dentro de um contexto determinado. Nesse ínterim, entram em jogo aspectos socioculturais que atuam significantemente na construção de identidades morais (NUCCI, 2001, 2004; TURIEL, 2002; LAPSLEY; NARVAEZ, 2004), mediante a "leitura" que o sujeito faz da realidade. Para Lapsley e Narvaez (2004), os significados dos eventos sociais são construídos rotineiramente, habitualmente e sem intencionalidade. Esses construtos que, segundo os autores, são inconscientes ${ }^{62}$, direcionam a regulação do self guiando julgamentos, avaliações, interações sociais e objetivos. Aliando tal visão à teoria proposta por Moreno Marimón e colaboradoras, vemos que aspectos culturais fornecem subsídios para a elaboração de modelos organizadores, constituindo-se em complexos de valores aplicados em situações que os solicitem. O comparecimento dos mesmos valores nos modelos organizadores traz fortes indícios de que os sujeitos constroem sua percepção da realidade por meio de valores socialmente acordados ou, ao menos, com base em tais valores. Isso porque pode tentar contrapor-se a eles, mas sempre os tendo como fonte.

\footnotetext{
${ }^{61}$ Lembramos que o item "outros" refere-se à vontade de ajudar outras pessoas para além do âmbito familiar.

${ }^{62}$ Ainda que não nossos resultados não possam contribuir para uma discussão sobre a nãoconsciência, visto que não nos propusemos, em nossos objetivos, a focar nosso olhar para tal aspecto, cremos que trazem indícios de que grande parte da elaboração dos projetos de vida e de resolução de conflitos morais, como veremos à frente, ocorre inconscientemente, o que nos leva a indicar, dentro do espectro do sujeito psicológico, uma maior interlocução entre consciência e nãoconsciência. Fica aberto o caminho para trabalhos posteriores que possam trazer maiores elucidações sobre tais relações.
} 
O elemento trabalho foi o que mais compareceu às projeções, estando ausente ou parcamente mobilizado apenas no submodelo 1c. Em todos os demais modelos, tal elemento compôs o projeto de vida, sendo indicado de forma central ou periférica na dinâmica de organização do pensamento de cada jovem. Quando designado como valor, o trabalho recebeu significados, comparecendo atrelado a outros valores (em grande parte dos modelos e submodelos) e isoladamente (apenas no modelo 2). A força de tal elemento nos protocolos comprova estudos sobre a juventude no Brasil que destacam o trabalho como valor importante para os jovens (SPOSITO, 2003, 2005; ABRAMO, 2005; THOMÉ; TELMO; KOLLER, 2011). O trabalho, para os jovens de nossa pesquisa, relacionou-se às suas ações no cotidiano e às suas projeções sobre o futuro, recebendo diversos significados: fonte de estabilidade financeira e consumo, realização pessoal, reconhecimento social, responsabilidade sobre a família e benefício à sociedade.

A integração que esse valor estabeleceu com outros gerou redes de relações, embasadas, sobretudo, nos significados atribuídos. O conceito de integração (BLASI, 1995) traz indicações de que os valores se integram aos sistemas motivacionais e emocionais, propiciando base para a construção da identidade moral. Segundo esse autor, a integração entre valores proporciona-lhes uma maior "intensidade", levando-os a se organizar hierarquicamente de forma mais ou menos central no sistema moral dos sujeitos. Nos projetos de vida dos participantes, averiguamos que a integração de valores gerou complexos em que estavam embutidos valores, significados e sentimentos que se posicionaram de forma mais central ou mais periférica na sua elaboração (DAMON, 1995; ARAÚJO, 1998, 2003a). Os valores (ou complexos de valores, como nos propomos nesse trabalho), morais ou não, podem caracterizar-se como centrais ou periféricos na concepção do self (DAMON, 1995), sendo fator determinante para esse posicionamento a carga afetiva que a eles se dirige (ARAÚJO, 2005, 2007).

As integrações realizadas nos modelos organizadores referentes aos projetos de vida estabeleceram-se entre: trabalho e família; trabalho e estudo; Deus, trabalho e família; Deus e "outros"; e trabalho, "outros" e Deus. O fato de haver a mobilização dos valores não caracterizou a integração entre eles. Os complexos de valores que efetivamente dotaram-se de intensidade que lhes garantiu um posicionamento central na elaboração do projeto de vida foram aqueles cuja teia de significações implicou no estabelecimento de relações que ofereceram coerência à formulação. Se verificarmos, por exemplo, a integração entre trabalho e família, percebemos que, no modelo 4 (mais detidamente no submodelo 4a), há pouca integração entre os valores, pois os dois são idealizados separadamente, recebendo como 
significados o fato de serem "bons" no futuro. Não há relações que formem um todo complexo entre os valores, o que os leva a se colocarem de forma não tão central, ou seja, com baixa intensidade nas projeções dos jovens. Já no modelo 5, os mesmos valores integram-se com significados em comum: o trabalho está relacionado à família, pois, a partir da estabilidade conquistada, o jovem visualiza que conseguirá cumprir com sua responsabilidade em relação à família. Tal integração reforça os juízos desses sujeitos, levando-os a projetar seu futuro sempre com base na força desse complexo de valores.

É interessante notar que a família também se mostrou um valor importante para esses jovens, mas sempre integrada a outro valor, o que nos indica que, muito embora tenha sido significada como apoio aos participantes, confirmando os dados de Souza e Oliveira (2011) ou até como fonte de sua responsabilidade, ela se posiciona de forma periférica na organização de seu pensamento. O mesmo se pode dizer do estudo, significado como um meio para atingir o trabalho, que somente compareceu à organização do pensamento desses jovens em integração com esse valor.

Deus e a religião, em contrapartida, são valores que se posicionaram da forma mais central até a mais periférica, recebendo maior ou menor carga afetiva de acordo com os significados atribuídos pelos jovens. Em nossa investigação, comprovamos o que nos informaram Marques, Santos e Dell'Aglio (2011), quando afirmam que a fé pode levar à autoconfiança e à transformação positiva de si mesmo, ao mesmo tempo em que podem fazer com que os jovens restrinjam suas projeções apenas a esse aspecto. Foi possível observar, nos modelos em que Deus e a religião compareceram de forma central, constituindo-se como valores para os jovens, que se integraram a outros valores, fortalecendo o projeto de vida (por exemplo, no submodelo 7a), ou, por se mostraram fortemente mobilizados pelos jovens, acabaram por restringir a projeção sobre o futuro apenas à adoração ou persecução de objetivos relacionados tão somente à igreja (como no submodelo 1c).

Nas relações estabelecidas, nessa rede que configurou os valores e seus significados, também se inseriram os sentimentos. Como pudemos verificar, nos modelos organizadores houve presença significativa dos sentimentos positivos de bem-estar, realização, felicidade e satisfação, significados pelos jovens como consequências de sua autorrealização e sucesso no projeto de vida, variando de acordo com o complexo de valores ao qual se projetaram. Os sentimentos negativos compareceram de forma mais isolada em alguns modelos: o cansaço, significado como resultado do esforço ao longo dos anos (modelo 2 e submodelo 6a), e a insatisfação e insegurança, referentes a uma situação difícil pela qual passaram (submodelo $5 b)$. 
Percebe-se que os sentimentos não apareceram de forma isolada, mas sempre integrados a outros sentimentos, que compreenderam um complexo. Tal constatação pode ser referendada no trabalho de Moreno Marimón e Sastre (2010) que estudaram o sentimento de amor. Consoante as autoras, qualquer sentimento agrega outros sentimentos que formam sistemas e que configuram o sentimento que se coloca para análise. Assim, preferem a definição de "complexo emocional" para designar a forma como um sentimento sempre está acompanhado de outros, tornando-se único para cada contexto em que é aplicado.

Além disso, esses complexos emocionais mobilizados em cada modelo organizador estiveram implicados nas relações estabelecidas, perfazendo, também, a rede de significados atribuídos aos valores e constituindo, de uma forma mais ampla, um complexo de valores $e$ sentimentos que foi mobilizado, de uma só vez, na elaboração do projeto de vida.

Dentro desse complexo que se construiu em cada modelo organizador do pensamento, pôde-se verificar processos fortemente atuantes de regulação entre valores e sentimentos. Tais processos, de fonte funcional, corroboraram a interação dentro do sistema moral e entre os demais sistemas que constituem o sujeito psicológico (ARAÚJO, 1998, 2003a). Os reguladores morais influenciam as relações intrapessoais, podendo interferir nos vários sistemas (afetivo, cognitivo, sociocultural e biológico) e as ações que decorrem dessas influências dependem e intervêm nos conteúdos externos. Por incorporarem diversos elementos que atuam concomitantemente, podemos sugerir que sua ação é altamente complexa.

Os sentimentos assumiram importante papel para a regulação que suportou a composição de cada modelo organizador, na medida em que reforçaram o complexo de valores e seus significados. O caráter regulatório dos sentimentos vem sendo estudado por diversos autores, mas principalmente pela força assumida pelas emoções autoconscientes, em inglês self-conscious emotions, que dizem respeito à vergonha e à culpa (ARAÚJO, 2003a, 2007; DE LA TAILLE, 2002; BARRET, 1995; PINHEIRO, 2009).

Ao abordamos os projetos de vida, por estarmos abertos a todos os sentimentos explanados pelos jovens, não mencionando diretamente ações contra seus valores, obtivemos, grosso modo, sentimentos positivos que vieram a reforçar aqueles destacados. Assim, conseguimos ampliar o espectro de entendimento sobre regulação de sentimentos ao perceber que os processos regulatórios incidem não apenas sobre sentimentos autoconscientes, como culpa e vergonha, mas também por sentimentos positivos que elucidam e trazem apoio às elaborações realizadas. 
Nossos resultados confirmam aqueles obtidos nos estudos de Pátaro (2011) e Arantes (2012), para quem os sentimentos exercem papel central no engajamento dos jovens nos projetos de vida. Destacam-se, nas investigações empreendidas pelas autoras, o senso de satisfação e de realização pessoal, além dos sentimentos que embasam as relações interpessoais e aos atribuídos ao bem-estar do outro. Na presente pesquisa, observamos, assim como as autoras, que os sentimentos assumem papel central na elaboração dos projetos de vida e se voltam efetivamente para uma projeção do sucesso obtido no futuro, chegando à autorrealização. Os sentimentos mobilizados também se voltaram ao bem-estar, principalmente com as ações presentes, envolvendo âmbitos de vivências e relações interpessoais.

Sobre as relações interpessoais, faz-se necessário enfocar o modelo 3 que indicou os elementos trabalho, família e amizade de forma a revelá-las como valor central. Foi o único modelo que trouxe o sentimento de amor, mobilizado pelos vínculos estabelecidos pelos jovens. O amor foi significado como necessário para tais relações e pôde regular seu comparecimento de forma central para os jovens que aplicaram esse modelo. Ainda nesse modelo organizador, verifica-se o sentimento de felicidade significado de forma bastante singular. Pela significação atribuída a esse sentimento, percebemos que ele se constituiu em um valor para os sujeitos. Eles projetaram sentimentos sobre o próprio sentimento: “é importante ser feliz”. Com isso, é possível acrescentar à definição exposta por Piaget (1956) e, posteriormente, por Araújo (2003a) que valores emergem das trocas afetivas que o sujeito realiza com o exterior, com objetos e/ou com pessoas e/ou com relações e/ou com sentimentos. Nota-se, pois, que o ser humano consegue projetar sentimentos sobre sentimentos, transformando-os em valores, dentro, claro, de um complexo que perfaz valores e sentimentos.

Dessa forma, valores, sentimentos e seus significados compreenderam complexos que foram construídos via relações estabelecidas pelos jovens diante dos conteúdos da "realidade". Esses complexos de valores e sentimentos assim foram constituídos pelo papel regulatório de reforço positivo de um complexo emocional, que envolveu sentimentos de bem-estar, realização e felicidade, conjuntamente à integração exercida pelos valores, logo que rechaçaram a abstração de outros, pelos significados que lhes foram atribuídos, para a composição do projeto de vida. Na medida em que se integraram, exercendo papel regulatório através da rede de significados atribuída, valores e sentimentos passaram a garantir maior centralidade na elaboração dos projetos de vida, posicionando outros elementos como valores periféricos, por receberem projeção afetiva branda, ou não chegando a mobilizá-los. Devemos 
postular, portanto, que os processos de integração e regulação de valores e sentimentos, compondo o que denominamos como complexos de valores e sentimentos, pautam-se em três eixos complementares: a) a integração entre valores e sentimentos; b) a articulação entre significados atribuídos aos valores e sentimentos, garantindo coerência ao pensamento do sujeito; c) a regulação exercida por tal integração, envolvendo valores, sentimentos e significados.

Um ponto interessante sobre a integração de valores e sentimentos está na inclusão, nesse complexo, da perspectiva do outro na rede de relações estabelecida a partir dos significados atribuídos. Percebe-se que abstrair, significar e tecer relações não apenas centradas em seu ponto de vista, mas incluindo outras pessoas necessariamente envolve a integração de valores, já que os jovens dessa investigação correlacionam seus interesses aos de outrem. Não se verifica, pois, uma visão totalmente altruísta, mas uma moral que se coloca, no mais das vezes, voltada a objetivos para o self (self regarding) e para o outro (other regarding); ao mesmo tempo em que não se percebe uma moral centrada apenas no âmbito público, mas também no privado (BENHABIB, 1992). É importante colocar, além disso, que esses valores não se mostram dicotômicos ao sujeito, mas complementares, na rede de relações que podem ser tecidas por eles. Veja-se, por exemplo, o submodelo $7 \mathrm{~b}$, o qual, em nossa opinião, contempla grande complexidade por estabelecer relações entre uma gama variada de valores e significados em intrínseca relação com os sentimentos de bem-estar, realização e felicidade. Os jovens que aplicaram esse submodelo integraram os valores trabalho, família e outras pessoas, que podemos entender como a sociedade como um todo. Os significados atribuídos a tais valores integram perspectivas do self e do outro, dos âmbitos público e privado, estabelecendo relações que não fragmentam os objetivos, mas, pelo contrário, apresentam-nos como inter-relacionados e dependentes uns dos outros. A rede de relações estabelecidas é: o trabalho servirá como realização pessoal, possibilidade de cuidados para com a família e retribuição a essa família pela criação/educação oferecidas, bem como oportunidade de fazer o bem social, ajudando a sociedade a melhorar aspectos que julga necessitarem de mudanças. O complexo de sentimentos articula-se estritamente nessas relações, reforçando-as pelo significado da autorrealização pessoal, além de visualização desses mesmos sentimentos aos outros que serão beneficiados por tais ações. Essa organização do pensamento em relação ao projeto de vida evidencia que, nos processos de integração e regulação de valores e sentimentos, na elaboração de redes de relações constituídas por significados, a construção de complexos envolve valores, sentimentos e 
significados que ultrapassa limites de perspectivas e de âmbitos, de acordo com as possibilidades que o sujeito apresenta para fazer tais relações.

Somos impulsionados a considerar que, em toda organização do pensamento (e não apenas as que possuem tamanha complexidade nas redes de relações como o submodelo7b), ocorrem processos de integração e regulação de valores e sentimentos perfazendo complexos, via estabelecimento de relações que comportam a perspectiva de si mesmo e do outro e que não estabelecem divisões entre os âmbitos público e privado. Claro está que haverá diferentes níveis de complexidade e tendências de privilegiar perspectivas em detrimento de outras ${ }^{63}$, e que nem sempre encontraremos o mesmo nível de complexidade na articulação entre valores, sentimentos e significados. Porém, é importante frisar que, em níveis diferentes, a construção desses complexos sempre ocorre na organização do pensamento para a elaboração dos projetos de vida.

Os resultados obtidos a partir da análise das respostas ao conflito moral no tocante aos processos de integração e regulação de valores e sentimentos comprovam, de certa forma, as descobertas efetuadas a partir dos projetos de vida. No entanto, por se tratar de uma dinâmica de organização diferente do pensamento, traz alguns dados relevantes para nossas considerações.

Assim como nos projetos de vida, na resolução do conflito extraímos sete modelos organizadores do pensamento, os quais buscaram explicitar o posicionamento do(a) jovem diante da situação hipotética. Devido à diversidade de significados e, conseguintemente, das redes de relações tecidas dentro de cada modelo, subdividimos alguns deles, tentando evidenciar nossa opção por uma análise fina e que revelasse as singularidades pertinentes ao pensamento dos jovens. Diferentemente dos projetos de vida, não obtivemos modelos que não se agruparam aos outros, mas, por outro lado, houve seis protocolos que não puderam ser analisados, pois estavam incompletos.

Como já expusemos em capítulos anteriores, resolver o conflito moral tratava-se de uma tarefa diversa daquela referente à elaboração do projeto de vida. A situação apresentada aos jovens possuía o conteúdo de um projeto de vida de um personagem, o qual era voltado para o trabalho. O conflito posicionava aos jovens dois elementos centrais, o trabalho e a família, que delimitaram as possibilidades de abstração e significação pelos jovens, apesar de haver possibilidades, ainda que embasadas em tal contexto, de imaginação e inferências de

\footnotetext{
${ }^{63}$ Pensemos, por exemplo, no modelo 2, em que a perspectiva do si mesmo é priorizada no objetivo voltado ao trabalho como possibilidade de consumo de bens materiais que são sonhos, principalmente, para o próprio sujeito. No entanto, mesmo não estando explícito nos juízos emitidos, sabe-se que tais objetivos envolvem o além do self (BUNDICK, 2009).
} 
elementos e/ou significados. Ademais, o conflito exigia uma tomada de posição frente a uma problemática, exigindo dos jovens estratégias mais "rápidas" de resolução, sem, necessariamente, requerer checagem de hipóteses, revisão de significados atribuídos e concatenamento de ideias para configuração de um todo coerente.

Consoante ao contexto proposto no conflito, os jovens abstraíram três elementos, estágio (trabalho), mãe/ família e curso (estudo), que puderam receber carga afetiva de forma a serem considerados valores para os jovens. Assim como nos projetos de vida, os processos de integração e regulação de valores e sentimentos sucederam-se para a organização da dinâmica de pensamento dos jovens, configurando complexos enredados pelos significados obtidos.

No conflito moral, apenas um submodelo (submodelo A1) não apresentou integração entre valores, indicando apenas o estágio como valor para os jovens. Todos os demais modelos e submodelos apresentaram algum nível de integração entre os valores de trabalho, família e estudo, ainda que alguns se posicionassem como periféricos na organização do pensamento. Assim como nos projetos de vida, a integração entre valores ocorreu pelos significados estabelecidos, acarretando uma rede de relações coerente para o jovem. Embora fossem praticamente os mesmos elementos, fato que se deve ao conteúdo da situação, as articulações mostraram-se diferentes na organização dos raciocínios dos participantes.

Notamos, nos resultados oriundos da análise das respostas referentes ao conflito moral, que a integração entre trabalho (estágio) e família (mãe/irmãos) recebeu significados relacionados à responsabilidade do jovem em relação aos cuidados com os familiares através do trabalho (modelo C), sendo uma mesma relação estabelecida em alguns projetos de vida. Contudo, outras relações articularam-se diante do conflito moral sobre a mesma integração de valores, por exemplo a necessidade de conciliar interesses para satisfazer as necessidades de ambos, o sujeito e a família (submodelos G1 e G2).

Foi possível também averiguar que, em alguns modelos e submodelos, tal integração obteve uma centralidade maior de alguns valores sobre outros. Nos modelos A e B, embora haja integração entre trabalho e família, as redes de relações apontam o trabalho como valor hierarquicamente superior à família; nos modelos E e F, o contrário se sucede, tendo a família ocupado valor hierarquicamente superior ao estágio. Nesses casos, a integração entre os valores não se mostrou tão fortemente mobilizada.

É interessante observar que houve uma integração diferente relacionada ao curso (estudo) e a família, o que não aconteceu nos projetos de vida. Para os jovens que aplicaram esse modelo diante do conflito moral, o curso é significado como possibilidade de continuar 
nos estudos e também satisfazer a família, no sentido de que haveria tempo para cuidar dos irmãos e, dessa forma, atender ao pedido da mãe. Essa integração apenas pôde ser observada nas respostas referentes à resolução do conflito.

O conflito moral trouxe, de antemão, possibilidades de integração, logo que apresentou aos jovens uma situação já apontando o estágio e a família. Esperava-se que os participantes articulassem tais elementos, valorando-os de acordo com características constantes em seu sistema moral. A complexidade da integração entre valores existiu nas respostas elaboradas pelos jovens, mas, pela força dos conteúdos do conflito, compreendeu um número menor de abstração de elementos e atribuição de significados, gerando redes de relações mais concisas.

Pelo fato de o conflito já trazer o estágio e a família, na interlocução dos pontos de vista do sujeito e do outro, no conflito percebeu-se uma maior articulação entre tais valores, em relação aos projetos de vida, estando mais explícita a consideração que os jovens tiveram sobre suas famílias, mesmo que as posicionassem de forma periférica na resolução da problemática.

Interessa-nos observar a força do projeto de vida no conflito. Grande parte dos modelos aplicados trazia fortemente a perspectiva do self, de seus planos e sonhos (menos mobilizada apenas nos submodelos F1 e F2), sem desconsiderar a perspectiva do outro (a única exceção foi o submodelo A1). Podemos apontar que os jovens de nossa investigação acreditam nos seus objetivos e se mostram determinados, diante de uma situação, a lutar por eles, sem desconsiderar as pessoas que o rodeiam.

Outro aspecto importante que compareceu à resolução dos conflitos concentrou-se nos sentimentos. Como se tratava de uma situação em que o jovem necessitou posicionar-se a favor e contra seus valores, houve não apenas sentimentos positivos, configurando complexos como os existentes nos projetos de vida (bem-estar, realização, satisfação, felicidade ${ }^{64}$ ), recebendo os mesmos significados (autorrealização dos jovens mediante seus projetos), mas também sentimentos negativos que perfizeram complexos, envolvendo mal-estar, culpa, arrependimento, insatisfação e tristeza. Sobre esses últimos, conseguimos observar a força que exerceram para regulação do comparecimento dos valores. A existência de sentimentos negativos perante o fato de imaginarem contrariar valores centrais, em nossa percepção, foi determinante para a organização dos modelos. Isso porque, confirmando estudos que se voltaram a esses sentimentos (ARAÚJO, 1998, 2003a; DE LA TAILLE, 2002; PINHEIRO,

${ }^{64} \mathrm{O}$ sentimento positivo de tranquilidade apenas compareceu aos submodelos G1 e G2, significados como consequência de se ter conciliado os interesses pessoais e da família. 
2009), verifica-se que são importantes reguladores para consciência do self sobre si mesmo, pois levam o sujeito a pensar sobre valores que lhes são centrais em seu sistema moral.

Embora se tratassem de possibilidades menores de abstração de elementos para os quais pudessem ser projetados sentimentos, mesmo com menos valores evidenciados nos juízos dos jovens, na resolução do conflito também se deram processos de integração e regulação, compondo complexos de valores e sentimentos, nesse caso tanto positivos quanto negativos, que organizaram o seu pensamento. Novamente, o fio articulador da composição de tais complexos, via processos de integração e regulação de valores e sentimentos, esteve nas relações estabelecidas pelos significados atribuídos. Assim, a integração de valores, por meio dos significados atribuídos, fortaleceu seu comparecimento com influências dos complexos de sentimentos, rechaçando outras possibilidades de mobilização de valores. Se observarmos mais detidamente, por exemplo, o modelo G, percebemos que integra os valores de trabalho (estágio) e família (mãe/irmãos) através do significado de que é importante conciliar os interesses e necessidades de ambas as partes. Tal integração, que recebe carga afetiva positiva, no sentido de que o sujeito se sente tranquilo, realizado e feliz por galgar um passo em relação a seu projeto, ao mesmo tempo em que consegue atender às necessidades de sua família, e carga afetiva negativa, com os sentimentos de culpa, mal-estar e tristeza, quando o jovem se imagina contra tal conciliação, rechaça outras possibilidades como mobilizar um desses valores de forma hierarquicamente superior ao outro.

O contexto e a forma como se solicita a organização dos raciocínios (refletir sobre projetos de vida ou se posicionar frente a um conflito moral) interferem de forma significativa para a mobilização dos processos de integração e regulação de valores e sentimentos e, consequentemente, para a configuração dos complexos de valores e sentimentos aplicados em cada dinâmica do raciocínio humano. A partir dos resultados que encontramos, estabelecemos que a elaboração dos projetos de vida e a resolução de conflitos morais, mesmo se tratando da mesma temática, configuram dinâmicas de organização do pensamento diferentes, tanto pelos complexos de valores e sentimentos que as perfazem, por conta dos processos de integração e regulação, quanto pela forma como o sujeito estabelece relações via atribuição de significados.

Tais diferenças puderam também ser constatadas pelos resultados referentes à distribuição dos sujeitos nos modelos organizadores do pensamento aplicados diante de cada instrumento.

Nos projetos de vida, observamos que todos os sujeitos mobilizaram complexos de valores e sentimentos. Contudo, verificamos que nem todos o fizeram estabelecendo relações 
que configuraram projetos de vida consolidados. Grande parte dos participantes ( $72 \%$ do total de sujeitos) mobilizou, por meio da articulação de processos de integração de valores e sentimentos, complexos cujos significados levaram a redes de relações que formaram um todo coerente ao sujeito. Apenas $28 \%$ dos jovens ativeram-se a processos frágeis, em que, por meio de respostas contraditórias e pouca projeção de valores, encontraram dificuldades em expor seu raciocínio. Portanto, percebe-se que, diante da complexa tarefa de refletir sobre seu projeto de vida, o que solicitava ao jovem que abstraísse e atribuísse significados a elementos do seu passado, de suas ações presentes e projeções sobre o futuro, grande parte dos jovens conseguiu indicar seus projetos de vida de forma integrada e coesa (ou parcialmente coesa), atingindo os propósitos da presente investigação.

Se, no entanto, observarmos a aplicação de modelos e submodelos, bem como as categorias por nível de complexidade estabelecidas pelos processos de integração e regulação de valores e sentimentos, nota-se que uma parcela significativa de jovens poderia ter atrelado significados mais consistentes entre valores e sentimentos, tornando seus projetos de vida mais fortalecidos. Verificando as categorias por nível de complexidade, vemos que os grupos A (com 28\% dos sujeitos), com baixa integração entre valores e sentimentos, respostas contraditórias e pouca projeção de sentimentos, e B (com $41 \%$ do total de participantes), em que há mobilização de um ou mais valores, pouca ou inexistente integração entre eles e regulação por sentimentos, perfazem grande número de sujeitos que chegaram a estabelecer redes de relações não tão coesas entre os valores mobilizados, deixando-os, de certa forma, enfraquecidos perante outros que integraram valores por meio de significados em comum, recebendo forte carga afetiva e em cujo processo se estabeleceu a regulação para seu comparecimento. Acreditamos que esses resultados são importantes para reflexões no campo da educação moral, o que faremos no próximo tópico do presente capítulo.

Os resultados referentes ao conflito moral, no que tange à distribuição de sujeitos nos modelos aplicados, mostraram-se diferentes, mesmo porque exigiam outras dinâmicas de organização do pensamento. Consegue-se observar que uma parcela significativa de jovens aplicou modelos em que considerou, mesmo que parcialmente, a perspectiva de si mesmo e do outro, mobilizando processos de integração e regulação de valores e sentimentos garantida pelas relações estabelecidas por significados comuns. O nível de complexidade entre os modelos deu-se de forma mais "homogênea", visto que as articulações dos processos que subjazeram a organização dos raciocínios aconteceram de forma a torná-los coesos. Vemos que um conflito moral, por trazer de antemão elementos em contexto determinado, corrobora 
a elaboração de juízos que contemplem o nível de complexidade exigido para o posicionamento frente à situação proposta.

Muito embora os sujeitos pudessem integrar valores centrais emanados de elementos do contexto (família e trabalho), grande parcela (65\% do total de participantes), como verificamos nas categorias de modelos, volta-se a articular processos de integração e regulação por um valor central e sentimentos. Destes, no último agrupamento entre modelos, observa-se que $40 \%$ enfocam como valor central o estágio e $25 \%$ a família. Ou seja, são modelos em que se posiciona como central estágio ou família, tecendo articulações com elementos periféricos e sentimentos. Por outro lado, tem-se $35 \%$ dos jovens que buscaram aliar valores centrais em integração, exercendo papel regulatório, juntamente com os complexos de sentimentos. Assim, demonstraram valores como trabalho e família, correlacionados à rede de significados e sentimentos estabelecida, na elaboração de seus modelos organizadores. Nesses últimos casos, notamos a forte mobilização da perspectiva do self e do outro, por exemplo nos modelos $\mathrm{C}$ e $\mathrm{G}$, em que os jovens correlacionam seus interesses de ingressar no estágio e as necessidades da família.

Embora a conciliação entre perspectivas não tenha ocorrido com o maior percentual dos modelos aplicados, gostaríamos de destacar que a grande maioria dos jovens que se posicionou frente ao conflito moral centrou-se no projeto de vida, lutando por ele acima de tudo, e tendo nenhuma ou alguma consideração pela família, ou tentando conciliar tal projeto com as necessidades da mãe e dos irmãos (seriam os grupos $\mathrm{A}$, com $40 \%$, e C, com $35 \%$ do total dos participantes). Isso nos mostra que os jovens de nossa investigação, diante de conflitos morais, lutam por seus objetivos, sonhos e desejos projetados para o futuro.

Postas tais considerações, devemos nos reportar a outro objetivo específico que nos ajuda a elucidar o problema geral de nossa investigação:

Identificar e analisar se existe ou não um continuum entre os processos de integração e regulação de valores e sentimentos nas duas situações: de explicitação dos projetos de vida pelos jovens e nas elaborações diante de um conflito moral formuladas por eles.

Foi-nos possível discutir sobre as relações estabelecidas entre os processos de integração e regulação de valores e sentimentos diante dos dois instrumentos aplicados no capítulo nono deste trabalho, trazendo apontamentos importantes que gostaríamos, no presente momento, de discutir de forma mais geral. 
Quando, no início deste tópico, indicamos a díade entre regularidade e diversidade na organização do pensamento dos jovens, referimo-nos a duas vertentes:

a) nas tendências de organização do pensamento de todos os sujeitos, a regularidade existente no grupo de participantes, verificando formas como jovens elaboram a "realidade", devido às questões culturais e de crenças socialmente compartilhadas; as singularidades existentes nesses agrupamentos de forma a evidenciar que cada sujeito, embora siga uma tendência, organiza seu pensamento de forma extremamente particular;

b) como um mesmo sujeito tende a elaborar seu pensamento diante de situações diferentes (regularidade), que lhe exigem, pelos conteúdos do contexto, maleabilidade e, assim, singularidade na organização de seu raciocínio.

Em um primeiro momento do capítulo nono, pautamo-nos no item "a", ressaltando que as regularidades que compuseram tendências de organização do projeto de vida mostraram-se, em alguns aspectos, diferentes daquelas que compareceram às formulações referentes à resolução do conflito moral. Dessa forma, percebemos que, embora alguns valores, no caso trabalho, família e estudo, tenham estado presentes em ambas as solicitações, receberam significados diferentes, estabelecendo relações também diversas. Ademais, os complexos de sentimentos, embora em grande parte estivessem relacionados aos sentimentos positivos, na resolução ao conflito moral também se voltaram a sentimentos negativos no todo que perfez a elaboração dos jovens. Em termos de regularidades "gerais", entre todos os sujeitos participantes da pesquisa, constata-se que não se pode pautar modelos aplicados diante de um instrumento por outros aplicados frente a outra solicitação, mesmo que estejam circunscritos a uma mesma temática. Nesse sentido, os conteúdos presentes em cada contexto, e mesmo a forma como se solicita a organização do pensamento, configuram redes de relações bastante singulares, atendendo aos propósitos de cada situação e da coerência que o sujeito deve sentir na interlocução entre aspectos pertinentes a si mesmo e ao meio.

$\mathrm{Na}$ distribuição dos jovens nos modelos organizadores extraídos das respostas emitidas nos dois instrumentos, percebem-se algumas tendências, principalmente se nos ativermos aos modelos organizadores, e não aos submodelos que já trazem uma especificidade maior de relações estabelecidas entre elementos abstraídos e significados a eles atribuídos. Verifica-se, na tabela e no gráfico expostos na página 332, que o fato de o modelo $\mathrm{G}$ estar presente majoritariamente em quase todos os modelos aplicados em relação ao projeto de vida indica que, mesmo diante de projeções frágeis ou de pouca articulação nos processos de integração e 
regulação de valores e sentimentos, os jovens podem, diante de um conflito moral, atender às suas necessidades pessoais, conciliando-as com as de sua família. Vemos, também, que grande parcela dos jovens do modelo 7 , em que há integração da vontade de ajudar o outro com outros valores (religião ou trabalho), aplica o modelo G, correspondendo à mesma visão sobre as necessidades do outro, mas que alguns sujeitos voltam-se para a aplicação do modelo A, em que se elegia o valor trabalho, sem considerar o pedido da mãe. Outro dado significativo está no modelo 4, em que se obteve um grande número de jovens que aplicou o modelo $\mathrm{A}$, em que se priorizava o estágio, o modelo $\mathrm{F}$, que dizia respeito à valorização da família em detrimento do seu projeto de vida, e o modelo G, da conciliação de interesses. São perspectivas bastante cabíveis, visto que, no modelo 4, os jovens manifestavam valores de trabalho e família de uma forma idealizada, sem grande integração.

Não discutiremos novamente todos os resultados encontrados, apesar de considerarmos que se mostraram tendências interessantes de aplicação dos modelos organizadores, porque cremos ser importante trazer nossa compreensão sobre eles. O que tais resultados indicam, em nosso ver, é a complexidade que perfez a organização do raciocínio dos jovens, por meio dos processos de integração e regulação de valores e sentimentos. Poderíamos obter dos jovens que aplicaram o modelo 1 menor articulação entre valores e sentimentos diante do segundo questionário, perfazendo complexos cujas teias de relações fossem estabelecidas por menor complexidade, o que não aconteceu. Poderíamos verificar que os jovens que elaboraram seus projetos de vida voltados a ações de ajuda ao outro, por meio do voluntariado e do trabalho, aplicariam modelos voltados à família ou à conciliação de seus interesses com os da mãe, mas isso tampouco ocorreu. E assim como outras associações que, em uma visão simplista, poderiam ser tecidas.

Assim sendo, tais resultados nos levariam a indicar que não existe continuum na aplicação dos modelos referentes aos projetos de vida e ao conflito moral. No entanto, isso nos levaria a contradizer todos os estudos voltados à identidade moral (DAMON, 1995; COLBY; DAMON, 1992; BLASI, 1995, 2004; NISAN, 2004; PUIG, 1996, entre muitos outros), que enfatizam a construção de valores no sistema moral do sujeito como componente fundamental de sua identidade. Todo ser humano constrói valores que se posicionam como centrais ou periféricos (DAMON, 1995; ARAÚJO, 1998, 2003a) em sua identidade e que os guia diante dos contextos morais. Se não houvesse constantes que determinam a identidade moral, a cada situação o sujeito deveria proceder como se nunca houvesse lidado com algo similar anteriormente. Entender que valores também se encontram nesse nível estrutural, 
sendo mobilizados pela via funcional, significa compreender que, diante de cada contexto, articulamos, de uma só vez, estrutura e conteúdos (MORENO MARIMÓN et al., 1999).

Enveredando por esse caminho, passamos ao item "b" da díade regularidade/singularidade, pautando-nos por entender como cada sujeito mantém constantes de valores, ou seja, suas regularidades, dentro da maleabilidade exigida por cada situação posta. Assim, elegemos cinco sujeitos, resgatando como aplicaram cada modelo organizador: na elaboração de seus projetos de vida e diante do conflito moral com esse conteúdo. O que pudemos observar dessa análise foi a existência de um continuum que constituiu a organização do pensamento do jovem nos modelos organizadores aplicados. Isso porque, embora tenha estabelecido relações entre significados diferentes a cada modelo, os jovens apresentaram coerência entre seus raciocínios, na medida em que estabeleceram relações críveis, mesmo diante de modelos que, aos nossos olhos, poderíamos considerar díspares.

Portanto, o continuum que perfaz a elaboração dos juízos de conteúdo moral dota-se de tamanha complexidade que não se pode medir ao nível geral dos participantes, mas dentro da lógica estabelecida por cada um deles, nos processos de integração e regulação de valores que compuseram complexos, os quais corroboraram a organização de seus pensamentos.

A centralidade de um valor para cada jovem encontrou-se no complexo que ele perfez com outros valores, sentimentos e com a rede de relações estabelecida pelos significados atribuídos. Valores centrais podem ser, para um mesmo sujeito, periféricos ou até contravalores diante das relações estabelecidas frente aos conteúdos do contexto. Um jovem, por exemplo, que aplicou o submodelo 7a, em que integrou o "outro" e a religião em seu complexo de valores e sentimentos, pode mostrar-se solidário a causas sociais, pretendendo ajudar pessoas por meio de ações religiosas. Contudo, diante de uma situação em que se veja em risco de perder uma oportunidade de dar um passo em relação ao seu projeto de vida, esse mesmo sujeito pode não ser solidário em relação à sua família, apesar de indicar preocupação com ela.

Acrescentamos, ainda, que os contextos apresentam possibilidades de revisão dos valores que constituem o sistema moral do sujeito. Em nossa análise, nos detivemos a um momento da organização psíquica dos participantes. É possível que, se refizermos a coleta de dados com os mesmos questionários, os jovens possam alterar seus modelos organizadores referentes aos projetos de vida, configurando, por meio dos processos de integração e regulação de valores e sentimentos, outros complexos. Isso se explica pelo fato de a organização do pensamento estar aberta a processos de "reiteração reconstrutiva", que ocorrem sempre que um contexto provoca a revisão dos modelos, fazendo com que eles 
aumentem a sua complexidade e a sua capacidade de perceber fenômenos complexos que antes o sujeito era incapaz de detectar (MORENO MARIMÓN; SASTRE, 2010). Os modelos, dessa forma, estão em constante transformação, pois o que foi elaborado pode até servir como base para uma nova formulação, mas o sujeito necessita sempre reformulá-los, diante de novos elementos que se apresentam ou que pode passar a perceber.

Tais considerações, em nosso entender, são profícuas para a compreensão sobre a organização dos projetos de vida e, para além deles, sobre processos que subjazem a elaboração pautada em valores e sentimentos. Sabemos que há muitas lacunas deixadas por nosso estudo e cremos que apenas poderão ser preenchidas por um corpo de análise consistente que venha, pela pesquisa empírica, a elucidar tais resultados ou refutá-los. A complexidade que perfaz a organização do pensamento humano exige estudos cada vez mais complexos, que abram o olhar para as diversas possibilidades que a díade regularidade/singularidade nos propõe. Esperamos, sinceramente, ter contribuído à compreensão da moralidade humana e ao campo da psicologia moral.

No próximo item desse capítulo, discutiremos sobre as possibilidades trazidas pelas principais descobertas de nossa investigação ao campo da educação moral.

\subsection{Contribuições para a educação moral}

Fecharemos nosso trabalho refletindo, à luz das principais descobertas aferidas, sobre a educação moral, o que contempla o último de nossos objetivos específicos:

A partir dos resultados revelados pela presente pesquisa, bem como das discussões que teceremos sobre eles, trazer indicações, apontamentos e reflexões para o campo da educação moral, visando ao desenvolvimento de práticas pedagógicas que levem os jovens a construírem projetos de vida que lhes sejam significativos e que visem à sua inserção ética na sociedade.

Os projetos de vida constituem-se em uma dimensão importante para a identidade moral na juventude, porque, além de se colocarem como necessidade de todo o ser humano, já que viver é um contínuo projetar (MACHADO, 2006), ter uma visão mais elaborada sobre projeções futuras, possibilita ao jovem compreender-se enquanto ser que possui valores e sentimentos, assim como entender o seu papel de sujeito no mundo. 
Pudemos vislumbrar os projetos de vida por uma via de complexidade, não os tomando como melhores ou piores entre si, mas pelos processos de integração e regulação de valores e sentimentos que subjazeram cada organização do pensamento. Tal posicionamento esteve calcado na percepção de cada jovem como um sujeito real, que atua em contextos diversos e que precisa "pôr à prova" seus valores diante de cada situação que se lhe apresenta. Esses jovens são constituídos por pensamentos, sentimentos, desejos, crenças, objetivos, sonhos... E esse, em nosso entender, é um dos principais desafios das instituições escolares na atualidade. Vemos, no Ensino Médio, uma preocupação exacerbada com conteúdos escolares que serão exigidos dos jovens nos vestibulares, mas o universo de relações que são tecidos por eles cotidianamente, envolvendo outros aspectos como relações interpessoais, dúvidas sobre o futuro, indecisões sobre inserção no mercado de trabalho etc., geralmente, não é fonte de ações da escola.

Como analisam Sastre e Moreno Marimón (2002), uma das crenças fortemente enraizadas em nossa cultura é da distinção entre cognição e afetividade, privilegiando-se a primeira em contraposição à segunda. É forte, no senso comum, a ideia de que a razão nos conduz à verdade, enquanto que as emoções estão impregnadas de armadilhas que nos conduzem ao erro. Concordamos com o posicionamento das autoras quando indicam que tal crença socialmente construída levou a sociedade a obter grandes avanços tecnológicos, mas também à formação cada vez menos humanizada das relações interpessoais. Trabalhar com a afetividade junto aos alunos e alunas significaria pautar-se em ações voltadas a pensar nos vínculos estabelecidos, nos sentimentos e no autoconhecimento.

Tais aspectos mostraram-se importantes para a formulação de projetos de vida. Sentimentos e valores perfazem complexos que atuam concomitantemente diante da elaboração sobre as projeções futuras, compreendendo vivências passadas e ações presentes. A complexidade que compõe tais juízos exige um nível de compreensão acentuado sobre si mesmo, na relação com o outro e com o mundo. Exigir do jovem que teça tal elaboração, em uma primeira vez, sem nunca antes ter formulado seu pensamento sobre esse conteúdo, significa solicitar uma tarefa que consequentemente trará, como resultados, formulações frágeis, a não ser que o sujeito, por si só, tenha construído paradigmas relacionados a elas, em um processo contínuo de reflexão para além da escola.

A moralidade, infelizmente, ainda é tomada como algo que deve ser cuidado pela família e pelo próprio sujeito. Vê-se que, muitas vezes, comparece ao contexto escolar diante de conflitos entre os alunos e/ou entre alunos e professores, entendendo-se a mediação como ação a ser tomada depois do conflito e nunca como elemento natural das relações humanas 
para obtenção de relações saudáveis (SCHNITMAN, 1999). Os projetos de vida, em virtude de se comporem de valores e sentimentos, por meio de processos de integração e regulação que os envolvem, estão intimamente relacionados com o campo da moralidade. Na medida em que solicitam um nível de elaboração de alta complexidade, já que compreendem abstração e significação de variados elementos, sendo alguns deles valorados pela projeção de sentimentos, em uma rede de relações que lhes atribui coerência ao sujeito, necessitariam um processo de idas e vindas, reflexões contínuas e trocas de experiências entre os pares e juntamente aos adultos, seus familiares e professores (DAMON, 2009).

Não é à toa que encontramos, em nossos resultados, um grande número de jovens que apresentou projeções frágeis ou que integrou, de forma branda, valores e sentimentos. $\mathrm{O}$ número significativo de estudantes que não conseguiu projetar um futuro com maior complexidade de significados atribuídos, gerando uma teia de relações possíveis, mostra-nos que as instituições escolares precisam trabalhar com a moralidade, trazendo-a de forma tão importante quanto os demais conteúdos escolares. A inserção dos jovens na sociedade dependerá, em parte, dos conhecimentos que adquiriu sobre conteúdos tradicionalmente escolares, mas estará grandemente correlacionada às suas formas de atuação ética, na importância que dão ao seu posicionamento social e nos valores e sentimentos que regularão suas condutas, visando ao Bem comum.

Sobre esse aspecto, lembramos os estudos promovidos por Lapsley e Narvaez (2004), em que os jovens criam padrões estáveis de experiência pessoal (esquemas) altamente acessíveis, que são ativados no processamento de informações das situações. Para os autores, os significados dos eventos sociais são construídos rotineiramente, habitualmente e sem intencionalidade, ou seja, estão em inter-relação entre o nível da consciência e da nãoconsciência. Assim, podemos entender que a formulação de um projeto de vida necessita de uma diversidade de experiências pessoais de reflexão para que o sujeito consiga criar, no intercâmbio entre as dimensões da consciência e do inconsciente, pautas de pensamento que sejam elegidas diante de contextos que solicitem seu posicionamento frente às suas projeções futuras.

Na Teoria dos Modelos Organizadores do Pensamento (MORENO MARIMÓN et al., 1999), vê-se uma proposição bastante próxima, já que os modelos estão contíguos à dinamicidade do pensamento. Segundo Moreno Marimón e Sastre (2010), os modelos estão em contínua transformação, já que são pautas para a elaboração de novos modelos a partir de outros elementos abstraídos e/ou imaginados pelo sujeito no contexto. O processo de "reiteração reconstrutiva" ocorre sempre que um contexto proporciona a revisão de modelos, 
fazendo com que eles aumentem a sua complexidade e a sua capacidade de perceber fenômenos complexos que antes se mostravam impossíveis de captar pelo sujeito. Os projetos de vida, conquanto sejam modelos organizadores do pensamento por trazerem, através da abstração de elementos, atribuição de significados e estabelecimento de relações/implicações entre eles, uma interpretação sobre a "realidade", que corresponderia às projeções sobre o futuro, estão abertos a mudanças nas dinâmicas de organização dos raciocínios dos jovens. Tais mudanças são passíveis de acontecerem caso o sujeito possa colocar seu pensamento "à prova", inserindo-o em novos contextos em que, pela inserção de novos elementos, seja possível ao jovem perceber que sua forma de pensar não dá conta da complexidade inerente às projeções sobre o futuro.

Por esse motivo, defendemos que os projetos de vida devem ser conteúdos trabalhados na escola por meio de ações diversificadas que permitam aos jovens repensá-los, com base em vivências e contextos diferenciados, modificando-os para que consigam elaborar modelos mais complexos e amplos, levando-os a obterem uma visão mais completa sobre seu futuro e a sociedade.

Para tanto, o conceito de processos de integração e regulação de valores e sentimentos mostra-se fundamental aos educadores que almejem trabalhar com os projetos de vida e também com a moralidade na escola. Como discutimos em capítulos anteriores, tais processos são inerentes à organização do pensamento frente a conteúdos morais, sendo estabelecidos por meio dos significados atribuídos à integração dos complexos de valores e sentimentos e, em consequência, das relações e/ou implicações entre eles. Em um trabalho voltado aos projetos de vida, aos educadores cabe instaurar a discussão e a reflexão sobre as possíveis integrações entre valores e sentimentos que se mostram presentes no grupo com o qual atua, indicando que os significados que perfazem tais complexos podem fortalecer a constituição da moralidade no self. Estamos de acordo com Damon e colaboradores (DAMON; MENON; BRONK, 2003; DAMON, 2009; BUNDICK, 2009) ao postularem que o engajamento em projetos de vida (purposes) imprime ao jovem um maior conhecimento acerca de si mesmo, trazendo maior certeza nas ações cotidianas, mesmo que tenha ciência de que seu pensamento está sujeito a mudanças provavelmente cabíveis dentro de novos contextos de formulação.

Outro aspecto importante dos resultados revelados em nossa investigação esteve nos processos de integração e regulação de valores e sentimentos que se centraram, principalmente, no trabalho e na família, apresentando de forma menos frequente estudo, Deus e vontade de ajudar os outros, por meio de significados que foram interconectados às redes de relações estabelecidas. Embora não tivéssemos a intenção de comparar modelos de 
acordo com um posicionamento mais ético frente à sociedade, chamou-nos a atenção as formulações voltadas prioritariamente ao bem-estar pessoal ou, no máximo, da família. Consideramos, com Bundick (2009), que trazer ao projeto de vida o trabalho como realização pessoal, implicitamente mostra a indicação de que tal projeção se estende à sociedade. Ao mesmo tempo, podemos inferir que os jovens que almejam ajudar os outros podem beneficiarse de tal ajuda, pelo fato de se sentirem bem com sua atitude ou por seguirem preceitos de uma religião, por exemplo. No entanto, a despeito dessas considerações, a escola pode provocar reflexões sobre tais relações, instigando nos jovens a reflexão sobre o seu papel no mundo e a sua possível contribuição para a família (no âmbito privado) e para a sociedade de uma forma geral (no âmbito público).

Também devemos destacar que, de acordo com os resultados obtidos, existe uma centralidade de complexos de valores e sentimentos em relação aos projetos de vida que constitui, pelas relações estabelecidas, um continuиm entre os processos estabelecidos diante de diferentes solicitações de organização do pensamento. A despeito de se tratarem de formas de articulação diferentes, que solicitaram mobilização dos processos de integração e regulação de valores e sentimentos que levaram cada dinâmica de organização do pensamento a se tornar altamente singular em relação ao contexto apresentado, foi possível perceber que, diante de cada instrumento, as formas como cada sujeito organizou seus pensamentos ressaltaram características constantes que identificam o self e seu sistema de valores. Dessa forma, a díade regularidade/singularidade, que caracterizou tanto a aplicação de modelos pelo grupo de jovens quanto por um mesmo jovem, revelou-se importante para revelar o que se mantém do self e o que se mostra maleável nas situações vivenciadas.

Pensamos, portanto, ser necessário tratar, na escola, das relações entre os valores que constituem a identidade do jovem e as possibilidades de estabelecer relações entre tais valores mediante a atribuição de significados nos contextos vivenciados. Assim, seria muito importante realizar um verdadeiro programa de educação moral em que os jovens fossem colocados para reflexão em trocas de experiências sobre alguns conflitos morais, em que os sujeitos pudessem imaginar-se contra os valores que consideram essenciais em seus projetos de vida. No caso de alunos que buscam apenas objetivos hedonistas, seria interessante debater sobre conflitos em que o jovem deixa de lado seu prazer pessoal, amigos, baladas, em favor de um estudo intenso para passar no vestibular. Sem emitir juízos de valores sobre as colocações dos jovens, o papel do educador seria o de incentivar vários posicionamentos, a fim de levá-los a perceber vantagens e desvantagens de cada organização do pensamento. 
Sobre o uso de conflitos, cremos que se apresentam como meios profícuos para a reflexão (SASTRE; MORENO, 2002) que toma por base processos de integração e regulação de valores e sentimentos. Em nossos resultados, observamos que, frente ao conflito moral, os jovens conseguiram atribuir maior força ao projeto de vida, não abrindo mão de seus sonhos e objetivos em relação ao futuro, mesmo que isso implicasse considerar, também, as necessidades e interesses da família. Por se caracterizarem como elaborações mais detidas ao contexto, contando com menor possibilidade de abstração e significação de elementos, assim como de estabelecimento de relações entre eles, foram formuladas com maior integração entre valores e sentimentos, mobilizando, inclusive, sentimentos negativos de culpa, arrependimento, mal-estar e tristeza. Devido a esses resultados, cremos que o trabalho por meio de conflitos morais pode ser acessível e provocar discussões interessantes para ampliar o espectro dos jovens a respeito de seus projetos de vida.

Um modo interessante de promover tal trabalho voltado ao exercício da moralidade no cotidiano encontra-se na proposta de Puig (2004) sobre as práticas morais, que se referem ao que as pessoas fazem a respeito de temas éticos e morais, pautando-se no cotidiano e na rotina de acontecimentos. Tais práticas são produzidas pela sociedade e pela cultura, passíveis de transformações pelos sujeitos e pela sociedade constantemente. Para o autor, as práticas morais devem possibilitar a reflexão, a clarificação e a deliberação a respeito de valores, princípios e normas da vida cotidiana.

Entendendo o conflito moral como cabível na proposta de práticas morais, postulamos que o trabalho com o projeto de vida deve conciliar momentos de reflexão sobre conflitos que compreendem situações do cotidiano dos jovens, colocando em jogo seus complexos de valores e sentimentos, alternados com momentos de elaboração sobre seus próprios projetos de vida. Cremos que, diante de diversas situações que envolvam tal temática, em diferentes níveis de articulação de valores e sentimentos, seria possível ao jovem conhecer mais sobre si mesmo, sentindo-se mais seguro diante de seu futuro e conseguindo perceber-se como ser ético, atuante na sociedade em que se insere. 


\section{REFERÊNCIAS}

ABRAMO, H. W. Considerações sobre a tematização social da juventude no Brasil. Revista Brasileira de Educação. Rio de Janeiro: Anped, n. 5, 1997.

; BRANCO, P. P. M. (Orgs.) Retratos da juventude brasileira: análises de uma pesquisa nacional. São Paulo: Instituto Cidadania e Ed. Fundação Perseu Abramo, 2005.

- Considerações sobre a tematização social da juventude no Brasil. In: FÁVERO, O.; SPOSITO, M. P.; CARRANO, P.; NOVAES, R. R. (Orgs.) Juventude e contemporaneidade. Brasília: UNESCO, MEC, ANPEd, 2007.

AFFONSO, S. A. B. Estados emocionais e os modelos organizadores do pensamento: um estudo sobre a violência de gênero. 2008. Tese (Doutorado). Faculdade de Educação, Universidade Estadual de Campinas, Campinas, 2008.

ARANTES, V. A. Estados de ânimo e os Modelos Organizadores do Pensamento: um estudo exploratório sobre a resolução de conflitos morais. 2000. Tese (Doutorado). Facultat de Psicologia da Universitat de Barcelona, Barcelona, 2000a.

Cognição, afetividade e moralidade. Educação e Pesquisa. São Paulo, v. 26, n. 2., p.p. 137-153, jul./dez, 2000b.

Afetividade, cognição e moralidade na perspectiva dos modelos organizadores do pensamento. In: ARANTES, V. A. (org.) Afetividade na escola: alternativas teóricas e práticas. São Paulo: Summus, 2003.

; SASTRE, G. Moralidad, sentimientos y educación. Educar. 31, 47-66, 2003.

; PINHEIRO, V. Cognition and Affectivity in Moral Reasoning. Association for Moral Education 33rd Annual Meeting, 2007, New York. Civic Education, Moral Education, and Democracy in a Global Society. New York - EUA: New York University, v. 1. p. 173-173, 2007.

; SASTRE, G. V.; GONZÁLEZ, A. Violencia contra las mujeres: significados cognitivos y afetivos en las representaciones mentales de adolescentes. Infancia $\mathbf{y}$ Aprendizaje, v. 30, p. 197-214, 2007.

ARAÚJO, U. F. O sentimento de vergonha como um regulador moral. 1998. Tese (Doutorado), Instituto de Psicologia da Universidade de São Paulo, São Paulo, 1998.

Conto de escola: a vergonha como um regulador moral. São Paulo: Moderna; Campinas: Editora da Universidade de Campinas, 2003a.

A dimensão afetiva da psique humana e a educação em valores. In:

ARANTES, V. A. (Org.) Afetividade na escola: alternativas teóricas e práticas. São Paulo: Summus, 2003b. 
Moderna, 2004.

Assembleia escolar: um caminho para a resolução de conflitos. São Paulo:

Educação em valores e democracia escolar: um estudo de Psicologia e Educação. 2005. Tese (Livre-docência). São Paulo, Faculdade de Educação da Universidade de São Paulo, 2005.

; PUIG, J. M.; ARANTES, V. A. (Org). Educação e valores: pontos e contrapontos. São Paulo: Summus, 2007.

Apresentação à edição brasileira. In: DAMON, W. O que o jovem quer da vida? Como pais e professores podem orientar e motivar os adolescentes. São Paulo: Summus, 2009, p. 11-15.

BARRETT, K. C. A functionalist approach to shame and guilt. In: TANGNEY, J. P.; FISCHER, K. W. Self-conscious emotions: the psychology of shame, guilt, embarrassment, and pride. New York: The Guilford Press, 1995.

BLASI, A. The development of identity: some implications for moral functioning. In: NOAM, G. \& WREN, T (Org). The moral self. Cambridge: The MIT Press, 1992, p. 99-122.

Moral understanding and the moral personality: the process of moral integration. In: KURTINES, W. (Org.). Moral development: an introdution. London: Allyn and Bacon, 1995, p. 229-254.

Moral functioning: moral understanding and personality. In: LAPSLEY, D. K.; NARVAEZ, D. (2004). Moral development, self and identity. Marhwash, New Jersey; London: Lawrence Eerlbaum Associates Publishers, 2004.

Moral reasoning and the moral functioning of mature adults. In: NARVAEZ, D.; LAPSLEY, D (Orgs.). Moral personality, identity, and character. New York: Cambridge University Press, 2010.

BECHARA, A. O papel positivo da emoção na cognição. In: ARANTES, V. (Org.) Afetividade na escola: alternativas teóricas e práticas. São Paulo: Summus, 2003.

BENHABIB, S. The Generalized and the Concrete Other. In: Situating the self: gender, community and postmodernism in contemporary ethics. New York, Routlege, 1992.

BERGMAN, R. Identity as motivation: toward a theory of the moral self. In: LAPSLEY, D. K.; NARVAEZ, D. (Orgs.) Moral development, self and identity. Marhwash, New Jersey; London: Lawrence Eerlbaum Associates Publishers, 2004.

BIAGGIO, A. M. B. Universalismo versus relativismo no julgamento moral. Psicologia, Reflexão e Crítica, Porto Alegre, vol. 12, n. 1, 1999.

BOUTINET, J. P. Antropologia do projeto. Porto Alegre: Artmed, 1999/2002. 
BUNDICK, M. Pursuing the good life: an examination of purpose, meaningful engagement, and psychological well-being in emerging adulthood. 2009. Dissertação (Doutorado). Stanford School of Education, Stanford, 2009.

BOCK, A. M. B. A perspectiva sócio-histórica de Leontiev e a crítica à naturalização da formação do ser humano: a adolescência em questão. Caderno Cedes. Campinas, v. 24, n. 62, p. 26-43, 2004.

CAMACHO, L. M. Y. A ilusão da moratória social para os jovens das classes populares. In: SPOSITO, M. P. (Coord.) Espaços públicos e tempos juvenis: um estudo de ações do poder público em cidades de regiões metropolitanas brasileiras. São Paulo, Global, 2007.

CAMARANO, A. A. et. al. Caminhos para a vida adulta: as múltiplas trajetórias dos jovens brasileiros. Rio de Janeiro: IPEA, 2004.

CANTOR, N. From thought from behavior: "having" and "doing" in the study of personality and cognition. American Psychologist, n. 45, pp. 735-750, 1990.

CARRETERO, M. Conocimiento y deseo en la obra de Jean Piaget. In: PIAGET, J. Inteligencia y afectividad. Trad. Maria Sol Dorin. Revisão e Notas. Mario Carretero. Buenos Aires: Aique Grupo Editor, 1991.

CELLÉRIER, G. Organização e funcionamento dos esquemas. In: In: INHELDER, B.; CELLÉRIER, G. O percurso das descobertas da criança: pesquisa sobre as microgêneses cognitivas. Lisboa: Instituto Piaget, 1992.

COIMBRA, C.; BOCCO, F.; NASCIMENTO, M. L. Subvertendo o conceito de adolescência. Arquivos Brasileiros de Psicologia, v. 57, n. 1. Rio de Janeiro, jun, 2005.

COLBY, A.; DAMON, W. Some do care: contemporary lives of moral commitment. Nova Iorque: The Free Press, 1992.

. The uniting of self and morality in the development of extraordinary moral commitment. In: NOAM, G. \& WREN, T (Org). The moral self. Cambridge: The MIT Press, 99-122, 1993.

COMTE-SPONVILlE, A. Pequeno tratado das grandes virtudes. São Paulo: Martins Fontes, 1995.

DAMÁSIO, A. O erro de Descartes. São Paulo: Companhia das Letras, 1996.

O mistério da consciência. São Paulo: Companhia das Letras, 2000.

DAMON, W. Patters of change in children's social reasoning: a two-year longitudinal study. Child Development, v. 51, 1980, p. 1010-1017.

The Free Press, 1988.

The moral child: nurturing children's natural moral growth. New York:

Greater expectations. San Francisco: The Free Press, 1995. 
O que o jovem quer da vida? Como pais e professores podem orientar e motivar os adolescentes. São Paulo: Summus, 2009.

; MENON, J.; BRONK, K. C. The development of purpose during adolescence. Applied Developmental Science, v. 7, n. 3, p. 119-128, 2003.

DELL'AGLIO, D. D.; KOLLER, S. H. (Orgs.) Adolescência e juventude: vulnerabilidade e contextos de proteção. São Paulo: Casa do Psicólogo, 2011.

DE LA TAILLE, Y. Prefácio à edição brasileira. In: O juízo moral na criança. São Paulo: Summus Editorial, 1932 (ed. brasil. 1994), 1994.

. Vergonha, a ferida moral. Petrópolis, RJ: Vozes, 2002.

Moral e ética: dimensões intelectuais e afetivas. Porto Alegre: Artmed, 2006.

Formação ética: do tédio ao respeito de si. Porto Alegre: Artmed, 2009.

DÍAZ-AGUADO, M. J.; MEDRANO, C. Construção moral e educação: uma aproximação construtivista para trabalhar os conteúdos transversais. Bauru, SP: Edusc, 1999.

ERIKSON, E. Identidade: juventude e crise. 2. ed. Rio de Janeiro: Guanabara, 1976.

FÁVERO, O.; SPOSITO, M. P.; CARRANO, P.; NOVAES, R. R. (Org.) Juventude e contemporaneidade. Brasília: UNESCO, MEC, ANPEd, 2007.

FERREIRA, A. B. H. Novo dicionário Aurélio da língua portuguesa. 3 ed. Curitiba: Positivo, 2004.

FLANAGAN, O. Varieties of moral personality: ethics and psychological realism. Harvard University Press, 1993.

\& RORTY, A. O. (Orgs.). Identity, character, and morality: essays in moral psycology. London: The MIT Press, 1990.

FRANKL, V. Em busca de sentido: um psicólogo no campo de concentração. Petrópolis: Vozes, 1959/ 1991.

FREITAS, M. V. Juventude e adolescência no Brasil: referências conceituais. São Paulo: Ação Educativa, 2005.

FRIMER, J. A.; WALKER, L. F. Towards a new paradigm of moral personhood. The Journal of Moral Education, v. 37, n. 3, sept., 2008.

GILLIGAN, C. La moral y la teoria: psicologia del desarrollo femenino. México: Fondo de Cultura Económica, 1985. 
Hearing the difference: theorizing connection. Anuario de Psicología. Facultat de Psicologia Universitat de Barcelona. Barcelona, vol. 34, $\mathrm{n}^{\mathrm{o}}$ 2, p. 155-161, 1995/2003.

GLASERSFELD, E. V. Despedida de la objectividad. Barcelona: Editorial Gedisa, 1994.

HAIDT, J. The emotional dog and its rational tail: a social intuitionist approach to moral judgment. Psychological Review, v. 108, n. 4, p. 814-824, 2001.

The moral emotions. In: DAVIDSON, R. J.; SCHERER, K. R.; GOLDSMITH, H. H. (Eds.). Handbook of affective sciences. Oxford: Oxford University Press, 2003.

2007.

. The new synthesis in moral psychology. Science, vol. 316, pp. 998-1002,

; KOLLER, S.; DIAS, M.G. Affect, culture, and morality or is it wrong to eat your dog? Journal of Personality and Social Psychology, v. 65, pp. 613-628, 1993.

HARKOT-DE-LA-TAILLE, E.; DE LA TAILLE, Y. A construção ética e moral de si mesmo. In: SOUZA, M. T. C. C. (Org.). Os sentidos de construção: o si mesmo e o mundo. São Paulo: Casa do Psicólogo, 2004.

HERRERO, M. T.; SASTRE, G. Los sentimientos en el ámbito de la moral. Educação e Pesquisa. São Paulo, v. 29, n. 2., p. 219-234, jul./ dez, 2003.

INHELDER, B.; PIAGET, J. Da lógica da criança à lógica do adolescente. São Paulo: Livraria Pioneira, 1976.

; CELLÉRIER, G. O percurso das descobertas da criança: pesquisa sobre as microgêneses cognitivas. Lisboa: Instituto Piaget, 1992.

; DE CAPRONA, D. Em direção ao construtivismo psicológico: estruturas? Procedimentos? Os dois são indissociáveis. In: INHELDER, B.; CELLÉRIER, G. O percurso das descobertas da criança: pesquisa sobre as microgêneses cognitivas. Lisboa: Instituto Piaget, 1992.

JOHNSON-LAIRD, P. M. Mental models: towards a cognitive science of language, inference and consciousness. New York: Cambridge University Press, 1983.

Mental models and probabilistic thinking. Cognition, 50, 189-209, 1994

KLEIN, A. M. Projetos de vida e escola: a percepção de estudantes do ensino médio sobre a contribuição das experiências escolares aos seus projetos de vida. 2011. Tese (Doutorado). Faculdade de Educação, Universidade de São Paulo, São Paulo, 2011.

KOHLBERG, L. The development of models of thinking and choices in years 10 - 16 . Unpublished doctoral dissertation, University of Chicago, 1958. 
From is to ought: how to commit the naturalistic fallacy and get away with it in the study of moral development. In: T. Mischel (Org.) Cognitive development and epistemology. New York: Academic Press, 1971.

1984.

Essays on moral development. São Francisco: Harper and Row. v. 1 e 2,

KOLLER, S. H. Diferenças de gênero no julgamento moral. 1990. Dissertação (Mestrado), Universidade Federal do Rio Grande do Sul, Rio Grande do Sul, 1990.

.; CERQUEIRA-SANTOS, E.; MORAIS, N. A.; RIBEIRO, J. Juventude brasileira: fatores de risco e de proteção. Relatório de pesquisa - World Bank. Porto Alegre, 2005.

KRISTJÁNSSON, K. Putting emotion into the self: a response to the 2008 Journal of Moral Education Special Issue on moral functioning. The Journal of Moral Education, v. 38, n. 3, sept., 2009.

LAPSLEY, D. K.; HILL, P. L. On dual processing and heuristic approaches to moral education. The Journal of Moral Education, v. 37, n. 3, sept., 2008.

A social-cognitive approach to the moral personality. In: LAPSLEY, D. K.; NARVAEZ, D. Moral development, self and identity. Marhwash, New Jersey; London: Lawrence Eerlbaum Associates Publishers, 2004.

LASSANCE, A. Brasil: jovens de norte a sul. In: ABRAMO, H. W.; BRANCO, P. P. M. (Orgs.) Retratos da juventude brasileira: análises de uma pesquisa nacional. São Paulo: Instituto Cidadania e Ed. Fundação Perseu Abramo, 2005.

LEMOS-DE-SOUZA, L. Modelos organizadores, gênero e moral na resolução de conflitos entre jovens na escola. 2008. Tese (Doutorado) Universidade Estadual de Campinas, Campinas, SP, 2008.

; VASCONCELOS, M. S. Modelos organizadores do pensamento: uma perspectiva de pesquisa sobre o raciocínio moral de adolescentes autores de infração. Psicologia em estudo, 8(2), 45-59, 2003.

; VASCONCELOS, M. S. Juízo e ação moral: desafios teóricos em psicologia. Psicologia \& Sociedade, 21 (3), 343-352, 2009.

LEWIS, M. Self-conscious emotions: embarrassment, pride, shame, and guilt. In: LEWIS, M; HAVILAND-JONES, J. M. (Org.). Handbook of emotions. $2^{\text {a }}$ ed. New York: The Guilford Press, 2004.

LIBÓRIO, R. M. C.; COÊLHO, A. E. L.; CASTRO, B. M. Escola: risco ou proteção para adolescentes e adultos jovens? In: DELL'AGLIO, D. D.; KOLLER, S. H. (Orgs.) Adolescência e juventude: vulnerabilidade e contextos de proteção. São Paulo: Casa do Psicólogo, 2011. 
MACEDO, L. Jogo e projeto: irredutíveis, complementares e indissociáveis. In: MACEDO, L.; MACHADO, N. J.; ARANTES, V. A. (Org.). Jogo e projeto: pontos e contrapontos. São Paulo: Summus, 2006.

1996.

(Org.). Cinco estudos de educação moral. São Paulo: Casa do Psicólogo,

MACHADO, N. J. Educação: projetos e valores.São Paulo: Escrituras Editora, 2004.

A vida, o jogo, o projeto. In: MACEDO, L.; MACHADO, N. J.; ARANTES, V. A. (Org.). Jogo e projeto: pontos e contrapontos. São Paulo: Summus, 2006.

MARGULIS, M.; URRESTI, M. La juventud es más que una palavra. In: La juventud es más que una palavra: ensayos sobre la cultura y juventud. Buenos Aires: Editorial Biblios, 1996.

MARÍAS, J. Breve tratado de la ilusión. Madri: Alianza Editorial, 1984.

MARQUES, L. F.; CERQUEIRA-SANTOS; DELL'AGLIO, D. D. Religiosidade e identidade positiva na adolescência. In: DELL'AGLIO, D. D.; KOLLER, S. H. (Orgs.) Adolescência e juventude: vulnerabilidade e contextos de proteção. São Paulo: Casa do Psicólogo, 2011.

MARTINS, S. M. P. Juízo e representação da ação moral: um estudo na perspectiva dos modelos organizadores do pensamento. 2003. Dissertação (Mestrado). Faculdade de Educação da Universidade Estadual de Campinas, Campinas, SP, 2003.

Cultura e gênero: um estudo na perspectiva dos modelos organizadores do pensamento. 2008. Tese (Doutorado). Faculdade de Educação da Universidade Estadual de Campinas, Campinas, SP, 2008.

MATURANA, H.; VARELA, F. A árvore do conhecimento. Campinas: Editorial Psy, $1987 / 1995$.

MELUCCI, A. Juventude, tempo e movimentos sociais. In: FÁVERO, O.; SPOSITO, M. P.; CARRANO, P.; NOVAES, R. R. Juventude e contemporaneidade. Brasília: UNESCO, MEC, ANPEd, 2007.

MONTENEGRO, T. A educação moral como parte da formação para o cuidado na educação infantil. 1999. Tese (Doutorado em Psicologia Social), Programa de Estudos PósGraduandos em Psicologia Social da PUC, São Paulo, 1999.

Diferenças de gênero e desenvolvimento moral das mulheres. Revista Estudos Feministas. Florianópolis, v. 11, n. 2, jul./dez, 2003.

MORENO MARIMÓN, M; SASTRE, G. Aprendizaje y desarrollo intelectual: bases para una teoria de la generalizacion. Barcelona: Gedisa, 1983.

; SASTRE, G. Conomiento y cambio: los modelos organizadores en la construcción del conocimiento. Barcelona, Paidón, 1998. 
; SASTRE, G. Falemos de sentimentos: a afetividade como um tema transversal na escola. São Paulo: Moderna; Campinas: Editora da Unicamp, 1999.

; SASTRE, G. Resolução de conflitos e aprendizagem emocional: gênero e transversalidade. São Paulo: Moderna, 2002.

; SASTRE, G. O significado afetivo e cognitivo das ações. In: ARANTES, V. A. (Org.) Afetividade na escola: alternativas teóricas e práticas. São Paulo: Summus, 2003.

; SASTRE, G. Cómo construimos universos: amor, cooperación y conflicto. Barcelona: Gedisa, 2010.

MORENO MARIMÓN, M. et al. Conhecimento e mudança: os modelos organizadores na construção do conhecimento. Campinas: Unicamp; São Paulo: Moderna, 1999.

MORIN, E. Ciência com consciência. Rio de Janeiro: Bertrand, 2000.

Introdução ao pensamento complexo. Lisboa: Instituto Piaget, 2001.

NARVAEZ, D.; VAYDICH, J. L. Moral development under the spotlight of the neurobiological sciences. The Journal of Moral Education, v. 37, n. 3, sept., 2008.

NISAN, M. Judgment and choice in moral functioning. In: LAPSLEY, D. K.; NARVAEZ, D. Moral development, self and identity. Marhwash, New Jersey; London: Lawrence Eerlbaum Associates Publishers, 2004.

NUCCI, L. Education in the moral domain. Cambridge University Press, 2001.

. Refletions on the moral self construct. In: LAPSLEY, D. K.; NARVAEZ, D. Moral development, self and identity. Marhwash, New Jersey; London: Lawrence Eerlbaum Associates Publishers, 2004.

OLIVEIRA, C. A. A.; COSTA, A. E. B. Os dilemas morais e não-morais no cotidiano de conflitos de adolescentes de Minas Gerais. Psicologia: Reflexão e crítica. Porto Alegre, 8 (1), p. 73-90, 1995.

OLIVEIRA, M. C. S. L. Identidade, narrativa e desenvolvimento da adolescência: uma revisão crítica. Psicologia em estudo, v. 11, n. 2. Maringá, maio/ agosto, 2006.

OZELLA, S. Adolescências construídas: a visão da psicologia sócio-histórica. São Paulo: Cortez, 2003.

; AGUIAR, W. Desmistificando a concepção de adolescência. Cadernos de Pesquisa, v. 38, n. 133, p. 97-125, jan./ abr, 2008.

PAIS, J. M. Traços e riscos de vida: uma aproximação qualitativa a modos de vida juvenis. Porto: Ambar, 2000. 
PÁTARO, C. S. O. Pensamento, crenças e complexidade humana. Ciências \& Cognição. 12, p.134-149, 2007.

Sentimentos, emoções e projetos vitais da juventude: um estudo exploratório na perspectiva da Teoria dos Modelos Organizadores do Pensamento. São Paulo. Tese (Doutorado). Faculdade de Educação, Universidade de São Paulo, 2011.

PAVÓN, T. Modelos organizadores y razionamiento moral: el sentimiento de culpa. Barcelona. Tese (Doutorado). Faculdade de Psicologia, Universidade de Barcelona, 2002.

PERALVA, A. T. O jovem como modelo cultural. In: FÁVERO, O.; SPOSITO, M. P.; CARRANO, P.; NOVAES, R. R. Juventude e contemporaneidade. Brasília: UNESCO, MEC, ANPEd, 2007.

PETERSON, C; SELIGMAN, M. E. P. Character strengths and virtues: a handbook and classification. New York: Oxford University Press, 2004.

PIAGET, Jean. O juízo moral na criança. São Paulo: Summus Editorial. (Ed. Brasil. 1994), 1932.

Intelligence and affectivity: their relationship during child development . In: Annual Reviews, Palo Alto-CA (ed.USA, 1981), 1954.

. A formação do símbolo na criança. Rio de Janeiro: Zahar Editores, 1975.

Biologia e conhecimento. $2^{\text {a }}$ Ed. Vozes: Petrópolis, 1996.

Seis estudos de Psicologia. Rio de Janeiro: Forense Universitária, 1964/ 2012.

PINHEIRO, V. P. G. Estados emocionais e os modelos organizadores do pensamento na resolução de conflitos éticos. São Paulo. Relatório de Iniciação Científica - Faculdade de Educação, Universidade de São Paulo, 2005.

A generosidade e os sentimentos morais: um estudo exploratório na perspectiva dos Modelos Organizadores do Pensamento. São Paulo. Dissertação (Mestrado). Faculdade de Educação, Universidade de São Paulo, 2009.

Preconceito, moralidade e educação moral para a diversidade. Revista Brasileira de Educação. Rio de Janeiro: Anped, jan./ abr., v. 16, n. 46, 2011.

PRIGOGINE, I.; STENGERS, I. A nova aliança: a metamorfose da ciência. Brasília: UNB, 1984.

PUIG, J. A construção da personalidade moral. São Paulo: Ática, 1996.

Práticas morais: uma abordagem sociocultural da educação moral. São Paulo: Moderna, 2004. 
Aprender a viver. In: ARAÚJO, U.. F.; PUIG, J. M.; ARANTES, V. A.

(Org). Educação e valores: pontos e contrapontos. São Paulo: Summus, 2007.

PUPO, K. R. Violência moral no interior da escola: um estudo exploratório das representações do fenômeno sob a perspectiva de gênero. 2007. Dissertação (Mestrado). Faculdade de Educação, Universidade de São Paulo, São Paulo, 2007.

REED, E. S.; TURIEL, E.; BROWN, T. (Org.). Values and knowledge. New Jersey: Lawrence Erlbaum Associates, 1996.

REED, D. C. A multi-leval model of moral functioning revisited. The Journal of Moral Education, v. 38, n. 3, sept., 2009.

; STOERMER, R.M. Towards an integrates model of moral functioning: an overview of the Special Issue. The Journal of Moral Education, v. 37, n. 3, sept., 2008.

SANTOS, R. S. Ser homem: percepções, significados e narrativas de rapazes negros e pobres da cidade de São Paulo. 2009. Dissertação (Mestrado). Faculdade de Educação, Universidade de São Paulo, São Paulo, 2009.

SASTRE, G. et. al. El derecho a ser y la autorrenuncia: sus modelos organizadores en la preadolescencia. Madrid, Educación y sociedad, 1994.

; MORENO MARIMÓN, M. Nuevas perspectivas sobre el razionamiento moral. Educação e Pesquisa. São Paulo: Faculdade de Educação da Universidade de São Paulo/ USP, v. 26, n. 2, p. 123-135, jul/dez, 2000.

; MORENO MARIMÓN, M.. O significado afetivo e cognitivo das ações. In: ARANTES, V. A. (org.) Afetividade na escola: alternativas teóricas e práticas. São Paulo: Summus, 2003.

; MORENO MARIMÓN, M.; PAVÓN, T. Cultura de gênero y diversidad en el desarollo moral. Educar, 22-23, 141-153, 2001.

; TIMÓN HERRERO, M. Los sentimientos en el ámbito de la moral. Educação e Pesquisa, 29, 123-135.

SCHNITMAN, D. (Org). Novos paradigmas na resolução de conflito. São Paulo: Artes Médicas, 2003.

SELMAN, R. The relation of role taking to the development of moral judgment in children. Child development. Blackwell Publishing, v. 42, n. 1, mar, 1971

El desarrollo sociocognitivo. Una guía para la práctica educativa y clínica. In: TURIEL, E. et. al. (Orgs). El mundo social en la mente infantil. Madrid, Alianza Editorial, 1989.

SHANTZ, C.; HARTUP, W. (Orgs.) Conflict in child and adolescent development. Cambridge University Press: Cambridge (England), 1992. 
SMETANA, J. G. Toddlers' social interactions in the context of moral and conventional transgression in the home. Developmental Psychology, v. 25, n. 4, jul, 1989.

SOAR FILHO, E. J. Novos paradigmas da psicologia e das terapias psicológicas pósmodernas. Psicologia: Teoria e Pesquisa. Jan.- abr., v. 14, 1998.

SOUZA, M. T. C. C de. O desenvolvimento afetivo segundo Piaget. In: ARANTES, V. A. (Org.) Afetividade na escola: alternativas teóricas e práticas. São Paulo: Summus, 2003

SOUZA, M. T. S.; OLIVEIRA, A. L. Fatores de proteção familiares, situações de risco, comportamentos e expectativas de jovens de baixa renda. In: DELL'AGLIO, D. D.; KOLLER, S. H. (Orgs.) Adolescência e juventude: vulnerabilidade e contextos de proteção. São Paulo: Casa do Psicólogo, 2011.

SPOSITO, M. P. Os jovens no Brasil: desigualdades multiplicadas e novas demandas políticas. São Paulo: Ação Educativa, 2003.

(Coord.) Espaços públicos e tempos juvenis: um estudo de ações do poder público em cidades de regiões metropolitanas brasileiras. São Paulo, Global, 2007.

Algumas reflexões e muitas indagações sobre as relações entre juventude e escola no Brasil. In: ABRAMO, H. W.; BRANCO, P. P. M. (Orgs.) Retratos da juventude brasileira: análises de uma pesquisa nacional. São Paulo: Instituto Cidadania e Ed. Fundação Perseu Abramo, 2005.

A pesquisa sobre jovens na pós-graduação: um balanço da produção discente em Educação, Serviço Social e Ciências Sociais (1999-2006). In: SPOSITO, M. (Coord.). O estado da arte sobre juventude na pós-graduação brasileira: Educação, Ciências Sociais e Serviço Social (1999-2006), Belo Horizonte: Argumentum, 2009, v. 1, p. 17-56.

STACH-HAERTEL, B. U. A constituição das subjetividades legitimadoras das desigualdades de gênero. 2009. Dissertação (Mestrado). Faculdade de Educação, Universidade de São Paulo, São Paulo, 2009.

TANGNEY, J. P. Shame and guilt in interpersonal relationships. In: TANGNEY, J. P.; FISCHER, K. W. Self-conscious emotions: the psychology of shame, guilt, embarrassment, and pride. New York: The Guilford Press, 1995.

THOMÉ, L. D.; TELMO, A. Q.; KOLLER, S. H. Inserção laboral juvenil: contexto e opinião sobre definições de trabalho. In: DELL'AGLIO, D. D.; KOLLER, S. H. (Orgs.) Adolescência e juventude: vulnerabilidade e contextos de proteção. São Paulo: Casa do Psicólogo, 2011.

TOGNETTA, L. R. P. A construção da solidariedade e a educação do sentimento na escola: uma proposta de trabalho com as virtudes numa visão construtivista. Campinas: Mercado das Letras; São Paulo: Fapesp, 2003.

TREVISOL, M. T. C. A construção do conhecimento social: um estudo dos modelos organizadores do pensamento em sujeitos entre 8 e 14 anos. 2002. Tese (Doutorado), Instituto de Psicologia da Universidade de São Paulo, São Paulo, 2002. 
; VASCONCELOS, M. S.; ARANTES, V. A. A pesquisa sobre representações mentais, significações e valores morais na perspectiva dos Modelos Organizadores do Pensamento. VI Congresso Brasileiro de Psicologia do Desenvolvimento, 2007. Vitória, ES, 2007.

TURIEL, E. The development of morality. In: DAMON, W. (org.) Handbook of child psychology. $5^{\text {a }}$ ed., vol. 3. Nova Iorque: Academic Press, 1988.

. The culture of morality. Cambridge: Cambridge University Press, 2002.

ULLER, W. Experiências escolares dos jovens e seus projetos vitais: um olhar a partir dos modelos organizadores do pensamento. 2012. Tese (Doutorado). Faculdade de Educação, Universidade de São Paulo, São Paulo, 2012.

VASCONCELOS, M. S.; BELLOTO, M.E.; ENDO, K. H. Significações de indisciplina escolar: um estudo de modelos organizadores abstraídos por alunos de $2^{\mathrm{a}}$ e $4^{\mathrm{a}}$ série do ensino fundamental. VI Congresso Brasileiro de Psicologia do Desenvolvimento, 2007. Vitória, ES, 2007.

VASCONCELOS, M. S. et al. Juízos e valores morais: a perspectiva de investigação dos modelos organizadores do pensamento. Paidéia, 20 (46), p. 207-217, 2010.

VELHO, G. Projeto e metamorfose: antropologia das sociedades complexas. Rio de Janeiro: Jorge Zahar, 1994.

WALKER, L. J. Gus in the gap: bridging the judment-action gap in moral functioning. In: LAPSLEY, D. K.; NARVAEZ, D. (Org.) Moral development, self and identity. Marhwash, New Jersey; London: Lawrence Eerlbaum Associates Publishers, 2004.

WREN, T. E. (Org.) The moral domain. Cambridge: The MIT Press, 1990.

; MENDOZ, C. Cultural identity and personal identity: philosophical reflections on the identity discourse of social psychology. In: LAPSLEY, D. K.; NARVAEZ, D. (Org.) Moral development, self and identity. Marhwash, New Jersey; London: Lawrence Eerlbaum Associates Publishers, 2004.

YEAGER, D. S.; BUNDICK, M. J. The role of purposeful work goals in promoting meaning in life and in schoolwork. Journal of Adolescent Research, v. 24, n. 4, jul., 2009. 